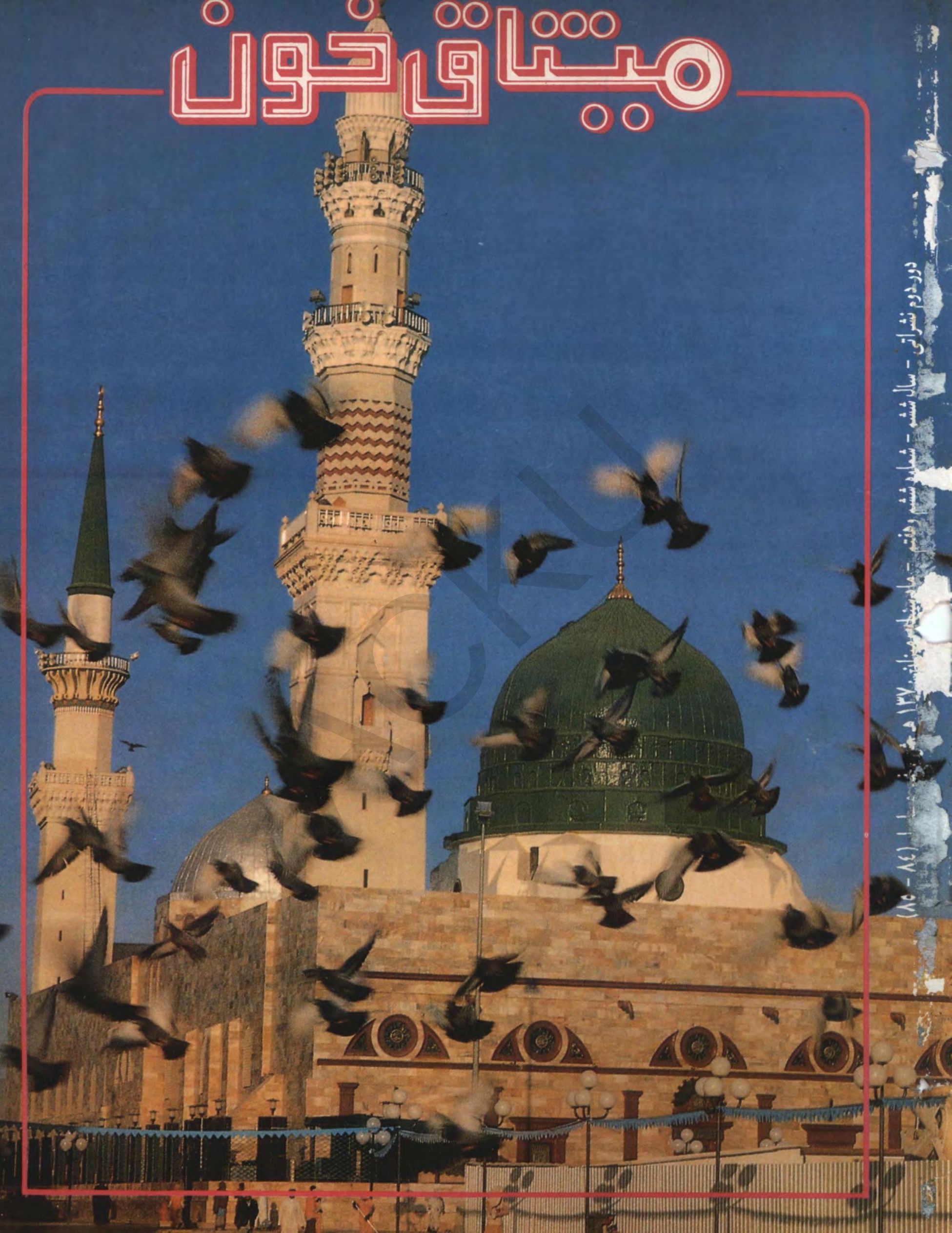




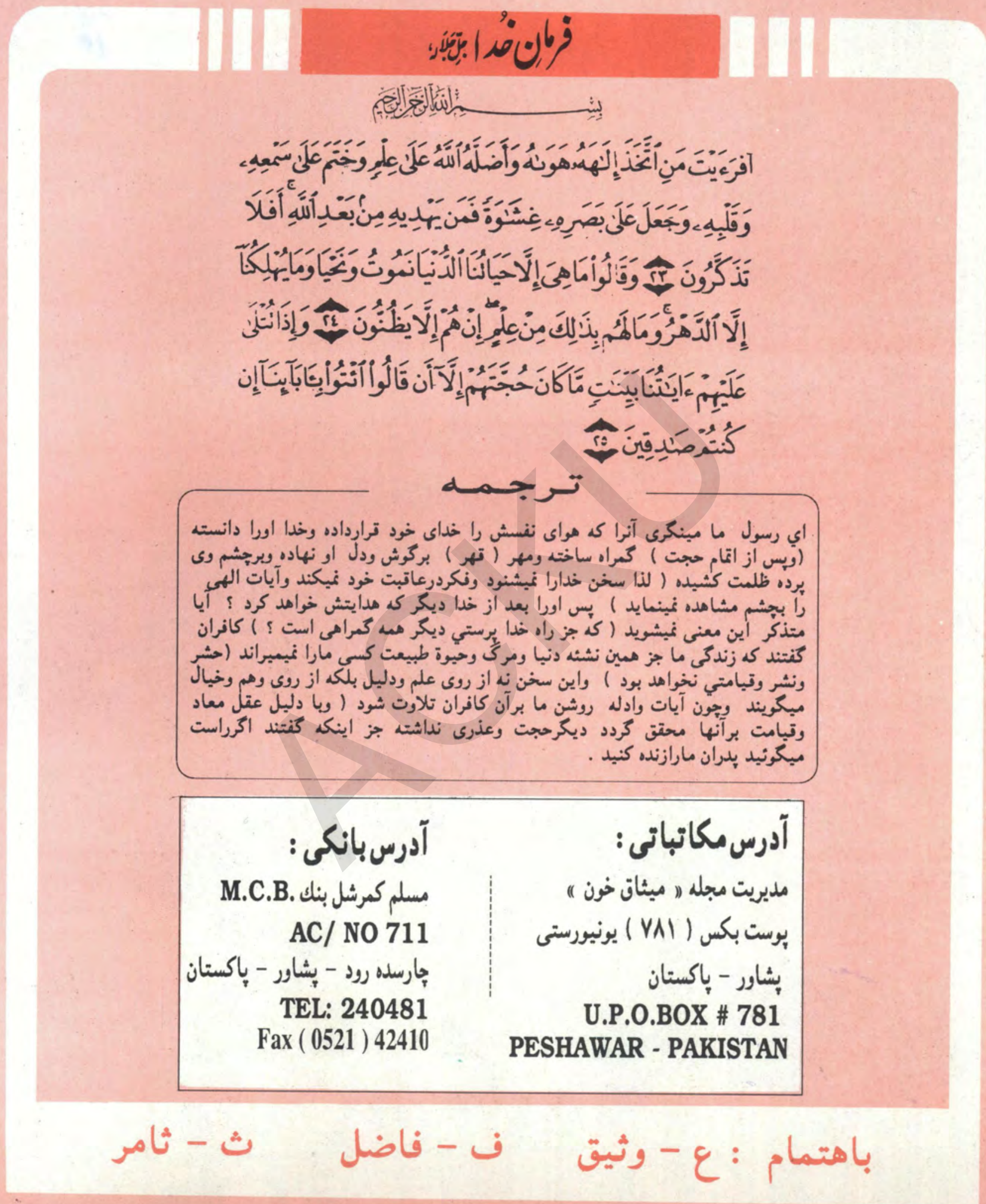

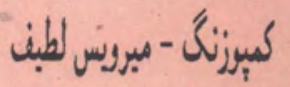




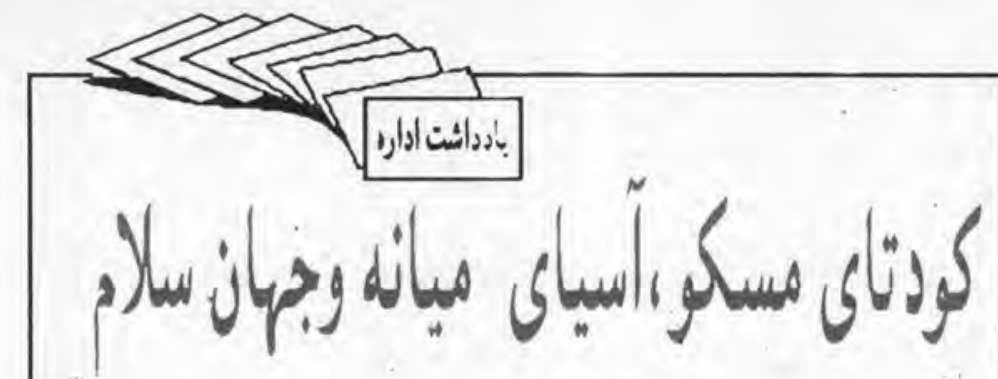

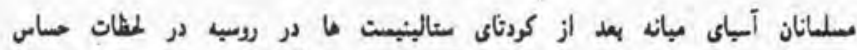

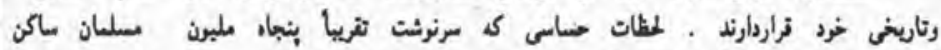

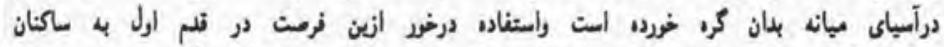

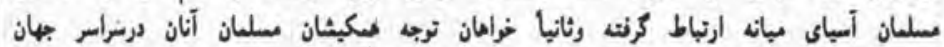

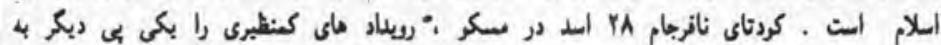

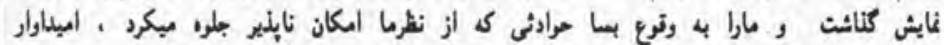

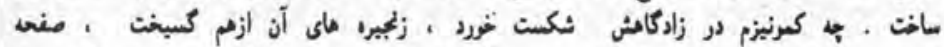

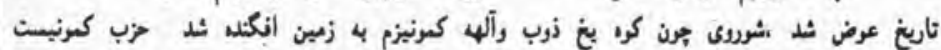

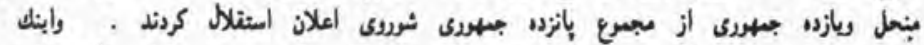

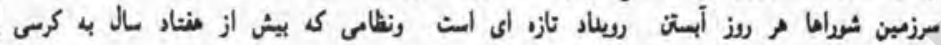

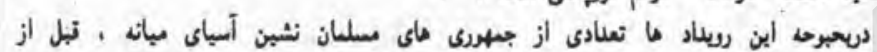

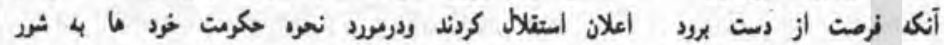

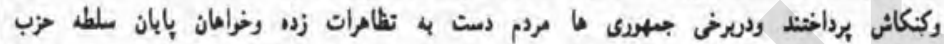

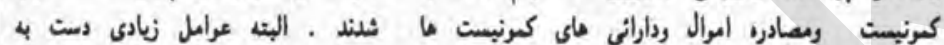

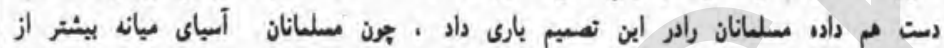

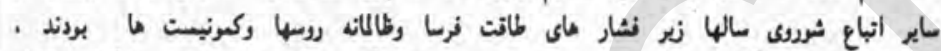

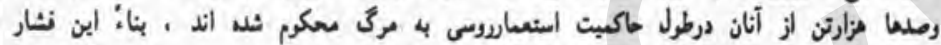

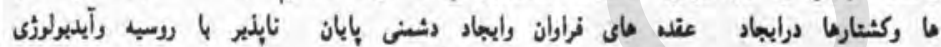

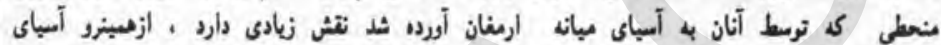

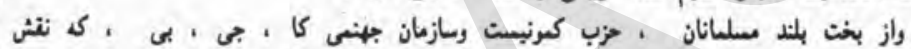

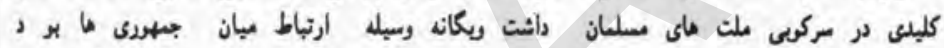

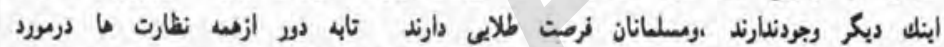

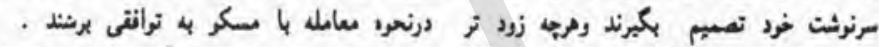

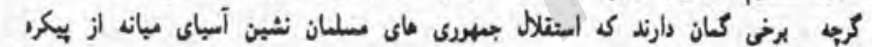

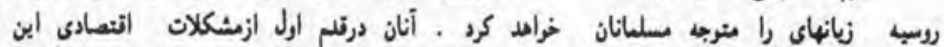

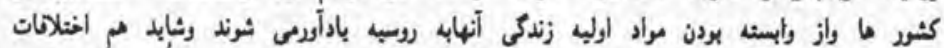

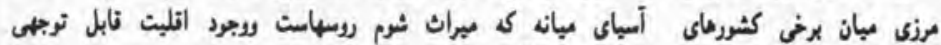

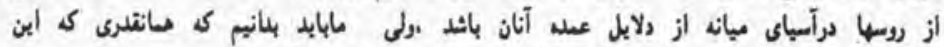

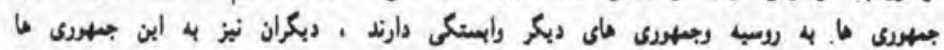

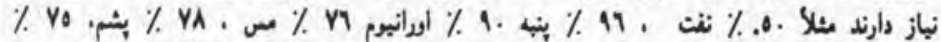

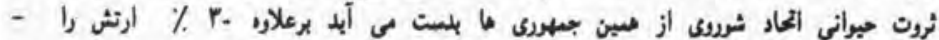

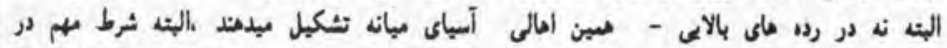

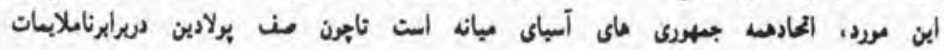

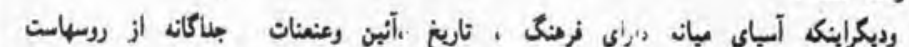

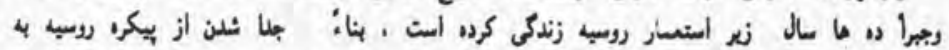

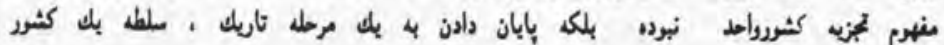

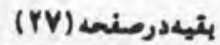

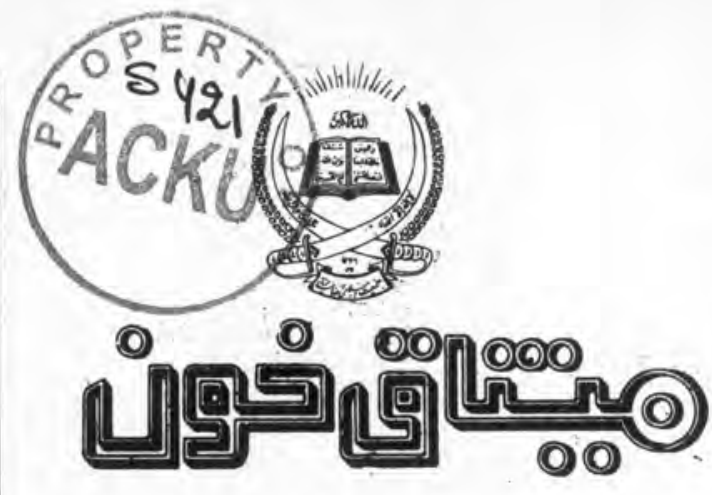

$$
\begin{aligned}
& \text { اركان نشراتى الججمن نويسندكان وسخنوران } \\
& \text { جعيت اسلامى انغانستان }
\end{aligned}
$$

دور دوم نشرانى - سال ششم - شعاره ششم ومانتم

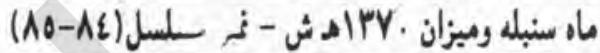

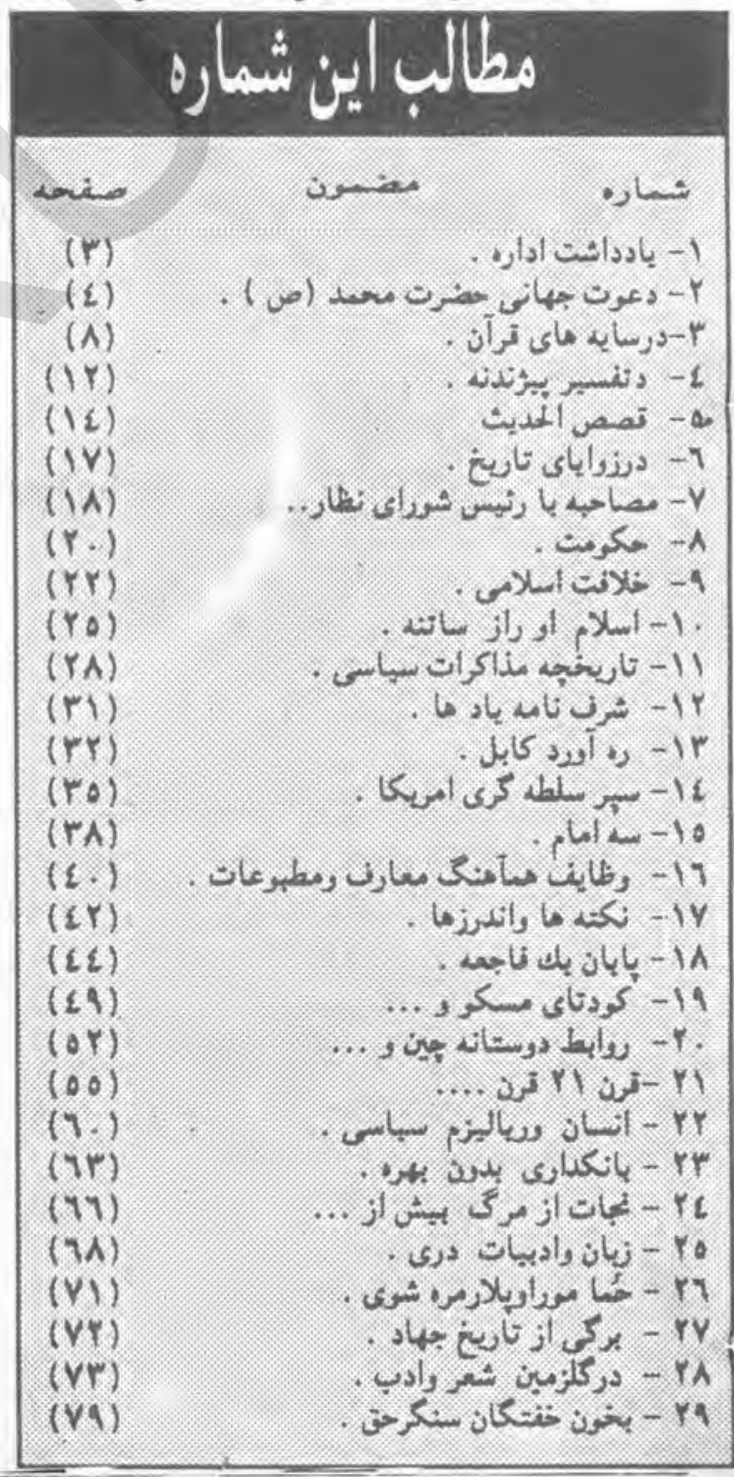




\section{: را}

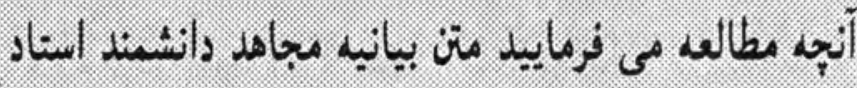

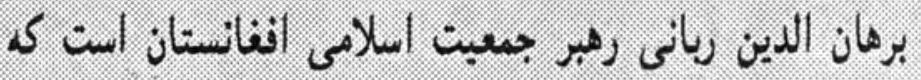

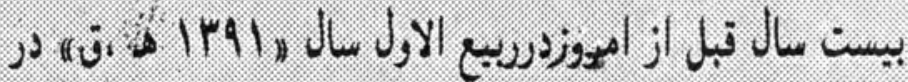

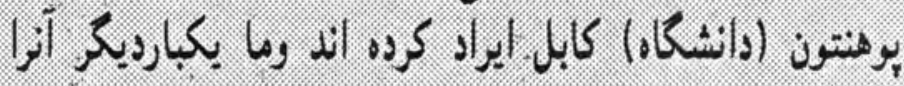

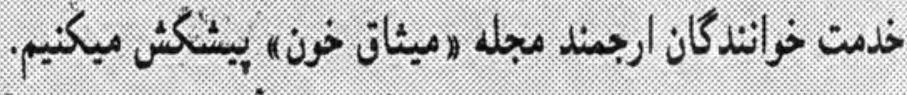

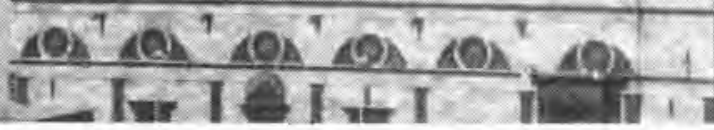
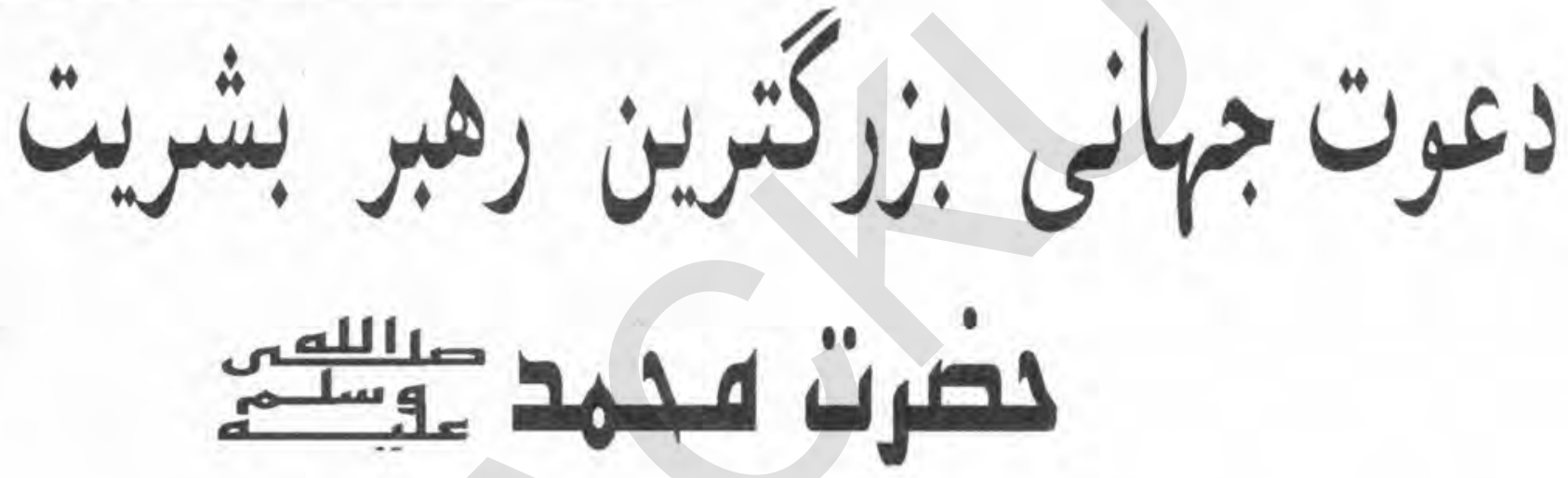

برتونازل نموديم ، رسالت توازجانب مايك ربالت

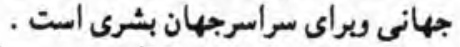

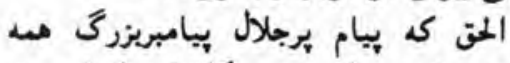
جوامع بشرى رادرمس مكانهاوزمانهادعوت بـاني

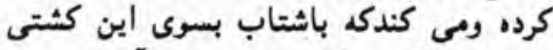

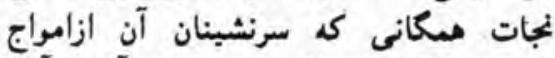
برتلاطم تبامى وبريادى دراماماندروآورندوآرام

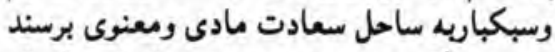

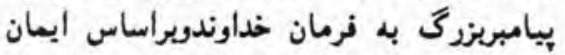
بدين حتيقت كة رسالت اوماندرسالت يبامبران بانيان

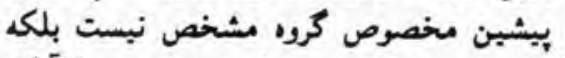

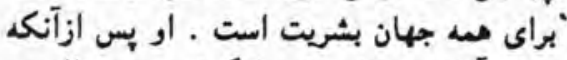
بيام آزادى بخش خودرابكوش جزيزيزة العرب

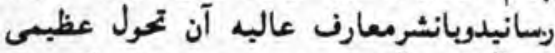

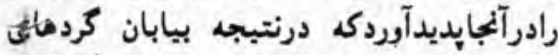

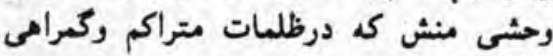
تبامكن بسرمى بردندازدرون جشهد هاى سيان.

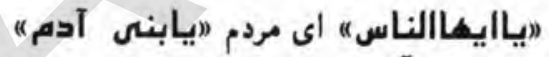

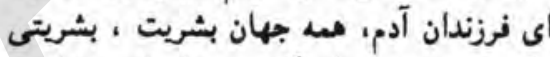

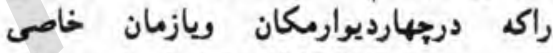

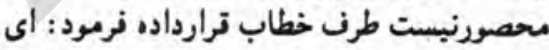

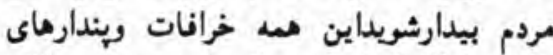

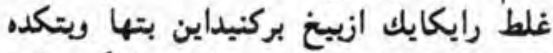

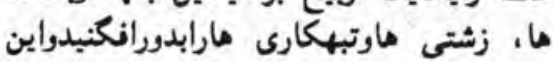

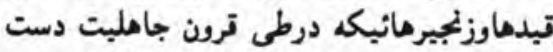

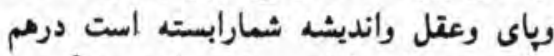

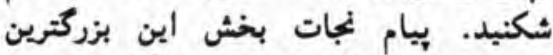

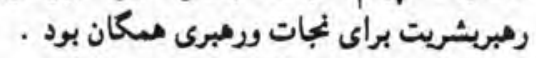

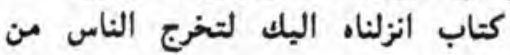

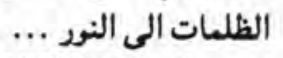

$$
\text { ومارسلناك الاكانة للناس }
$$

اي يبامبراين كتاب مقدس رابراي آنكه

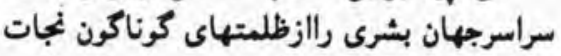

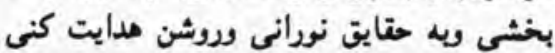

(هوالذى ارسل رسوله بالهدى الهون وحين الحز ليظهره على الذين كله

وكنى بالله شهيدا ) درسلسله حوادث تاريخ روزميلادفرخنده وياسعادت رسول اكرم صلم الله عليه وسلم نه

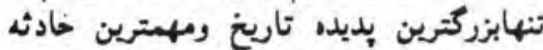

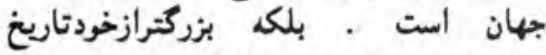
وبالاترازمستواى حوادث است .

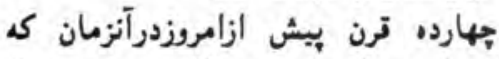

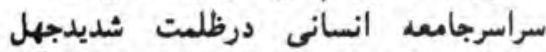
وبيدانشى ترارداشت كرامى ترين فرزند آدرئ آدم

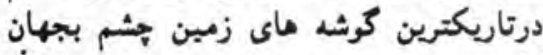

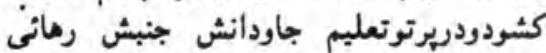
بخش وتحول عظيمى رابراه انداخت . اين جنبش عظيم كه مجرواي تاريخ

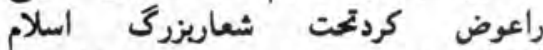
آغازكرديداين بعارجاويد باخطابهاى 
خلل نابذيرييامبرتاب مقاومت راازدست داد.

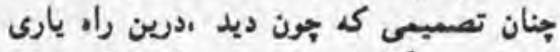

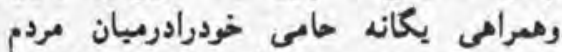

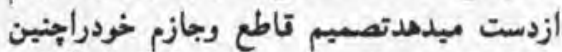
اعلان كرد : هاى عم بندخواريخداتسم اكراين

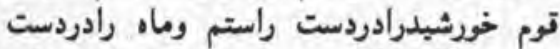

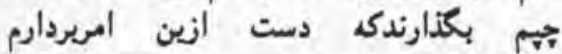

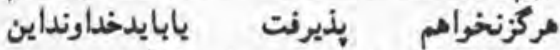

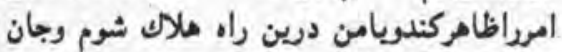

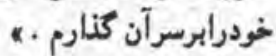

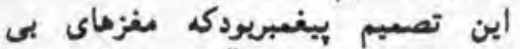

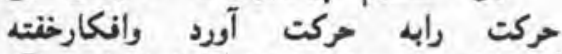

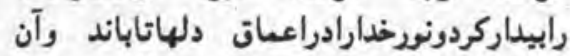

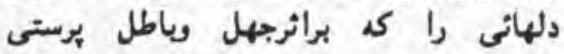

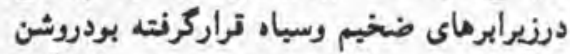

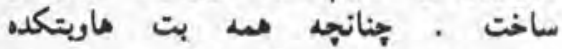

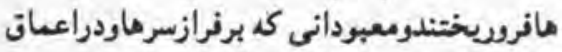

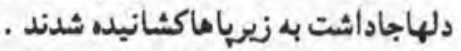

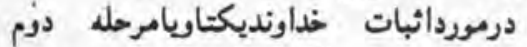
روش دعوت ييامبراكرم صلم الله علبه وسلم

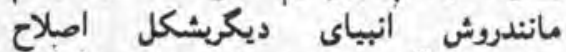
عتايدبعمل آمدودرين راه براهين واستدلال هاي

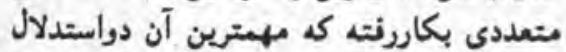

1- استدلال ازراه نطرت وياشعورياطن -

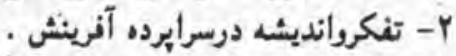

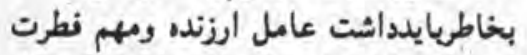
ياشعورياطن رابايدتابش اتومات دانست كد تبل

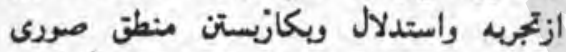

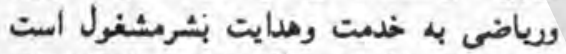

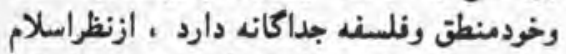

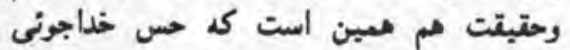

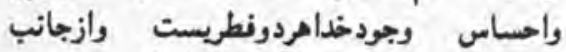

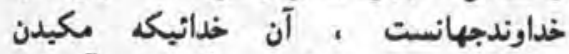
موادمفيدزمين رواندين

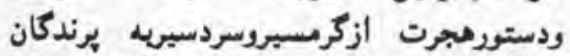

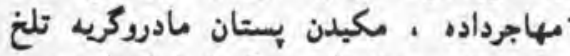

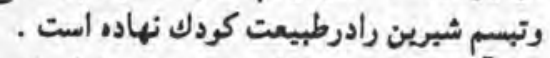

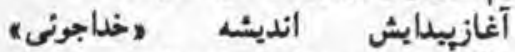

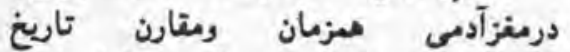
ظهوربشراست وتقاضاى دين كه توسط انبياء بـان مردم عرضه مى شوددرواعلات شعورآدمى نهنتها

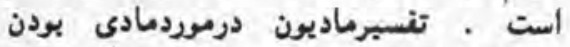

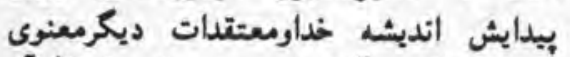

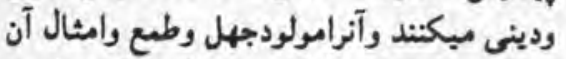

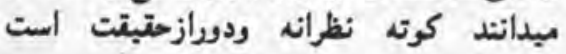

مذهبى ويالزيم ازيبن رفنت منانع شان موانعى

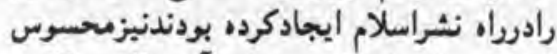

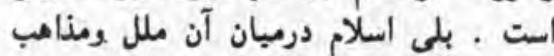

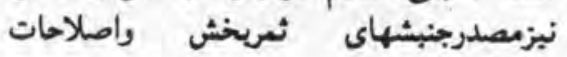
بيشهارى كرديد .

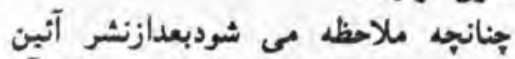

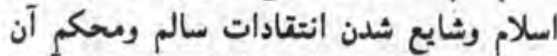

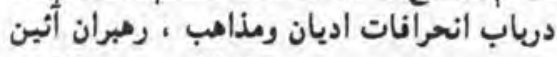

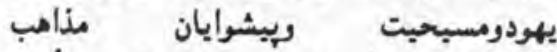

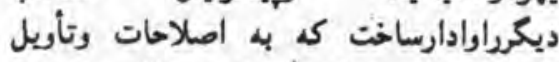
هاوتفسيرهايى دراصول ونروع مذاهب خهايش

ابن تصبم بيغبربودكة مغزهاى بى حركت

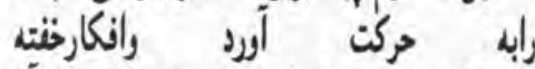
رابيداركردونوخدارادراعات رلهاتاباند رآن

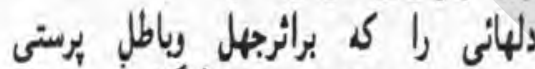

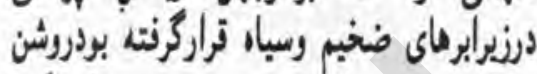

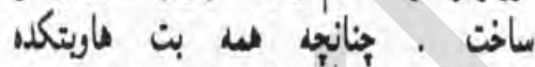
هافروريغتنلومعبردانى كم برنرازسرهاودراعان

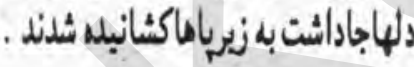

روآوردند . بطهيورييوستن بروتستانت وانتلاب

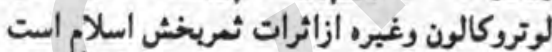

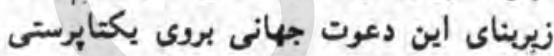
وتوخيداستواربودواين

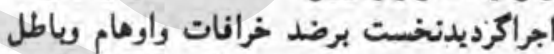

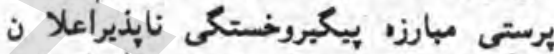

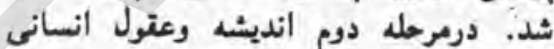

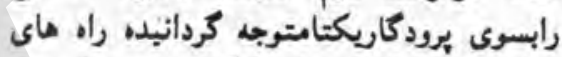

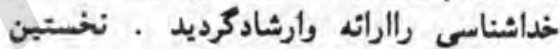

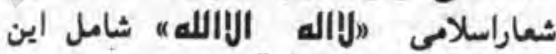
دومرحله است جزء. اول آن منهوم نفى خدايان

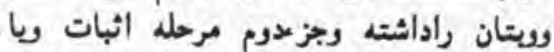
معرفت خداى يعاثه است وران

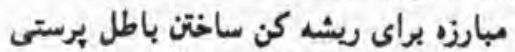

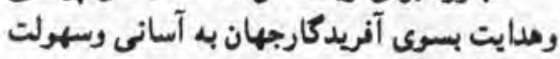
اليجام نكرنت ، تيام دريرايرعتايدمردمى كه نسل

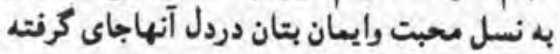

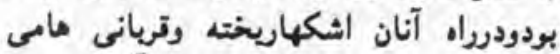

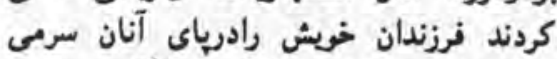

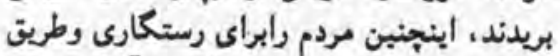

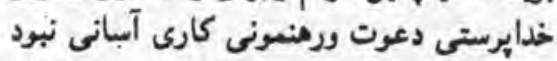
،أما اين مشكل بغرنج دربرايرتصسيم واراده
ونرسود، وازكوشه ركنارصحراهاى سوزان

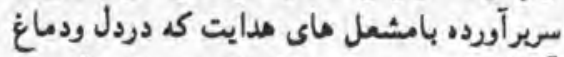
آنهايجادشده بودشهرنشينان متحدن رابسوى ماري

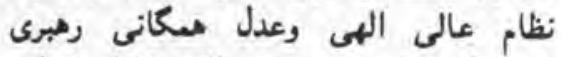

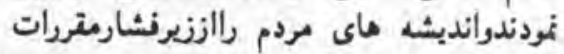

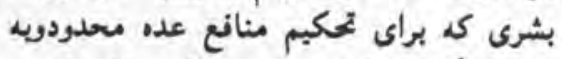

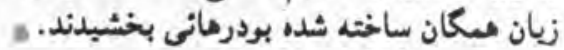

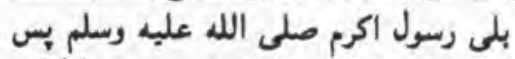

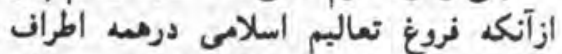

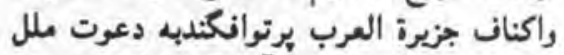

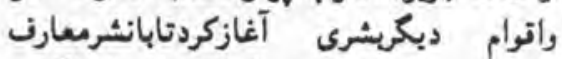

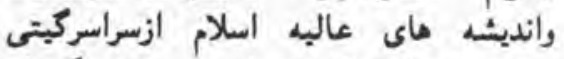

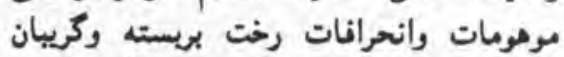

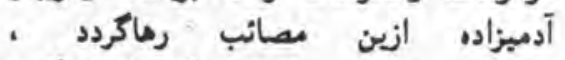
تاتواندبلرستى راه سعادت ونيكى رإيش كيرد

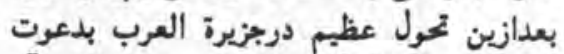

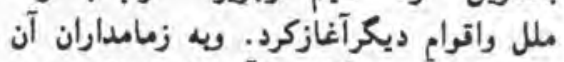

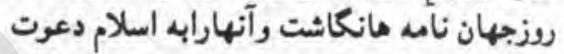

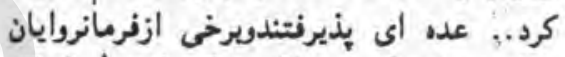

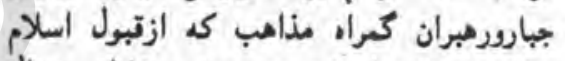

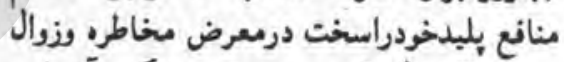

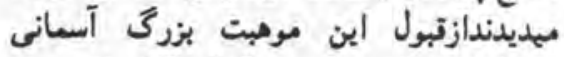
سرتانتندوموانعى رادرين راه ايجادكردند.

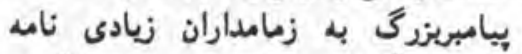

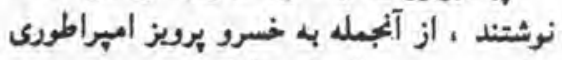
ايران بدين شرع نامه فرستادند :

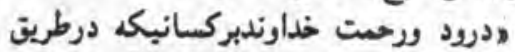

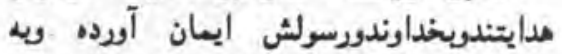

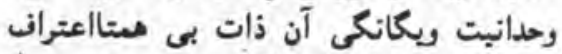

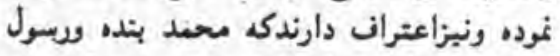

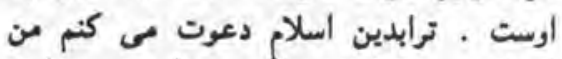

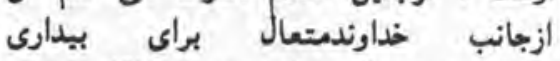

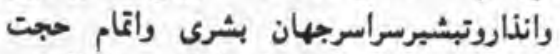

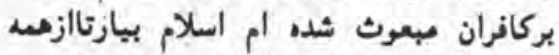

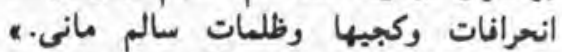

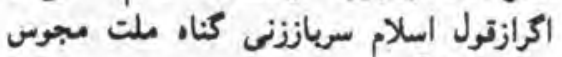
وانحرانات آنهابعهده توست كرئ

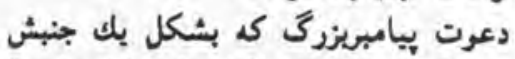

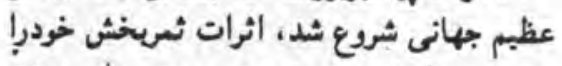

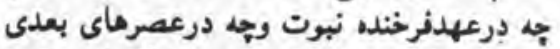
درمس جوانب حيات انسانى رومناكرداند ،تمدن ورين على امروزياحذف حواشى بيرايه ماى بلى بليد

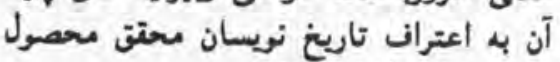

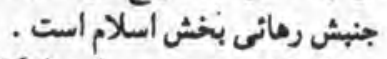

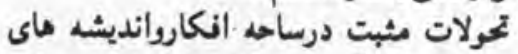
مذهبى درميان آن مردم كل به علت تعصبات 
دريك نضاى باصغاى صعيميت ومدكارى

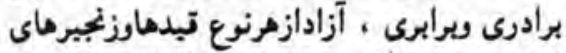

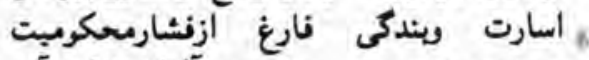

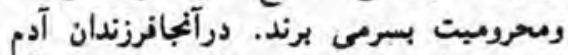

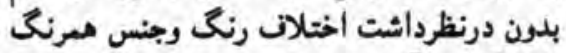

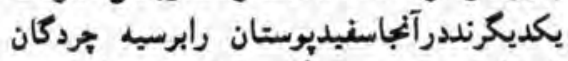

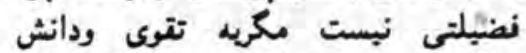

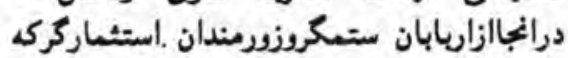

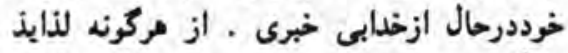

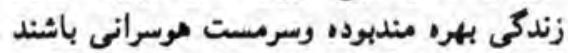

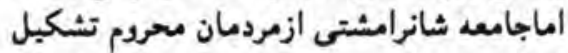

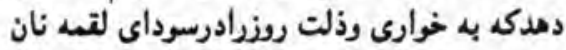

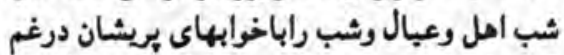

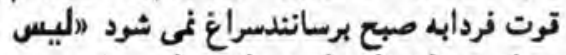

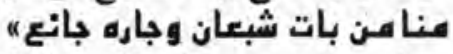

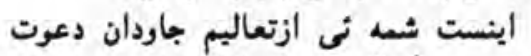

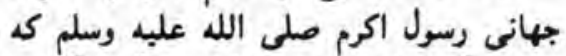

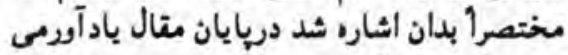

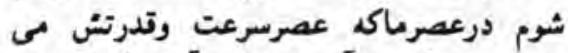

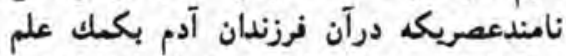
وتكنالوزى راه خودرابسوى كهكثانهابانيازنوده

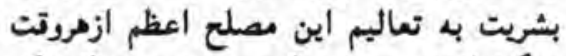

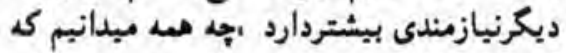

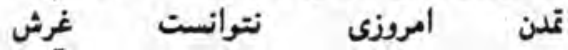

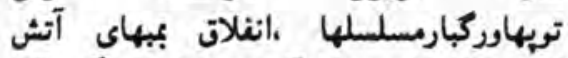

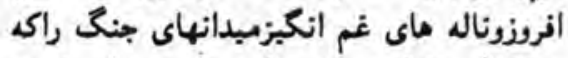

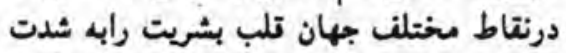

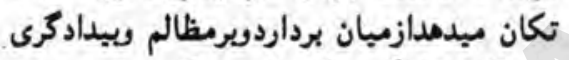

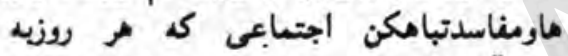

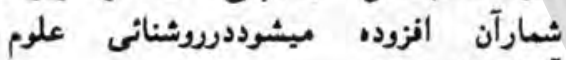

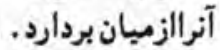

جامعه ماكه خوشبختانه ازمزاروجندصدسال باينطرن اين دعوت رالبيك كثته دبنركترين انتخارات وجنبش عاى ملى ملى خودرادركذركا. تاريخ مرهون تعليعات برارزش مآن آن ميدانديد

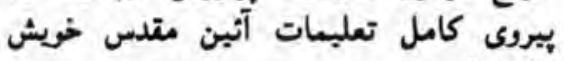
درين لحظه كه هزاروجهارصدمبن سالكرد

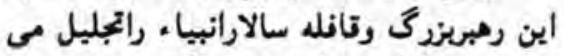

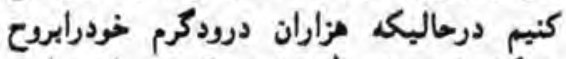

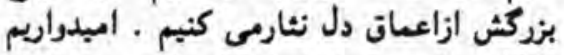

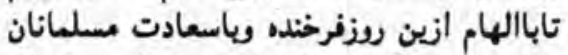
معاصردريرتوكرايش كامل به به تعاليم جاودان

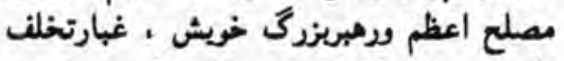
رالزجهره خودياك نموده وموتف اعنف شايسته خويش رادرجهان امروزاشغال نمايند .
امل سعارات دراسلام شحض بل نيردى

'بعت بلكيك درطي تاريخ برانتخار اسلام درجوانب

مختلن زنلدى نطيبن شلها است داستان ناطه

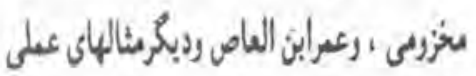

ثاملابين حتبنت است أزادى وعدالث اجتعاعى

بهنين عنصرابن دعرت راتشكيل مبلهل،

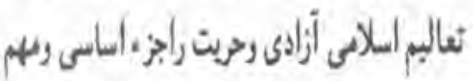

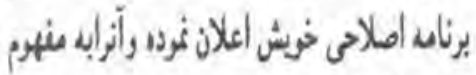

جامع ركاملى تنسبرمبنعابل.

آزادى وعدالت اجتماعى سهترين عنصراين

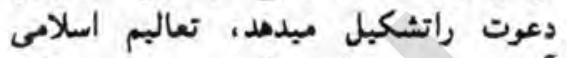

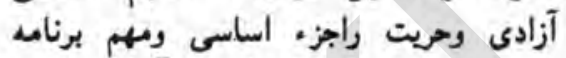

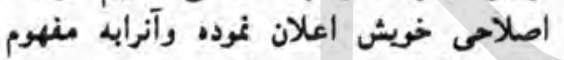
جامع وكاملى تنسيرمينمايد.

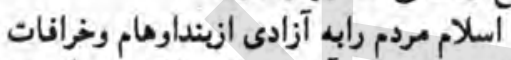

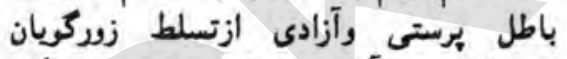

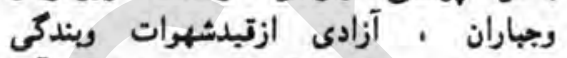

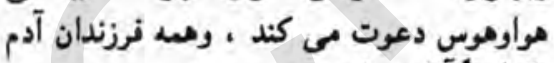
رانطرتا آزادميداند.

ناروت اعظم اين مطلب راجنين بيان مى

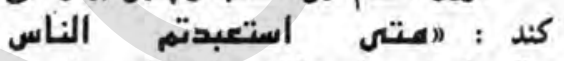

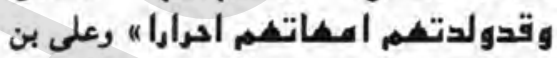

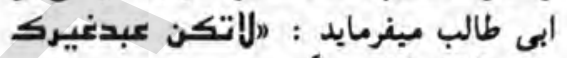
وتحخلتك الله حراً "

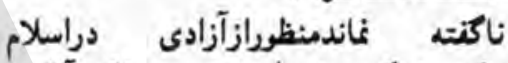
انساركسبختكى وخودسرى نيست بلكه آزادى

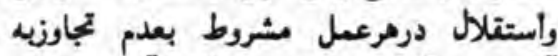

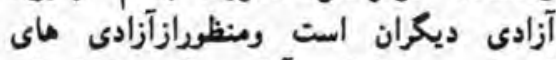

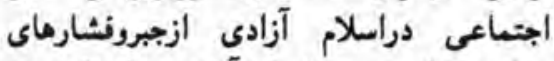

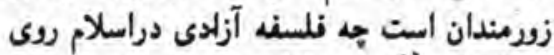
اين اصل بزرخ استواراست لانه ستم كنيد

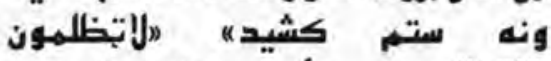

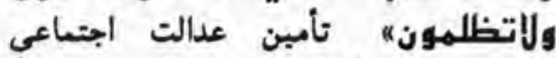

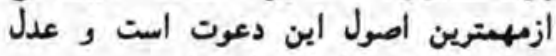

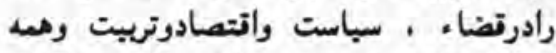

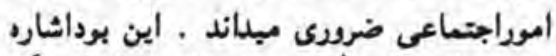

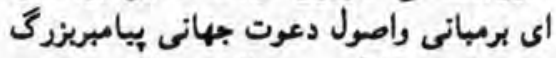
. استواركرددجامعه أيست كد هـ مردم ائمد درآن
محتقان علم الاديان وجامبه شناسى باتحقيقات

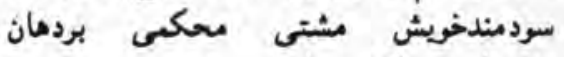
ماتريالست هاكويبده اند.

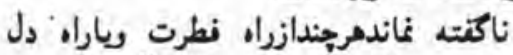

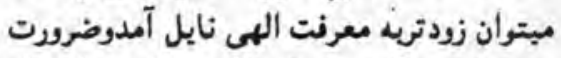

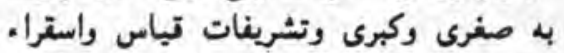

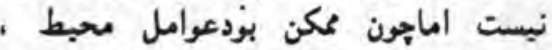

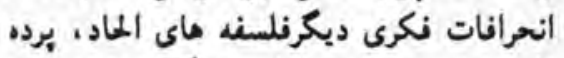

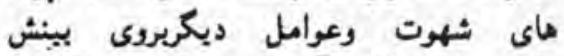

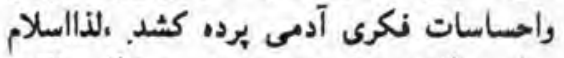

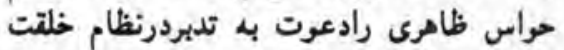

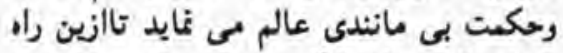

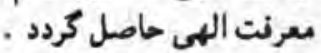

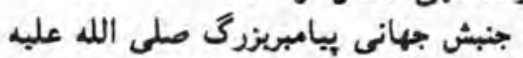

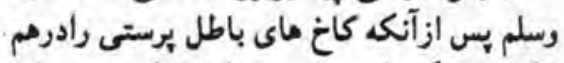

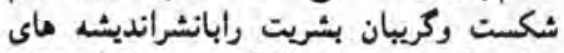

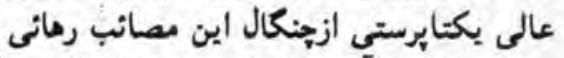

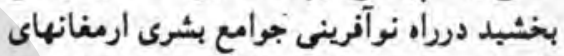

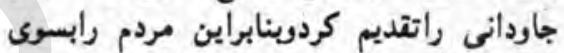

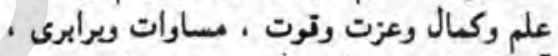

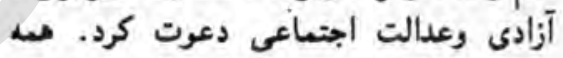

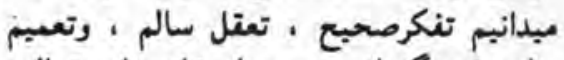
علم وفرمنح ازمهيترين ارمغان هاى تعاليم

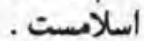
نضيلت ويرترى ازنظراصول وموازين تعاليم

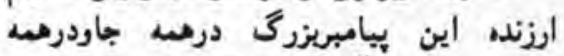
مواردمريوط به آنهانيست كه علم بيشتروعتل درونل بيدارتروانديشه باشند"يرفع الله الذين اهنواندا والذينين اوتوا العلم درجاته . نيرومندى وتوت شعاريزرى اين دروات دعوت

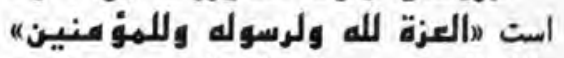

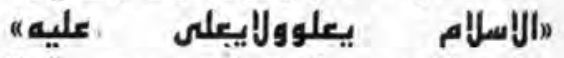
"واعدوالهم عـاستطعتم عن توة عاليم اصل مساوات ازمهنترين أصول اين جنيش

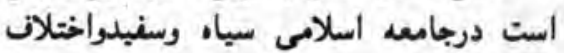

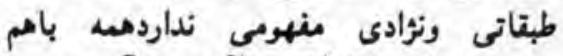

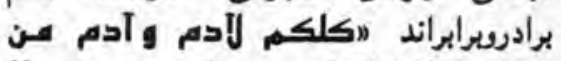

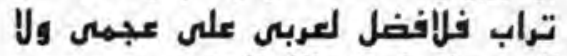
لاسو دعلى ابيض الاباالتقواى" اصل مساوات دراسلام محض يك تيل تيودى

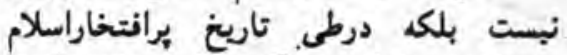

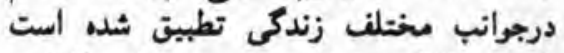

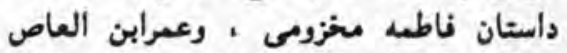
وديكرمثالهاى عملى شامداين حقيتت است وعراين العاص 
بسم الله الرحن الرحيب

\section{دمجاهد داعى مولوى جميل الرحمن دشهادت يه أرهن دافغانستان اسلامي جمعيت اعلانهيه}

ولاتحسبن الذين تتلوا في سبيل الله أمواتا بل احياء عندربهم يرزتون الحمد لله وكفى وسلام

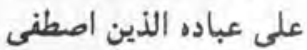

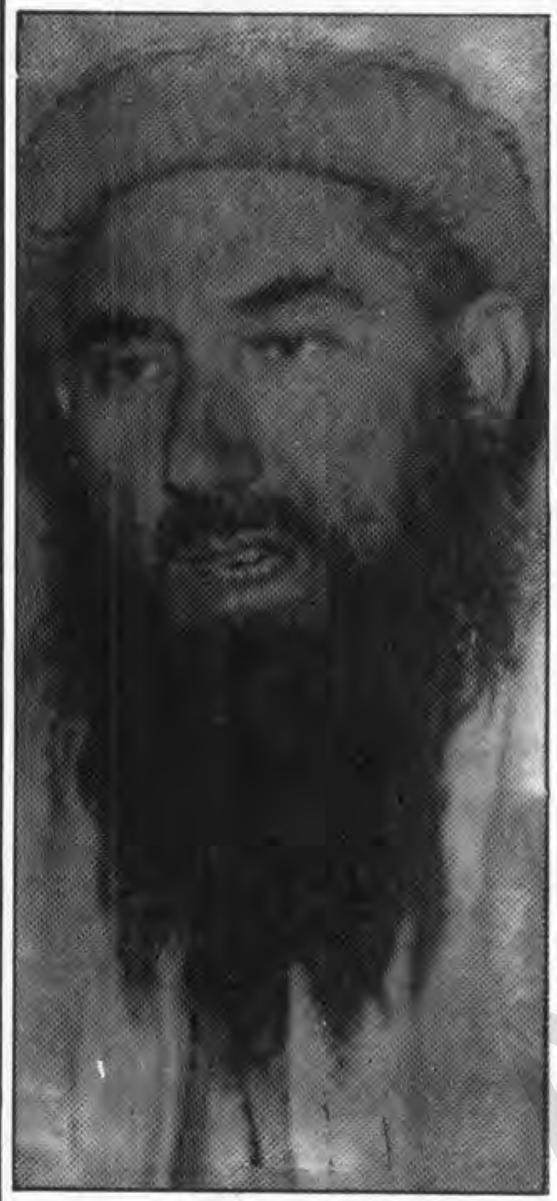

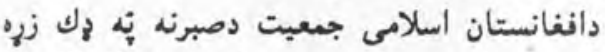

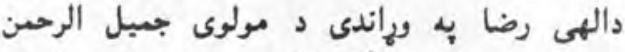

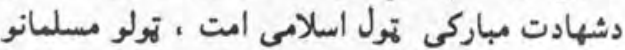

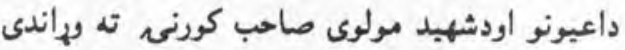

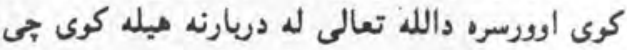

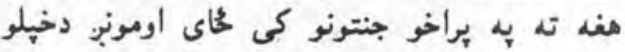

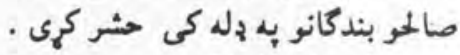

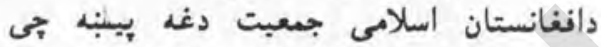

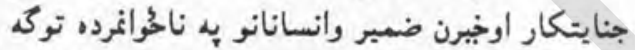

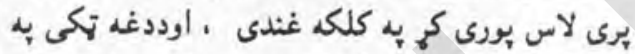

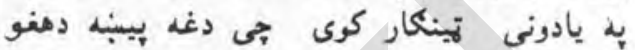

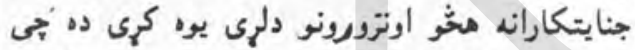

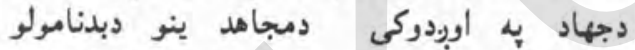

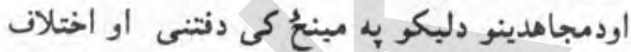

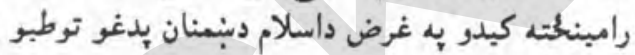

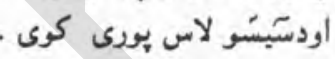

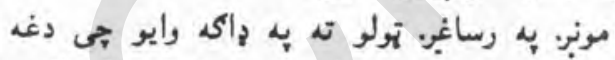

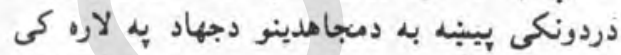

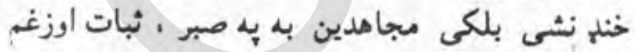

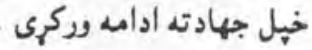

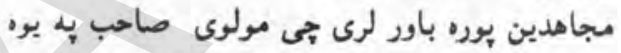

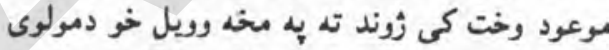

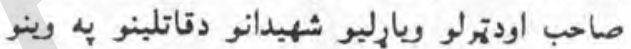

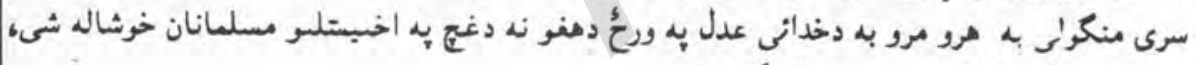

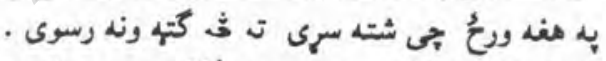

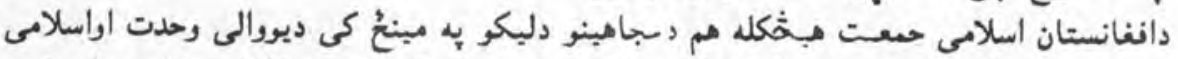

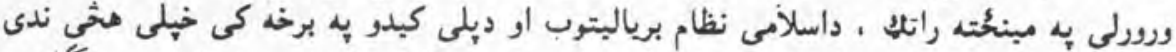

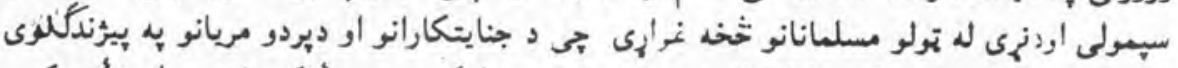

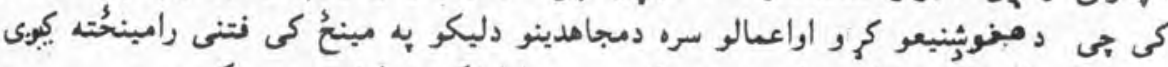

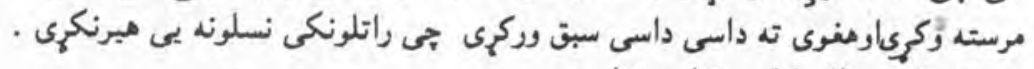

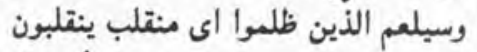
وسبحانك اللهم وبحمدك ،تشهد أن لااله الا انت نستغفرك ونتوب إليك.

برمان الدين سانمى

دانغانستان اسلامى جعيت لاربنود
متن يَام رهبر جمعيت اسـالامى افنانســان به مناسبت فتح ولسوالى شغنان ولايت بدخشان

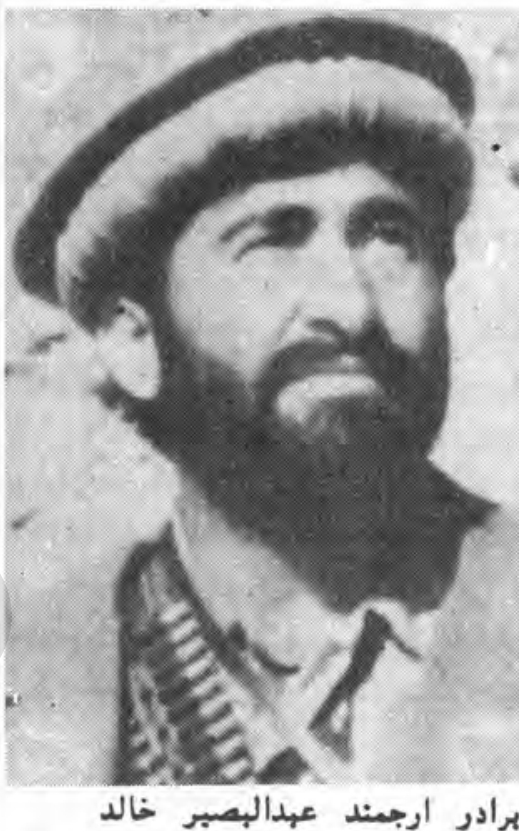
حفظه الله تعالى

السلام عليكم ورحة الله وبركاته وبعد :

دردوران نتع واخان وشغنان بيرون ازي ديارهجرت بودم براستى فتوحات اخير ولايت

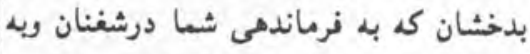

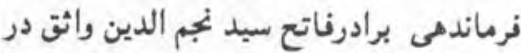
واخان ، اشكاشم بوزيباك صورت كرفنته بود

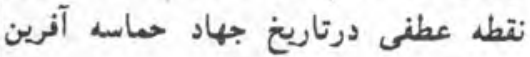

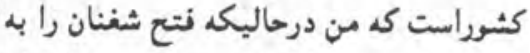

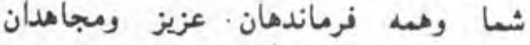

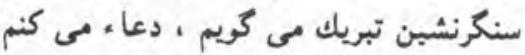

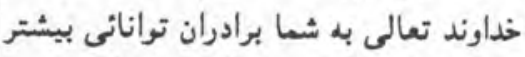
عطا فرمايد تاهس باهم آخرين بِايكاه دشمن را درشهر محاصره شده فيض آبادياد نتح

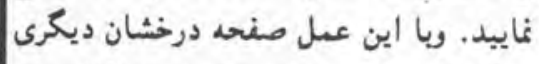

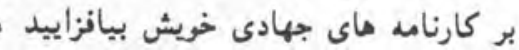

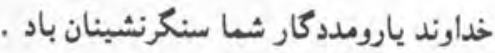

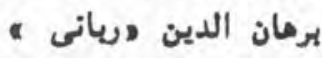
امير جمعيت اسلامى انغانستان 
اين ترتيب تنسير زشت ونادرستى ازكله.

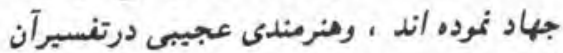

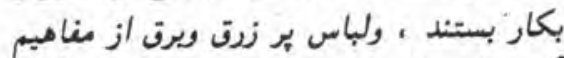

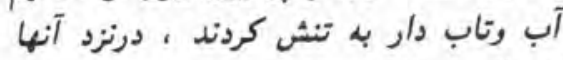

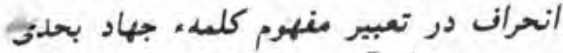

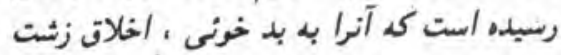

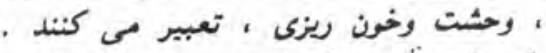

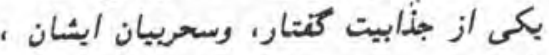

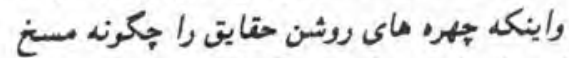

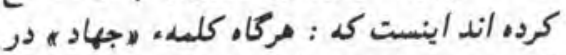

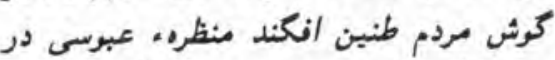
ييش نظر شان مجسم ميشرد كى كريا كاروان

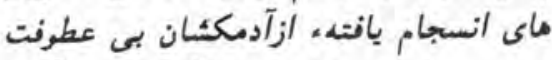

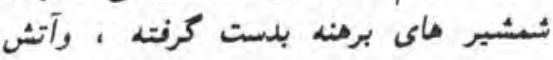

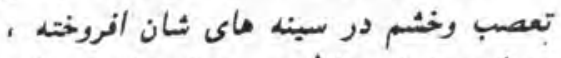

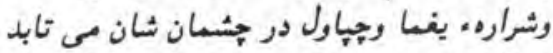

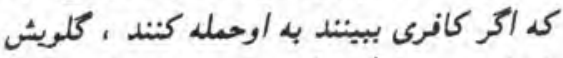

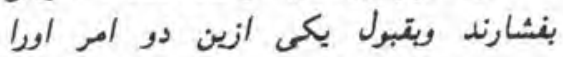
مجبورسازند كد يا كلده، لاإله الا/لله بخواند ارئد ويا آنكه سرش ازتن جداكتند ويلنش درخدرن

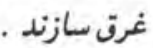
مغرضين حيل كر جنبن صحنه، را با با آب

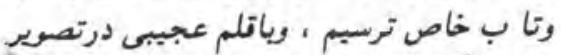

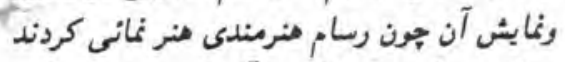

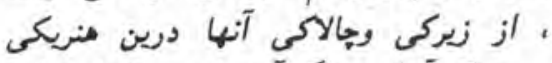

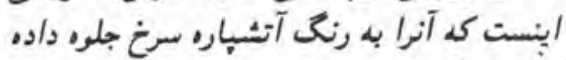

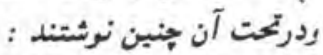

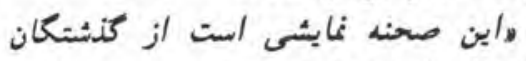

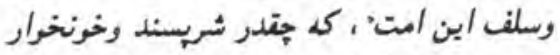
بوده ، وجه اندازه خون بى كناهان ريخته المتون تعجب بزرى دراينست ، آنهانيكه خود

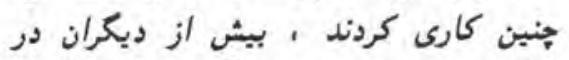
ارتكاب اين جرانيم ونمايش آن درانظار ديكران آندان سهم داشتند ، اينها خود كسانى اند كه نسل آنسل

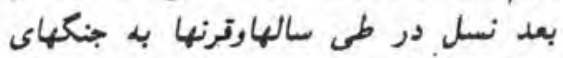

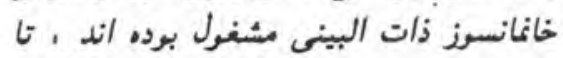

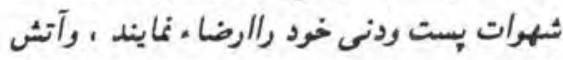

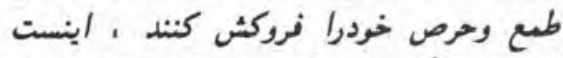

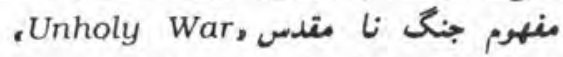

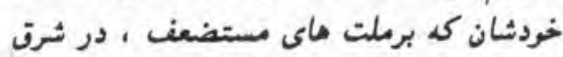

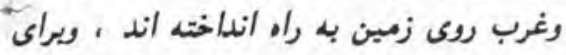
بازار يابِ كالاها وتعمير مستعمره هاى خريش اندان
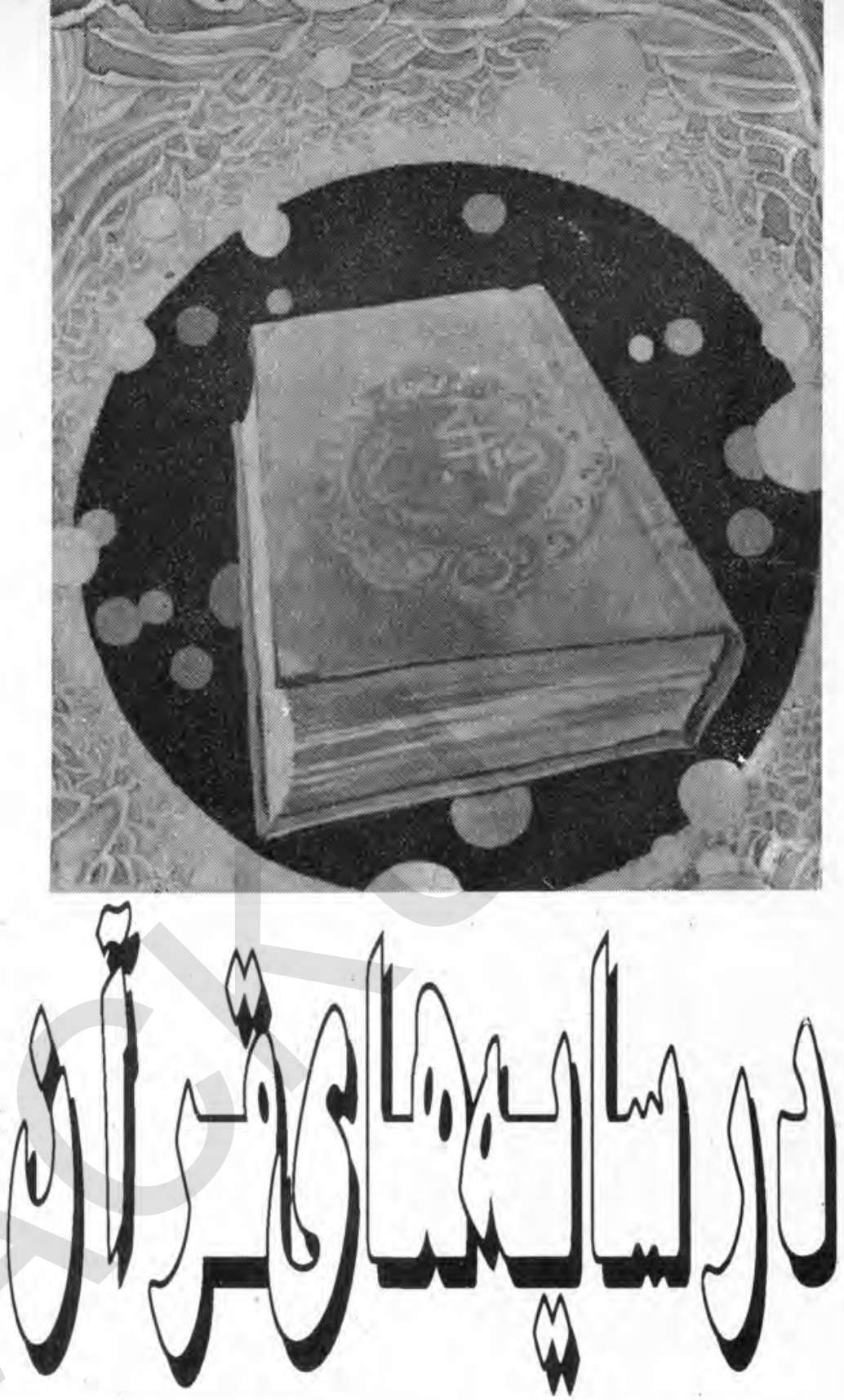

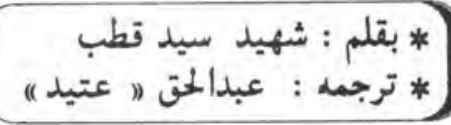

، ويراى /معيت موضوع مابه اقتباس بعضى از از

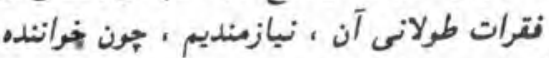

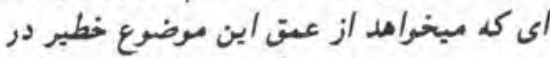

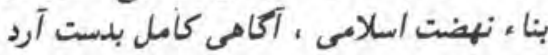

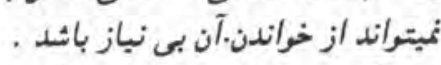

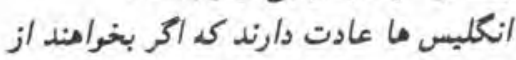

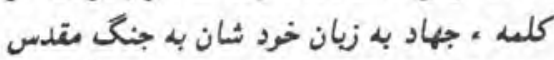
تعبير كنند ميكويند, Holy War, آنها بـ بـ بـان
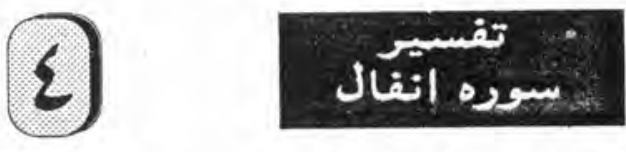
آزرده نشود ، وخواب مست تان بريشان نكرود

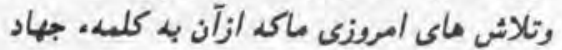

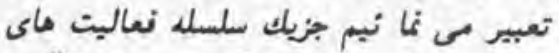

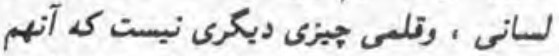

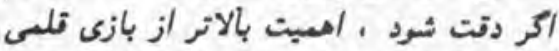

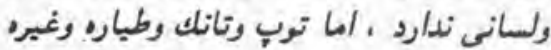

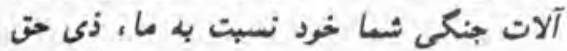

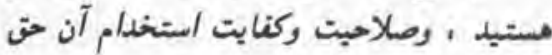

شئساست.

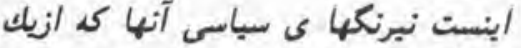

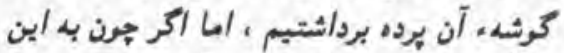

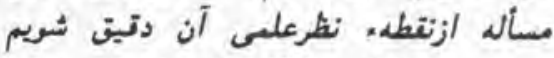

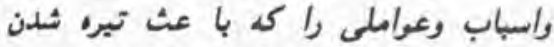

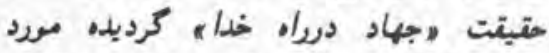
بررسى تراردهيم ، كه اين حقيقت درازهان

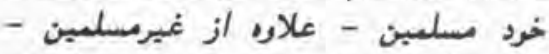

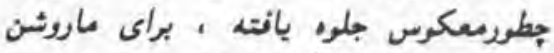

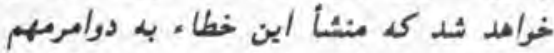

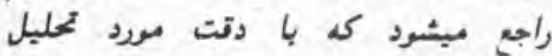
ترازنكرنته ريد حتبتت كنه آن بيى برده تثده.

اول /ينكه : آنها اسلام را جون يكب مذهب (Religion) كلس مذهب (Religion) عسوما بدان اطلات ورماينكه : آنهامسلعانان رابصنت يك امت Nation,

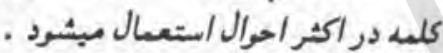
درحتيقت اشتبا، اين طانته ، درفلهم وشناخت اين دوامر مهم ، وعدم توضيت التيح آنها

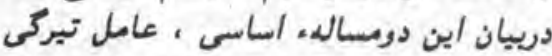

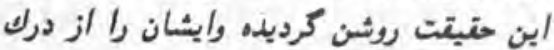

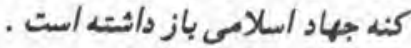
حتيقت / ينست ، خطاى اساسى كه ورمورد

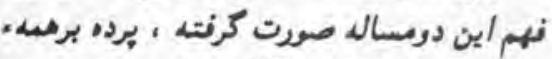

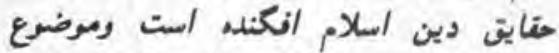

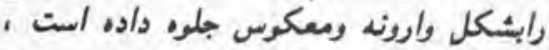

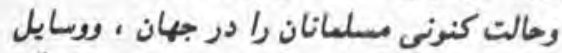

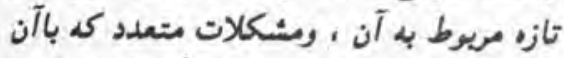

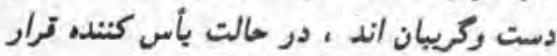

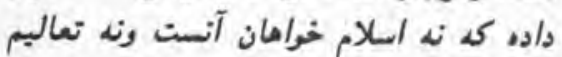

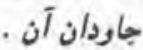
بنابرين مذهب Religion, برحسب

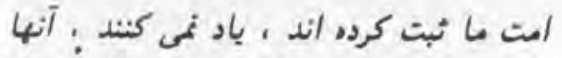

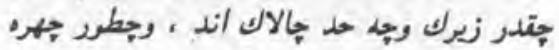

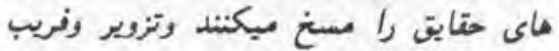

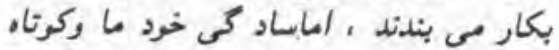

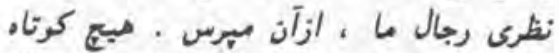

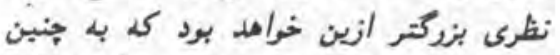

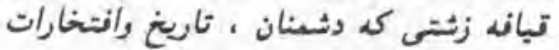

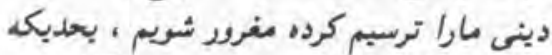

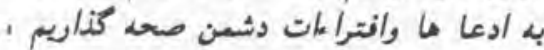

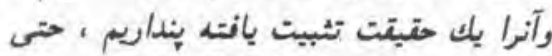

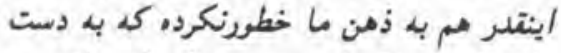

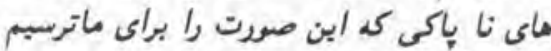

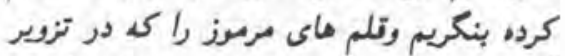

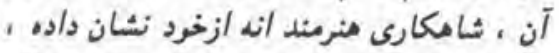

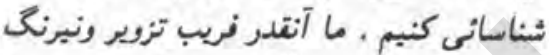

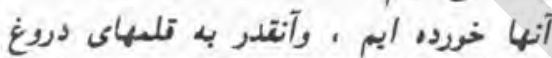

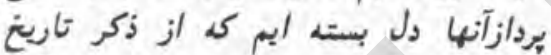
وانتخارات دين خويش درخود احساس خجالت

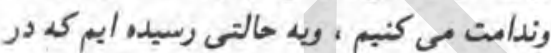

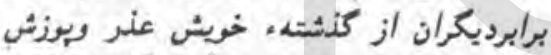

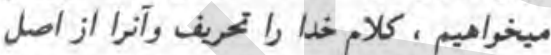
مطلب وارٔكوته تأويل مبكنيم ويراى دشينان

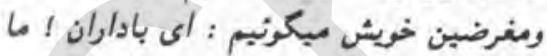

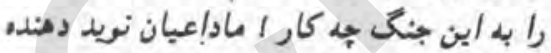

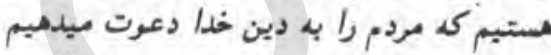

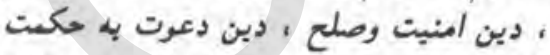

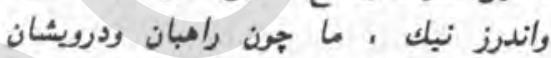

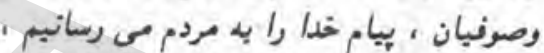

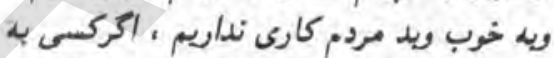

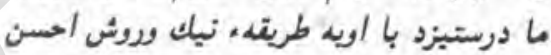

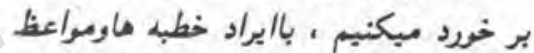

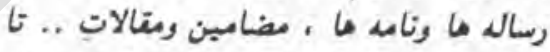

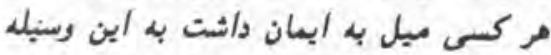

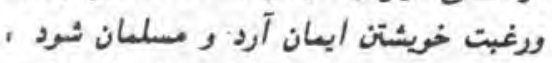

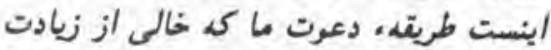

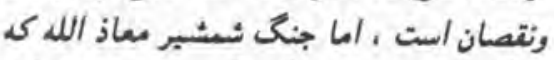

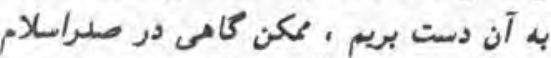

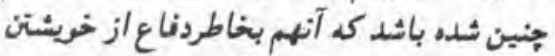

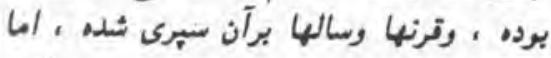

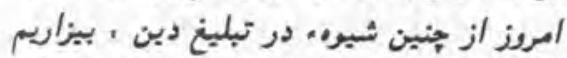

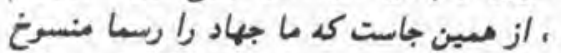

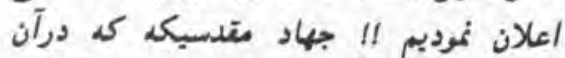
شسشير بكاربرده ميشود ، تا خاطرشعا آقايان
به سراغ دروديار مستضعفين مى بردازئد ،

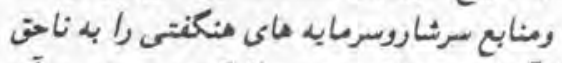

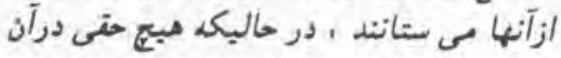

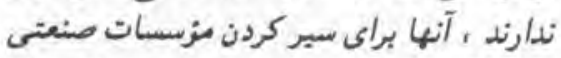

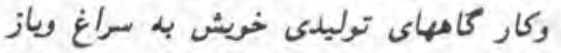

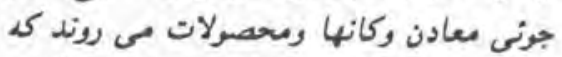

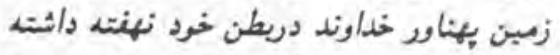
است ، آنها ور حاليكه وريى تحصيل / ينهيد

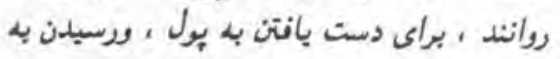

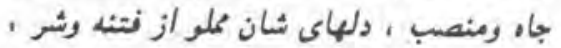

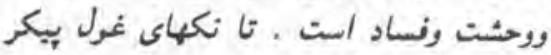

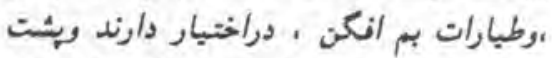

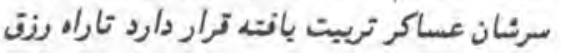

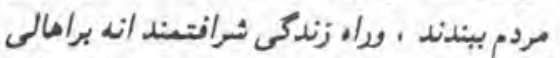

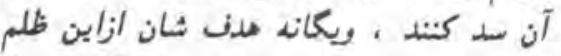

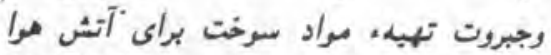

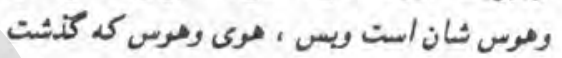

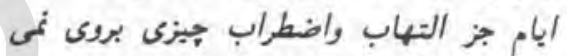

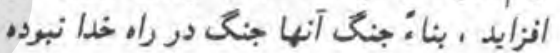

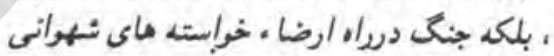

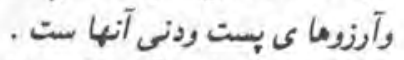

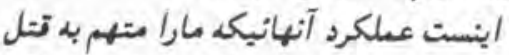

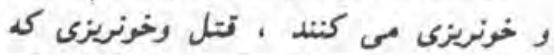

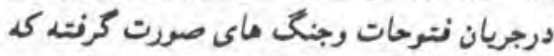

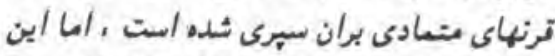

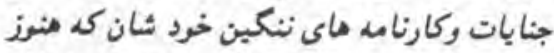

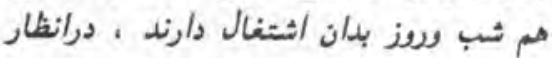

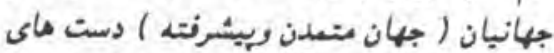

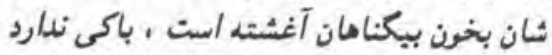

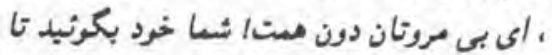

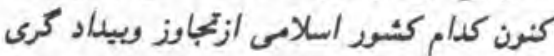
تان مصنون مانده است ، وكدام مملكت اسلامى إسى

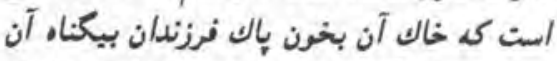

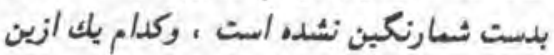

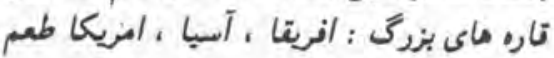

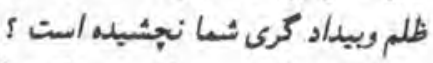

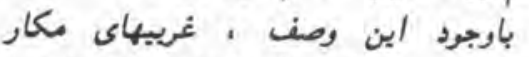
وثرتيلاى حبله كر جطور كوئيده اند باجنين آب وتابى جهره مارا درنظر جهانيان زثريت

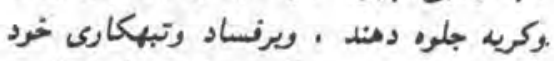

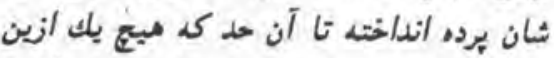

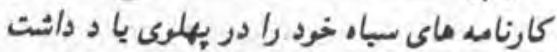

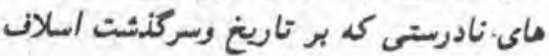

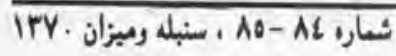


رسالت وترضيع مطالب دعوت خويش تهاده

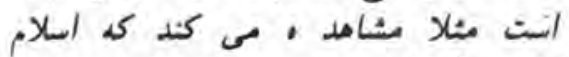

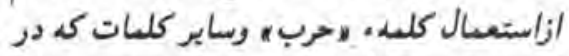

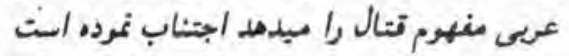

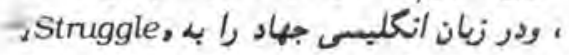

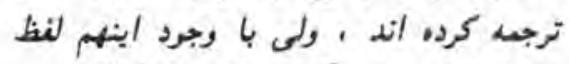

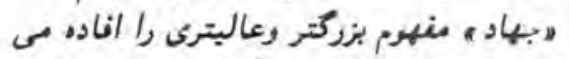

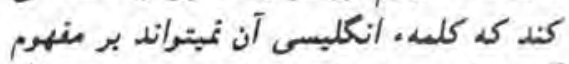

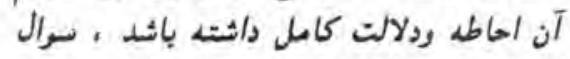

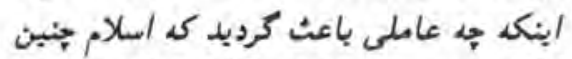

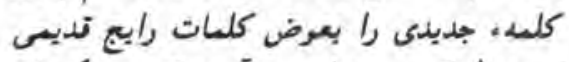

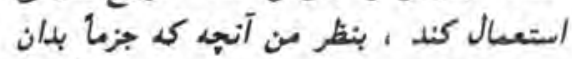

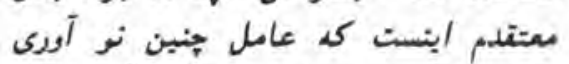

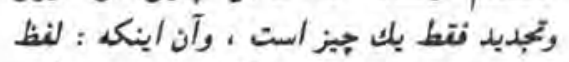

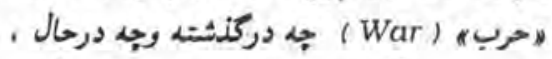

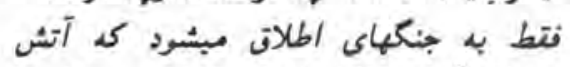

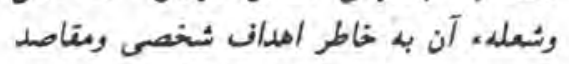

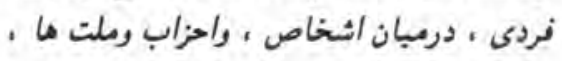

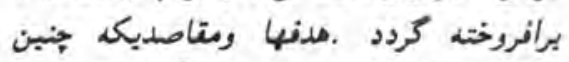

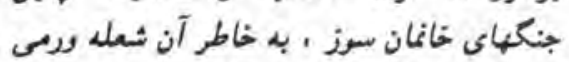

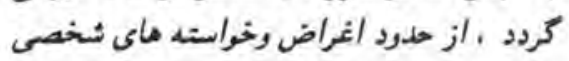

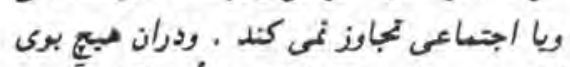

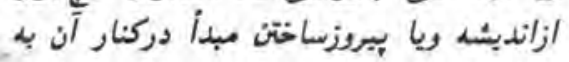

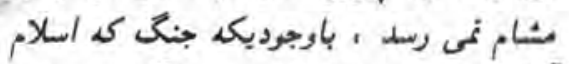

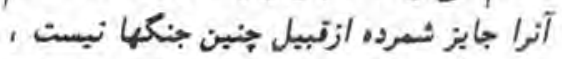

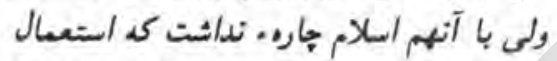

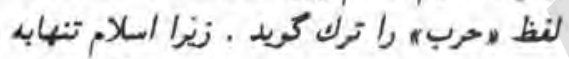

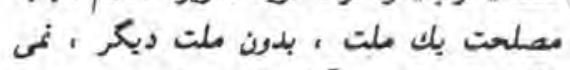

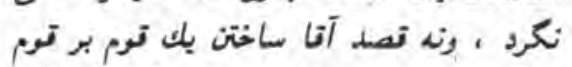

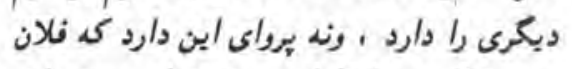

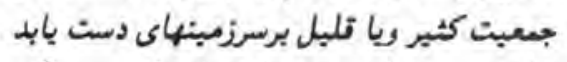

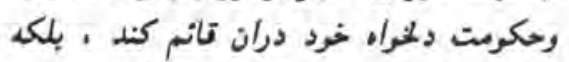

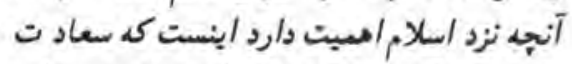

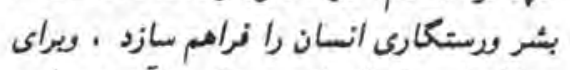

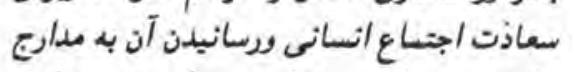

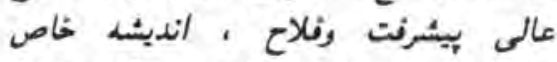

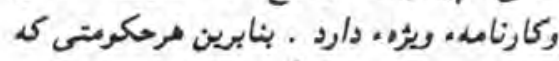

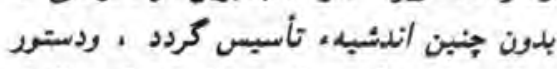

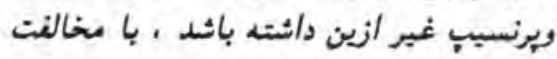
تشديدى اسلام روبرو خوامد شيد وتاطعانه عليه

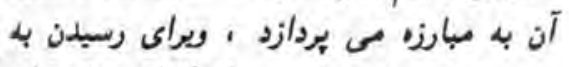

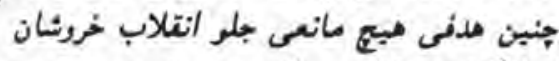

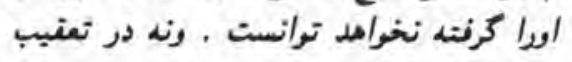

نيز مكروه ونا بسند شعرده اند ، اما صسرت دوبم

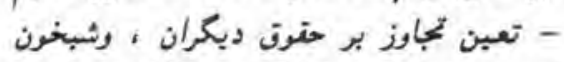

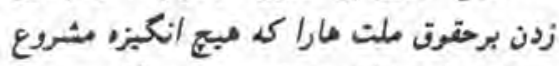

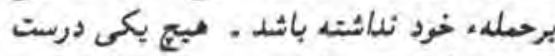

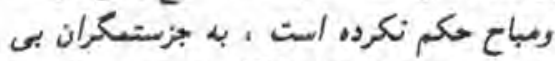

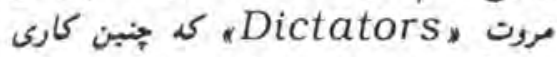

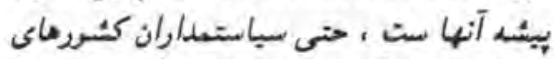

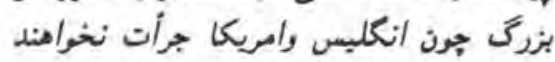

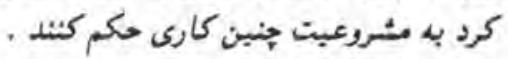

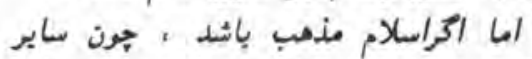

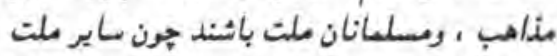
هاي جهان ، بلدون شك ورجنين تصروى لاجيهاد

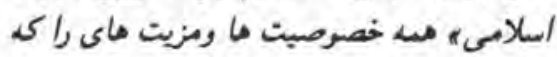

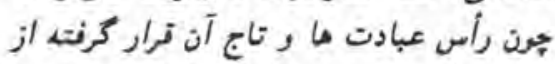

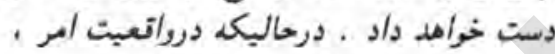

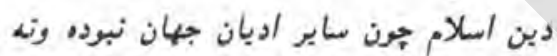

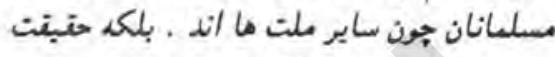

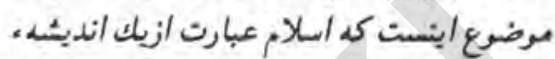

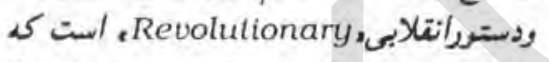

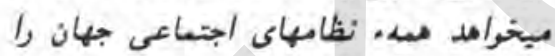

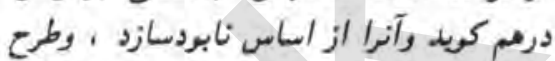

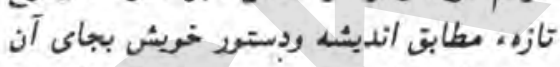

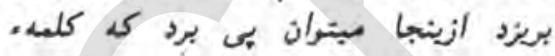

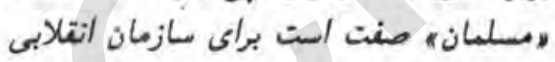
Internationul Revolutionary, جهانس Party

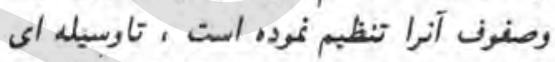

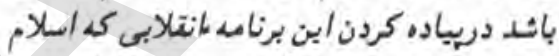

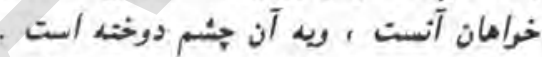

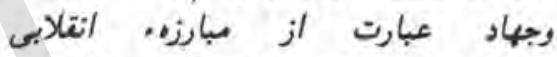
Revolutionary Struggle, تهضت داتم ويابرجا كد براى رسبيدن به اين اين

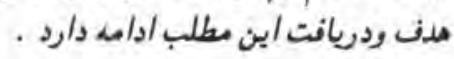

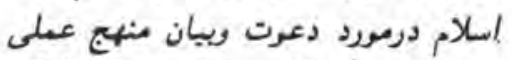

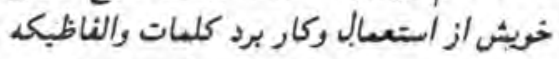

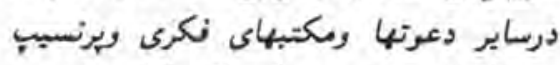

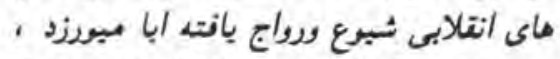
ورعوض يكسلسله اصطلاحات - Termi

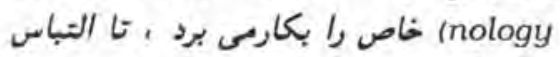

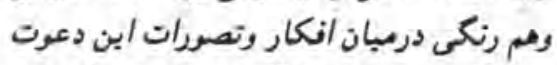

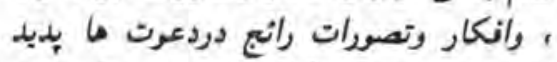

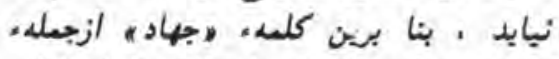

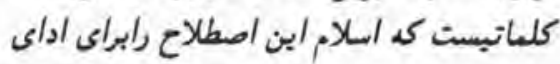

اصطلاح كى نزد ثان شابع كرديله بيش از

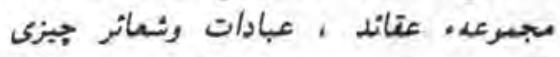

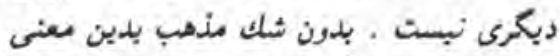

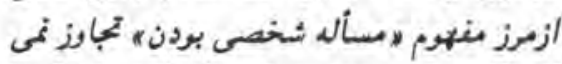
كند كن درينصورت ورعقيدة اعى كن ميخواهى

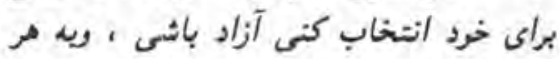

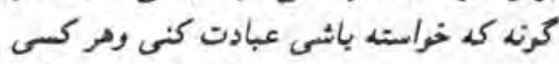

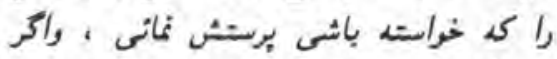

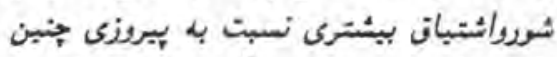

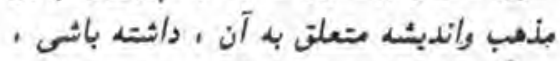

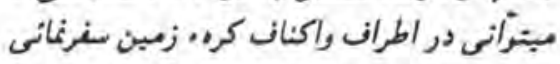

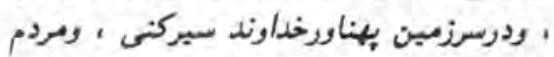
را به جنين عتيذه وعوت وهى ، وباراثن دليل

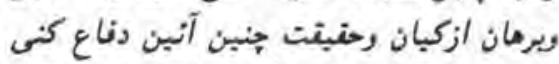

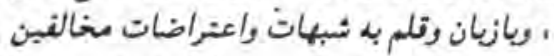

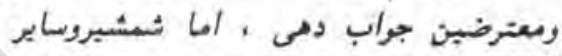

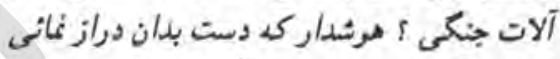

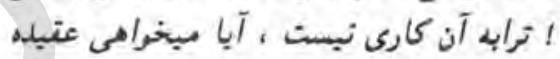

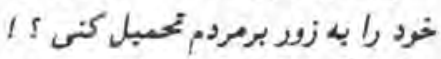

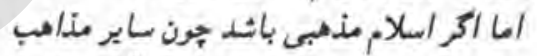

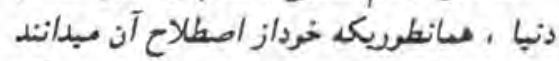

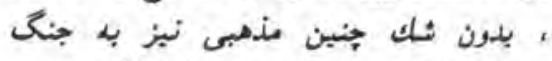

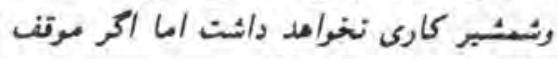

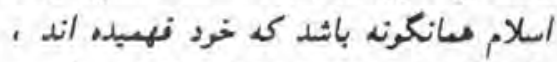

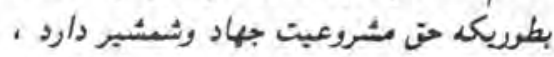

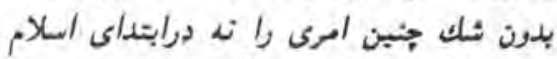

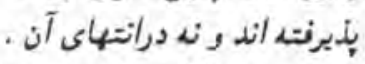

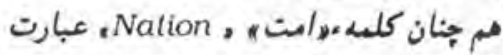
است از طانفه مروميكه ور مبان خود به به توانق

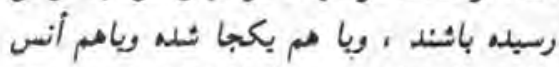

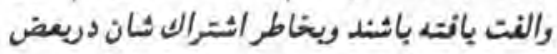

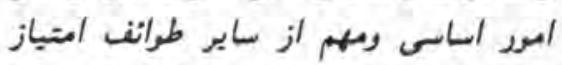

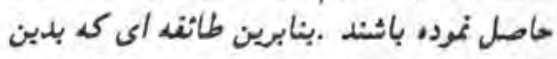

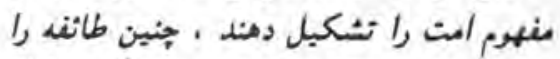

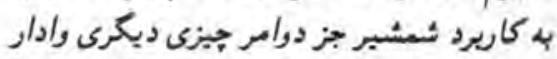

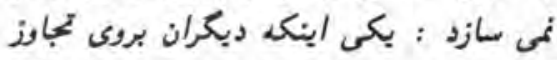

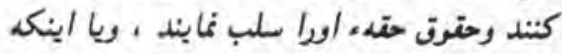

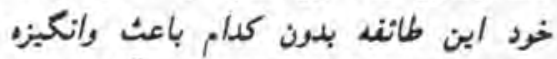

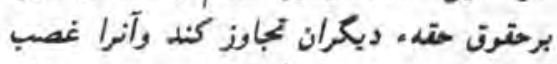

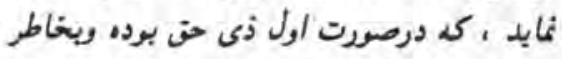

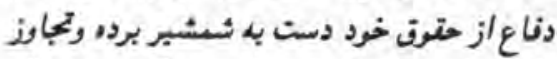

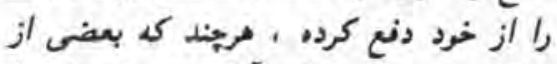

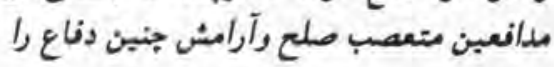




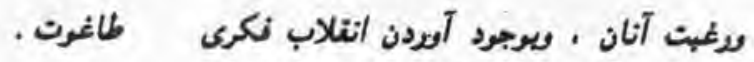
مر بهنان آيت كريسه لاياليالعالناس اعبد وال ربكم الذي غاتكهم والذين هن

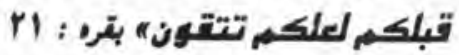

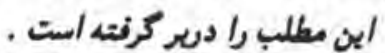

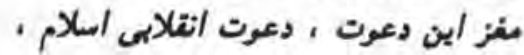

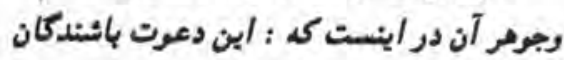

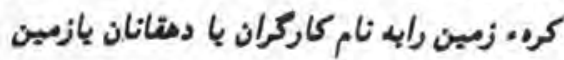

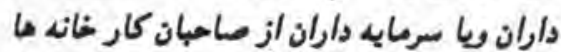

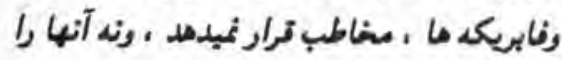

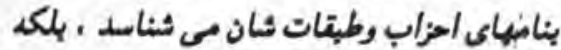

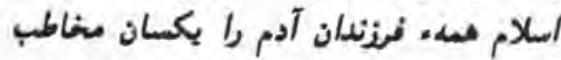

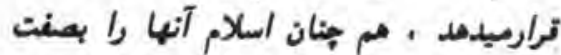

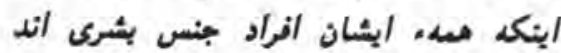

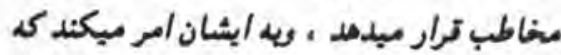
خدا رابه يكاتكى برستش كنثد ويه بع شريك تايل تشرند ، ونه معبود ويرودكار ديكرى

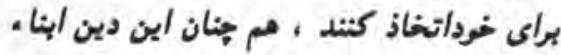

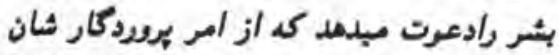

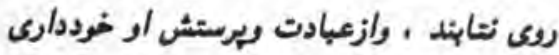
تكنثل ، ويناحق در روى زمين تكير وعصيان تونزتلد ، همن مكومت وامرونهى مد ازان خداوند واحد است ، اوست كد كليدماى آسطان

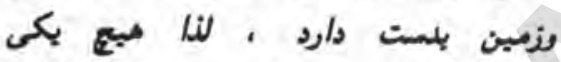
ازمخلوتاتش - مركسيكه باشد - خد ندار

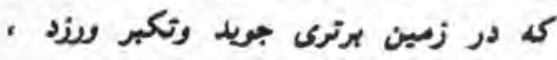

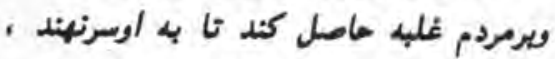
وفرماتش يرند ، وتسليم ظلم وستم اوششوند .

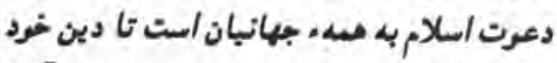
را خاص براى خدا سازند ، ينابين معه، آنها دراين عيوديث سرتا سرى معانطوريكه درمرآن آملد مساوى اند: راتخل يا اهل الهل الكتاب

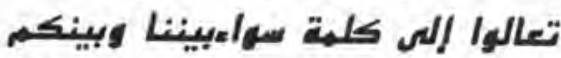

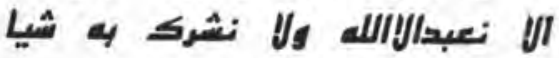
ولايتنذ بعضنا بعضا اربابا هن دون ( ادامد داردة) "اله

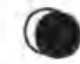
وذمنى در آنان بواسطه تلم ، نوعى از انواع.

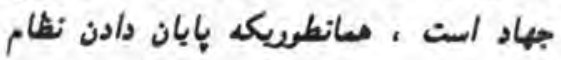

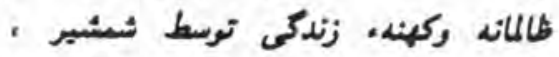

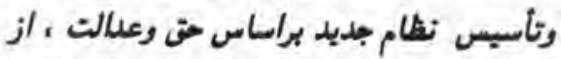

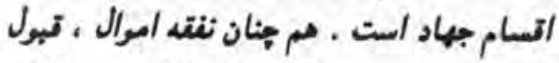
تكاليف ، بنجه نرم كردن يامشكلات ، مركلام

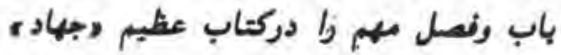

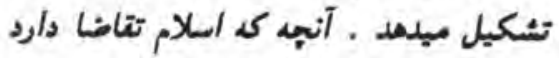

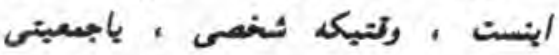

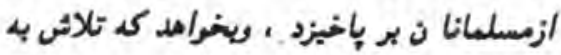

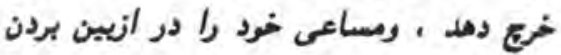

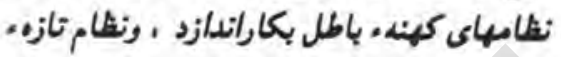

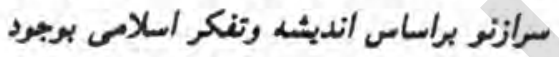

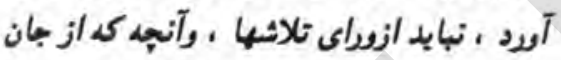

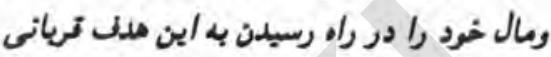
من كند ، مطلب ومتصدى غيرتأسيس تثام عادلاند كه حق وعدالت را در ميان مردم بيا

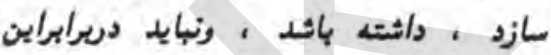
ترياتيهاى خويش ، عرض ويدل دراين دنياى

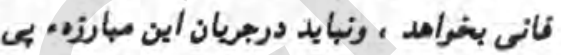
كير وجهاد ييهم بخاطر اعلاى كلعة الله ، توجه

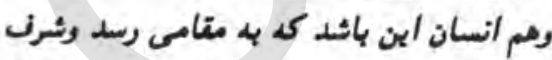

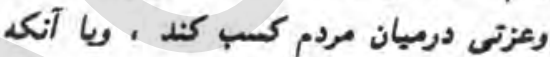
مردم ازوتمبيد كنند . ونهايد در جريان اين تلانهاى به دريغ ومساعى قيمت دار خريشتي

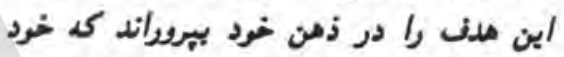
واتارب وخريشاوندان خرد رابه منصب ورجاء

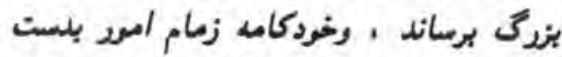

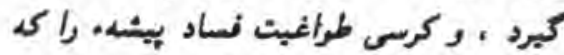

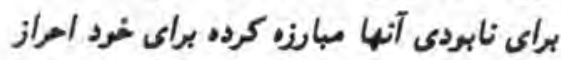

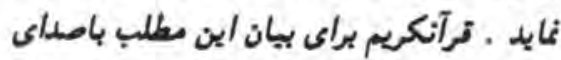

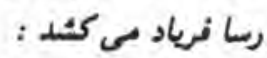

الذين الهنوا يتاتلون فاد سبيل الله والذين كنغروا يتاتلون في سبيل الطاغوته نساء : V1 آنهاتيكه / بعان آوردند مى جنكند درداه خدا رآنها نيكه كافر شدند مى جنكند در راه

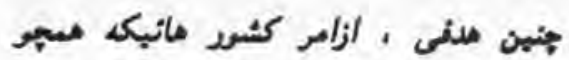

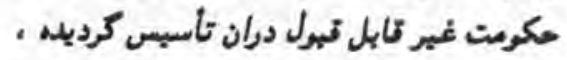

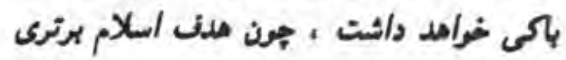

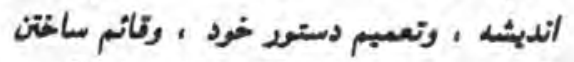

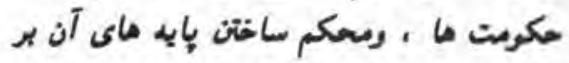

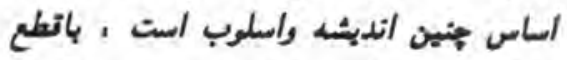

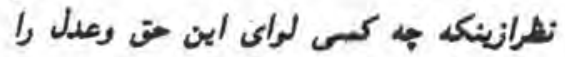

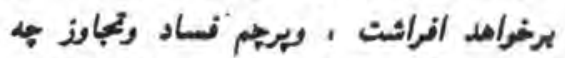

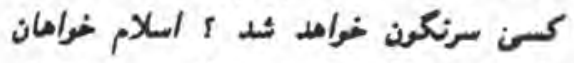

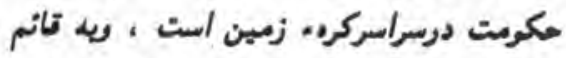

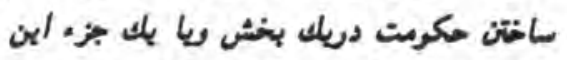
خال تماعت نلارد ، بلكه ميخواهد درسراسر اين مسلوده حكرمت خرد را تاتم سازد ، أيث خواسته /سلام به /ين مغهوم نيست كه آنرا نير

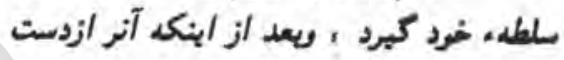

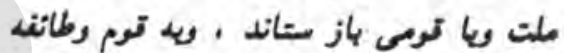
معين آترا هيخشد تا از درآمد ماعى سرثشارآن

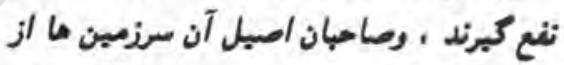

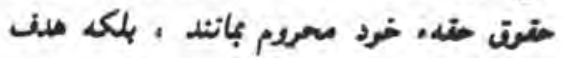

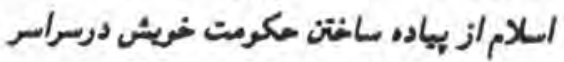
زمين اينست تا معه افراد يشر از انديشه.

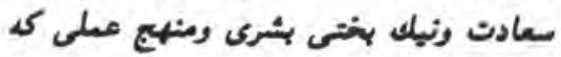

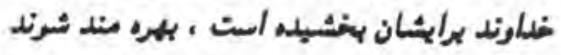

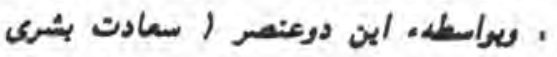

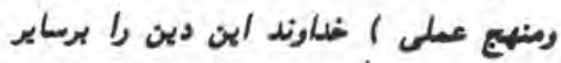

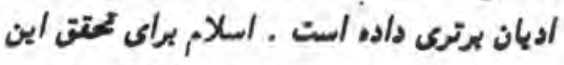

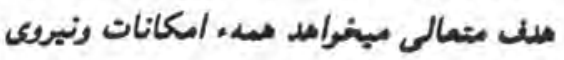
خهئ رادر جهت يجاده ساختن هنين انتلاب

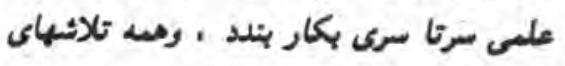

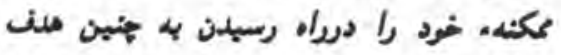

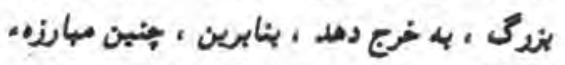

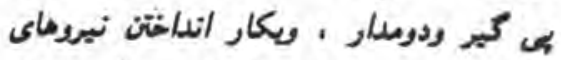
ككثه را تا سرحد تهائم واستعطال وسايل

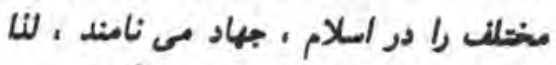

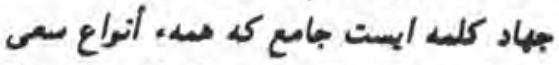

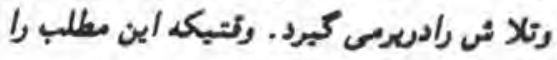

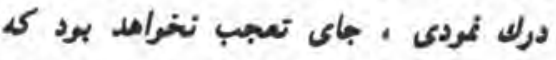
بحرئى : تغيهرجهاء نثرمردم ، وتبديل ميل 
الذين اهنوا ولم يلبسوا

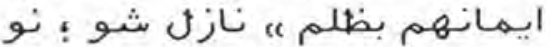

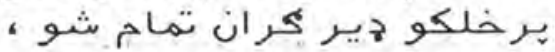

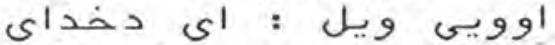

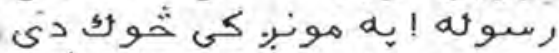

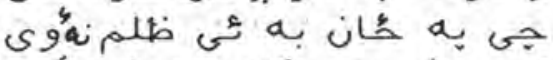

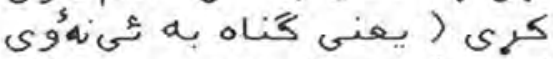

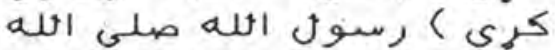
عليه وسلم وفرمايل : داهيله

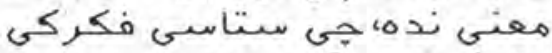

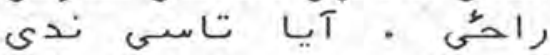

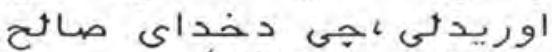

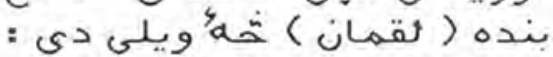

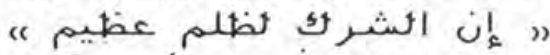

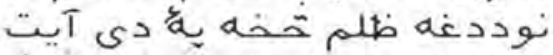

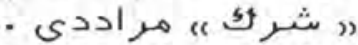
צ- دتفسير تاريخى مر ملفى

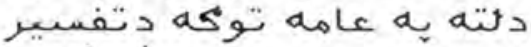

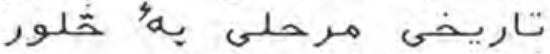

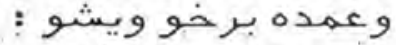
1

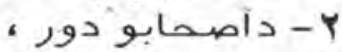
، ب- دتابعينو مر دورله

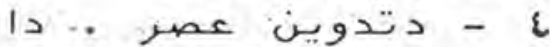

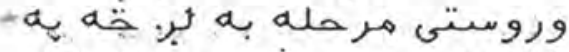

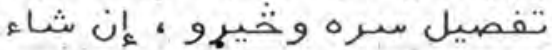

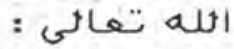
الف : دييفمبر عليه السنلام

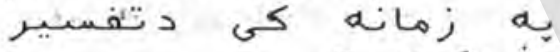
صَّرنحوالى دصضرت رسبوله الهه صلى

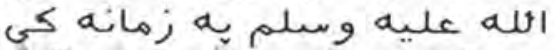
دقرآن تفسير يخيله قرآ

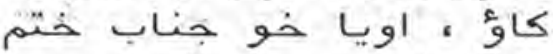

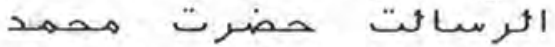
مصطفى صلى الله عليه وستيم دقرآن عظيم البشأن تفسير ولهيم ك a

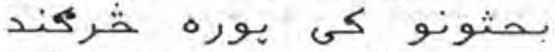

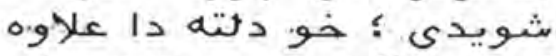
كووجى آيا رسول خوله الله صليى علاه

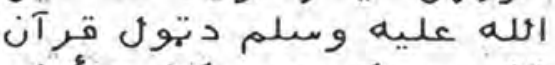

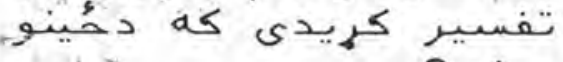
برنو

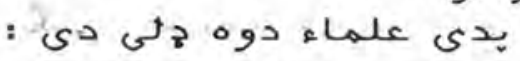
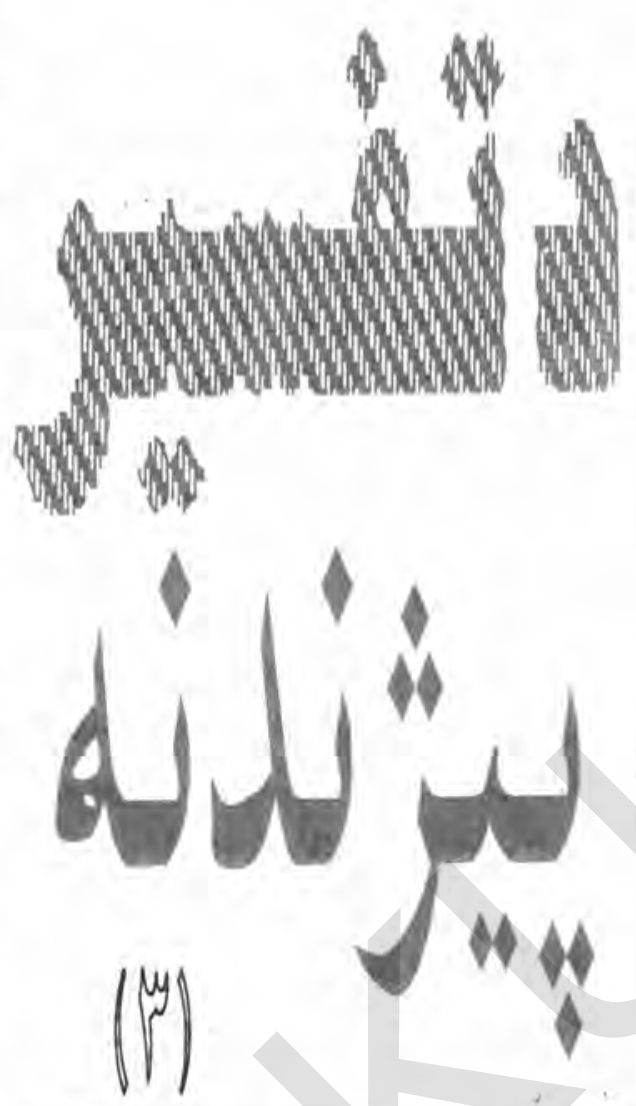

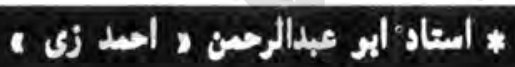

إن علينا بيانه ، بياد دي آنه زئه

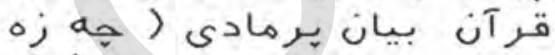

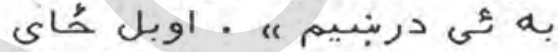
رسول الله وايى : " وانزئنا إبيك الذكرثتبين للناس مانزل

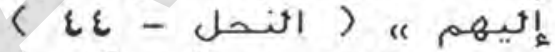

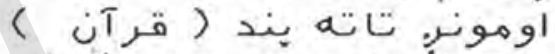
راكوز كمرنه

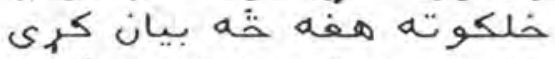
هم دوى ته

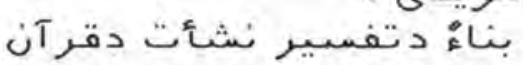

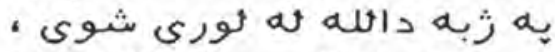
اوبيا يه خيله دله رسول لهوله الله دغه

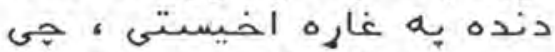

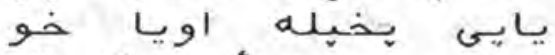

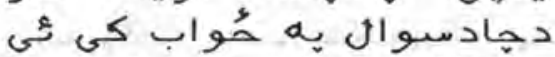
دقرآن دآن دآيتونو توضيح فرمايلى دهن د.

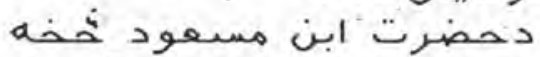
روايت دى مئى : كله دا مآيت

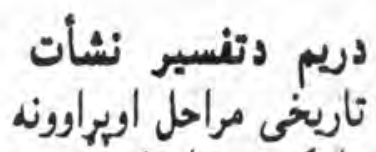

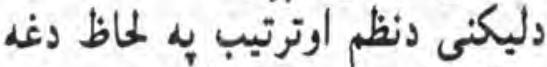

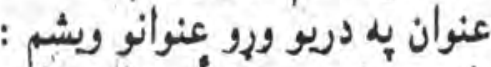

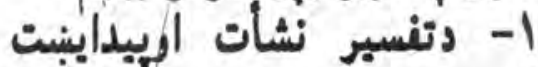

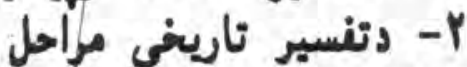

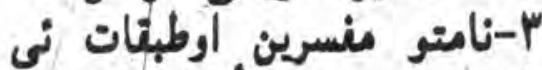

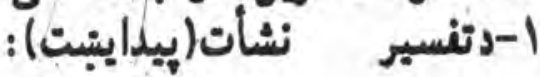

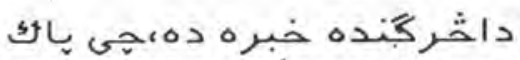

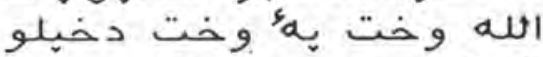
بندكانو دهدايت اولارنينو دونى

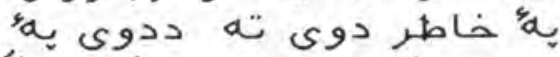

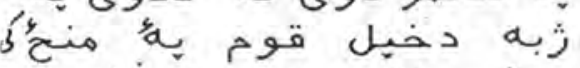

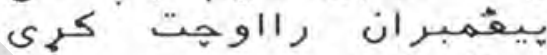

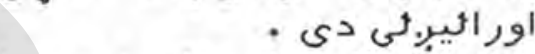

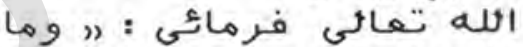

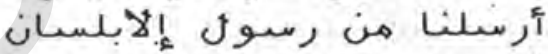

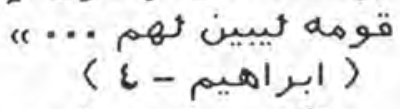

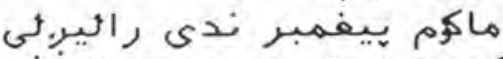

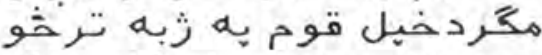
دوى ته دفداى المكام بيان . كرئ.

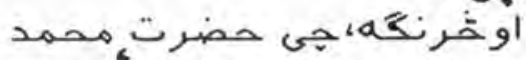

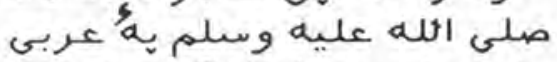

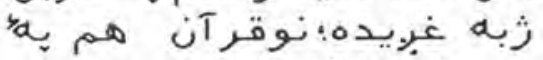

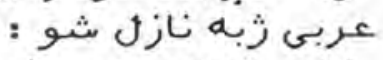

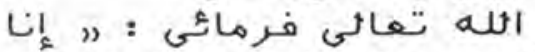

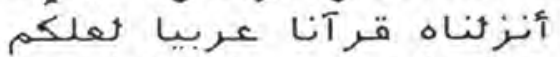

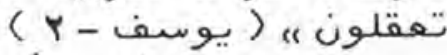

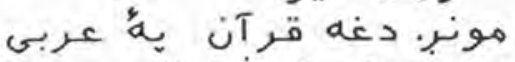
ثبه نازل كمر ترشّو تاسى هرى

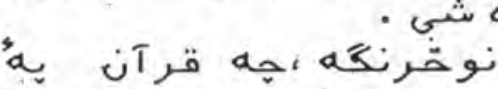

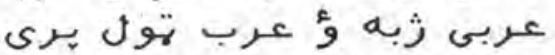
يوهيدل ل خودئ

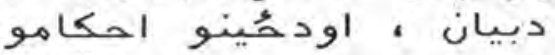

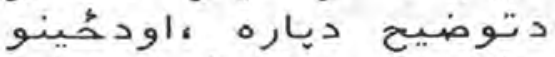

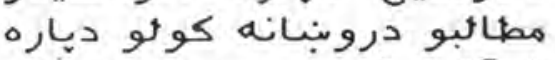

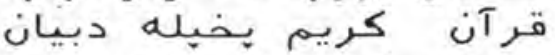
وعده وركوى اونه بيا دييفهبر

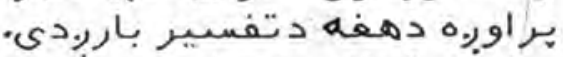
الله تعالى فرمائى : " ثمارير 
- 0 و

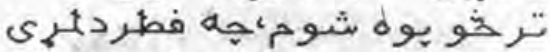

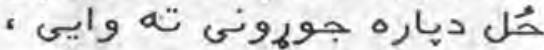

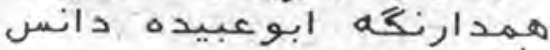

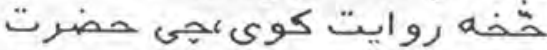

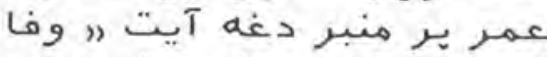

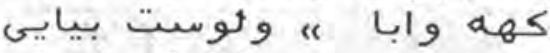

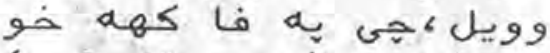

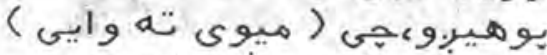

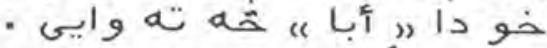
بياثى قئى دان

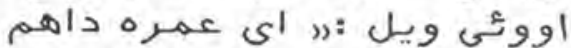

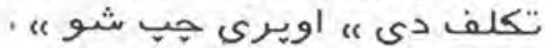
بهأlili

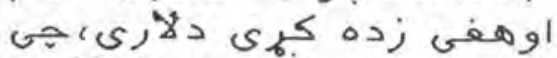

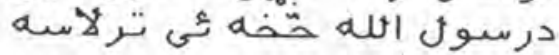

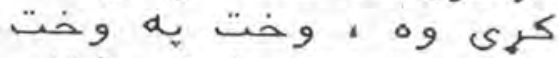
كسرى

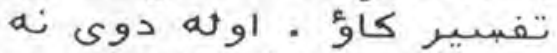
وروسته بيادا كارتأبعينو

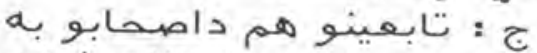

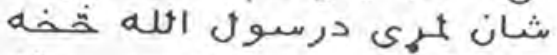
روايت شونويو تفسير ورته

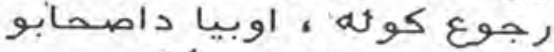

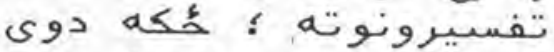

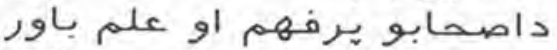

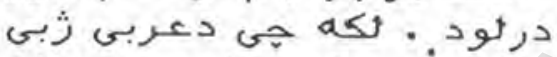

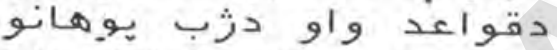

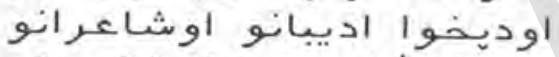

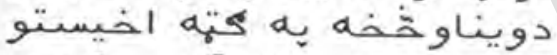

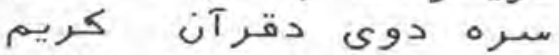

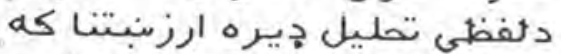

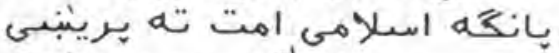

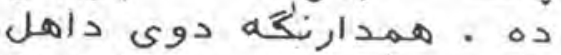
كتاب ده في ماته

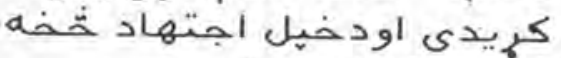

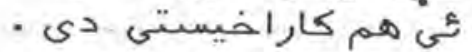

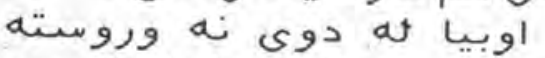
داسى يولهان يبدا شوله د تفسيسر يو هان

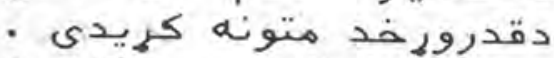
a

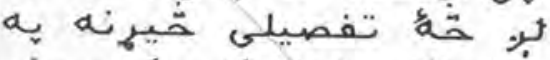
1.
وصلم دقرآن دضرورت ف فاطر تفسير كريدى اوعالو 

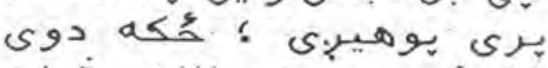

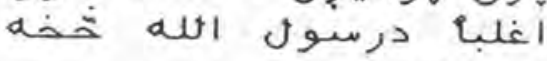

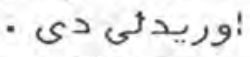

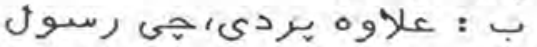

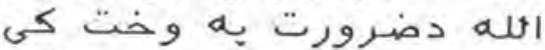

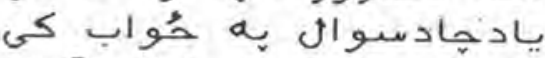
دقرآن كريم دهباركو آيتو

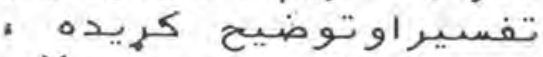

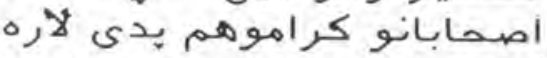

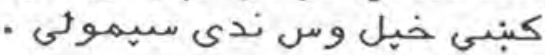

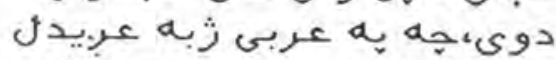

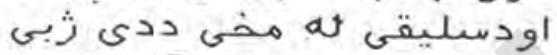

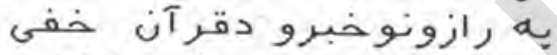

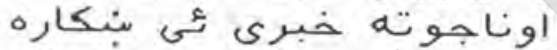

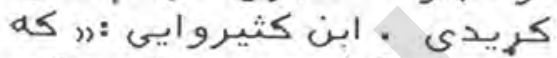
ى تفسيرييدا نكرو، نو داصواتونو

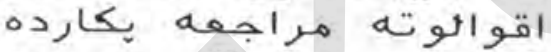

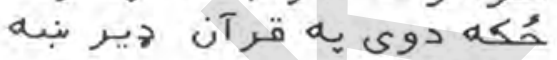
"

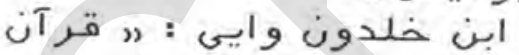

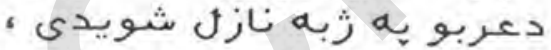
او ددوى دربه

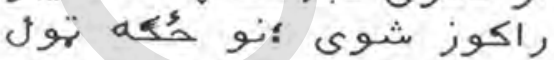

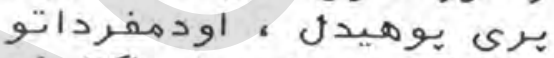

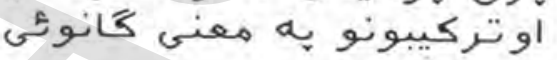
يوه وפי

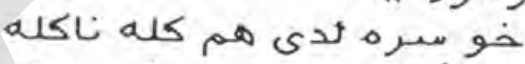

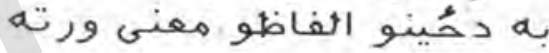
sr a a gl og ais

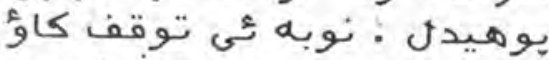

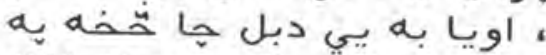

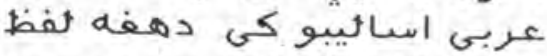

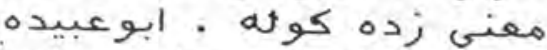
دمجام معند

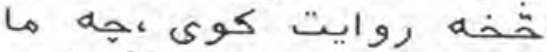

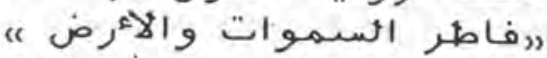

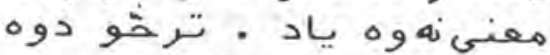

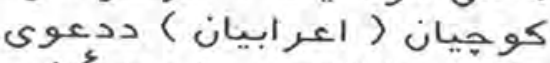

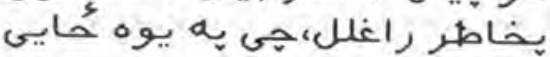
دعوى وه . يوه واعلماهيل

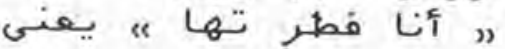

يو ه له

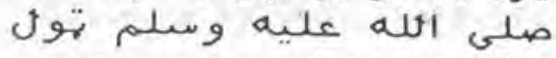
قرآن تفسيركيميدى آنه ددوى

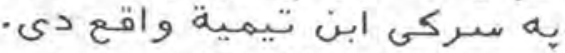

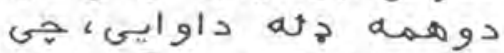
رسول

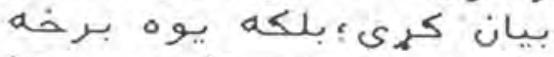

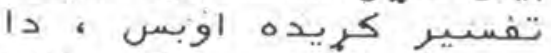
دسيوطى اودده دملكرو اونظر - va

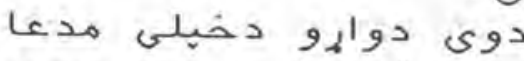

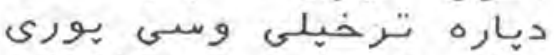

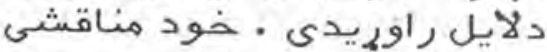

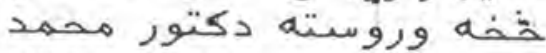

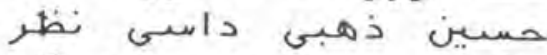

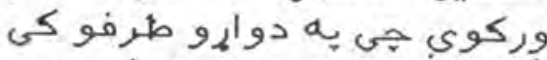
-

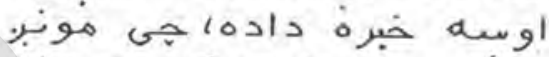

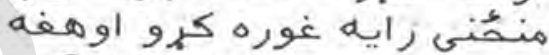
دا من

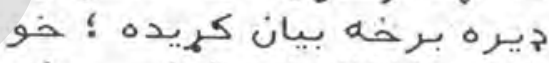

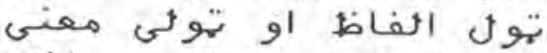

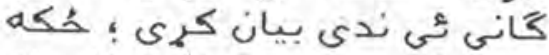
ه ارهيا نلرى اوهى

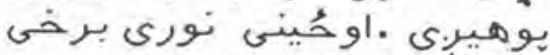

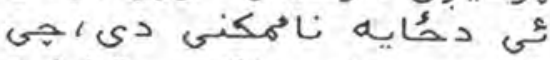

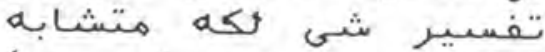
آيتونة هادئه اويادروح حقيقت اوداسي نورت

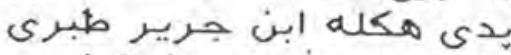
دابن عباس مَفه روايت كوى

: a

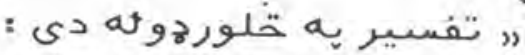
يوكئه

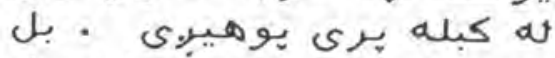

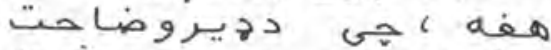

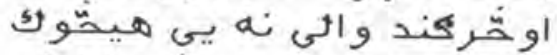

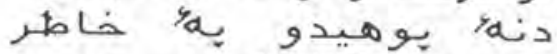

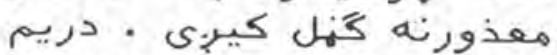
- vor

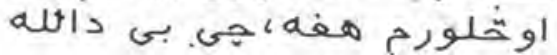

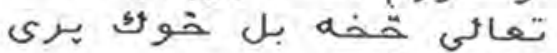

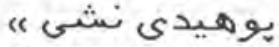
نو ميى رسور الله صلى الله عليه 
مبكردم جون متبِيَّن نبودم كه آنها اسرار مرا

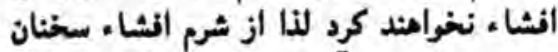

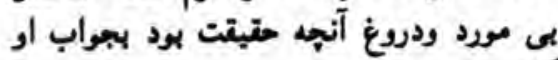
كنتم.

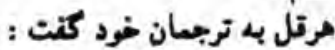
بيرس كد نسب اودرميان شعا جكونه است.

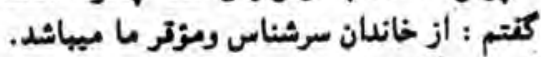

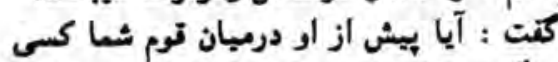
ديكرى مثل اودعوى بيغميرى كرده بود أبها كنتم : نغخبر. كثت : تبل از دعوى نبوت ميجمامى بلدرغ

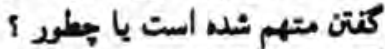

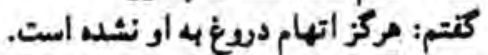
كتت: آيا از اجداد واتارب أوكسى بادشاه بوده،

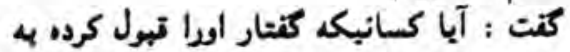

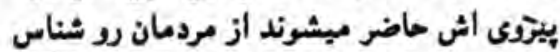

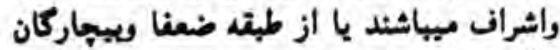
؛تتم : يبروان اواشخاص ضعين ميباشند.

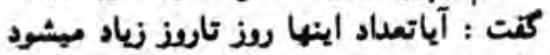

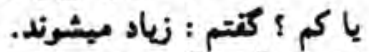
كنت : آيا ازآنعده كسانبكه دين اورا بذئرفته اند بعد ها نسبت كراميت ودشوارى آن دين باز آنساز كشته انديا جطور 5 كنتم : نتخير. كنت : دريبمان خود 4 شعا كامى يرخلاف بيعان كارى كرده است.

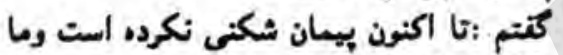

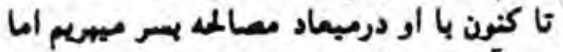

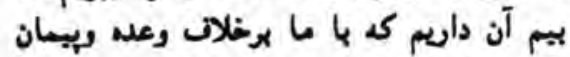
خود عمل نايد. ابوسفيان ميكريد : درجريان مثران مين سوال

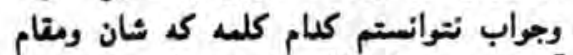

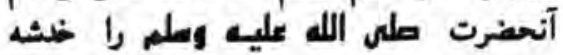

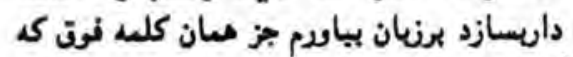
(مايااو درين ايام درييعان مصالحه ترارداريم

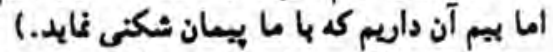

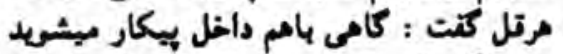

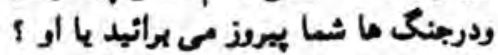

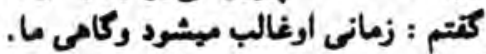
كنت : شعا راله به امر ميكند.

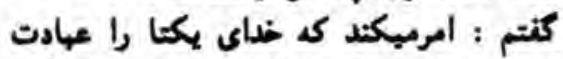

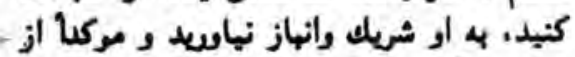

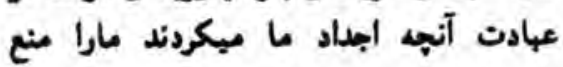

وسلم به تبصر داده شد از محتويات آن آكاهى

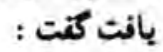
درشهر برويذ ، جستجو كنيد تا يكى از اتوام

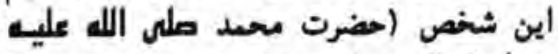

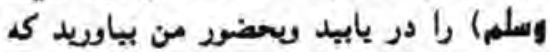
من از اوسوالاتى دارم تا دريابم كن درياره اين باريد

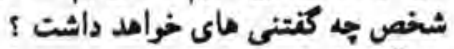

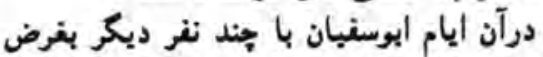

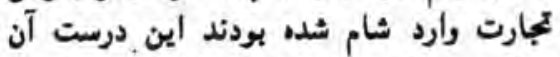

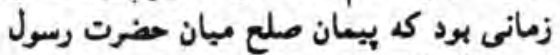

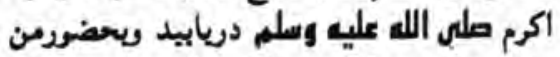

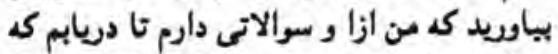
دريار، + اين شخص جه كنتنى هاى خوامد داري

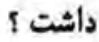

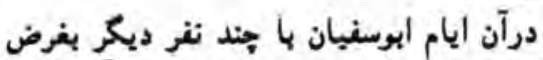

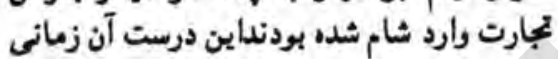

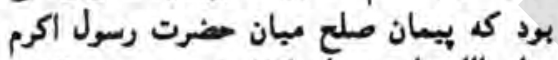
ملى الله عليث وسلمهركنار تريش مرعى الاجر

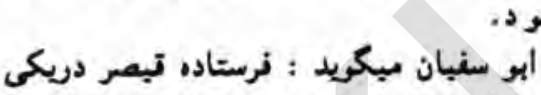

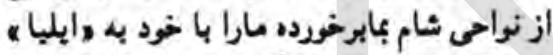

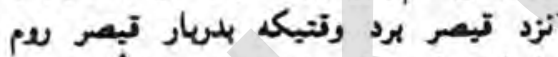

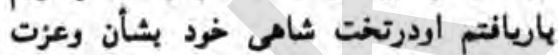

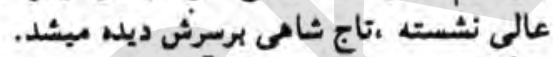
بزركان دربار بحضورش كرد آمده بودند.

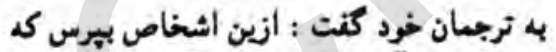

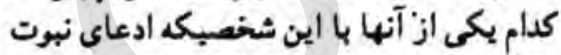
ميكند از روى نسب ترابت آنسايت دارد.ابوسفيان

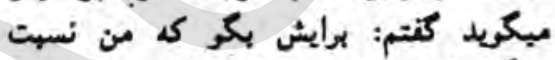

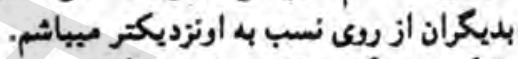

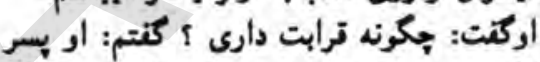

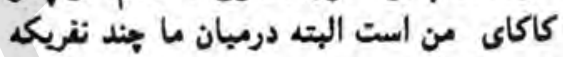

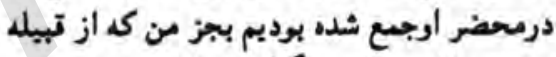
و عبد منافه بودم ديكران نبودند.

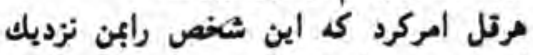
يباريد من هـ او نزديكتر شلم رنقايم را. در ائر عقب من نشاندتد. آنكا، يترجمان خود كنت برنقائ اين شخص بكو : بكان

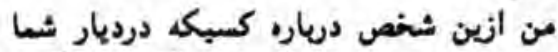

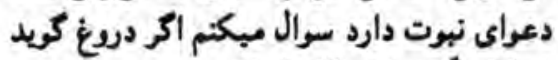

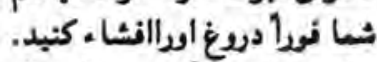

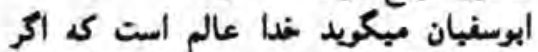

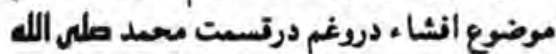

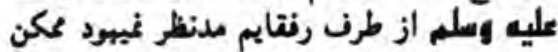

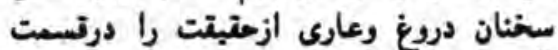
آنحضرت صلى الله عليه وسلم يراى تبصر بيان
قصصى الدحيث

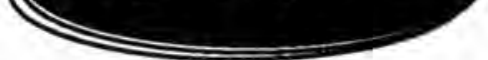

* غلام حضرت , نذرى فرغارى *
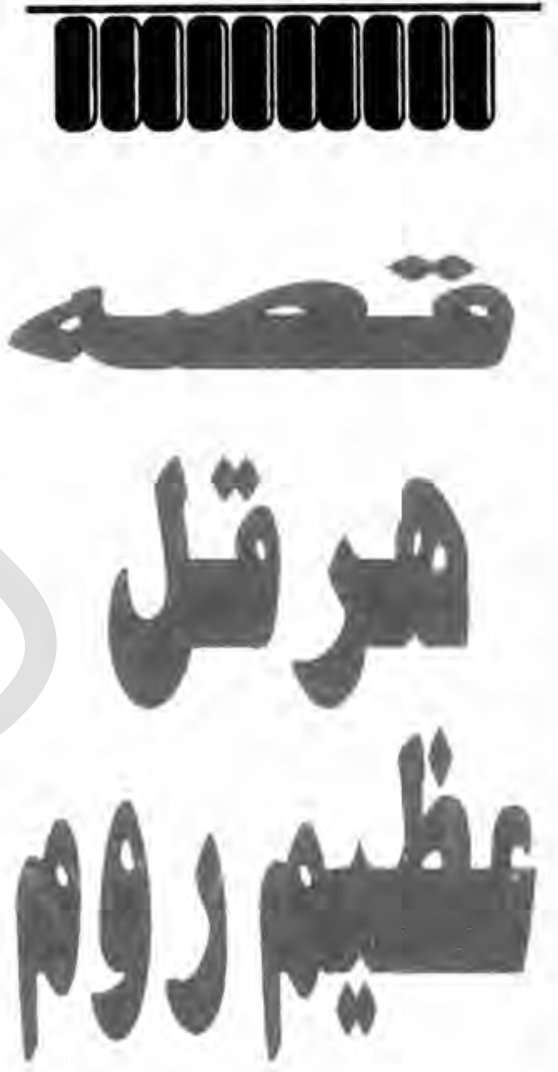

حضرت عبدالله بن عباس رضى الله تعاله عنه

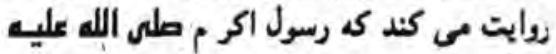
وسلم نام به تيصر ردم فرستاده والرا بدرين

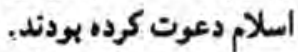

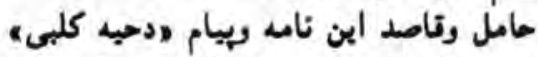

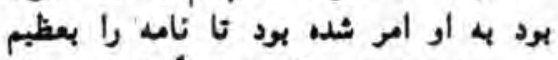

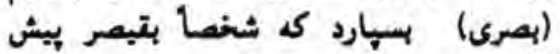

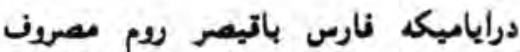

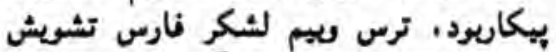

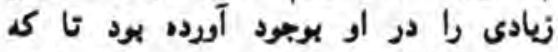

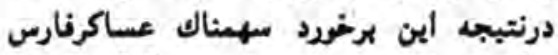

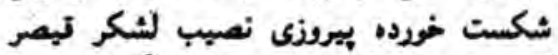

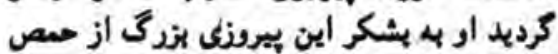

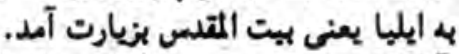
آنكا، كه نامه حضرت رسول اكرم ملى الله عليه 
تبيله انصاركه ساكن شام بود مبكويد :

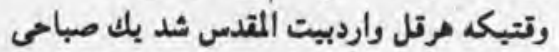

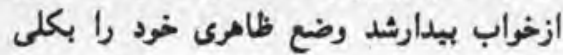

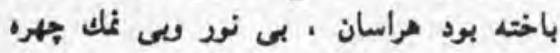

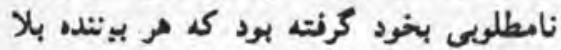

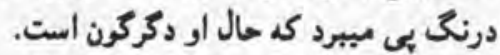

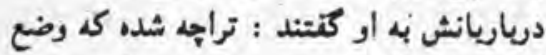
ظاهرى ات بكلى متغيير شده وحواست برت أرت

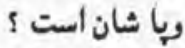

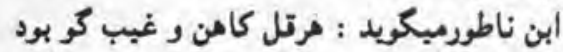

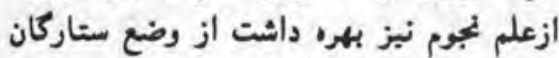
جيز هاى استنباط مبكرد. او بجواب مقريان خود كنت : جيزيكه از وضع إنعان ستاركان بمن وانمود مبشود آنست كد بادئان "ختان،(1) عنتريب برودى زمين مسلط

ميثشود.

آيا كدام يكى از شعا جنان مردمى را سراغ

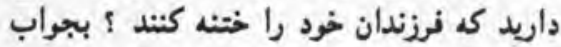

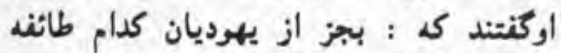

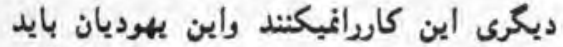
باعث انديشد شها نبوده باشئد جار، كارآنها

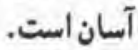

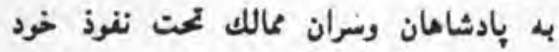

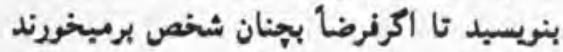

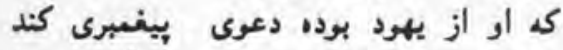

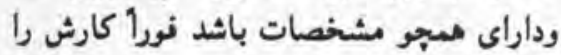
يكطرنه نمايند. دراثناي مين جرويحث وابراز نظريات كوناكون

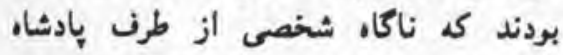

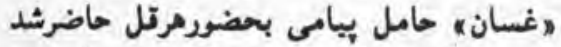

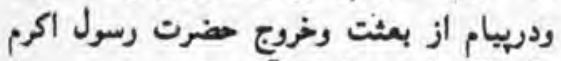
ملى الله عليه وسلم يادآدرى شده بودئ

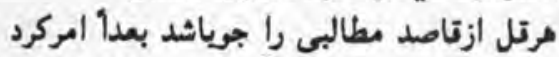

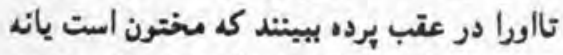

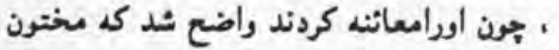

هرتل ازقاصد برسيد كه آيا اعراب مم مثل

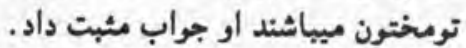

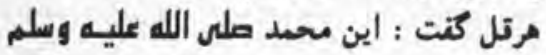
بادشامى است كل بزودى سيطره او ار عالمكير

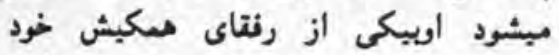

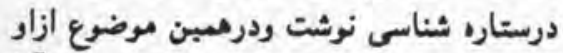
طالب يارى ومعلومات كرديد تابيبند كى آيا
حريف درمابين شما جطور است ؟ كنتيد كامى

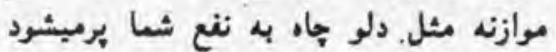
وكاهى به نفع او. جنان است بيامبران بيجنان

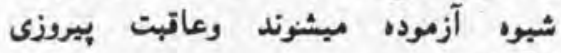

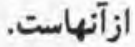

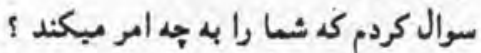
كنتيد : امرميكند باينكه خدا رابرا رابه تنهائى عبادت نموده هيج موجودى زا با با اوشريك وانباز

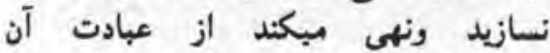

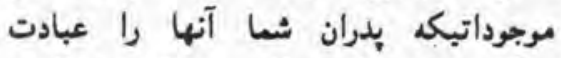

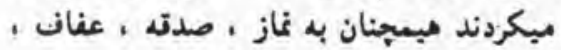
وفا به عهد واداي امانت امر ميكند. هرتل كنت :اينها تماما از اوصان بران بيامبران

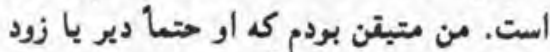

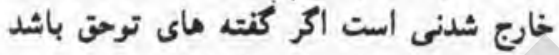

عنتريب مين جاى بائ مرا مالك ميشود.

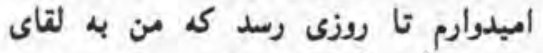

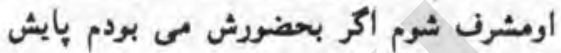
رامى شستم ومى بوسبدم. ابو سفيان ميكويد: بعد ازين ماجرا نامه

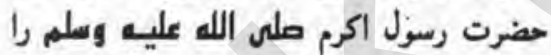
خواسته درمحضر اطرافيان خورد آنران آنرا ترانت كردودرآن هنين كلهاتى تحرير شده بود :

$$
\text { بسم الله الرحهن الرحيم }
$$

من عدهد بن عبدالله ورسوله الى هرتل عظيم.

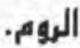

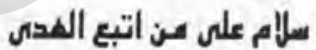

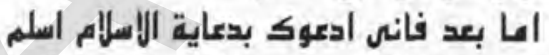

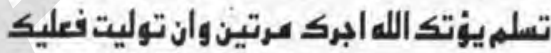
اثم الإيسين ويا امل الكتاب تعالوا الى كلينة سواء s بيننا وبينكم الإنعبد الا الله ونشرك به شينا ؤلانتخذ بعضنا بعضا اربابا عن دون الله فان تولو افتولوا الشهدوابانا عسلهون. ابوسفيان رضى الله تعالى عنه مبكويد : بعداز اينكه سخنان هرتل وقرانت نامه آنا آنحضرت

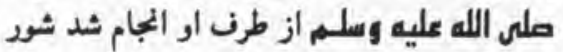

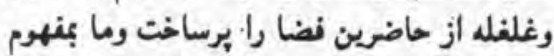

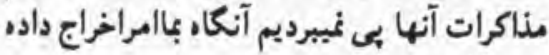
شد وما بيرون رنتيم. روايت ديكردرمورد عكس العمل هرتل از

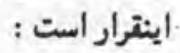
ابن ناطور نام رفيق ومصاحب خاص هرتل از

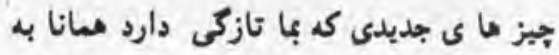

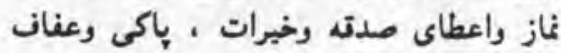
ورنا به عهد وييعان مارا امر ميكند.

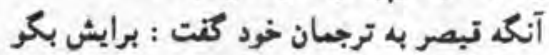

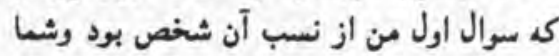

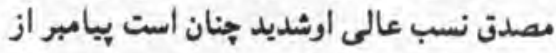

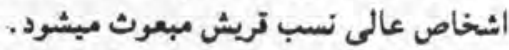

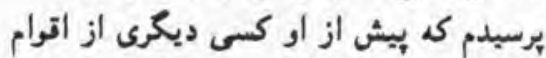

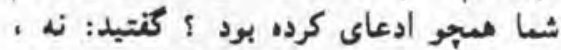

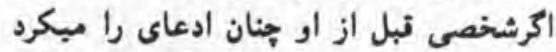

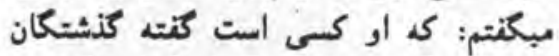
خود را مبكويد ويبروى كنتار آنها ميكند.

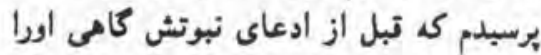

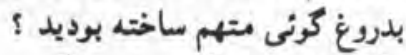
كنتيد نخير. اكراو بدروغ كوريى متهم ميبود

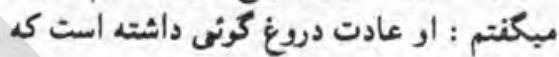
مكن بخواهد دروغ بكويد. يرسيدم كي آيا از اباو اجدادش كسى بادشا.

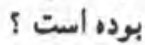
كنتيد نه. اكر يكمى از اجدادش بادشا، ميبود

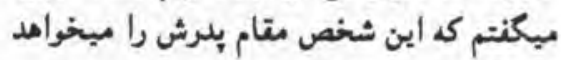

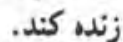
سوال كردم كد آيا اشراف ويزركان توم از او كئل

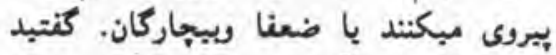
ضعناى توم بيرو آنند.

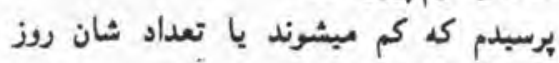

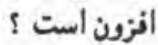

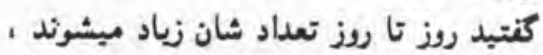
جنان است ايمان در زيادت است تا تكميل كردد

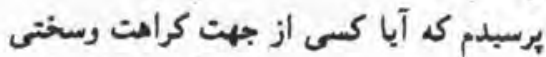

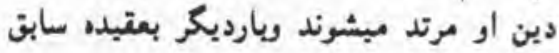
خود برميكردند ؟ كنتيد نه. جنان است وتتبكه نورايمان درجبين ويشاشت برديت

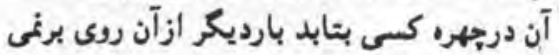

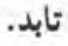

يرسيدم كه آيادرعهد وييمان خود باشما جطوراست آيا كاهى نتص بيمان كرده است. كنتبد : نه. بلى بيامبران خداوند هيجكا، جنان كارى را.

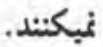
برسيدم كه آيا با اومقاتله مبكنبد وموازنه 


\section{لشنى با برادر}

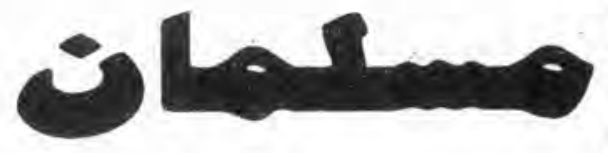

از انس رضى الله تعالى عنه روايت است كم :

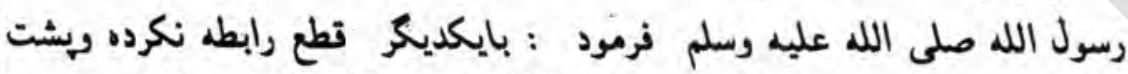

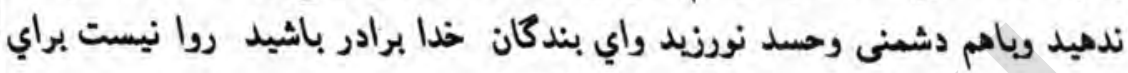

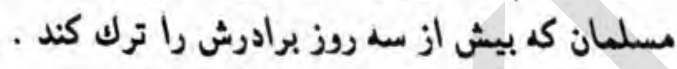
* * *

از ابوايوب رضى الله تعالى عثه روايت است كه :

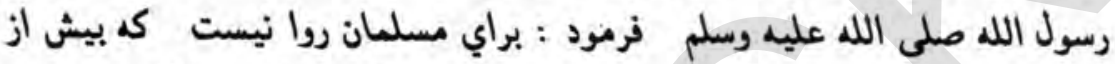

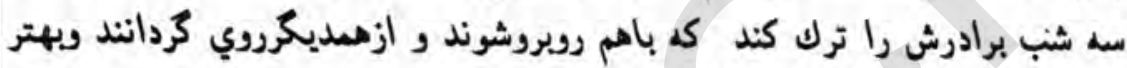

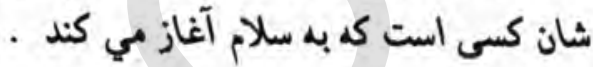
***

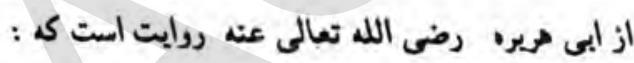

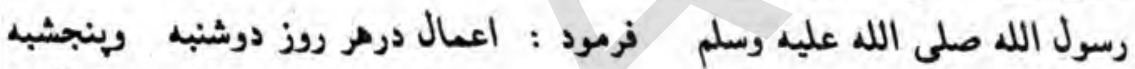

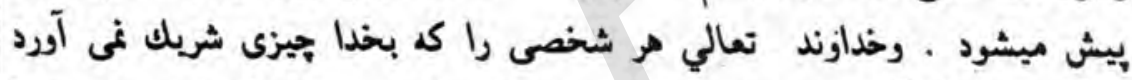

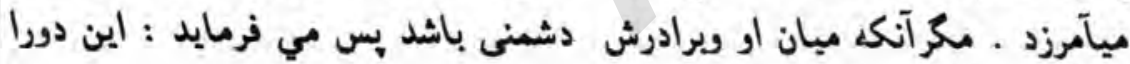
بحال شان بكذاريد تابهم صلح نمايند.

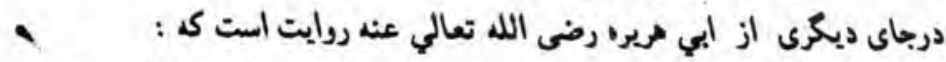

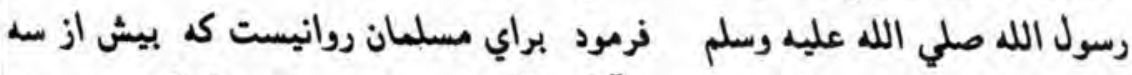

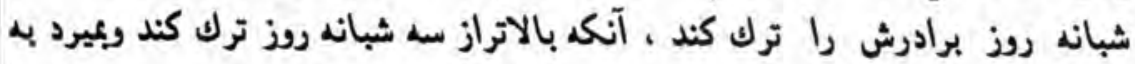
دوزخ داخل مي كردد .

\section{* * *}

ازابوخراش حلرد بن ابى حدرد اسلمي رضى الله تعالى عنه روايت است كه :

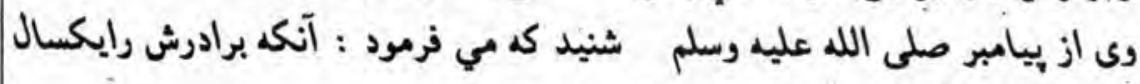

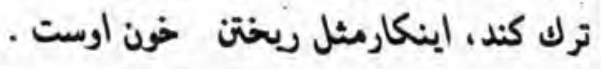

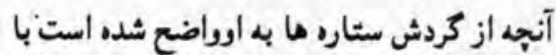
مشاهدات رفيتش بكسان ازآب بدر خوراهد آمد آند يا طورديكرى. خودش بطرن حصص براه انتاد جواب ستارن

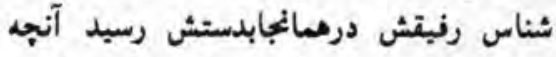

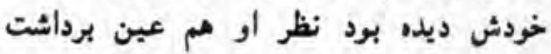

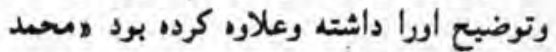
ن نبع موعود است.

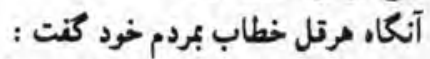

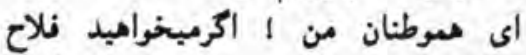

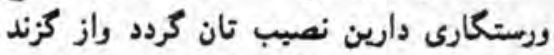

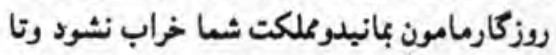

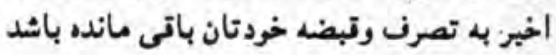
بايد به أين بيغبر ايمان بياوريد

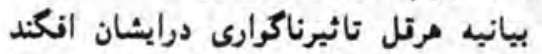

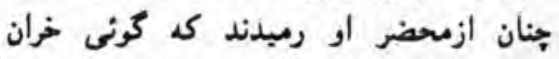
وحشى از انسانها ميكريزند و بديده ننرت به بهن

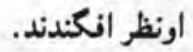
جون اين طائفه بدبخت وبى نصيب بدرب خانه هاى خود رسيدند ديدند كه دروازه ماي خان خانه بروى شان بسته است.

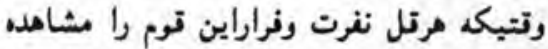

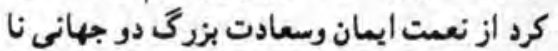

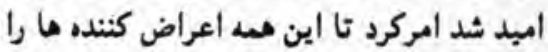
بحضراويارديكرجع كنتد امر اوعملى شدر.

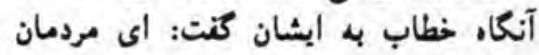

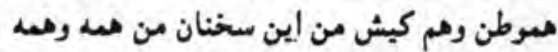
براى امتحان شها بود تابدانم كه شعا دركيش

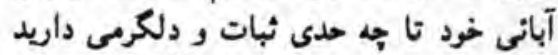

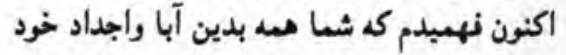

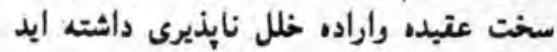

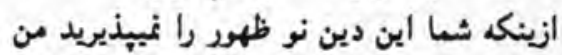

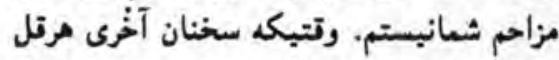

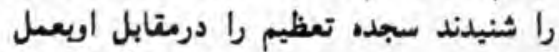
آردرند وازين بشتيبانى او از كيش آبانى شان آنيان أمنون ومتشكركزديدند. اين دكركونى رأى مرتل دراخير نسبت بقاى

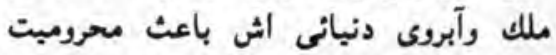
اوازايعان وسعادت دارين او كرديد. 11 إختان : كثن شدكان . منت شدكان. 

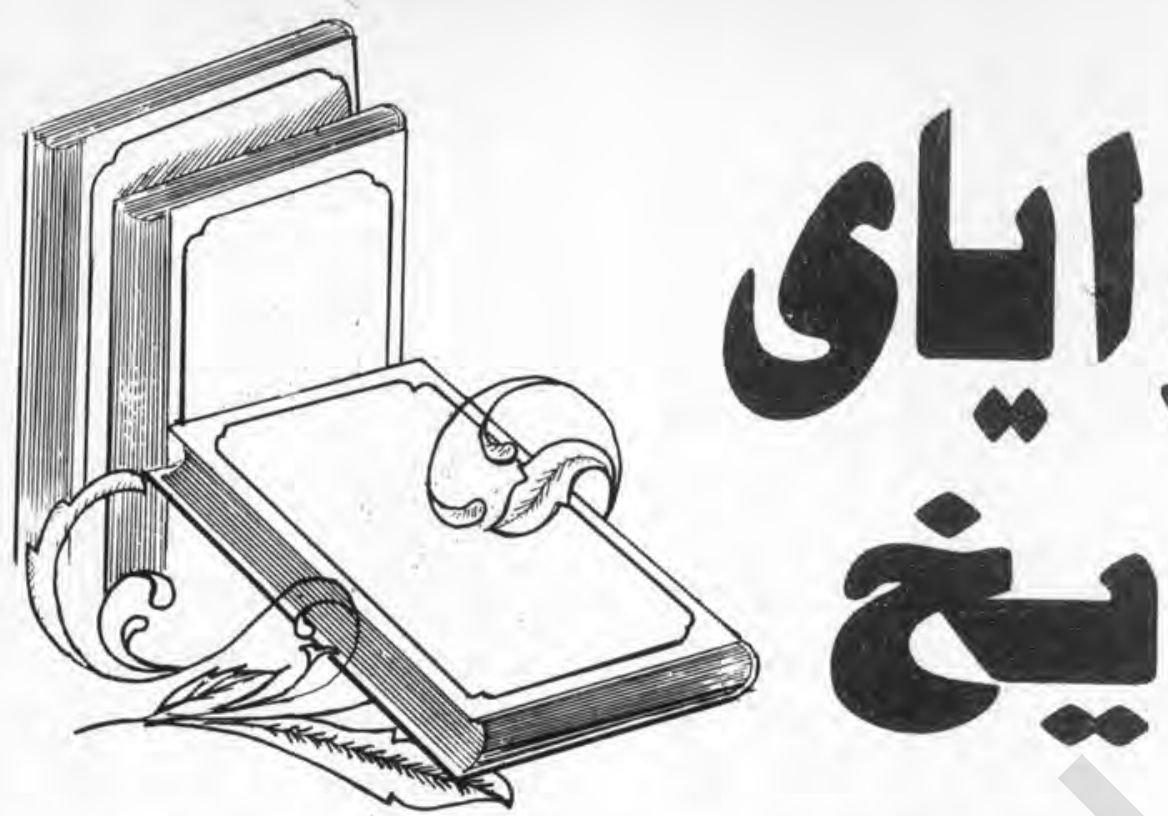

اروا ، دستكيرنورد ، ودر زير جير كهنه نشاندند ، تانتبجه

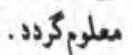

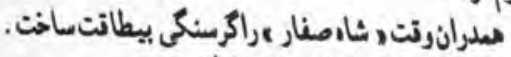

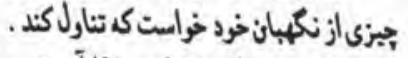

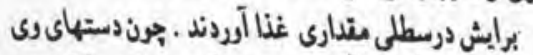

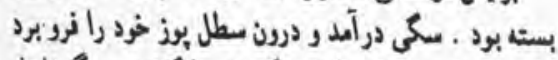

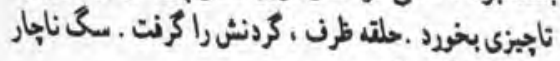
سطل رابة كردن كشيده ، بلدرشد.

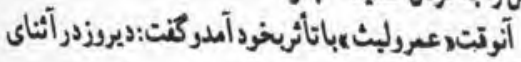

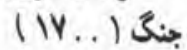
شتر مطنخ مراحل مبكرد ر امروز سكى آترا بدين ختن وسكى حل مبكند.

\section{* * *}

وتتبكه نهفت سلجوتيان مركزآسبا ،خاصه ، وطن

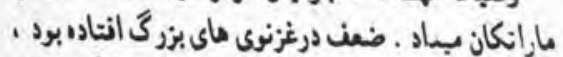

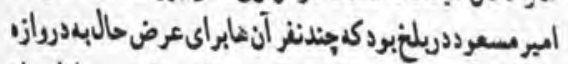

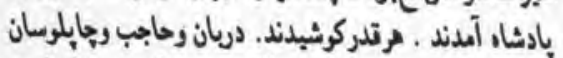

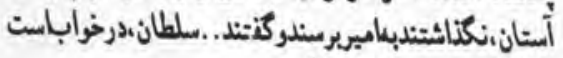

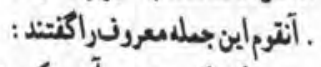

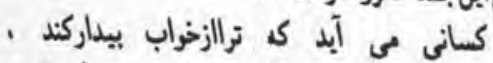

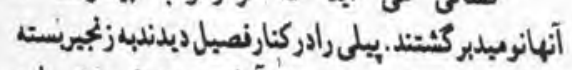

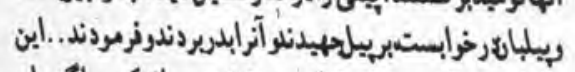

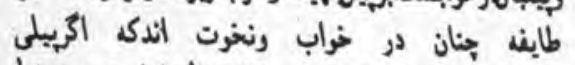

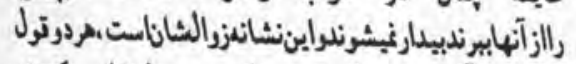

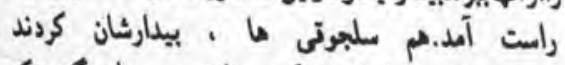

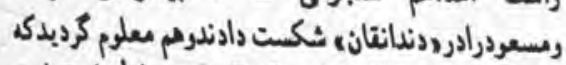

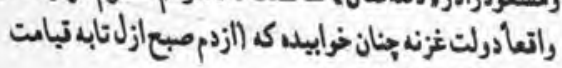

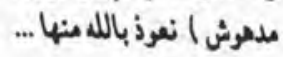
نااعتبروا

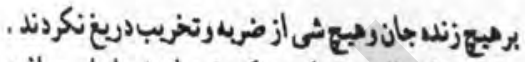

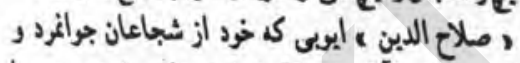

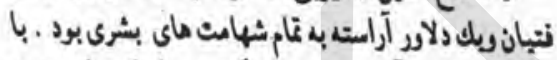

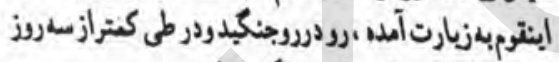
مسراباكشتويا اسير كردوباكرينتاند.

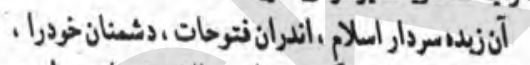

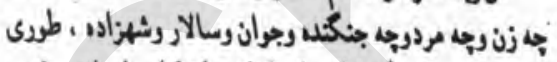

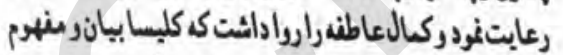

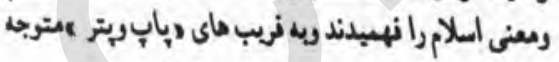

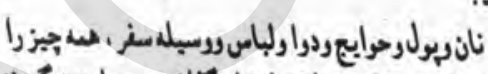

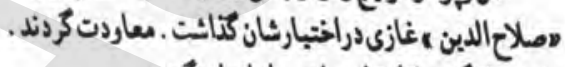

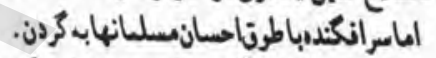

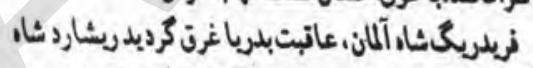

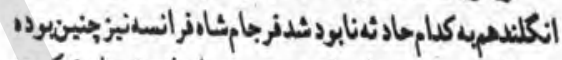

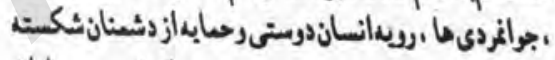

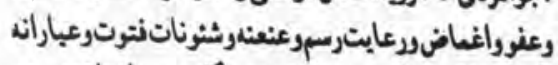

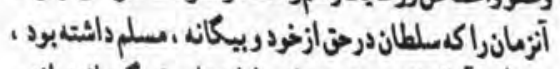

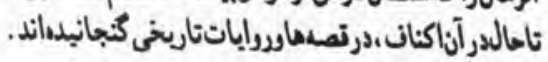

$$
\text { ** * }
$$

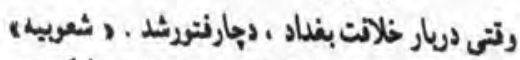

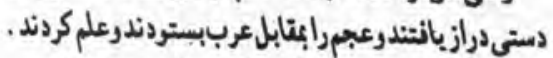

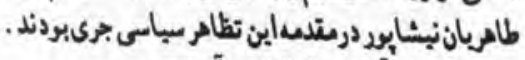

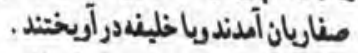

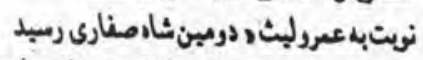

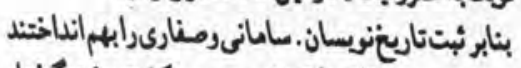

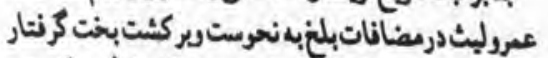

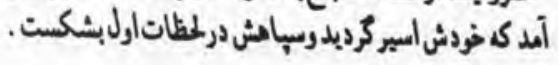
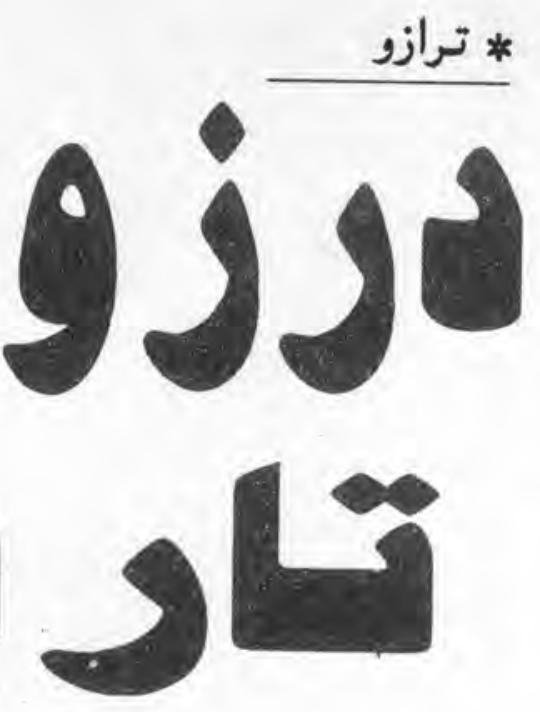

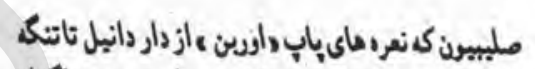

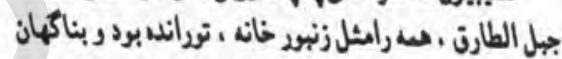

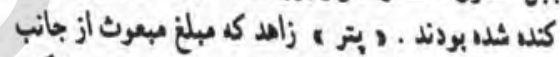

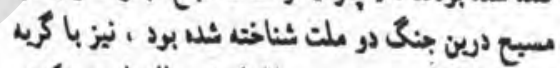

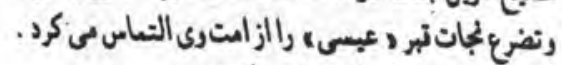

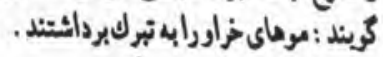

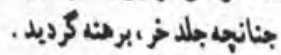

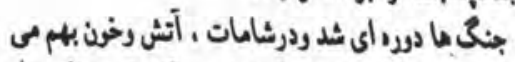

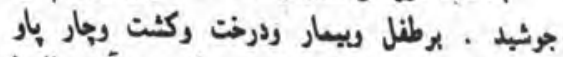

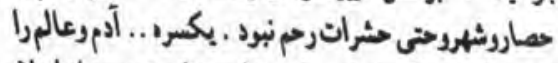

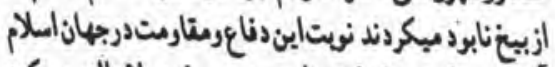

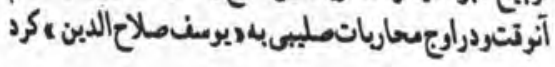

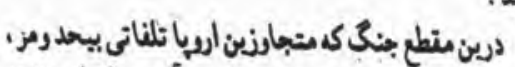

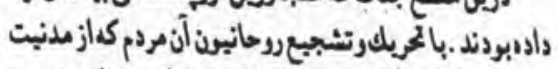

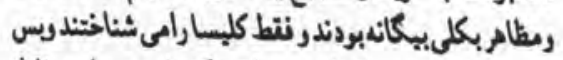

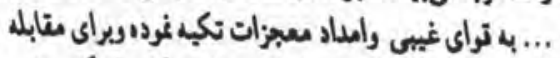

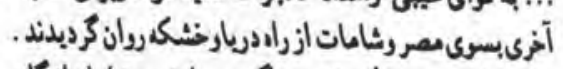

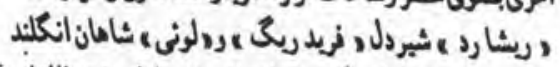

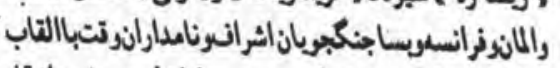

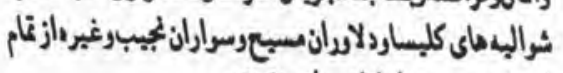

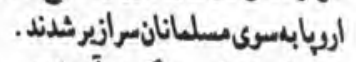

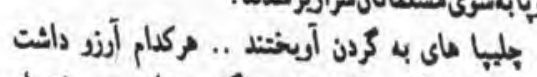

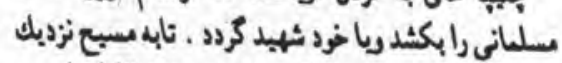

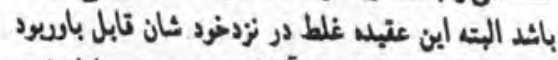

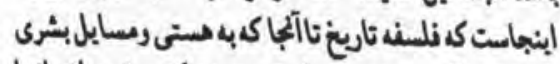

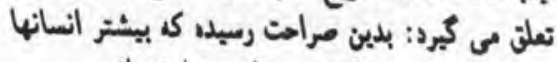

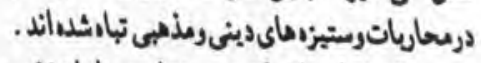
سبامبان اردياتى كه در مرزهاي مسلمان نشين رمبديدند 


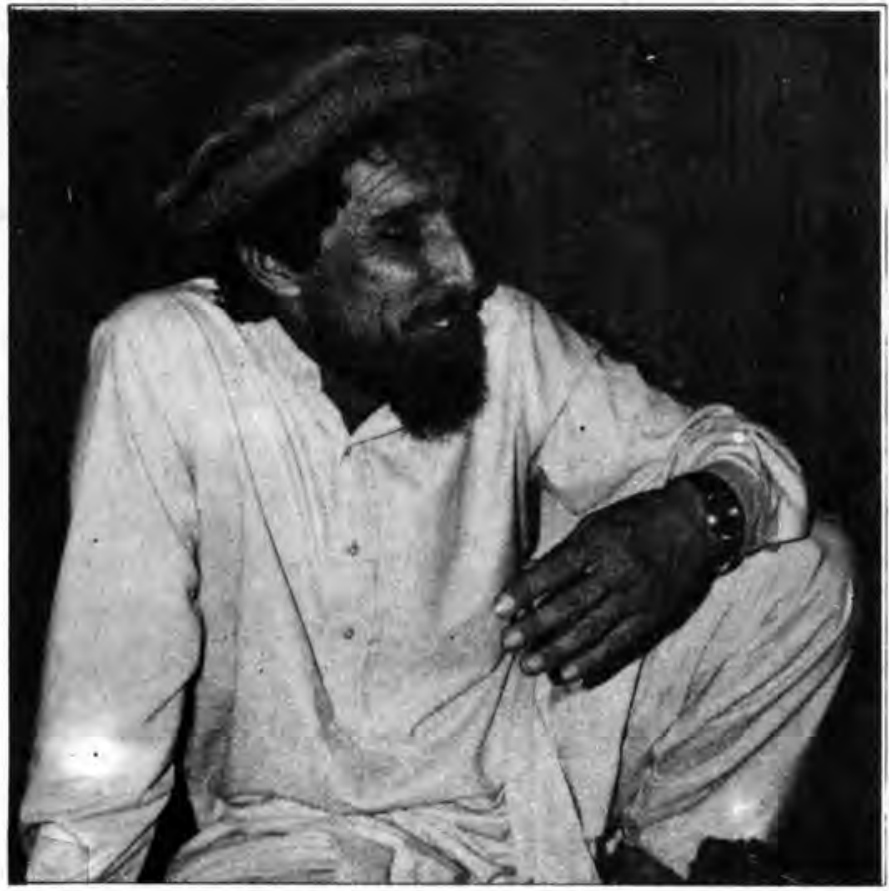

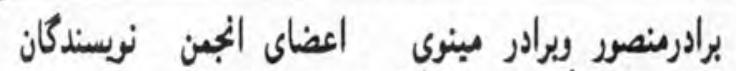

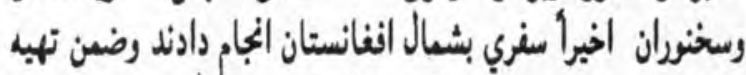

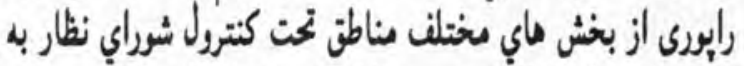

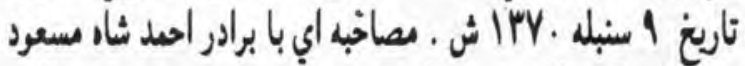

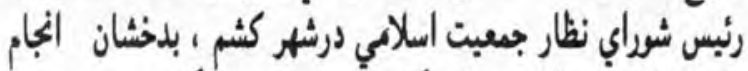

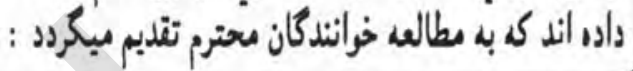

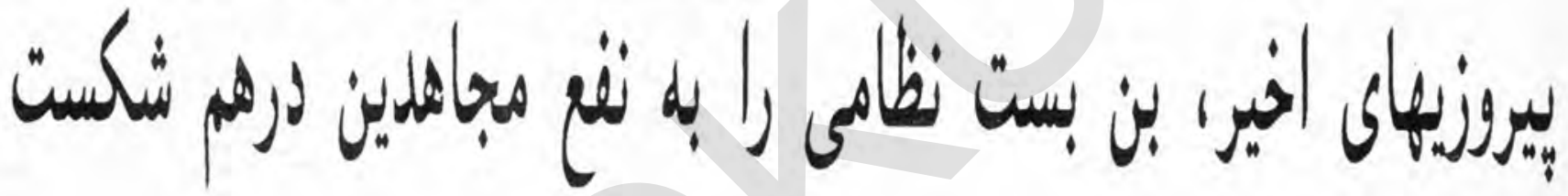

س : در ارتباط به استرتيزي كام به

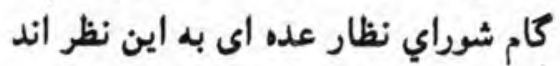
كه هدف آن تضعيف كردن احزاب سياسي رقيب در بهلوي رثيم كابل است

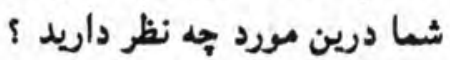

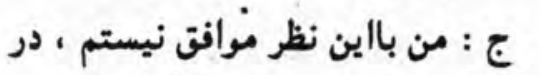

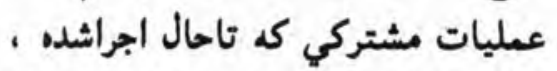
احزاب شركت كننده در عمليات نه تنها ضعيف نشده بلكه در ميان عامه مردم مقبوليت بيشتر كسب كرده اند وبا آزاد شدن مناطق وبذست آوردن بلاح واموال غنيمتي تقويه كرديده اند . تنهاحزاب ويا جبهاتي ضعيف شده اند كه در عمليات ها اشتراك نداشتند . س : اكر جلال آباد ويا كرديز بدست

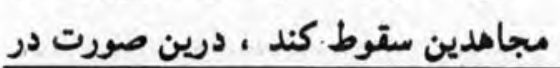

سريع رثيم كمنستي كابل را دارند .. -ميشود بكوئيد درين ارتباط بلان شورا درسال جاري جيست ؟ ج : بيروزي ماي اخير بن بست داريت نظامي را بـ نفع مجاهدين درمه شكست مايت ودشسن را در حال مدافعه منفي قرار

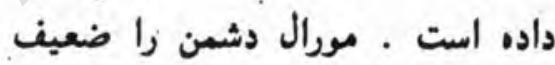
ساخته وبرعكس مجاهدين مم از نظر

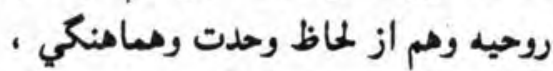

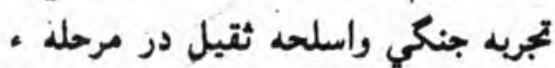

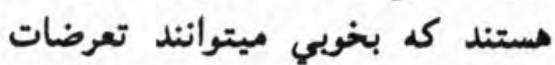

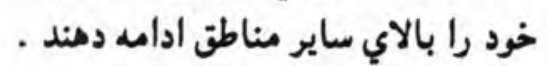

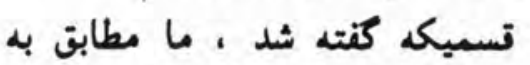
استراتيثي شوراي سرتاسري توماندانان قدم به قدم عمليات خودرا از اطراف بسوي مراكز دشمن بيش خواميم برد .
س : نتوحات اخير شوراي نظار را جكونه ارزيابي ميكنيد ؛

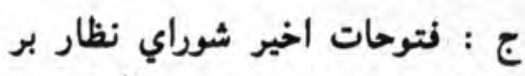
اساس استراتري كه در خزان سال كذشته در شوراي سرتاسري توماندانان براي

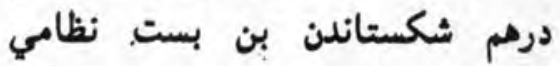

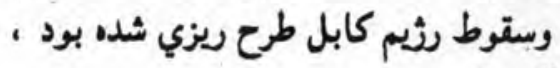

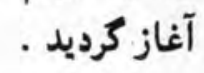

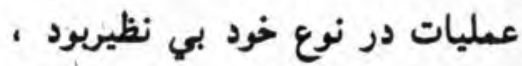
وطي مدت كوتاهي ينج ولسوالي وجهارعلاقداري از تسلط دشمن آزاد كرديد واسلحه ثقيل وخفيف قابل

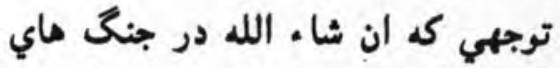

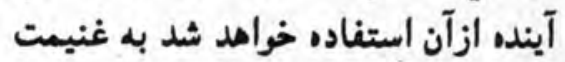
كرنته شد . س : مردم افغانستان انتظار سقوط 


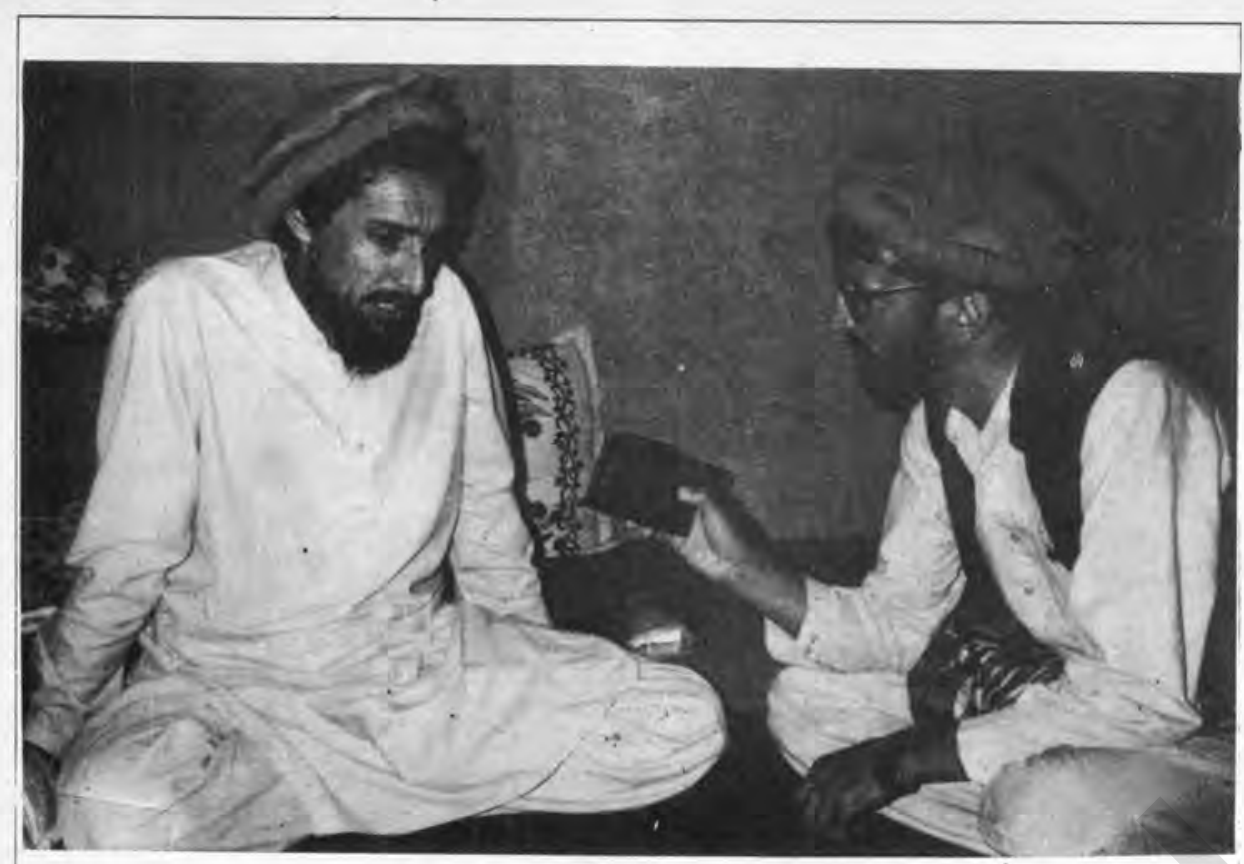

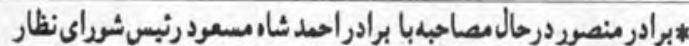

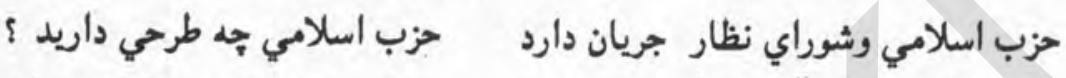
ج : قسميكه همه اطلاع دارند زمينه

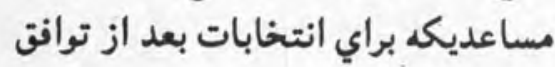

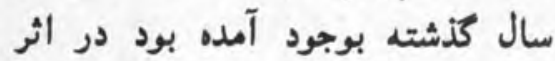

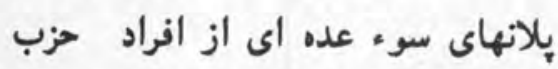

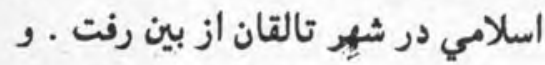
فعلا طرح جديدي درين قسمت روي

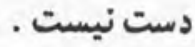

س : تحولات اخير شوروي جه تاثيري بالاي رثيم كابل خواهد نمود ؟

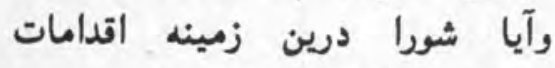
مشخصي اتخاذ خواهد كرد ؟ ج : از آنجائيكه رثيم كابل از جهات مختلف به شوروي وابسته است تحولات إنات اخير در شوروي اثرات ويرانكري بالاي

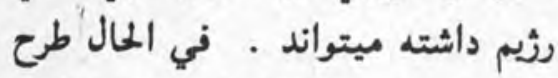
مشخصي در رابطه باوضع جديد نداريم اما درآينده بادرنظر داشت دابط انكشاف

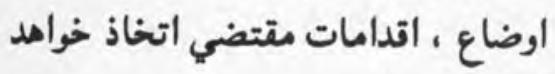

استراتيري شودى جه تغييري وارد

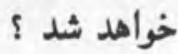
ج : سقوط جلال آباد وكرديز خود مطابق به استراتيزى ايست كه در كذشته وله از سوى شوراى سرتاسرى قوماندان طرح شده بود م

س : بنا بر رايور هاي منتشره ، شما

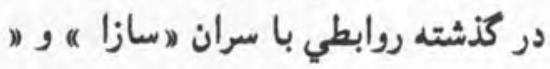
سفزا " داشتيد ، دستاورد تان ازان

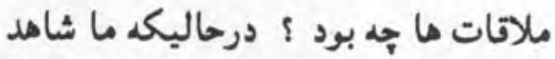
وركيري ماي شديد ميان شوراي نظار

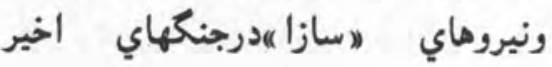
بوديم؟

ج : ما بعد از خروج قواي شوروي و عان عان اعلان عفو عمومي از جانب رهبران

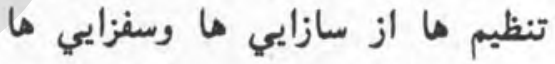
خواستيم تا از دشمني با اسلام ومردم

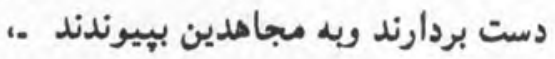

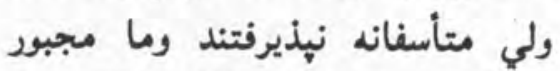
شديم از طريق جنى مناطق را از وجود وماني

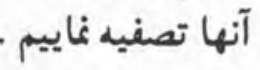
ـ ف :نظرتان راجع به بيشنهاد ينج نقره الئملل متحد راجع به افغانستان س : سال كذشته براي ايجاد وحدت با حزب اسلامي براي اجراي انتخابات

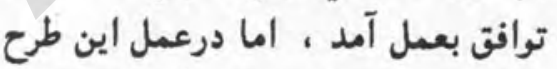

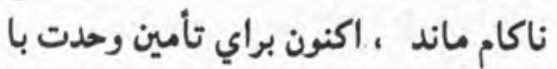

ما بعد از خروج تواي شروري ر اعلان

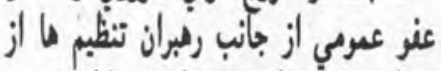

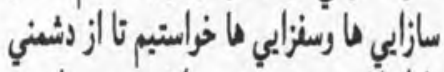

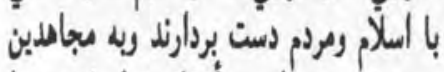

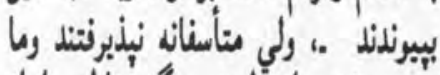

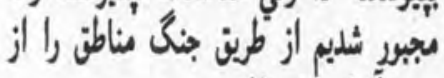

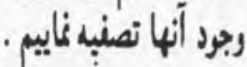

جيسن ؟ جره

ج : بيشنهاد ملل متحد نكات كنگ

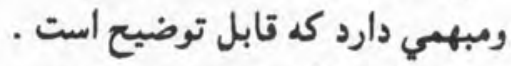
س : از نظر نظامي رثيم كابل در

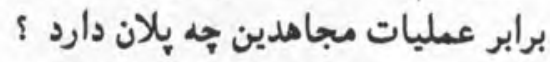

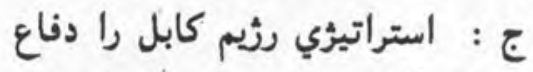
ازشهرها وكسترش قدم بقدم نفوذش در

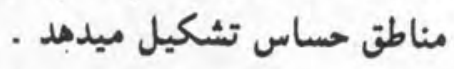
س : كساني مستند بدين عقيده اند كه اكنون جنگ براي كسب قدرت ميان 


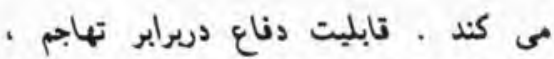

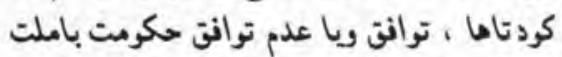

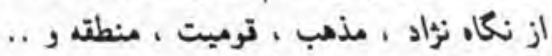

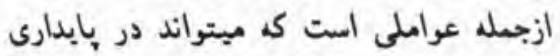

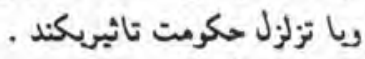

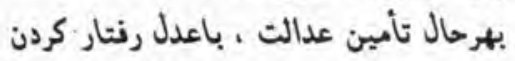

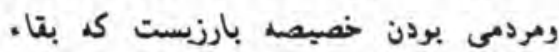

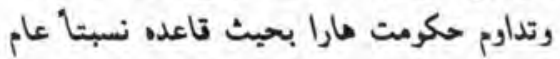

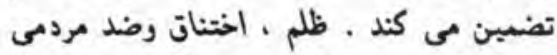

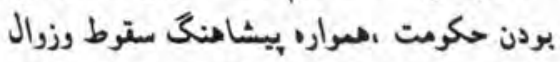

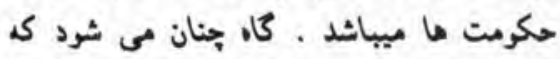

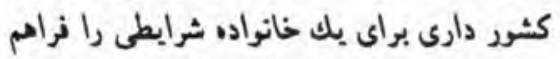

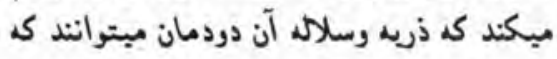

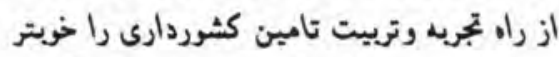

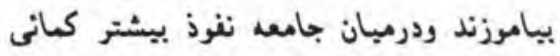

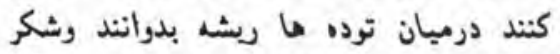

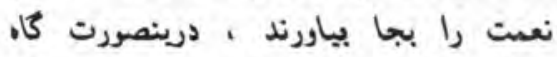

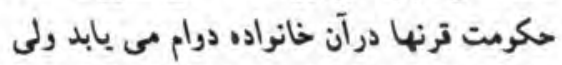

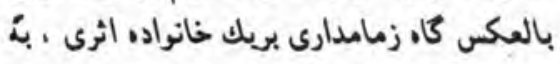

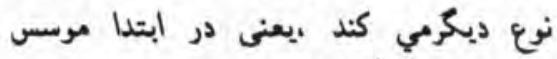

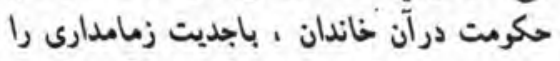

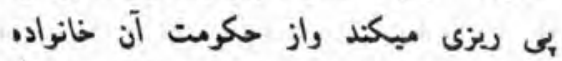

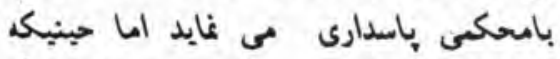

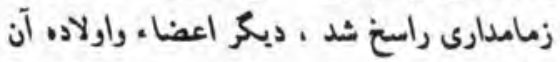

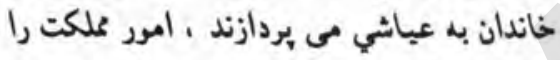

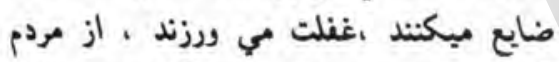

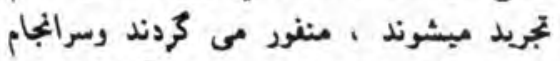

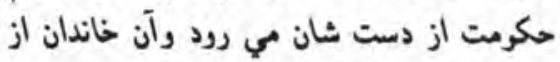

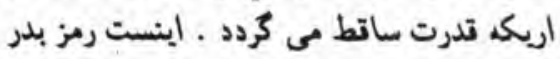

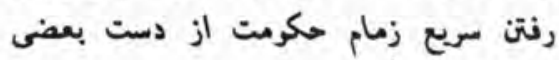

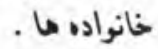

امروز علوم جامعه شيناسى ، سباست

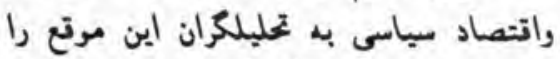

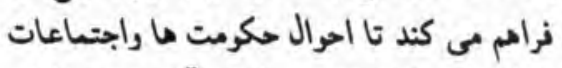

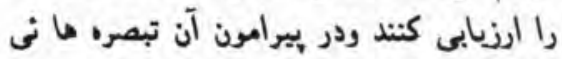
ابراز كنتد وتحليل هاى بعسل بيارند .

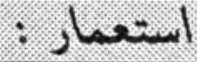

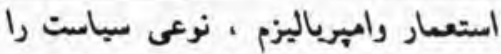

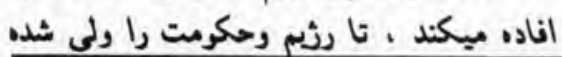
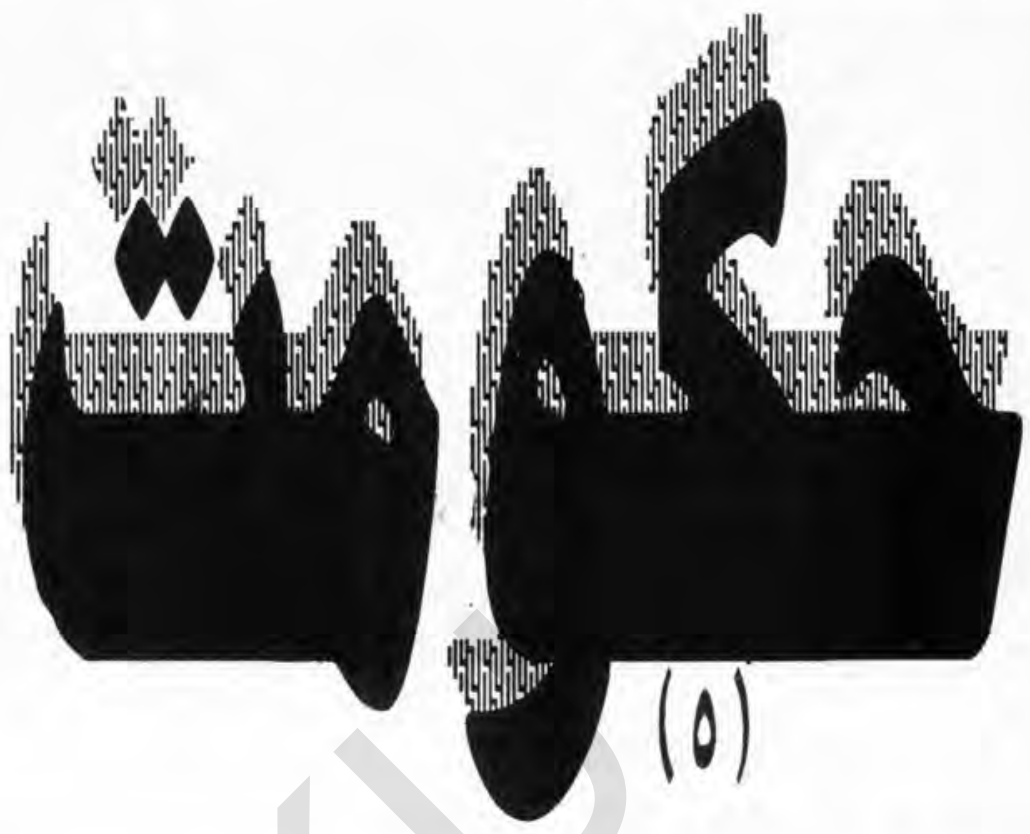

دانشكامى از خود جديت بيشتر به خرج مى دئ

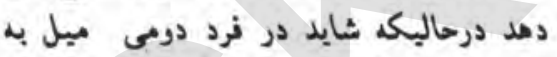

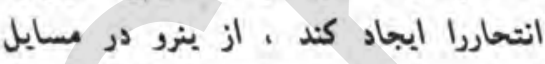

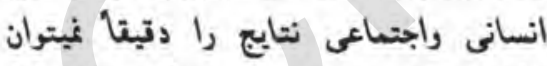

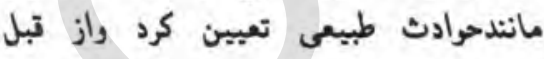

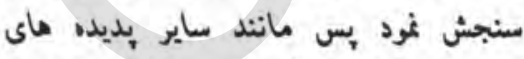

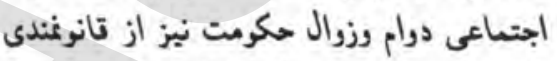
هاى خاص تبعيت ميكند الما دريك مسير باز

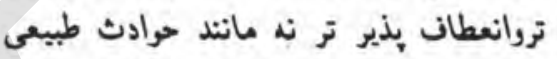
دربك مسير باريك وكانكريتى . نلسفه تاريخ

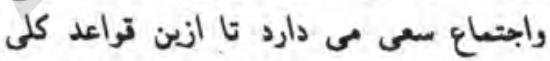

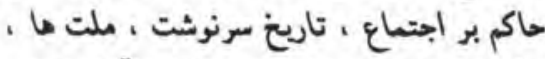

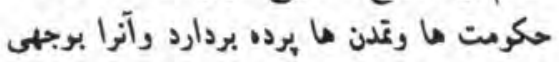

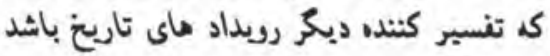

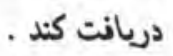

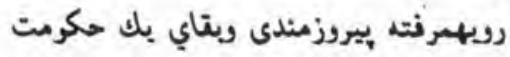

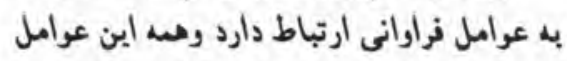

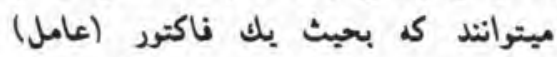

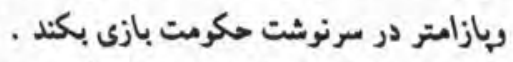

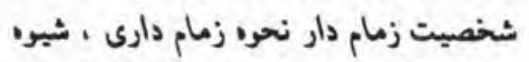

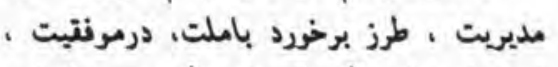

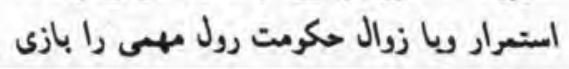

\section{* نوشت : داكتر عبدالمى *}

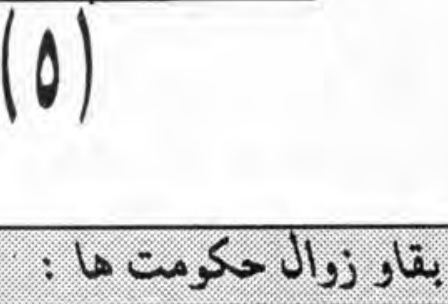

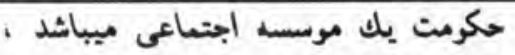

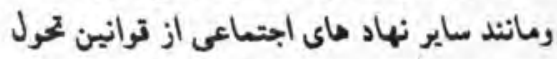

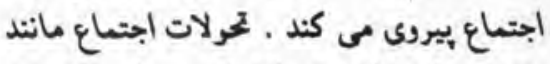

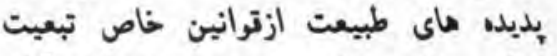

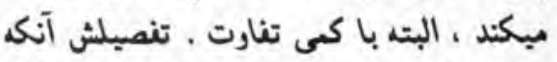

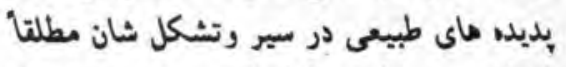

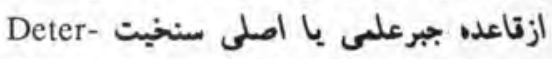
minisme

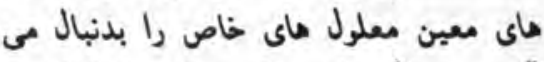

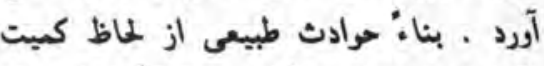

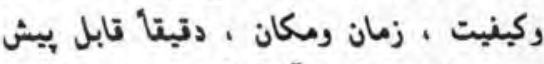

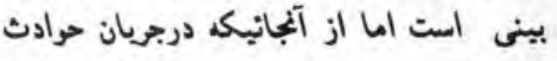

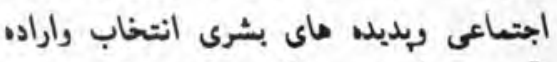

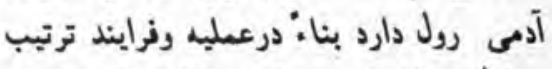

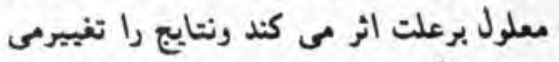

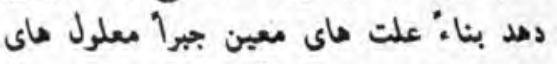

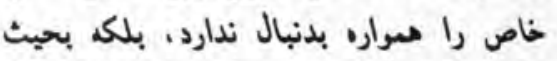

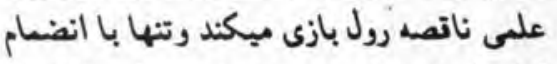

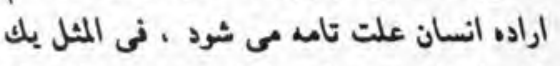
خرد انسان در براير ناكام شدن در المتحان المان 
وميراث شوم استعار را درميان ملل اسلامى آلئ انكشت نشان بدارند ودر جهت المها ـ ـ آن آن

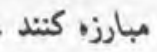

استعطار بيشترازين بر اشغالكرى هاي ارويا

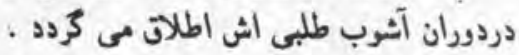

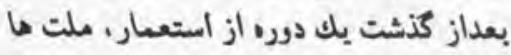

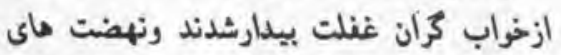

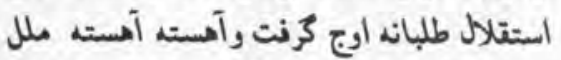

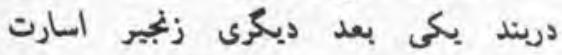

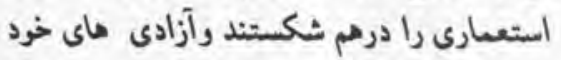

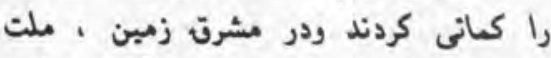

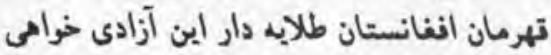

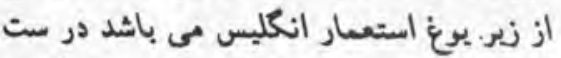

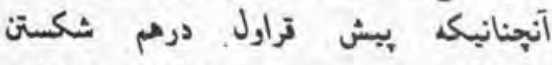
امبراطرىى درسيه نيز درين زمان ، بـه عنايت

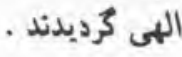

امورز بجز جند كشور ديكر بم آن شير،

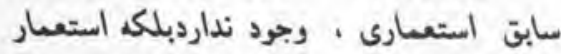

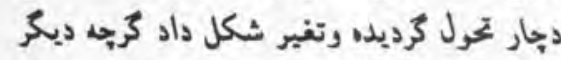

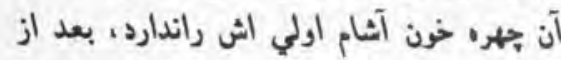

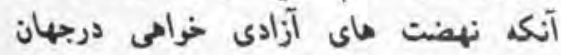

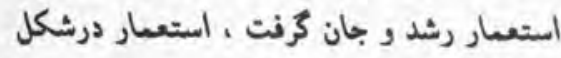

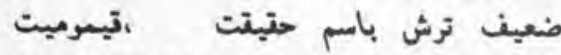
ركثورهاي دو مينيون ( تحت الحسابه ) تبارز

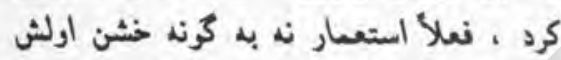

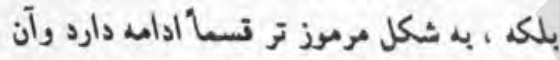

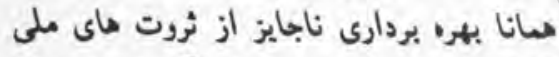

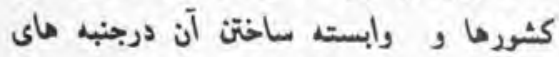
مختلف است تا نتواند خورد كناء شورد

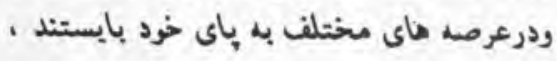

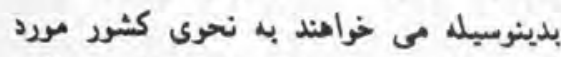

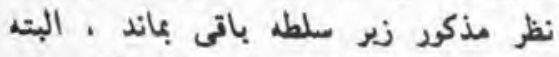

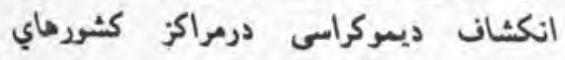

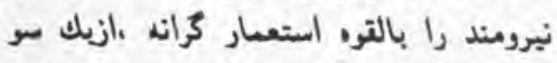

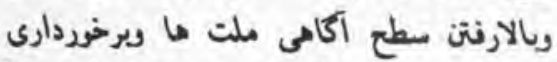

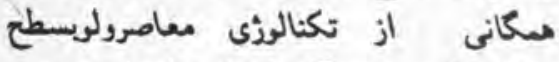

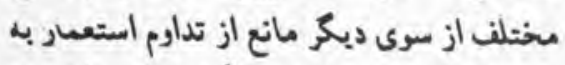

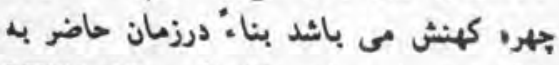

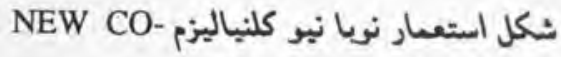
( I) (a) )
ويانتن بازار براى عرضه كالا هاى توليدى

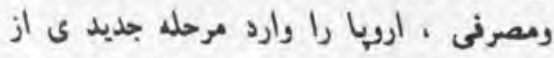

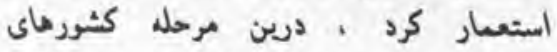

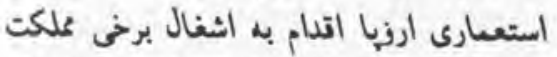

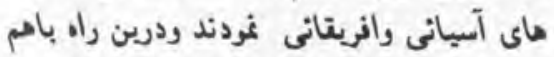

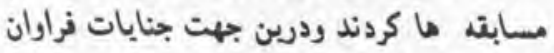

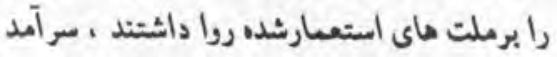

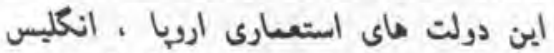

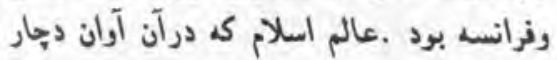

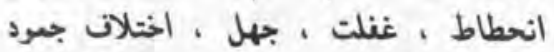

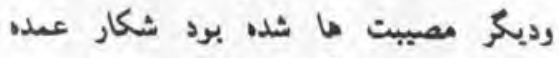
درندكان استعار 3ر بود وازين بابت خسارات

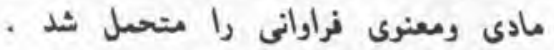

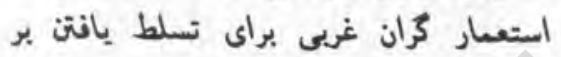
كشررماي اسلامى وبراى حنظ تدرت ران رمنانع

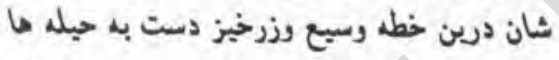

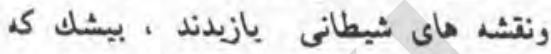

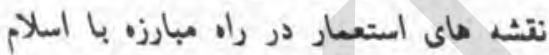

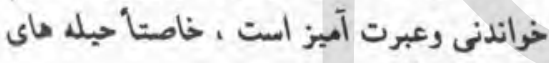

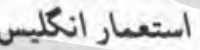

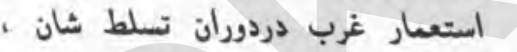

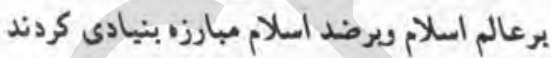

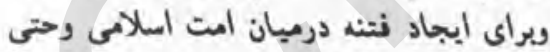

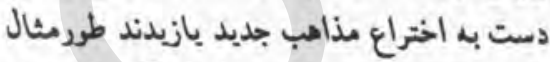

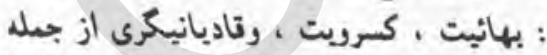

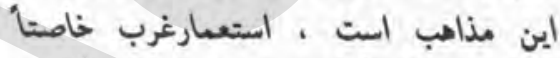

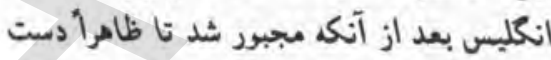

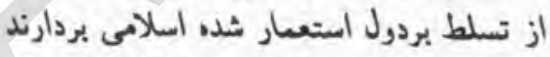

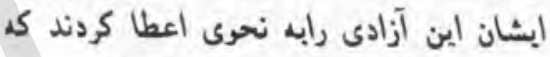

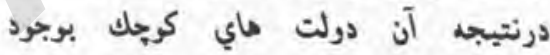

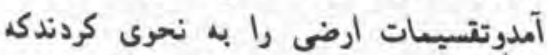

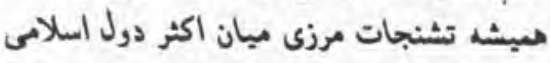

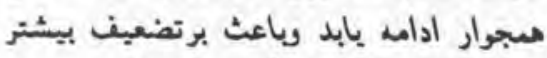

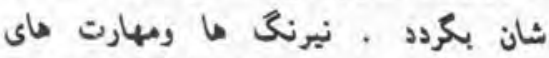

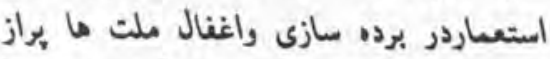

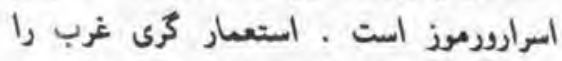

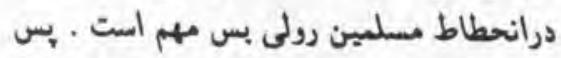

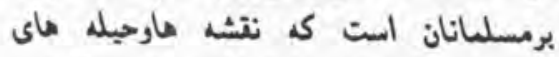

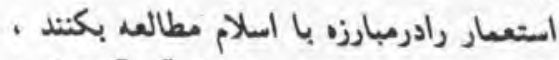
تحليل بدارند ، ومردم را با آن آشينا كنند
ميتواندك صنت رئم واتع شود ربه اين اعتبار

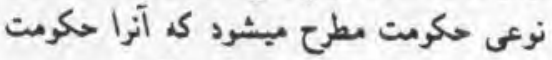
استعطارى واميرياليسنى ياد ميكنتد .

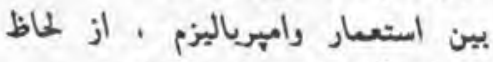

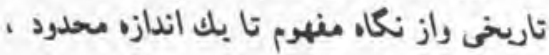

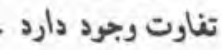

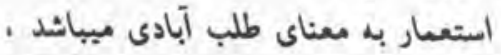

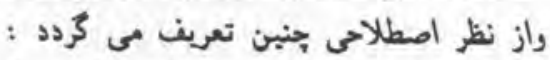

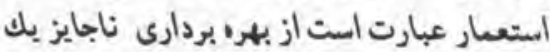

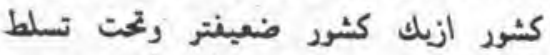
درآرددن آن ، بـ منظور تأمين برخى الهدان اتتصادى سياسى وجاه طلبانه . كشور كثانى بدين شكل سابقه بسيار طولانى درتاريخ بشرداردودر درازاي تاريخ بدريخ

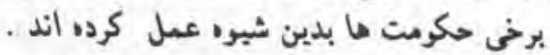

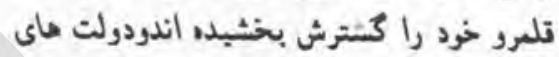

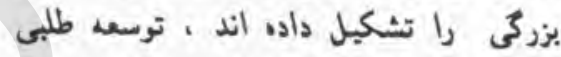

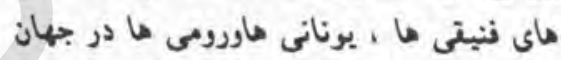

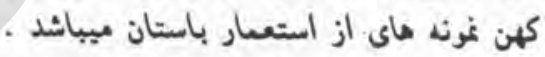

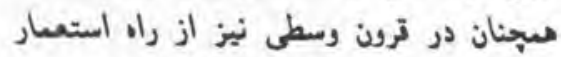

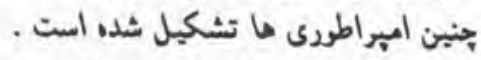

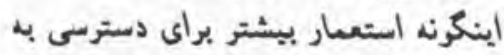
اهدان اتتصادى ، سياسى وجا، طليانه بودها

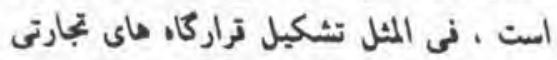

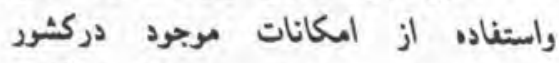

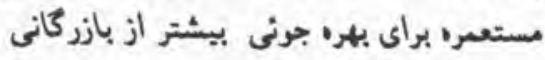

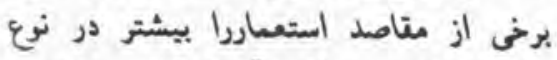

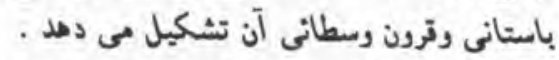

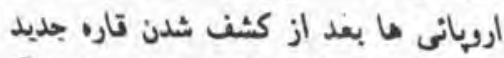

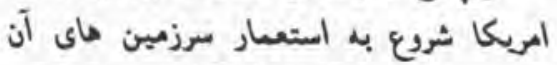

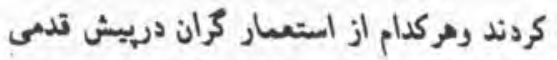

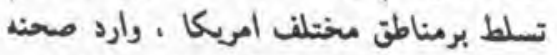

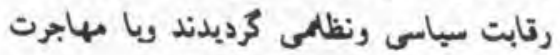

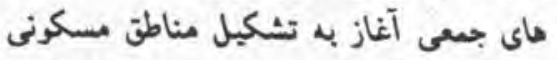

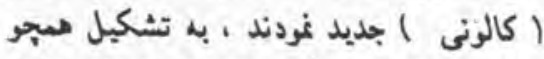
مناطق مسكونى جسعى COLONISALION كلونيز اسيون مى كريند وجه تسبي استعار

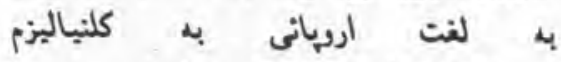
COLONIALISME با صنعى شدن ارديا ونياز به مراد خام 
حضرت ابويكر صديق رضى الله عنهباختيار خود

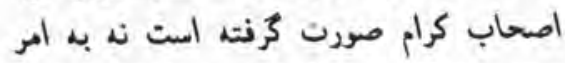

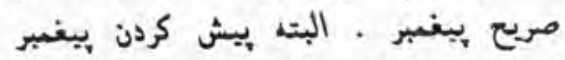

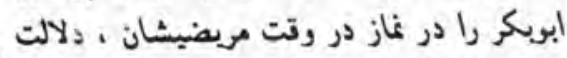

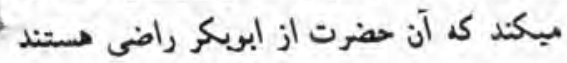

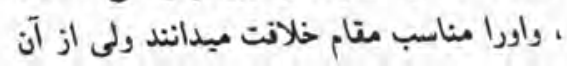

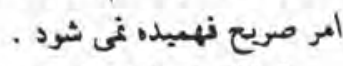

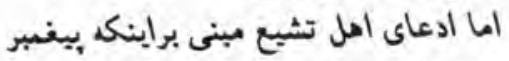

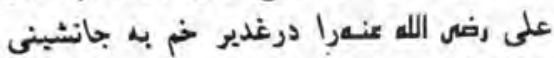
خود بركزيد ، درنزد الهل سنت مستند به ديليل

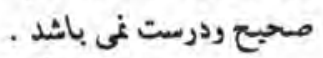

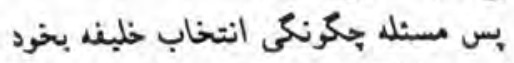

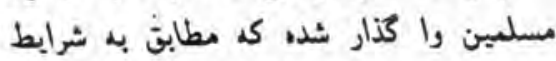

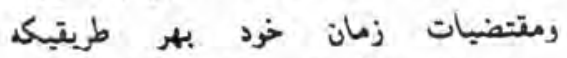

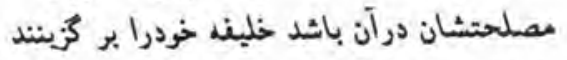

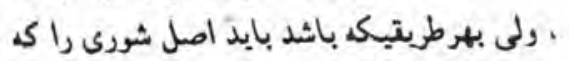

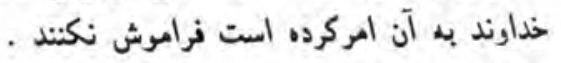

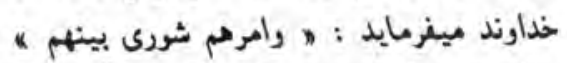

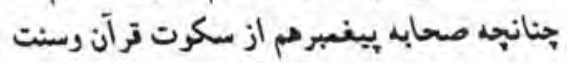

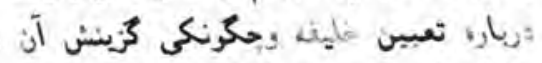
واز اين امرخداوند كه ( وامر مث شورى بينهم)

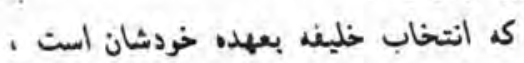

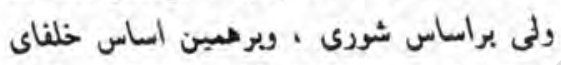

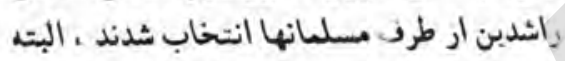

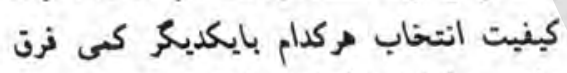

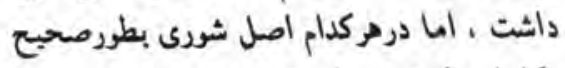

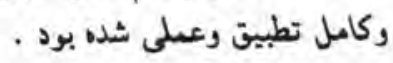

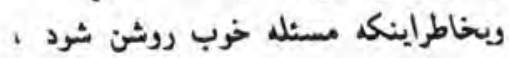

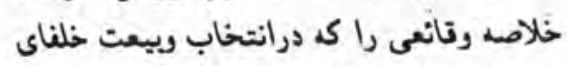

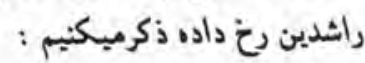

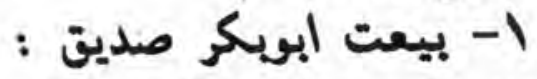

بعد از وفات يبغبر اكربحلى الله عليه وسلم

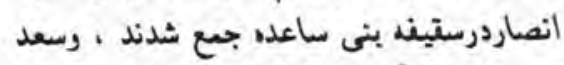

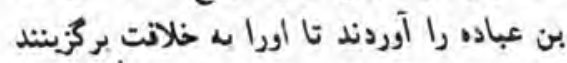

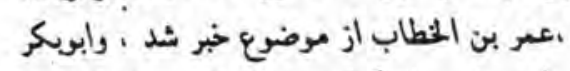

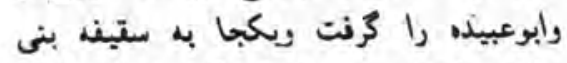

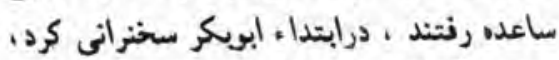

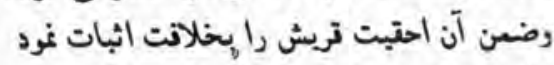

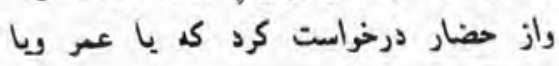
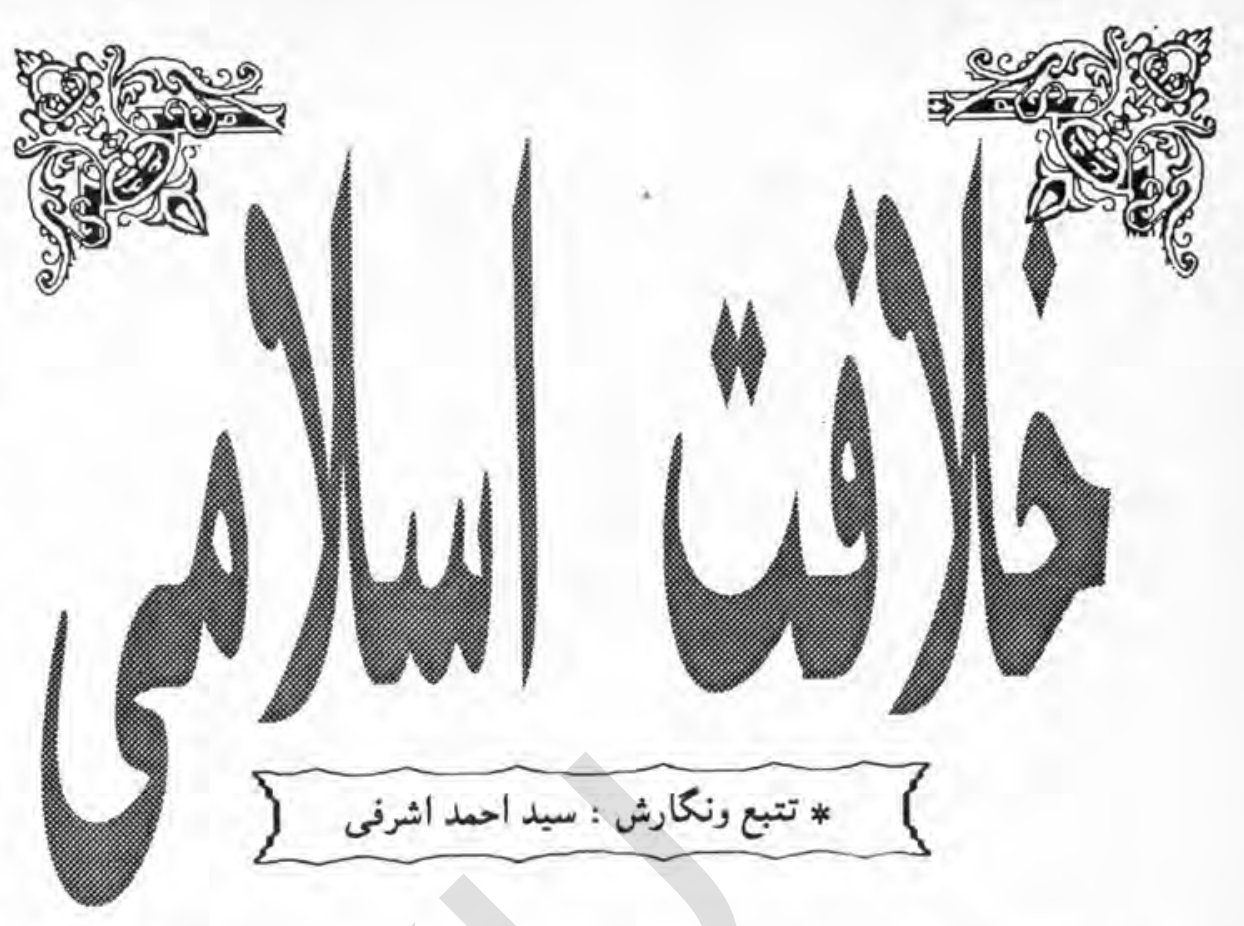

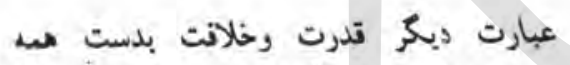

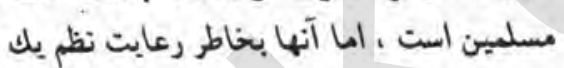

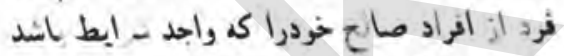

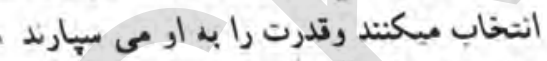

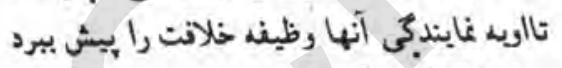

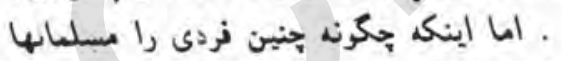

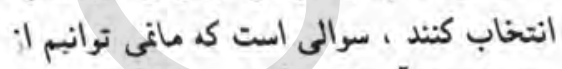

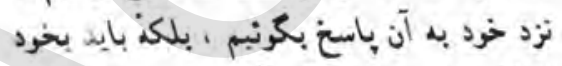

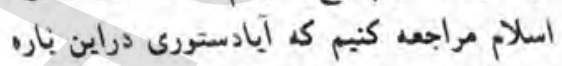

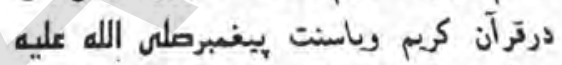

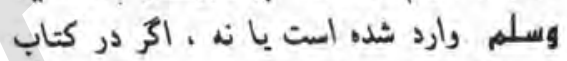

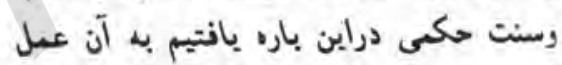

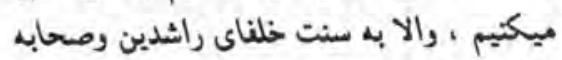

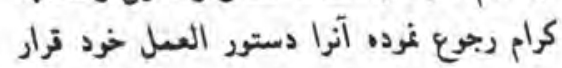

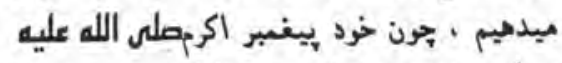

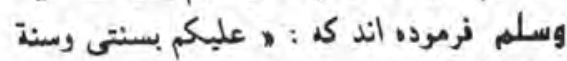

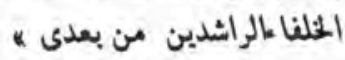

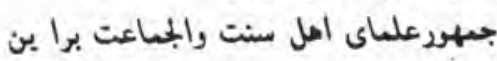

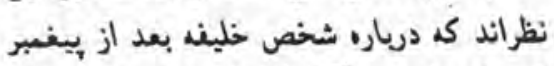

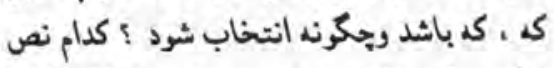
تطعى وارد نشده است ، رييغبر اسلام وفات أندات

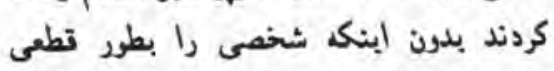

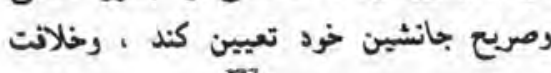

خدارند متعال درتر آنكيم ميذرمايد :

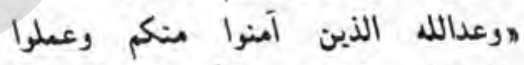

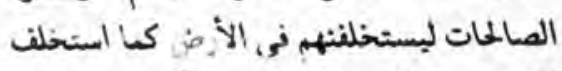

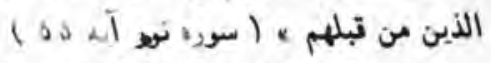

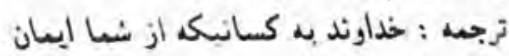

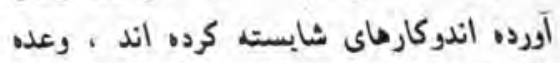

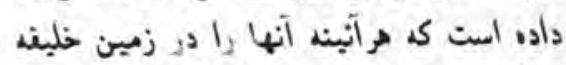

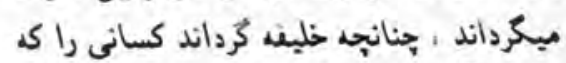

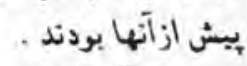

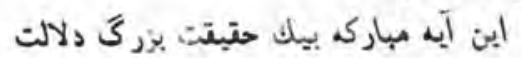
ميكند رآن اين است كه : خدأوند تمام مؤمنين

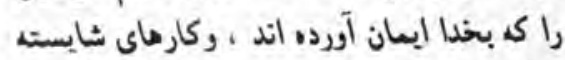

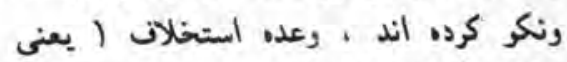

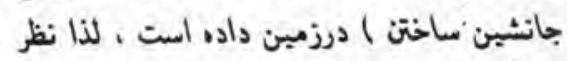

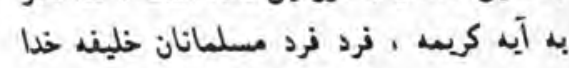

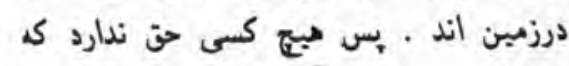

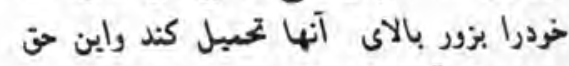

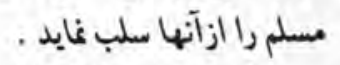

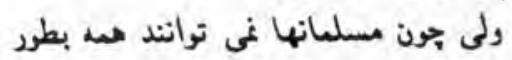

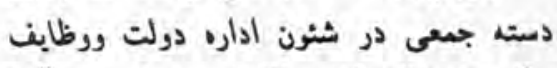

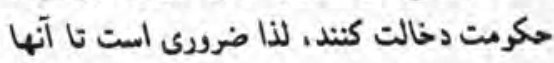

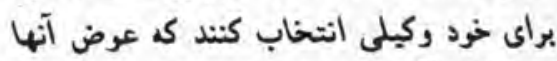

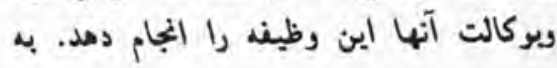




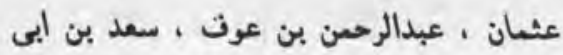

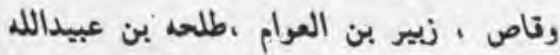

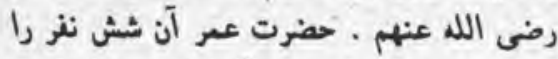

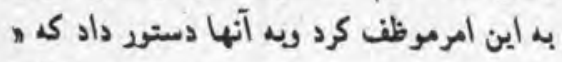

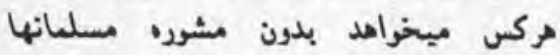

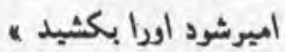

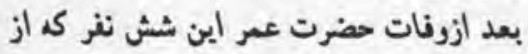

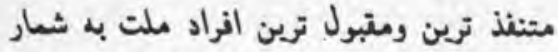

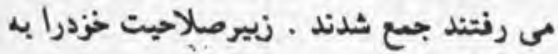

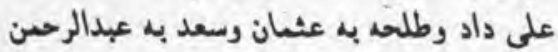

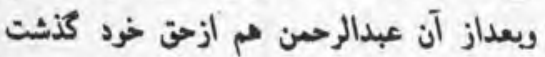

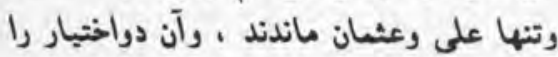

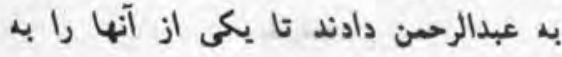

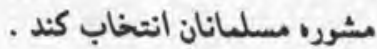

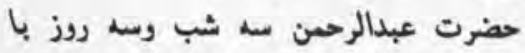

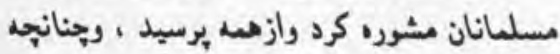
دربعضى روايات آمده است حتى بازنهاى خانه

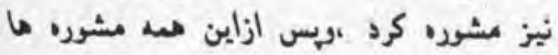

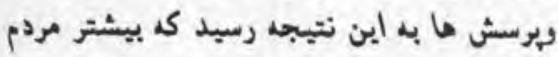
بحضرت عثلن ميل دارند ، بنابر اين عثلان

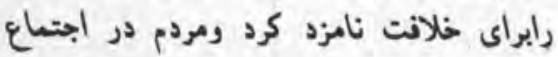

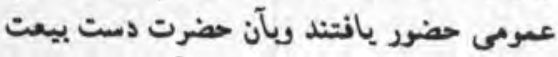

(ع) إناند

دراينجا مـ ميبينم كد عمر كسى را بمردم

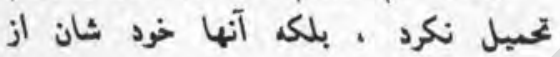

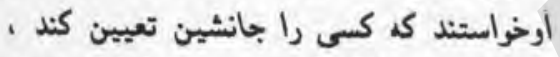
وار شش نغررا كه از بهترين مسلمانان بودند

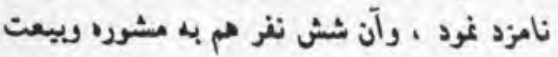

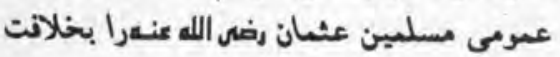

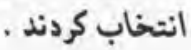

\section{: le}

وتتيكه حضرت عثان به شهادت رسيد صحابه

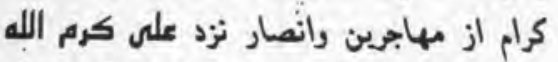

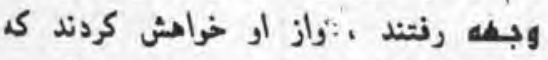

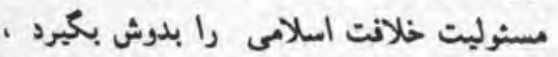

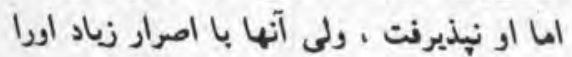

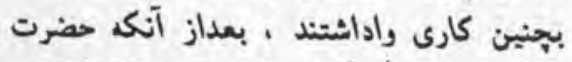

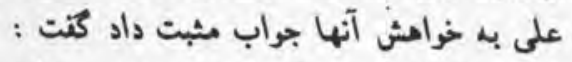

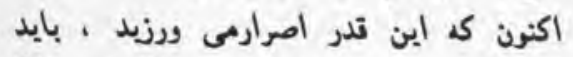

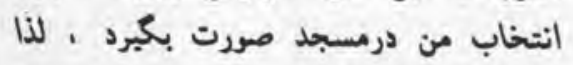

دراينجا مى بينيم كم ابوبكركدام خويش

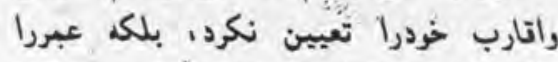

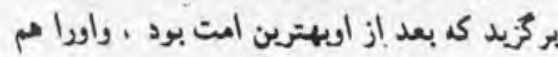

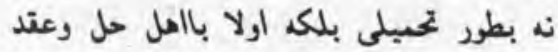

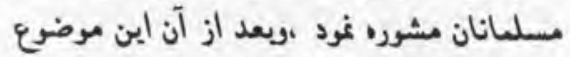

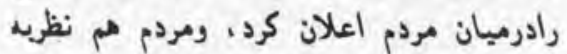

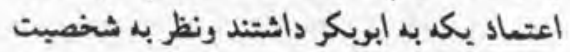

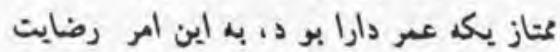

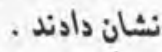

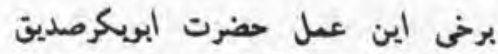

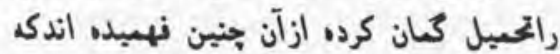

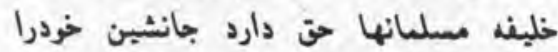

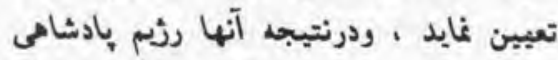

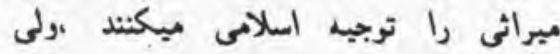
جنانهه ازتعن در روايات تاريخى نهيدا

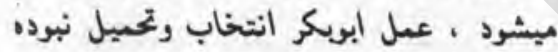

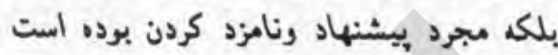

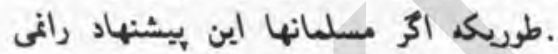

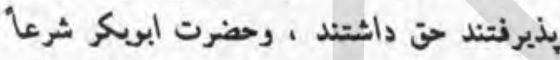

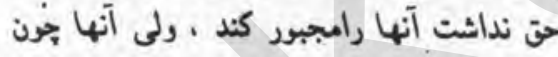

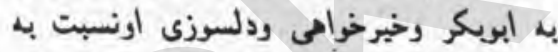

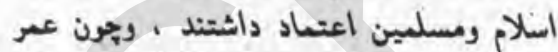
راجد شه شرايط خلانت بود لذا مسلمين اين ودين

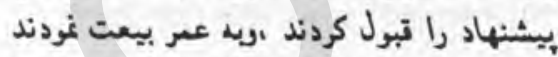
وخلانت حضرت عبر شرعا ورسا وتنى ثابت

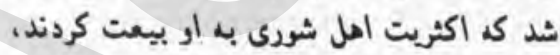

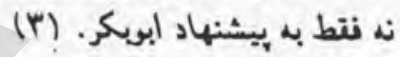

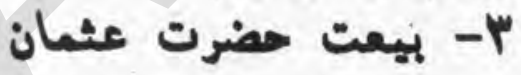 رضى الله عنه :}

وتتيك حضرت عمر زخم برداشت

مسلسانان از او تقاضا كردندكه شخصى رات

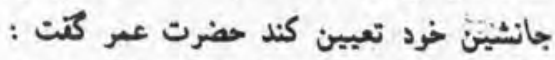

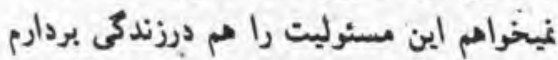

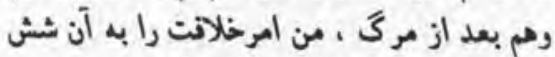

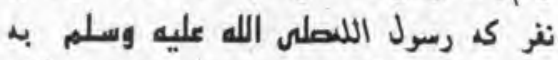
بهشتى بودن آنها شهادت داده است واز آنها

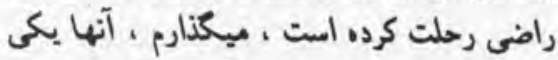

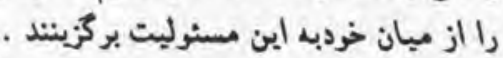

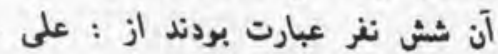

ابوعبيده رأ منحيث خليفه انتخاب نايند ،ولى

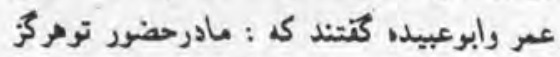
اين وظينه رابدوش نيكيريم زيرا توازيد

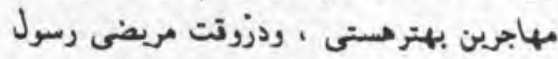

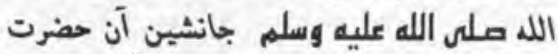
درنماز شده بودى ، بس تويه اين مقام حقدار

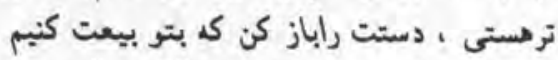
، حضرت ابربكر صديت رضى الله تعالى عند

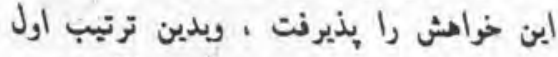

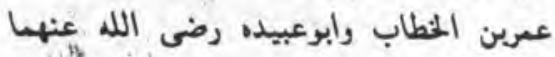

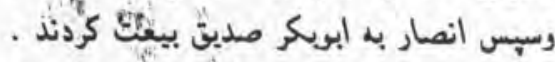
يك روز بعد حضرت ابوبكر صدينت رضس الله

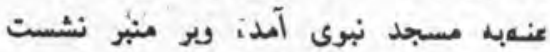

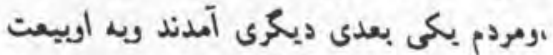

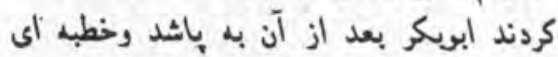

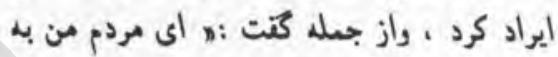
رياست شا بركزيده شدم واز شار بها بهترنيست

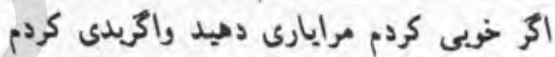

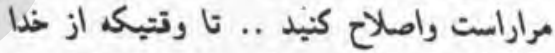

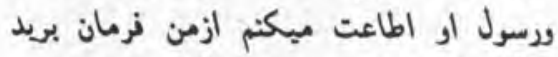

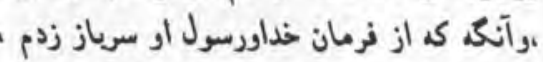

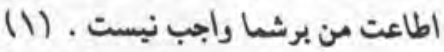

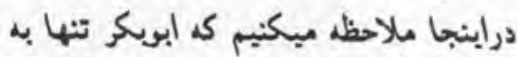

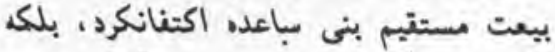
بيعت عاله مسلمين را نيز بدست آرورد . بئي

\section{Y- بيعت عمر بن الحطاب}

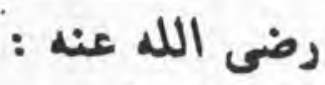
وتيكه ابوبكر صديت مريض شد راحساس

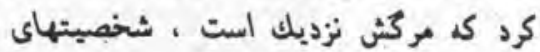

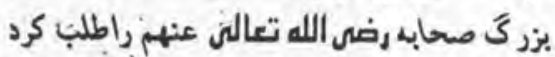

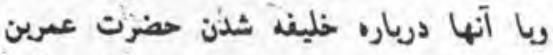

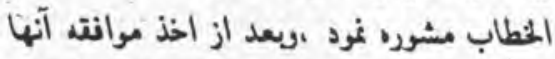

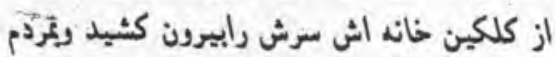
كه دراطران خانه جسع شده بودند كنت :

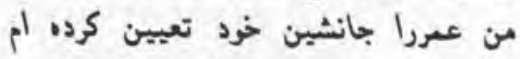

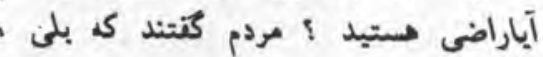
مسجنان إين مطلب رادرمكتوين نوشت وامركرد

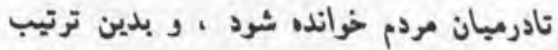

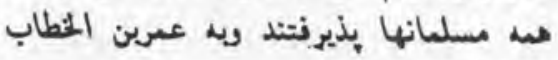

(Y) بيعت كردند 


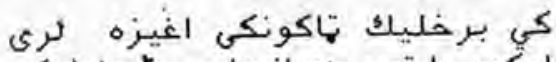

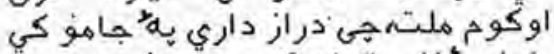

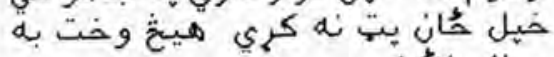

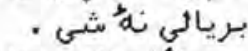

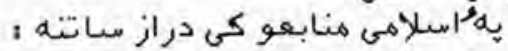

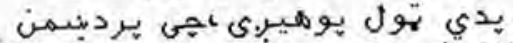

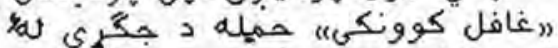

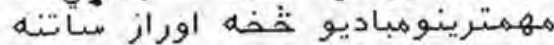

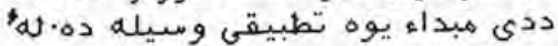

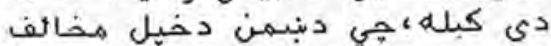

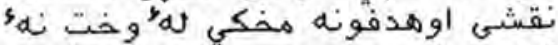

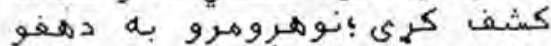

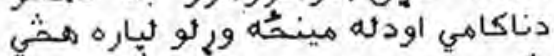
راز ساتنه،ي دهروسنلمان دغوره

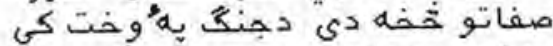

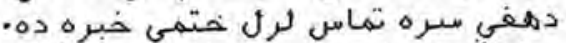

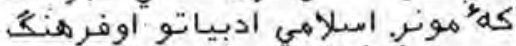

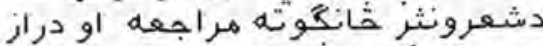

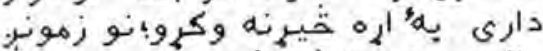

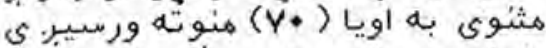

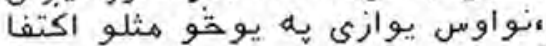

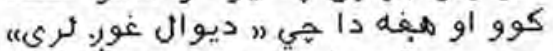

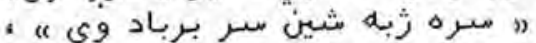

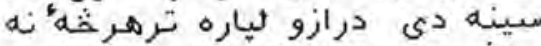

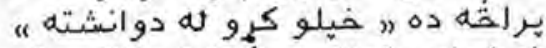

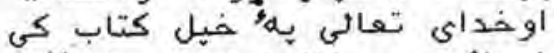

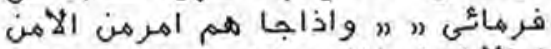

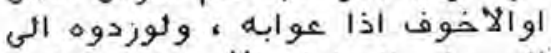

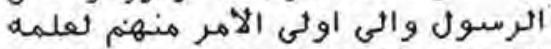

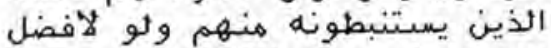
الله عليكم ورحمة لاتبعتمتهم الشيطان

الا قليلالان

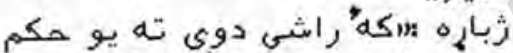

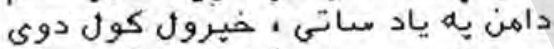

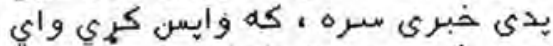

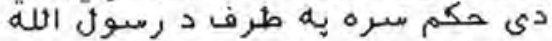

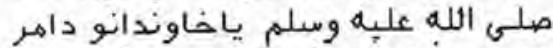

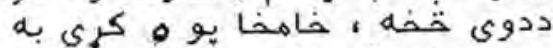
واي هغd كسانه

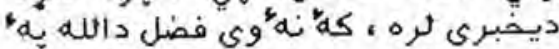

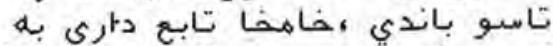

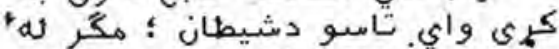

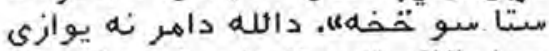

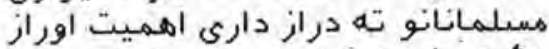

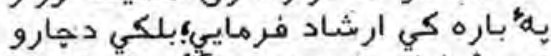

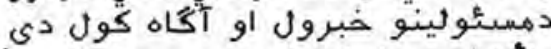

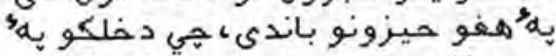

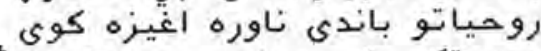

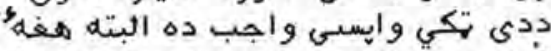

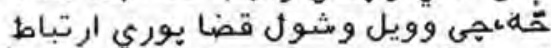

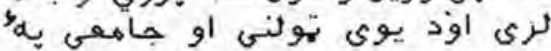

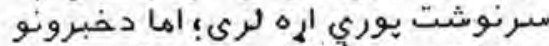

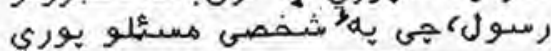

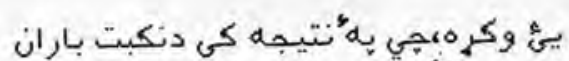

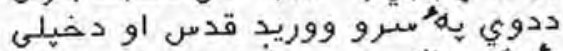

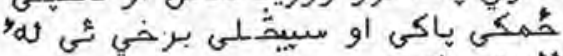

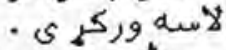

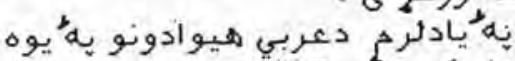

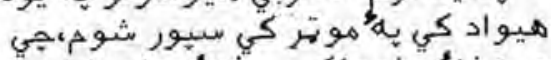

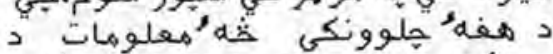

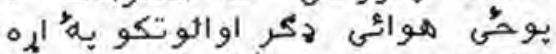

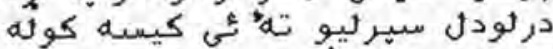

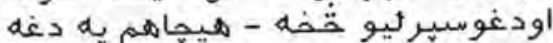

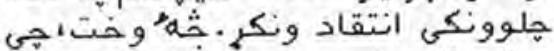

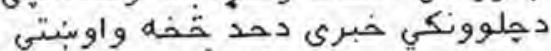

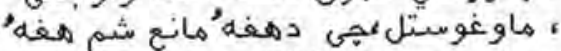

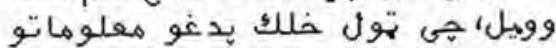

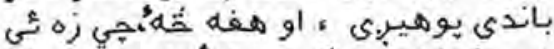

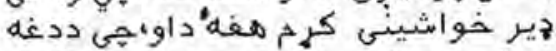

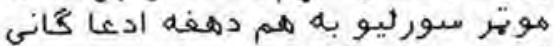

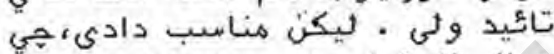

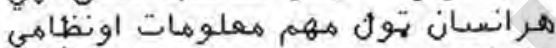

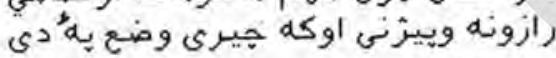

\section{داسرائبل بوحى مسرٔلبنر اعلاز وكر \\ كن مهترين اسباب،جي بر عريو باندى دورى دكامبابي سبب ركُُبيل، داسرائبل استخبارانى نتش ار رولؤ.}

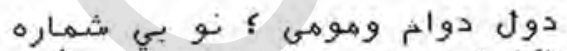

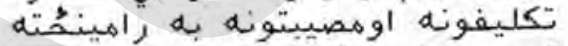

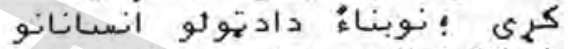

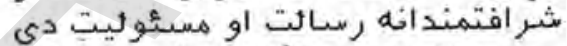

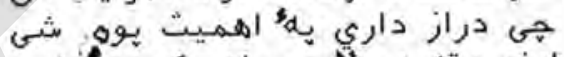

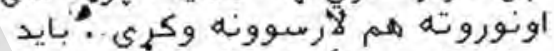

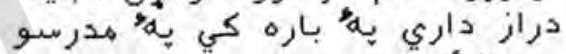

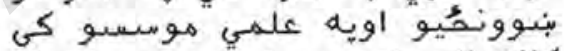

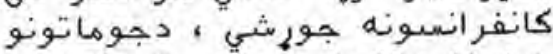

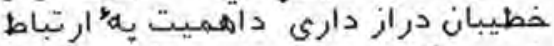

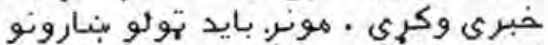

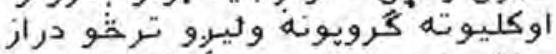

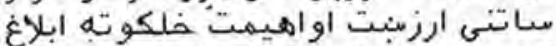

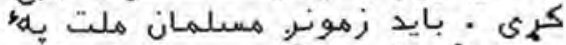

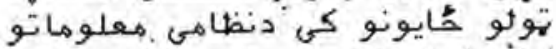

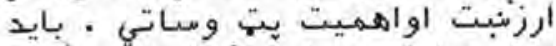

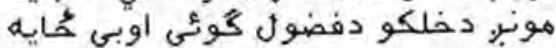

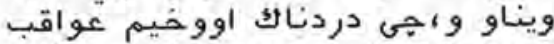

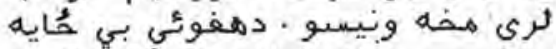

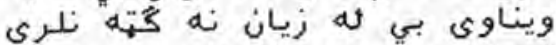

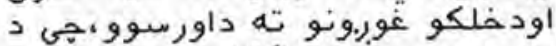
رازداري مسئله يهُكاهيابى اوناكاهى

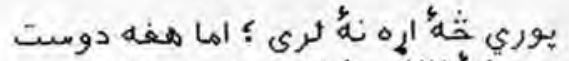

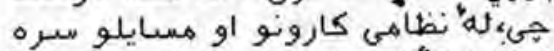

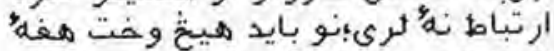

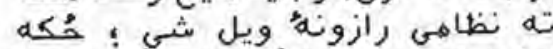

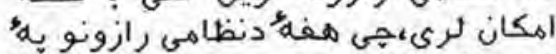

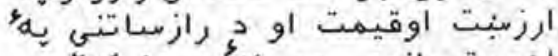

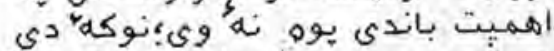

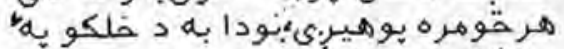

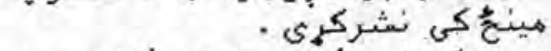

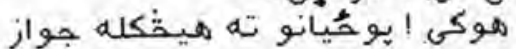

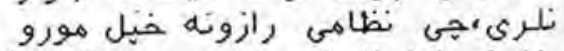

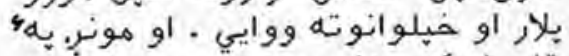

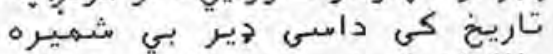

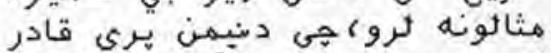

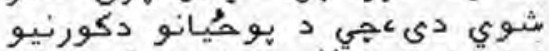

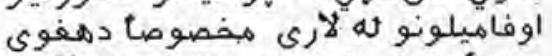

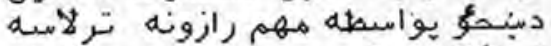

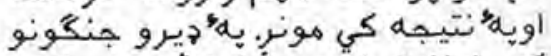

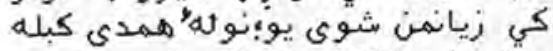

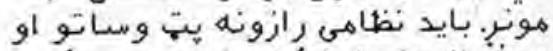

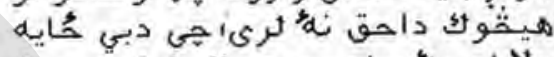

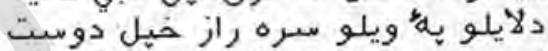

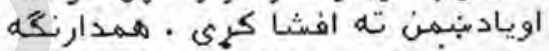

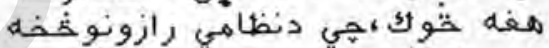

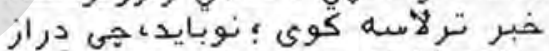

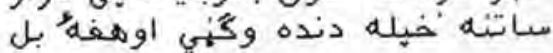

\section{ماته افشا نة كُكرى}

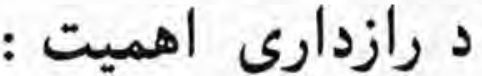

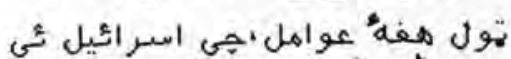

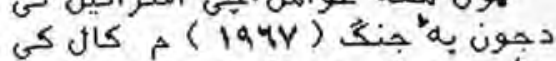

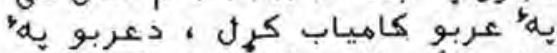

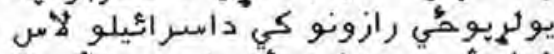

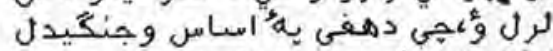

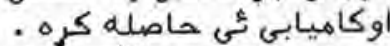

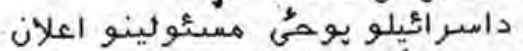

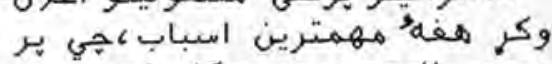

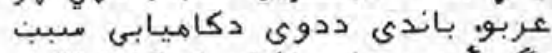

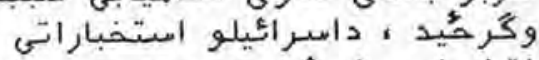

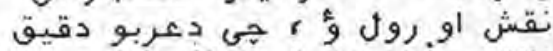

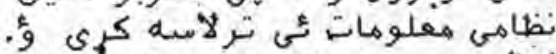

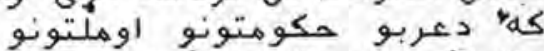

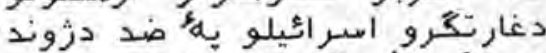

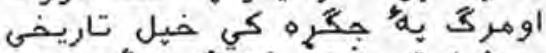

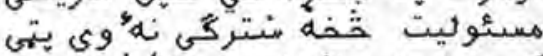

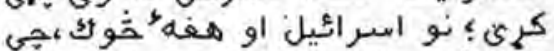

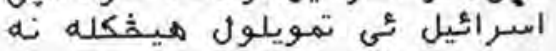

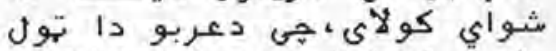

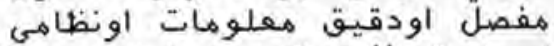

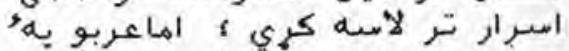

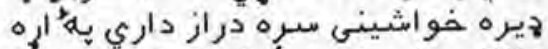

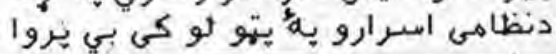




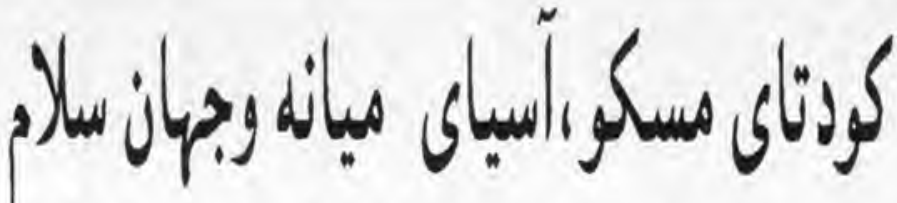

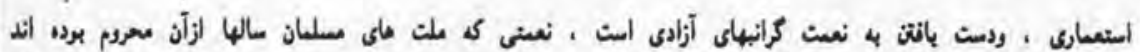

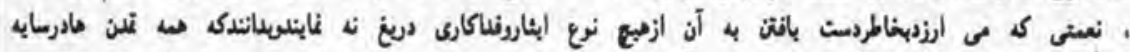

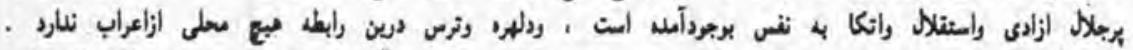

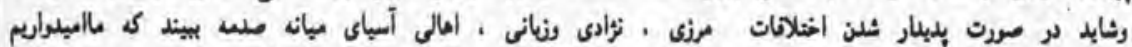

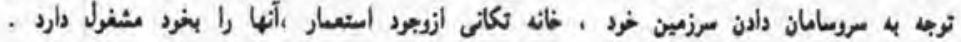

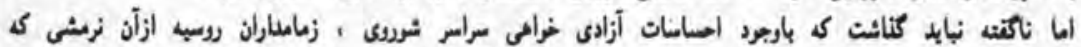

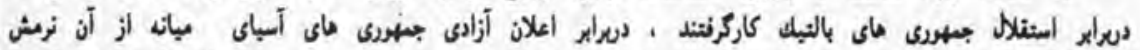

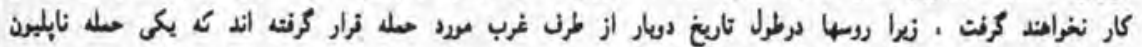

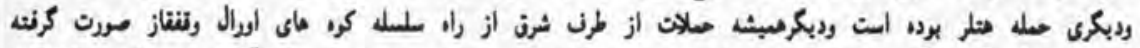

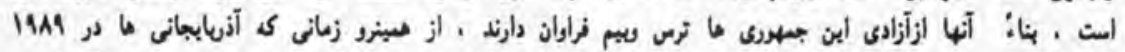

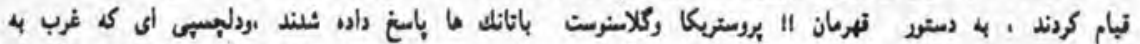

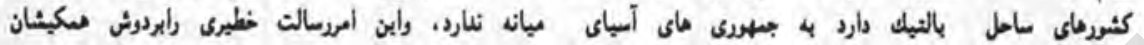

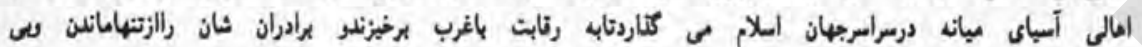

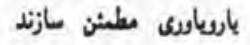

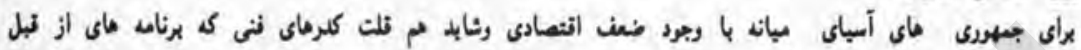

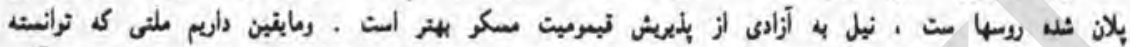

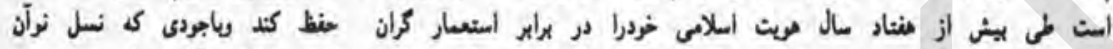

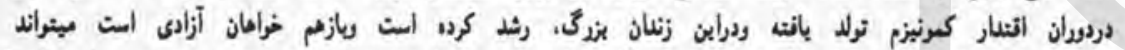

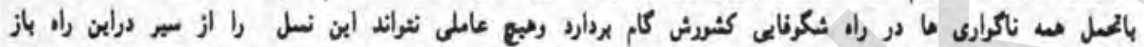

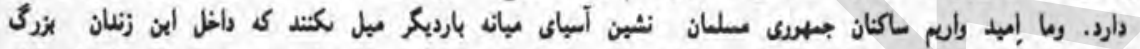

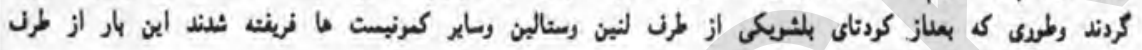

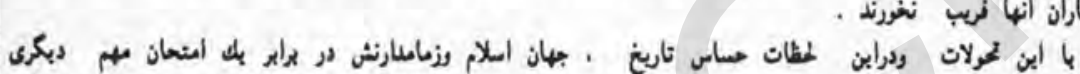

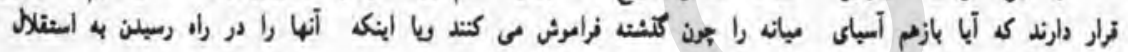

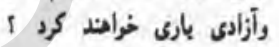

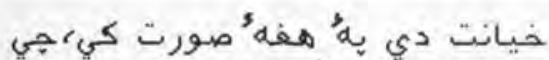

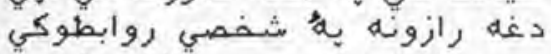

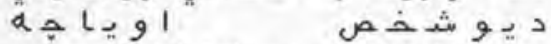

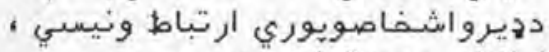

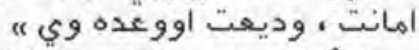

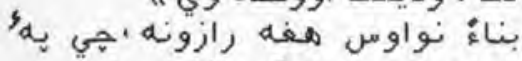

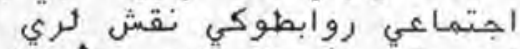

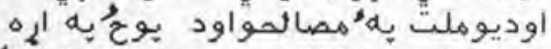

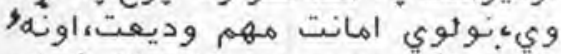

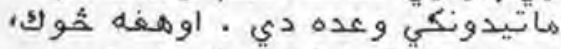

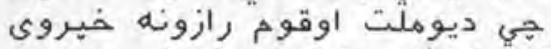

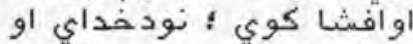

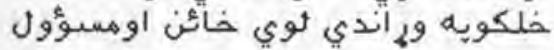
$\cdot{ }^{2}$ -

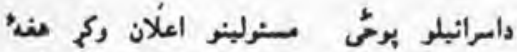

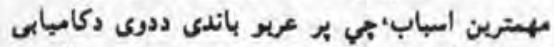

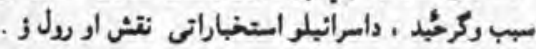

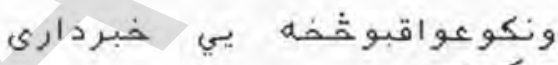
- وركيماندو

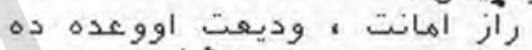

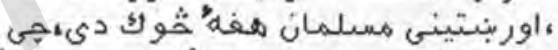

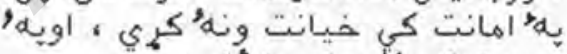

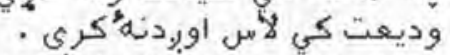

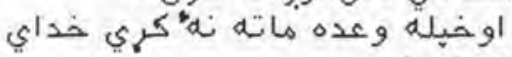

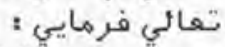

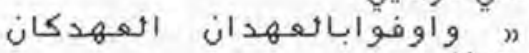

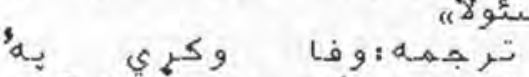

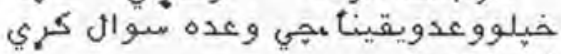

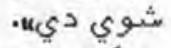

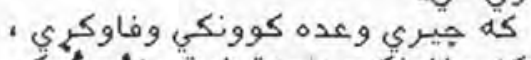

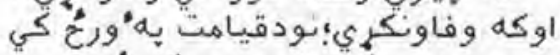

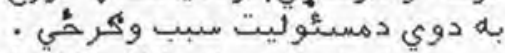

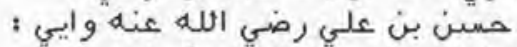
" دخيل وروررأزافشاء كول يوقسم
هربوط وى ، تجسس دى ، ، اويةٌ هيخة

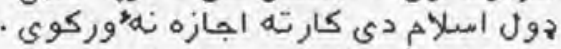

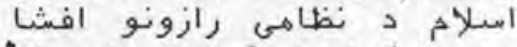

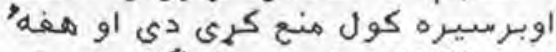

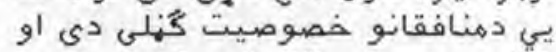

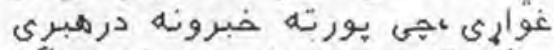

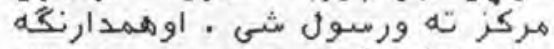
دائى تأئيد كري لئه

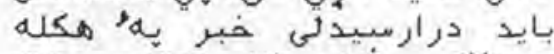

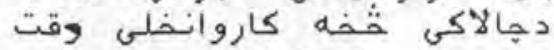

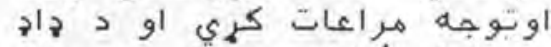

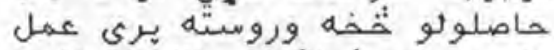

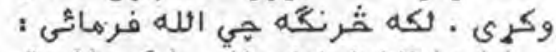

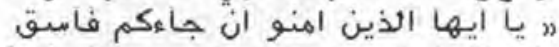

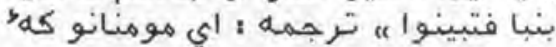

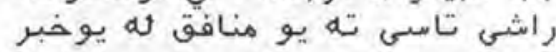

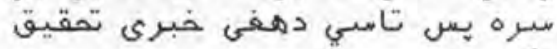

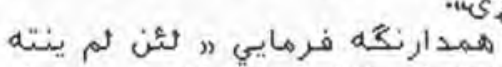
45 .

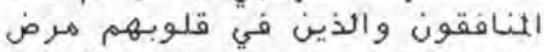

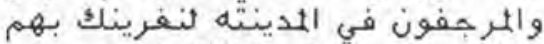

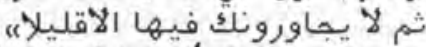

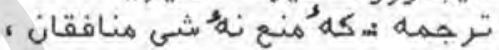

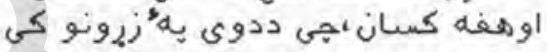

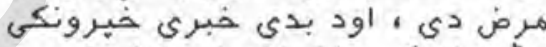

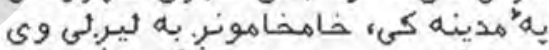

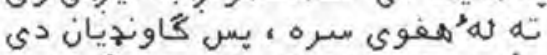

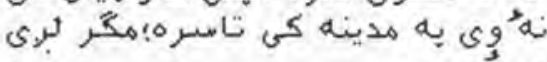
ورى

رسول اكرث صلئى الله عليه ومسلم

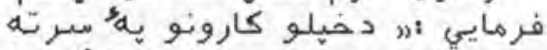

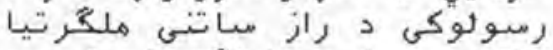

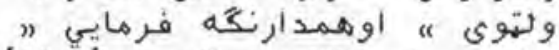

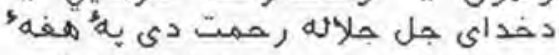

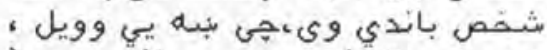

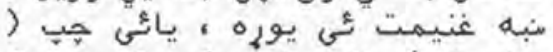

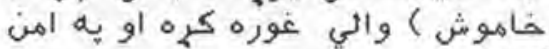

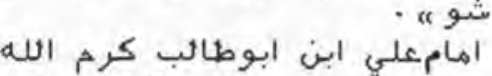

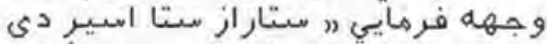

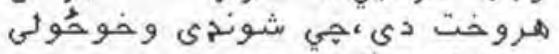

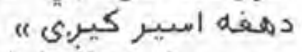

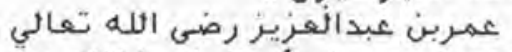

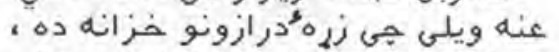

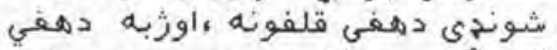
كلى كانى دى دى أنوهر مسرى

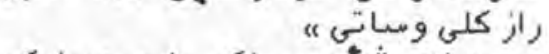

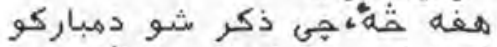

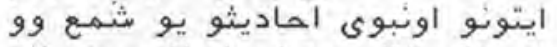

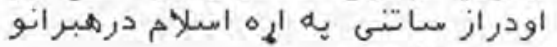

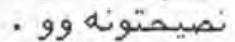

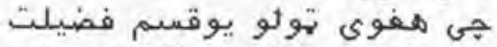

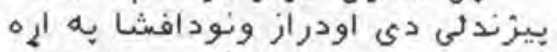

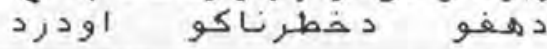




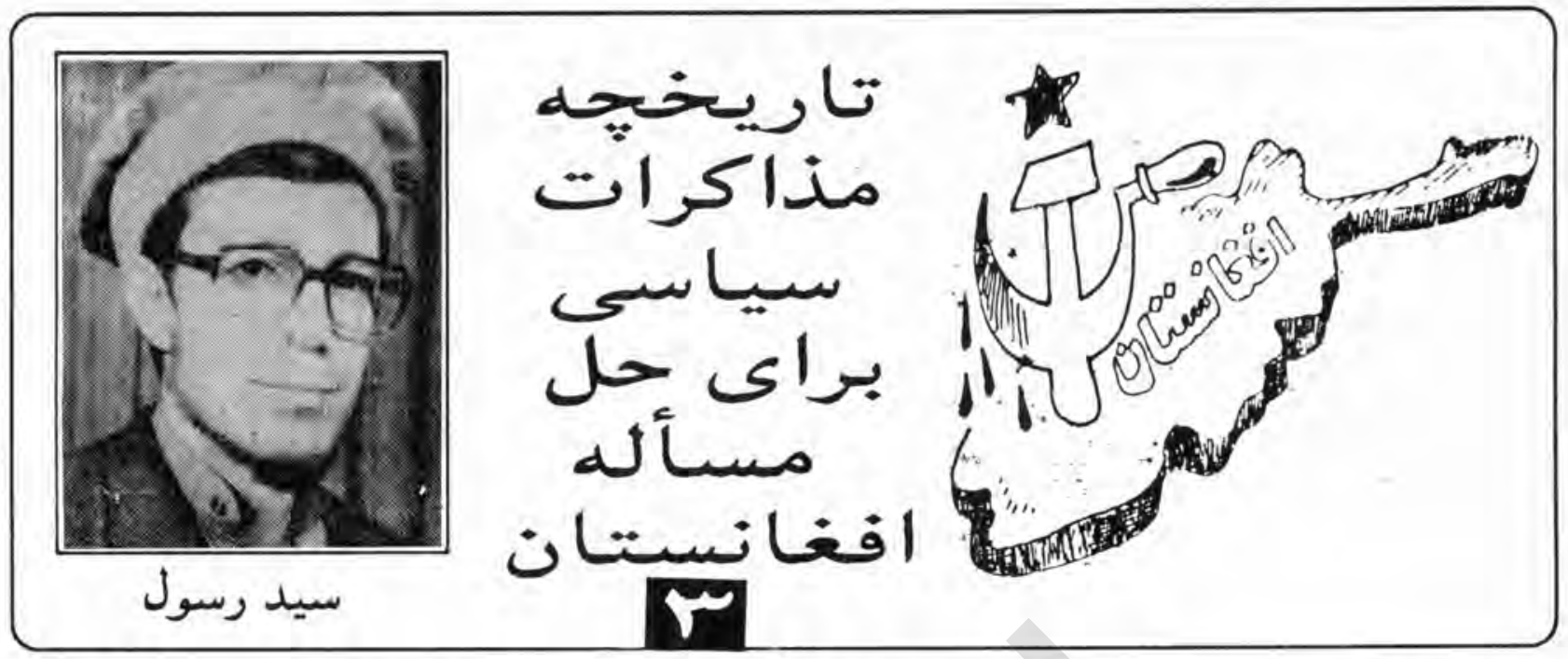

كابل نكر مبكرد كه در مورد سه اصل مطروحه خرد شان با باليا

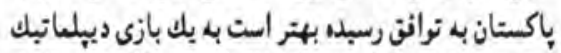

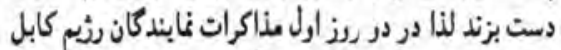

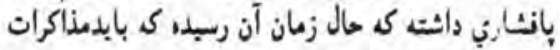

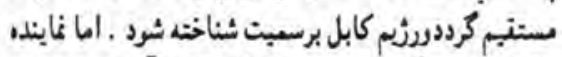

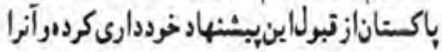

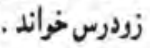

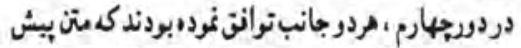

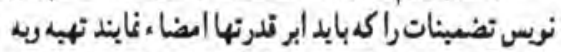

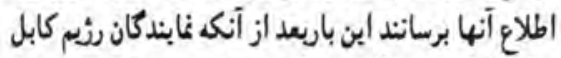

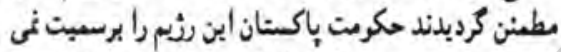

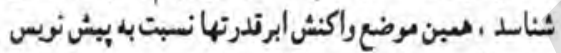

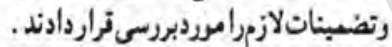

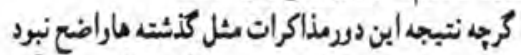

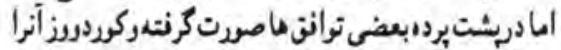

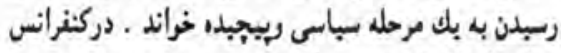

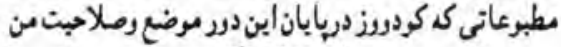

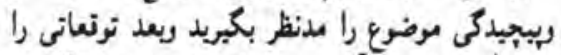

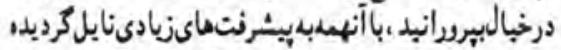

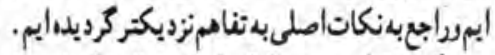

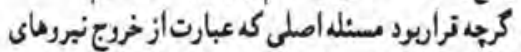

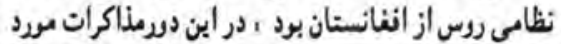

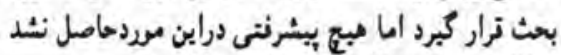

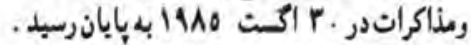

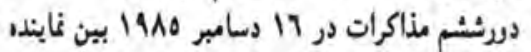

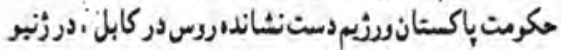

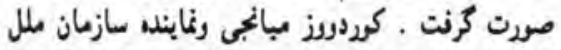

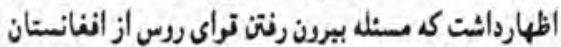
وارائه جدول زمانى اين اتدام ازععدا ترين مسانل اين فردي أنغان

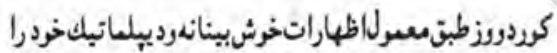

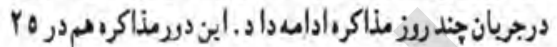

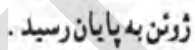

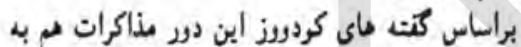

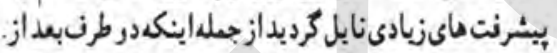

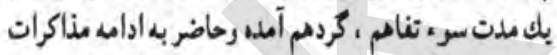

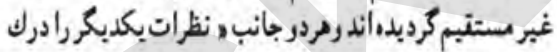

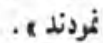
هان كودورن ك نبلا خوش بين بود رنكرميكرد

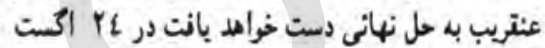

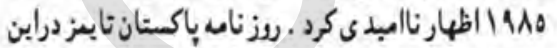

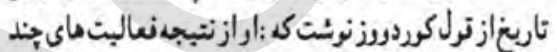

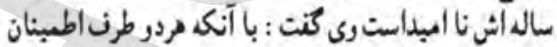

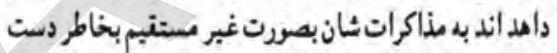

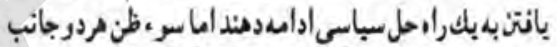

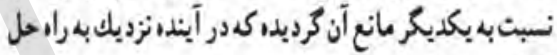

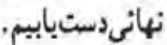

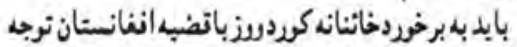

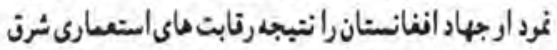

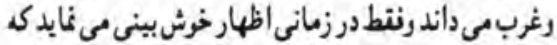

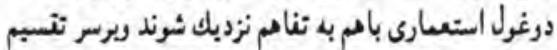

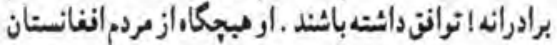

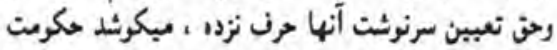

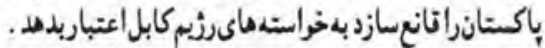

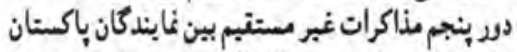
درئ كعرنبستى كابل در YV اكست آغازشد

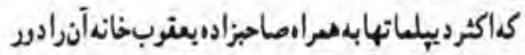

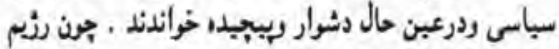

درسوم مذاكراتغير مستنبمرئبودريارهانغانستاندر

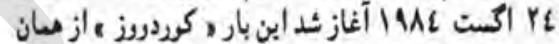

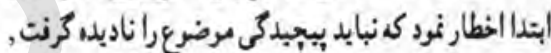

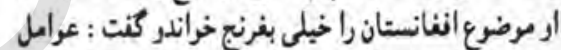

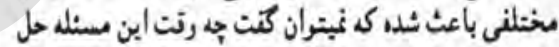

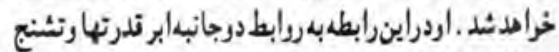

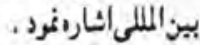

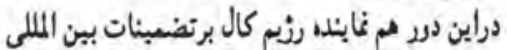

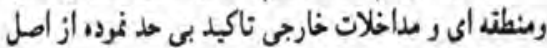

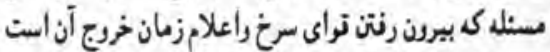

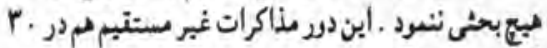
اكتَت بإبانيانت.

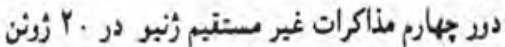

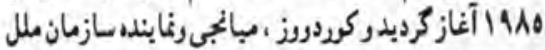

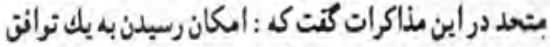

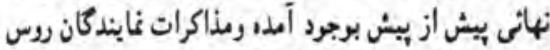
رامريكا مر ابن اميدرارى را بيشتر سانته أست ، نمايندكان

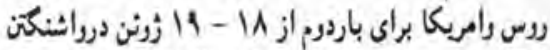

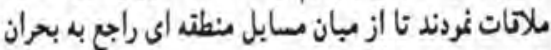

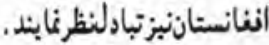

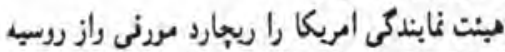

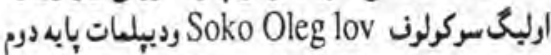
سفارتروسدرامريكا بولي البسبي

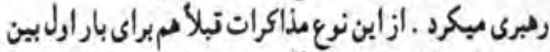

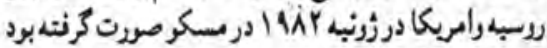

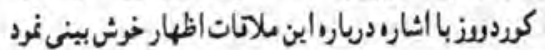

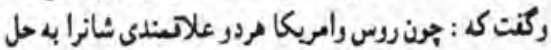

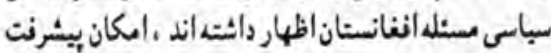
هائزيادى دراينزمينهرجود دارد . 


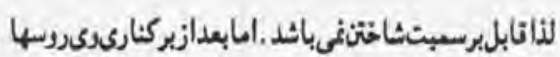

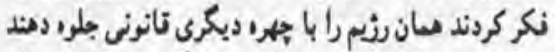

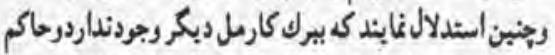

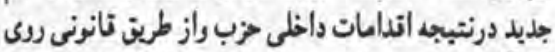

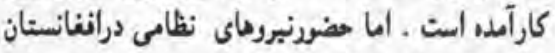

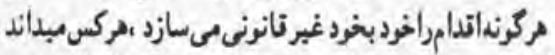

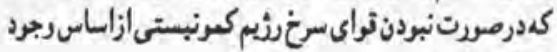
نخواهذداشت. تبل از آغاز دورنته مذاكرات غيرمستتبر در زنبر

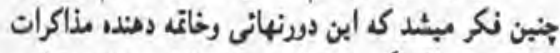

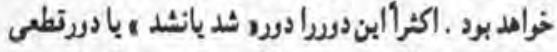

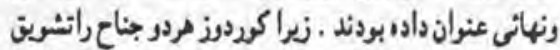

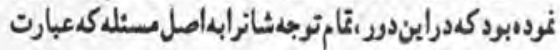

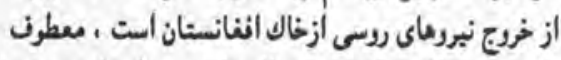

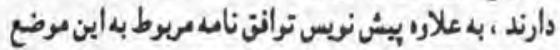

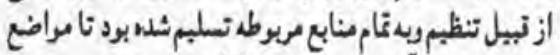

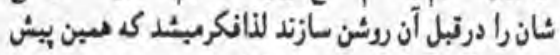

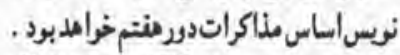

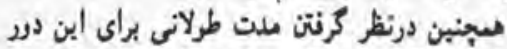

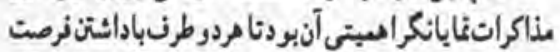
كافى راجع به اصل موضوع بعنى اخراج تراى روسى ورتمام

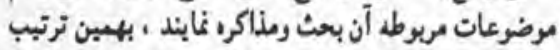

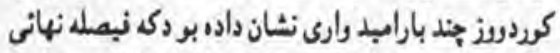

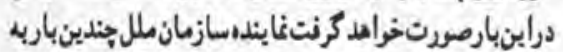

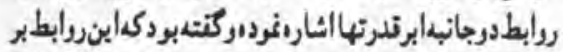

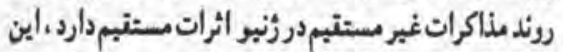

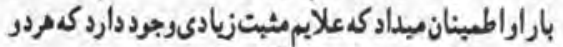

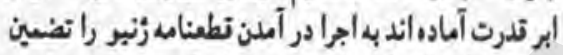

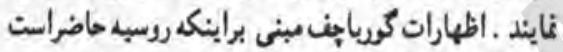
نبروهاي نظامى اش را از انغانستان بيرون بيرد رهبنينين

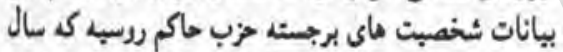

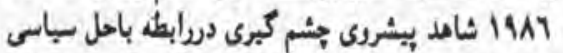

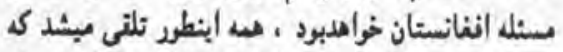

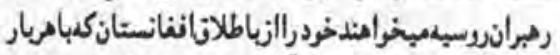

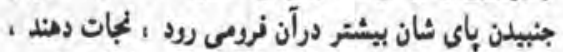

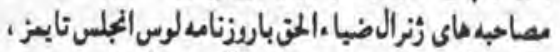

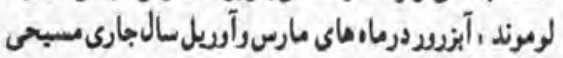

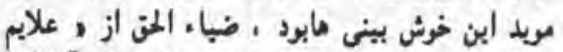

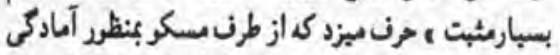

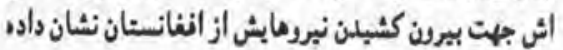

دروهنت مذاكرات غيرمستنيم بين نمابندكان حكومت

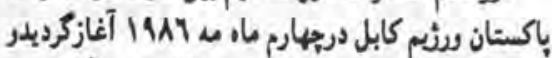

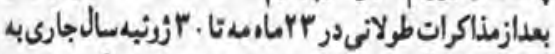

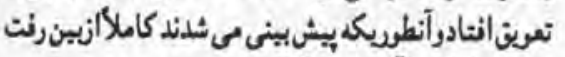

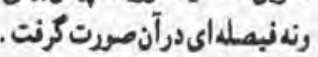

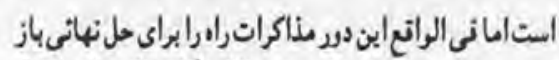

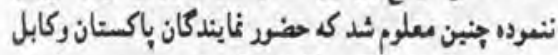

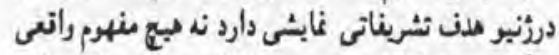
ديحرى . جناح كابل بد صورت مذاكرات مستنيم ناكيد دارد

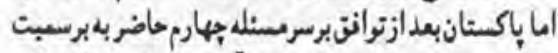

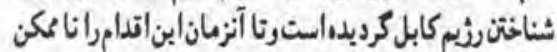

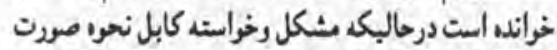

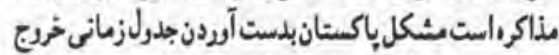

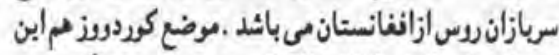

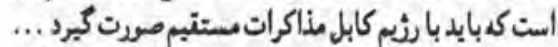

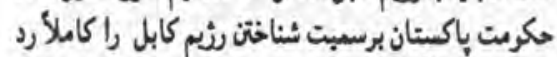

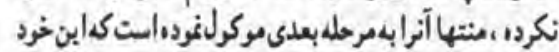

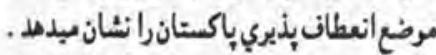
مسيله صورت مذاكرت كى يكى ازعلتهاى بإيان يانتن

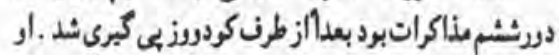

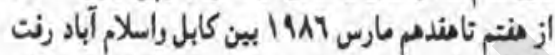

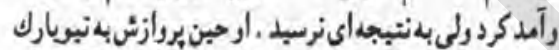

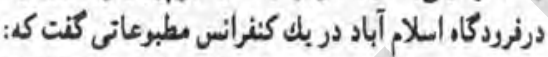

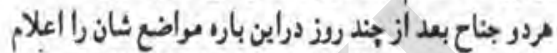

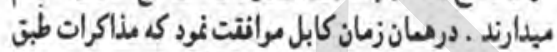

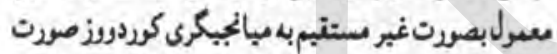

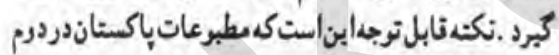

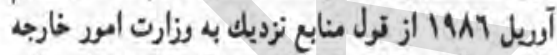

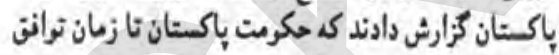

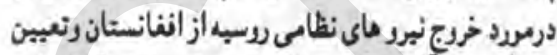

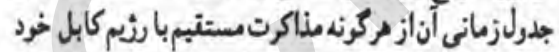

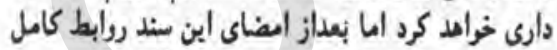

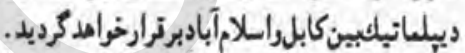

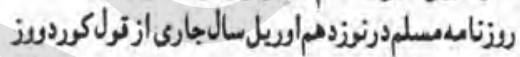

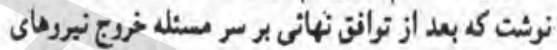

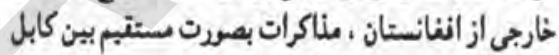

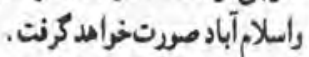

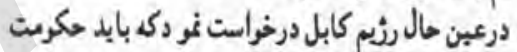

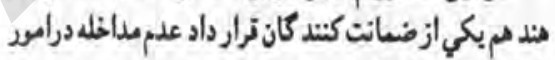

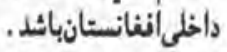

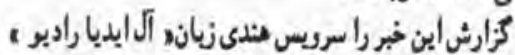

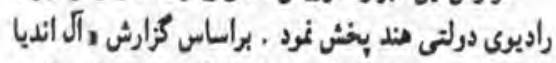

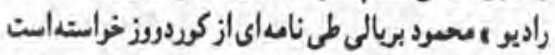

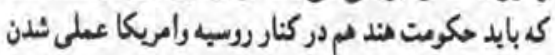

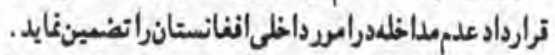

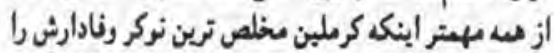

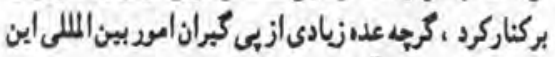

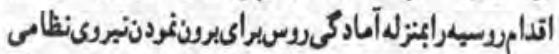

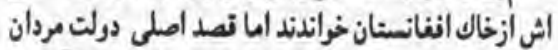

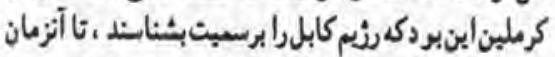

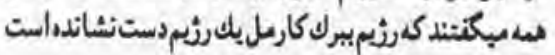

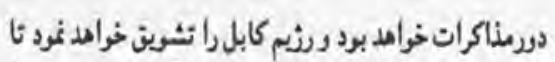

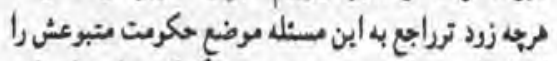

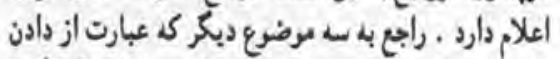

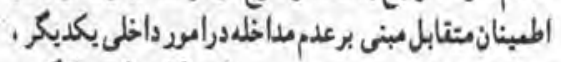

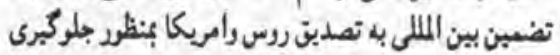

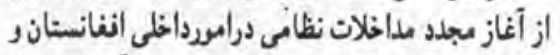

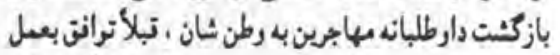

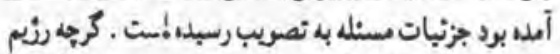

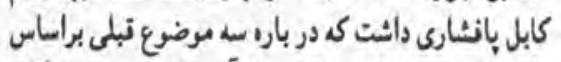

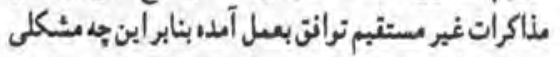

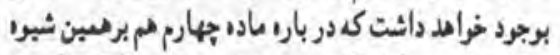

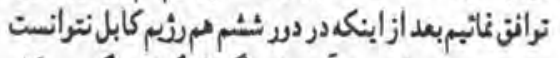

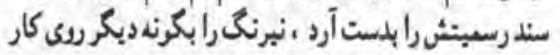

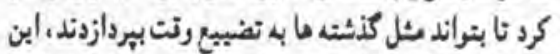

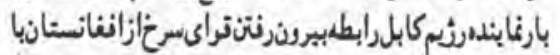

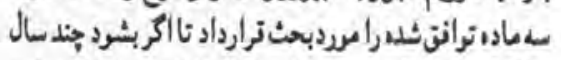

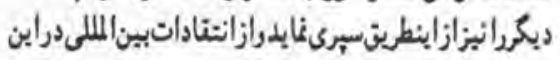

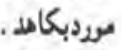

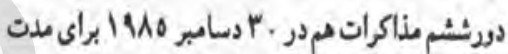

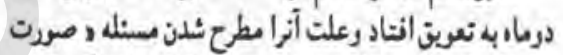

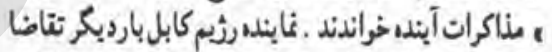

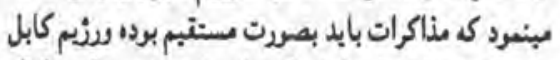

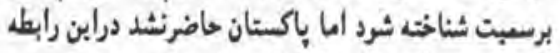

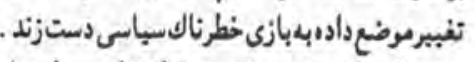

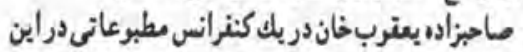

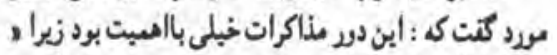

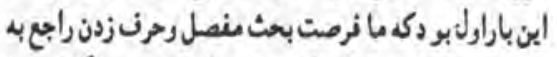

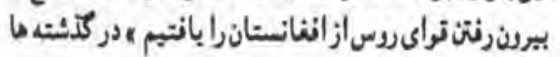

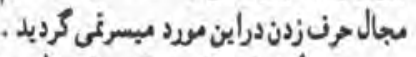

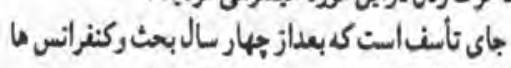

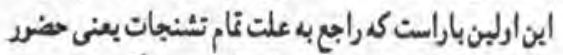

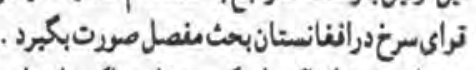

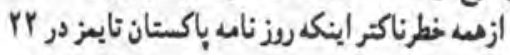

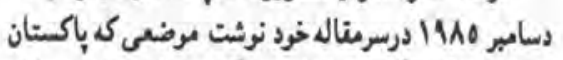

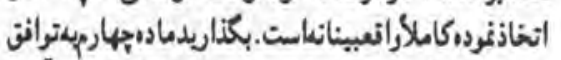

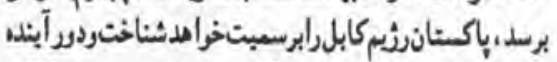

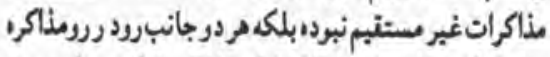

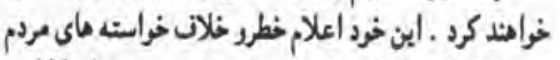

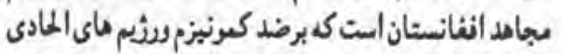

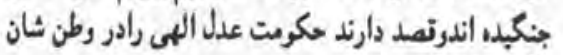

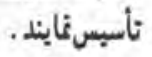

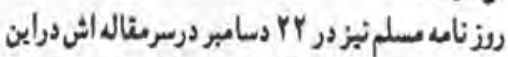

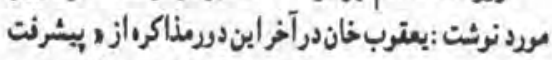

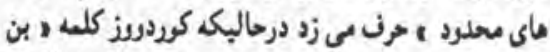

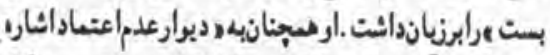
نمرد . كريه آشتى دادنيا اين نوع الظهارات مثناتض مشكل 
مسنله دخالت ندارند . مجاهلين كه س مردم انغانستانرا

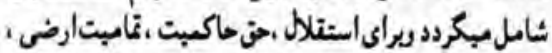

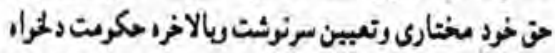

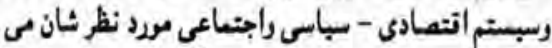

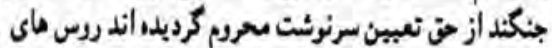

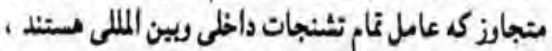
تنها به عنوان يكى از تلدرتهاى تضعين كنتلدها اجراي مرانتي

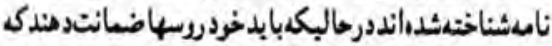

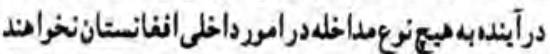

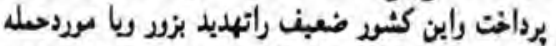

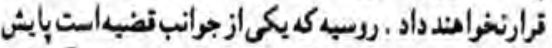

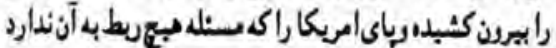

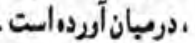

دخالت نداشتن مباهدين درتضبه رمذاكرات مشكل

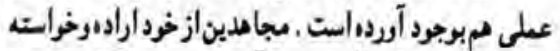

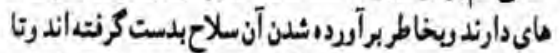

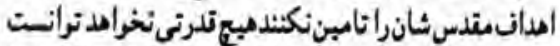

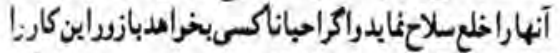

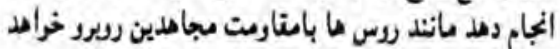

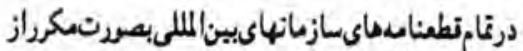

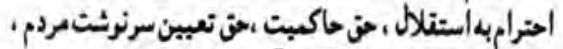

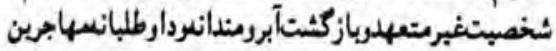

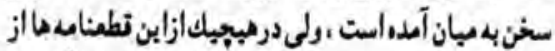

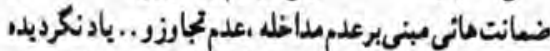

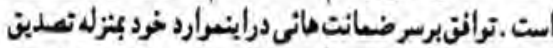

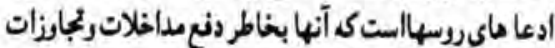

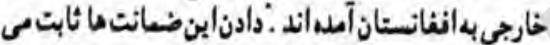

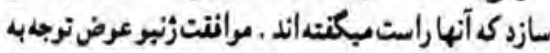

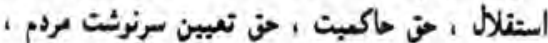

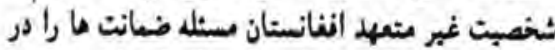

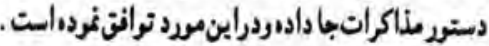

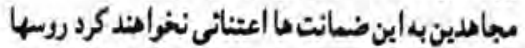

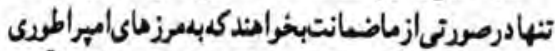

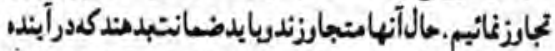

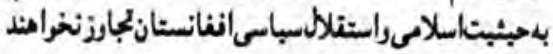

كرجهاما اميد رانتظارى ازمذاكراترينر نداريباما با اين

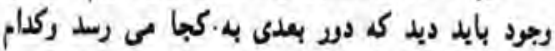

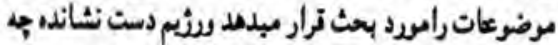
نيرنكهايديكرانرابكارميبرد.

والسلام

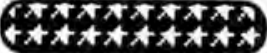

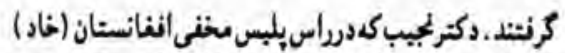

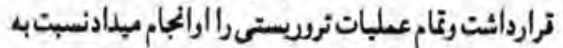

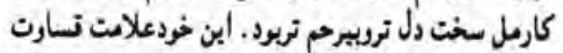

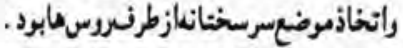

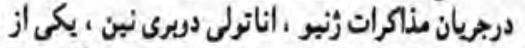

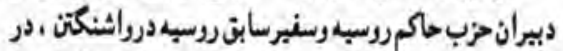

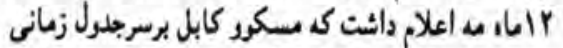

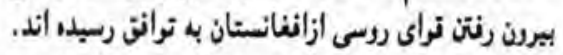

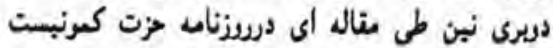

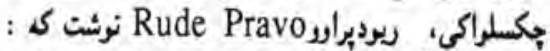

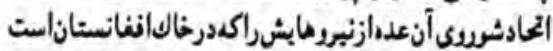

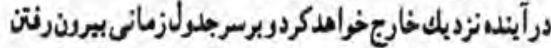

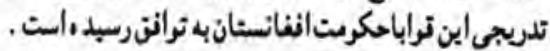

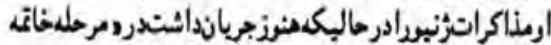

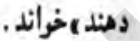

اماديايان مذاكرات معلوم شدك اين اظهارديرى نبن

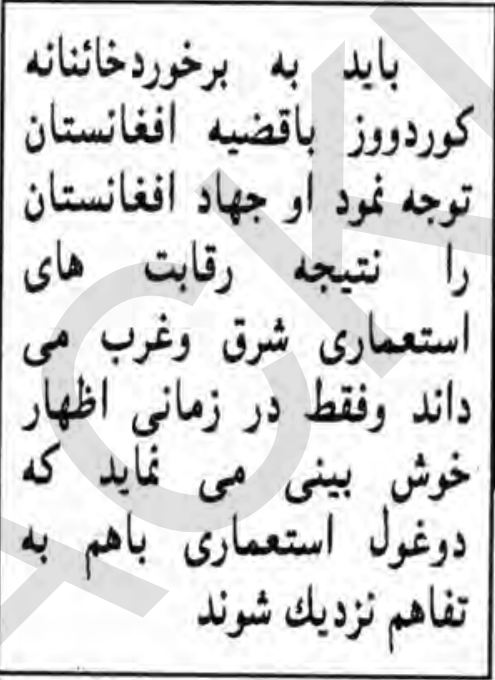

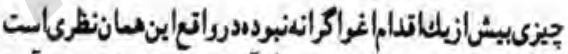

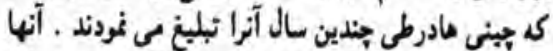

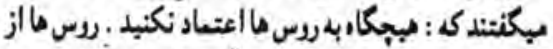

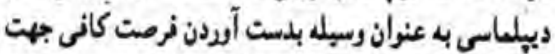

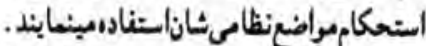

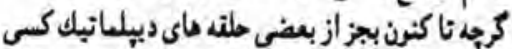

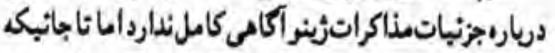

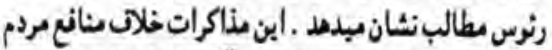

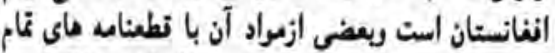

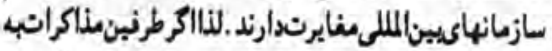

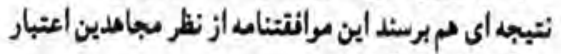

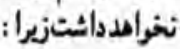

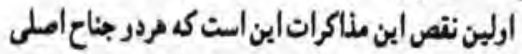
تضبه بعنى مباهين دروس هاى منجانز درنيصله دادن
موضوع عدده مردبحث دراين اجلاس خروج نيررهاى

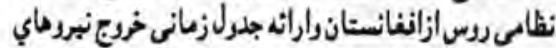

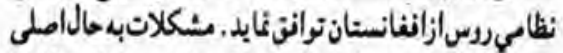

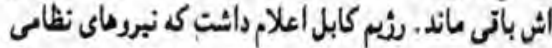

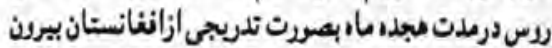

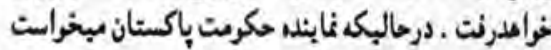

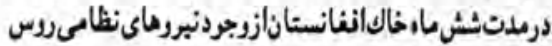
بالكردد. علارو برآن اين مم معلرم نبودكي عتب نشبنى توائ سرخ

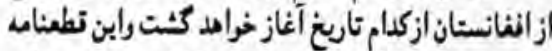

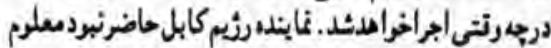

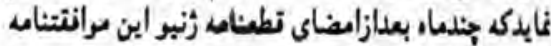

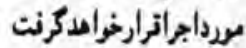

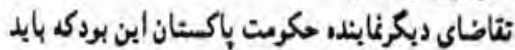

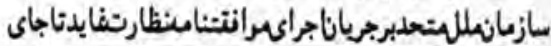

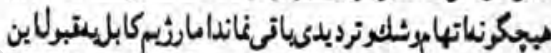

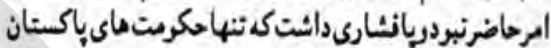

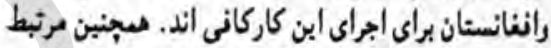

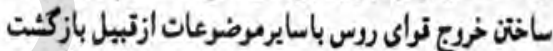

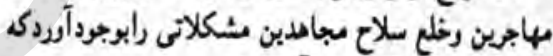

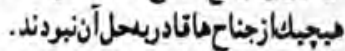

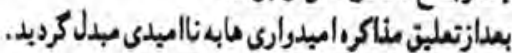

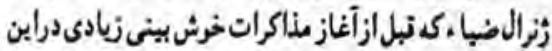

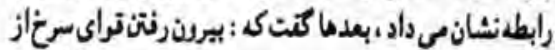

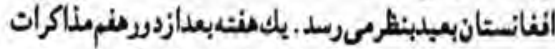

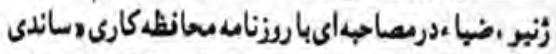

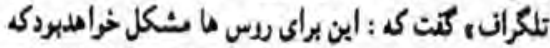

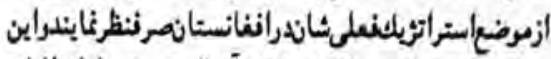

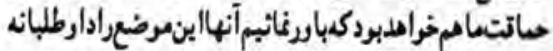

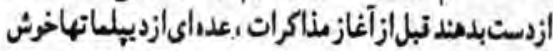

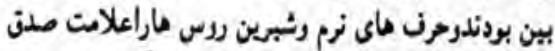
رصفاى سياس مسكرميدانستينداماعدن ديكرى واتع بينانه

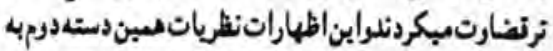

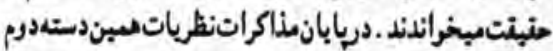

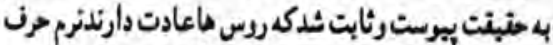

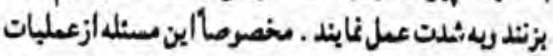

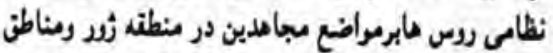

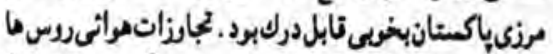

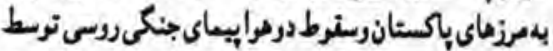

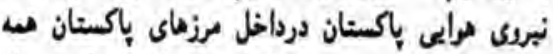

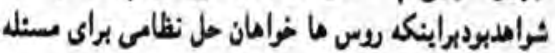
انفانستانهستند.

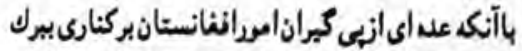

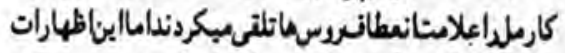

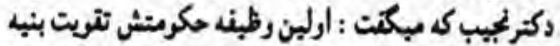

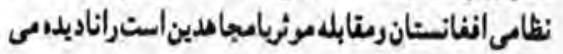


برتانك هامي جهند و ظرن رآتش زده زبر

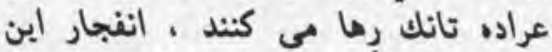

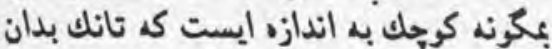
عظمت را با سرنشينان آن تك تك مي مي كي

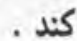
اين يسرك يدر شهيد ظلم روسهاى دشعن

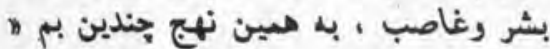

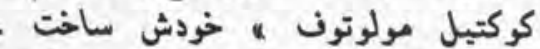

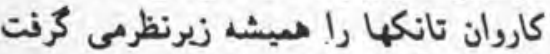

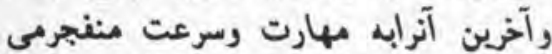

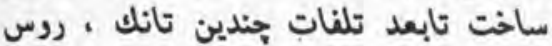

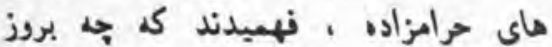
كارشان مى آيد آ... با احتياط وجشمان مسلح وتدابيرنامردانه

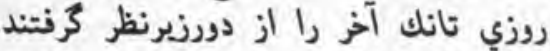

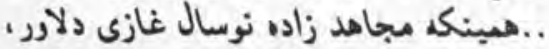

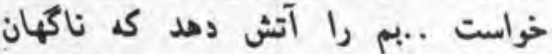
برخاكش انكندند وتانكها بر جسدش كذشت آنت

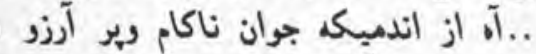

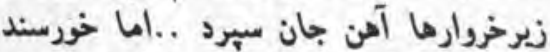
وراضى بودكه انتقام بدرخودرا بارها زئران

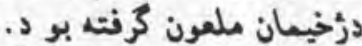
اين تصه نورى به كابل آتد رنقل محافل

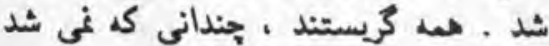
جلو اشك را كرفت . سر كنشت بـ ... جوجيد مجاهد وفرزند شجاع عبدالله برج خيلى

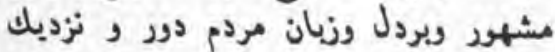

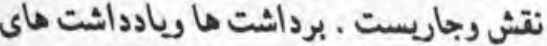

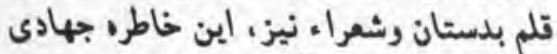

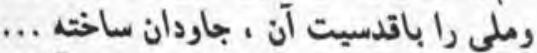

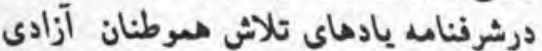

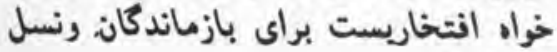

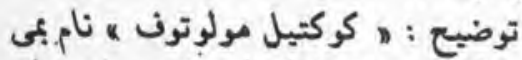
است كه بصورت خيلى ابتدانى وساده براي نائ

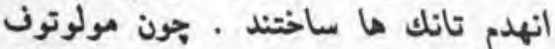
وزيرخارجه روس وطرن عناد ونفرت معالك ورئل

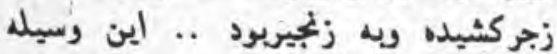
انفجار را بنام ننكين وى مسبى ساختيند .

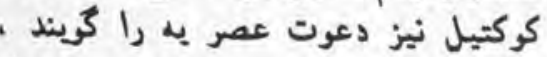

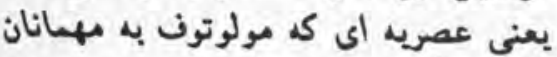

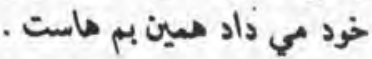
0
وطن ها سرازير شدند ، درين واحه زيبابا

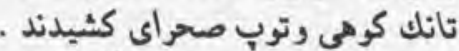

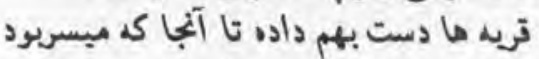

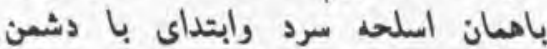

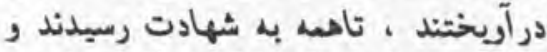

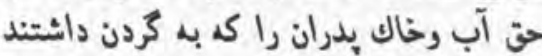

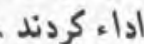

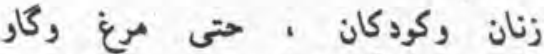

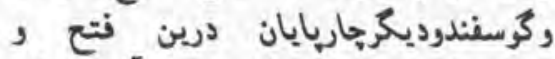

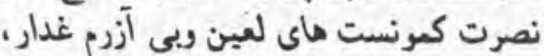
نيز از بين رفتيند

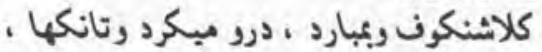

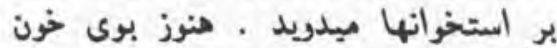
وآثش ، درينديار ، باوزش بادهاي نابهنكام

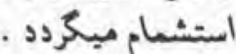
آب ها مى كريندودرختان ، ز زان روديداد

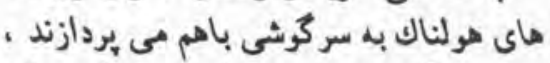

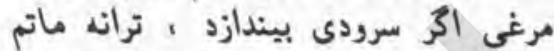

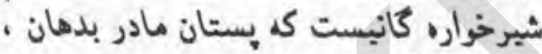

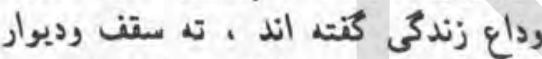

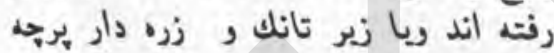

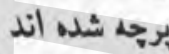
هدرين غوغا وسلاخى وآدمكشى ، روزى ، روري

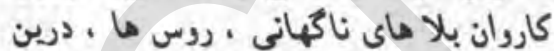

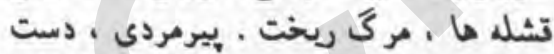

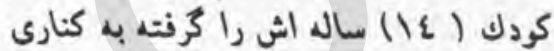

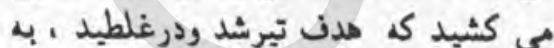
برس هيبت كرد كم عتب درختى ينهان تانكا ها ربيد و اجزاى بيرمرد شهيد رادر ريخ هاي خونين فروبرد .

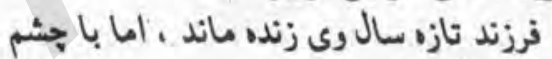
تر و دل بريان ويراز كين ..وى مثل اسلان التان

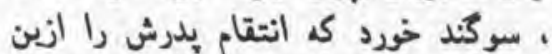

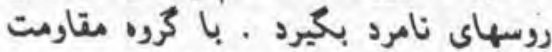

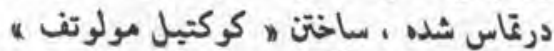

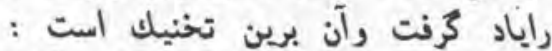

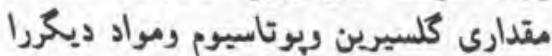

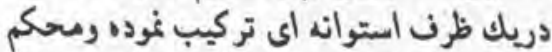

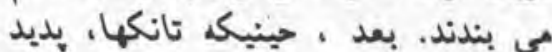

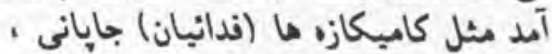

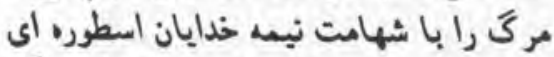
يونان باستان ، يذيراشد، واز كينكا.
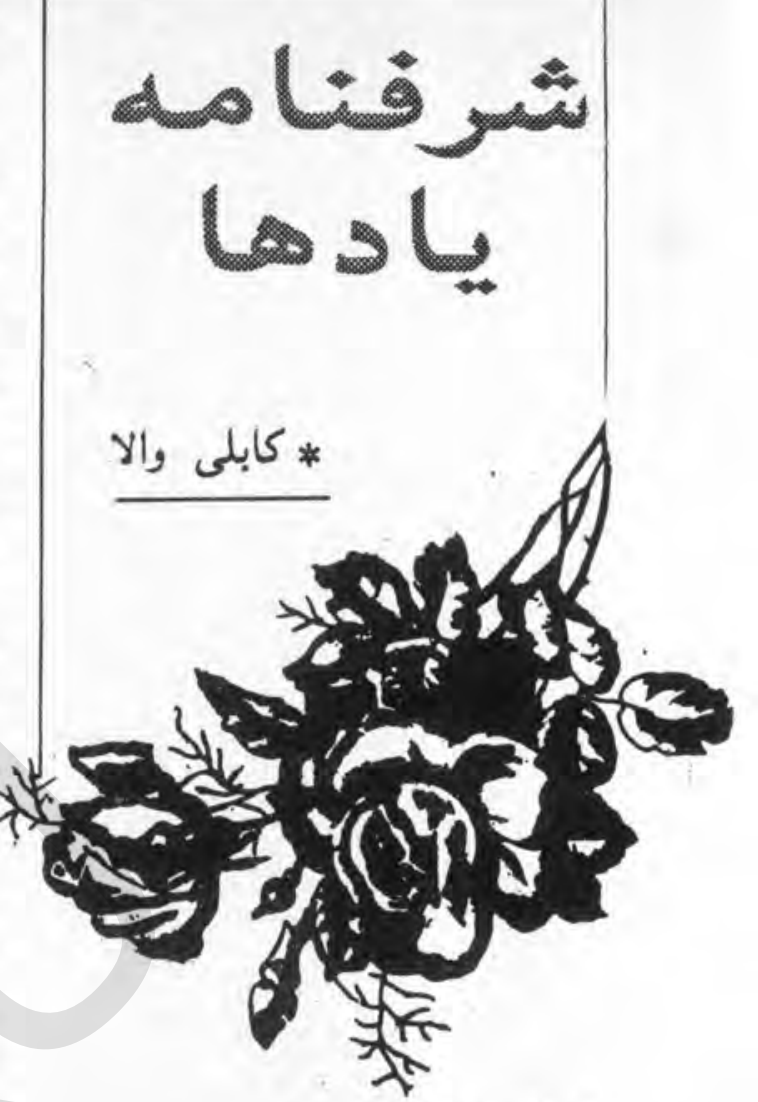

نرزند عهدالله برج : برجي

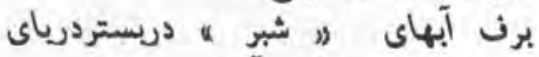

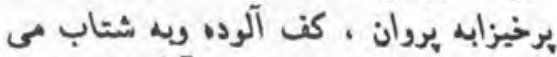

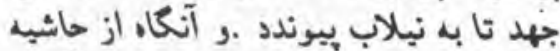

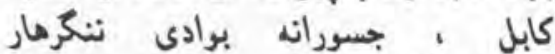

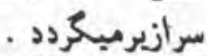

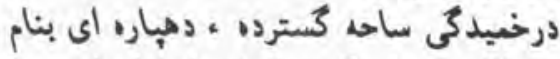

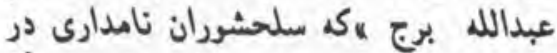

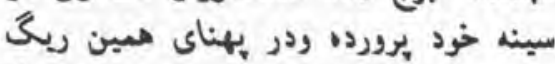

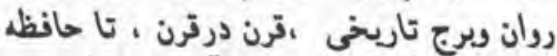

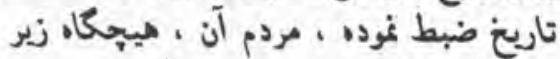

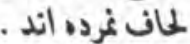

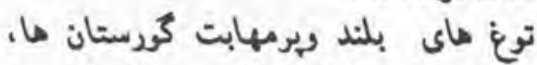

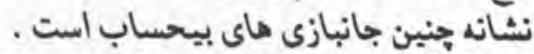
" عبدالله برج ه در زماند هائ تديم ، كدام

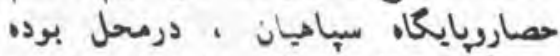
وبعدا بنام خان ياملكى زان جان جان ، ناميدان

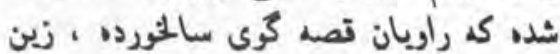

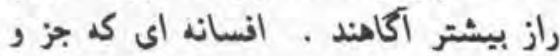

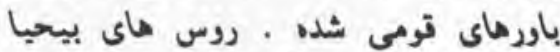

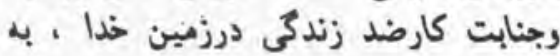


بسوى انغانستان سرانير شدند ولى با باني

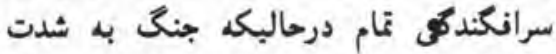

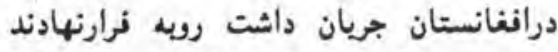
وخوابهاى ننكين بطر ، تزارها وكمونست هاى دراي جهانكير به حقيقت نيبوست . واينكه بعون الله بس از يازده سال ركود تلم وسخن مجال لازم مى يابم كه در كشور ديكرى شرح وقايع

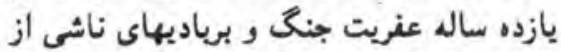

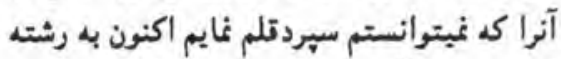
تحرير درمى آورم ودرين مدت طولانى كه ريع

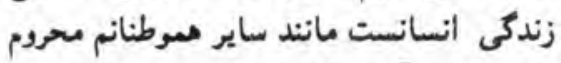
از هركوته آزاديهاى انسانى بوده ام أم يعنى

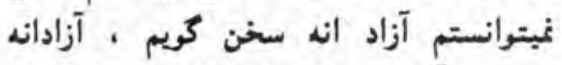
بنويسم وآزادانه حركت نمايم ودرين سالهاى يز الهن
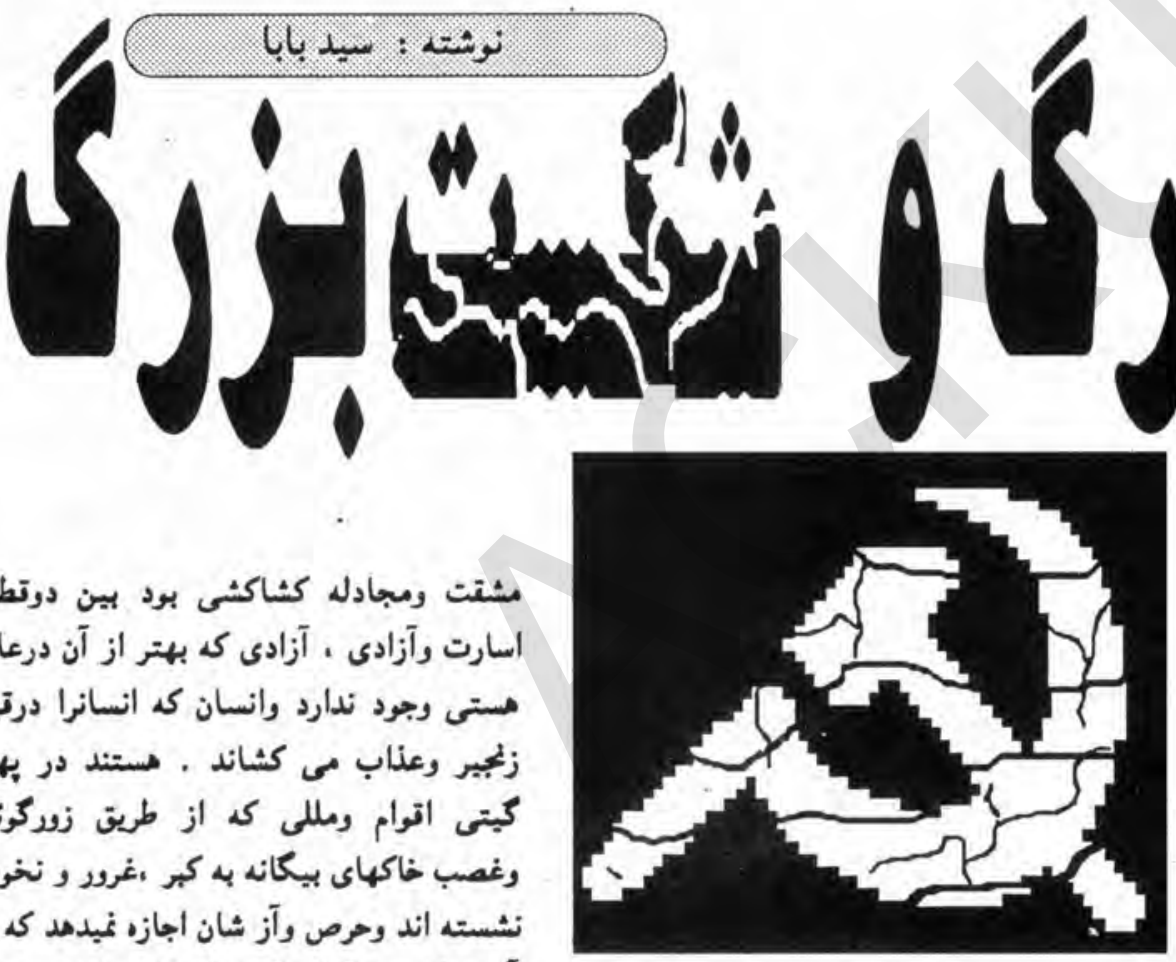

مشتت ومجادل كشاكثى بود بين دوتطب

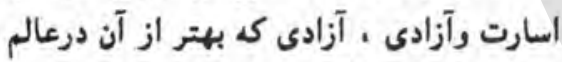
هستى وجود ندارد وانسان كه انسانرا درتبد وراند زيجير وعذاب مى كثاند . مستند در بهنه

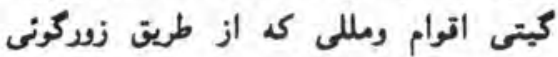

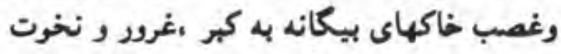

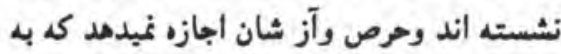

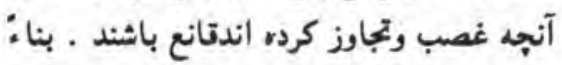
درصدد مى انتند كه به تهاجم خود بيفزايند وخاكهاى بيشترى را به غارت ويغها بيرند.

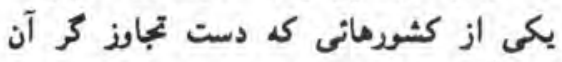
درطول تاريخ بسوى سرزمين هاى هعسايه دراز

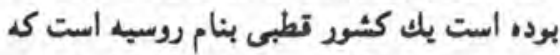
اميراطوريت بزرى امروزى دنيارا تشكيل داده كه از لينتكراد وكشورماى بالتيلك ارويا روزى تزاركنته بود كه تواى ما در آبهاى كرم

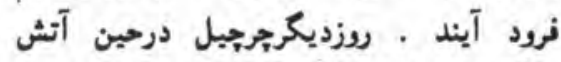
جنى دريارلمان انخليس دربرابر اين شورى آيند

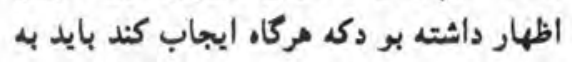

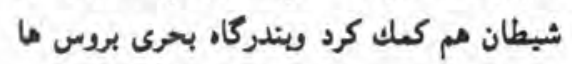
داد . بالاخر، تانك ما، تويها وطبارات روسى
آسيانى خودرا يس از سقوط نجيب وباند

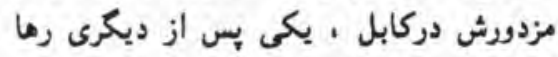
كرده بروند ( صداى امريكا ) ).

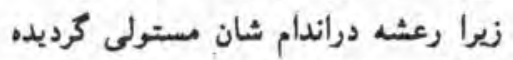

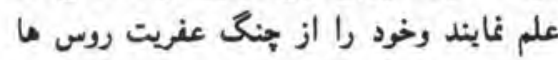

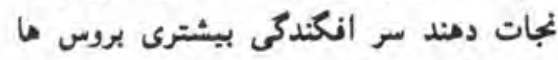

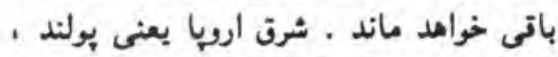

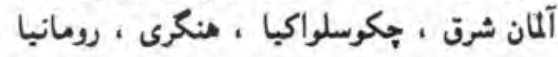

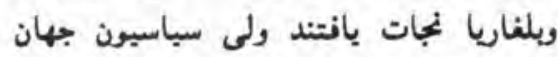

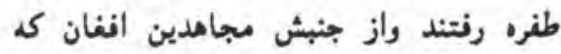

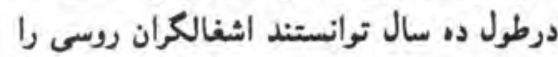

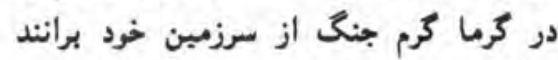

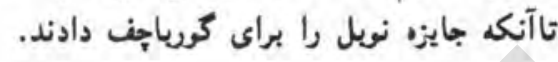

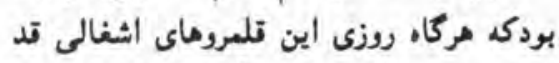

از ستنان كوباهف : انغانستان زخم خهف بكان است، مابه هرجانيكة

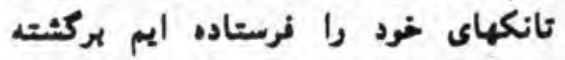

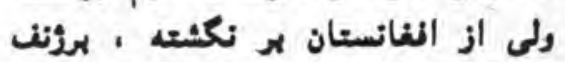

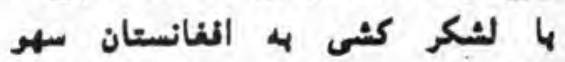

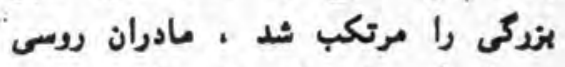

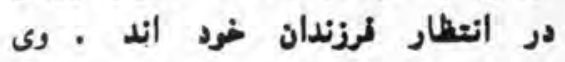
درولادى واستوك درحضور جنرالان متقاعد

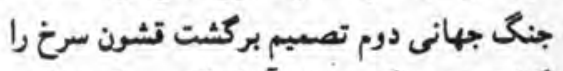
كرنت تشونيكه تعداد آنرا بالغ بر يك ميليون تن وائود كرد . ( راديو امريكا ) )

ديديم كه در افغانستان روس ما شكست

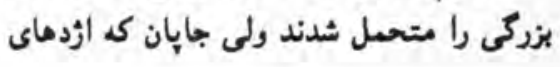

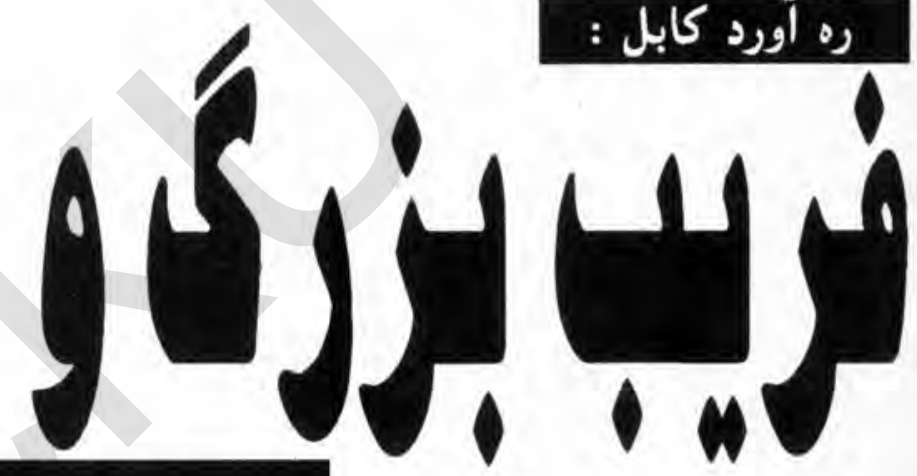

شرت محسوب ميشد مونق نحرديد كه روس هارا از جزاير كوريل كه درمحاربه دوم جهانى

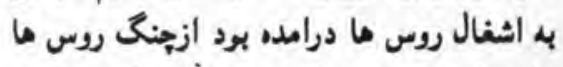

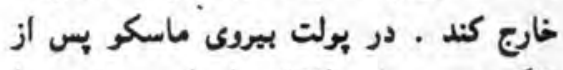

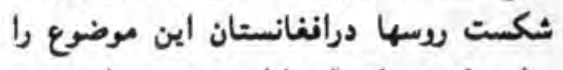
مطرح كردند كه أمبراطودى روسيه بصورت وسيعى خاكهاى بيكانه رالشغال كرده است .

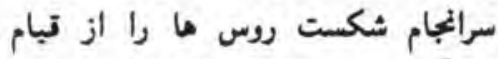
احتعالى آينذه سرزمين ماى اشغالى به خوف

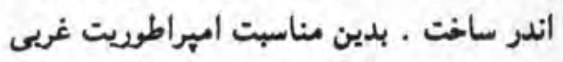

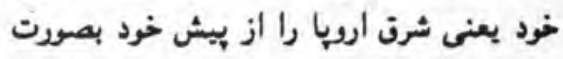

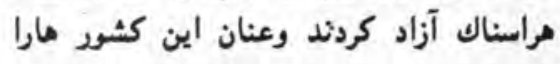

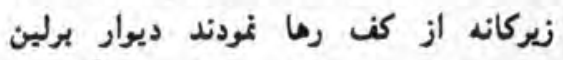

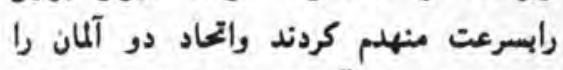
بذيرنتند ومنتظر آن باقى ماندند كد تلمروماي وائ دواد 
كي كريا مردمان ترب وجوار درحوالى خواجه

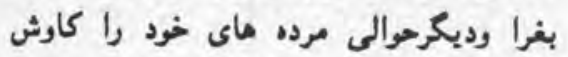

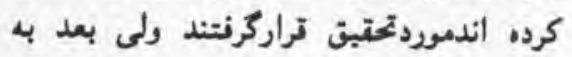

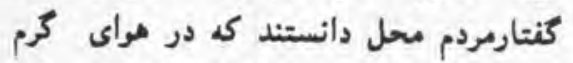

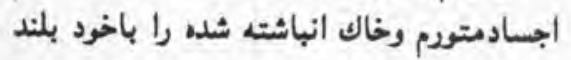

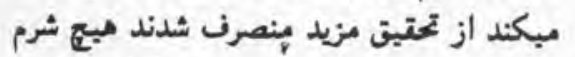

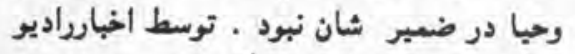

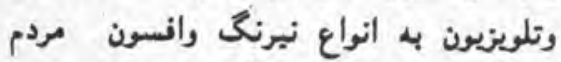

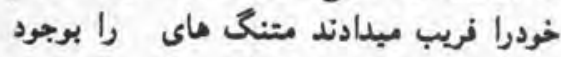
مى آوردند تامردم را غافلكيروسركرم نكهدارند

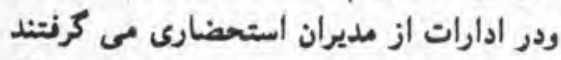

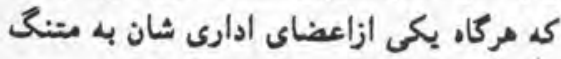

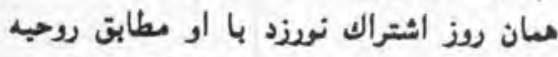

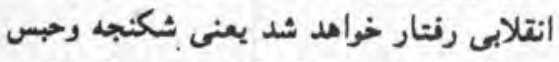

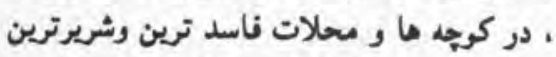
افراد را بحيث وكيل كذر وكلاتتر كوجه برمى وندي

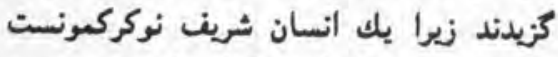

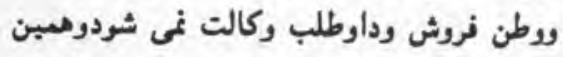

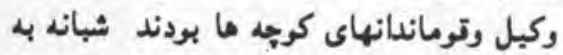

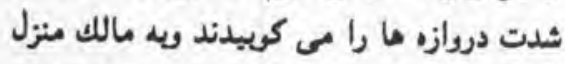

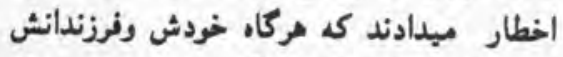

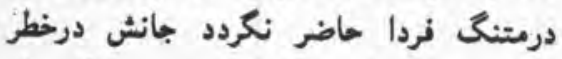

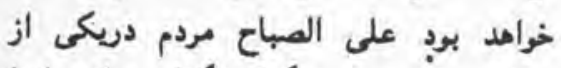

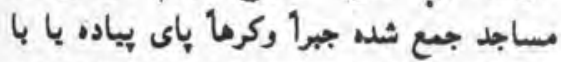

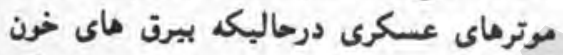

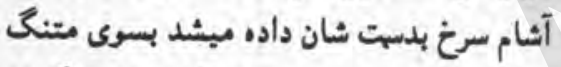

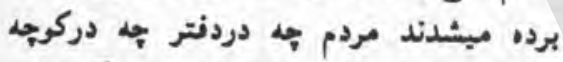

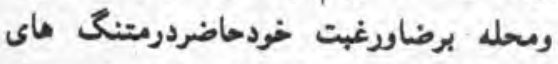

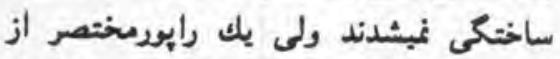

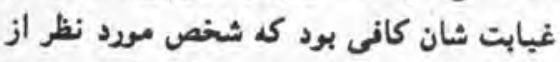

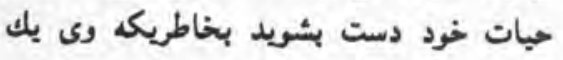

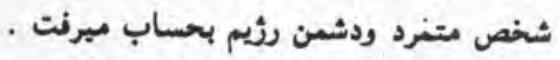

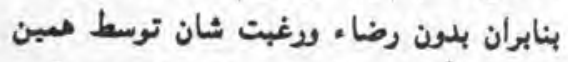

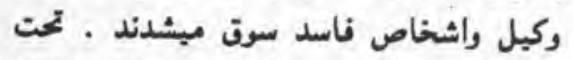

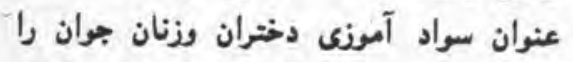

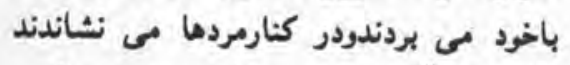

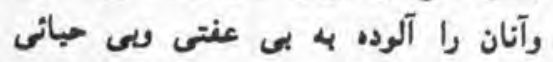

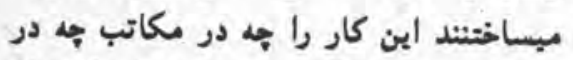
دناتر وجه در منازل الجام ميدادند بائد بايه كارشان بع ناموسى وبى حيانى بود. يك ماموددولت
لر انفاستان روس ها ثكست

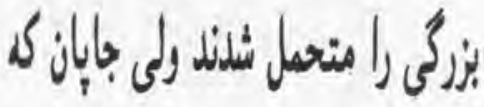

أزرهام شرن محسرب مبشل مونق

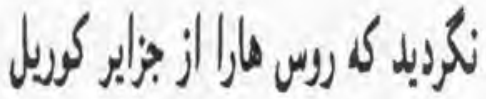

كم درمحاريه لدوم جهاني به الثفال

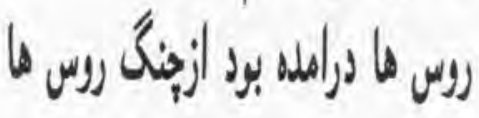

خارج كنل .

برمردم انغانستان وارد وبيشرمانه ، شريف ترين

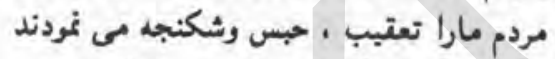

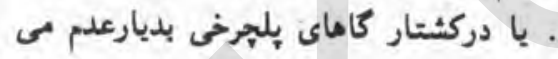

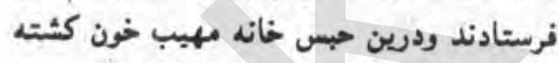

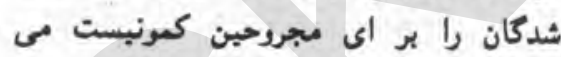

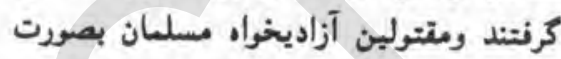

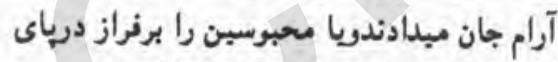

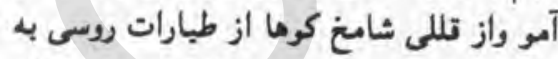

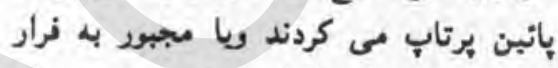

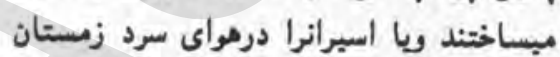

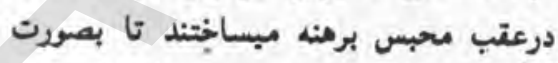

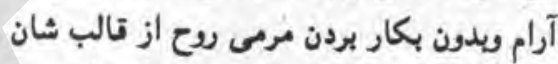

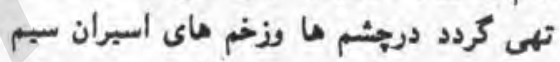

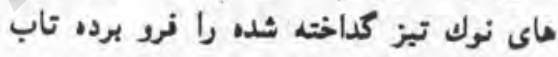

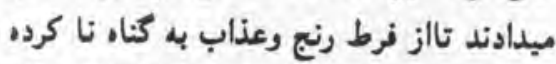

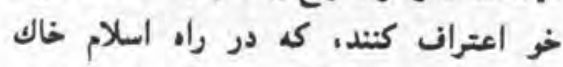

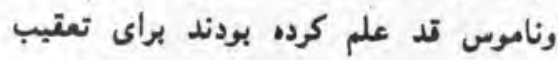

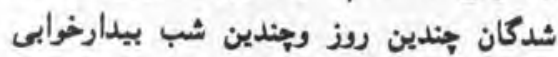

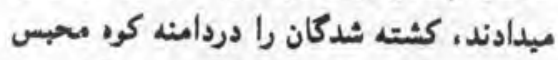

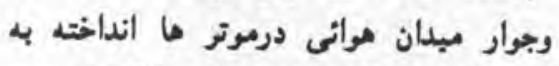

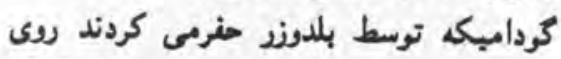

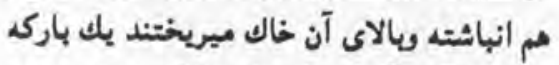

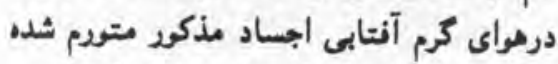

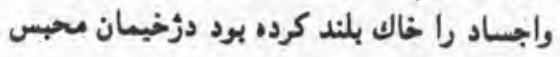

تامنتها اليه شرن آسيا يعنى واردى واستوك را

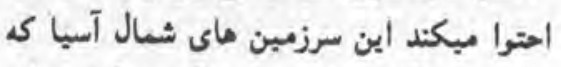

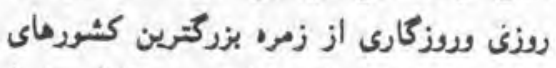

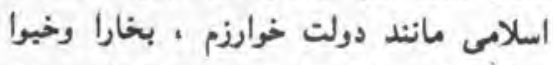

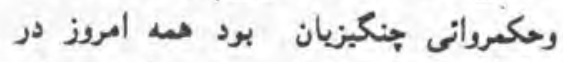

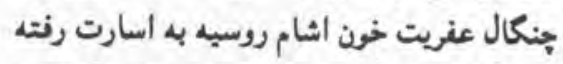

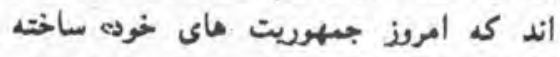

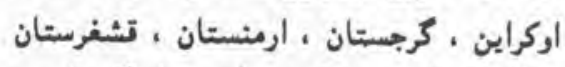

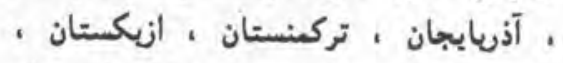

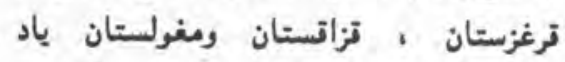

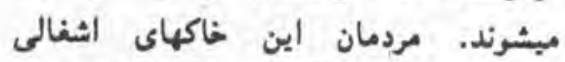

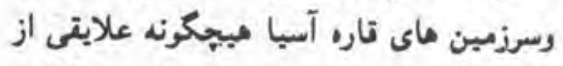

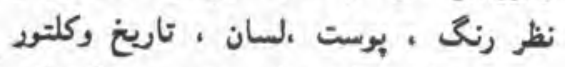

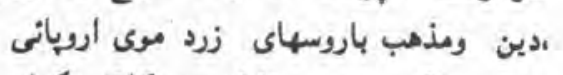

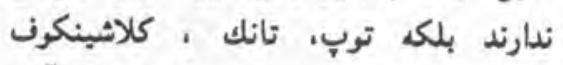
وطيارات مركبار روسى است كي نهضت آنارن آنداد يخواهى وحريت طلبى را درنهاد آنها خغه كرده

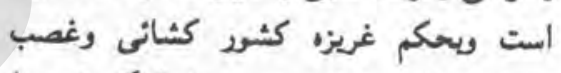

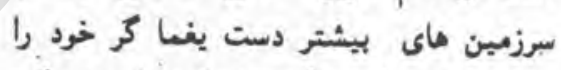
بسوى كشورهاى ديكر دراز كرده است. يكمى درئ

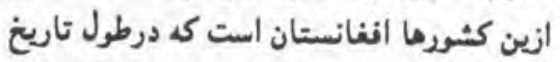

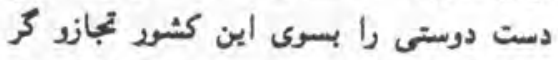

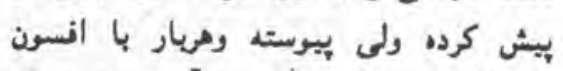

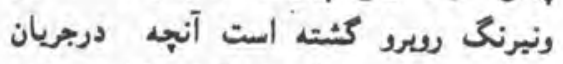
تاريخ مورد استعمال تراركرفته كلعه بيجان

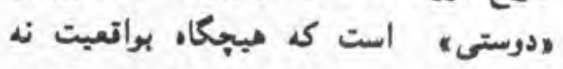

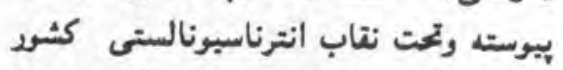

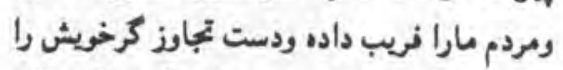

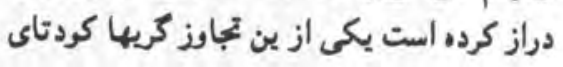
ننكين Vو لور است كد تحت طلسم اين كودتا اشغال افغانستان را توسط تواى شيطانى خود بد بيشدستى وطن فروشان بى وطن مبنواست

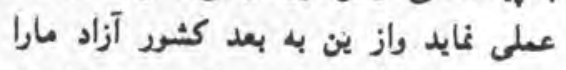

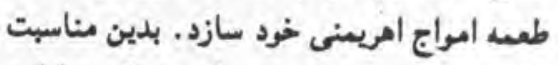

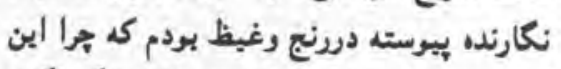

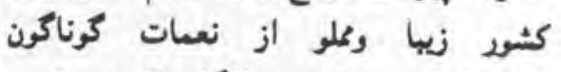

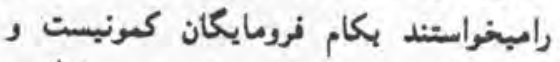

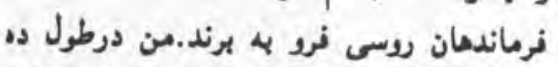

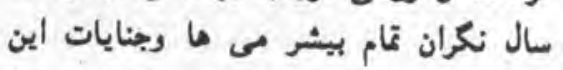

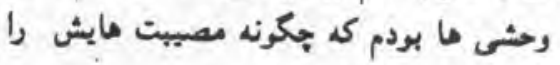


تجاوز وبيرحمى هارا تحسل كردند كه از جانب إزبا يك ابر تدرتى كه نبعى ازآسياونبمى از ارويا

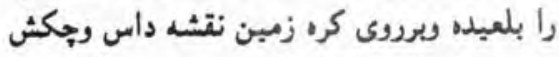
را به عنوان اشغال آينده ترسيم وآرزوى بردي ناياكى رابراى انغانستان درمخيله خود برورده

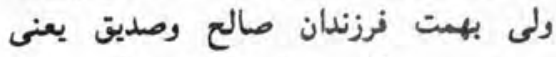

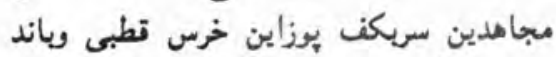

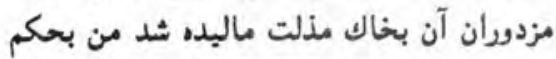

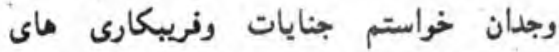
كمونيبت را كه فاقد ترحم وعاطفه اند ند تنها

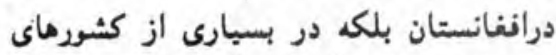
جهان كه درطلسم آن كير آمده اند تا با جانبكه نكر وتلم يارى كند باز كو نمايم وبراى آندي آنكه نهيده شود اين تجاوزات ونريب كاريها جكوند

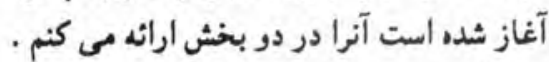
اول: دوره تراز وتجاوزات آن.

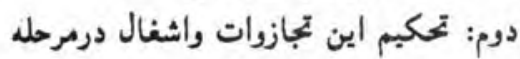
بعدى يعنى فريبكارى هائ لنين ورنقايش :

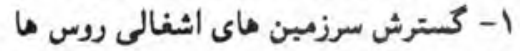

\section{( ادامه دارد )}

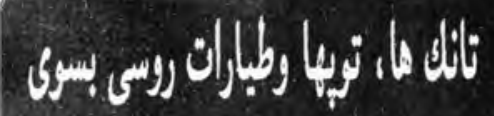

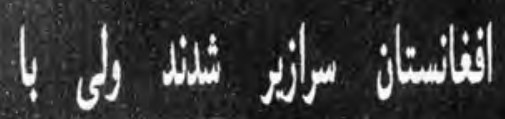

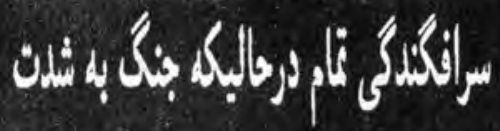
Lys

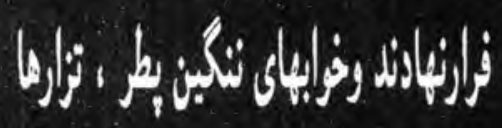

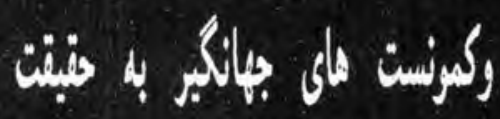
$\therefore$ iming

بكارمى كيرندواخرجنبش برادران مباهد نباشد

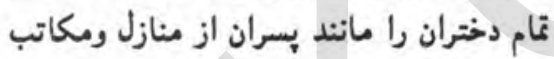

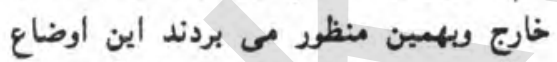

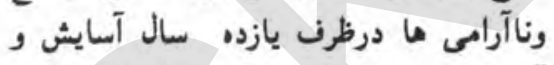
آرامش مردم ما را بهم زده بود بازدم مردم ما آين

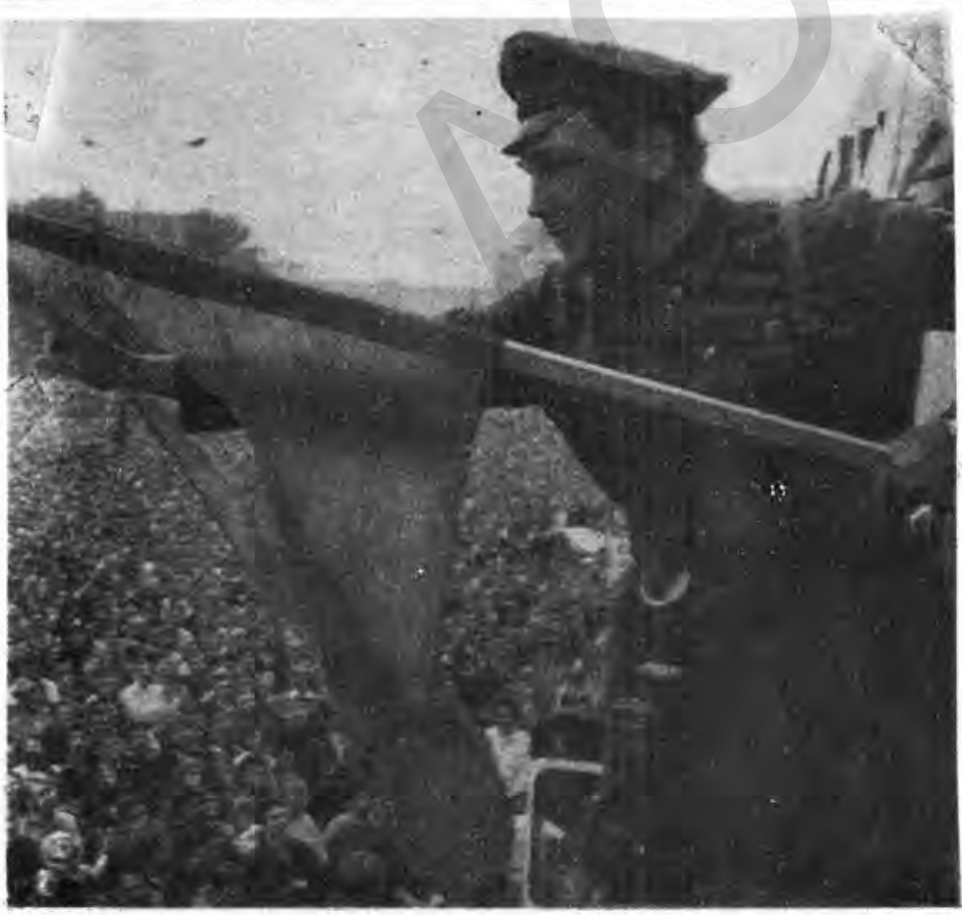

بشريت سرنكونى نظام جنايتباركونيزمرابا بزير كشبدنيرجم ننكين آن بشنمي ميرد

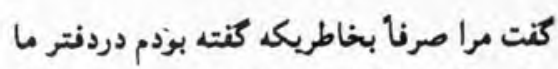

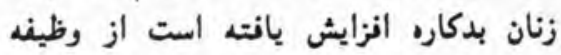

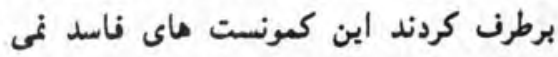

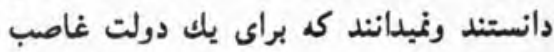

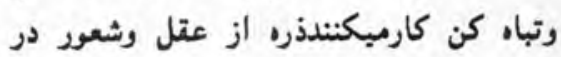

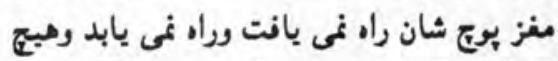

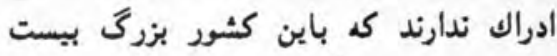

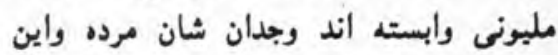

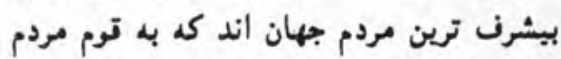
وكشور خود مرتكب خيانت وخباثت مي شون شوند

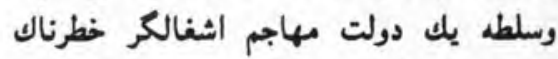

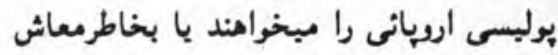

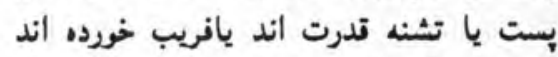

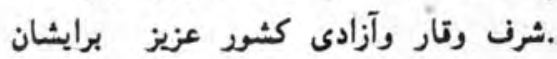

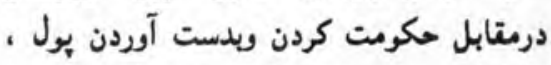

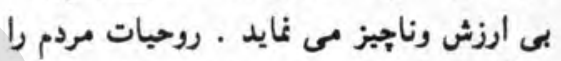

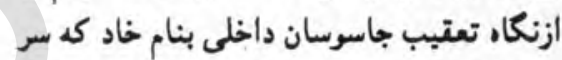

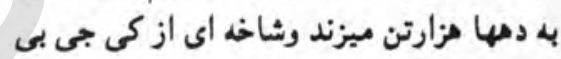

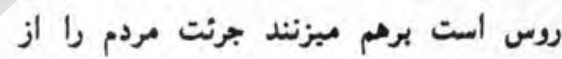

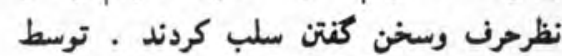

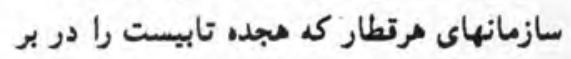

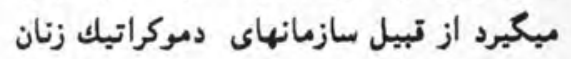

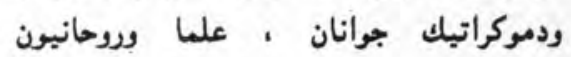

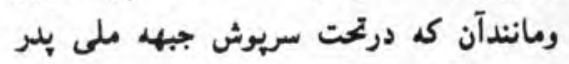

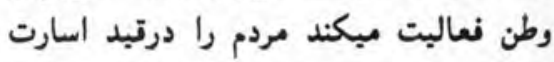

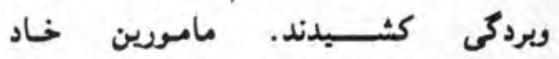

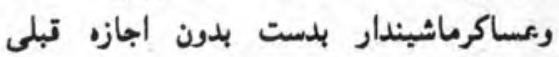

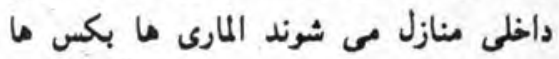
ورخت خواب ها را باز ومحتويات آنرا كارش الماري

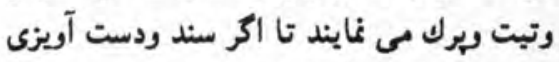

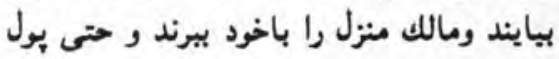

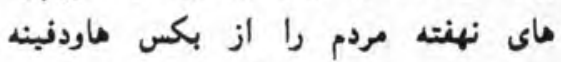

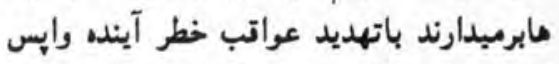

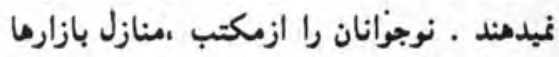

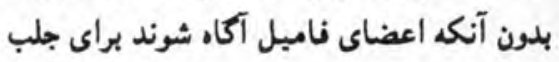

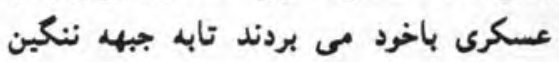

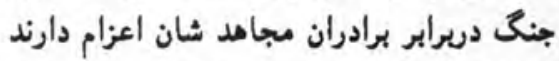
دختران راكى در سازمانهاى نحاشى جذب شران شده اند برى استفاده نامشروع عساكر ومامورين حزبى وجهت كارهاى شرارت انكيز ديكر وماهرين 


\section{نظم نوين جهانى}
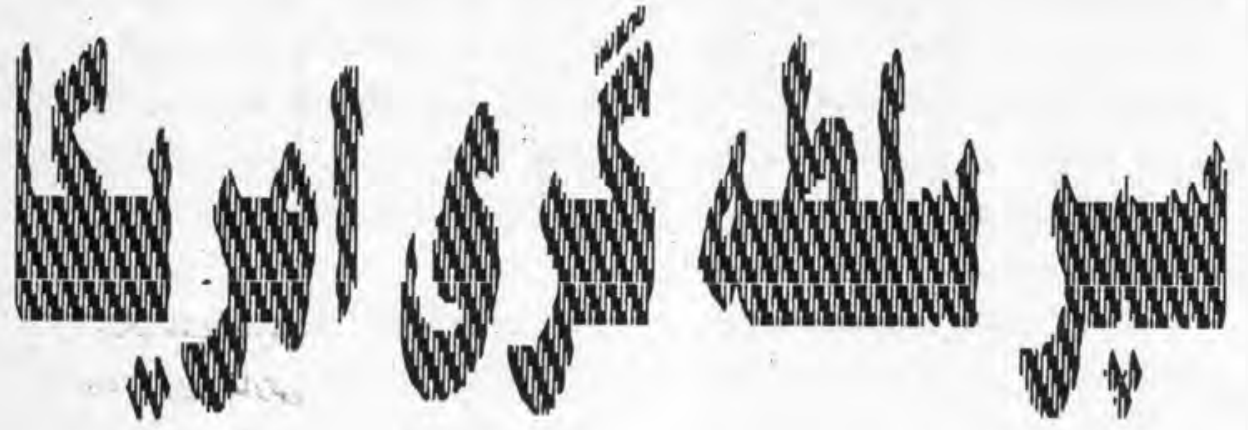

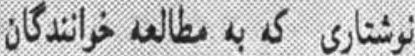

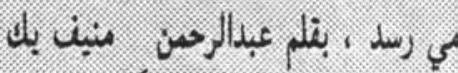

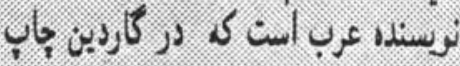

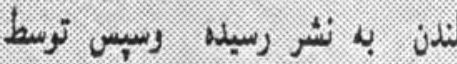

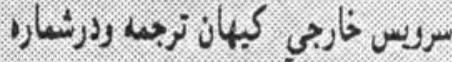

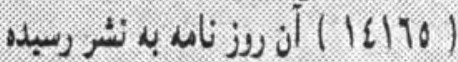

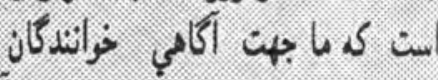

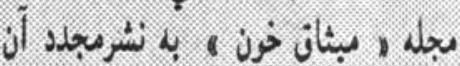
$(,||) \mid$,

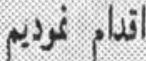

إين بدترين شروع مككن براى يك نظم

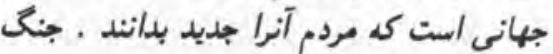

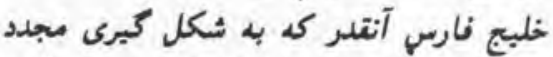

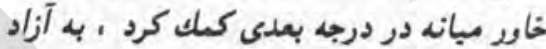
سازى كويت يا اجراى تطعنامه ماى سازمان ملل كعك نكرد . در اين رابطه ، تعداد زياد

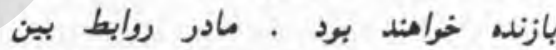

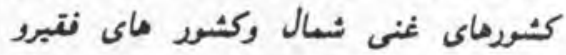

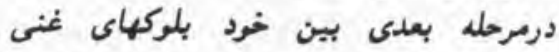
|تتصادى شاهد وخبم تر شلدن روابط خواميم

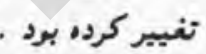

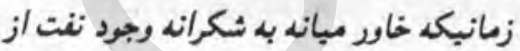
امبت ويزء اى برخوردارئد ، مركز رتابت بر بران

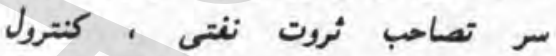

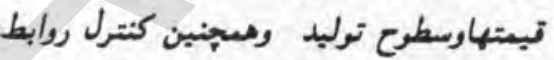

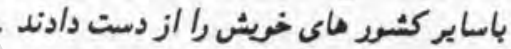
روابط با كشورمانبا بيد براساس ادادي كلعات زيبا وعده ما و ويا روياهاى دست نيانتنى بايه يايه كذارى شُود ، روابط بايد براساس توزان تدري

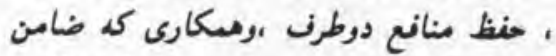

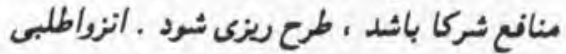

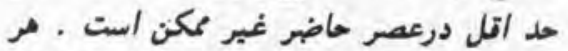

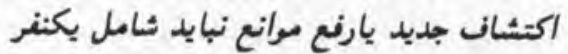

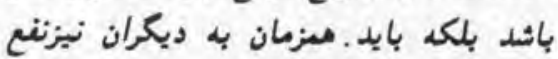

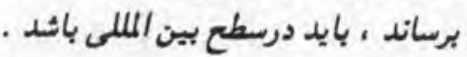

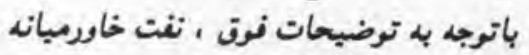

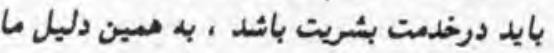

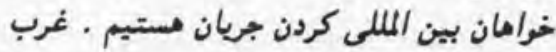

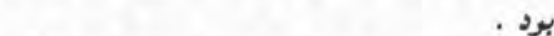

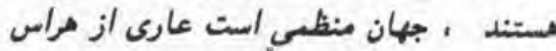
اسلحه وجنح ، نظى بريايه معكارى ، تبادل

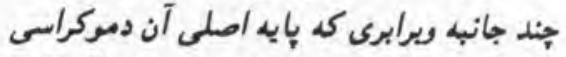

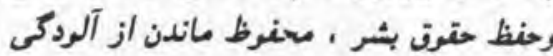

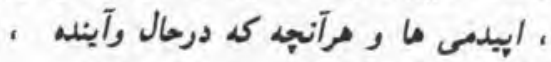

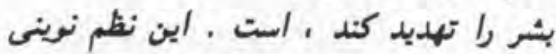
است كم.مردم درجستجوى آن مستند ، إما آيا

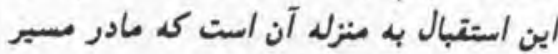

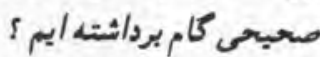
وتتبكه درجنگ جهانى اول ، اعراب معراه

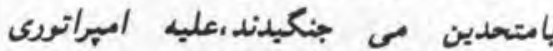

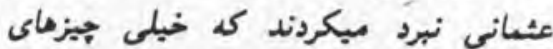

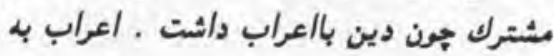

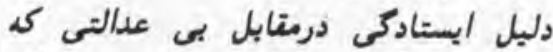

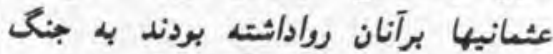
كشيده شدند ومدف آنان كسب آزادى بو د. نظم نوين جهانى كه مردم عادى در يمى آن 
بناهاى تاريخى وغيره خراب كردند .حتى إنى

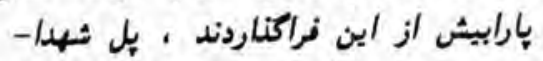

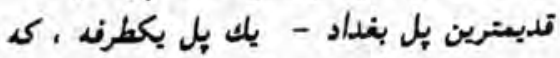

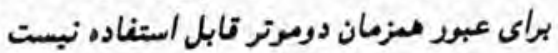

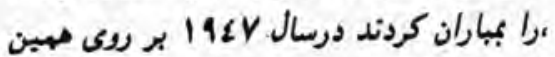

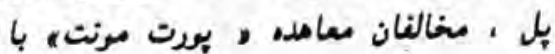
انكلبس به شهادت رسيدند كه درميان آنان بران

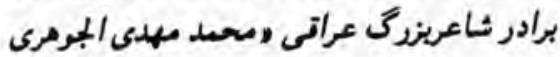

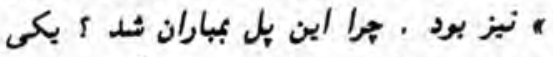

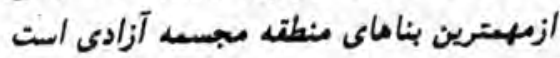

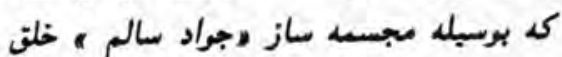

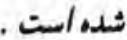

محتعل اين مجسس را آتش زده باشند

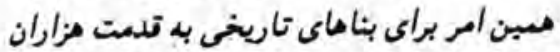

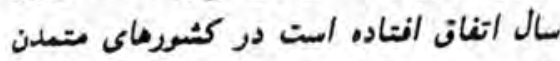
رامى جز /ز طريق تخريب آثارياستانى آنها

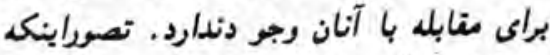

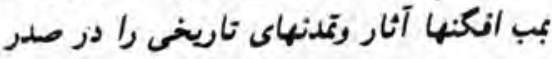

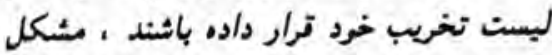

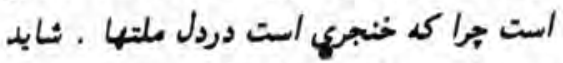

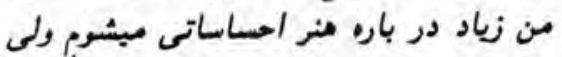

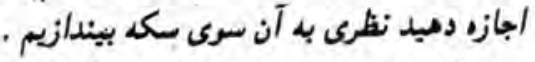

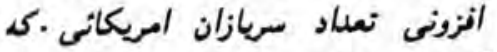
درجنح خليج فارس دخالت داشتيند تمايل

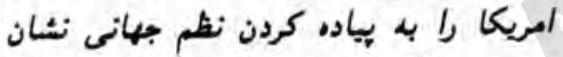

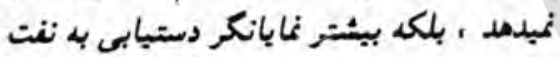

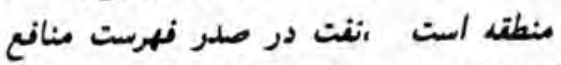

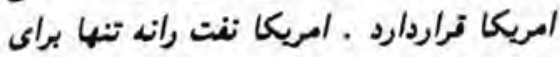

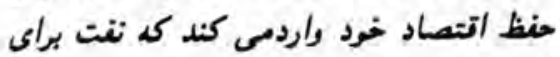

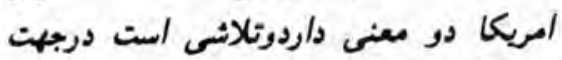
كنترل آينده مردم . مرو معنم اكنبون ماسوال ديكرى را درمودرنظم نوين

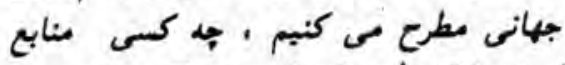

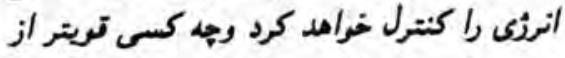

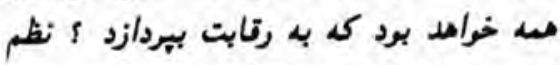

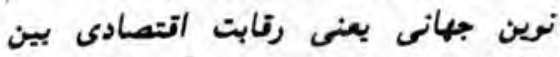

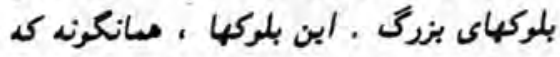

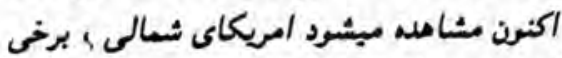
كشورهاى آسياى شرقى ونشعروى مستند . نفت يكم از عرامل مهم دررتابت مبان آنها

دريغداد بو د. عليرغم تمام تلاشهانى كد بعل

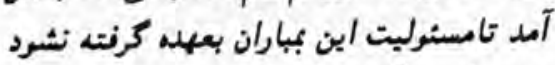

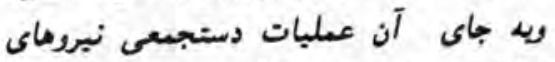

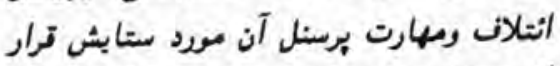
كيرد ، تمام جهان شاهد اين حتبتت انكار نابذير

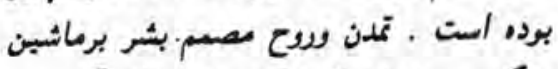

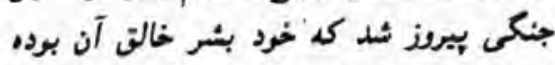

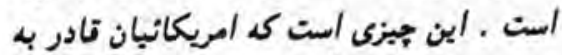
درك ياحتى تصور آن نيستند. من مصد ندارم غربرملى ملتها رابرانكيزم

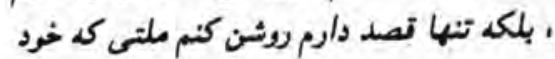

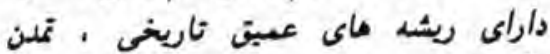
وفرمنح است بارمكنران از راه رسيله ایى كى تارن

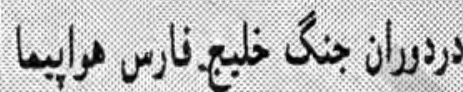
إن

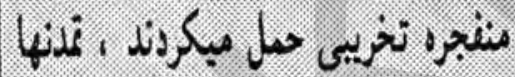

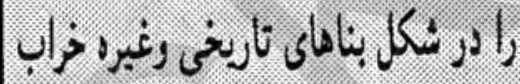

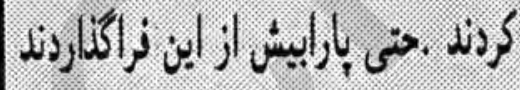

به اثر اتنإث دورمم جمع شلده اند وتصصر مى كم تمان

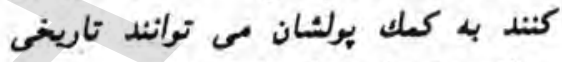
متعلق به خود ايجاد كنندفرت دارند . بران

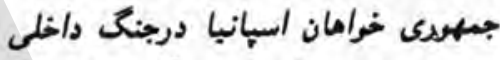
شكست خرودند ، ولى تمدن وآينده رابلدست

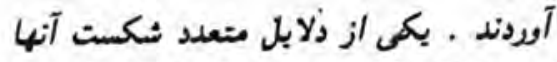

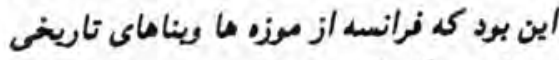

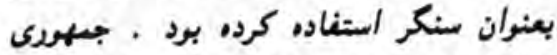

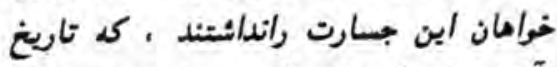

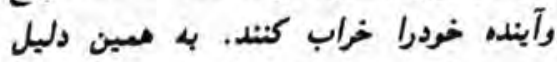
ترجيع دادند عقب نشينى كنندويك بر برئ بريسم

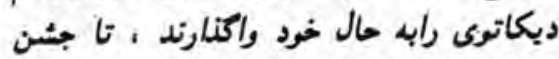

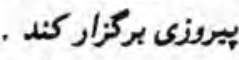

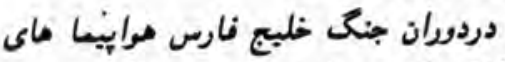

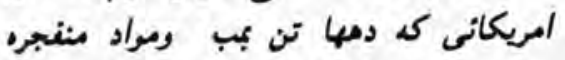

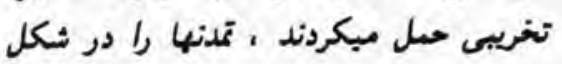

روزى شاهد خرامبم برد كد ثلاثها براى

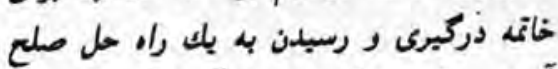

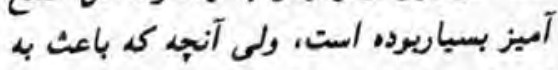

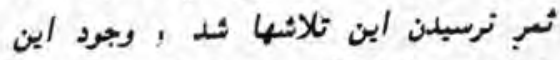

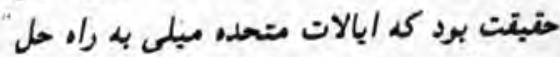

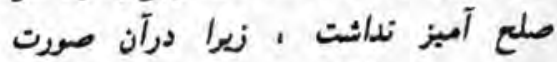

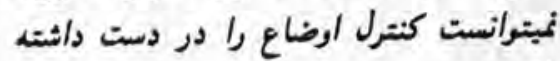

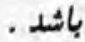
جنح خليج نارس با دوجنخ جهانى از نظر

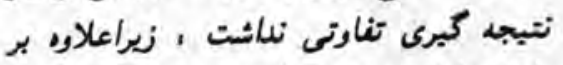

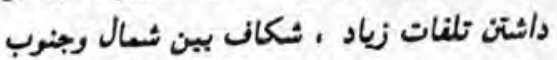

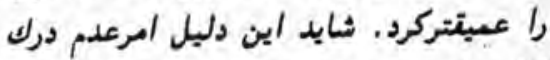

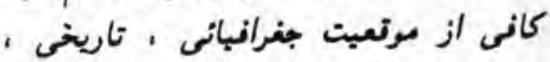

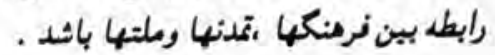
من تصد كريك كردن ميزان توانانى

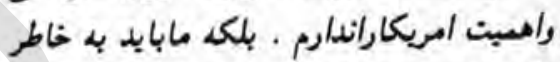

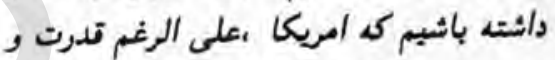
برترى خود ناقد جنبه تاريخى وزيانى است.

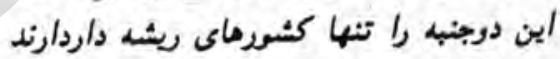

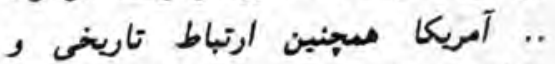

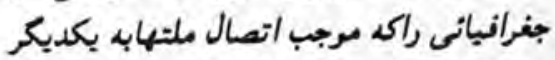

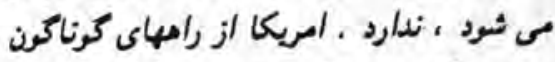

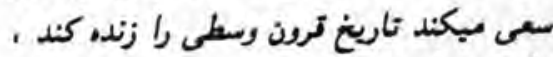

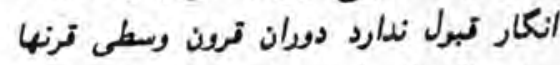

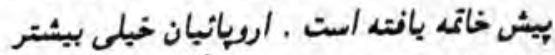

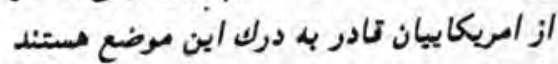

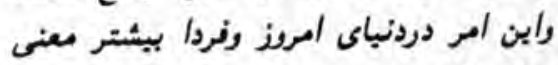

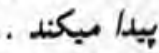

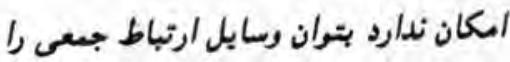

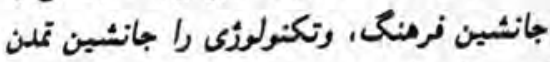

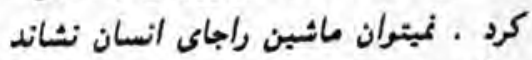

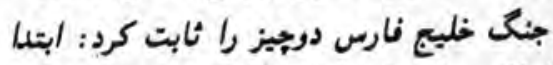

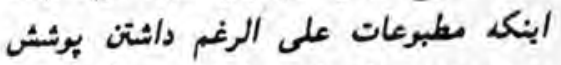

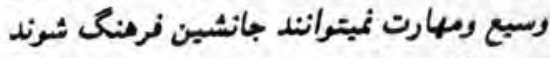

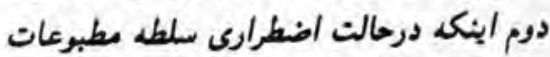

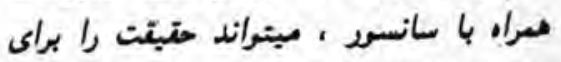

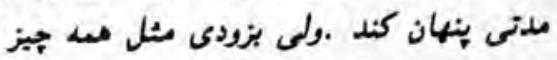

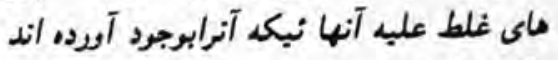

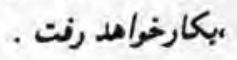
ثاهد ساده ملعى،بهباران بنامكا، راميريه، 
تا وتتبك انكارعمومى نقش بارزى نداشته باشد ، تارتتبكه بشر حقانبت

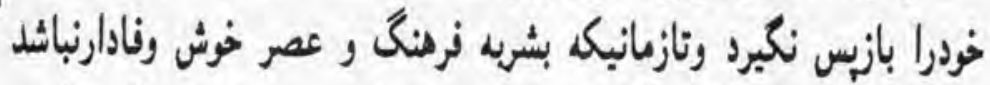

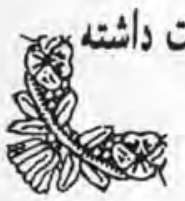

از تاريخ محلود نمى شود د. بيشتر آنجه كل

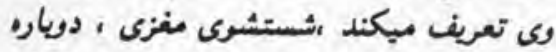
شكل دادن خاطره اشخاص براى ايبجاد افراد

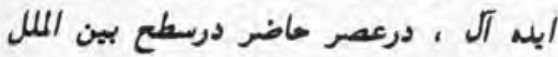

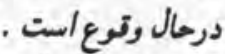

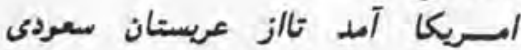

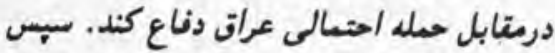

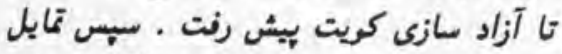
خرورا بل تخريب ماثشين جنكى عراق

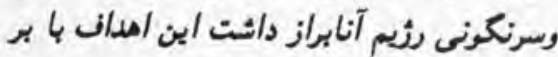

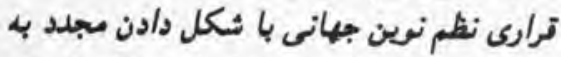
منطته ازنظر نسياسى وجغرافيانى مغاير است.

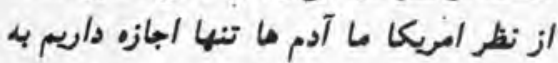

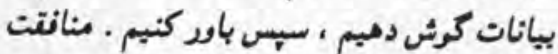
كنيم واطاعت كنيم . مركس مخالنت كند بند

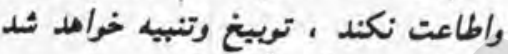
وركليله ودمنه آمده : كزكى نياز به خوردن بره ماداشت ولمى خورا

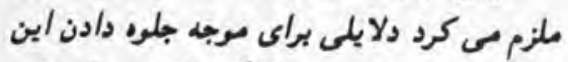

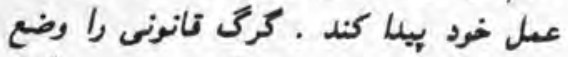

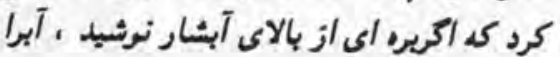

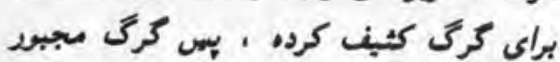
است آن بره رابيلعد آكريد

مبيشه دلايل وجود دارند وروطينه ماباور كردن واطاعت كردنازآنهاست . تا وتتيكه افكارعمومى نتش بارزى نداشته باشد ، تاوتتيكه بشر حتانيت خودرا بازيس

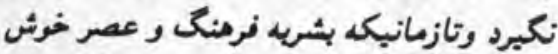
وفادارنباشد ،ميجكاء نميتراندبعداز جنخ سرو

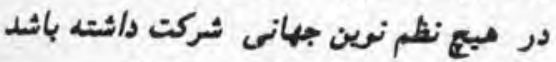

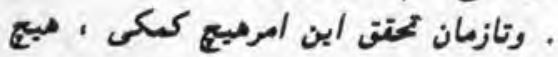

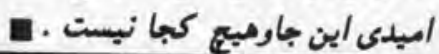

درموارد ويكر مبع كارى نكرده است .

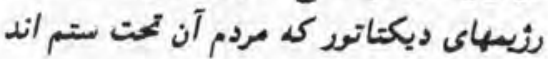

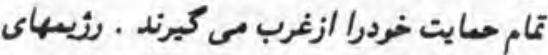

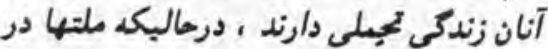

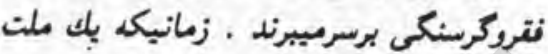

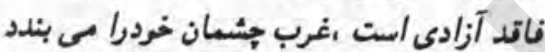
.

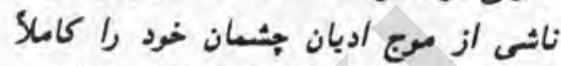

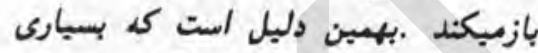
ازعريها معتدند ستعى كه به آنان روامى شهرد. ،تيجه وسبس بين رئهاى ويكتاتورى البته تعداد زيادى از متفكران عرب فرق

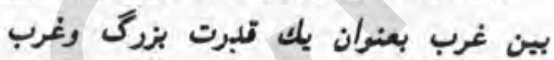
بعنوان يك كروه /زكشروما ، تمدنها و فرمنكها

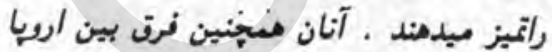

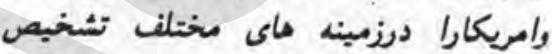

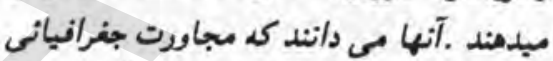

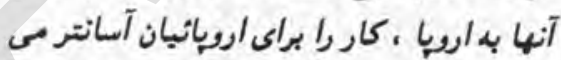

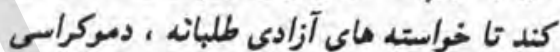
ويرابرى را درك كنتد. آنها مسبنين اثر متتابل

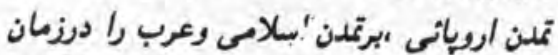

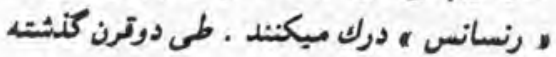

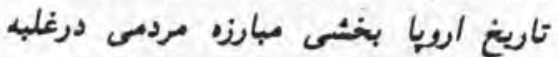

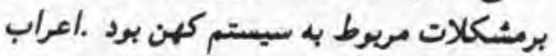
نيز ورجنين راهى تلاش كردند ولمى كترمبرد

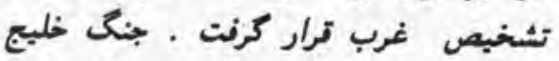
فارس سواع اثرات نطامى اث ، مواردى ماتند

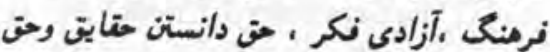

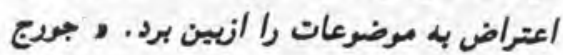

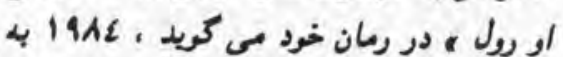

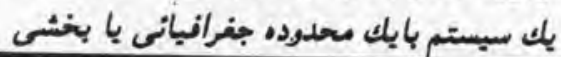

خواهد بود نيرا براى مثال زاين ، تمام نيازنتحى

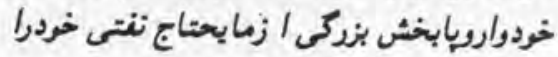

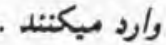
امريكا از طريق شركتهاى خود وارتباطات آنان با كثشرماي توليد كنتده نغت به بيشترين

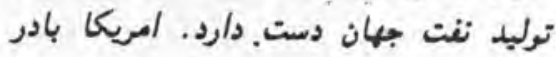

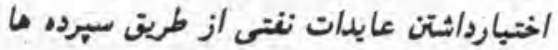

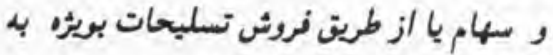

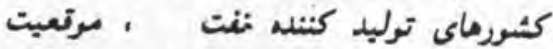
اتتصادى خرد را معكم مي كند . امريكا اكنون ور موتعيتى است كل يك نظم نورين

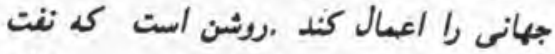

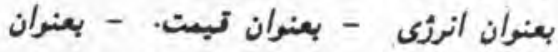

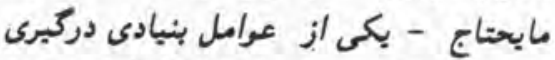

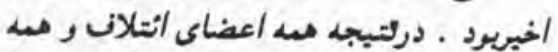

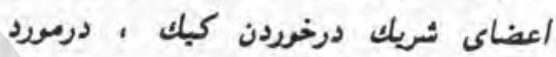

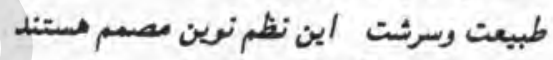

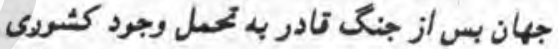

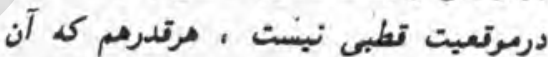

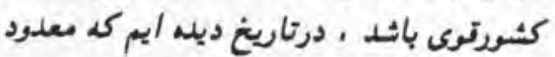

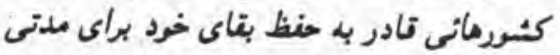
طولاتى بعنران تك تطبى بوده مكرامبراطورى رم باستان . آنجه كه بسيارى از"غريبها بدان بع توجهان

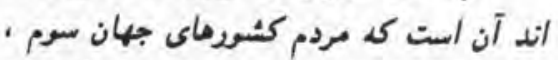

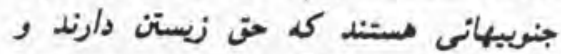

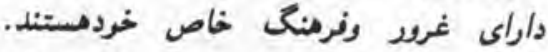
دريشت مسل تجريات تلغ جهان سرم اشتباهات

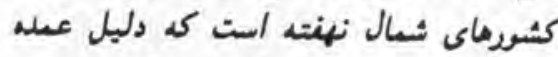

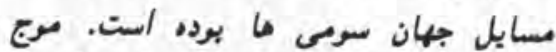
خصومتهايس كد اكنون خاورمياته رادربركرنت مانت

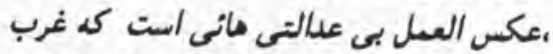

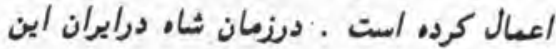
عكس العدل نمايان بود واكنون درجهان بعرب

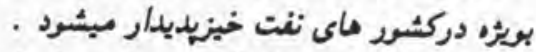

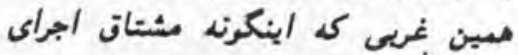

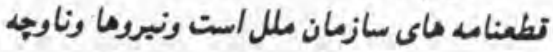

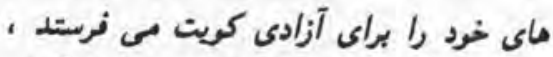

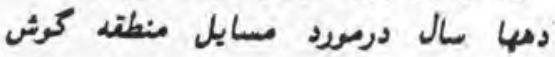
شنوانداشته ودرمورد تطعنام هاي مردو مشابه 


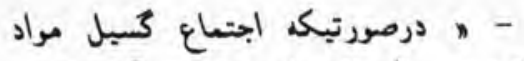
مطلوب جنرال رانيصله ميكند ، آيا شخصى

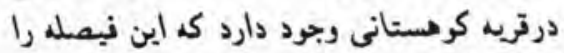

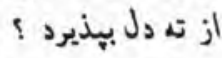

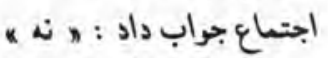

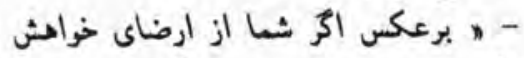

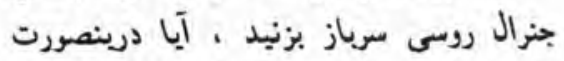

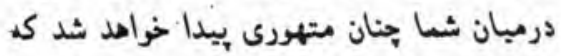

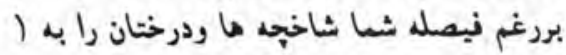

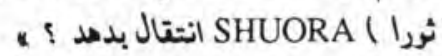
بازمم جواب منفى مواصلت ميكرد . اما درين وتت جنين استباط ونتيجه كيرى

- ه در جنين صورتى من ارضاى خواهش

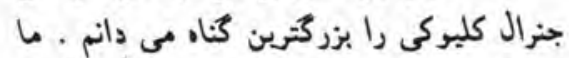
به كافر جواب رد مستقيم نمى دهيم ومى كرئيم

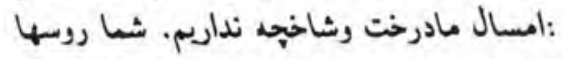
درمين نزديكيها باغهاى مارا تطع كرديد واهالى اونسوتول كارشمارا به بايان رسانيدند

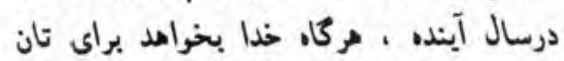
خواهيم نرستاد .

شامل سخنش را جنين بم بايان برد :

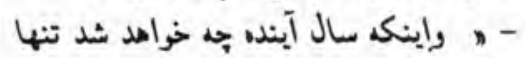

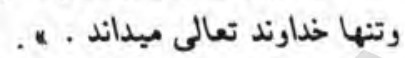

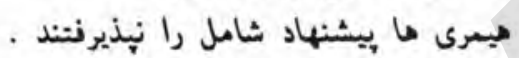

اما با نارضانى از محفل به خانه بركثت . درراه يكى از خويشارندان المام بنام ابراهيم

$$
\text { بار جنين كنت : }
$$

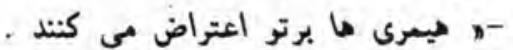

آنان مى كريند تومى خوامى كم به تنهانى

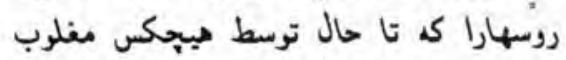

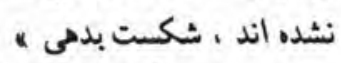

ازمين هنكام شامل از كسانى كه بـ كفار

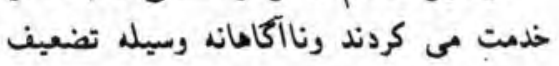
وتخفيف آنين مقدس ميشوند سخت منزجر

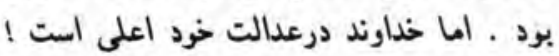

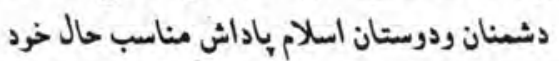

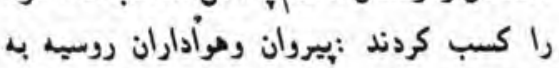

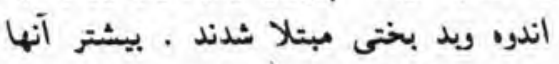

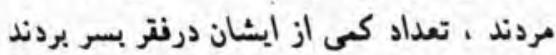

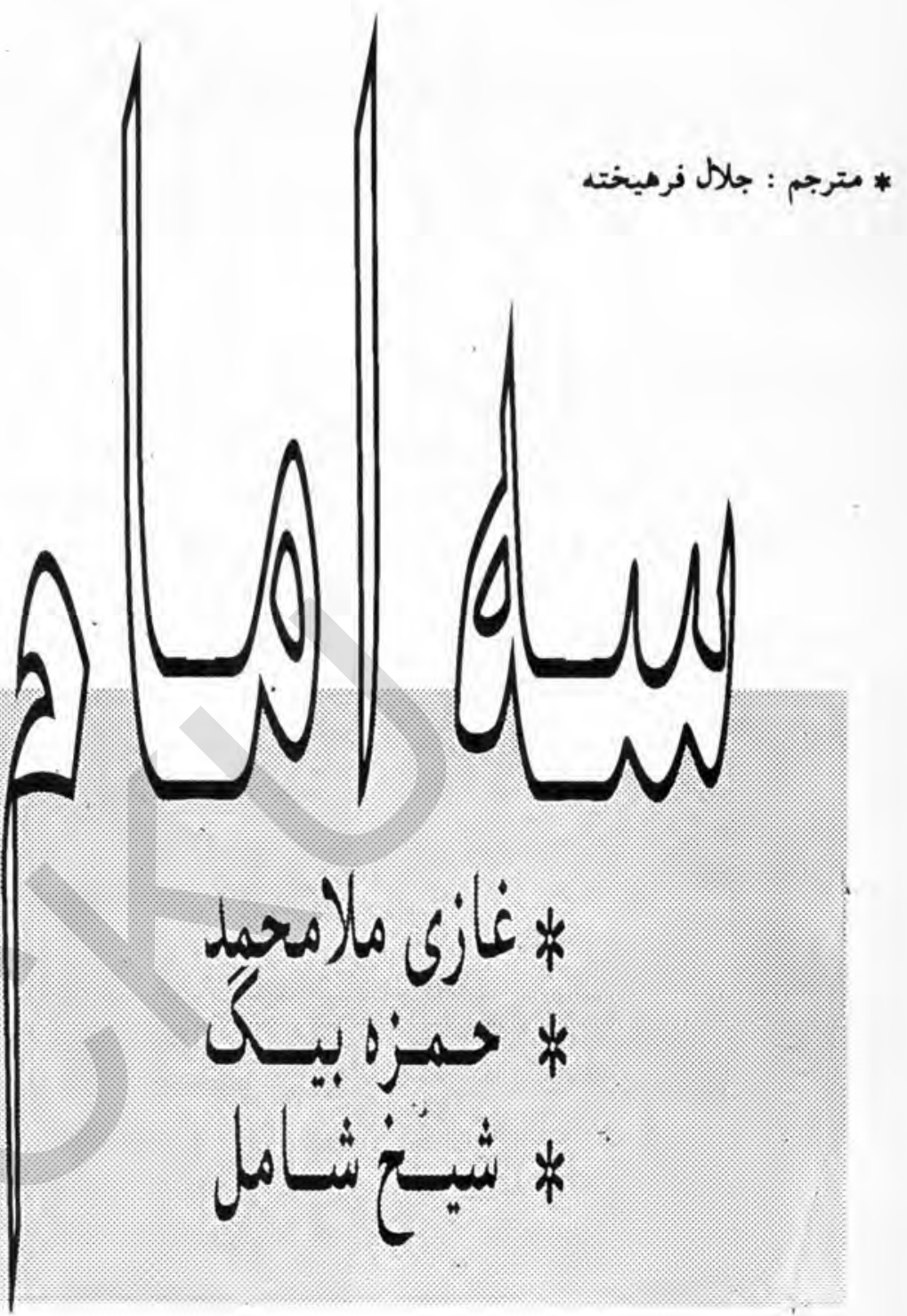

جنرال كليركى ازهيسرى ها خراشش كرد تا

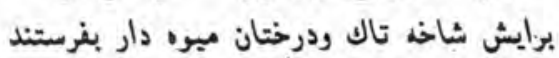

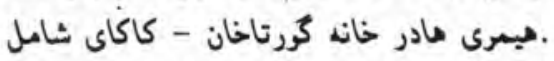

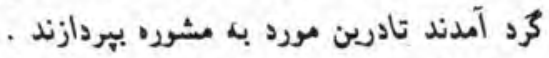

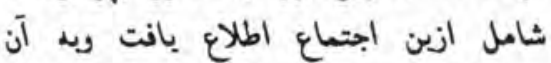
سوشتانت . اورا از جريان أكا، ساختندواعلام إني

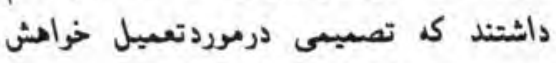
رئيس روسى اتخاذ شده است .

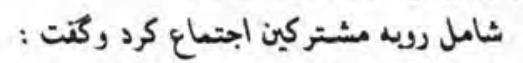

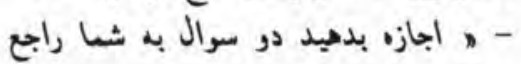

كنيم . اجتماع جواب مرانتت آميز داد، .

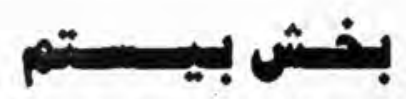

انكيزه هاى نرار شاعل به هينشلتو Minshiltoo

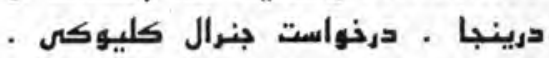

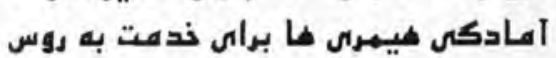
اعتراض ناعوفتانه . اعضار اهالى

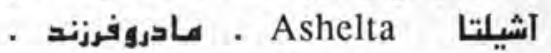
عماجرت . عبارزه بارسو هم وعادِات فاسد.

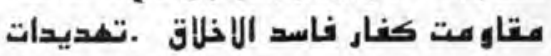

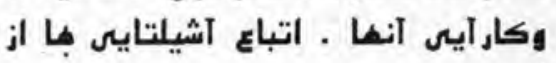




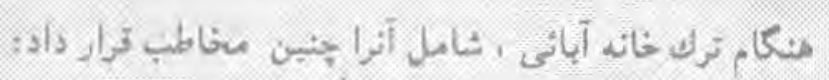

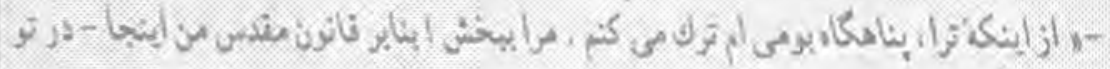

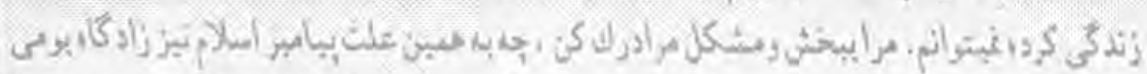

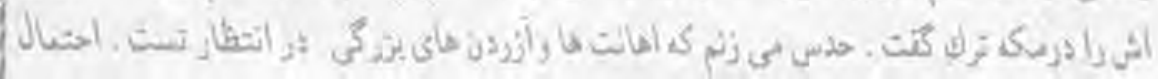

s.

را بخود سرى وخود راتى متهم مى كردند

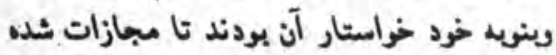

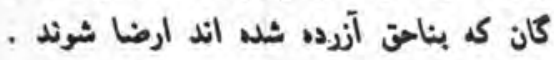

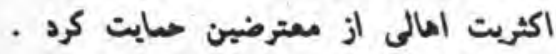
شاهل را از موانع ومقاومت موجود اخجار كردند

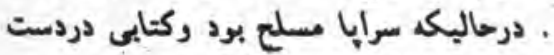

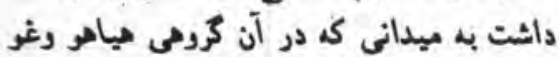

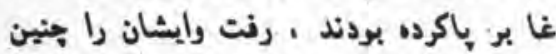

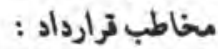

\section{I آل}

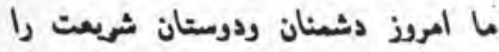

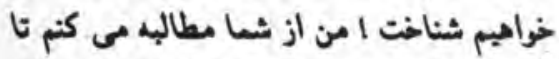

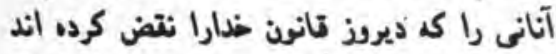

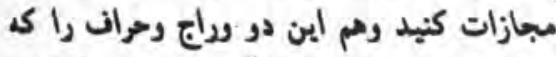

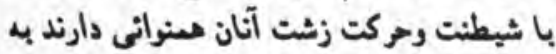

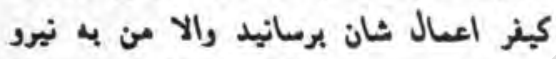

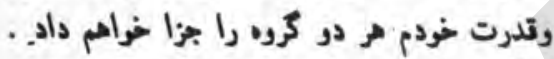

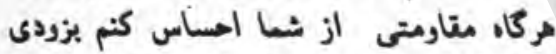

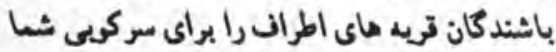

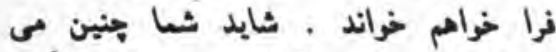

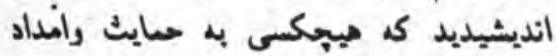

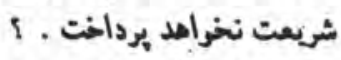

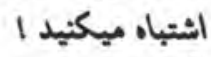

آيين متدس همواره ودرهركبا مدافعان

$$
\text { راستين خودرا مى يابد ! }
$$

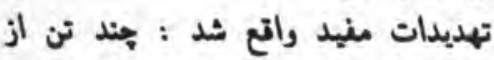
آشوبكر ان نتست مجيورشيدندتا جوال مارا بـ

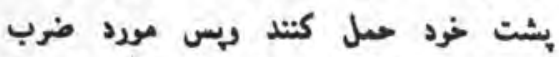

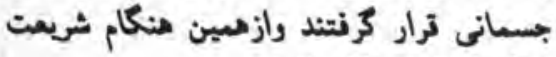
درآثيلتا استحكام يانت كراز

(ادام دارد)
رمادرعزيز خرد را تنها مى كذارى ؟

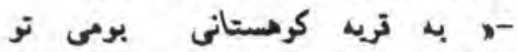

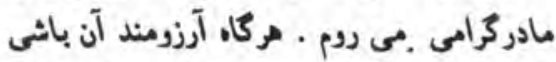
كم درمتام غنها واندون ها ، ، مصايب وناملايعات

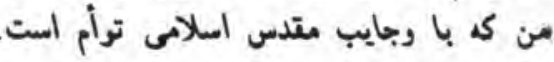

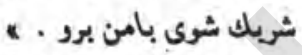

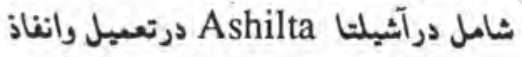
شريعت بأموانع كترى به تناسب با تريه بومى دري خودش مواجه شد .

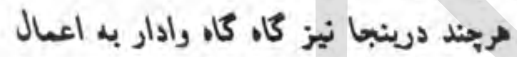

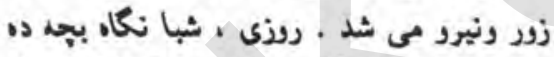

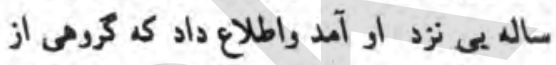
زنان ومردان براى كرييدن خرمن جوارى برسم

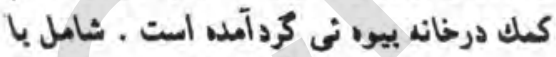
جويى دردست بدنبال كودل بصوب محل

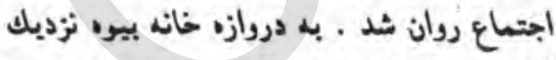

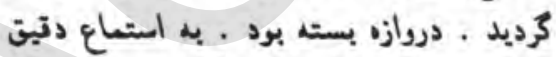

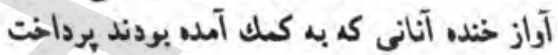

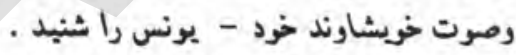

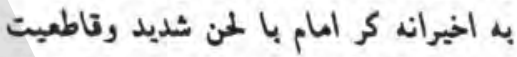

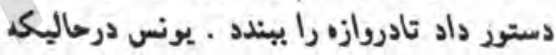

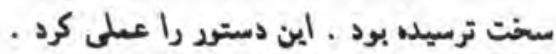

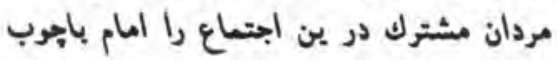

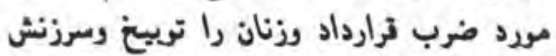

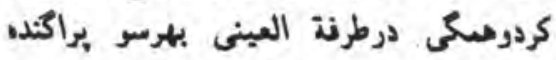

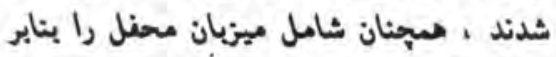

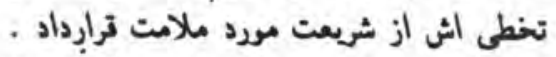

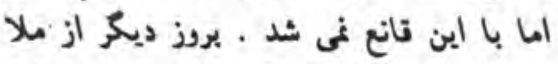

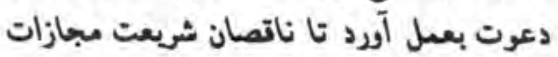

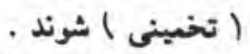

دوتن از اهالى آشيلتا با خراست ملا مبنى برمبازات متخلفين مخالفت كردند آنان شامل الثرال

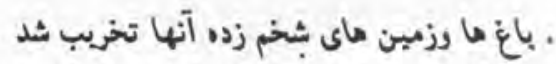

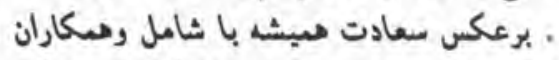

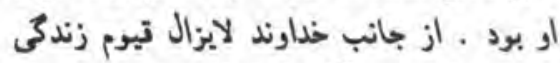

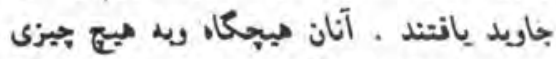

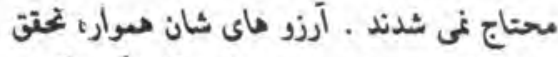

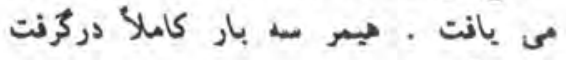
ودجارآتش سوزى شد ولى خانه شامل هيحكا. آَسيبى نديد .

جندين بارنيز آشيلتا آتش كرنت ولى خاند

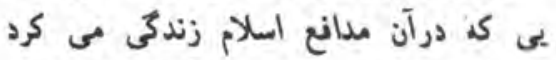
درميان توده شاى خاكستر سالم وسلامت ماند

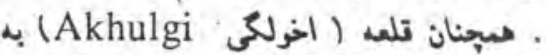
خاكستر مبدل شد ولى خانه زير زمينى المان

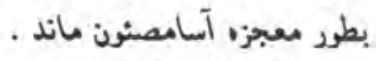

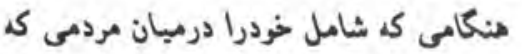
با ار درمساعى متدسش هنواثى نى كردند تنها بانت ، تاصدى بم نزد الهالى آثبليل

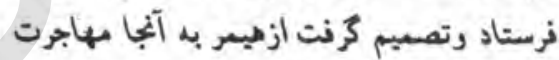
كند . شب هنكام هرٔده تن مريدان بحضود

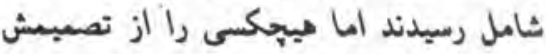

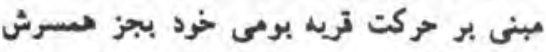

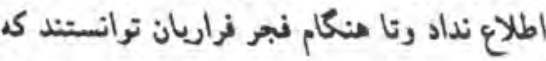

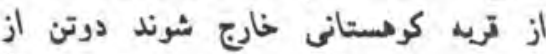

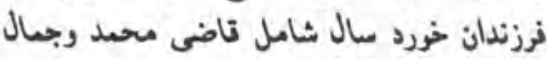
الدين را آثيلتانى ها بردوش هاي شان اندان انتال

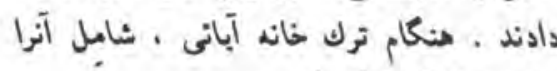

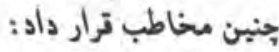

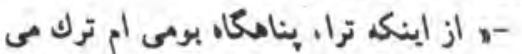

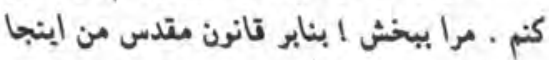

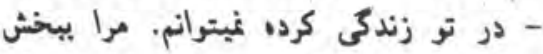

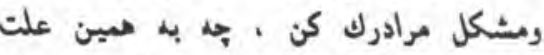

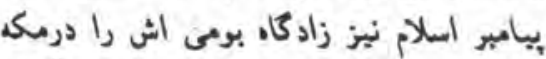

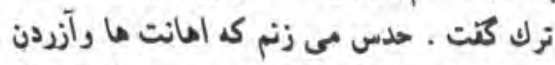

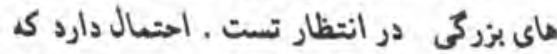

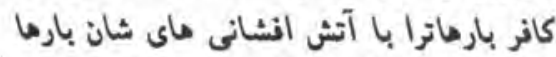
توهين كنتد ولكد مال نايند .

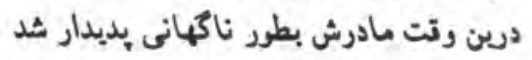

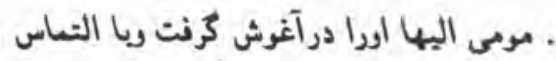
Sis - , نرزند كم بيدا ى من كجامى كريزى : 
زندمى دارند ، نغات دربين 3روه هاي جهادى

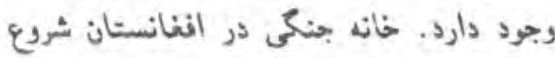

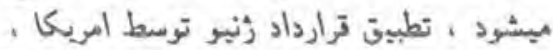

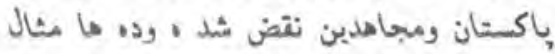

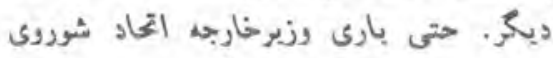

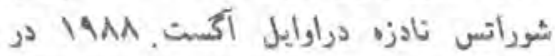

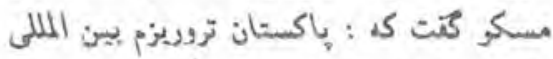

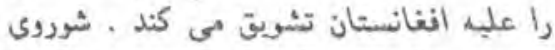

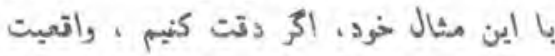

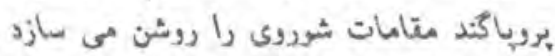

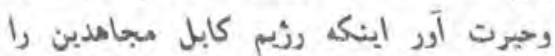

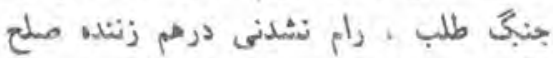

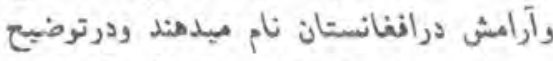

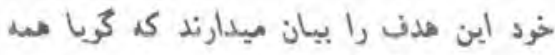

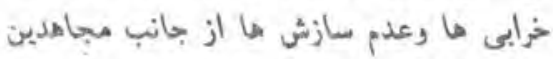

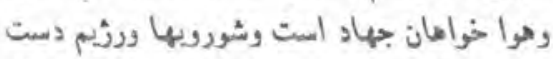

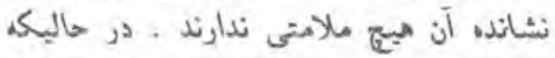

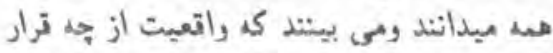

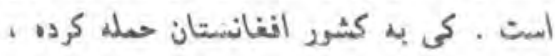

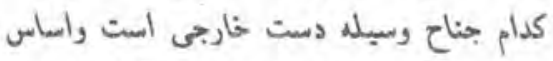

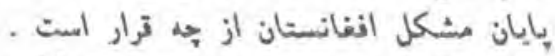
استادان كد هرورز بم صنف ميايند ، حتعا آنها

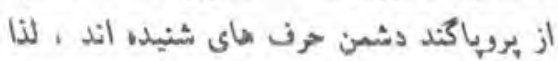

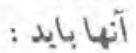
1 - هوضوع عده بورياكندى را تشخيص

Y- موضرعات رانظريه درجه صنف بندى

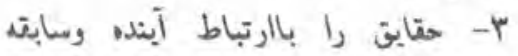

$$
\text { وبيان كنيد . موضرع }
$$

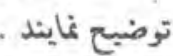
ع- به سوالات شاخردان جواب بحريند

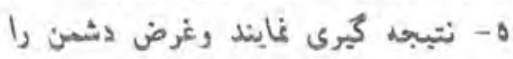

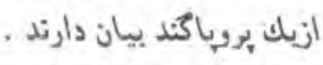

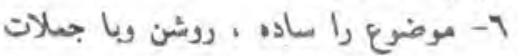

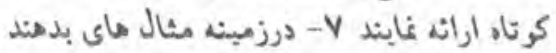

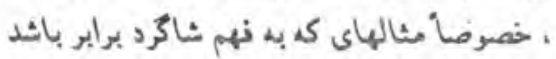

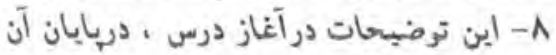
ويا خارج از درس موتع تغريح اراته شده داندان اندان

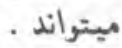
طور مثال اكراستاد ميخواهد بروياكند
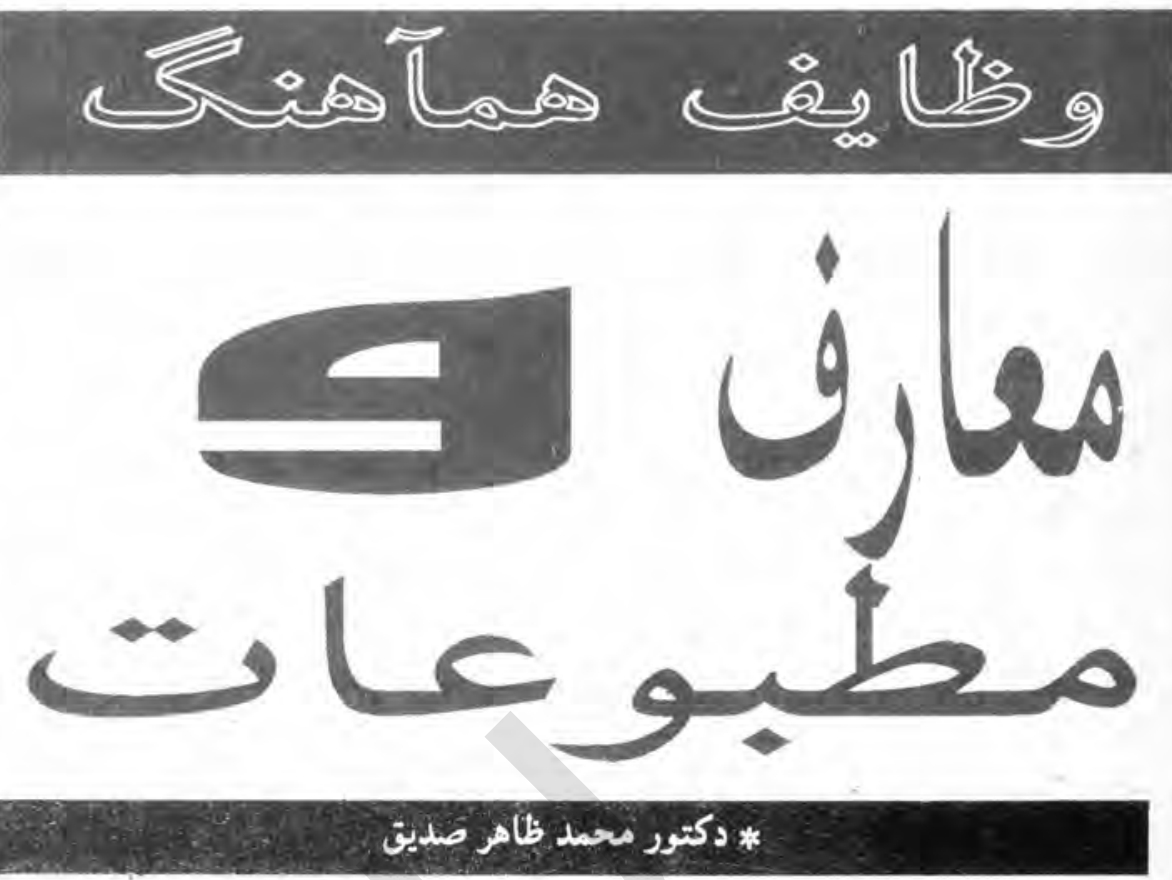

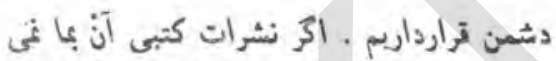

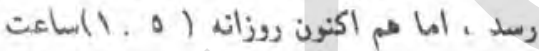
نشي ات و تبليفات

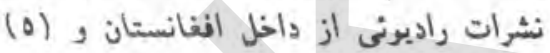

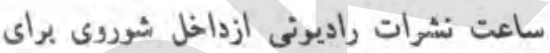
تانيد سياست شوروى درمورد حالات انغانستان صورت ميكيرد ،هين تسم نعاليت

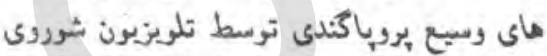

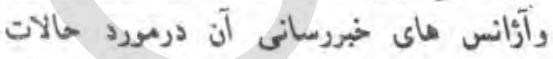

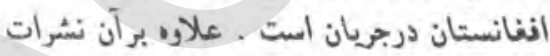

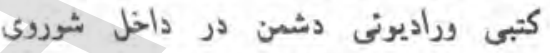

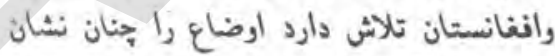

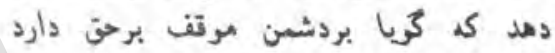
ومجاهدين ومهاجرين وسيله دست بيكاته شده بردي است است. درجنين حالت كه شبكه عنكبوتى تبليغات

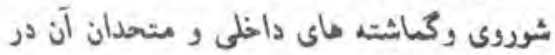

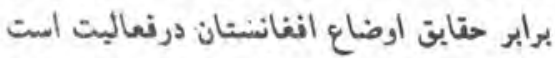

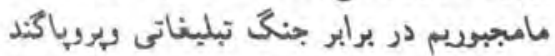

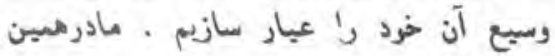

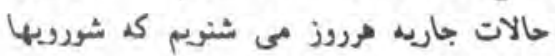

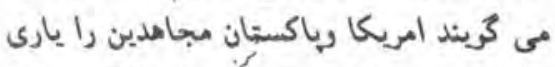

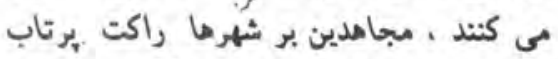

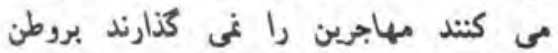

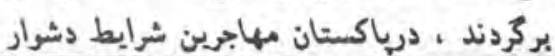

وسايل مناسه جعى دراساس امروز در كثرد هاى جهان نعاليت خودرا در سه كتكردى دنبال مى نمايد : 1- مطبوعات كثور هائ غربى كه مدعى آنى داشتن يك مطبوعات آزاد رآناقى اند عرئ وسوسياليستى كه مله جيز زيرتاثيرمستتيم ايديالوزى كرنيزم بيان ميشود .

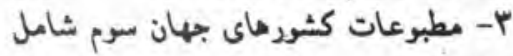

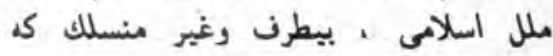

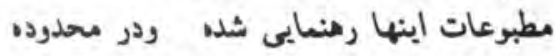

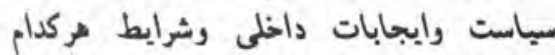

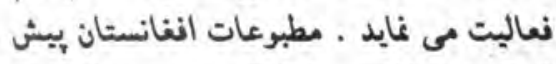

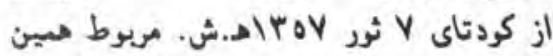

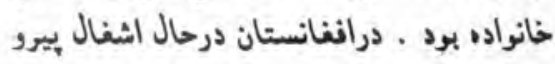

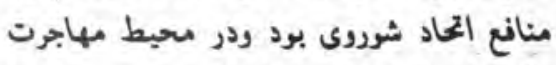
باكستان وايران تابع شرايط ومحدوده سياست جهاد وجوكات روش تنظيم هائ اسلامى است .

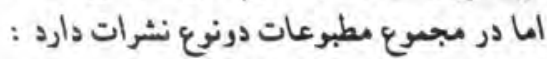

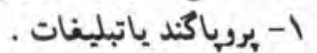

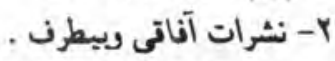

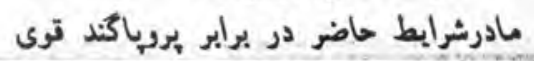

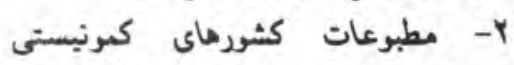


روزمره از طريت جهره ماى نهيم زدلسوز وبا

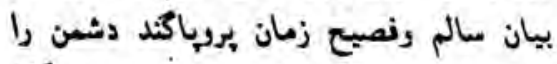

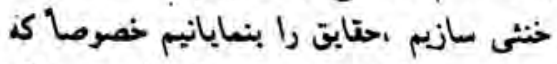

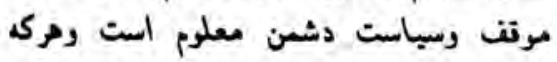

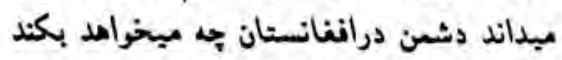
وغرض آن تا امروز درانغانستان جه بوده است دران

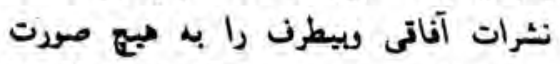

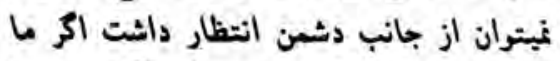
بترانيم تشرات خودرا بصردت آناتى رمبرا

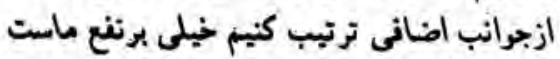

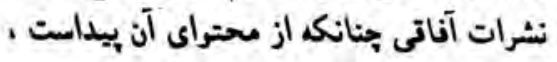
نتط جانب حت وراتعيت را مى كيرد .

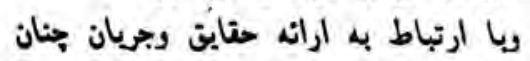

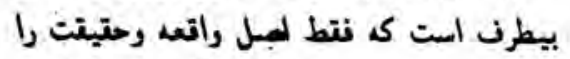
ميكريد وجيز غير واتعى درآن نمى انزايد . مانى توانيم از موضِوع درحيد دادن دراراثي

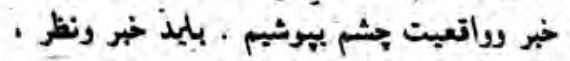

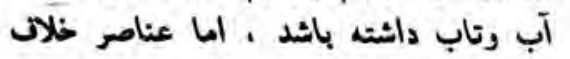

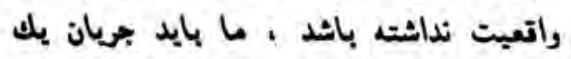

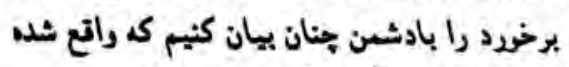

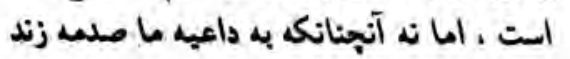
ما ازبك خير ورك واتعه تلفات وخسارات

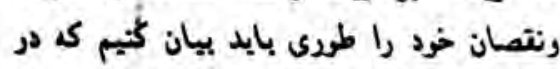
روال جهاد اثرمنغى نداثته باشد الما اين بيان كا مم جنان نباشد كه واتعه را واروند نثان دمد. زيرأ واتعه را خلات واتعيت بيان كردن

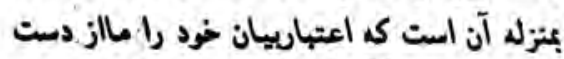

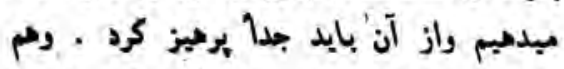

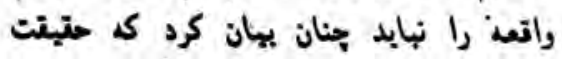

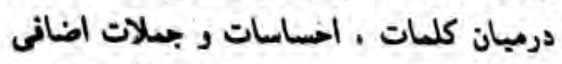
بكلى بوشيد، شود وخوانتده وشنرند، نداند كه

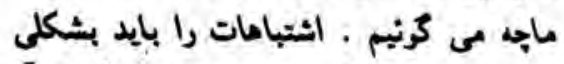

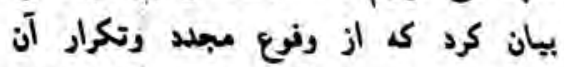

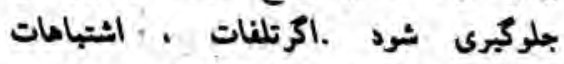

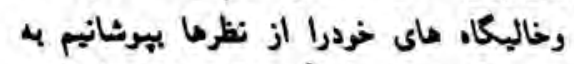
معنى آنست كه ماجرأت بيان حتيتت ران الناريم ويا خراهان دوام اثتباه خود م باثيم كه هردو يضرد ماست ورامان دوان.

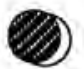

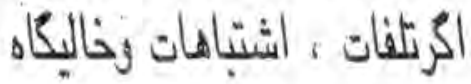

هائ خودرا از نظرها بيوشانبر

بك منى أست كه ماجرأن بيان

حقبقت را ناريح ويا خواهان

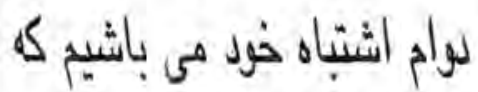
لمرلو بضرر ماست

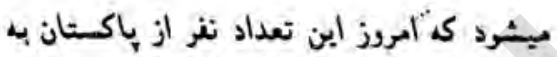

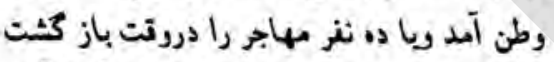

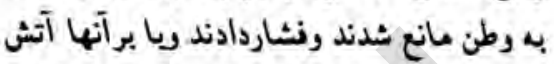

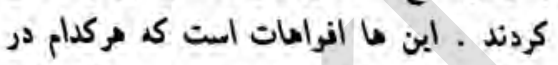

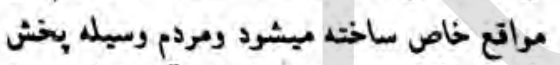

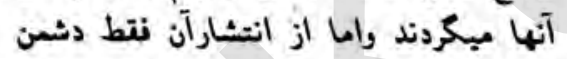

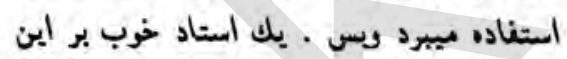

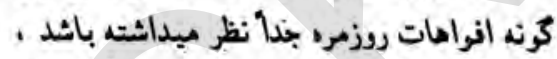

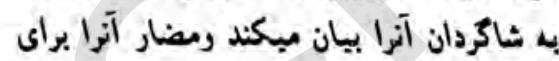

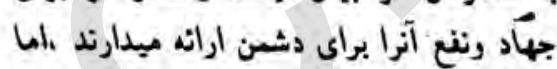

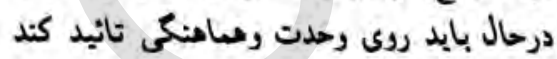

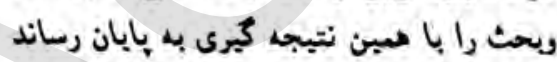

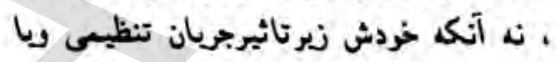

درمجبوع بروياكند زعرياشى دشعن است

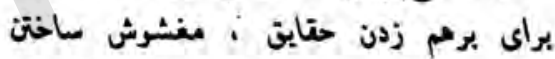

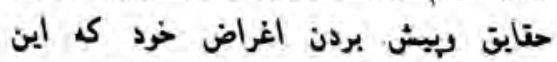

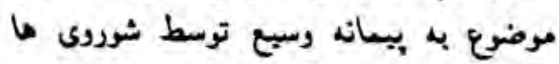

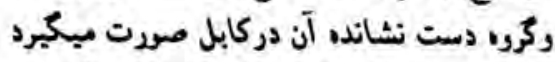

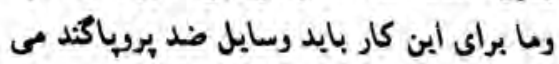

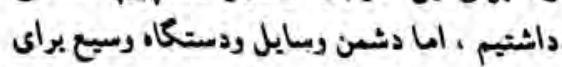

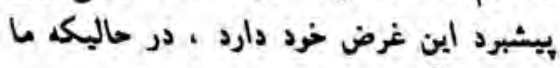

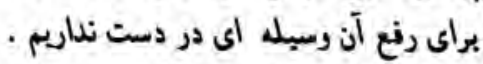

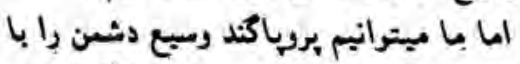

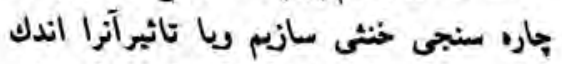

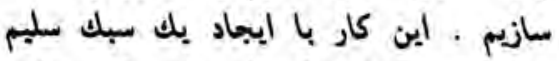

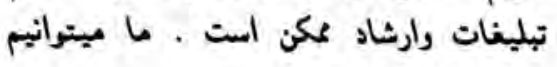

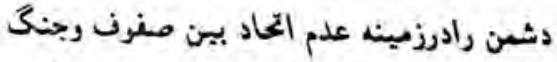

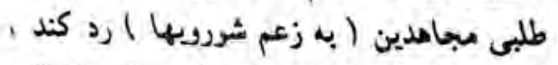

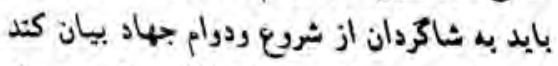

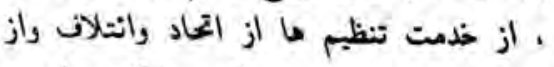

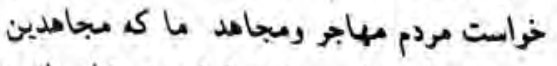

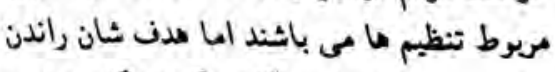

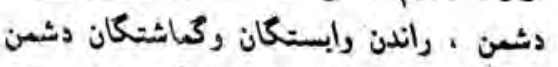

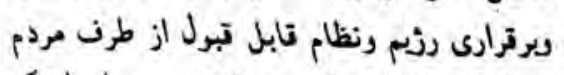

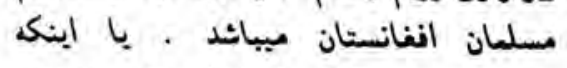
مباهدين حق دارند تازمانيكه دشسن درخاك

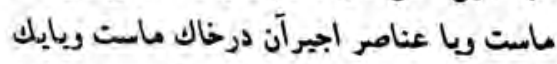
رذيم دلحواه مردم خودرادروطن بتدرت نرسانيد.

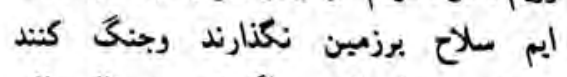

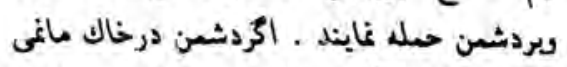

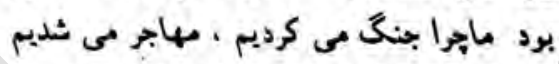

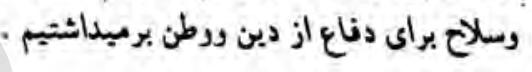

\section{أفواه}

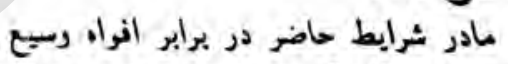

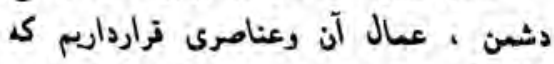

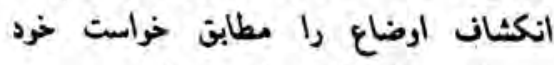

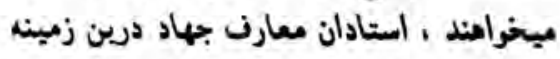

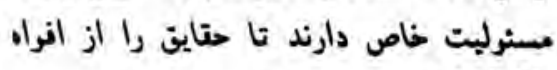

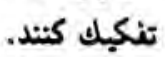
انواه را براى آن دريين مهاجر ومباهد

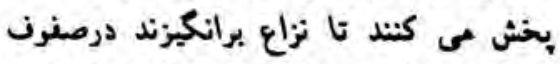

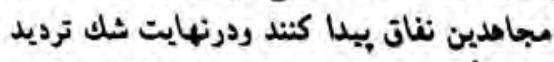

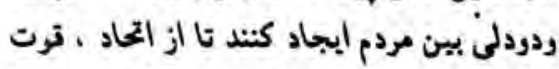

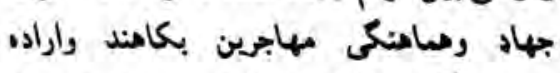

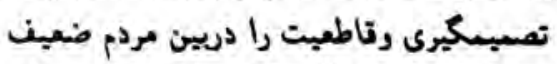

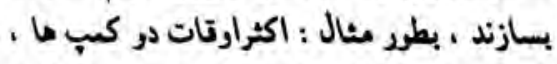

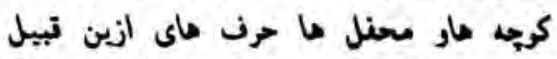

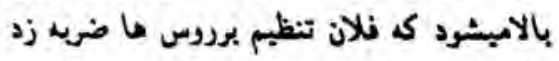

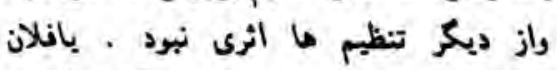

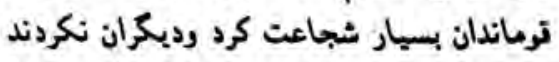

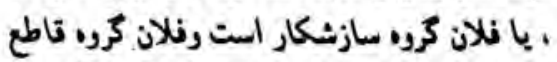

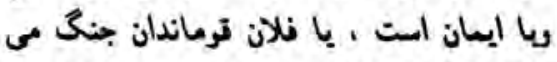

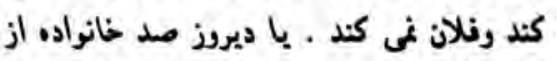

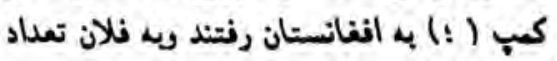

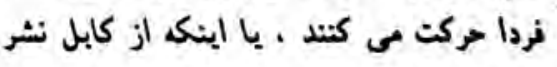


وصيت حضرت ابزيكر صديق رضى الله تعالى عنه درياره جانشينى حضرت عمر رضى الله تعالى عن

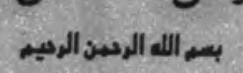

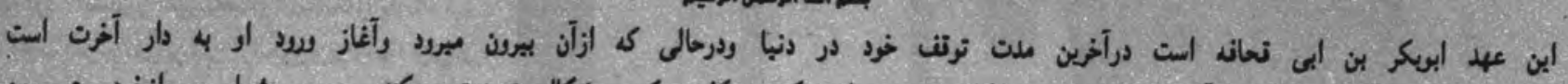

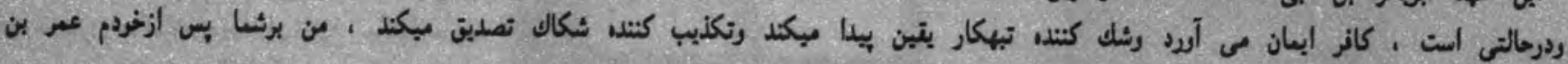

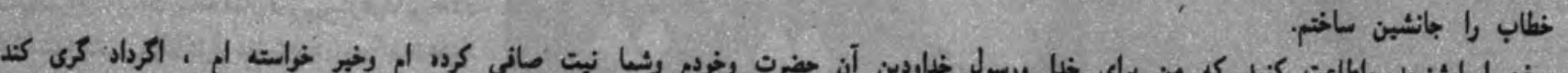

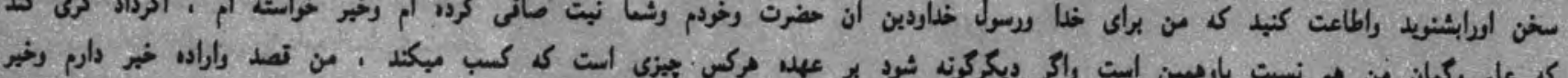

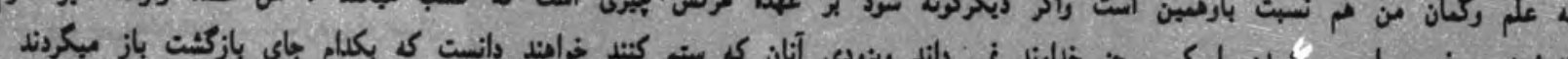

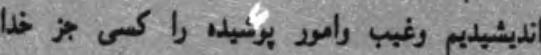

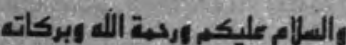

خانه وخاتون ؛

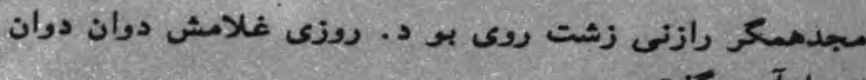
نزو اوآمده كنت

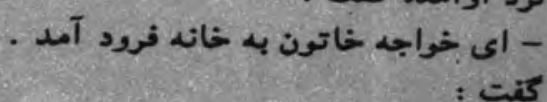

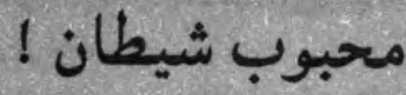

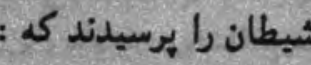

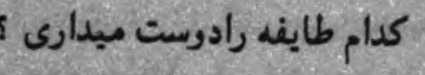

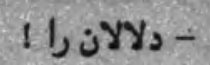
: - كفت :

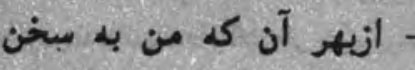

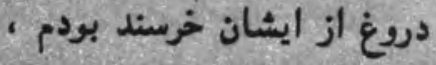

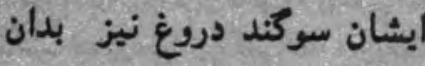

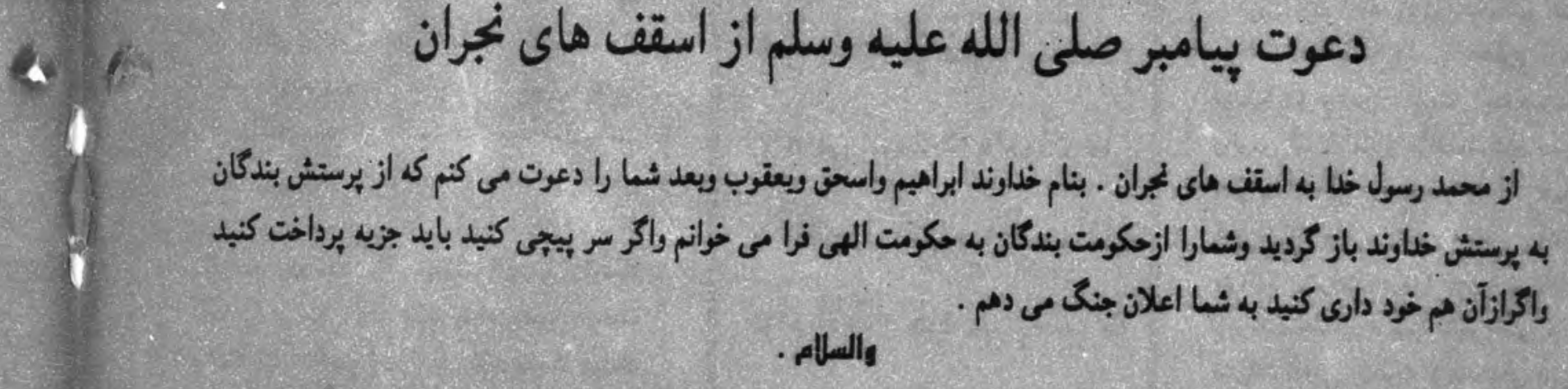

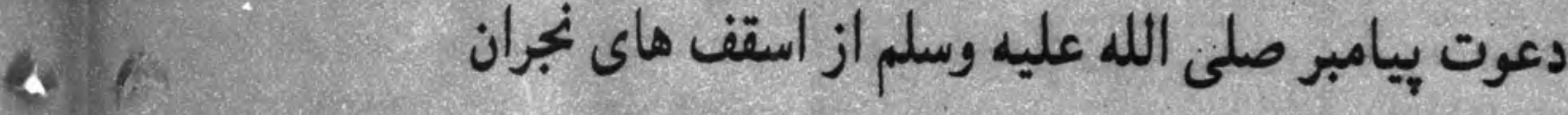

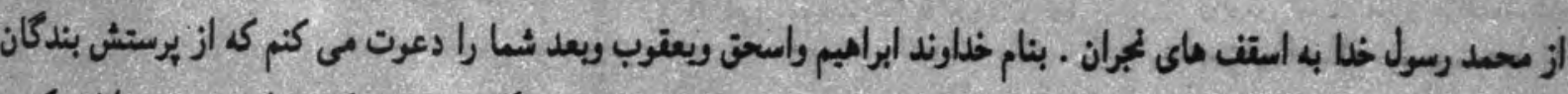

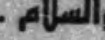

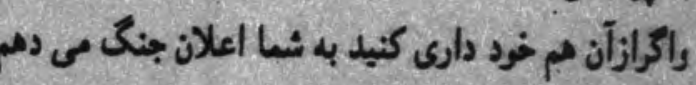

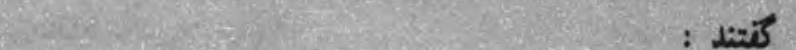

كتث : آزادش كنبل ، بكتاريد خردش بكيرد وخروش

1 بخورد 1

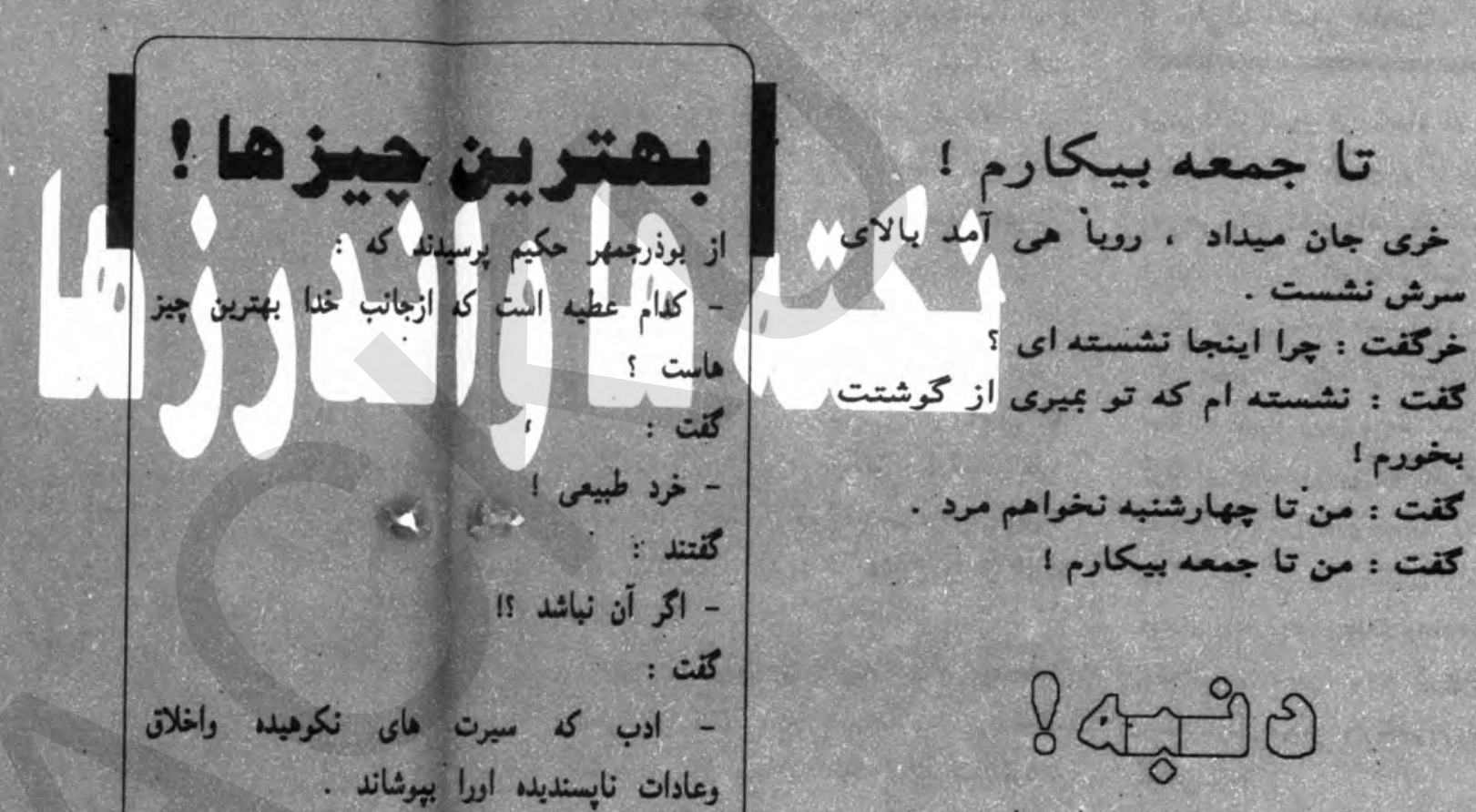

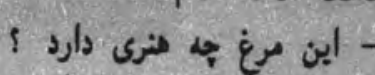

f) Iا كتئد :

خوى خوش كى با خلالم مدارا كند : خلم

: أكتئن

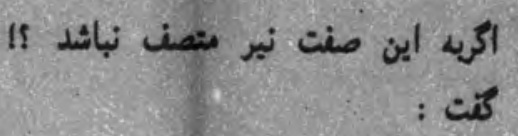

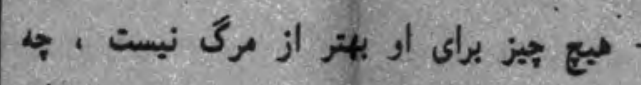

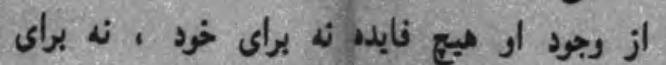

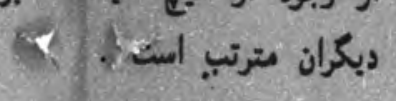

ريذى سلكان محصود بـ دارالمجانين رنت ، از ديوانه يرسبد :

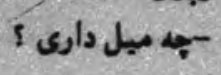

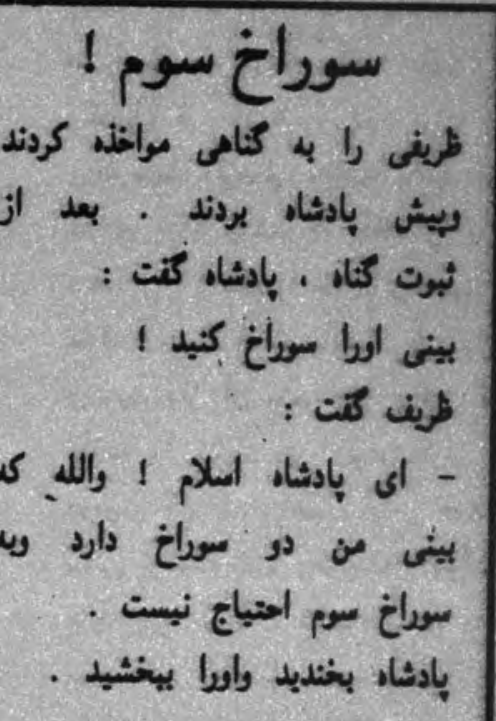

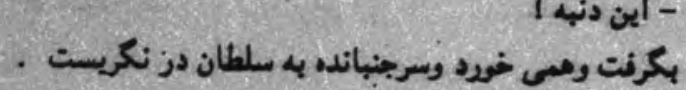

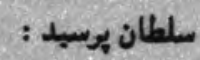

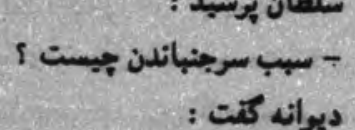

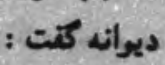

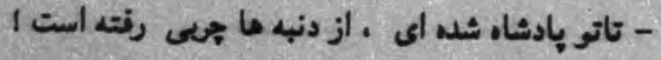

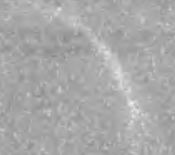




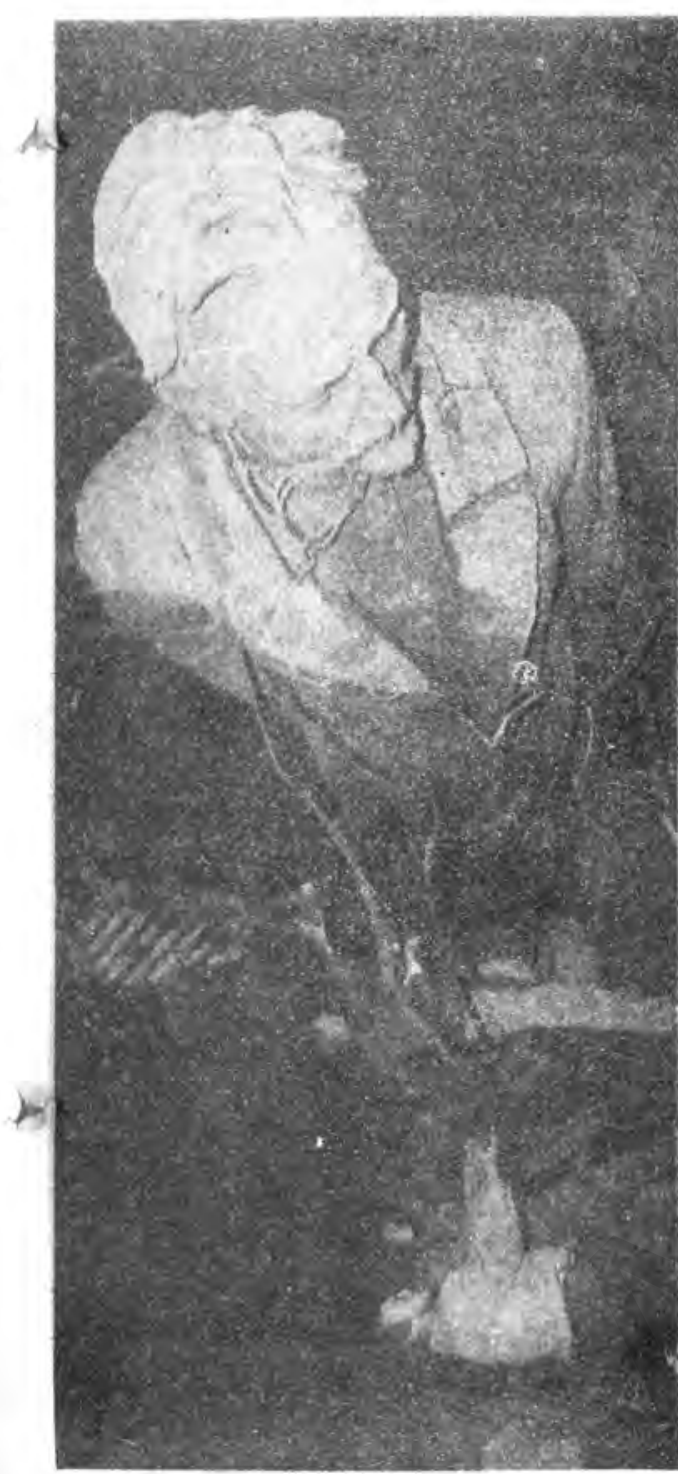

:دزرئنسكى ينيانكنار (بكا) سازماز اطلاعاتى روسي

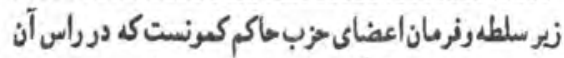

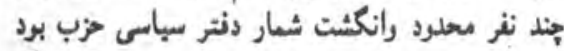

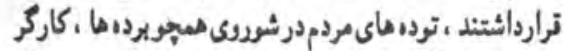

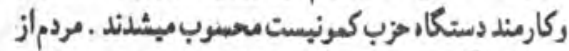

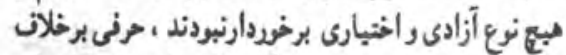

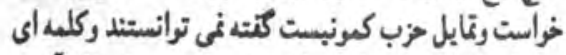

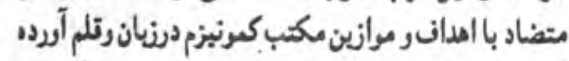

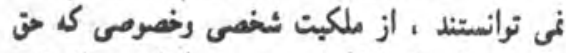

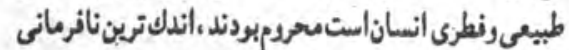

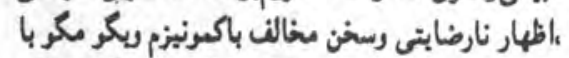

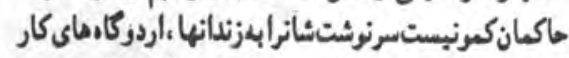

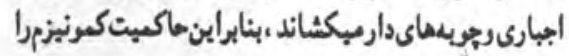

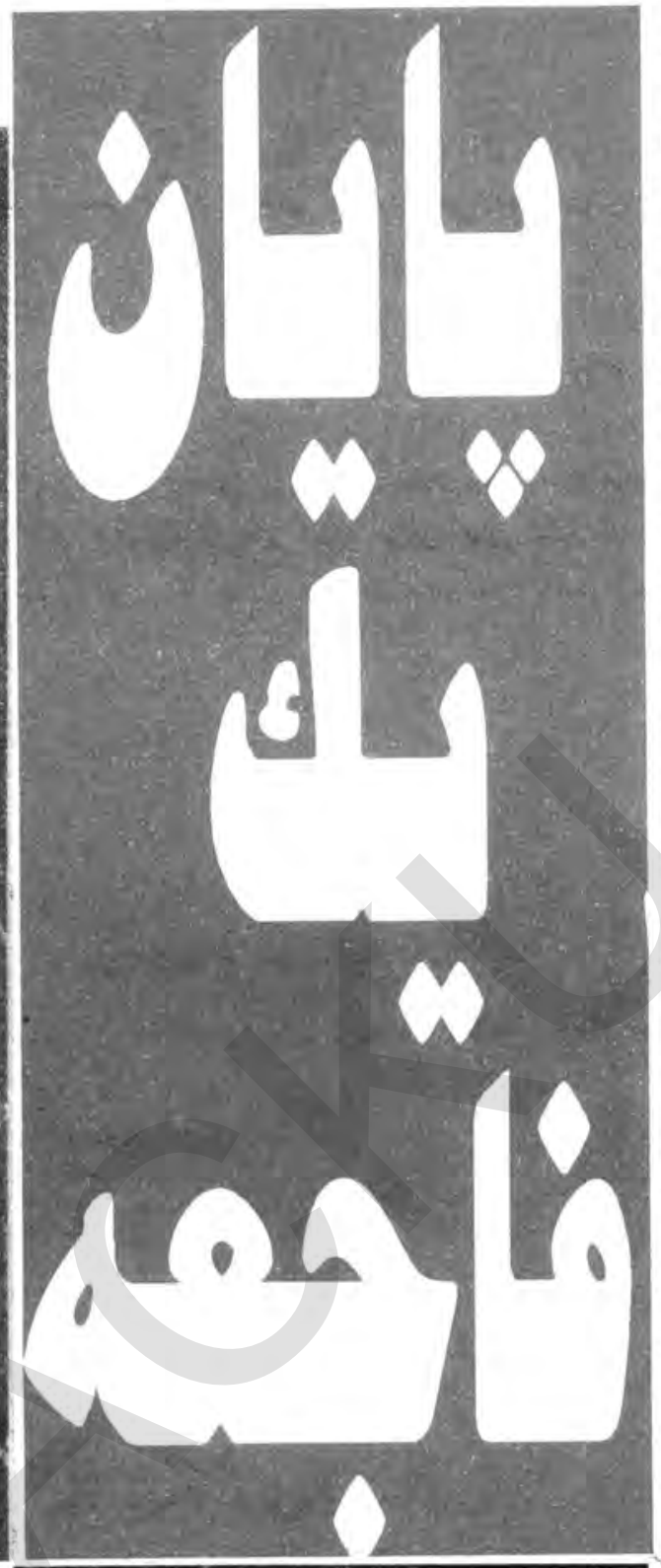

\section{* محعل اكرام " انديشسند}

آن دورن با امررز بيشتر وننكين تراز دران بردكى محسوب ميشود.

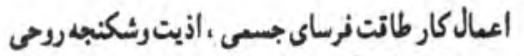

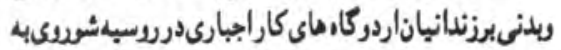

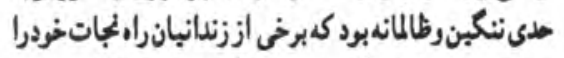
در انتهار سراغ ميكردند وعده أى مم در زير كار مشتنت باروطاتتفرساتدربجأجانمبدادند.

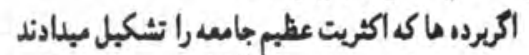

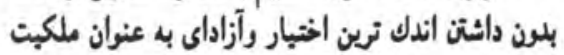

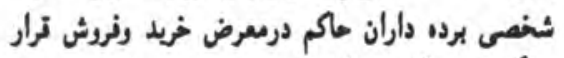

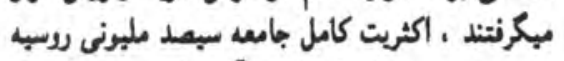

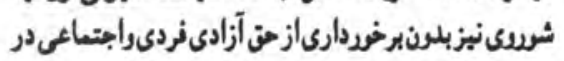

بلدون ترديذ حاكبت كعرنيزم طى هنتانسال اخير در

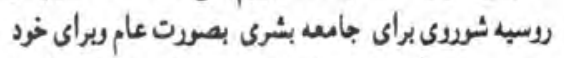

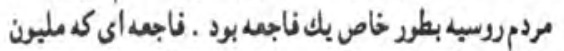

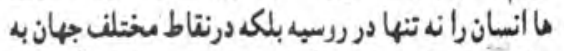

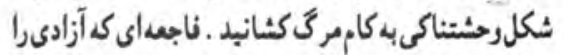

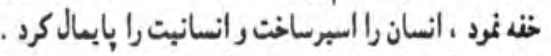

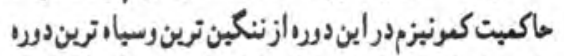

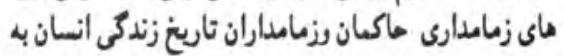

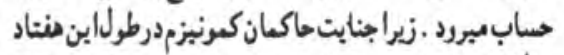

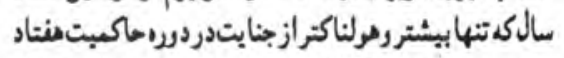

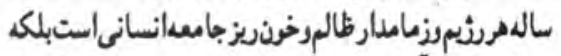

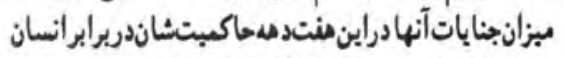

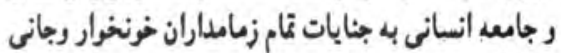
درولتاريغبرابرى مبنمابد.

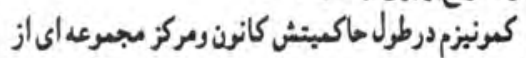

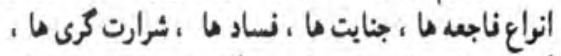

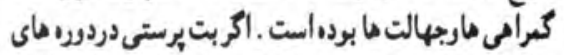

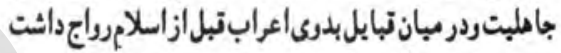

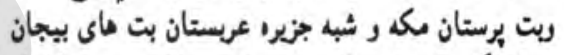

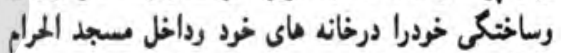

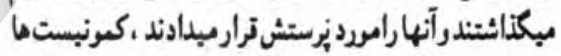

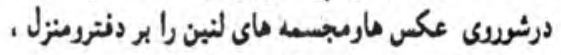

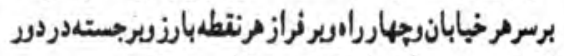

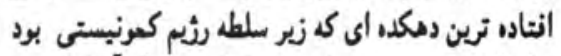

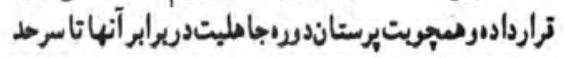

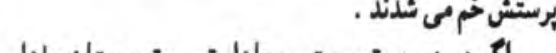

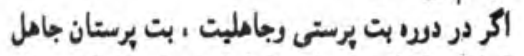

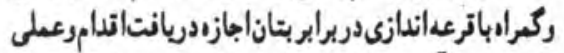

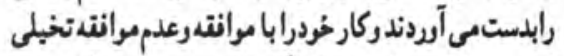

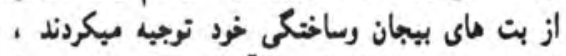

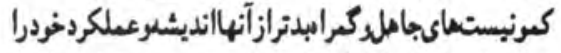

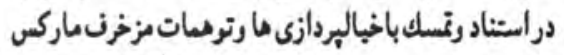

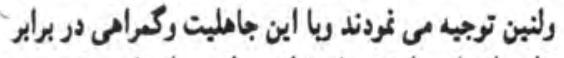

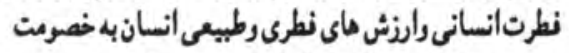

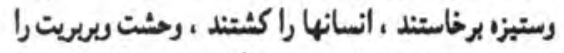

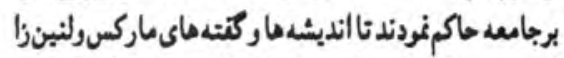

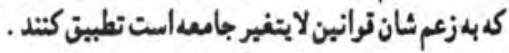

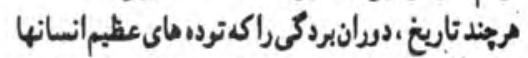
رانعداد انكشتشمارى مودد بهراكشى ظالماند ترارمبيدادند

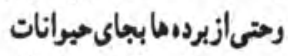
درمزارع ركشت زارما استفاده ميكردند ، سياه ترين

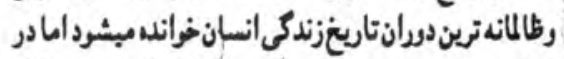

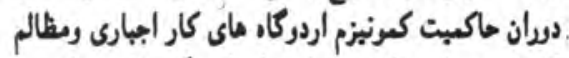

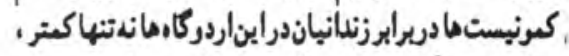

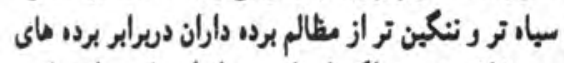

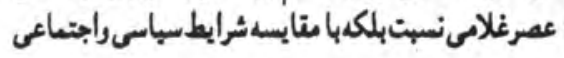




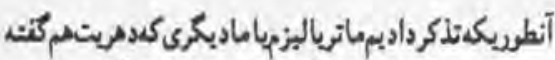

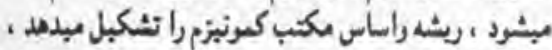

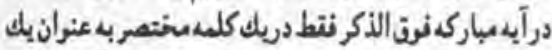

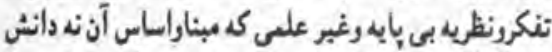

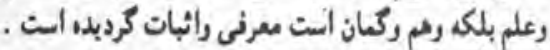

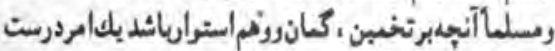

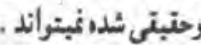

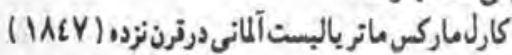
برخبالاتريندارهاي ماتريالبستى انزرد وآنرا به عنوانيك

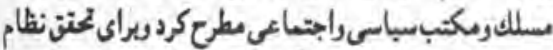

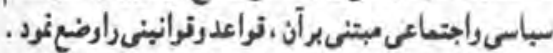

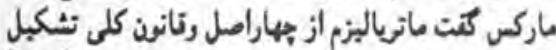

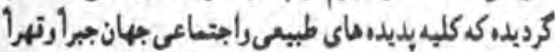

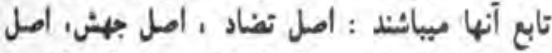

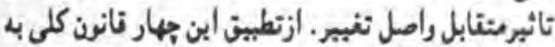

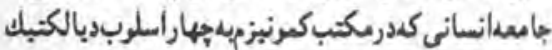

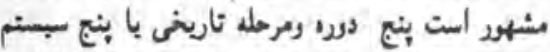

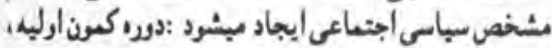

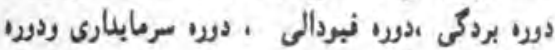

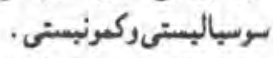

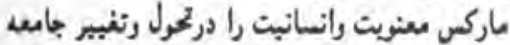

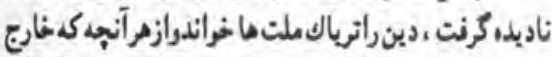

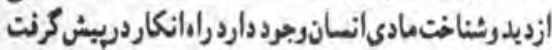

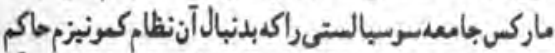

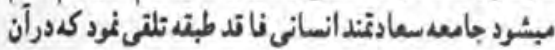

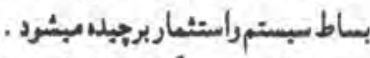

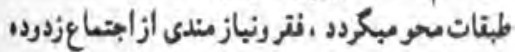

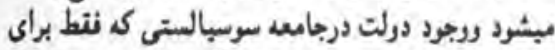

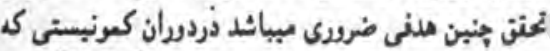

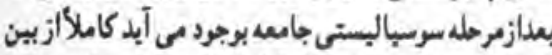

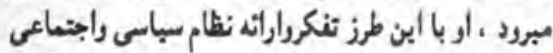

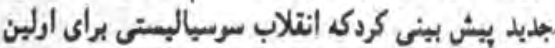

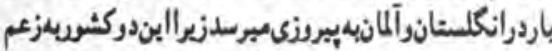

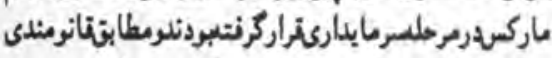

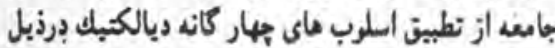

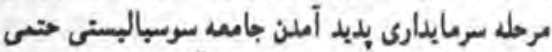

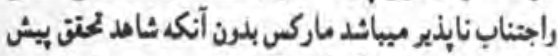

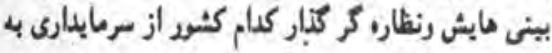
سوسياليزميائدبيرودهياتكتث.

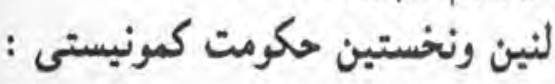

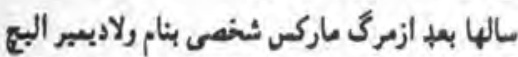

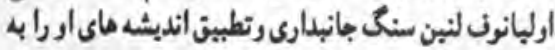

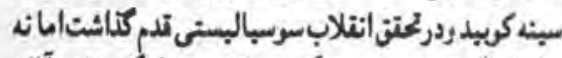

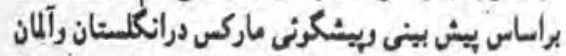
بلكه در روسبه ، روسب كه از ديد كا، ماركس درمرحله

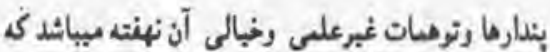

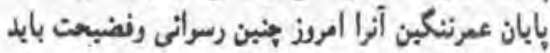
درهين خرافى بودن ،غير على بودن وغير نطرى بردنش

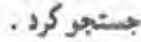

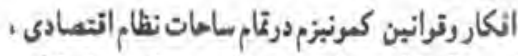

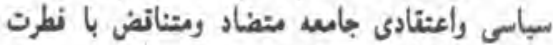
إخصروصيت نطريانسان است.

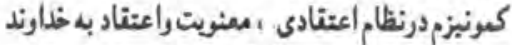

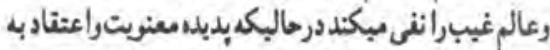
خارند ثعالى يك امرنهبته شدد، نظرى درنطرت رطبيعت

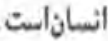

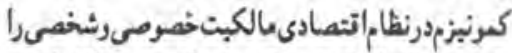

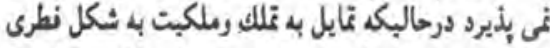

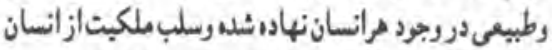
كاريست كي با نشارززند برخلات ميل نطرى اش صردت بكيبرد.

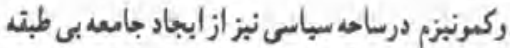

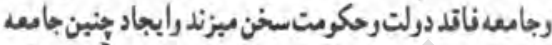

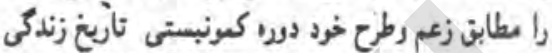

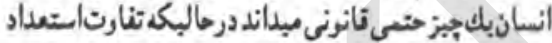

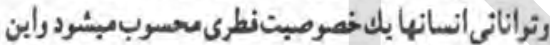

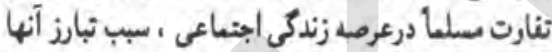

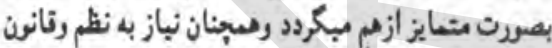

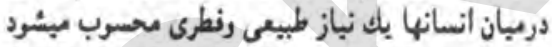

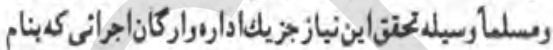

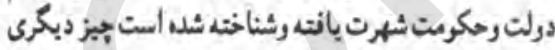

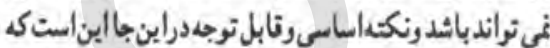

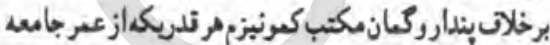

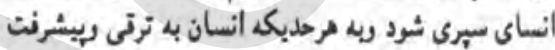

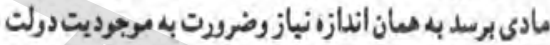
رهكومت كه مجرى نظم وثانون ميباثلد بيشتر وأنزونتر

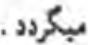

راركاد ترين تصرير راتعىرا غير على بودنماترياليزم

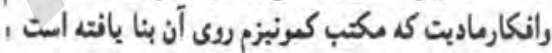

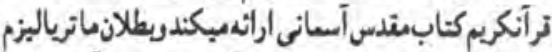

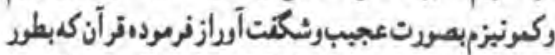

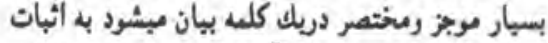

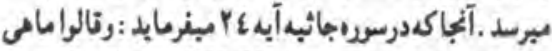

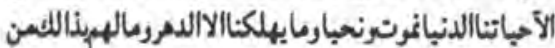

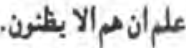

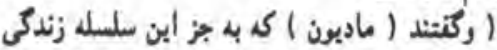

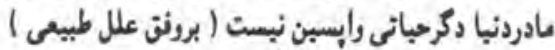

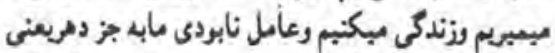

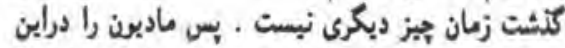
انديشه اساس على نبست وله جز وم ويثلارمايه واساس

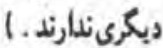

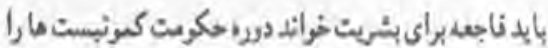

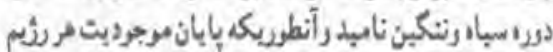

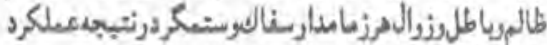

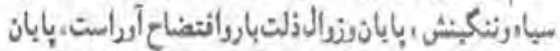

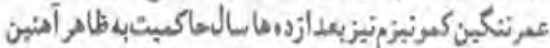

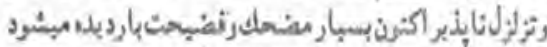

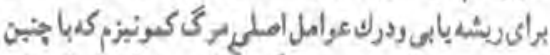

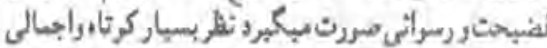

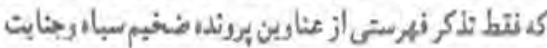

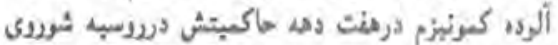

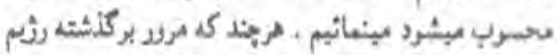

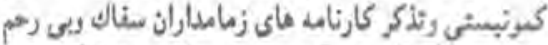

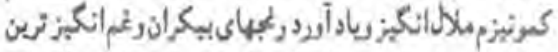

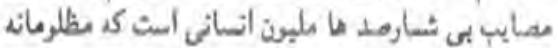

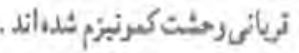

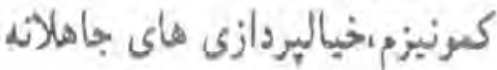
وبراز تناتضض :

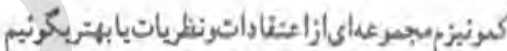

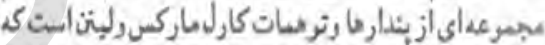

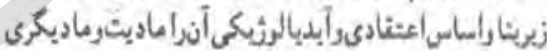

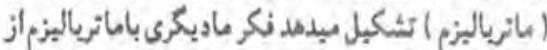

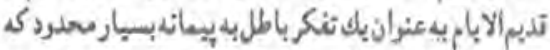

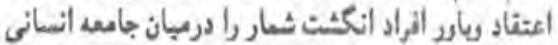

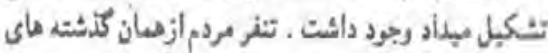

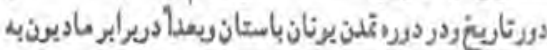

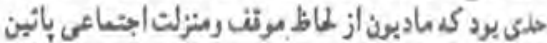

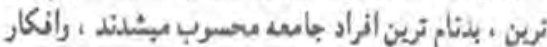

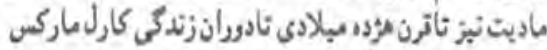

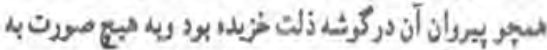

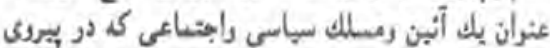

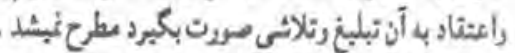

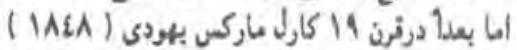

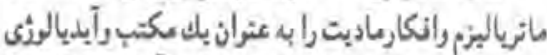

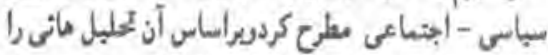

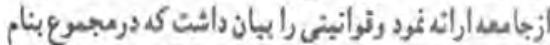

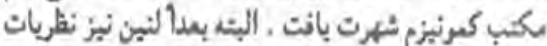

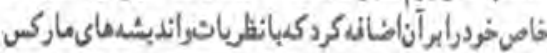

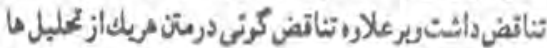

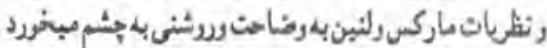

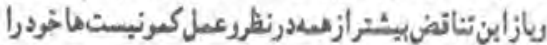

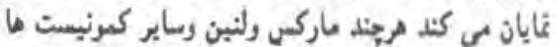

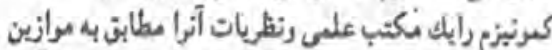

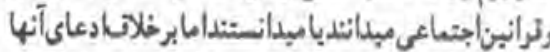

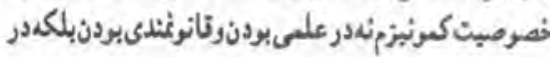




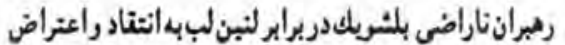

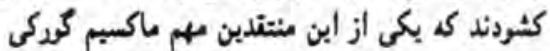

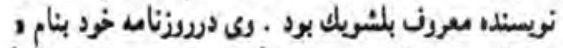

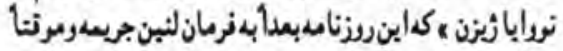

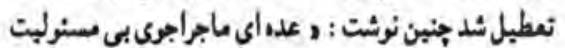

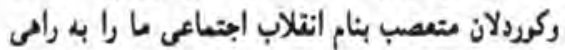

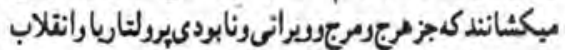

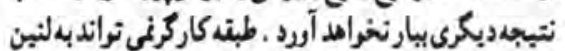

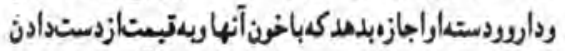

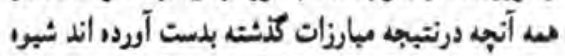

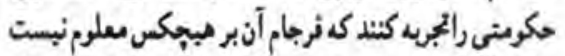

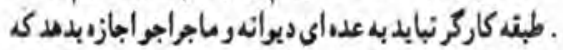

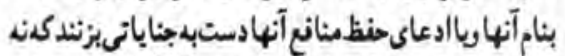

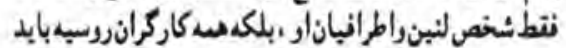

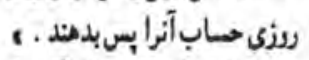

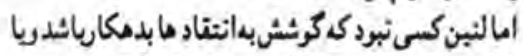

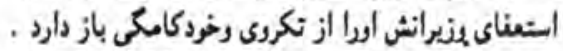

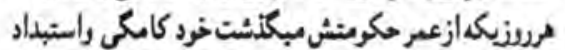

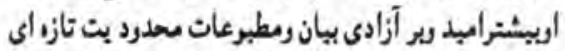

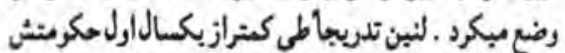

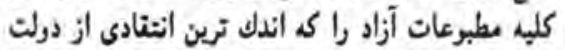

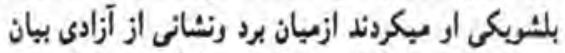

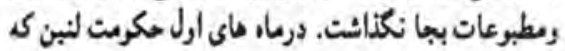

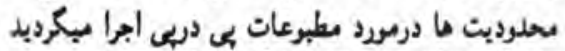

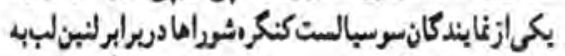

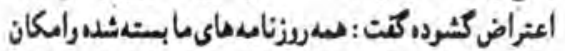

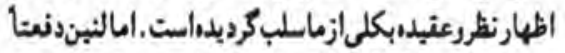

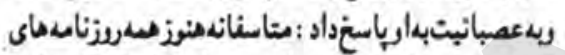

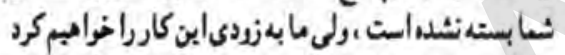

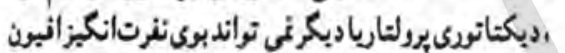

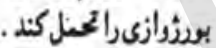

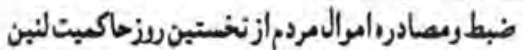

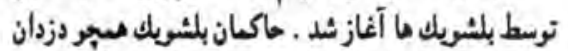

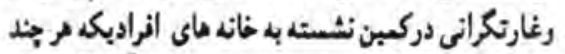

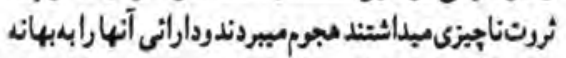

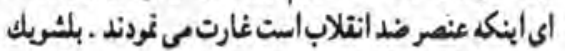

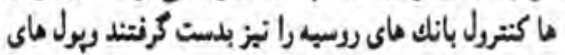

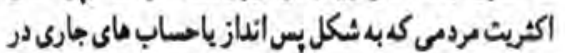

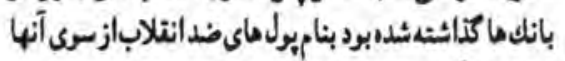
غصب مبكريد.

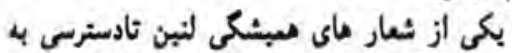

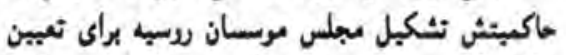

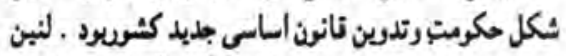

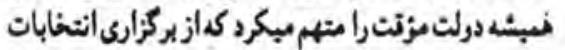

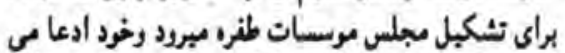

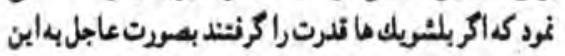

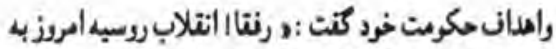

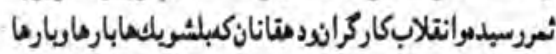

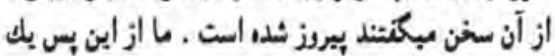

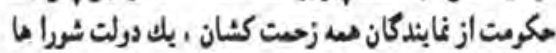

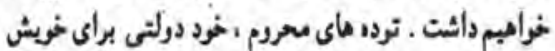

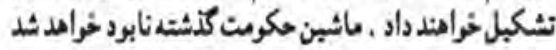

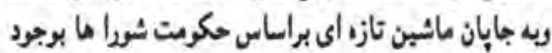

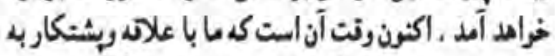

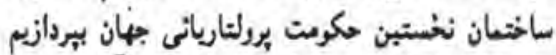

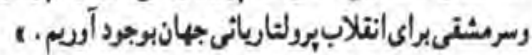

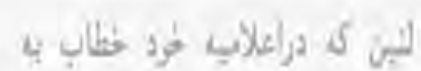

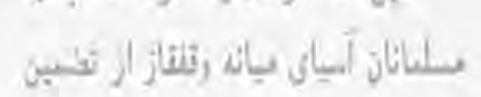

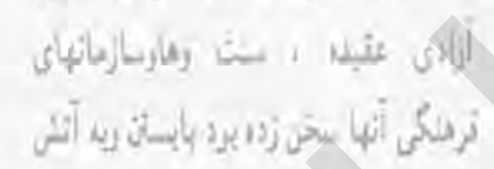

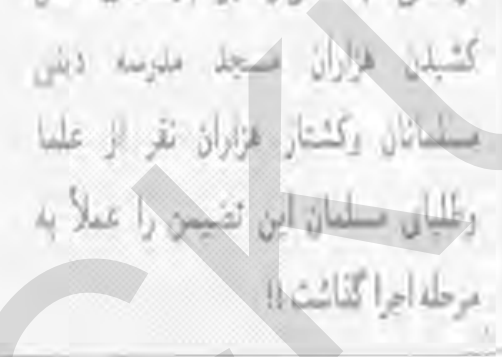

كنين دراين سخنرانى براى فريب دادن اكثريت اعضاى

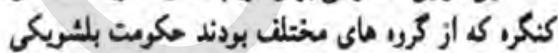

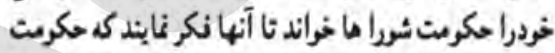

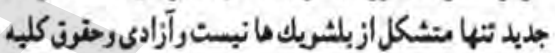

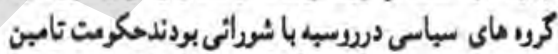

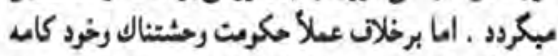

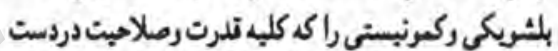

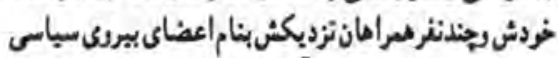

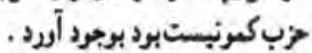

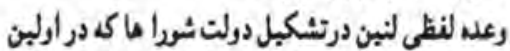

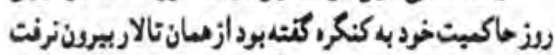

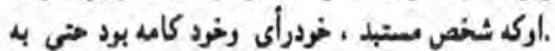

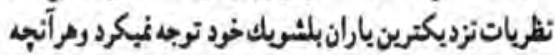

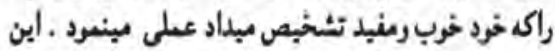

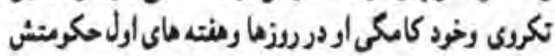

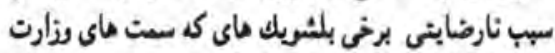

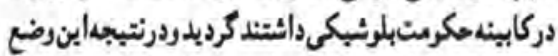

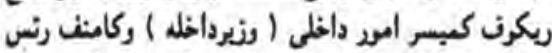

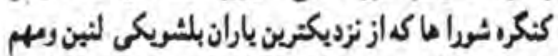

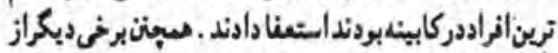

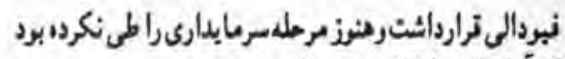

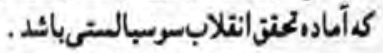

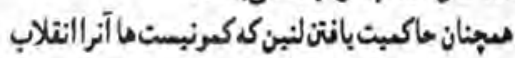

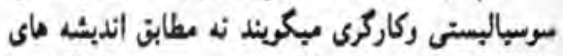

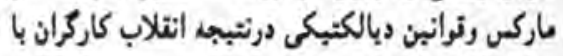

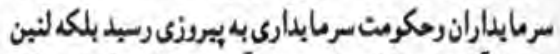

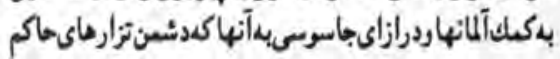

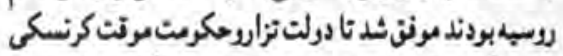

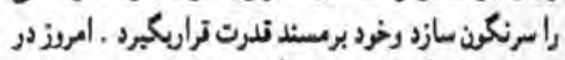

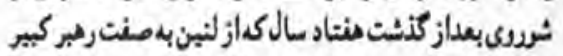

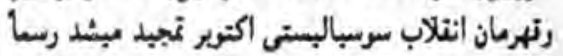

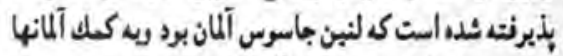

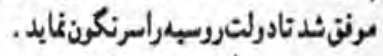

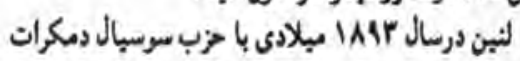

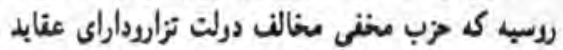

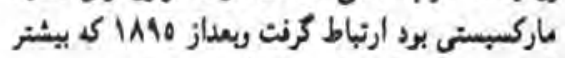

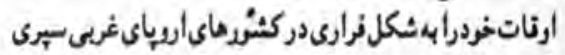

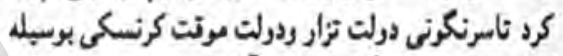

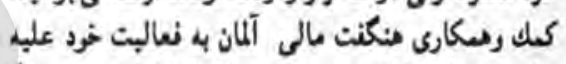

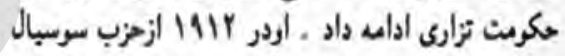

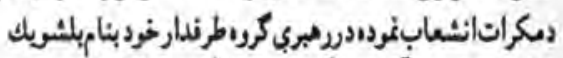

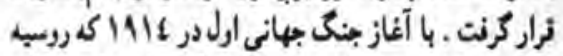

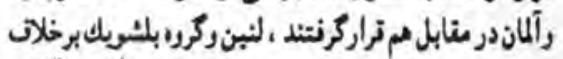

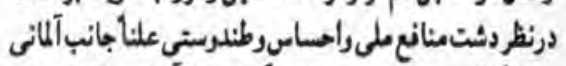

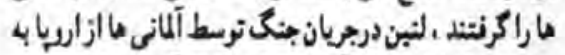

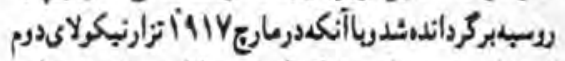

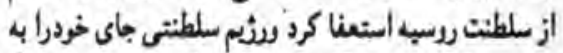

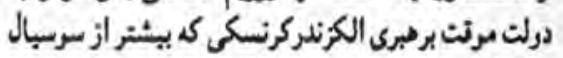

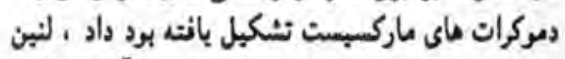

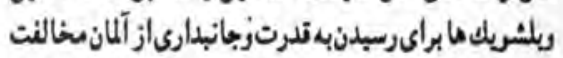

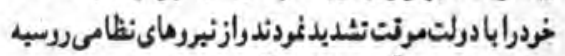

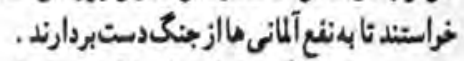

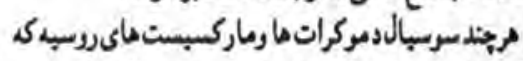

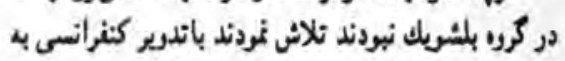

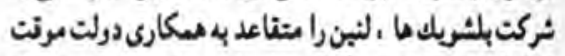

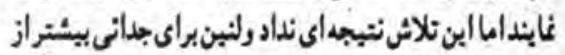

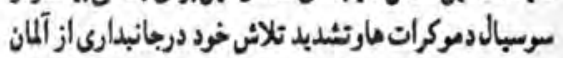

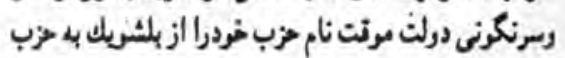

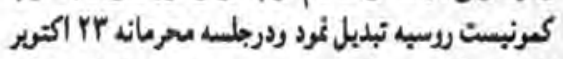

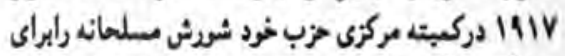

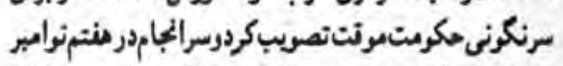

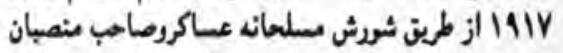

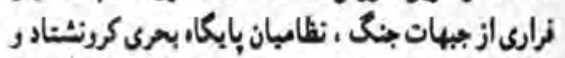

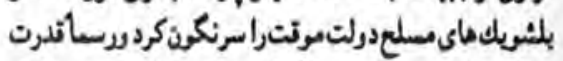

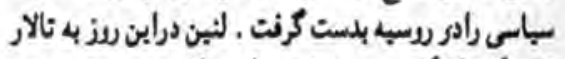
فابندكان كنكر، ردسب رنت رطى نطقى درمورد بيررذى 


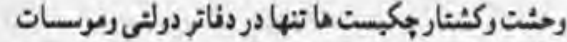

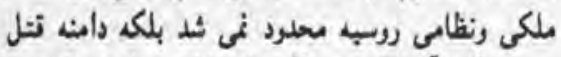

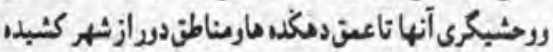

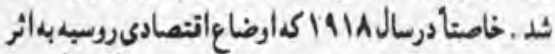

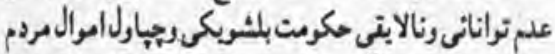

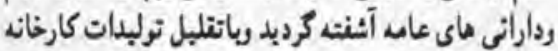

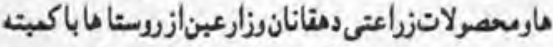

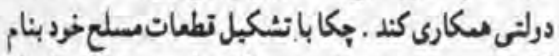

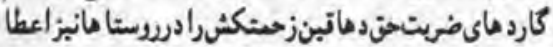

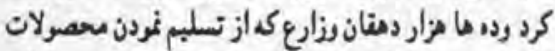

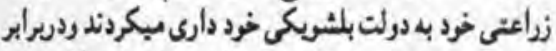

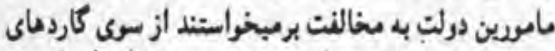

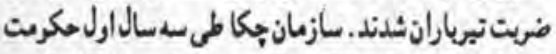

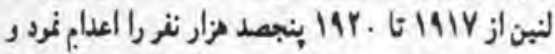
كلبمايناعدامها بدرنمحاكس صروتكرنت.

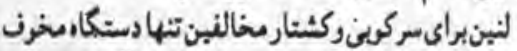

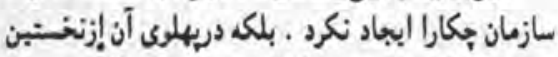

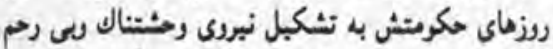

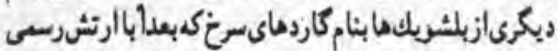

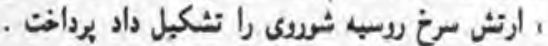

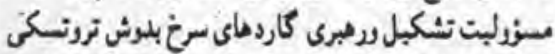

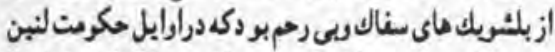

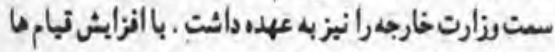

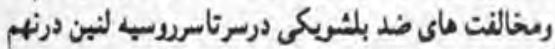

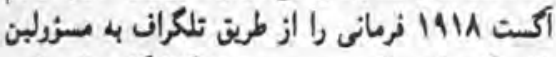

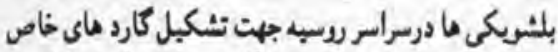

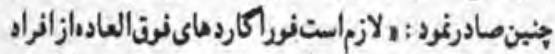

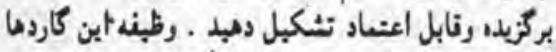

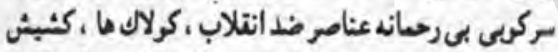

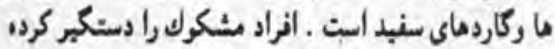

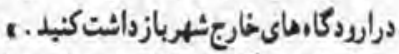

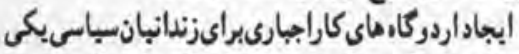

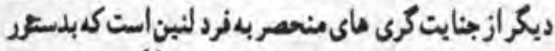

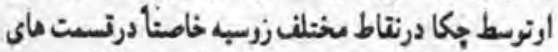

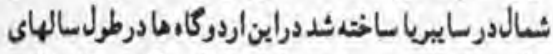

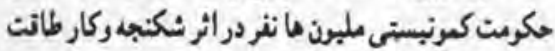

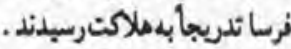

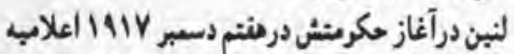

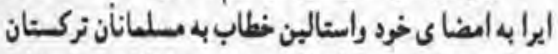

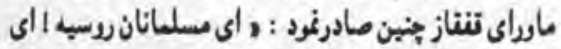

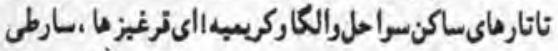

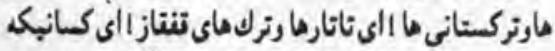

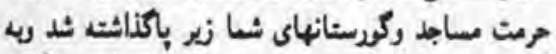

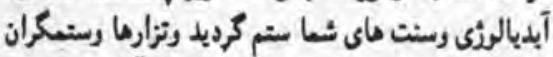

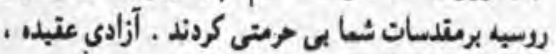

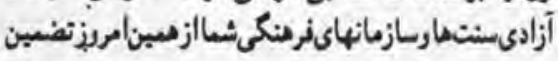

لنين سازمان بولبس مخفى روسبه را بنامر جيكا ع بوجود

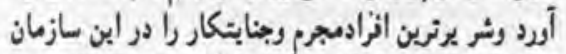

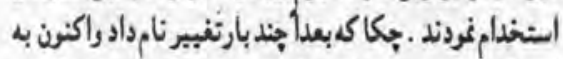

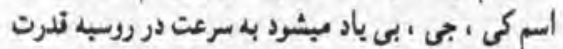
كرنت روحشت ناكترين حكومت غارتكرى وكشتارداليجاد

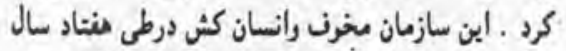

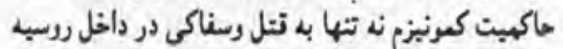

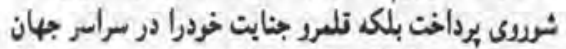

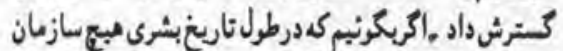

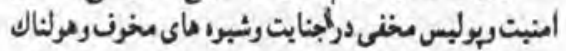

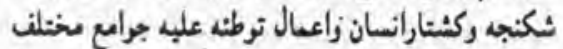

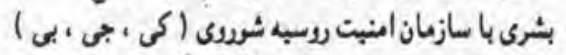

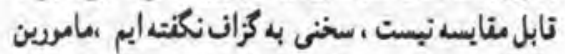

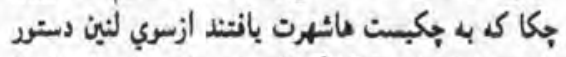

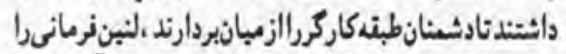

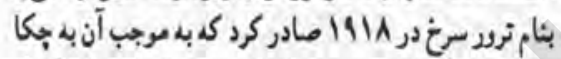

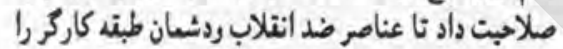

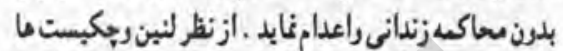

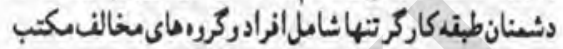

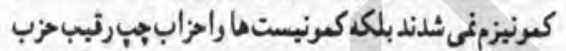

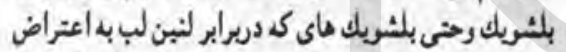
ومخالنت مى كشودند درلست دشعنان طبته كاركر ترار

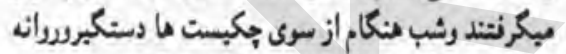

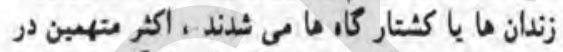

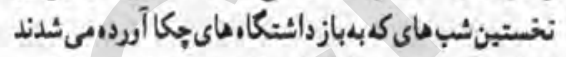

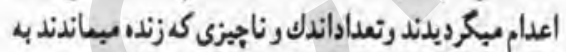

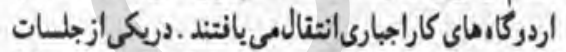

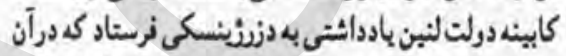

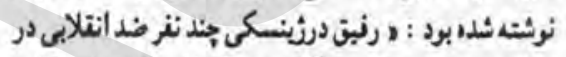

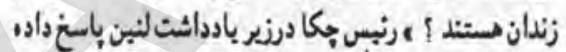

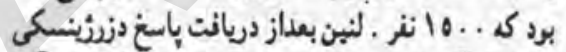

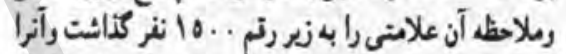
دوباره بـ دزدئنسكى نرستاد ـ دزرثينسكى با ملاحظم

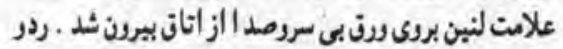

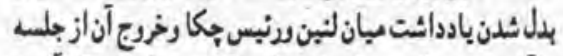

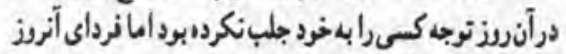

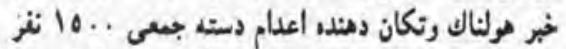

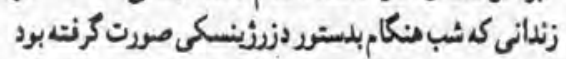

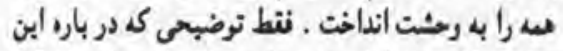

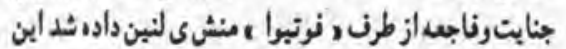

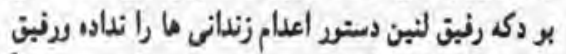

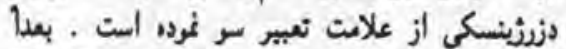

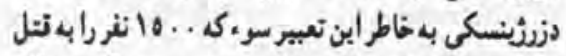

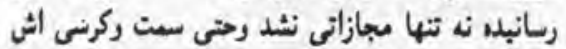

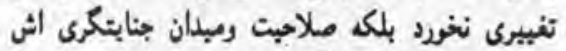

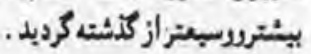

أمراتدام مينعايند ، لثين وتنيك به كرس زمامدارى روسبي

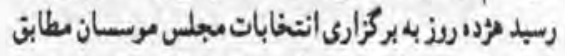
زمان تعيينشدهاز سرى درلت مؤتت مخلوع باتى ماندا بود

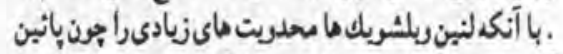

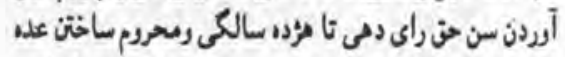

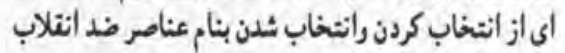

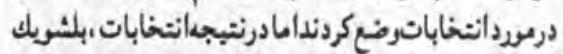

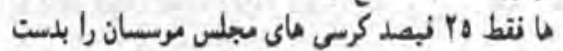

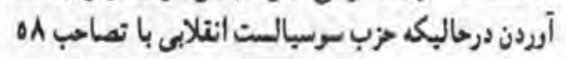

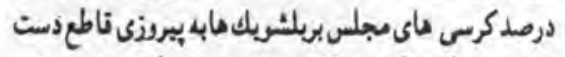

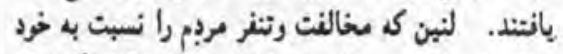

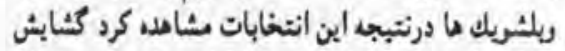

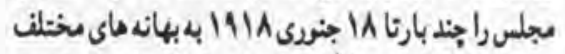

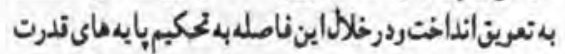

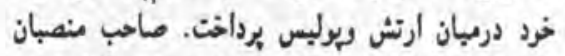

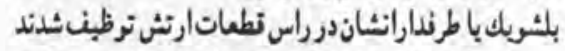

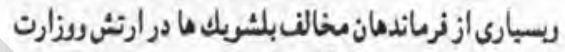
داخلدبازداشتروتيربارانكرديدند.

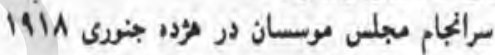

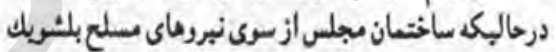

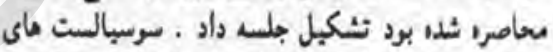

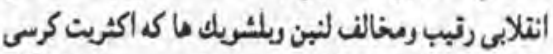

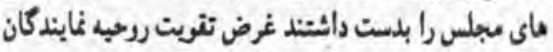

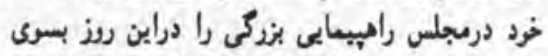

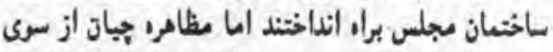

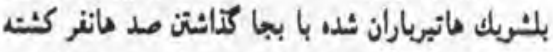

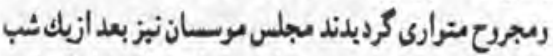

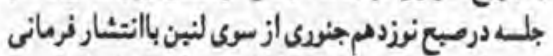

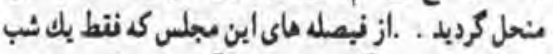

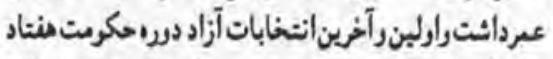

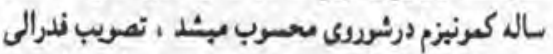

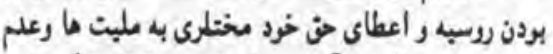

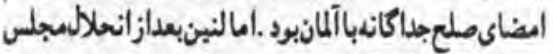

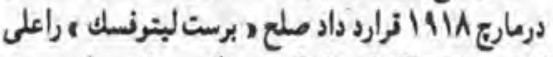

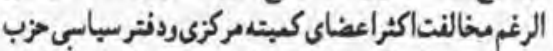

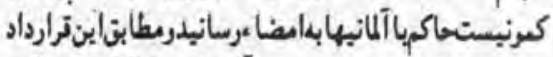

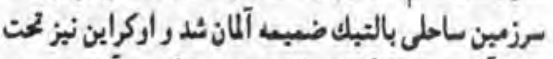

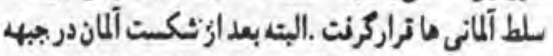

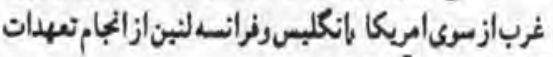

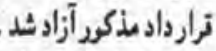
تشكبل سازمان امنبث با بولبس منفى روسب از ارولين

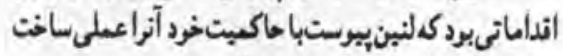

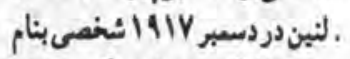

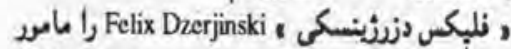

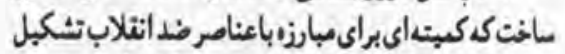
رنعالبت خود راكـرش دهد . دزدئنسكى براساس فرمان 


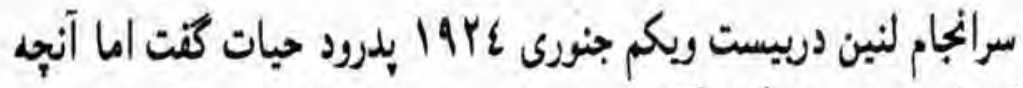

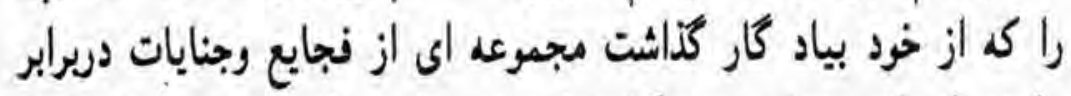

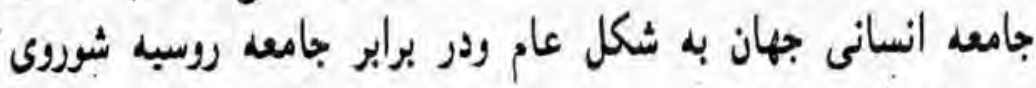
بصورت خاص بو د.

كرنتار مصابب فاجعه حاكمبتروحشتناك كونيزم كردندك

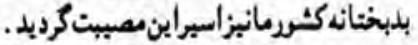

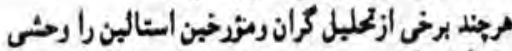

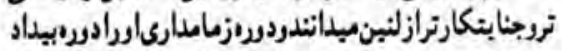

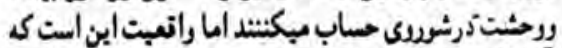

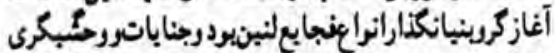

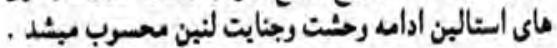

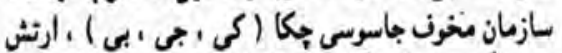

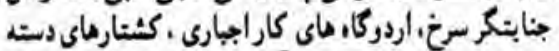

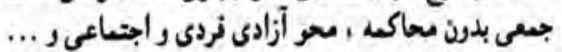

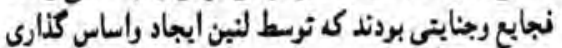

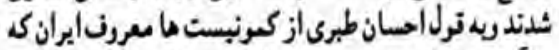

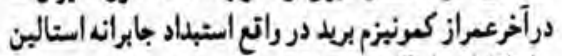

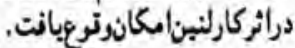

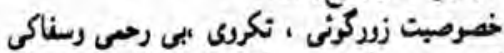

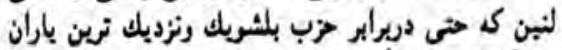

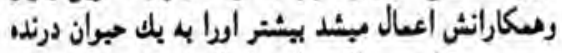

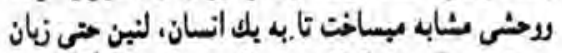

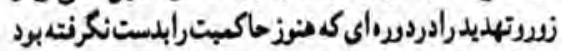

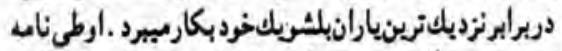

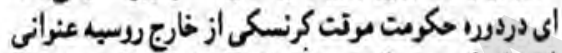

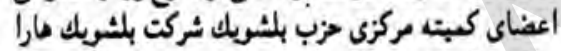

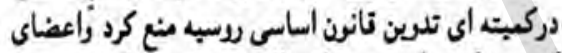

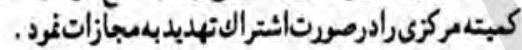

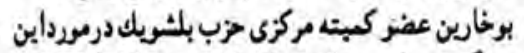

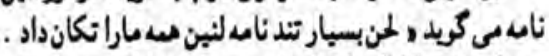

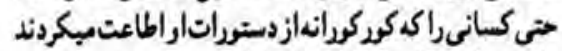

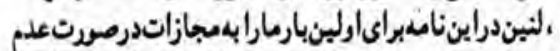

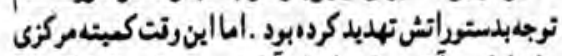

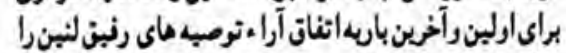

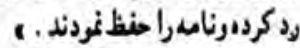

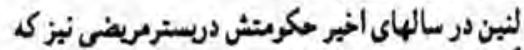

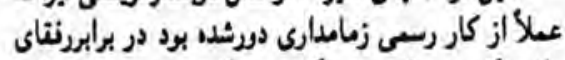

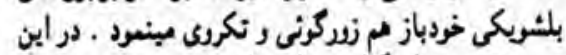

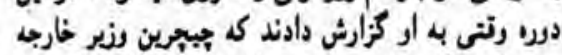

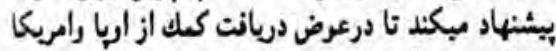

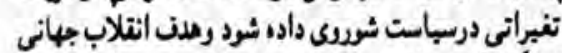

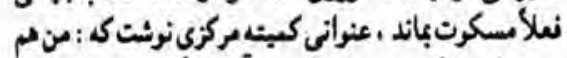

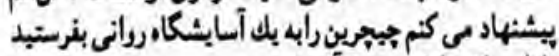

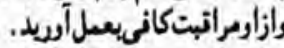

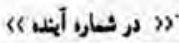

در سرنكونى حكرمتمونت حسابت: كرد ريسرنخمابت آنها

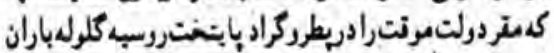

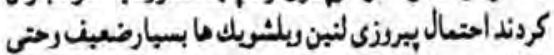

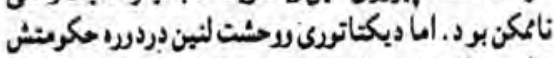

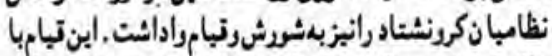

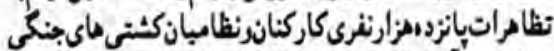

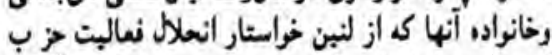

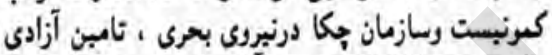

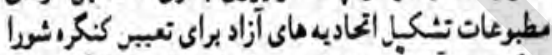

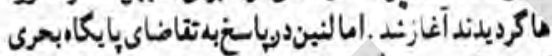

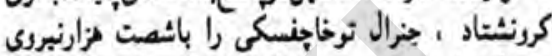

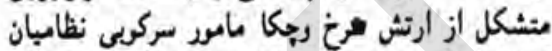

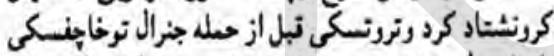

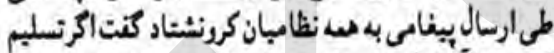

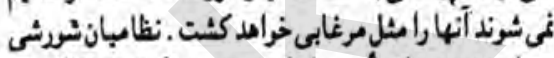

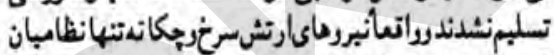

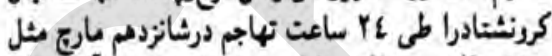

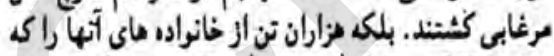

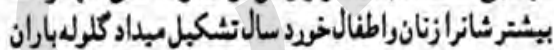

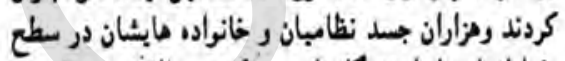

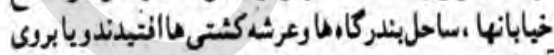

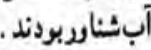

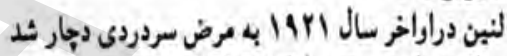

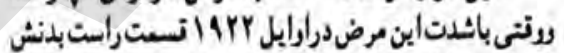

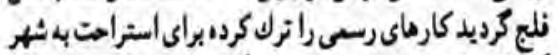

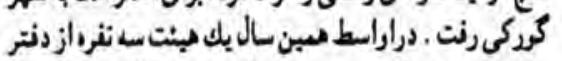

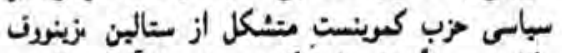

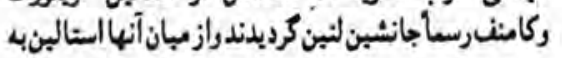

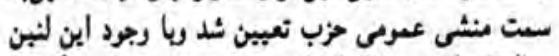

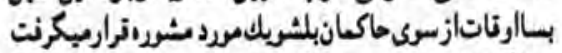

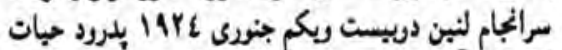

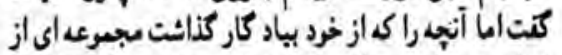

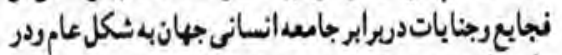

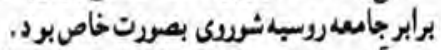

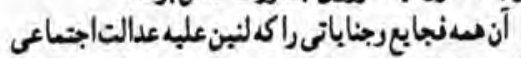

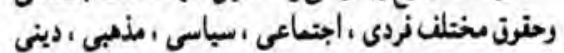

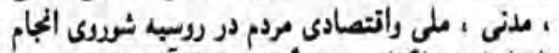

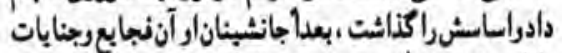

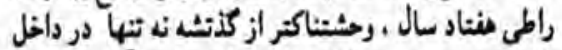

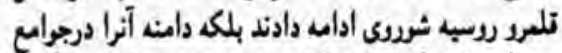

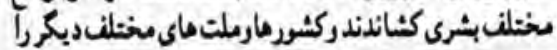

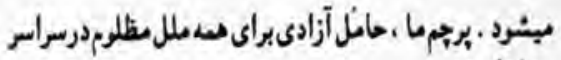

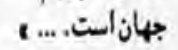

الما ميانتت ونيرنخ ، دجاوز وغارتكرى ، سناكى

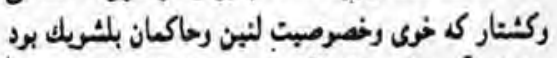

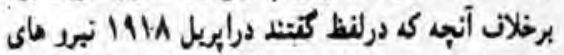

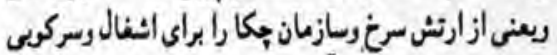

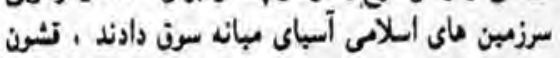

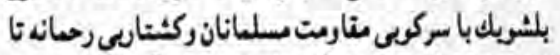

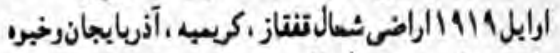

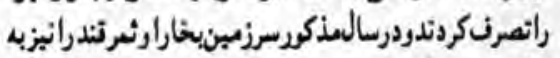
خال وخرن كشيدند .مرجند مسلفانان درسراسر مناطئن

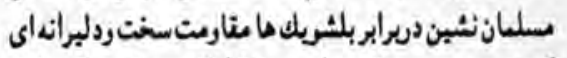

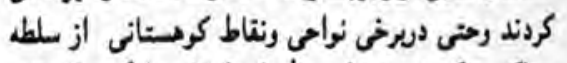

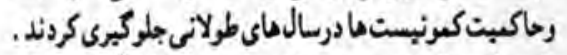

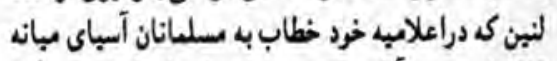

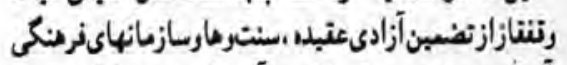

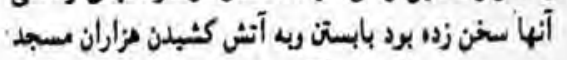

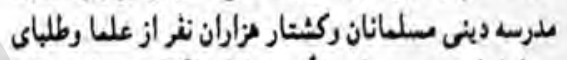

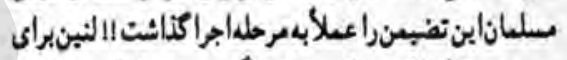

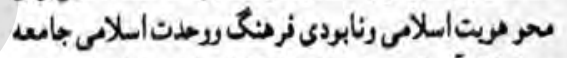

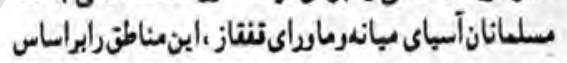

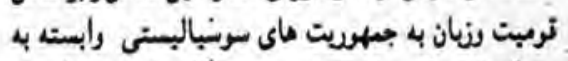

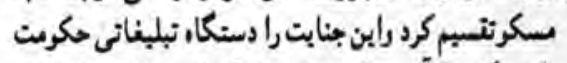

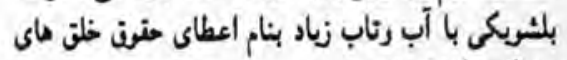
مختلف تيلبز تمردند. لنين كه درآغاز حكومت خرد براى مردم رعدد تامبن

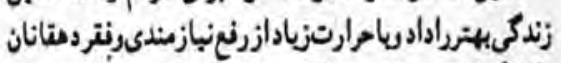

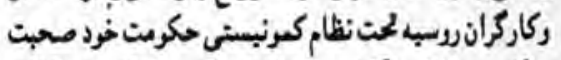

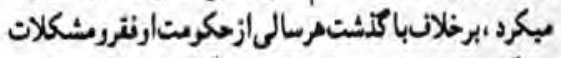

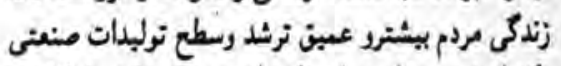

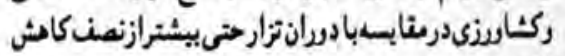

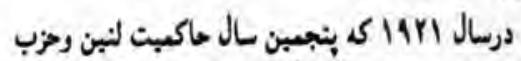

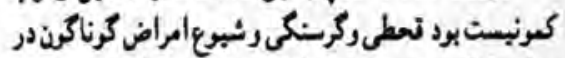

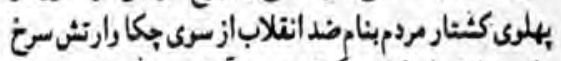

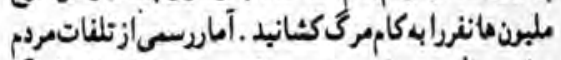

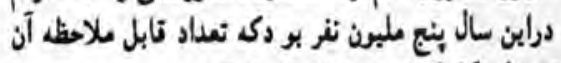
توسط بكا وارتش سرخت تئل عام شدئد.

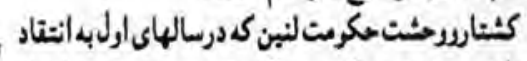

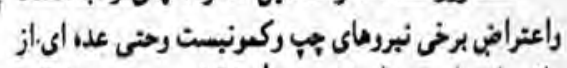

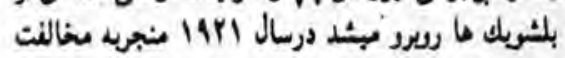

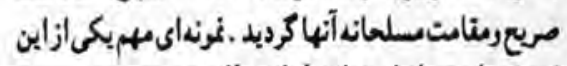

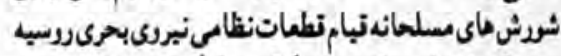

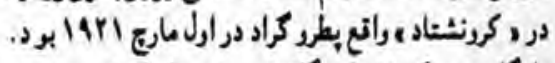

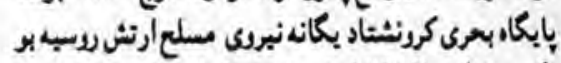

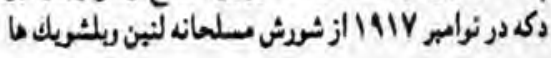




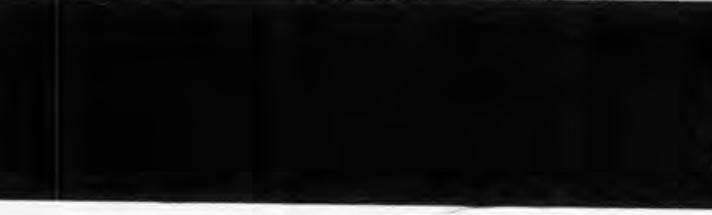

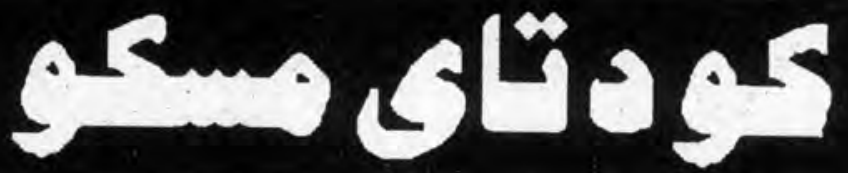

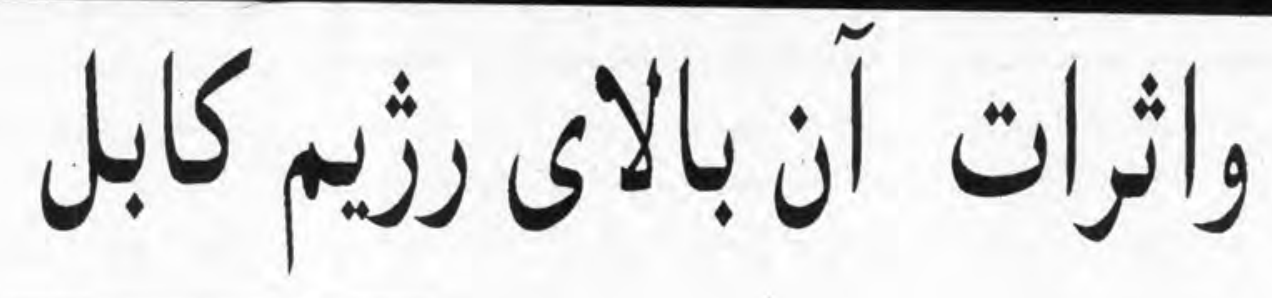

ترجمه ونكارش : ن - ثاقب

راما برخى ديكر از تحليل گران امور

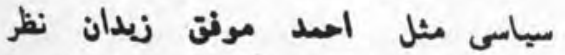

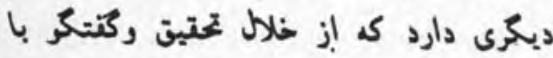

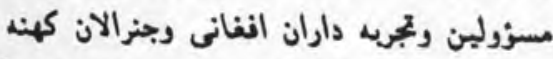
كار كه درموسكوتعليم وتربيه ديده اندواخيران

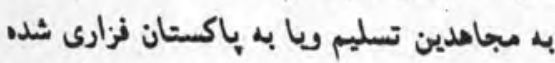

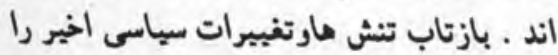

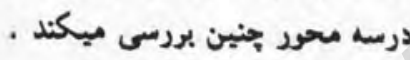

خرياجف وحكومت وسيع القاعده درافغاتستان :

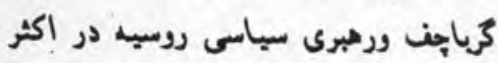

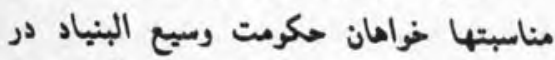

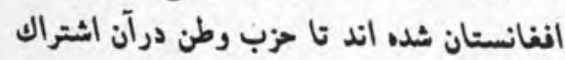

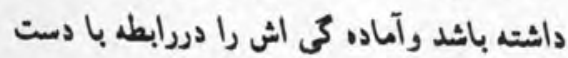
برداشتن از حلايت لجيب .درمقابل المتياز

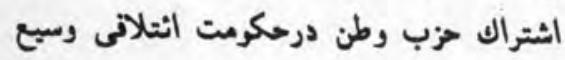
ابراز داشته است.

وآخرين تصربحات رهبرى شوروى درين بارن الظهارات ( نيكولاى كرذيرون )

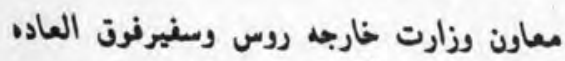

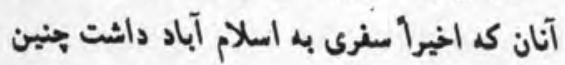

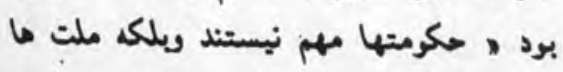

كرياجون خواهان بك حكرمت با تاعده وسيع

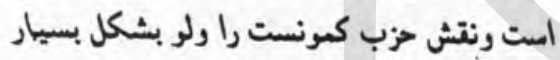

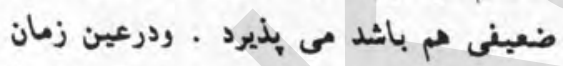

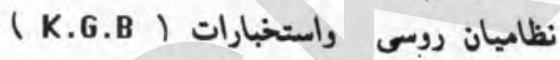

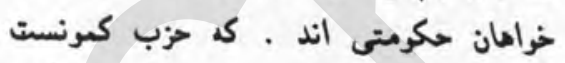

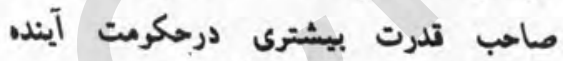

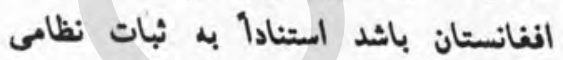

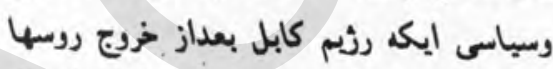

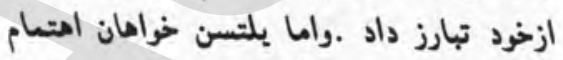
بيشتريه تضاياى دأخلى روس است وكنار

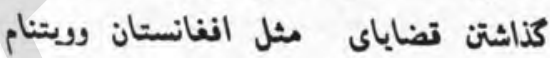

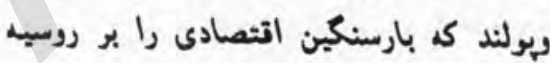

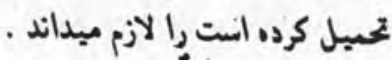
بعضى از كأرُشكران امور سياسى ازجمله

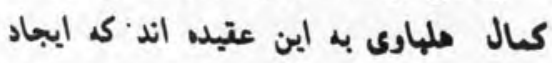

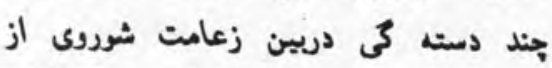

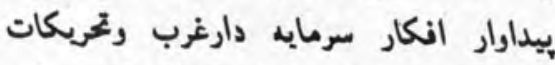

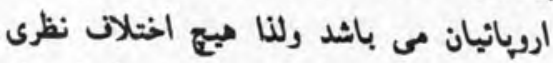

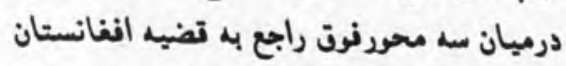

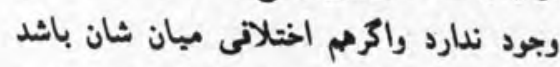
خيله ها جزنى است كه تاثيرى درسياست خارجى كشورش درتبال مسئل انغانستان

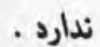

E در كيرى هارجريان تنش هاى جديد سياسى

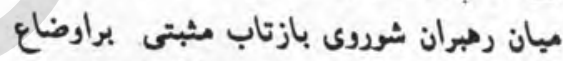

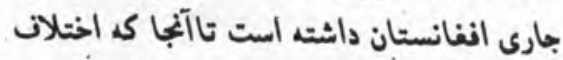
عيتى درسياست وياليسى خارجى شوروى

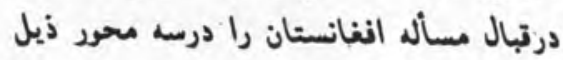
بطرد مشخص تبارز داده است.

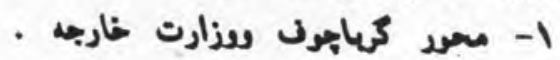

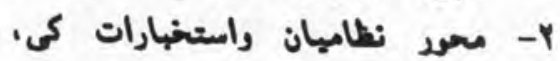

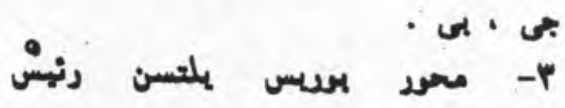

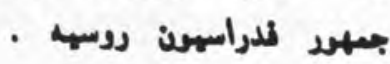

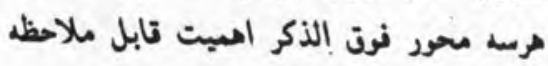

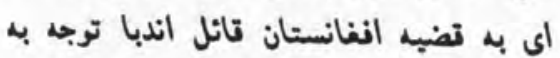

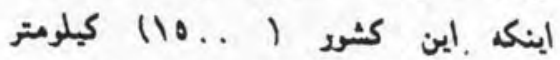

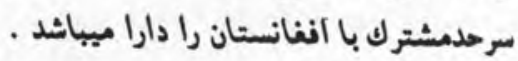

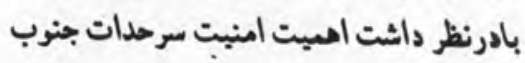

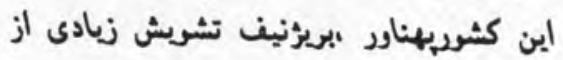

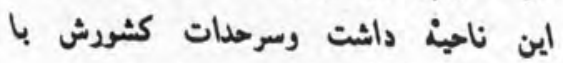

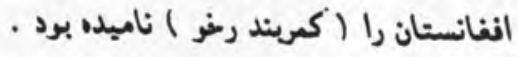

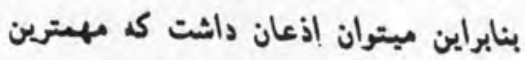

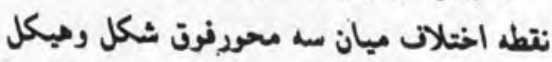

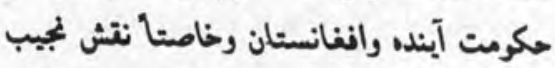
وحزب كمرنست درآن مى باشد ، وزمانيكه 


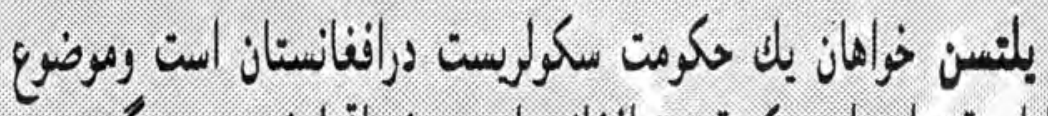

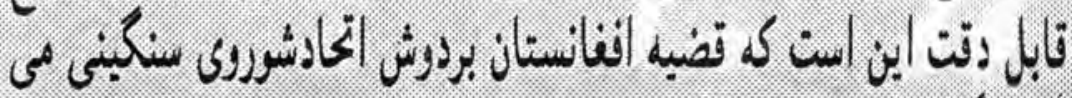

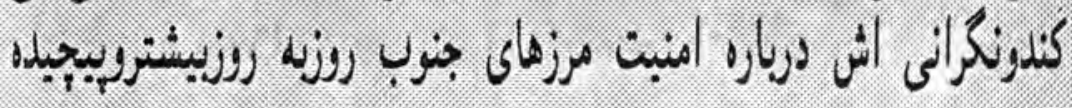

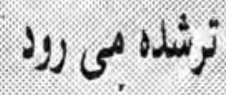

دررابطه باطرزديدكرياجنى به اين عتيده اندك أني

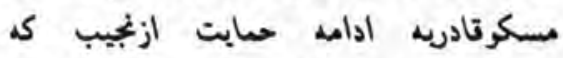

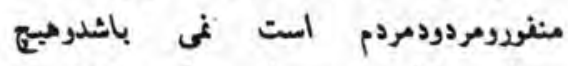
مصلحتى ازاين ناحيه براى مسكومحتق نيست

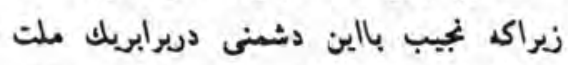

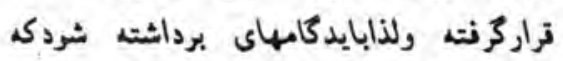
كذشته فرامرش شود تاباشد امنيت آيتده جنوب روسيد تضمين كردد.

\section{:}

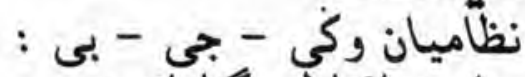
وسياست افراطى كرايانه : جراني جنرالان ذرارى وتسليسى النغانى وكسانى

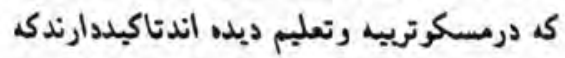

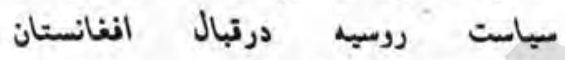

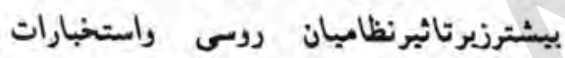

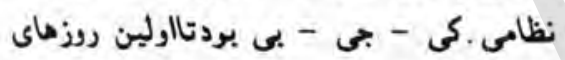

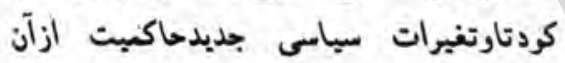

$$
\text { دواركان نوت بود. }
$$

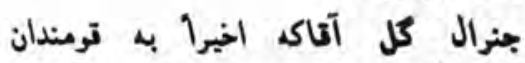

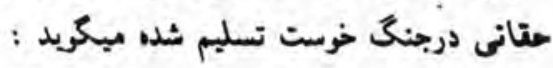

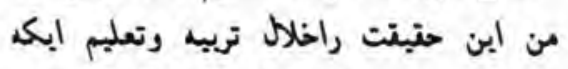
درروسيه ديدم درك كردم كه نظاميان درس رائين

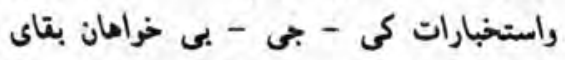

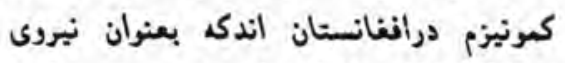

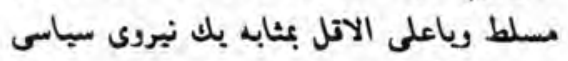

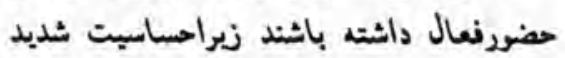

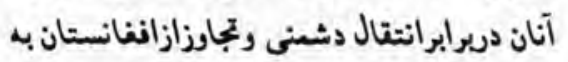
جنوب روسيه ويالينكه انغانهادست به انتقام

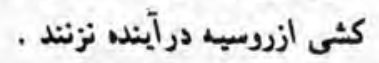

آماد، كذشت از نجيب خواهد بو د ومشجنان

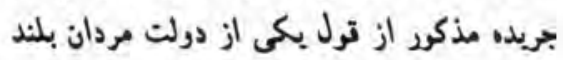

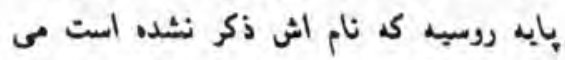

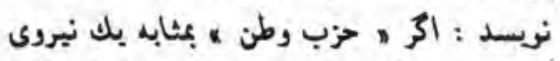

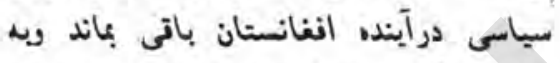

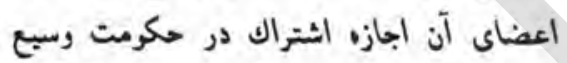

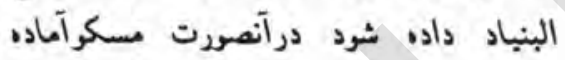

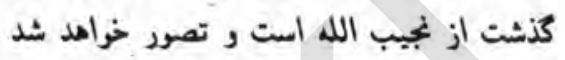

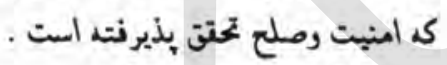

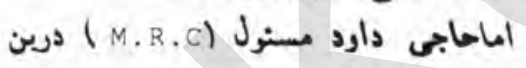

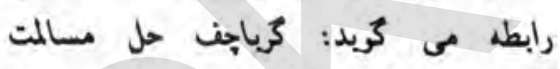

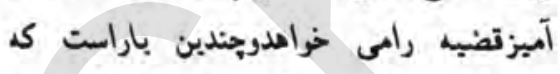

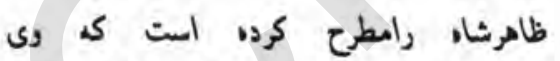
ميتراندرهبرى حكرمت انتتالى باتاعده وسيع رابدوش داشته باشد.

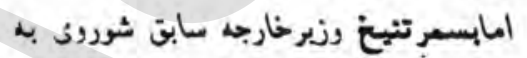

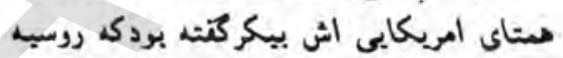

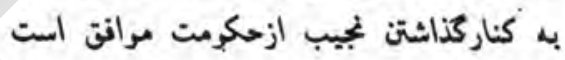
واماجه كسى تضعين سرحدات مارعدم مداخله انغانستان رادرامورداخلى ماميكند.

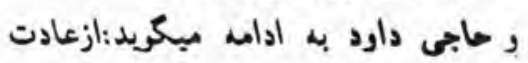
انغانهاست كه درامورداخلم كسى ماردي مداحلد

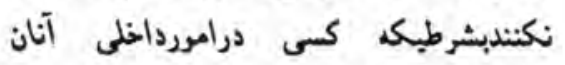
مداخله نكندونكرد. باشد. وى اضاف ميكندماهيج روابطى بارياست

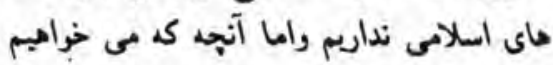

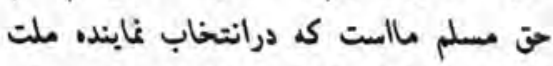

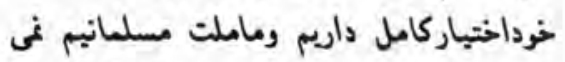
خراميم كسى درامورداخلى مامداخله كند.

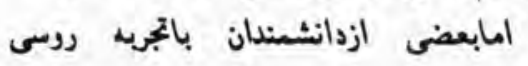

مهم تراند . ، وظاهرا آهادقى موسكو را در

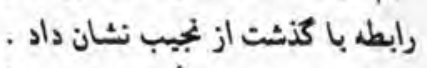
كرجند در بن رأبطه جريده انكليسى زيان

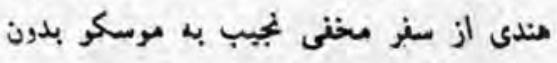

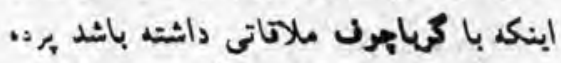

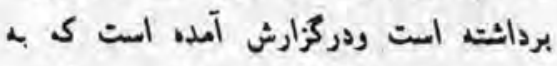

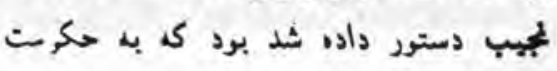

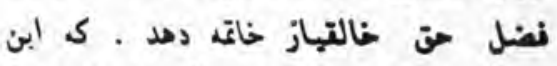
مرضوع بيانكرعدم رضايت نجيب از اندامات أنات اخير كرياجون است .

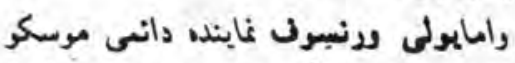

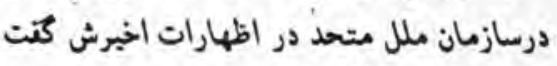

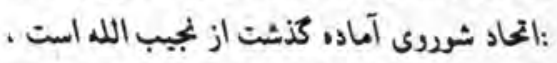

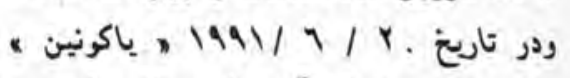

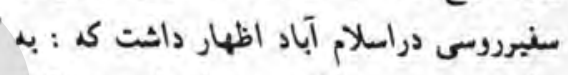

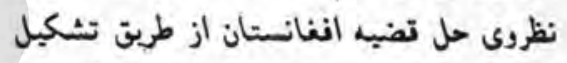

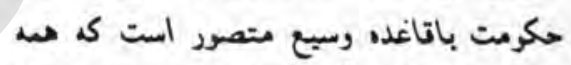

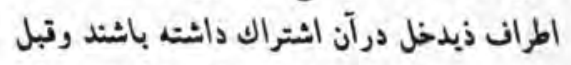

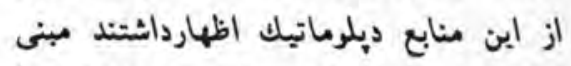

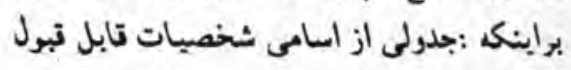

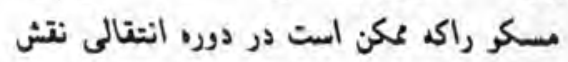

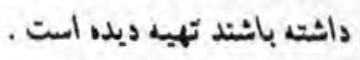

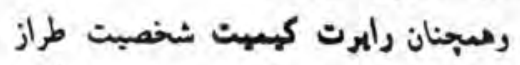

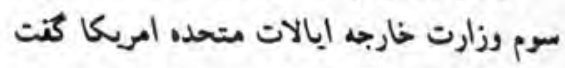

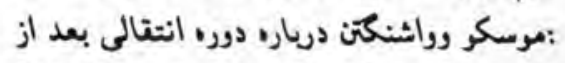

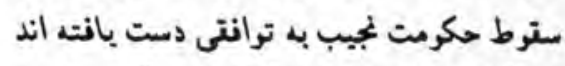

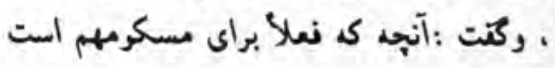
تضمين حيات وزندگى شخصيت هاى بزرى

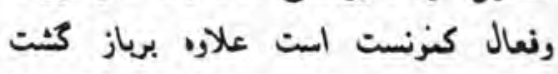
آرامشى نسبى وجاكميت اراضى انفانستئان بطريكه عدم انتقال دشنى وعدم مداخله بـ اريد

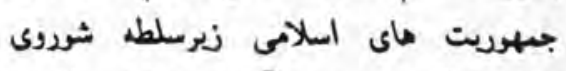

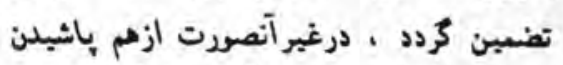

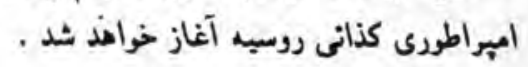

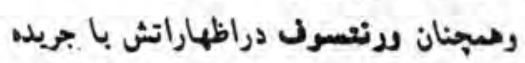
رلاس الجيلس تايمز ، كتت : أخرمصالح

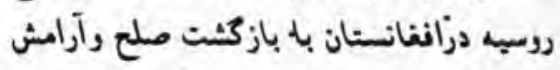
درين كثور تضمين شود . ـ درآنصورت روسيه 
اضاند مى كندكي : نعلا دوعنصر نزديك بم

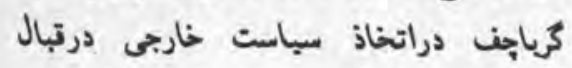

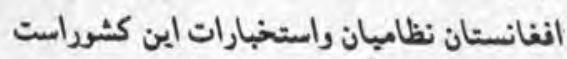
: يلتسن وسياست نشئستى نفيان

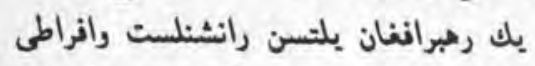
ميخواندواضانه ميكند : كان ميرودك اين خصيصه جزء طبايع مردم فدراتيف روسيد باشد .ذرمانده عهدالحتى درين رابطه ميكريد:

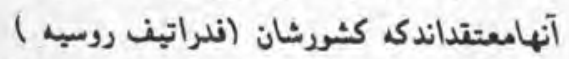
سرشارازمعادن وثروات اتتصادى است بناء

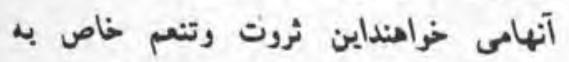
خودشان باشدودرين شكى نيست كه يلتسن

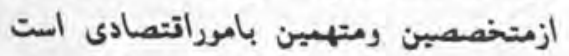

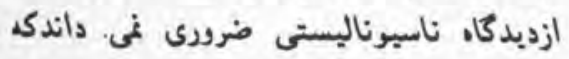

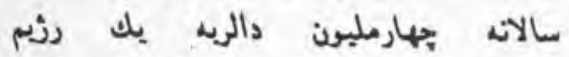

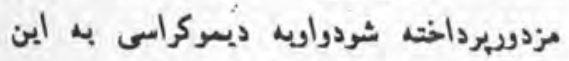

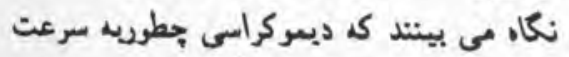
كشرش رادرجواركثردهاى بيشرنت ارويايى بيسي

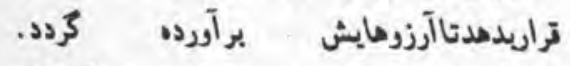
وميكريددرين شكى نيست كل بين كرارياجن ريلتسن تفارت زيادى دارد، زبراكه نفايندا. بلتسن درمحانل تصرنات. بريزنف ، كرياجن راغيرعاتلاته خواند، وجندين بارازمباهدين

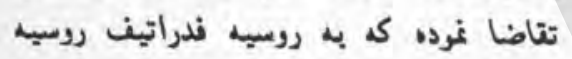

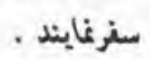

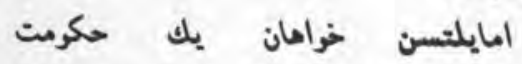
سكولريست درانغانستان است وموضوع تابل دتت اين است كي تفيه انفانستان بردوش دوران

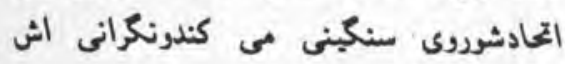

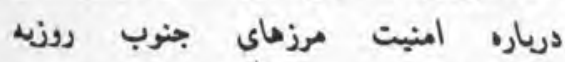

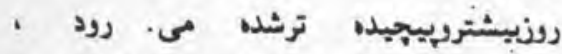

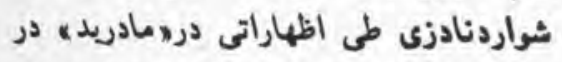

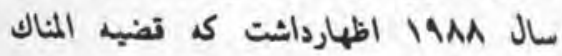
انغانستان دردوالم ماست دراختيارمانيست ماسانطورمجبوريم تبول آن وردان شديم وماجبرا وكراهتا درفيصله هايجبوريد

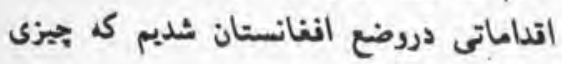

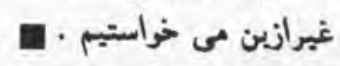

جنوب اين كثورمى توانديك حيله ويهاند خوب باشد براي ادامه حسايت ازرئم غير تانونى وكرنيستى كابل وتوجهى براي مداخلات بي إنى

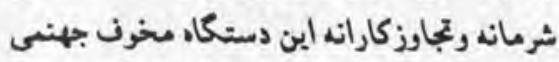
درامورانغانستان .

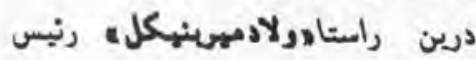
استخبارات شوروى درتاجكستان به كيته

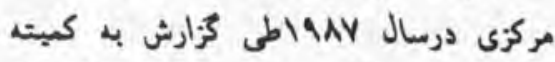

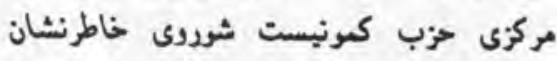
ساخته بودكي مسلمانان درداخل جريهريت

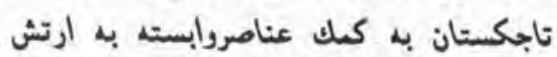

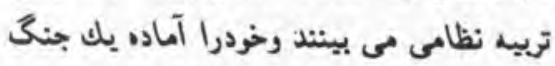

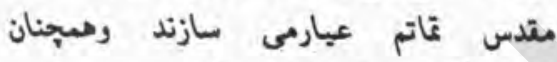
اظهارنكرانى استخبارات نظامى روسيه توس صعودى رامى بيبايدودرسال

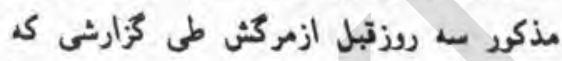

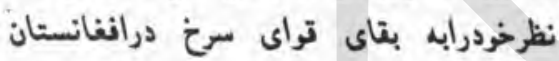

غيرتابل تحل مينرد بنا: بيانات اخيرمسكردررابطه بالمنيت جنرب شوروى كي خاصتا ازطرن كى -جى - بى صادرشد راخيرا آن اظهارات يك افسراستخباراتى درتاجكست فيتان بودكى باكستان رابه مداخله درامورداخلى

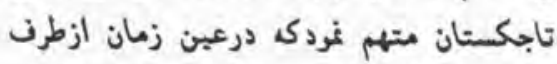

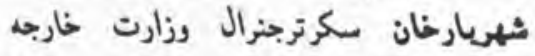
باكستان ردخرديد ركتيه شدكي مداخله دراموديكران ازسياست شاي كثوش نيست على رغم اينكه روابط نرهنى وتاريخى كثرش باجمهرويت هاي اسلامى سرابت تاربخى دارد. بنابرين ، اين اظهارات بيانكرنراروكريزدورلت

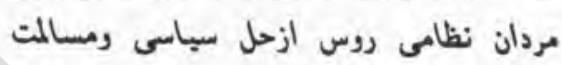

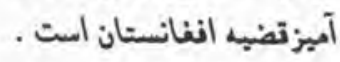

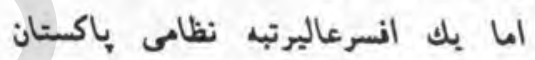
ومعارن الستخبارات إين

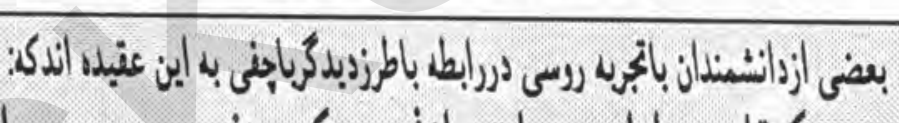

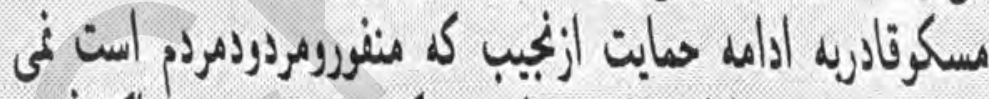

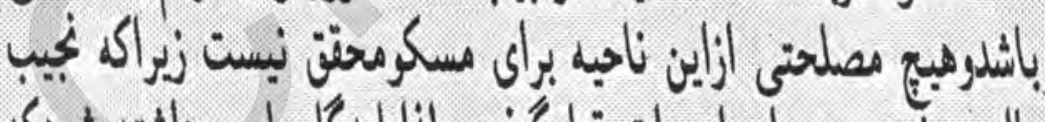

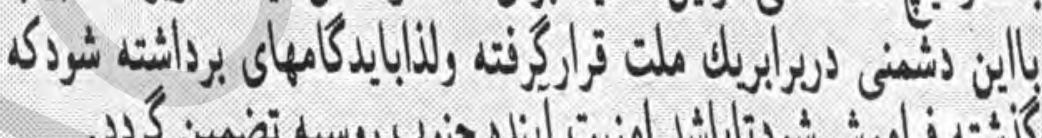

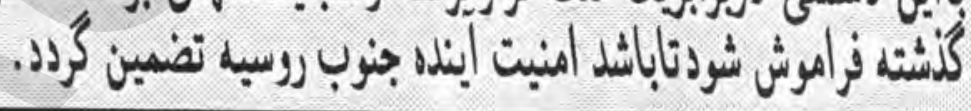

وباعلى الاتل باقى ماندن تستى ازآنان

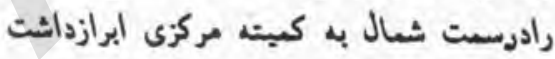

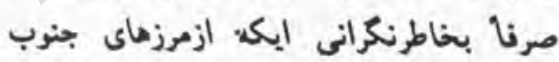

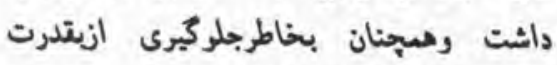

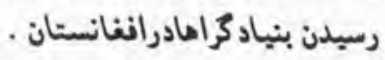

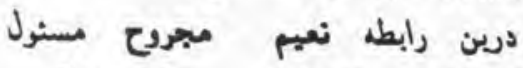
هركزاطلاعات انغانستان ميكويد:بزركترين

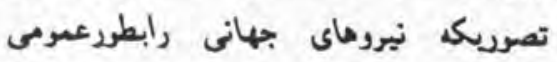

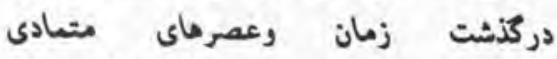

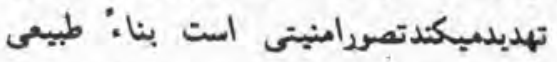
خواهدبودك نظاميان روسى درسياست شان درتبال انفانستان بخاطراهيت ايكه امنيان

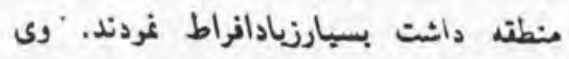

(مغمديوسف ) كم مسنورل ,انغان سيل،

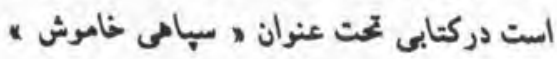

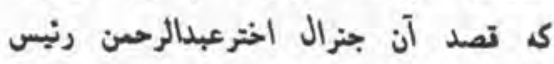
استخبارات سابت نظامى باكستان است كهرئ

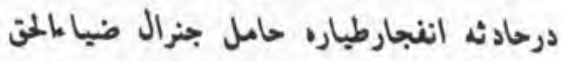
شهيد كثته شد اعتران مى كند كه اين اركان

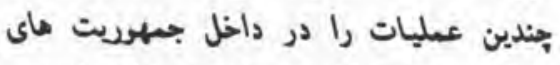

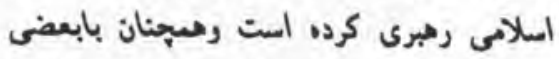

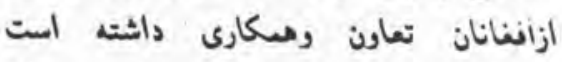

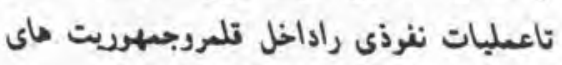

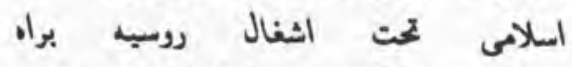
اندازنداما ابرازنكرانى وخرن استخبارات نظامى روسيه كى -جى - بى ازعدم امنيت درمرزهاي 


\section{دوابط دواستانه هين با ثُوروك}

\section{امين الله ( خراسانى )}

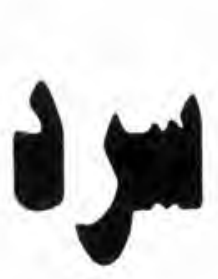

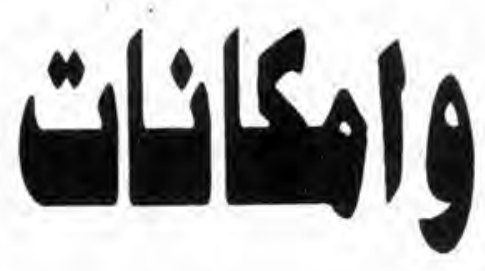

جان كيندى ) بـ كرسى رياست جهيهورى امريكا

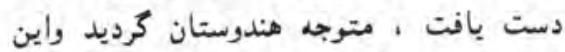

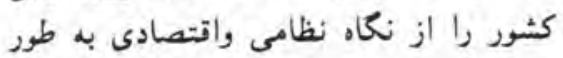

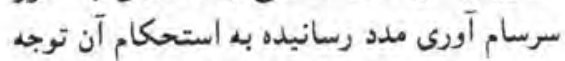

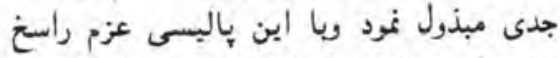

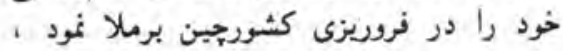

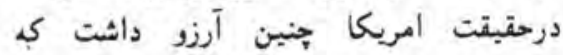
هندوستان رانوعى بايكاء نظامى ساخته وراز

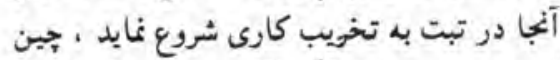

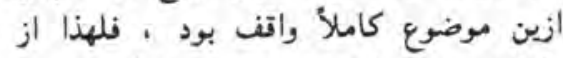

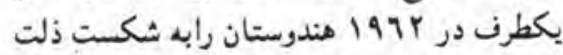

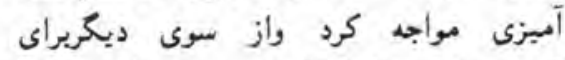

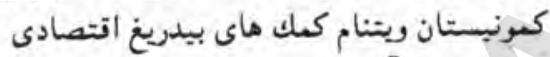

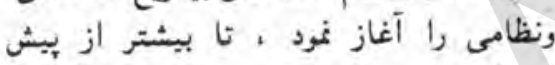

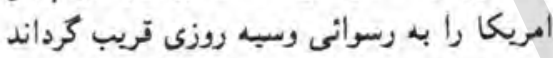

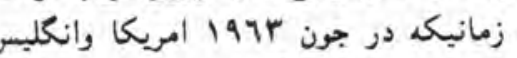

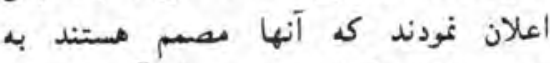

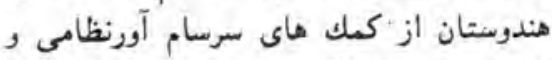

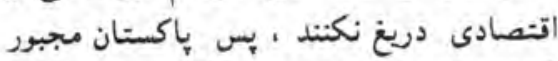

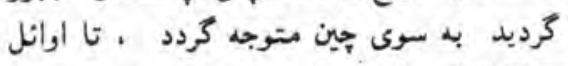

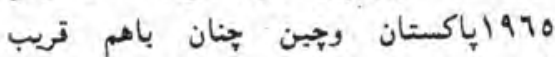

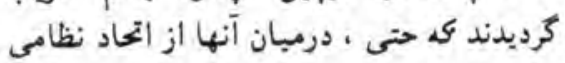

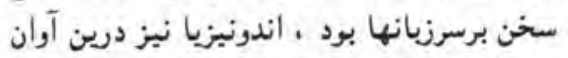

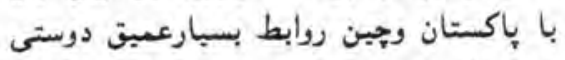

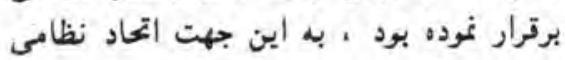

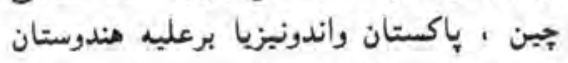

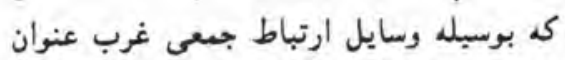

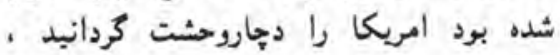

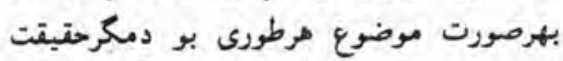

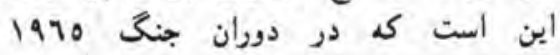

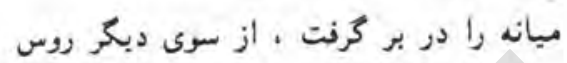

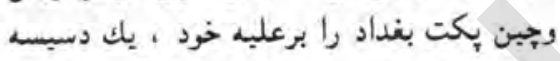

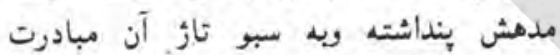

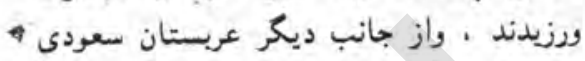

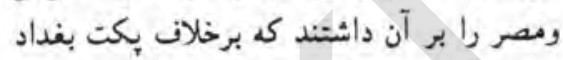

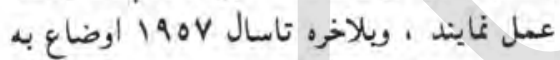

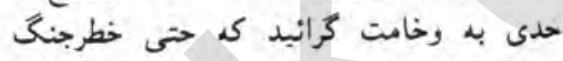

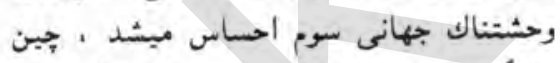

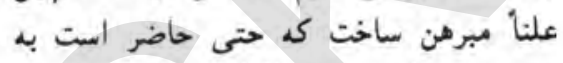

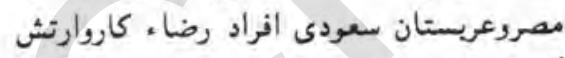

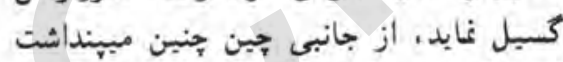

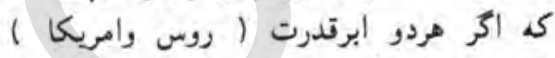

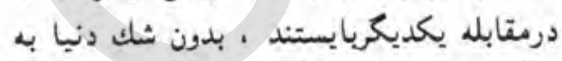

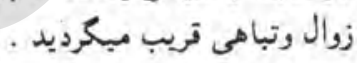

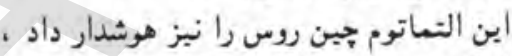

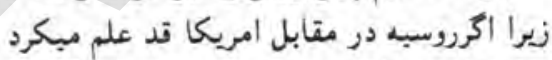
و اوضاع به طرز فجبعى به وخامت ميكرائيد

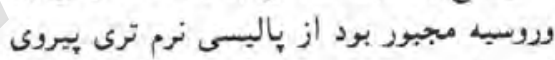

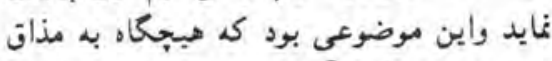

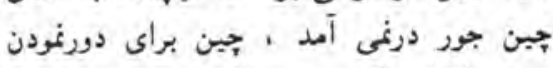

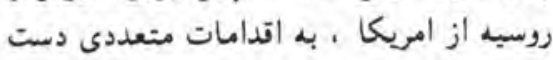

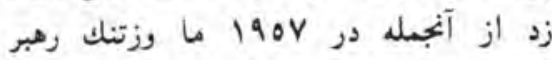

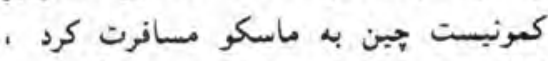

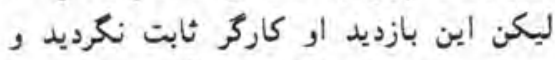

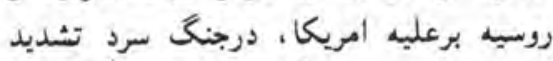

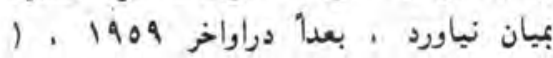
خروشجف ) براى ملاقات رئبس جمهور امريكا

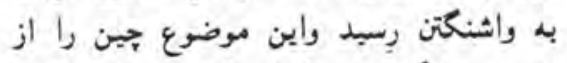

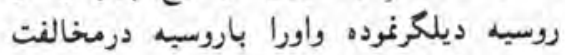

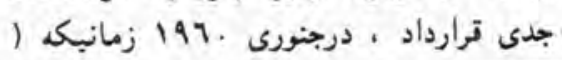

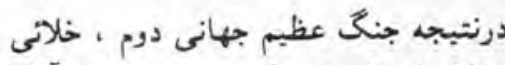
كى از اختتام قدرت نظامى واتتصادى آلمان

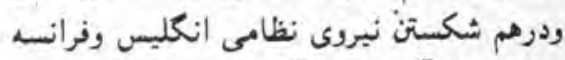

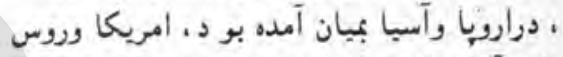

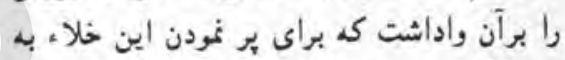

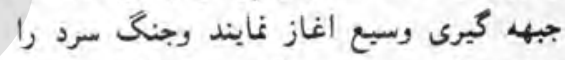

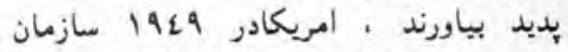

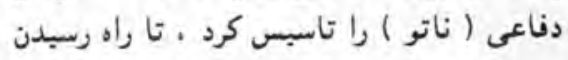

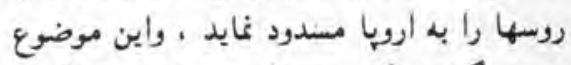

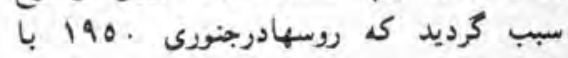

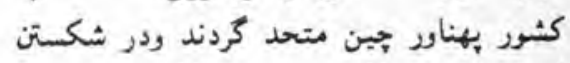

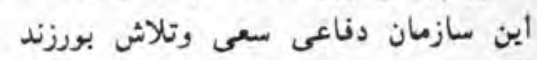

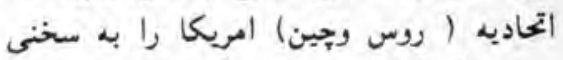

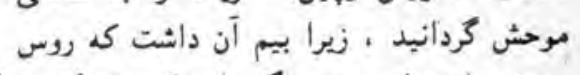

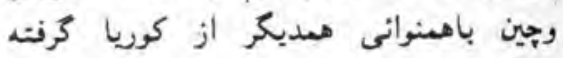

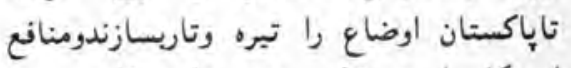

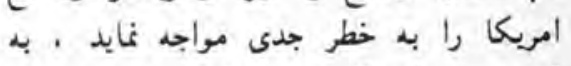

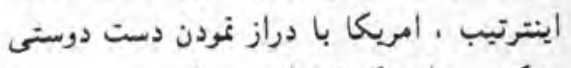

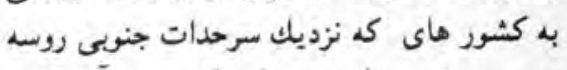

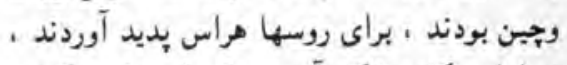

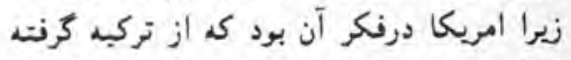

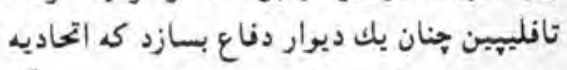

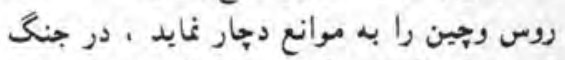

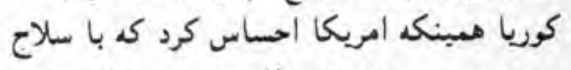

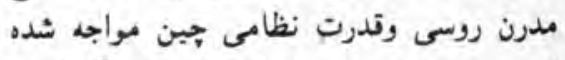

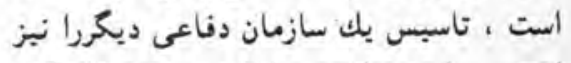

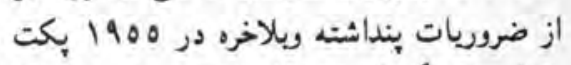

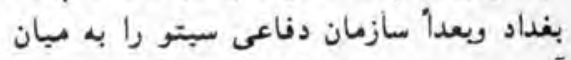

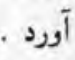
با تبارز بكت بغداد ، انرشى شديدى خاور 
معلوم بو دكه نقط جين مى تواتست ازين

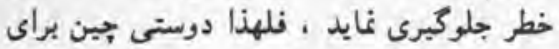

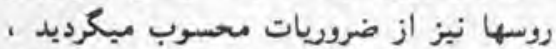
طوريكه تذكر بعمل آمد روابط دوستانه امريكا

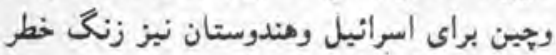

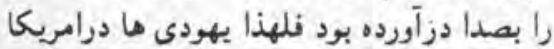

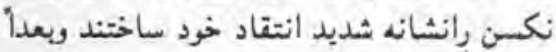
در دبيسه نى بنام تضيه واتر كيت أور ملوث

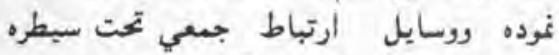

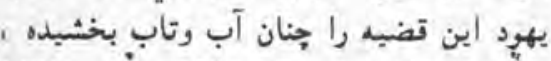

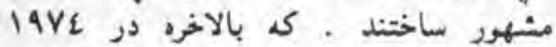
ريبحاردنكسن ناتوان شده از تصرسفيد اخراج كرديده به اين طريق روسها تاهندو ها واسرانيل

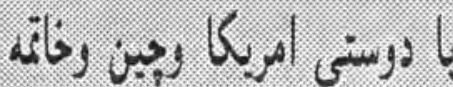

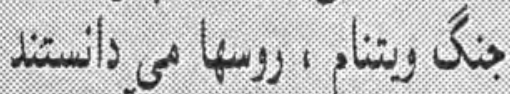

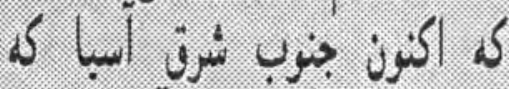

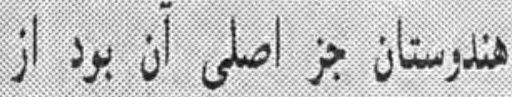

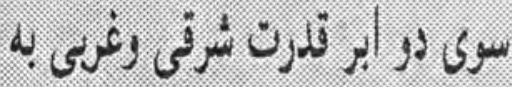
s. U.j)

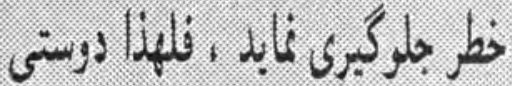

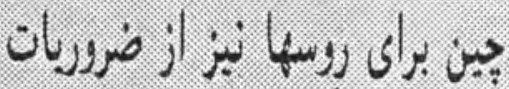

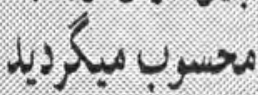

ها ظاهراً درين سعى وتلاش كامياب كرديدند و, وريت

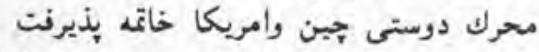
بعداز ين ، روسبه اميدوار بودند كه روابط وابط دوستانه امريكا وجين بتدريج ازهم كسيخته

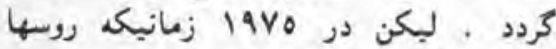
درخطه انكولا به بيشقدمى سياسى جغرافيانى درون

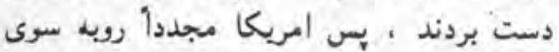

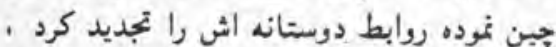

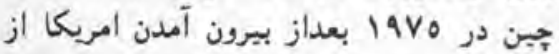
ويتنام درمقابل تجاوزات كعونستان ويتنام

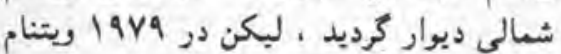

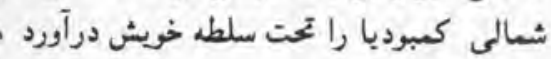

اختلافات مرزى وتنازعات سرحدى به طرز

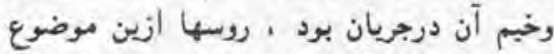

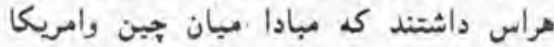

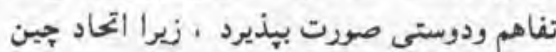

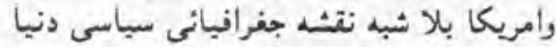

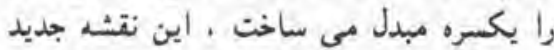

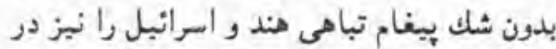

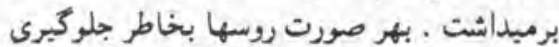

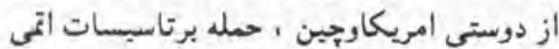

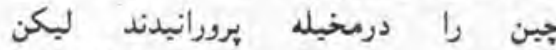

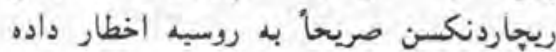

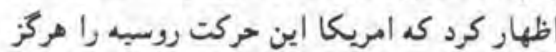

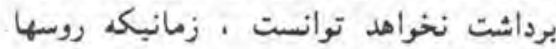

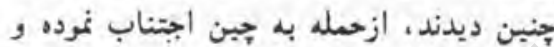

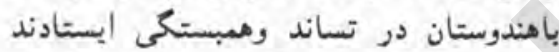

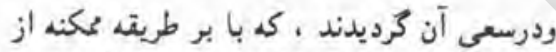

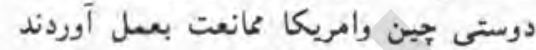

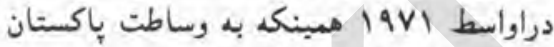

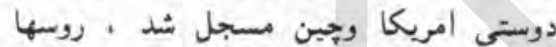

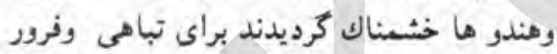

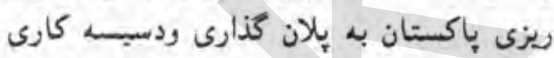

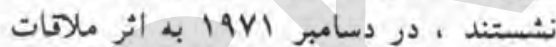

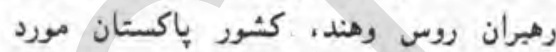

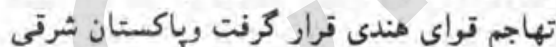

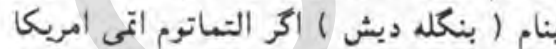

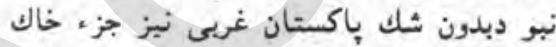

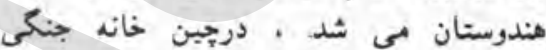

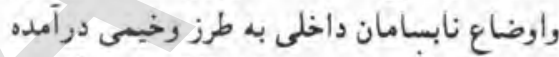

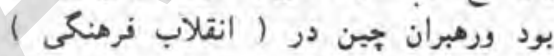

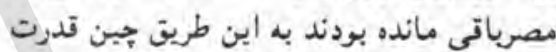

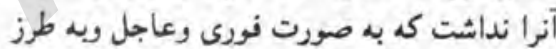

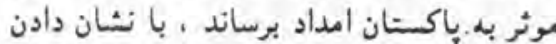

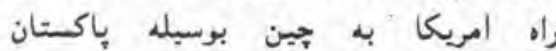

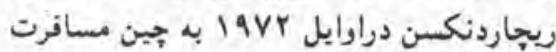
نود ، وامريكا براى رهائى خود از مرداب

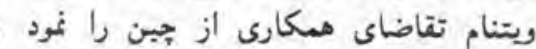

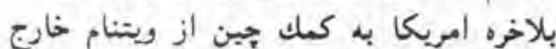

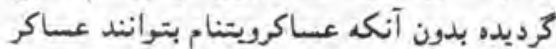

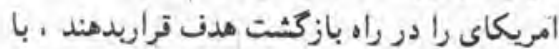

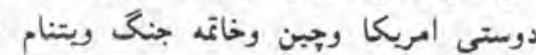

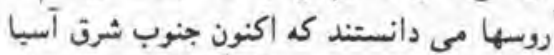

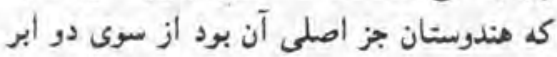

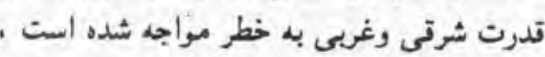

هندوياكستان ، كشبورماى جين واندونيزيا بـ

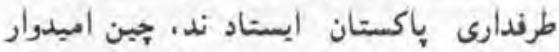

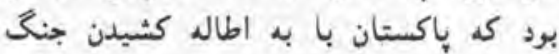

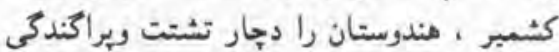

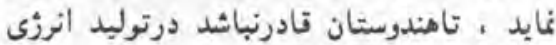

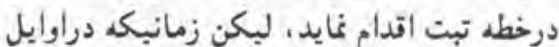

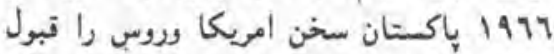

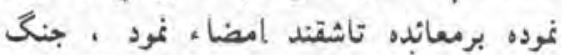

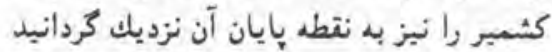

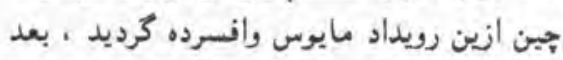

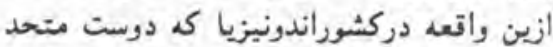
ومشترك باكستان وجين بود ، كودتأى نظامى إنى

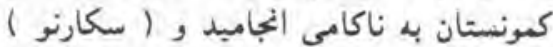
جبرأ مستعفى كرديد اندئ

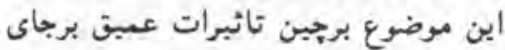

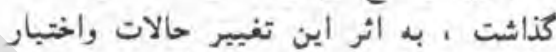

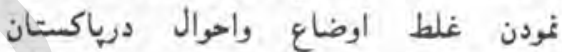

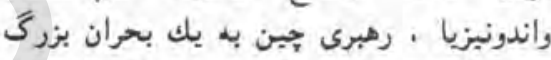

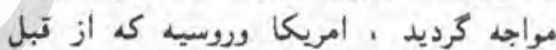

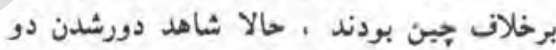

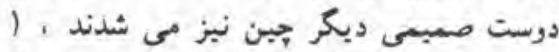

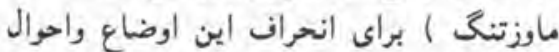

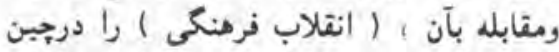

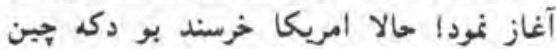

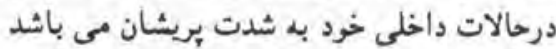

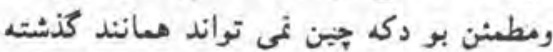

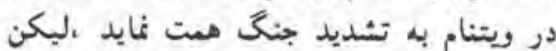

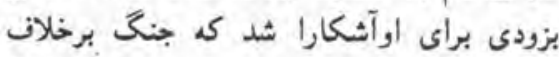

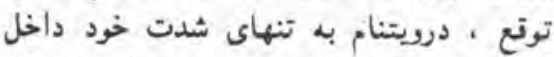

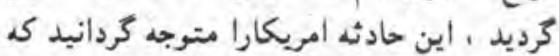

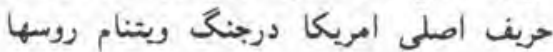

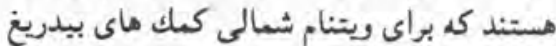

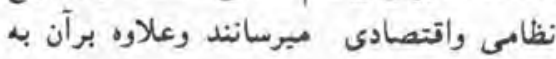

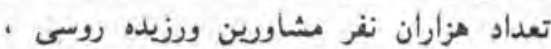

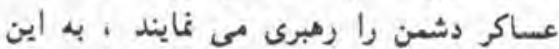

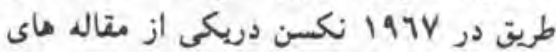

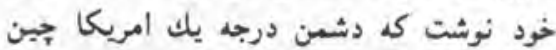

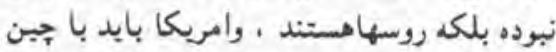

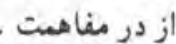

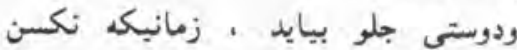

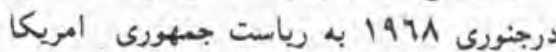

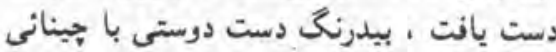

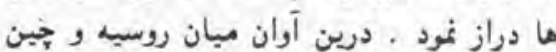


درهم ريخت وبر شرق ميانه مسلط كرديد . وحالا بدون شك يه حبث بك سوير بِاور واحد

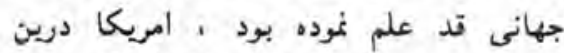

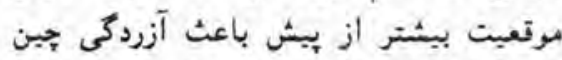

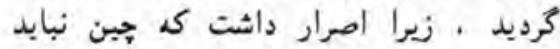

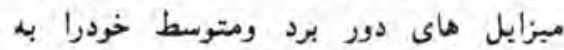
كثورهاي جهانى بنروش برساند وضمناً عوام

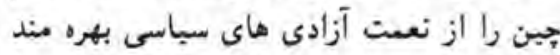
كرداند . قانون دانان امريكانى بـ رئيس جمهيور

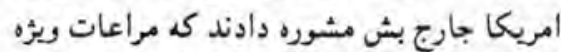

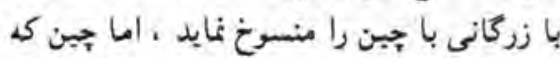

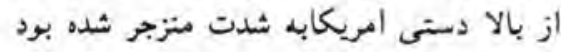

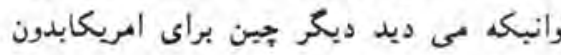

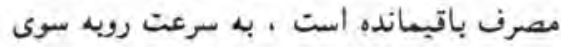

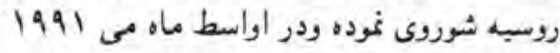

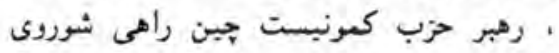
كرديد ريا رهبران كرملين هركونه اختلافات

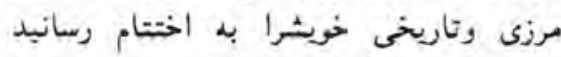

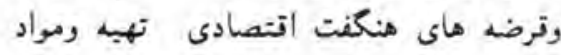

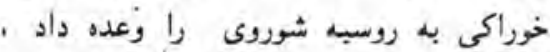

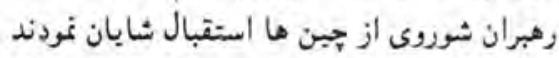

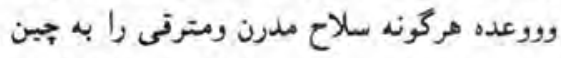

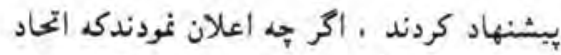

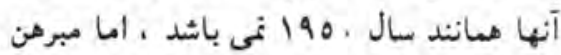

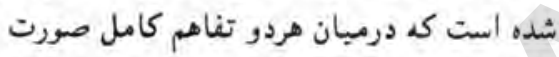

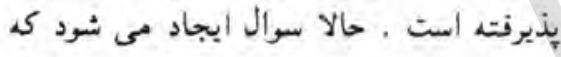

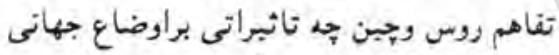

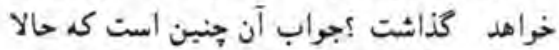

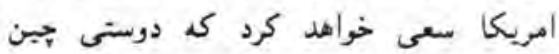
وروس تاحدى باشد كد نتواند موقعبت أمريكا

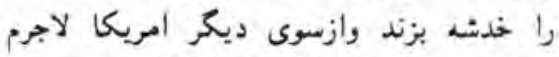

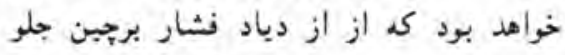

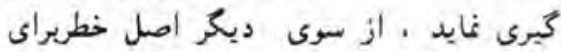
امريكا اين خواهد بود كد باتفاهم روس وإيدرين

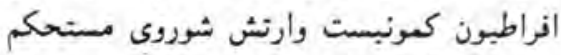

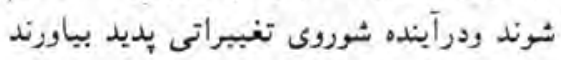

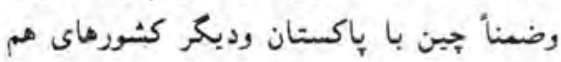

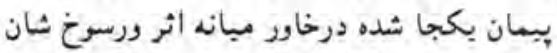

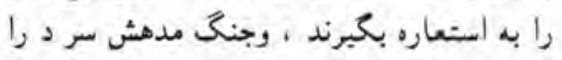

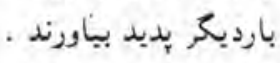

آسانى خاته بيابد واروياتى شرقى بـ شكل. دراماتيك از تسلط روسيه شوروى خارج گُردي

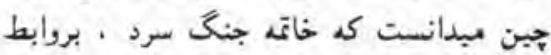

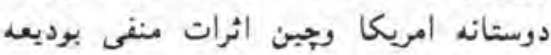

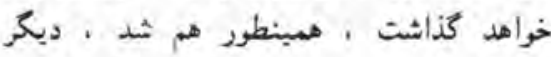

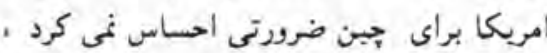

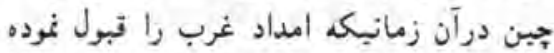

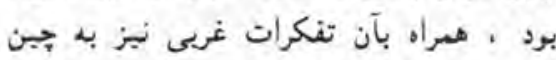

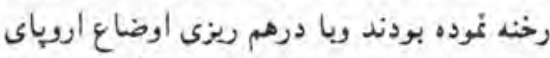
شرقى · جبن ببش از ببش متاثر كرديدوفرياد

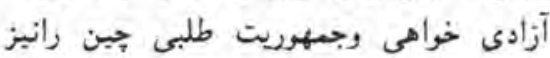

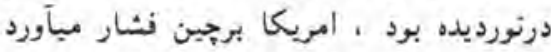

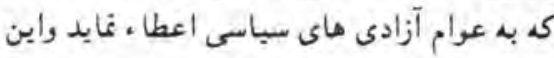

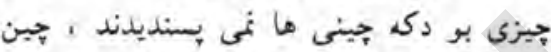

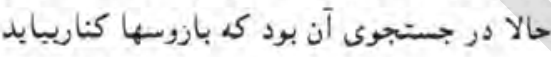

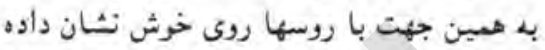

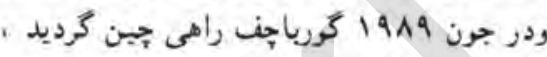

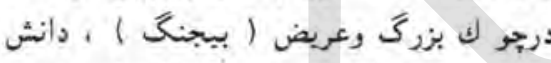

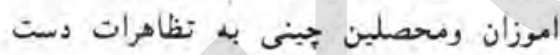

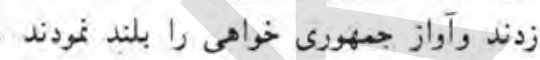

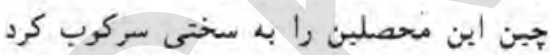

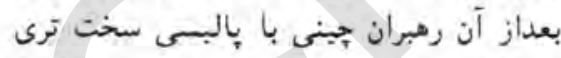
درمقابل مردم جلوه

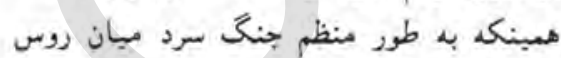

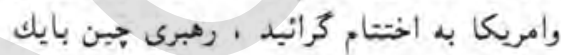

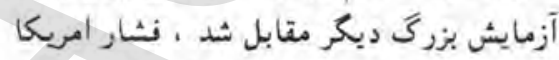

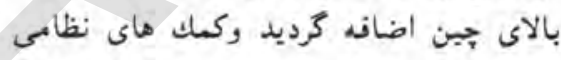

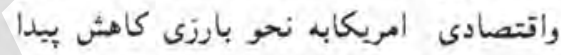

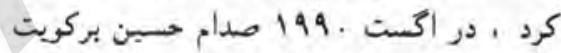

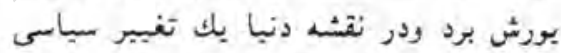

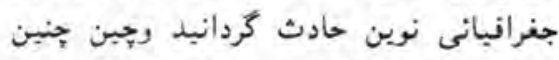
ينداشت كن بارديكر مبان روس وأمريكا جنى

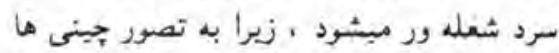

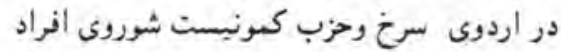

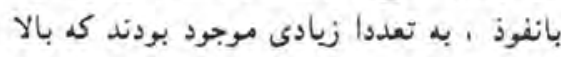

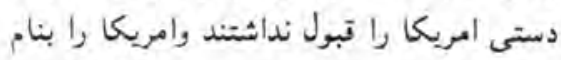

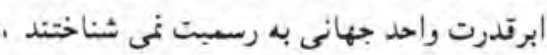

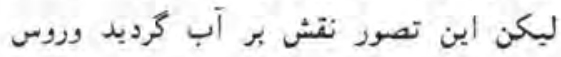

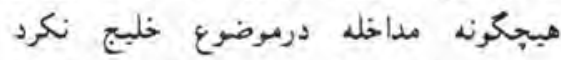
وامريكا باهيبت وقسباوت بي نظبرى عران راني
جين تحسل نكرده ، برويتنام حمله آوردشهه ويد شدت وحدت ويتنام شمالى را كوشعالى داده بردي ازآنجا بيرون راند ـ درين دوران روابط دوبتانت

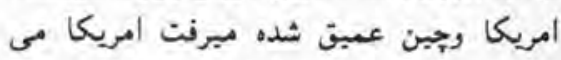

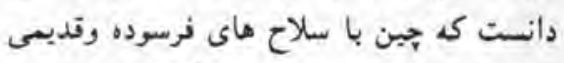

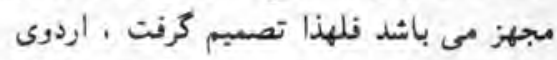

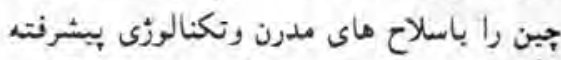

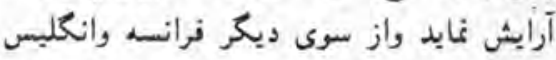

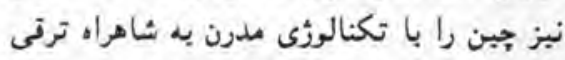

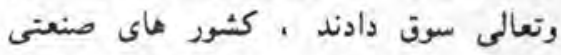

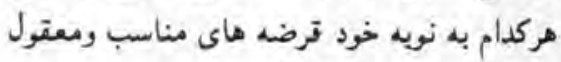

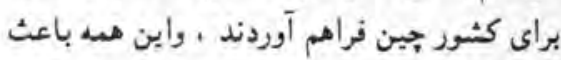

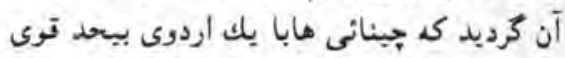

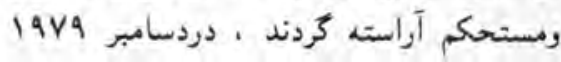
همينبكه روبسها بر خطه مبارك افغانستان يورش بردند واين كشور صلح دوست رين رادر

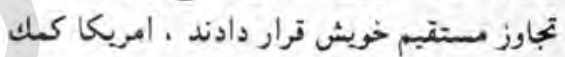

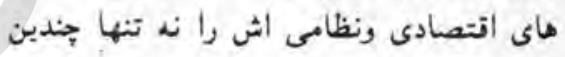

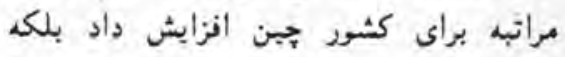

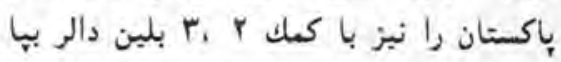

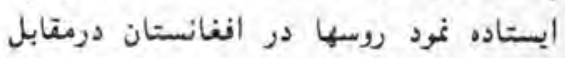

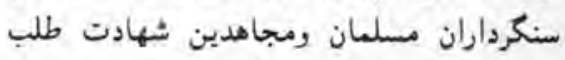
جنان ربون ومضسحل كرديدند كم حتى راه

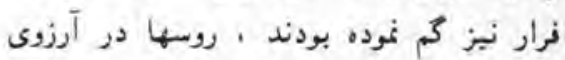

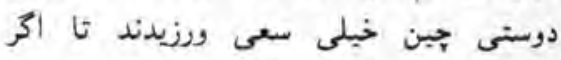

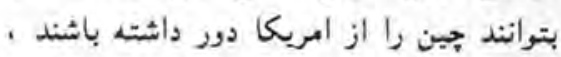
مكررهبران جينى ، روى خوش به روسهبا نشان

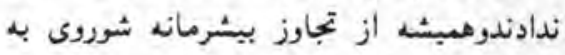

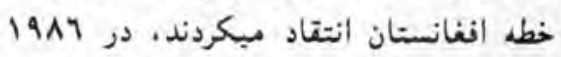

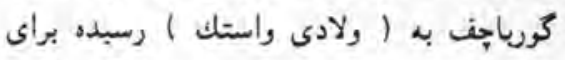

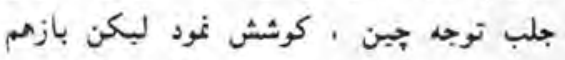

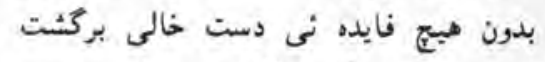

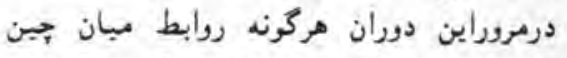

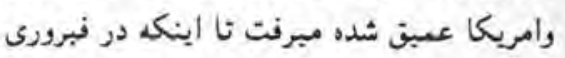

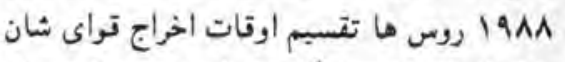

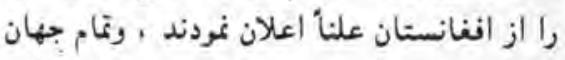
را در ورطه حبرث فرو بردند ، بديهى است كه

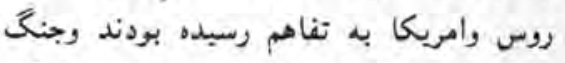

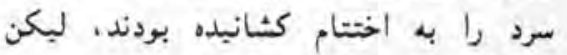

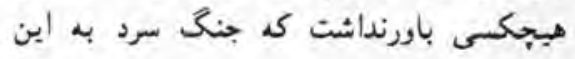




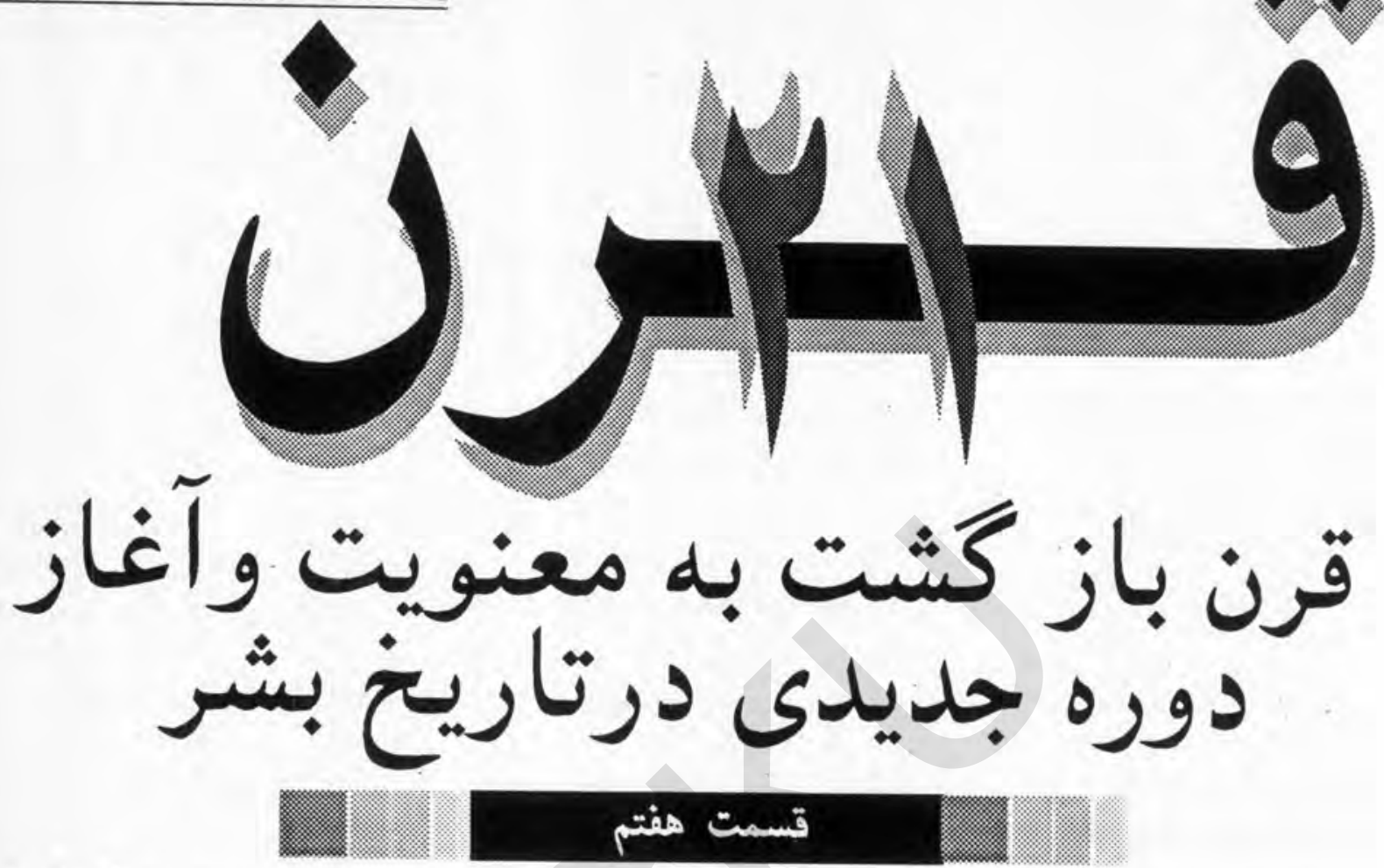

ايرباى نجات مريض درحال مرى ماركسيسم

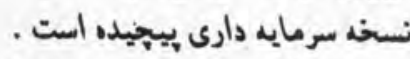

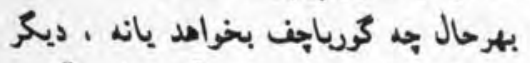
زمان نظريه ماركسيسم بسر آمداء وإين آخرين تلاشهاى مذبوحانه نسلى است كن ميخواهد آدرائ

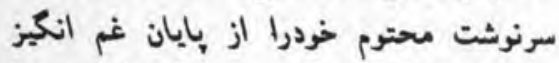

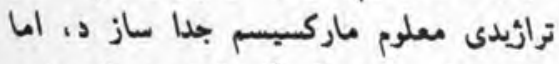

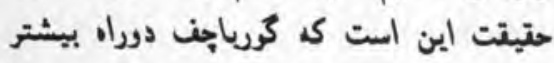

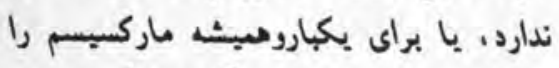

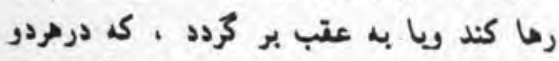
حالت ملت شوروى انتقام خويشرا ازآنها نيك دردي

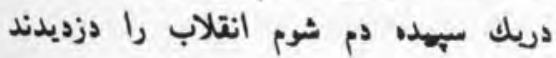
بازخواهد كرنت . برن.

$$
\text { نيكسون معتتد است : بازئ }
$$

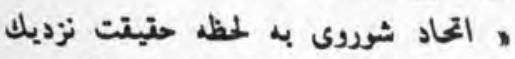

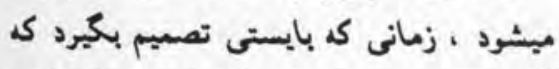

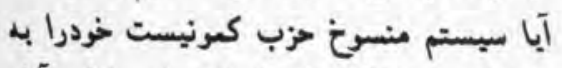

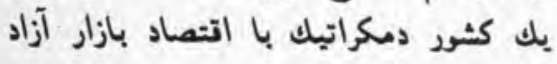

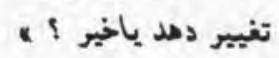

حال مرى وحيات سياسى خود را در زوال

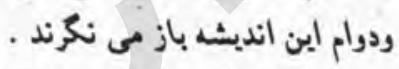

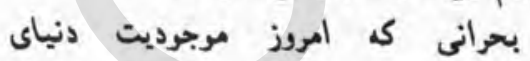

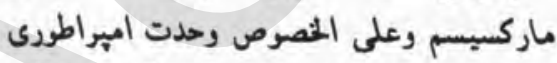

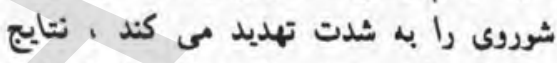
منفى عملكرد هنتاد سالد رهبران وفرمانرورايان

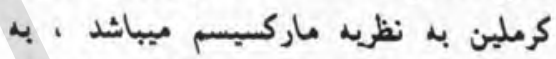
عبارت ديحر ايده نولوزئى ماركسيسم ناتوانى

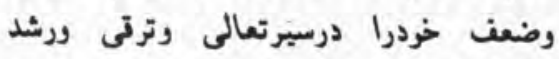

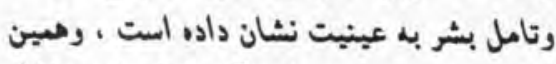

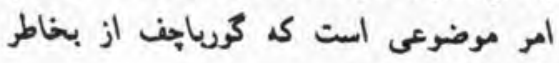

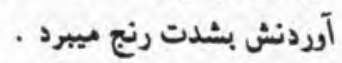
ار از يكطرن در تلاش است كه اصلاحات

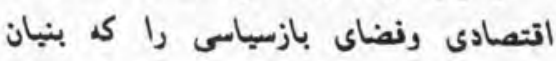

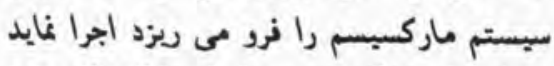

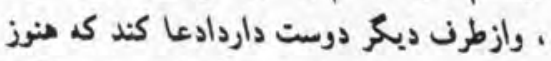

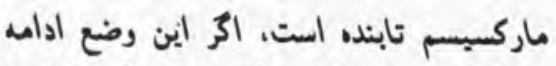

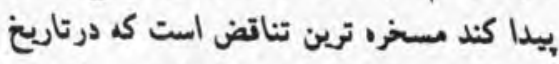

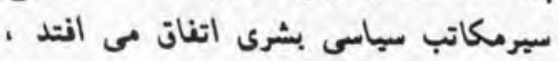

كرياجف وآخرين تلاشها :

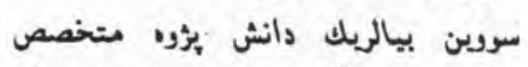

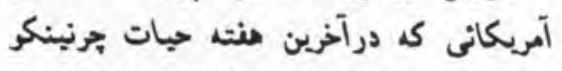
مسكر را ترك نموده است خاطرات خرات خودرا جنين

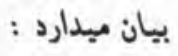

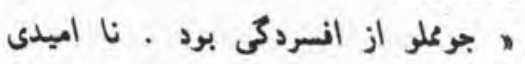

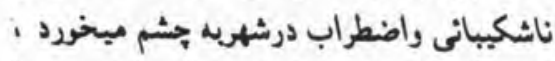

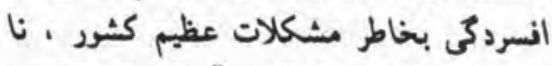

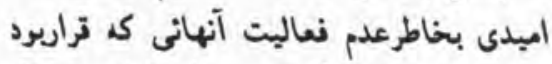

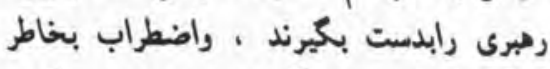

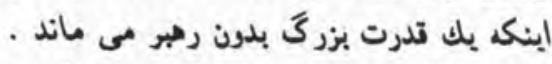

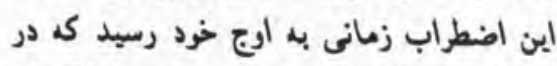

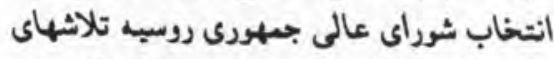

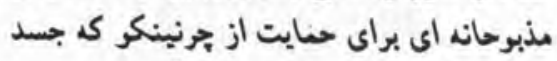

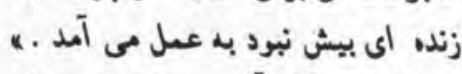

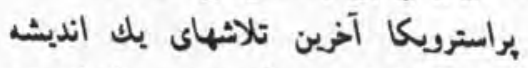

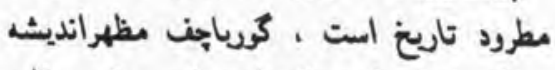

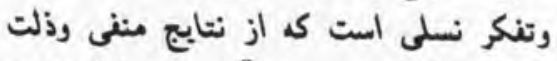
بارمكتب كونيزم بستوه آمده اند ، الما درعين ونين 


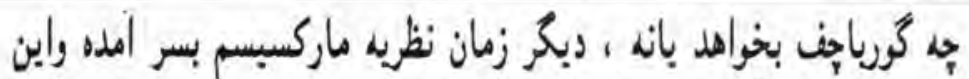

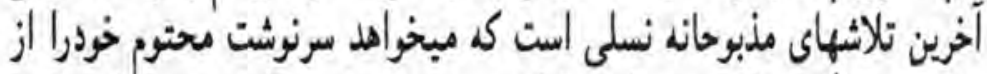

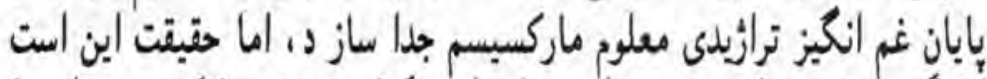

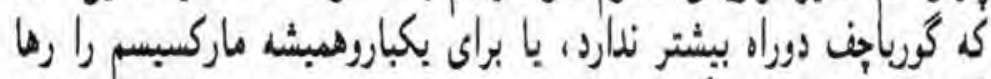

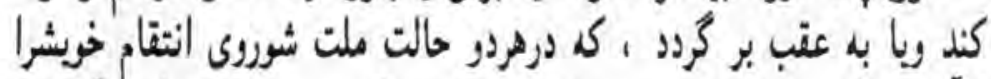

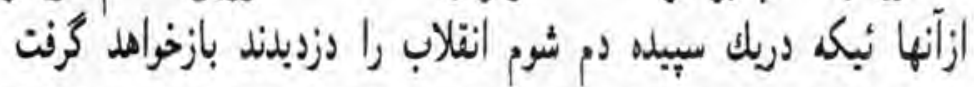

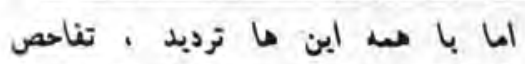

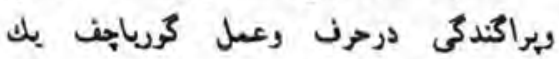
امرمشخص ومعلوم است. نيكسون درياره كرياجف كنته است :

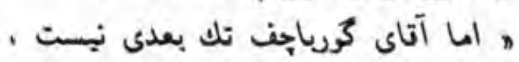

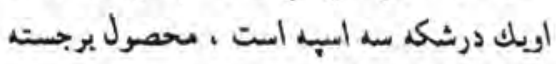

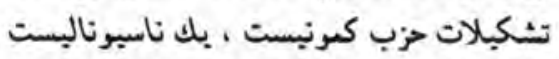
وطن برست روس كى تدرت را دوست دارد

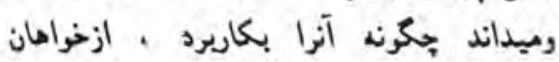

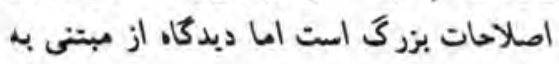

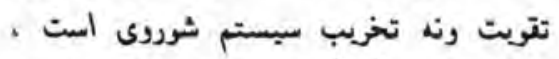

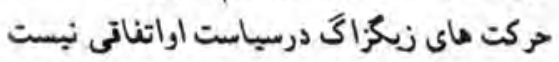

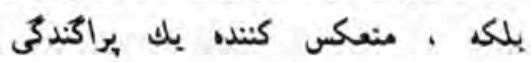

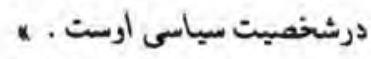

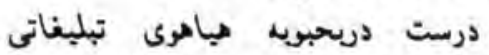
براستروركا وكلاسنوست ودرآغاز انتادات

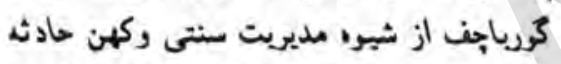

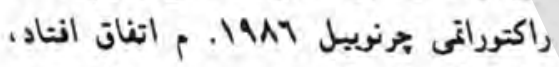

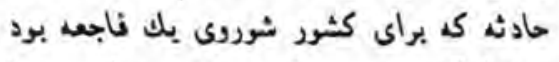

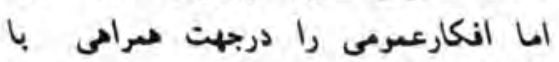

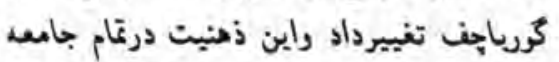
بوجود آتد كه شوروى بم اصلاحات شتئابان

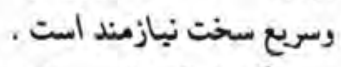
كُرياجف تغيير داد راين ذهنيت دربتام

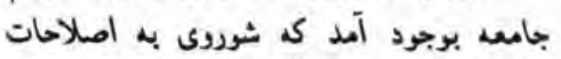
ثتابان وسريع سخت نيازمند است .

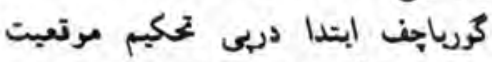

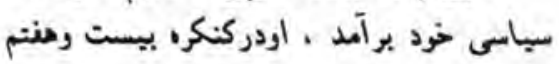

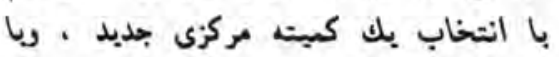

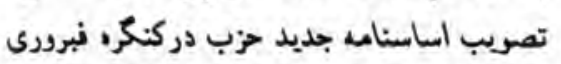

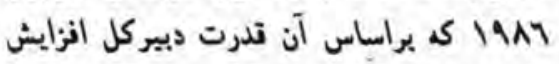

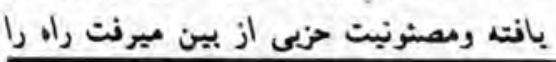

GLASNOST

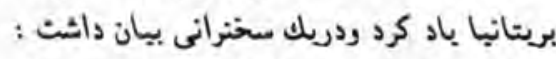

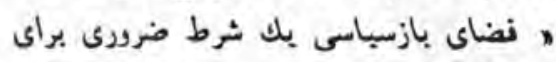

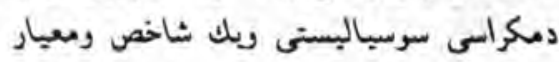

$$
\text { زندكى اجتماعى استى }
$$

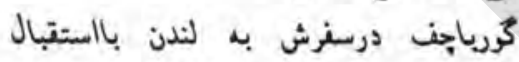
هرشكو، مواجه شد ومطبوعات انكليس از اوبه

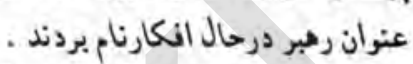

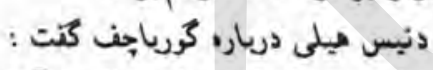

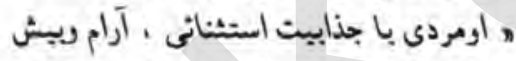

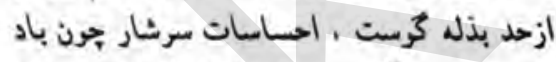

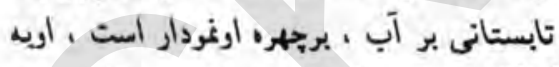

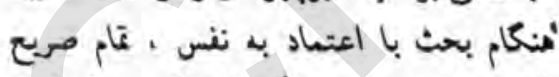

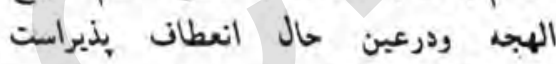

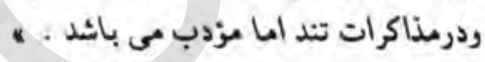

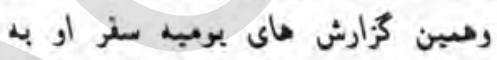

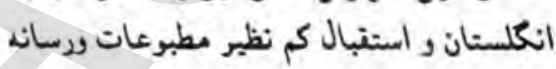

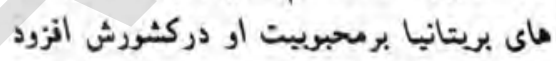

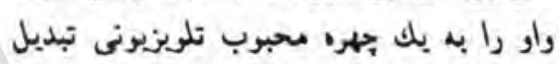
Sرد سرانجام روز دمر مارس

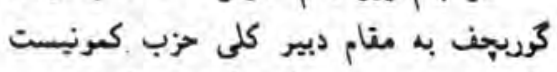

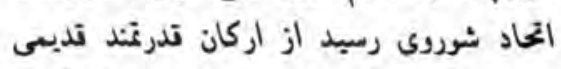

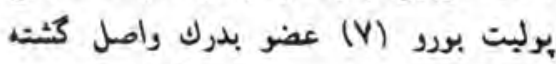
ونتط (Y) عضو بجاي آنها آتده بودند وامل وبد

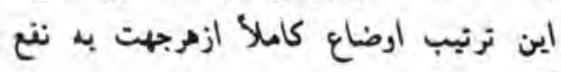

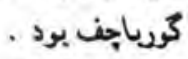

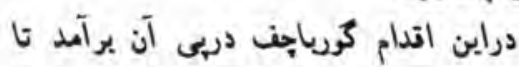

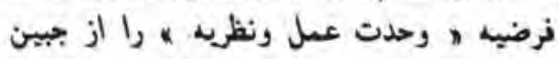

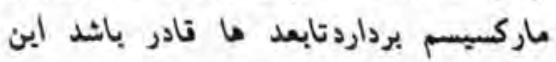
تابوت نازنين را بـ موزيم تاريخ بسيارد .
نابسامانى هاى اتتصادى ،عدم خلاتيت ،

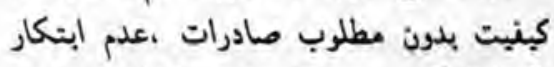

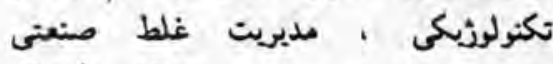
رمجبوع نتابج مصبيت بار (VO) سال نظمام

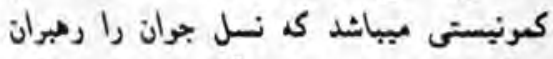
مسكردريى جارن جويى بر آيند .

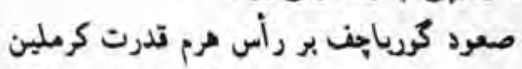

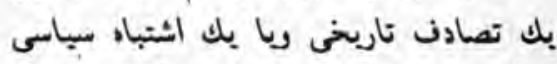

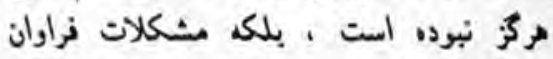

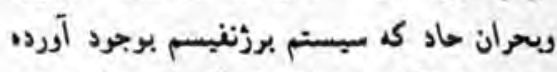

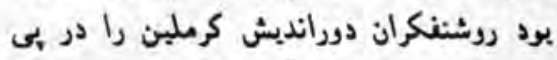

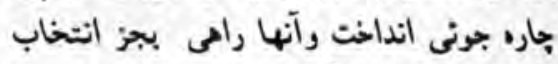

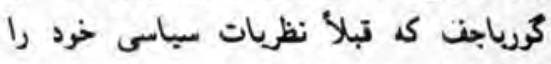

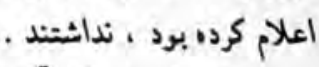
هرجند با روى كارآثدن اندرويون سرد آغاز

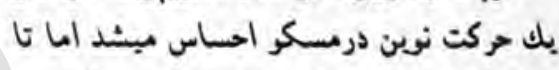

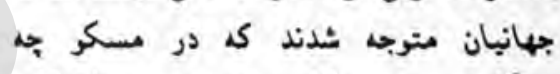

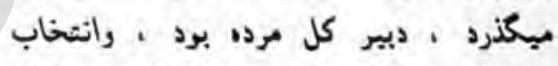

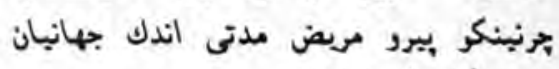

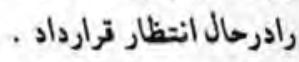

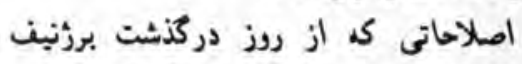

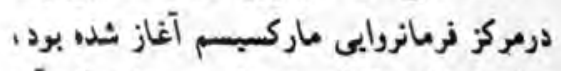

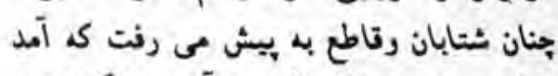

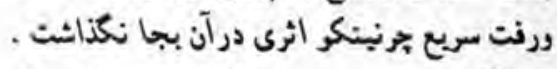

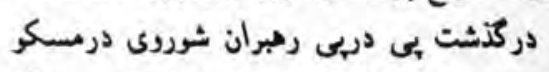

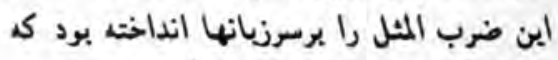

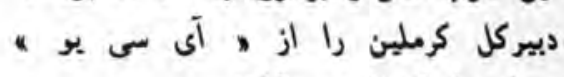
يبمارستان انتخاب مى مثابند .

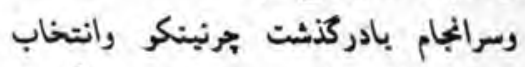

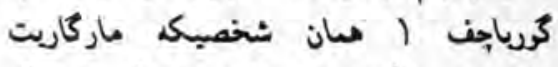
تاجرجند سال تبل إجن سنارش اورا به مركز

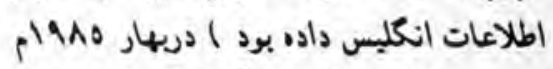

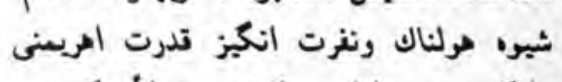

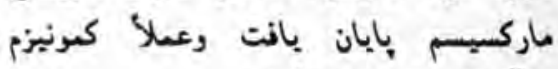

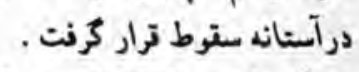

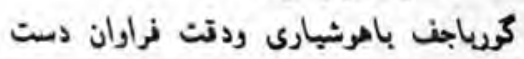

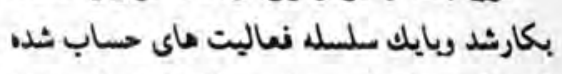

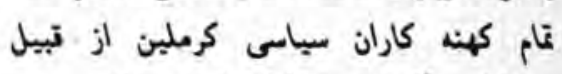
رومانف ، كريشن وتخانف رابيرون راند . كورباجن براى اولين باراز اصطلاح 
جداكانه هسته اي را رد نمود الما به مرحال

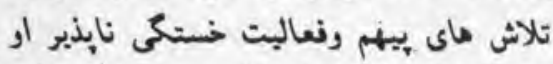

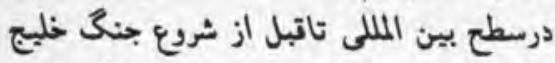

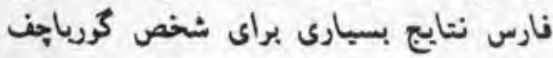

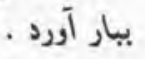

البته انعطان بذيرى كرياجف دريرابر

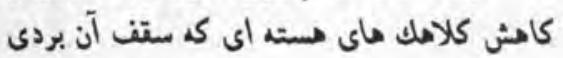

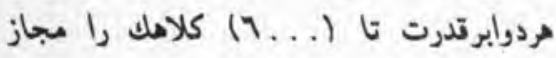

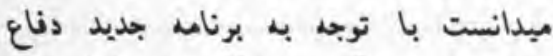

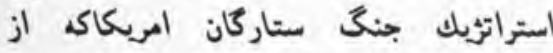

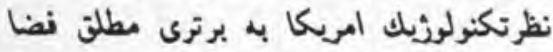

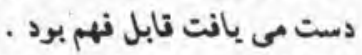

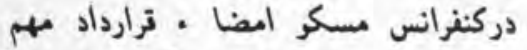

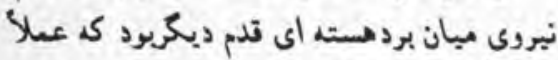

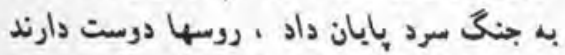

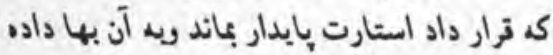

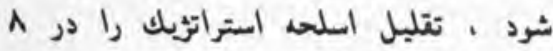

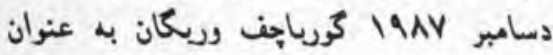
معاهده نيروهاى ميان بردهسته اي امضاء

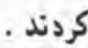

بق ترديد توانت مذاكرات امريكا وشوروى

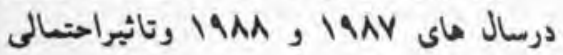

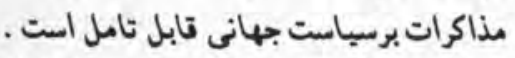

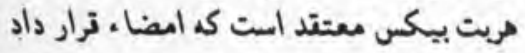
نيروهاي ميان بردهست ائ از جهار حيث حادئ 1- مبين تغيير تنكر نظامى دو ابرتدرت ميباشد . - مئر ץ-مبارزه إيده نولوزيك فروكث نوده است

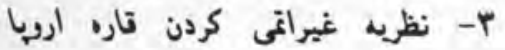

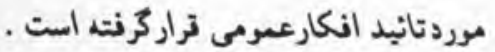

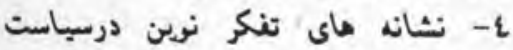

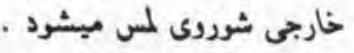
تلاشهاى كررباجف تاتجنا كاركرانتاد كي

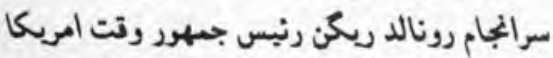

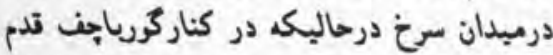
ميزد كنت : كه ديكر به اتحاد شوروى به مثابه

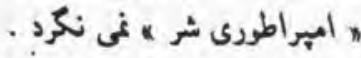

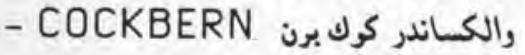
ALEXANDER بيان داشت كs , مونيخ كرن
جبس ، اتهام ،نتض تانون ضرب وستم وتصفيه

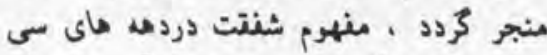

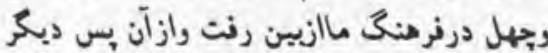

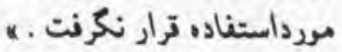

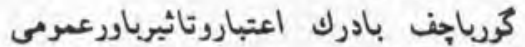

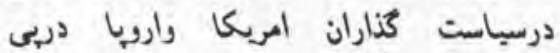

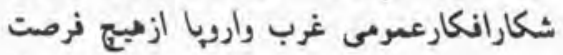

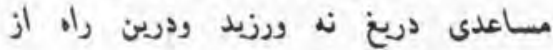

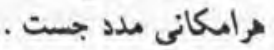

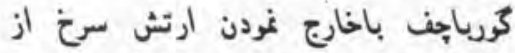
مغولستان دريى بهتر شدن روابط اش با با جين

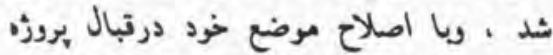

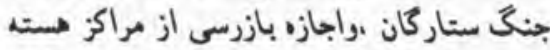
اي شوروي توسط كارشناسان المريكانى

$$
\begin{aligned}
& \text { أر هيه ماجرا جوئي هاي بي باكاثله } \\
& \text { صدام حسين ديككاتور وفرمانرواى } \\
& \text { بغلاء ملتى توجه بين الملى رإيخود } \\
& \text { هعطرن ساتت الها بارديك } \\
& \text { افكلرعمريى مترجه مسكاست } \\
& \text { تايينتل ، كم سرانجام إين أمراطورى }
\end{aligned}
$$

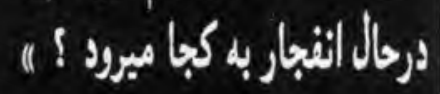

وسرانجام باشكست ارتش سرخ در انغانستان وخروج آن دريى ايجاد روابط بهتر با إيالات

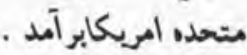
كورياجف دركنغرانس آيسلند با تبول

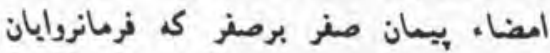

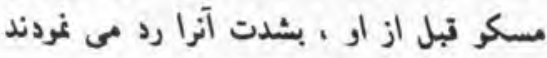

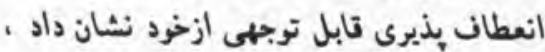

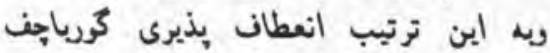

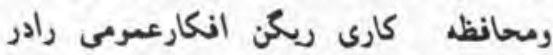

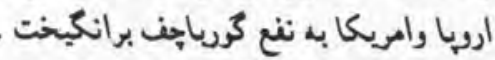

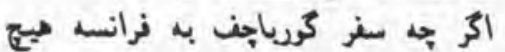

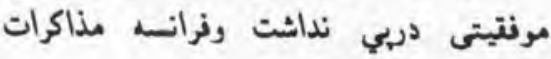

براى اتدامات بعدى هعرار ساخت .

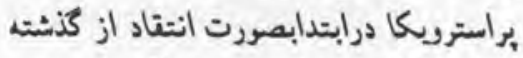

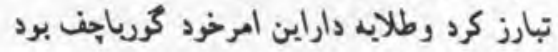

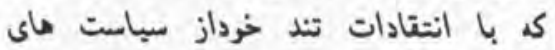

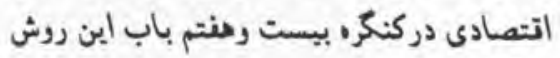
راكثاد. بدنبال اظهارات كررباجف وإبجاد نضاى باز سياسى صدها هزارنامس كه يملو وسرشاراز انتادات بجا وبحث ملت شوروى از ظلم وبيداد

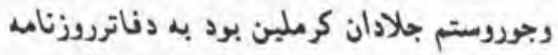

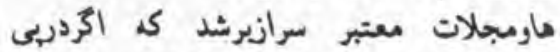
كنترول آن برنى آَررند خودش اننجار وطوناني

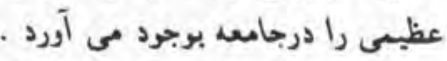

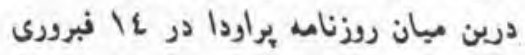
IAAY

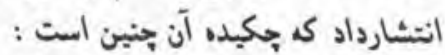

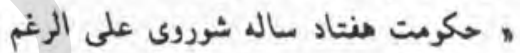

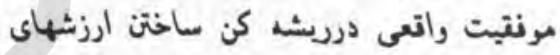

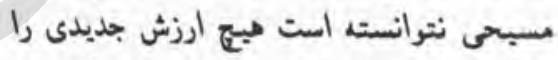

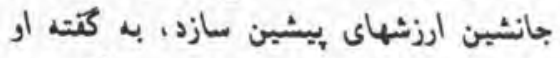

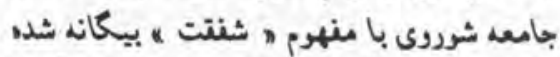

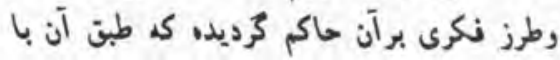

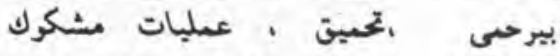

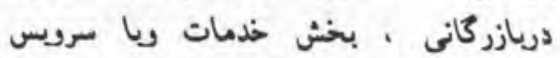

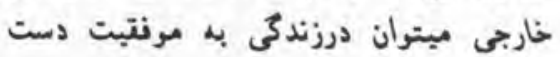

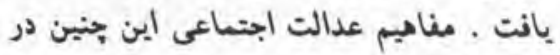

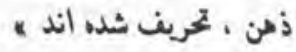

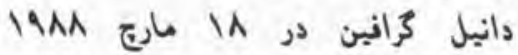
درليتراتروناباكازتا نوشت :

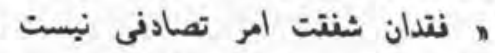

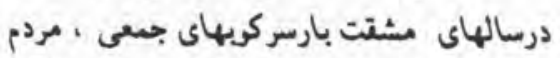

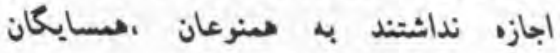

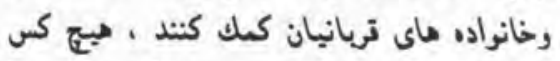

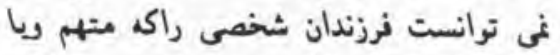

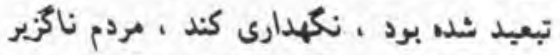

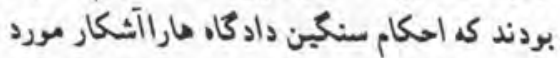

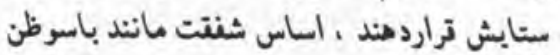
نكريسته ميشدند وحتى جرم نلتى مبكرديدند

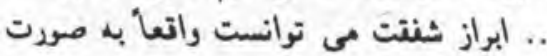

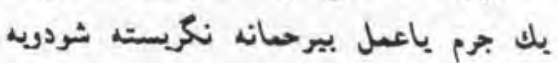




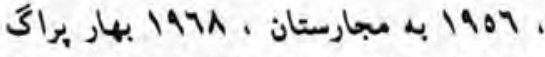

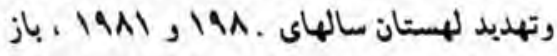

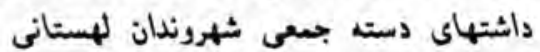

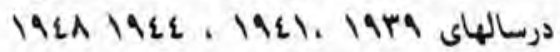

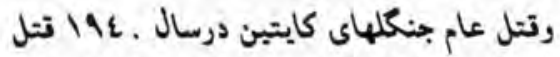

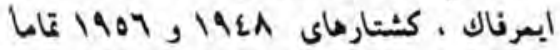

$$
\text { بايد منتشر شود . }
$$

كنادى كراسيمون سخنكوى ثروباجف دركنغرانس مطبوعاتى IAAV در برابر ابن كرئ

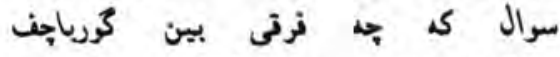

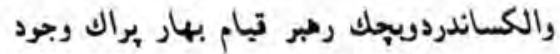

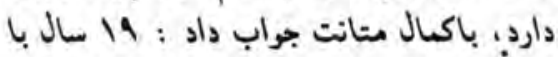
ازميان رنتن نظريه جهان وطنى ماركسيسنى

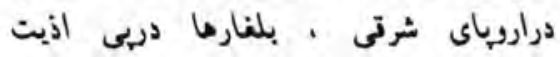

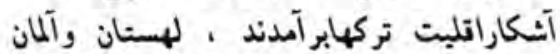

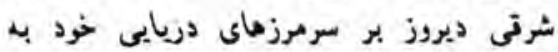

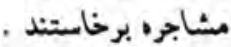

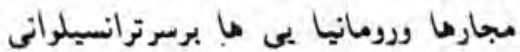

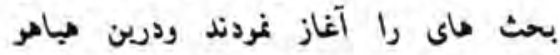

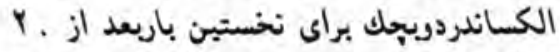

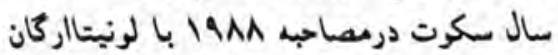

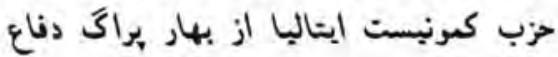

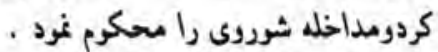

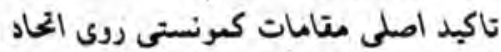

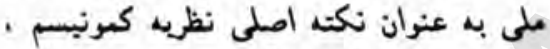

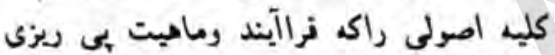

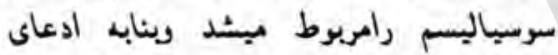

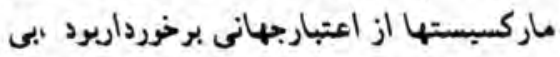

$$
\text { معنى جلره داد . ماركيت }
$$

درابن ميان كررباجف تدم ديكر جلورت

كذاشت ودرجلسه انتتاحيه نوزدمين كنيف كنغرانس

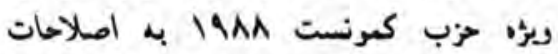
سياسى بيش از اصلاحات اتتصادى تاكيد

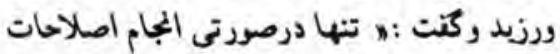

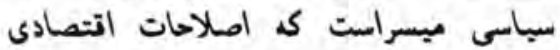

ميتواند به مونتيت بينجامد ماسي

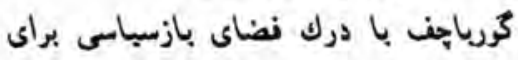

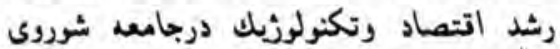

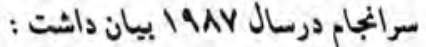

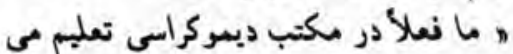

زٔرس مدرون سباستدارودانشيند برجست ناراضى شوروى دريارا كرياجن عنبده دارد ك :

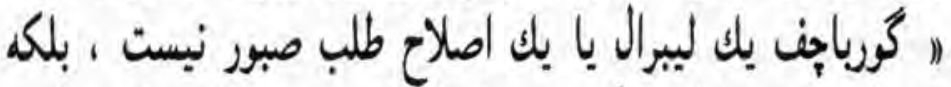
اوتعديل درشيوه هاي حكومتى واصلاحات مجدود اقتصادى را به

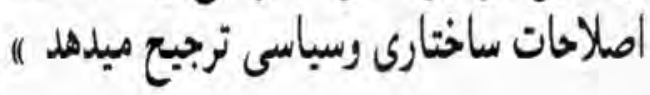

كرياجف با مصر نيز دربى ايباد روابط

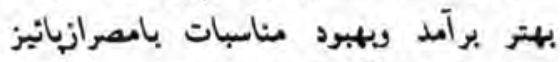

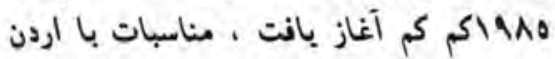

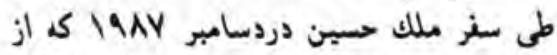

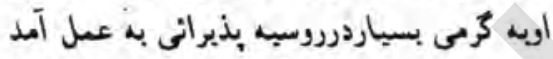

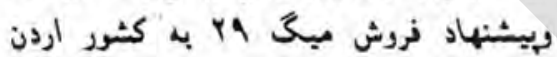

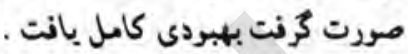

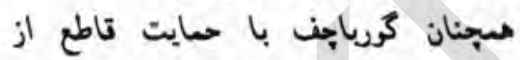

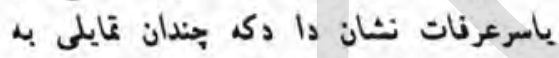

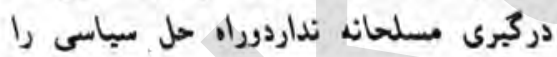

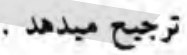

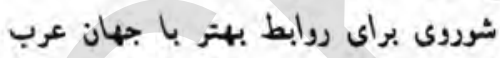

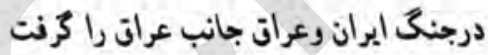

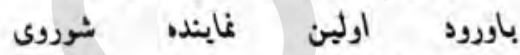

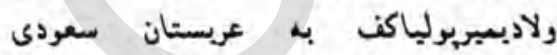
كرياجف با يبام مخصوص خراستار روابط بليط

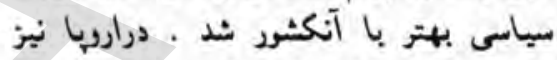
تجديد حيات سباسى لهستان مهكى بود براي

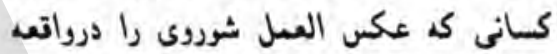

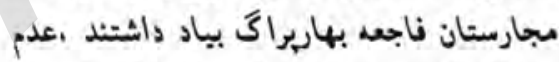
مداخله شوروى درتضيه لهستان اولين اعتباد

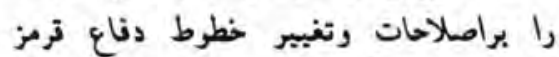

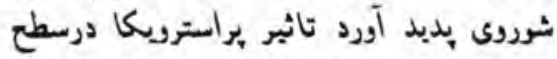

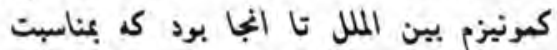

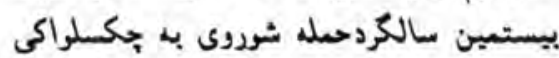

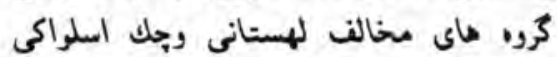
دريانه مشتركى خراستارشدند كه :

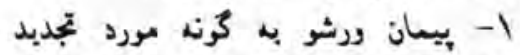

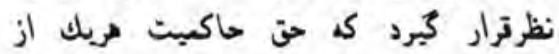

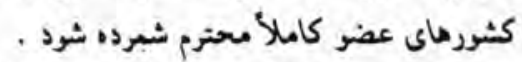
Y- اسناد مداخله شوروى
را درمسكو مى بيند * وكرباجف را منونز امروزى نوبل جمبرلين مى شعارد 1

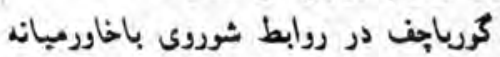

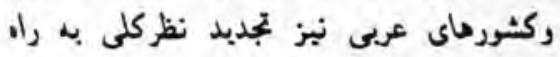

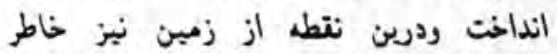
امريكارا آرام ساخته .

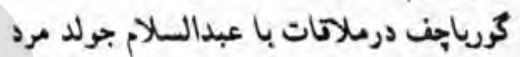

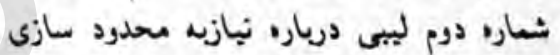

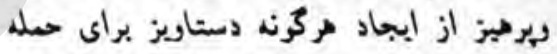

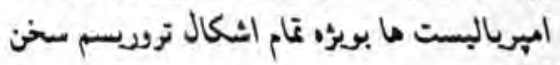
كiت .

در إبريل IAVV حانظ اسد رئيس

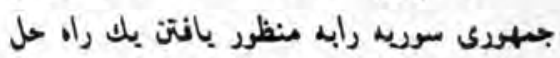

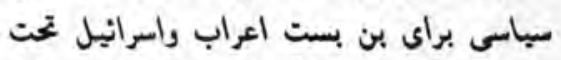

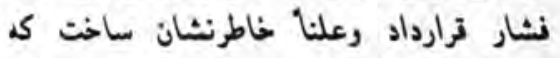

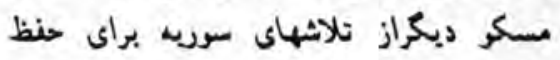

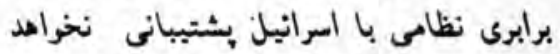

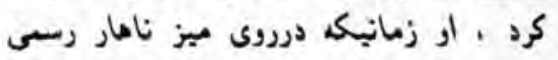

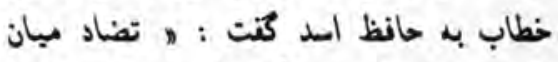
اسرانبل راعراب صرنا از طريت سياسى تابل هليل حل است آب سردى براى الدان استراتيك سرريم ريخت . اخير| مسكر به منظور انزايش اعتبارخود

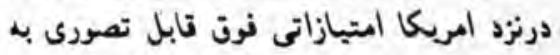

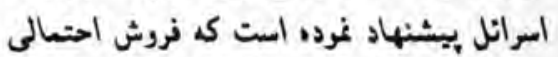

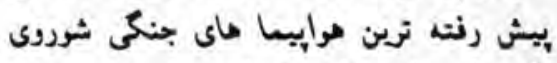

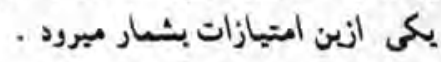

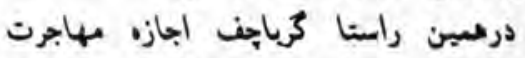

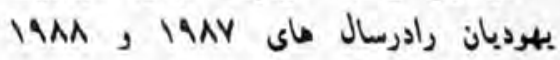
انزايش داد . 


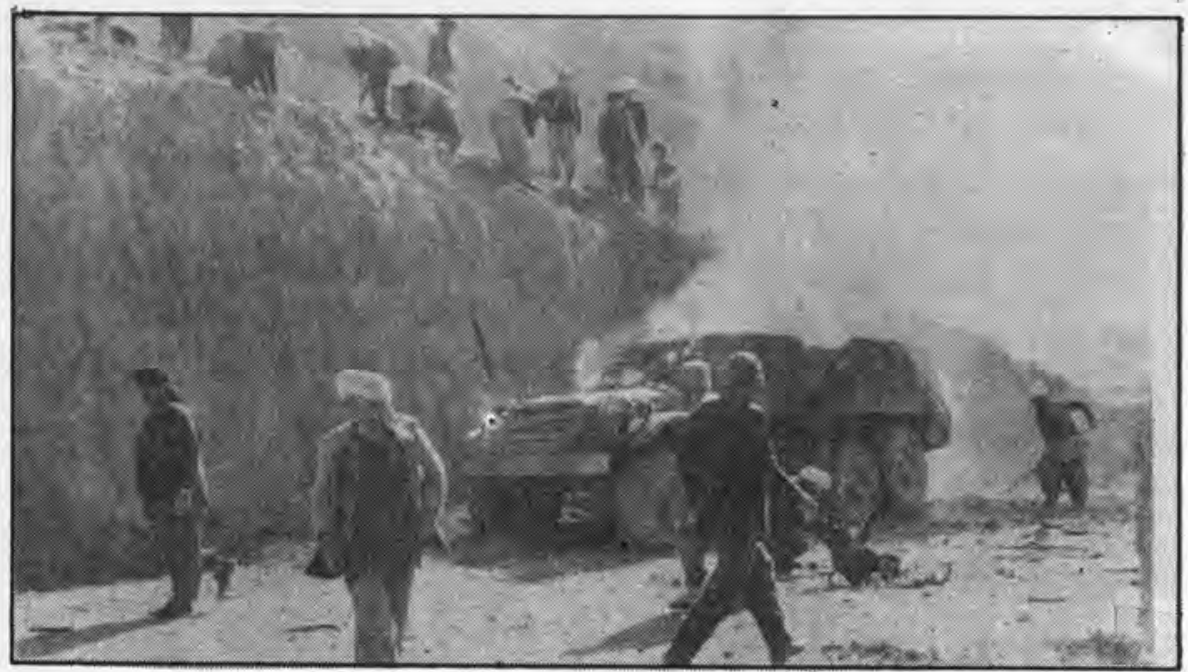

ميباشد !

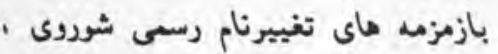

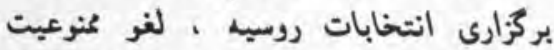

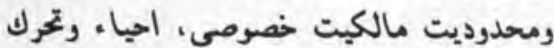

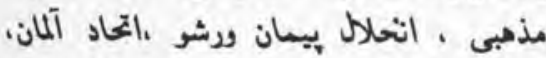

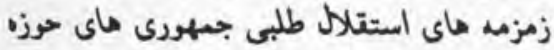

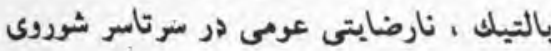

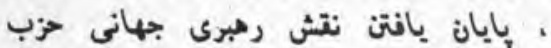

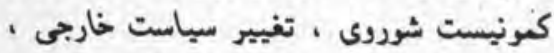
تغيير خط ترمز دناعى واستراتثى شورئي

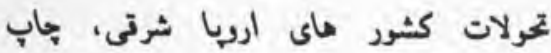

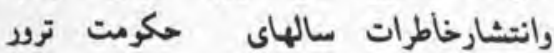

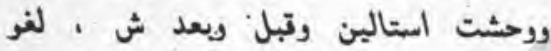

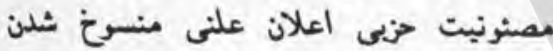

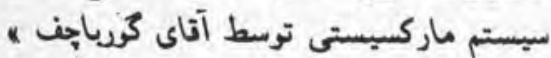

علاك نظريه ماركسيسم جمدانهاى خردرا بسته ودرانتظار جبرواز به سوى كلكسيون

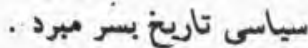

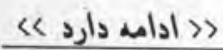
: منابع وماخذ مجبوعه مقالات براسبترويكا - باتريك فلاهرنى

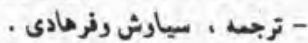
مقالاتى از مانتلى ديوبو

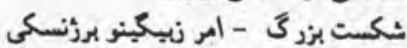

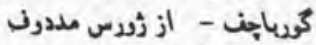

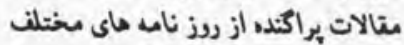

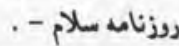

درحاليكه برى كارت رايت بحران نعلى

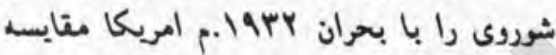

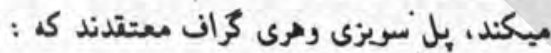

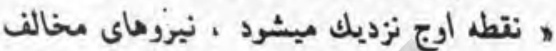

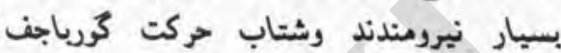
بسيار تند اكر جه ماجرا جونى هاى بى باكانه صدام حسين دبكتاتور وفرمانرواى بغداد مدتى توجه بين المللى رابخود معطون ساخت الها بارديكر انكارعمومى متوجه مسكواست تابيينند ، كهون

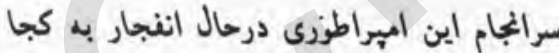

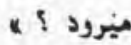
دوكوستين فرانسوى .بعد از سفرى كه يك

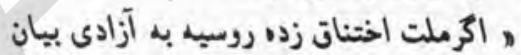

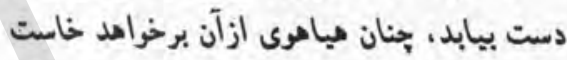

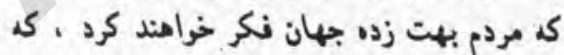

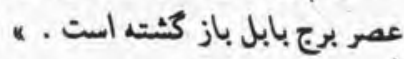

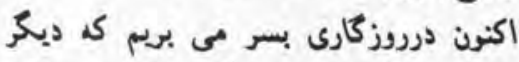
ماركسيس آن انديشه مطرح بـر ونظريد جذاب

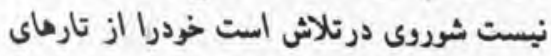

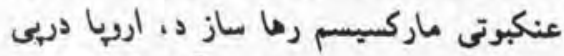

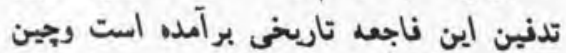

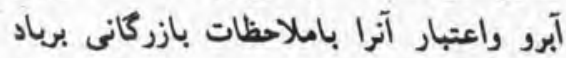

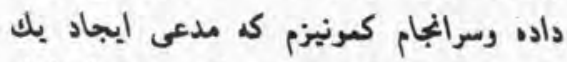

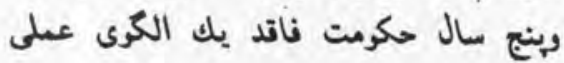
ونيم ترن تبل به شوروى داشته است دركتاب

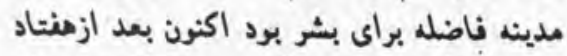

بينيم ، درس مى آموزيم ، ماهنوز يك

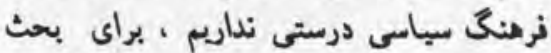
كردن معيار ويايد درستى نداريم ديراي احترام ندام براي نهادن به عتيده ديكران حتى به عتيده دوستان

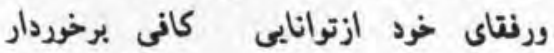

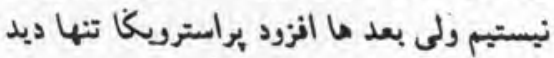

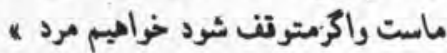

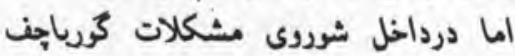

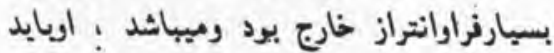

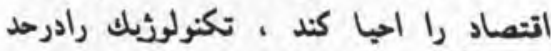
مطلوب رونت دهد ريد حترت بشر كه جز

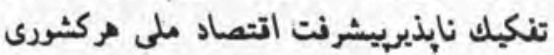

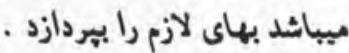
ثروس مددون سياستعدارودانشيند برجسته

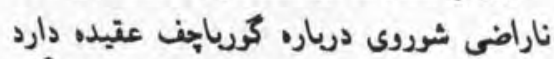

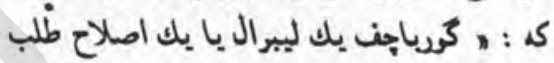

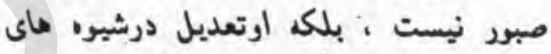

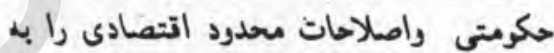

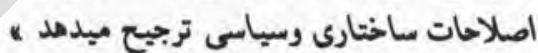
درزمينه اتتصاد بارنع محدوديت ازواحد

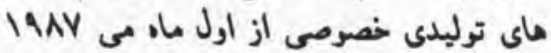

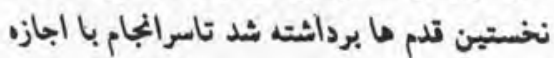
كامل مالكيت خصوصى درسال جارى حركت برد اتتصادى تحرل تازه يانت .

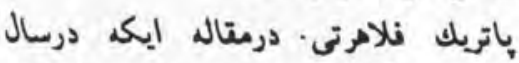

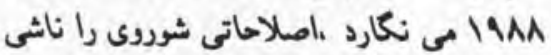

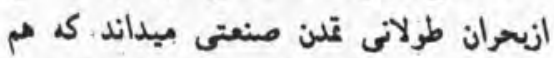

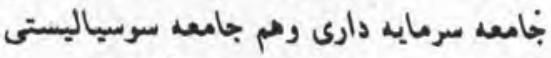

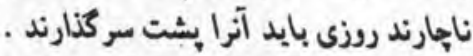

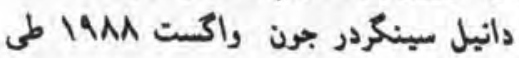
مقالاتى نوشت :

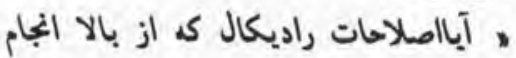

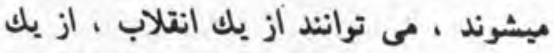

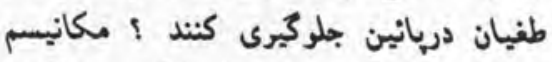
نرماندمى ازيالا بامنهوم ماركس مطري كابتت نداشت . ندمث دنيل سينكر مى كريد : بعضى از ازئ

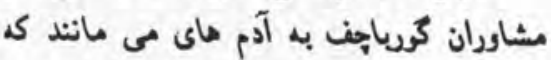

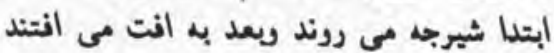

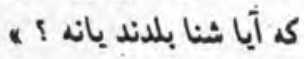


ها وطبيعت هائيست كه او داشته رلى بالاتر

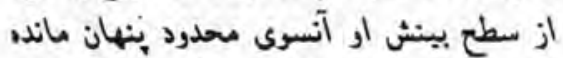

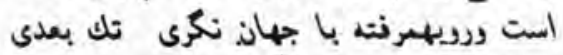

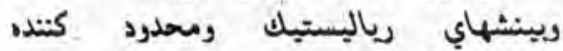

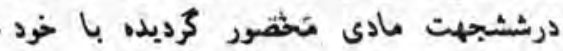
آزادى · مريلندي وسايرارزشهاي انسانى

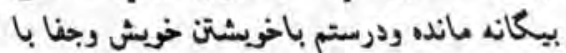

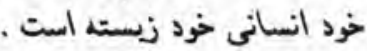

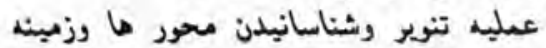
هاى زندخى معاصر بم انسان، تدابير روشنيكراني ديكريست كم درسر نصل مبارزي، آرمانكراياند

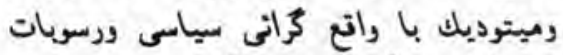

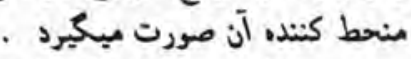

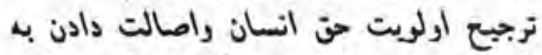

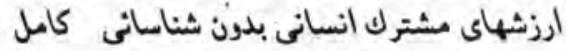

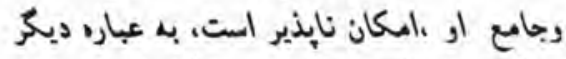

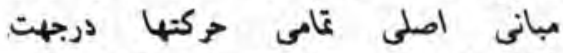

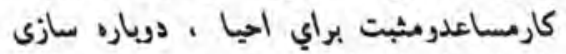

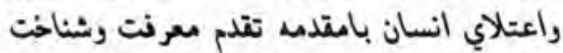

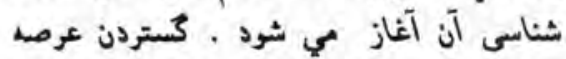

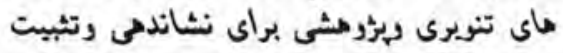

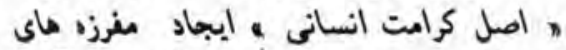

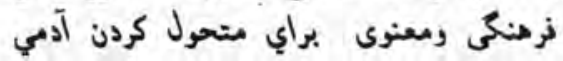

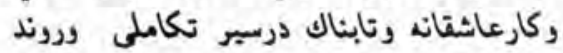

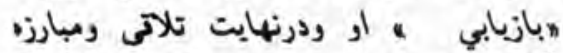

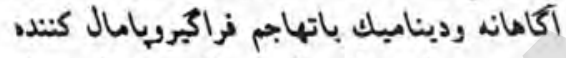

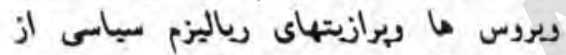

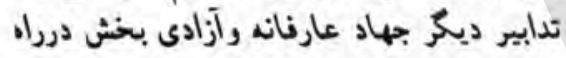

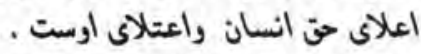

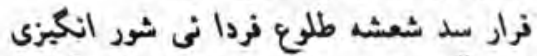

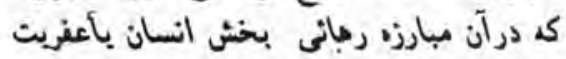

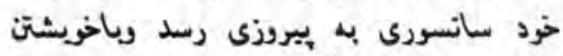

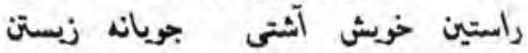

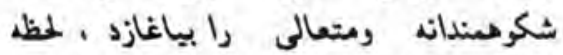

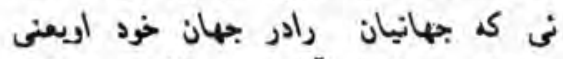

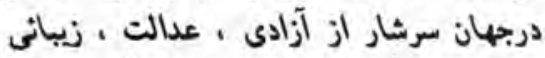

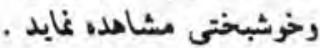

\section{وماتوفيقى إلا بالاله}

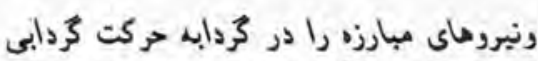

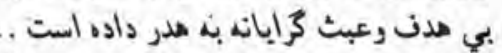
موسسات تنويرى وفرهنكى رياليزم شئياسي

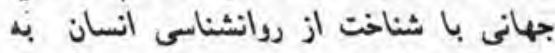
تدوين تاكتيكهاى متناسب مبارزن با مبأرزات انيات

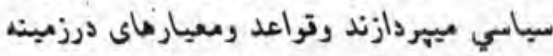

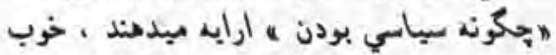

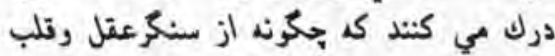

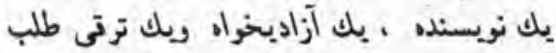

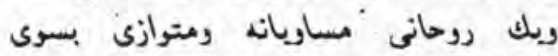

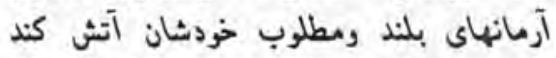

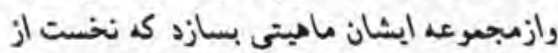

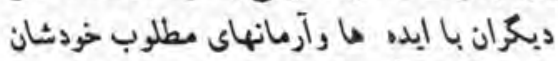

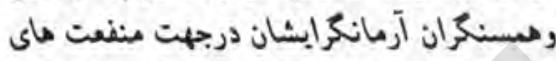
مادى ومصلحتهاى سياسى نو مطرح شده شان.

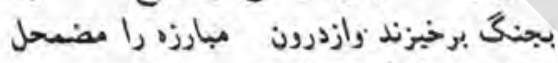

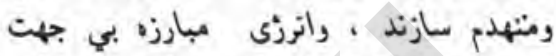

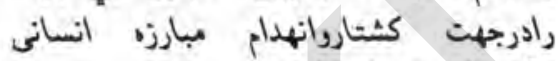
وآرمانكراياند بكار كيرند .

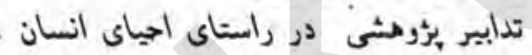

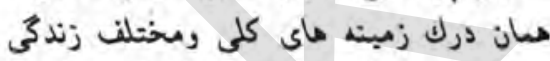

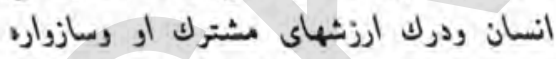

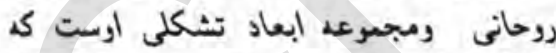

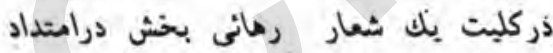

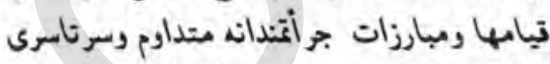

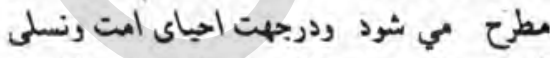

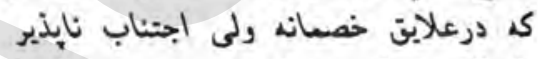
بارياليزم سياسى " زنده مي ميرد ، ه ترار دادي دانش بح مبانى واصول بين المللى كردن

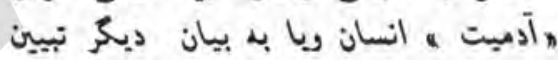

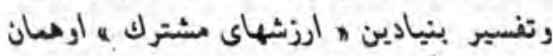

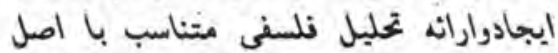

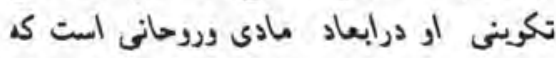

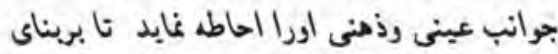

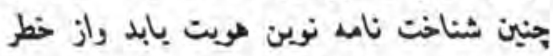

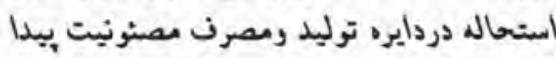

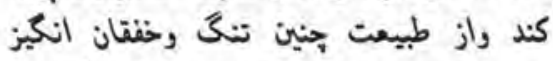

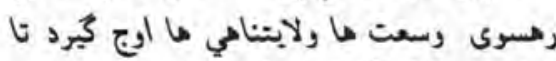

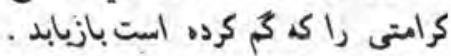

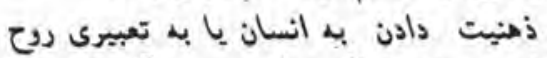

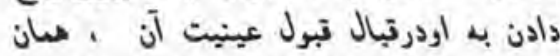

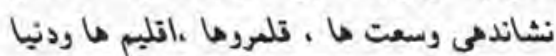

راليزم سياسي را متهم مينمانيم كه باحس

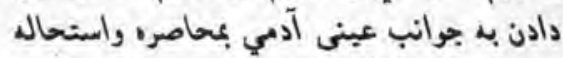

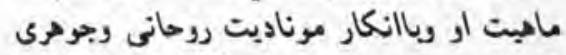

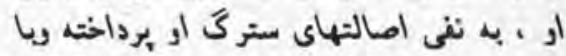

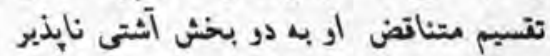

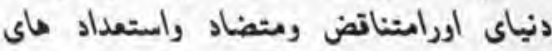

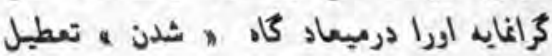

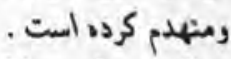

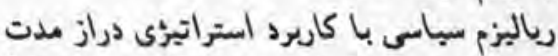

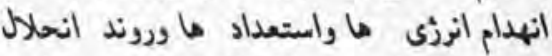

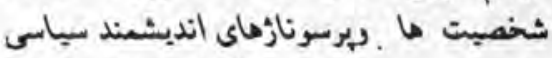

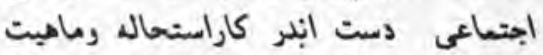

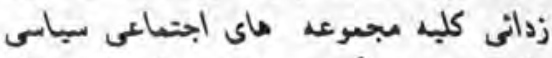

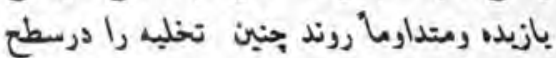

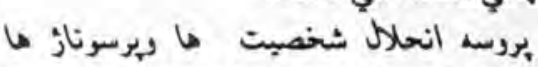

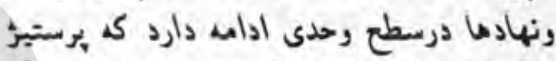

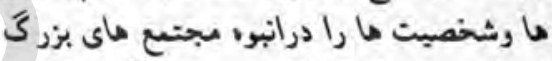

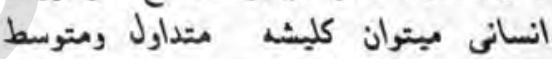

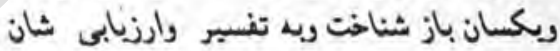
برداخت ورنان.

درسر نصل نتيجه ناهه مبارزاتى تحريك

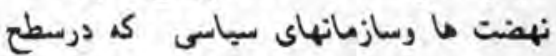

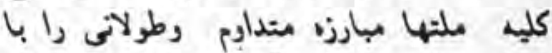

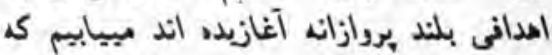

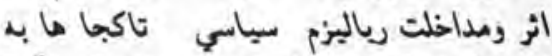

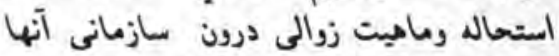

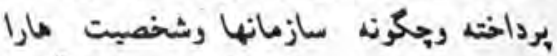

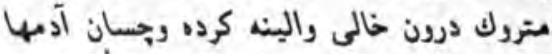

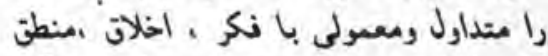

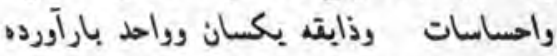

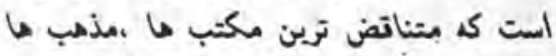

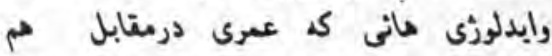

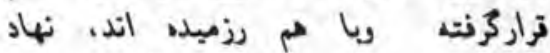

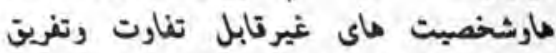

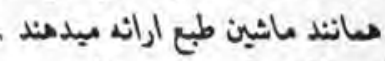

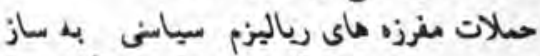

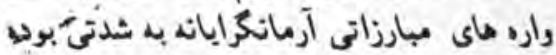

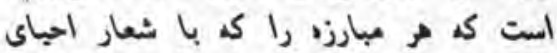

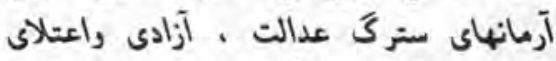

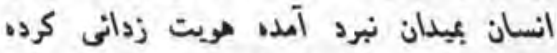

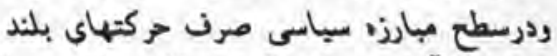

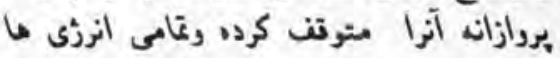




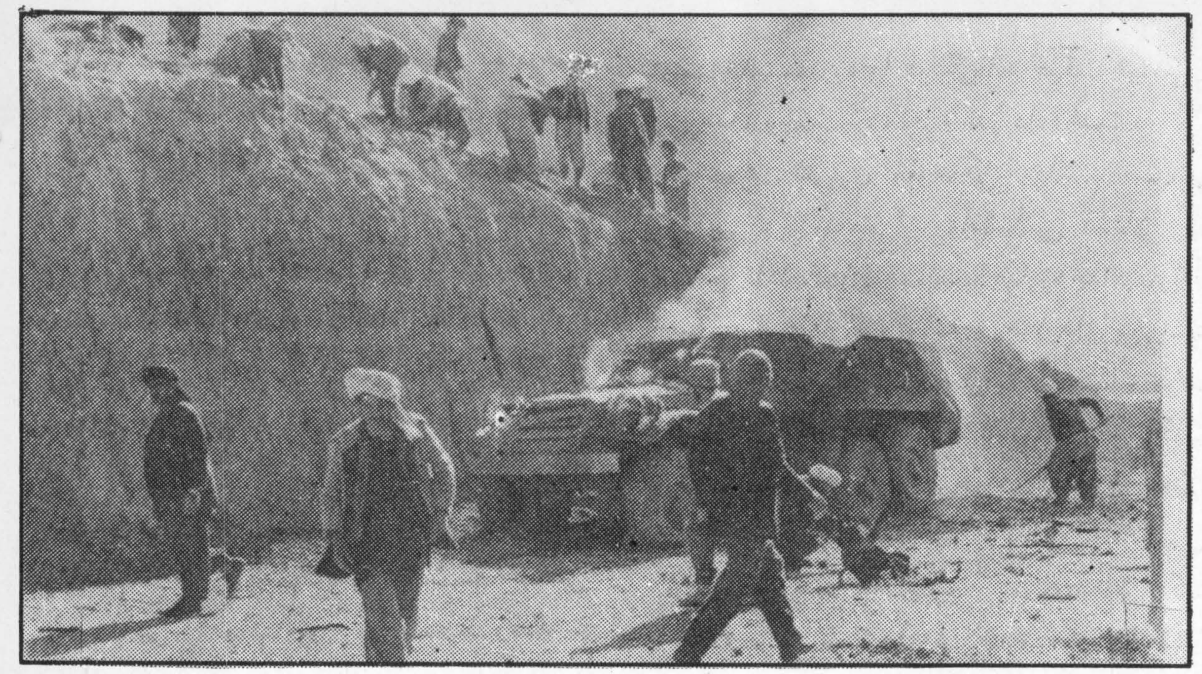

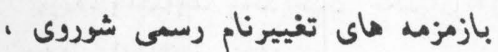

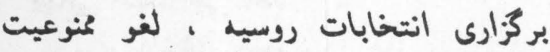

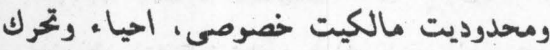

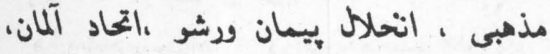

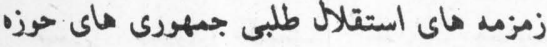
بالتيلك ، نارضايتى عومى در سرتاسر شوروى

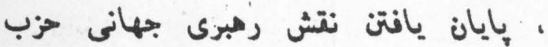

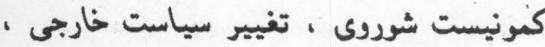
تغيير خط ترمز دناعى واستراتزى شوروى

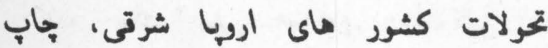

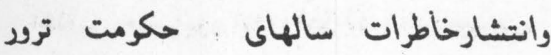

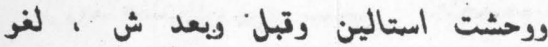

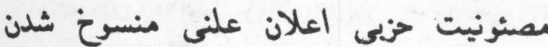

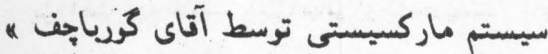

علاً نظريه ماركسيسم بمدانهاي خودرا بسته ودرانتظار برواز به سوى كلكسيون

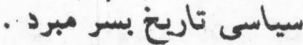

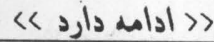

\section{منابع وماغذ}

مجموعه متالات براسبتريكا - هاتريك فلاهرتى

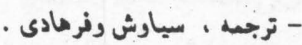
مقالاتى از مانتلى ريويو

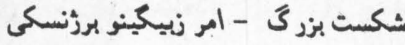

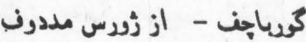

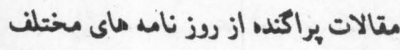

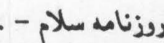

درحاليكه برى كارت رايت بحران نعلى

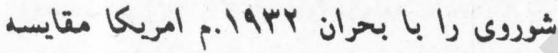

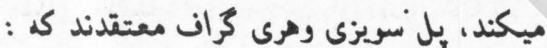

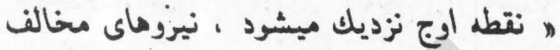

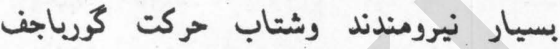

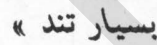

ا\$ر جه ماجرا جونى هاى بـ باكانه صدام

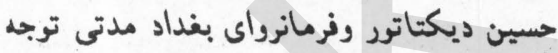
بين المللى رابخرد معطون ساخت امنا بارديكر

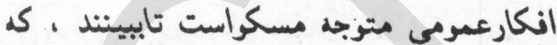

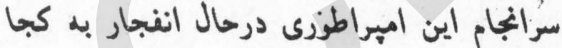

من

دوكوستين نرانسوى .بعد از سفرى كه يك ونيم ترن تبل به شوروى داشته است دركتياب نامه هاى أز روسيه مى نويسد : دست بيابد، جنان هياهوى ازآن برخواهد خاست

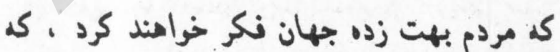

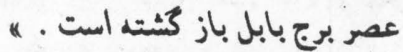

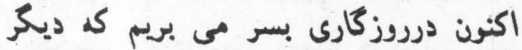

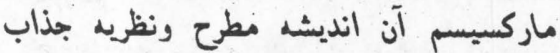

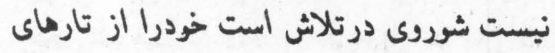

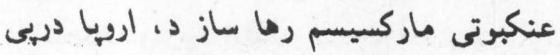

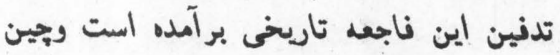
آبرو واعتبار آنرا باملاحظات بازركانى بردي بردياد

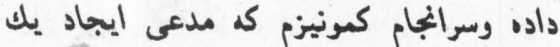

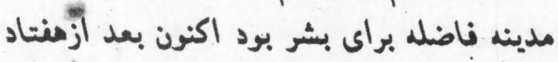

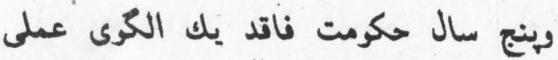

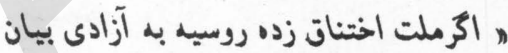

بينيم ، درس مى آموزيم ، ماهنوز يك

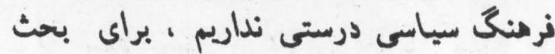

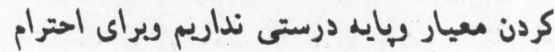
نهادن به عقيده ديكران حتى به عقيده دوستان

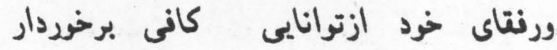
نيستيم ولى بعد ها انزود هراستروديكا تنها ديد

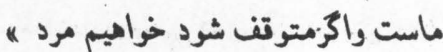

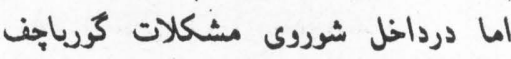

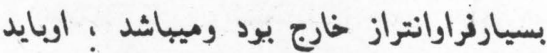

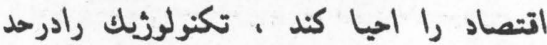
مطلوب رونت دهد وبه حتوت بشر كه جز

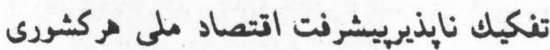

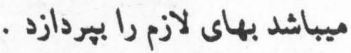
زورس مددون سياستمدارودانشمند برجسته

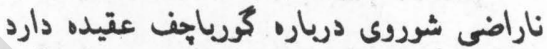

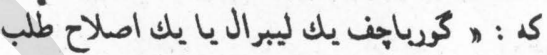

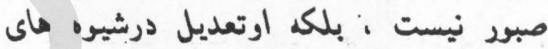

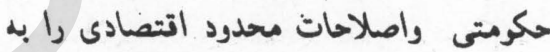

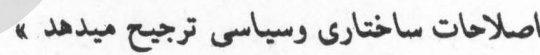
درزمينه اتتصاد بارنع محدوديت ازواحد ودئ

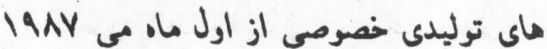

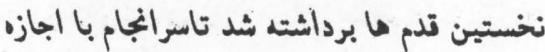
كامل مالكيت خصوصى درسال جارى حركت اتتصادى تحرك تازه يانت .

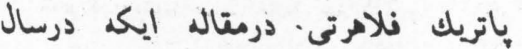

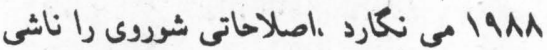

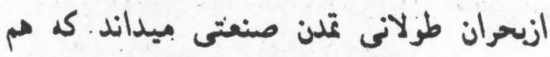
جامعه سرمايه دارى ومم جامعه سوسياليستى مدئي

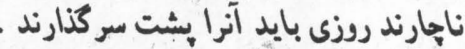

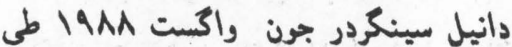
مقالاتى نوشت : " آياصلاحات راديكال كه از باللا انجام

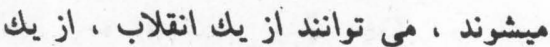

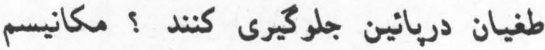
فرماندمى ازيالا بامفهرم مُاركس مطابقت

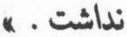

دنيل سينكر مى كريد : بعضى ازئ

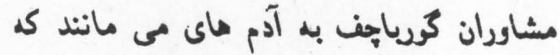

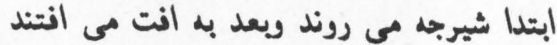

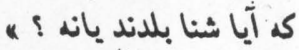


ها وطبيعت هانيست كه ار داشته ولى بالاتر

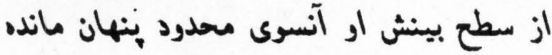

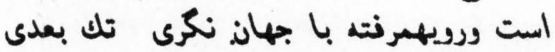

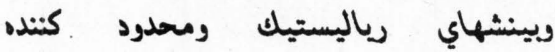

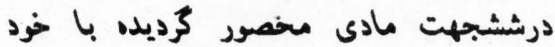
آزادى ، سريلندي وسايرارزشهاي انسانى بيكانه مانده ودرستم باخويشتن خويش وجفا با بانيا

$$
\text { خود انسانى خود زيسته است . }
$$

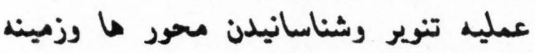

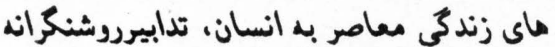
ديكريست كه درسر نصل مبارزن آرمانكرايانه

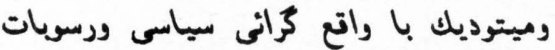

$$
\text { منحط كننده آن صورت وال ميكيرد }
$$

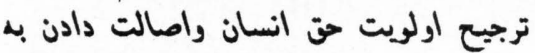

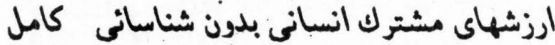

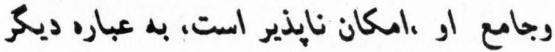

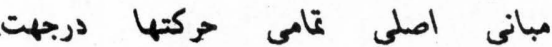

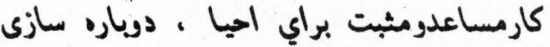
واعتلاي انسان بامقدمه تقدم معرنت وشناخت

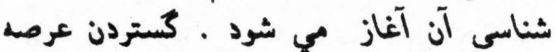

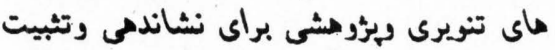

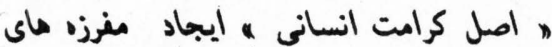

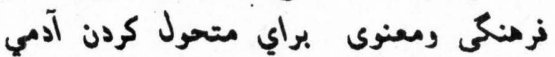

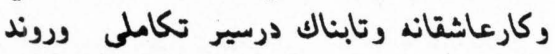

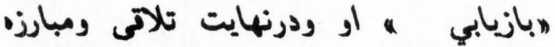

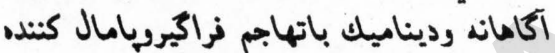

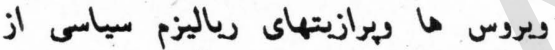

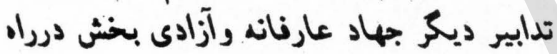

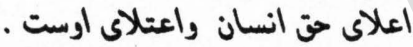

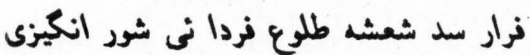

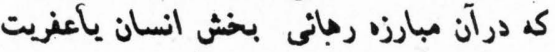

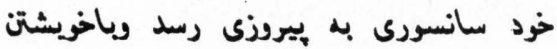

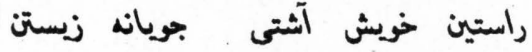

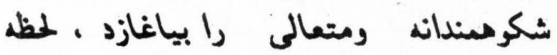

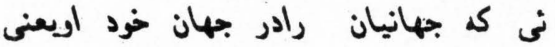

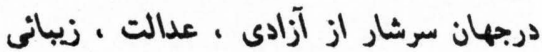
وخوشبختى مشاهده نايد .

$$
\text { وماتوفيقى إلا بالاله }
$$

ونيروهاى مبارزه را در كردابه حركت كردابي

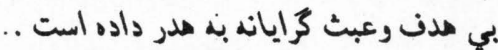
موسسات تنويرى وفرهنكى رياليزم سئياسي

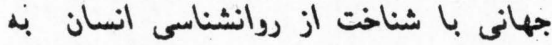

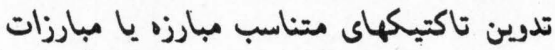

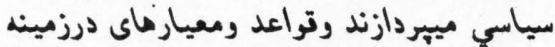

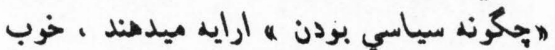

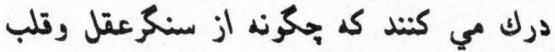

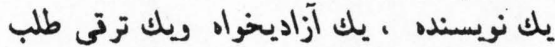

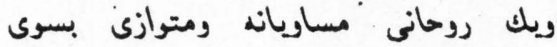
آرمانهاى بلند ومطلوب خوداني موشان آتش كند

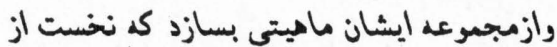

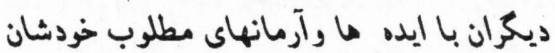

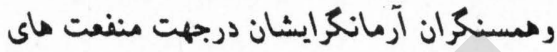

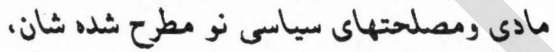

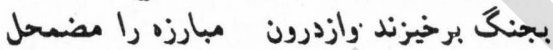

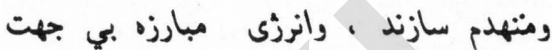
رادرجهت كثتاروانهدام مبارئ مبارزن انسانى بئن وآرمانكرايانه بكار كيرند .

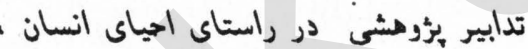

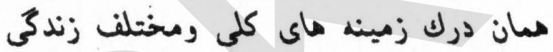

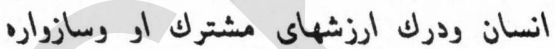

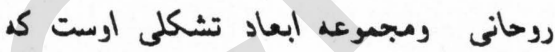

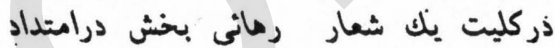

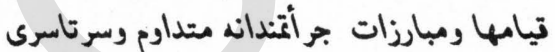

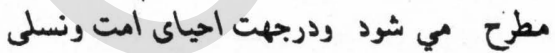

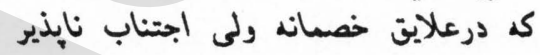
بارياليزم سياسى " زنده مي ميرد "، ترار داده

دانش بن مبانى واصول بين المللى كردن

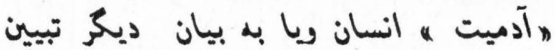

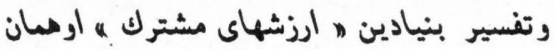

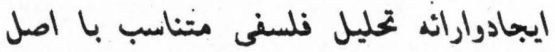

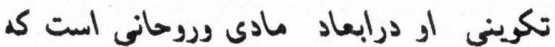

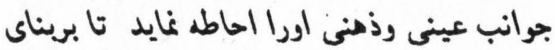

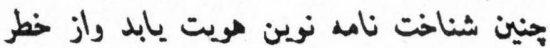

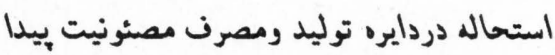

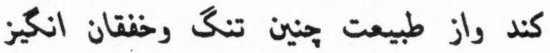

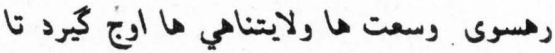

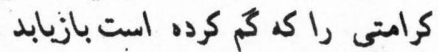

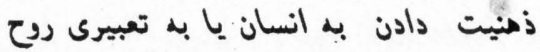

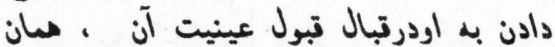

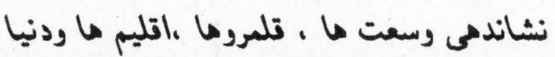

رياليزم سياسي را متهم مينمائيم كه باحس دادن به جوانب عينى آدمي بمحاصره واستحالي

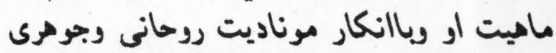

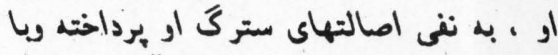

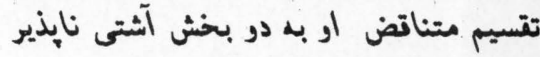

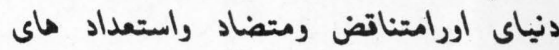

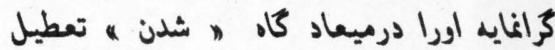

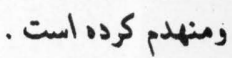

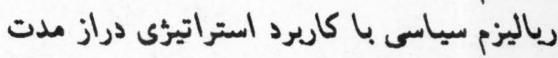

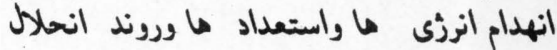

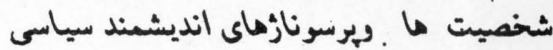

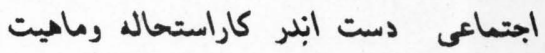

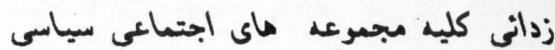

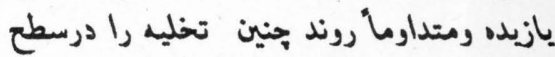

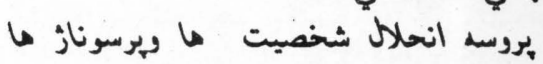

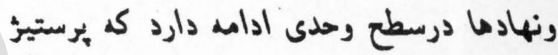

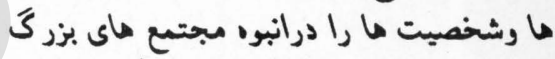

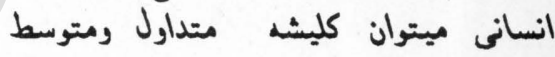

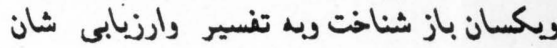

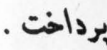

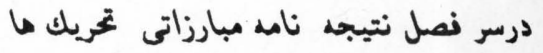

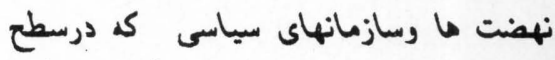

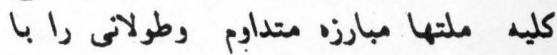

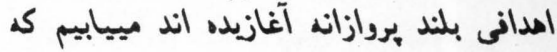

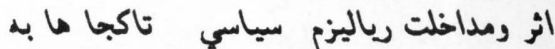

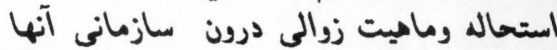

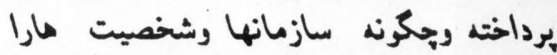

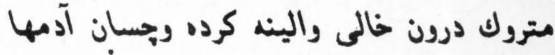

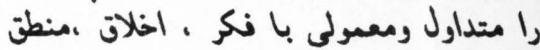

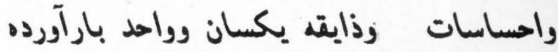

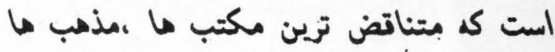

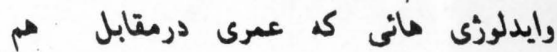

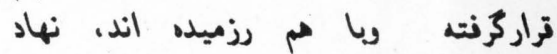

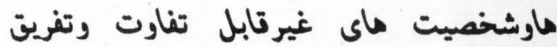

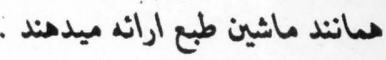

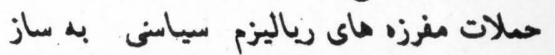

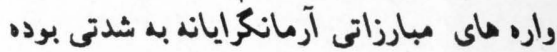

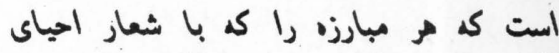

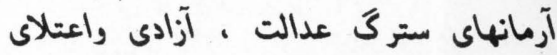

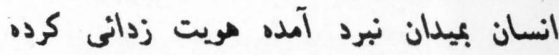

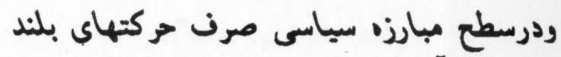

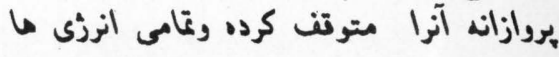


مترجم : عبدالقدير لفطرت "
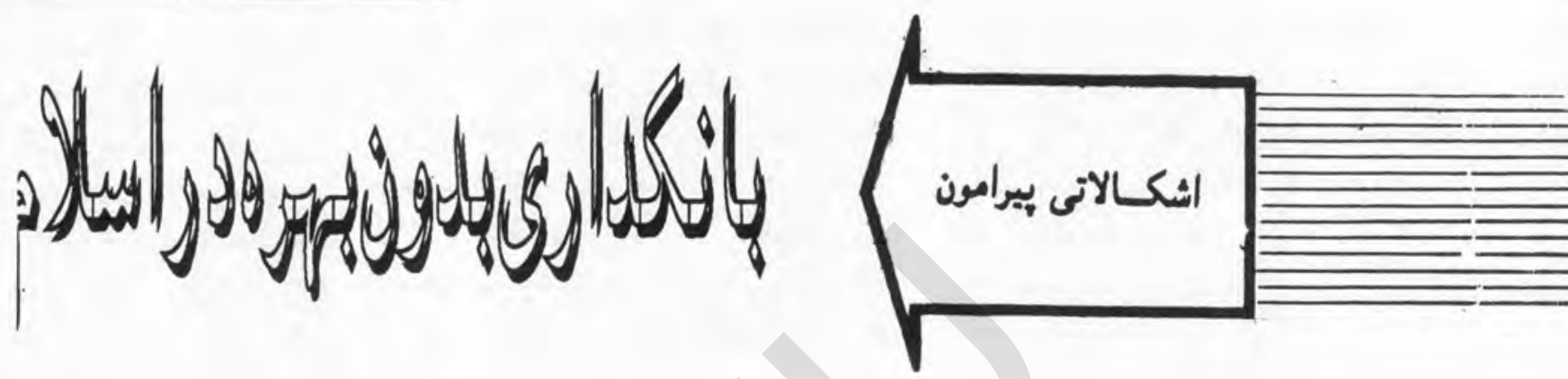

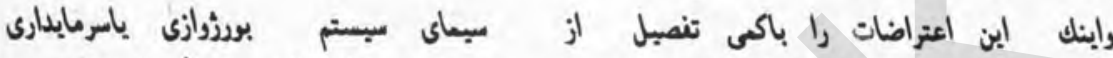

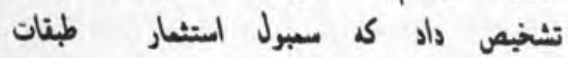

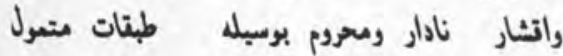

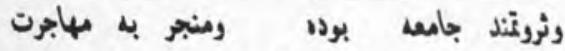

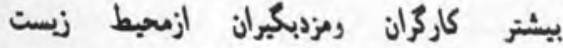

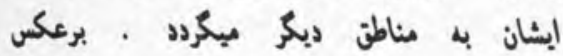

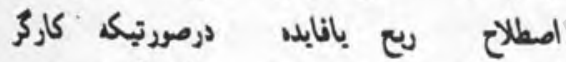

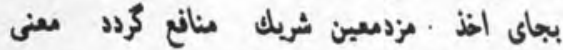

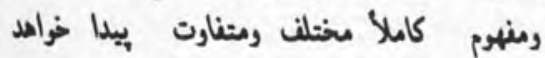

هرجند ازتنكرنون كث براصول واساسات

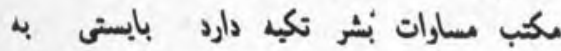

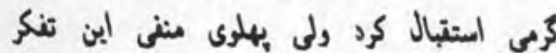

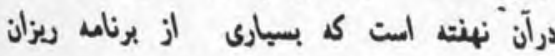

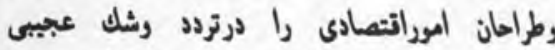

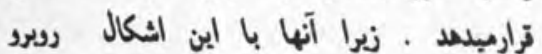

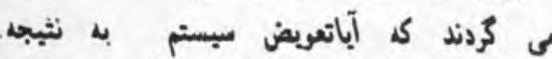
مطلوب خواهد رسيد ويانه . آنهاتا كنون

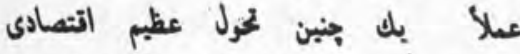

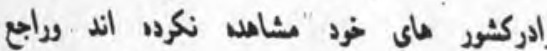

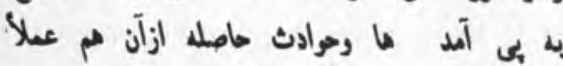

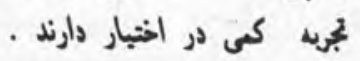

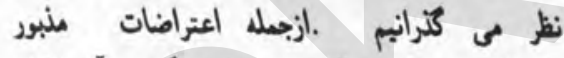

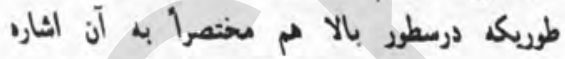

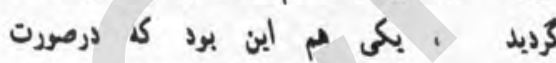

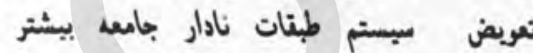

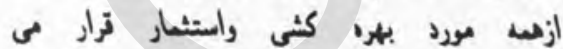

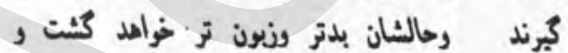

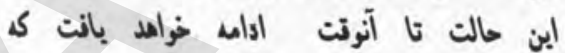

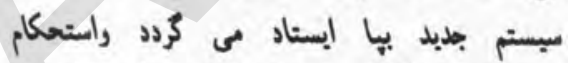

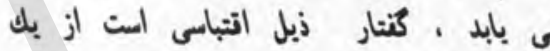

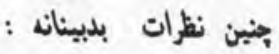

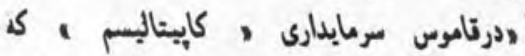

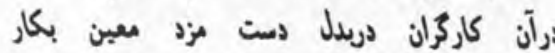

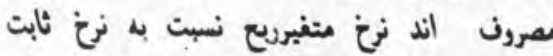

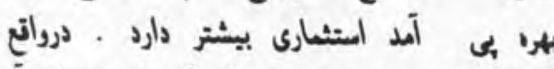

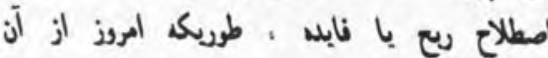

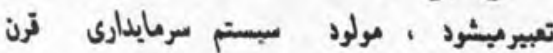

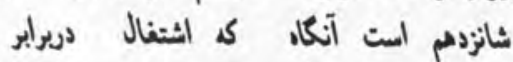

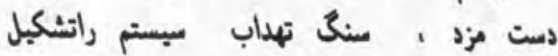

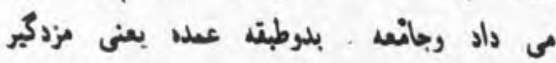

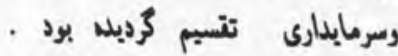

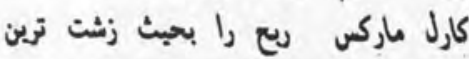

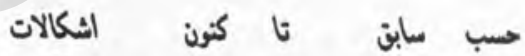

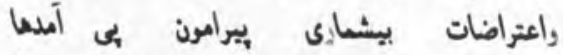

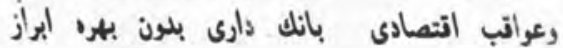

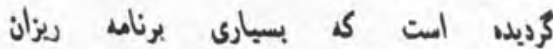

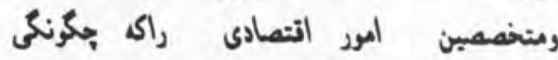

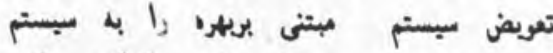

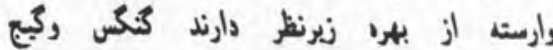

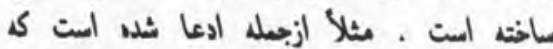
تعويض سبست بانكى سودى بـ رئم بانكى إنى

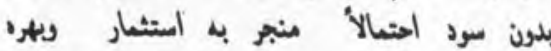

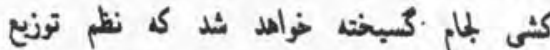

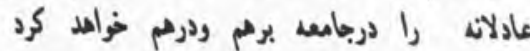

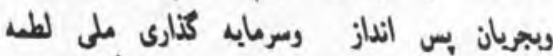

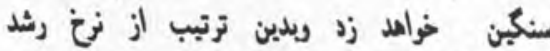
خواهد كاست وبى كارى فراوانى را به ارمغان

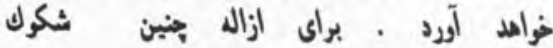

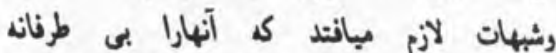

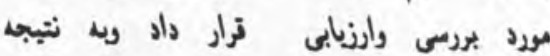

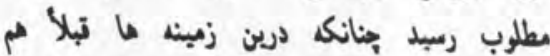

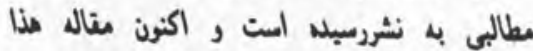
.

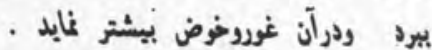




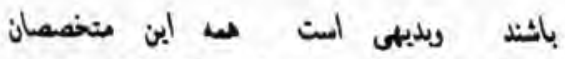

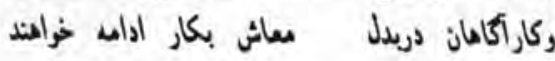

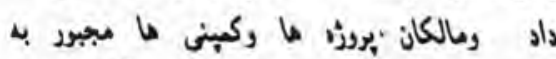

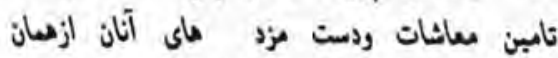

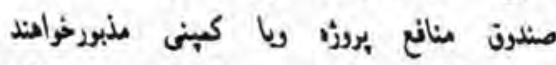

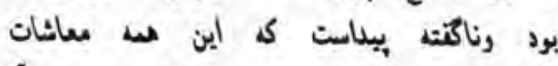

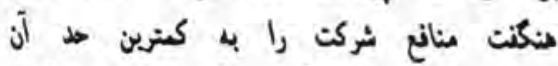

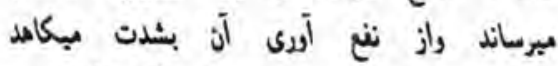

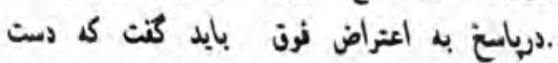

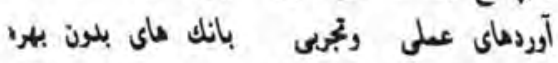

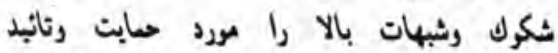

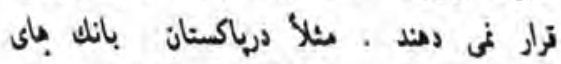

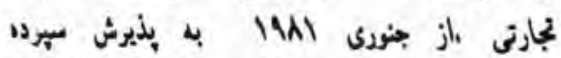

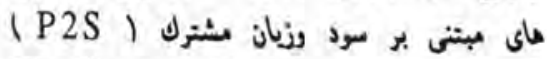

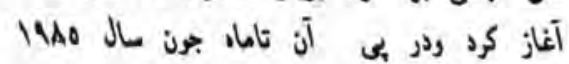

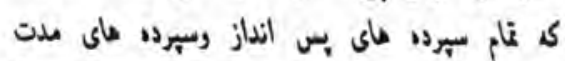

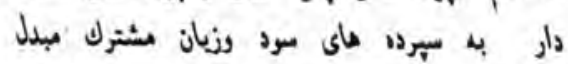

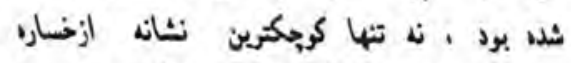

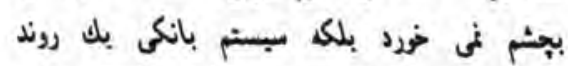

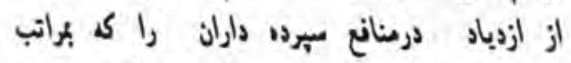

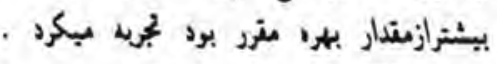

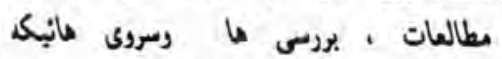

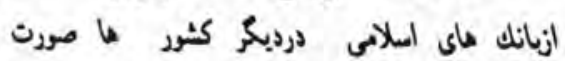

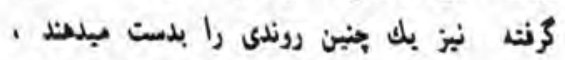

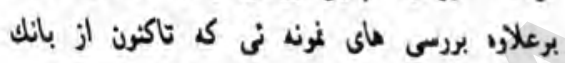

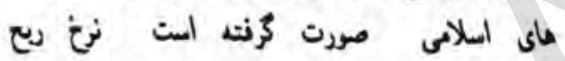

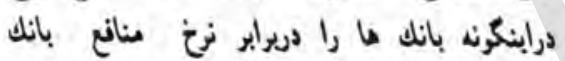

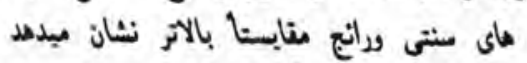

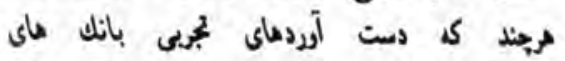

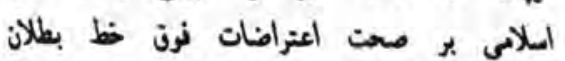

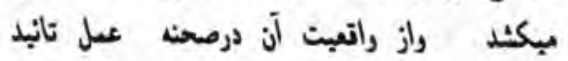

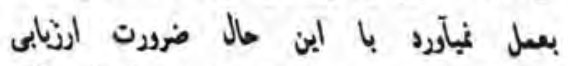

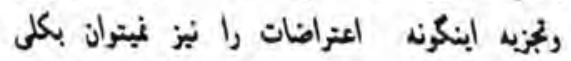

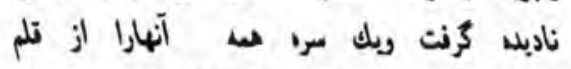

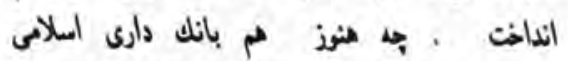

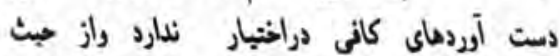

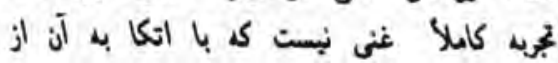

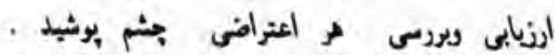

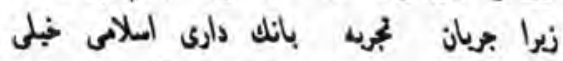

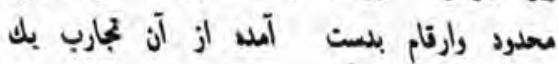

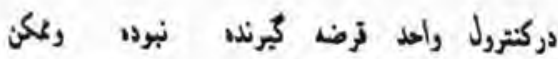

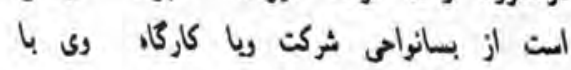

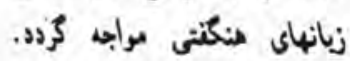

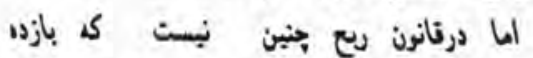

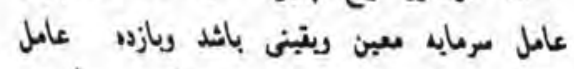

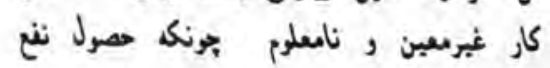

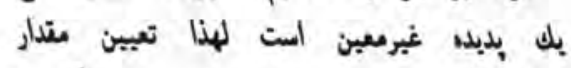

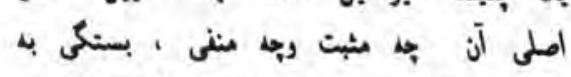

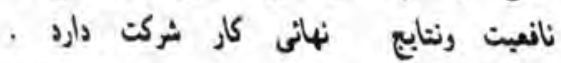

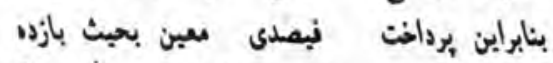

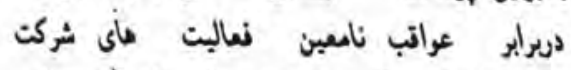

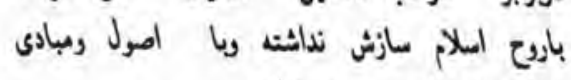

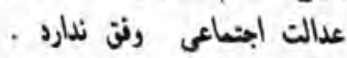

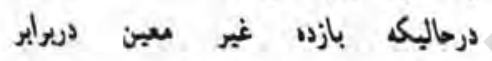

نعالينهاى توليدى غبر معين با دور

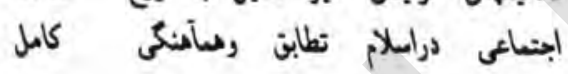
دارد

معذا الخر نزخ ربع در بك انتصاد اسلامى

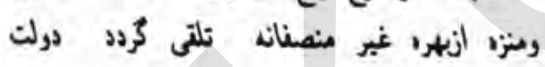

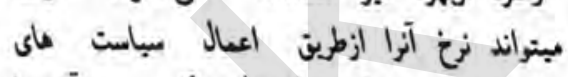

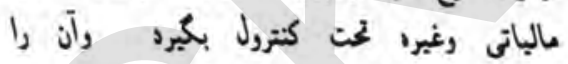

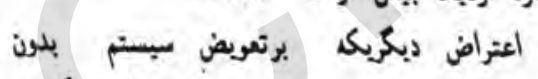

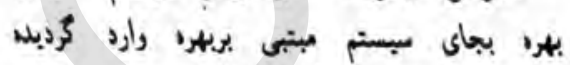

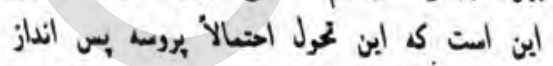

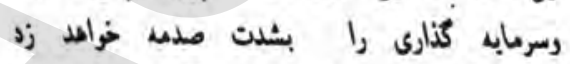

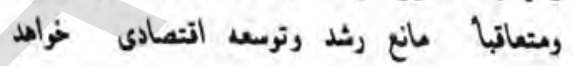

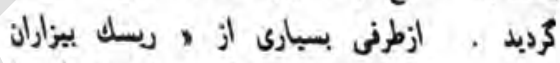

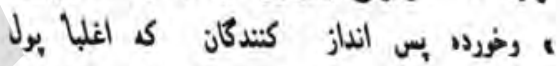

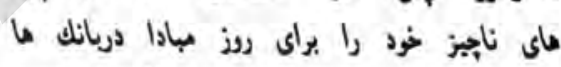

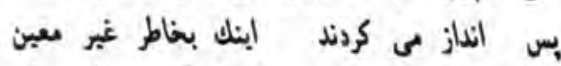

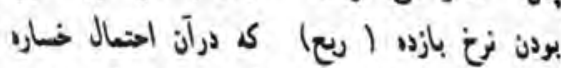

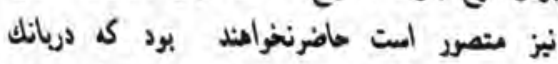

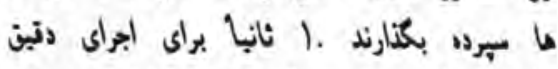
ركامل نظام سود وزيان مسترى لسبستم بلدون

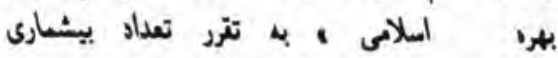

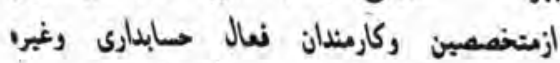

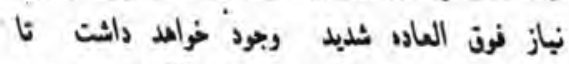

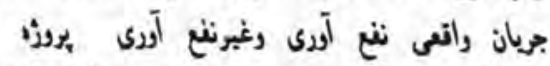

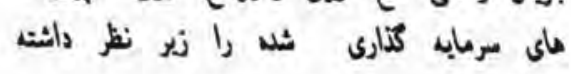

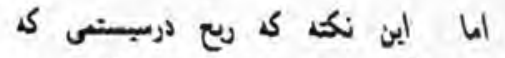

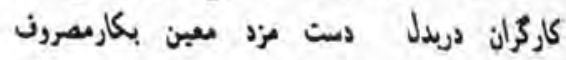

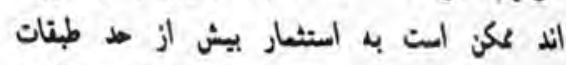

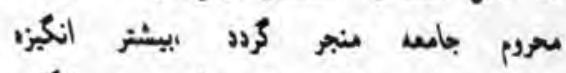

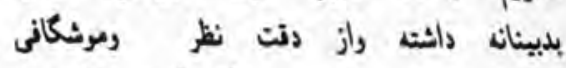

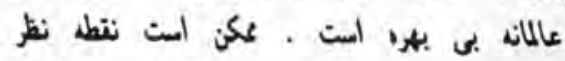

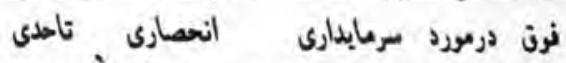

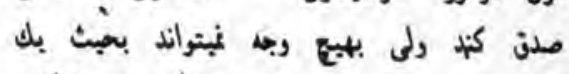

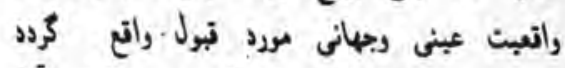

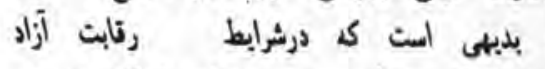

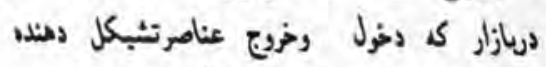

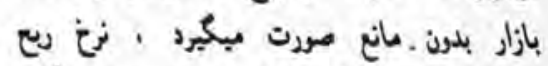

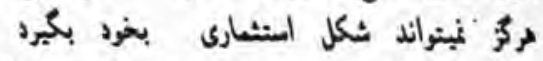

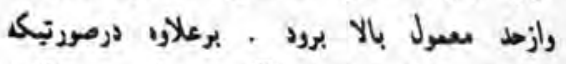

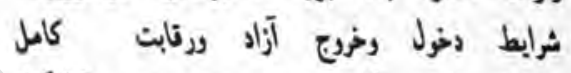

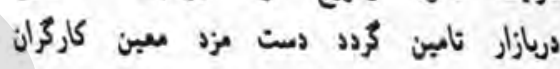

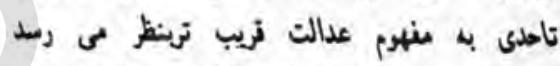

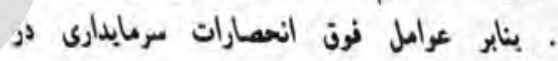

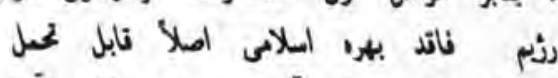

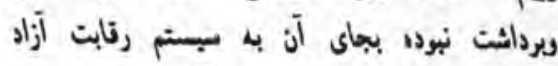

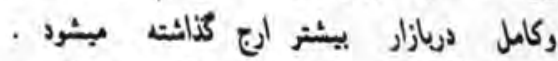

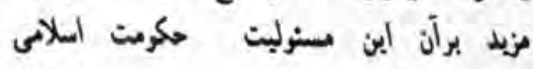

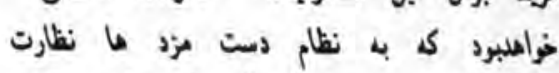

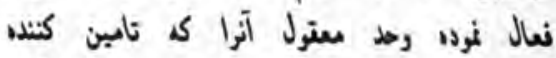

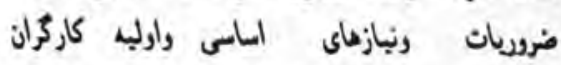

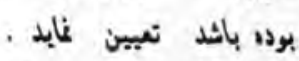
بكذار درينجا بـ فرن ما وتغارتهاى اساسى

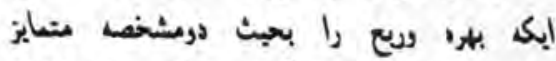

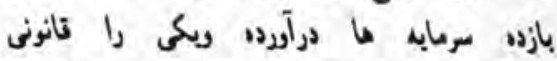

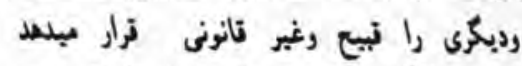

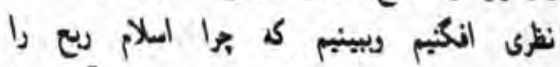

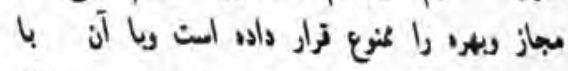

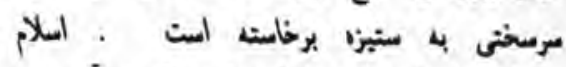
بخاطر ربا را حرام ترارداد، است ك درآن بازدها

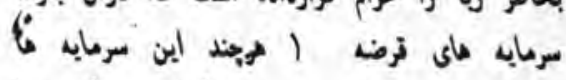

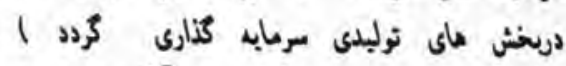

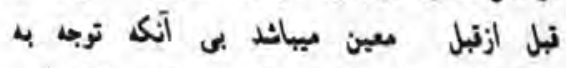

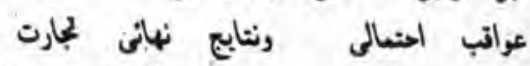

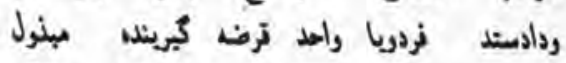

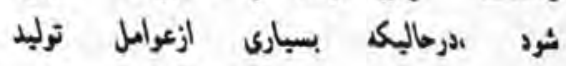




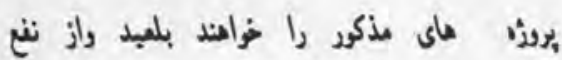

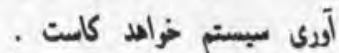

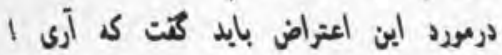

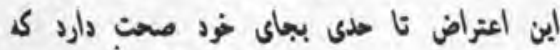

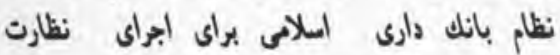

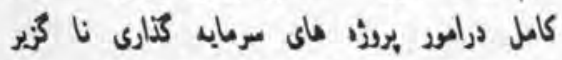

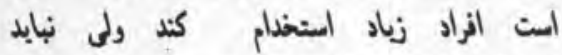

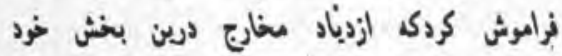

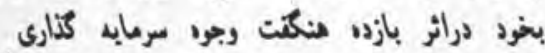

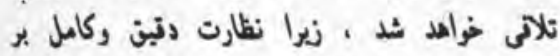

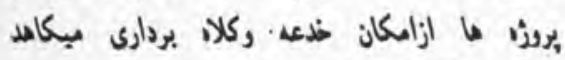

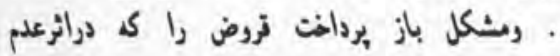
بازرس نظام در بانكدارى سنتى مبيث

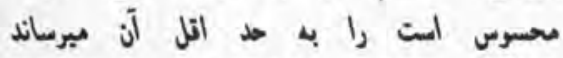

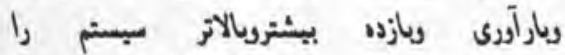

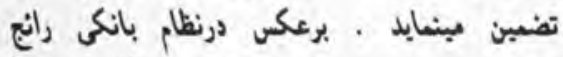

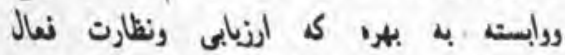

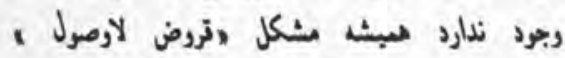

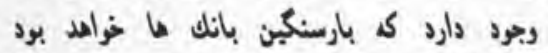

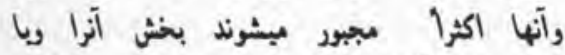

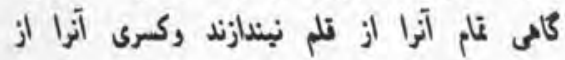

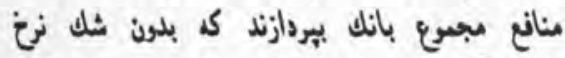

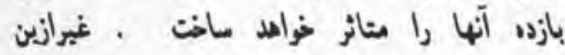

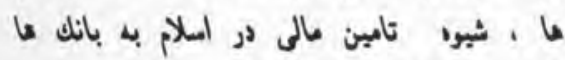

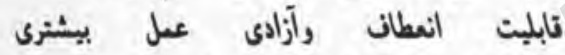

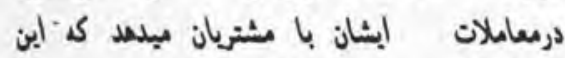

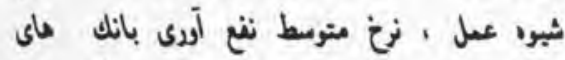

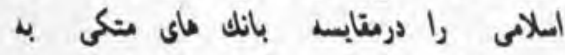

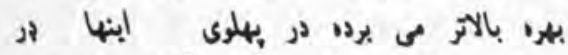

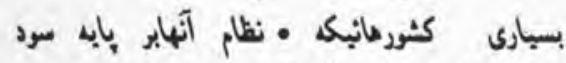

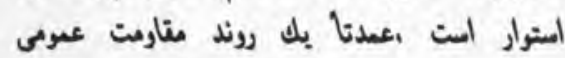

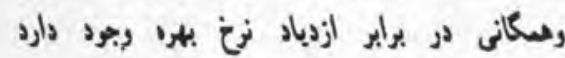

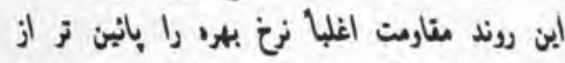

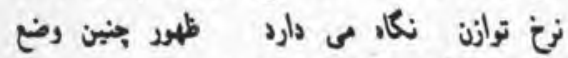

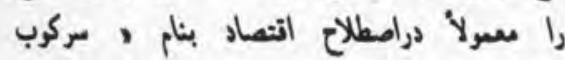

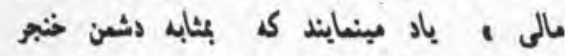

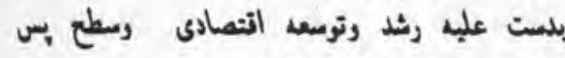
انثاز عبومى تلقى مكردد .

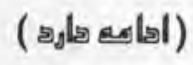

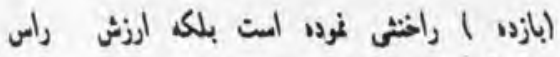

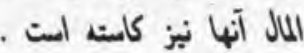

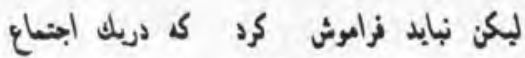

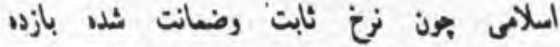

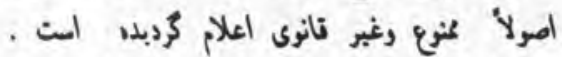

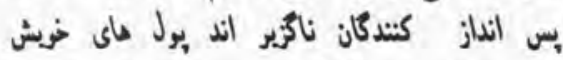

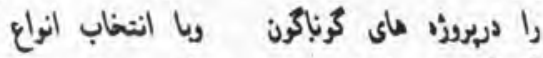

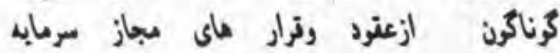

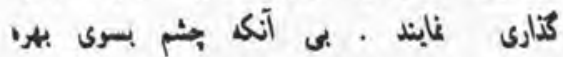

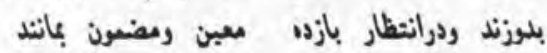

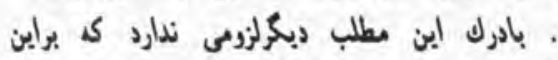

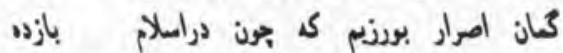

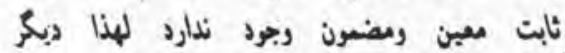

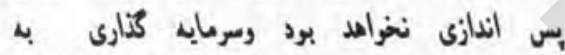

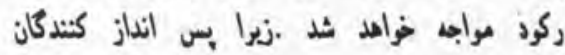

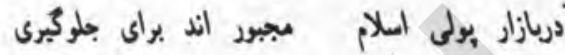

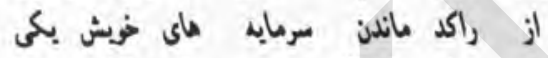

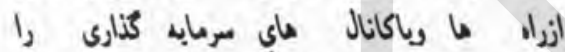

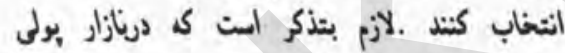

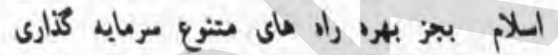

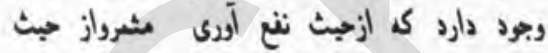

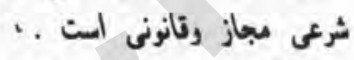

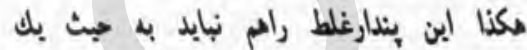

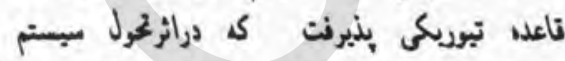

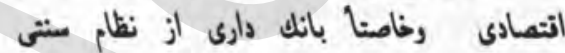

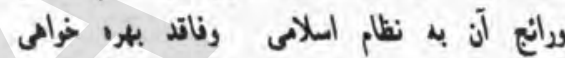

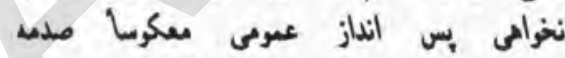

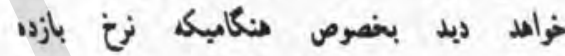

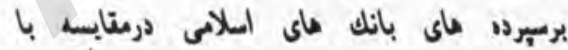

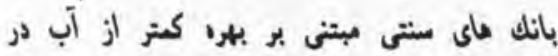
بكى از اعتراضات كي تبل مـ ذكرى ازآن

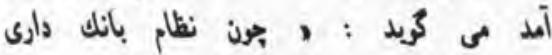

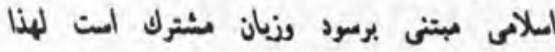

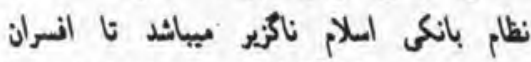

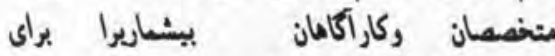

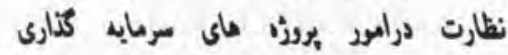

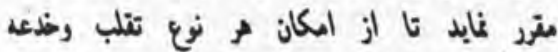

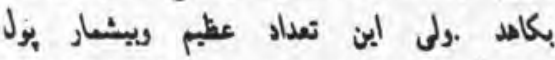

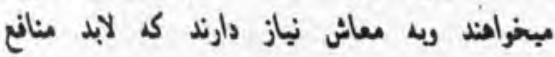

عرصه خبلى كوتا، از زمان را تشكيل مبدهد

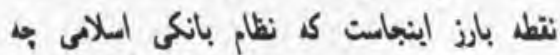

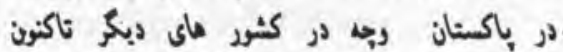

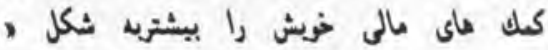

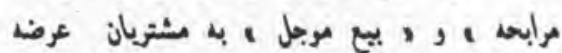

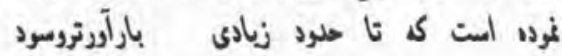

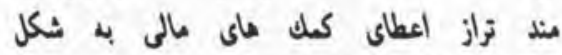

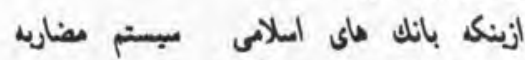
وثركت را كتر مورد آزمابش تراردادي اندائ

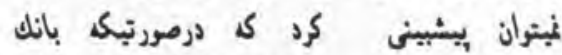

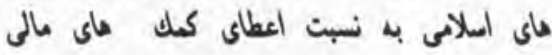

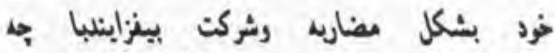

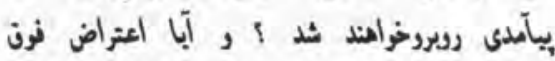

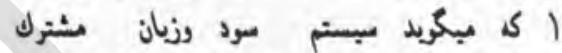

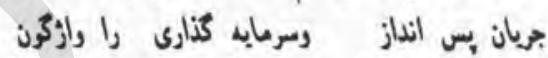

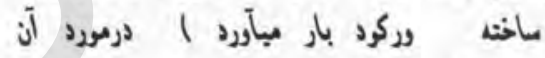

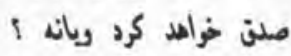

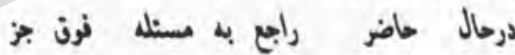

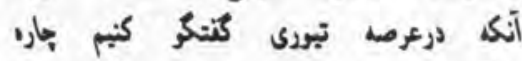

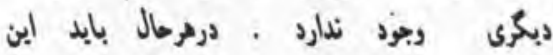

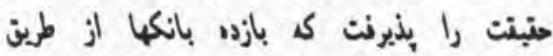

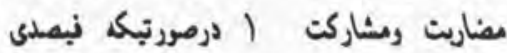

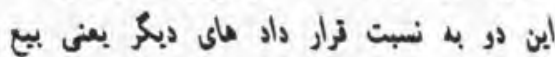

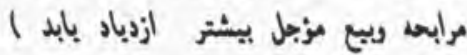

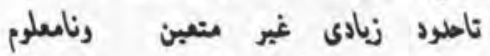

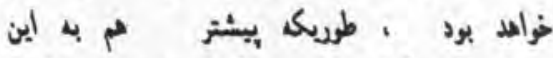

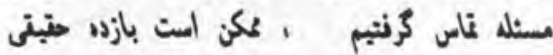

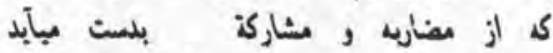

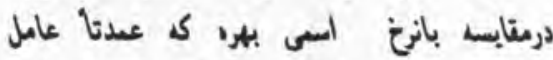

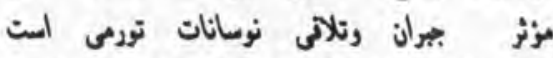

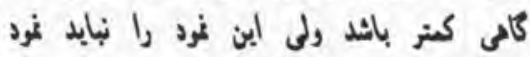

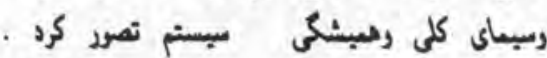

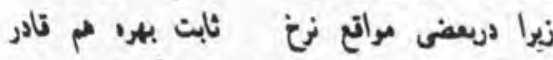

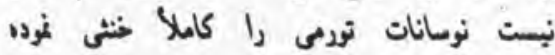

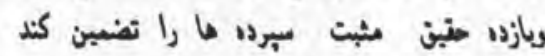

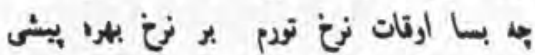

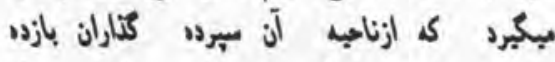

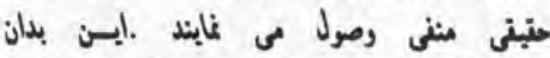

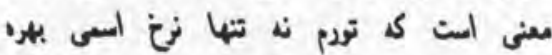



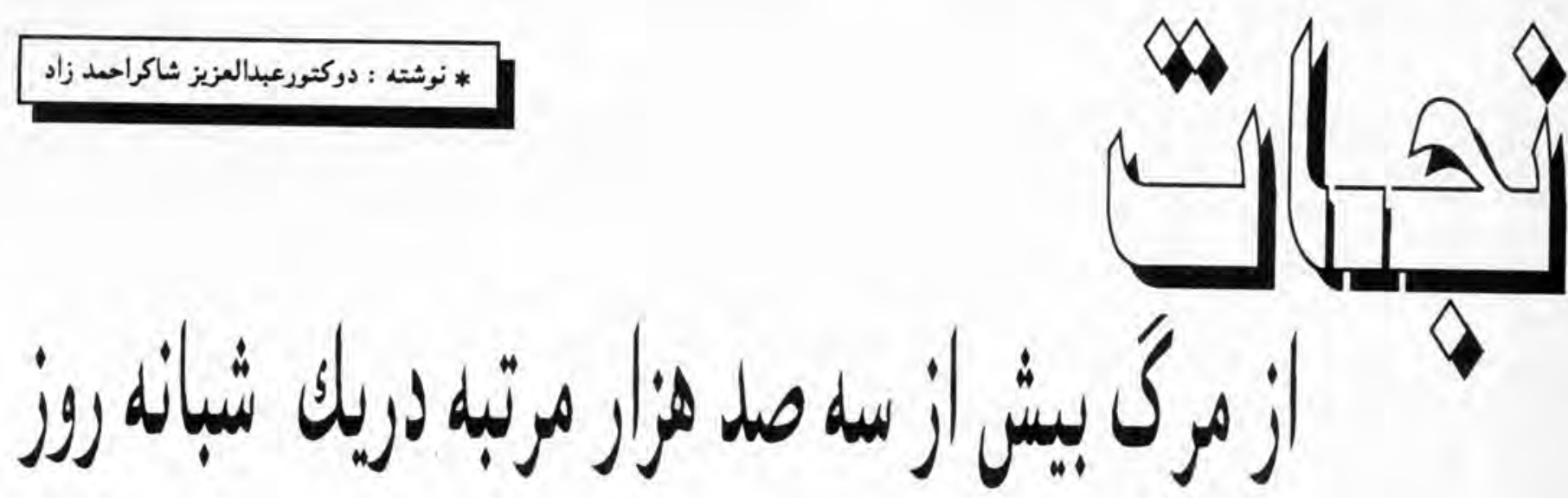

موتر وغبره وغير • ميباشد دروحالبكه مين

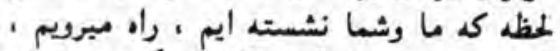

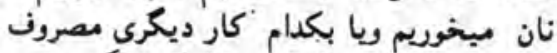

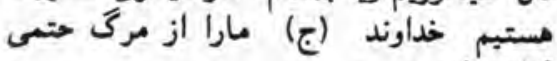

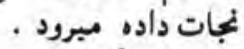
اخر نرضا شخص ماده مبرود درين آن غرت ميشود

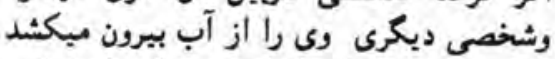

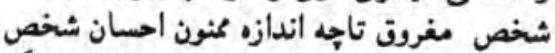

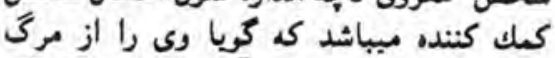

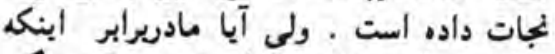

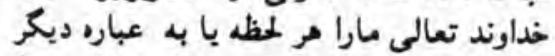

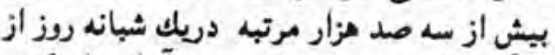

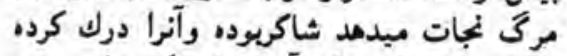

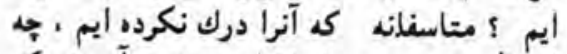

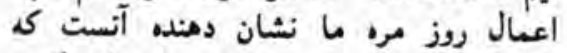

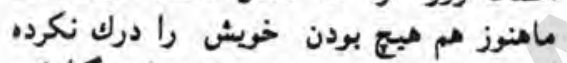

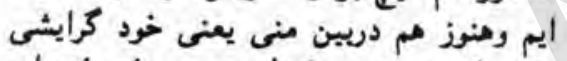

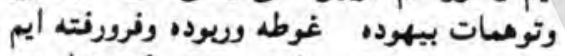
يس برماست تادر برابر هرمرتبه كه خداوند

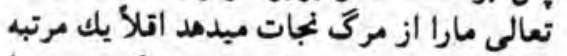

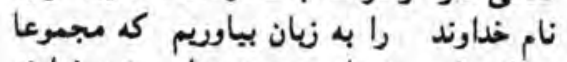

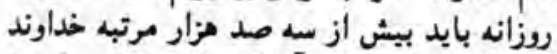

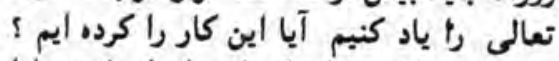

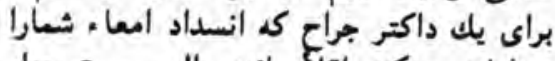

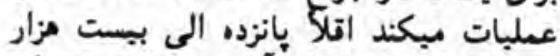

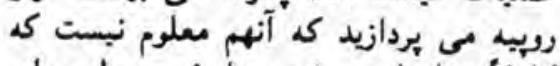

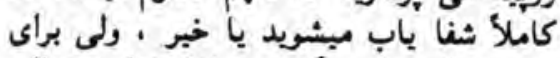

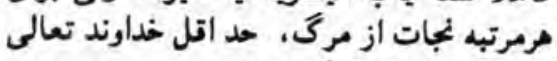

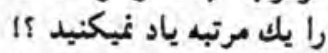

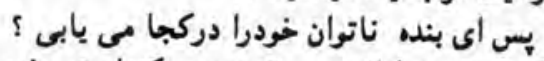

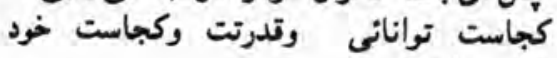

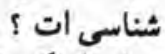
براى أينك خوانت إنده كرامى مدلل شده باشد كل

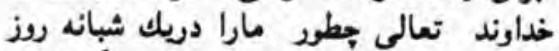

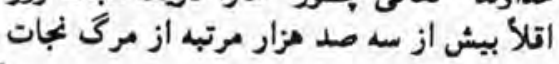

مى فرمايند ( من عرف نفسه نقد عرف ريه )

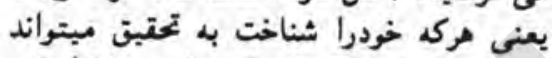

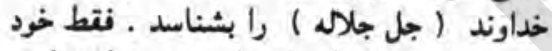

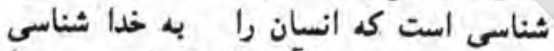

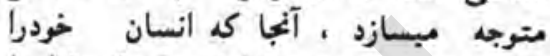
شناخت بدون شك وى خداوند جل جلالم ) رامى شناسلد بلدون هر تدر كم بطرن خود شناسى بيش مير هيريم

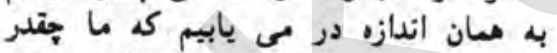

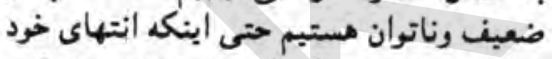

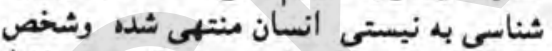

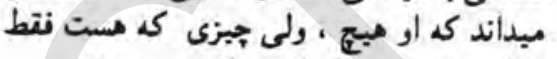

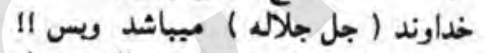

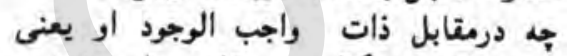

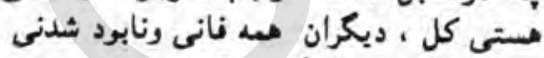

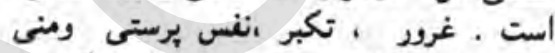

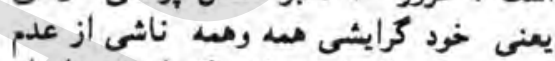

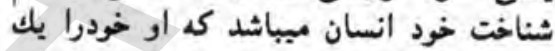

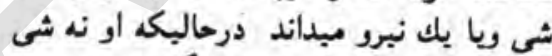

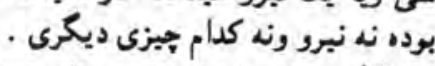

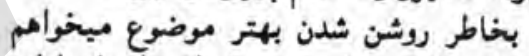
نتط مثالى را ازعجز وناتوانى انسان ارايـ

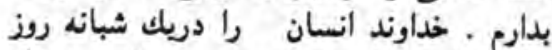

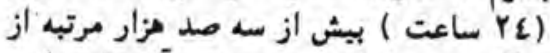

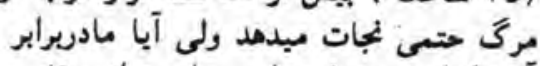

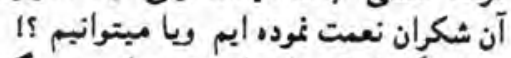

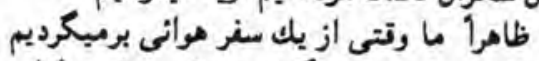

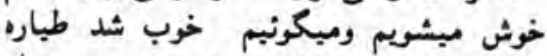

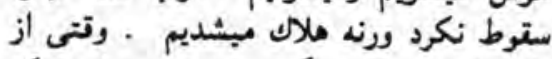

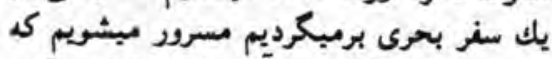

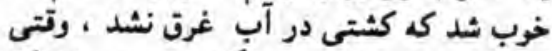

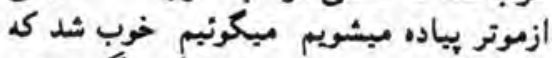

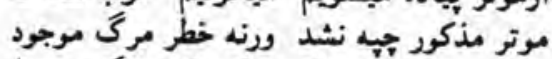

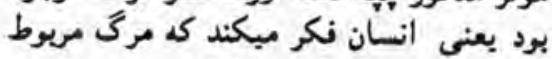

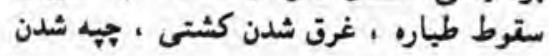

\section{سن عرلف نغسه نتح عرنه ربه}

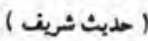
خداوند تدير آن ذاتيست يكتا ولاشريك وبى العديث

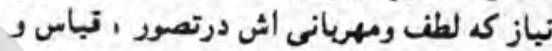

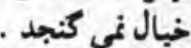

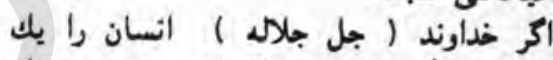

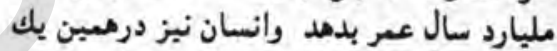

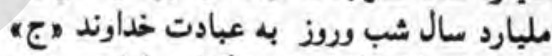

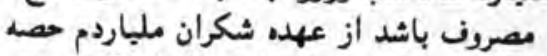

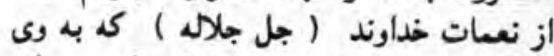

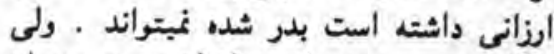

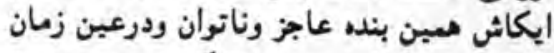

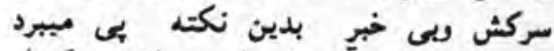

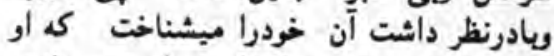

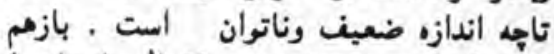

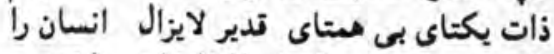

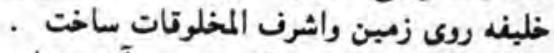

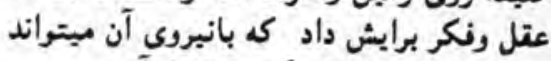

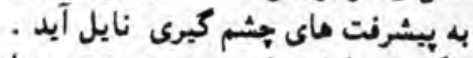

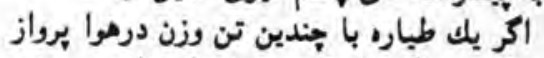

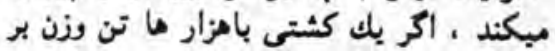

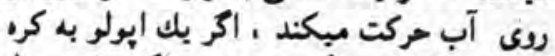

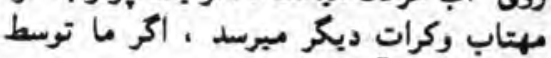

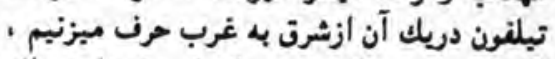

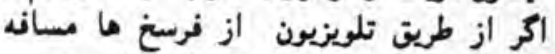

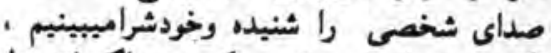

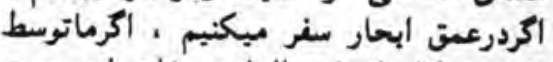

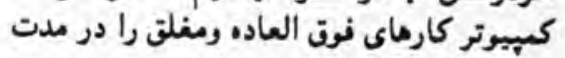

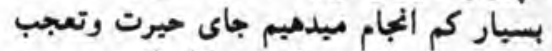

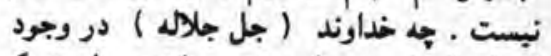

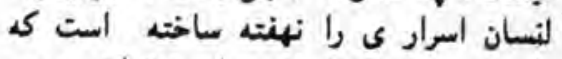

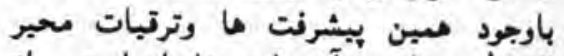

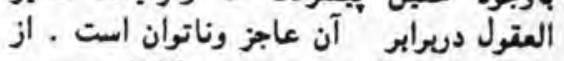

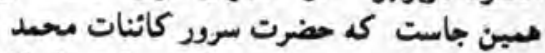
مصطفى صلى الله عليه وسلم بيامبر اسلام 


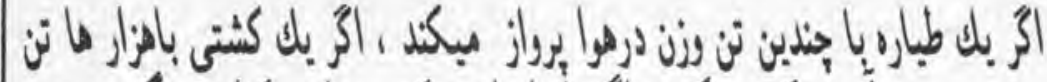

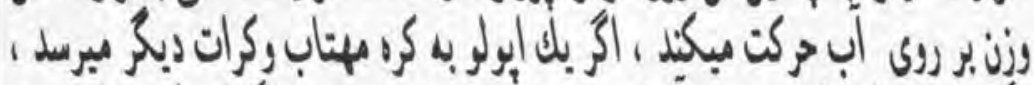

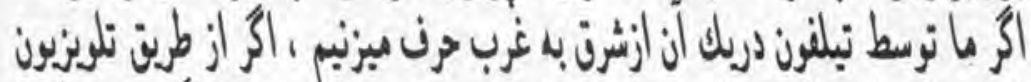

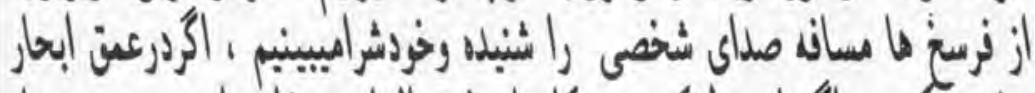

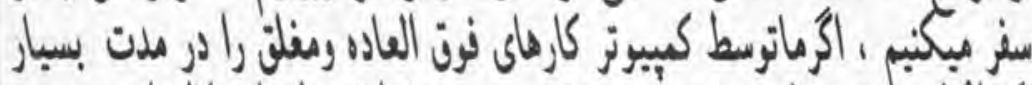

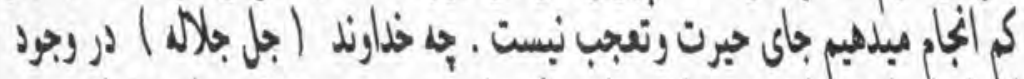

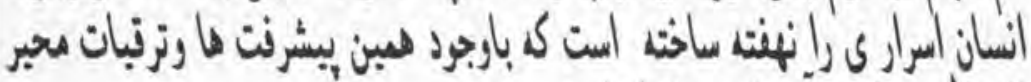
العتولدريرابر أن عاجز وناتوان اسن.

كه ادرار را از كرده ما به مثانه انتقال (ers

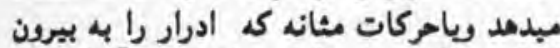

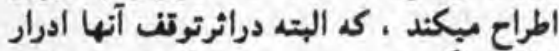

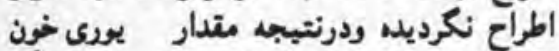

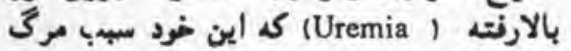
شده ميتواند . الأن علاوتا تعداد زياد ميكانيزم ماي ديكرى

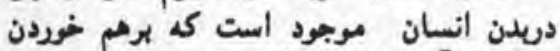

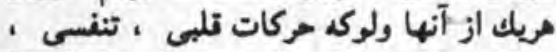

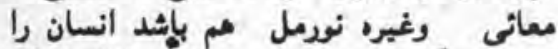

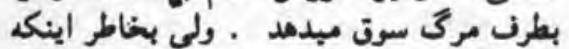

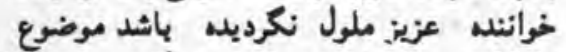

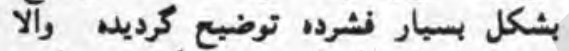

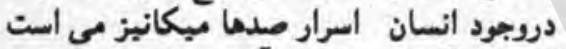

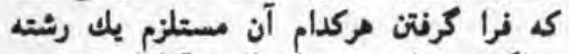

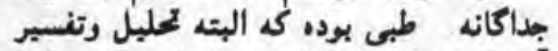

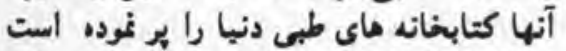

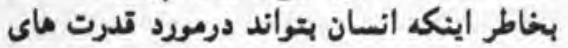

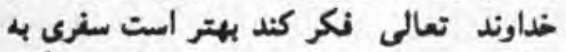

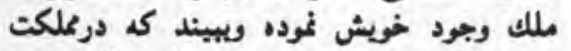

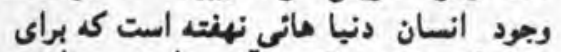

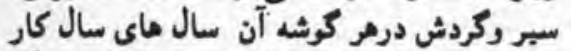

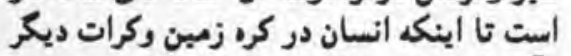

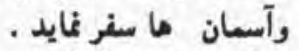
اي خدا (ج) كبا توان بجان آورد شكران نعمت مايت رائا و بيفشاى به لطف خويش كه جز توديكر رحمان نبست

\section{وهر الله التوفيت}

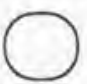

ذفير بوده كه دوياره به شهيت تبديل نشده

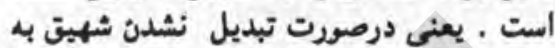

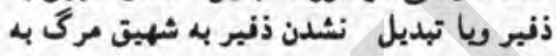

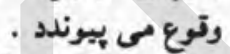

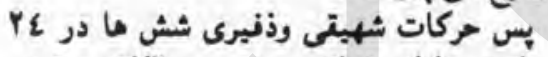

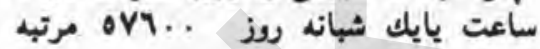

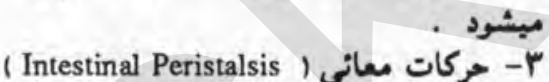

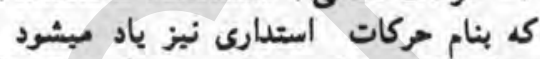

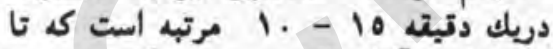

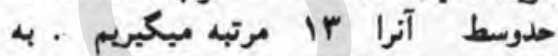

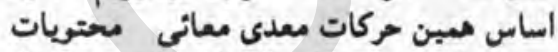

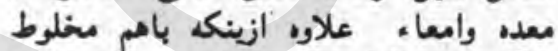

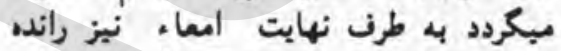

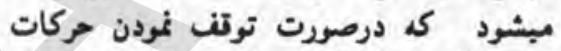

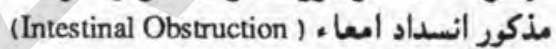
يوجود ميايد ـ انسداد امعاء ـ يك بك واتعه عاجل

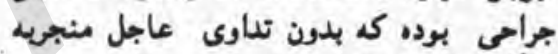

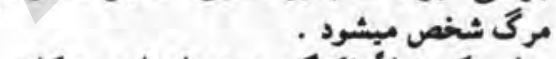
طوريكه تبلا زكركرديد تعداد اين حركات

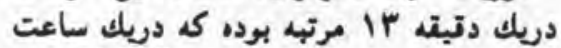

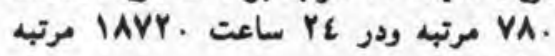

حالاكه ماصرف حركات تلب ، حركات مركات تنفسى

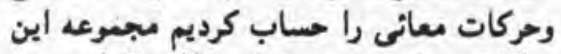

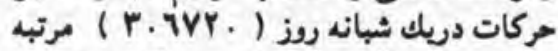

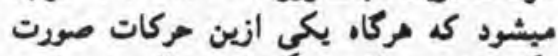

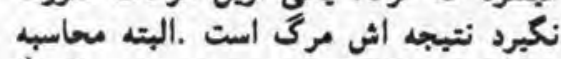

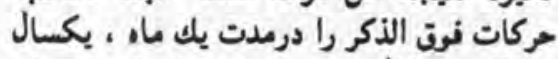

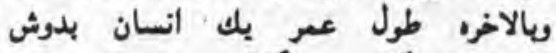

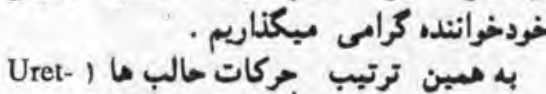

مبدمد ذيلا ميهردازيم بـ محاسبه كه البته اين

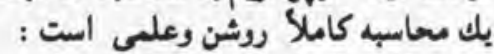

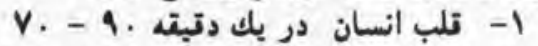

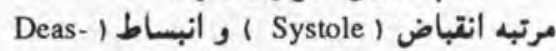
( tole

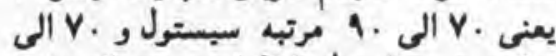

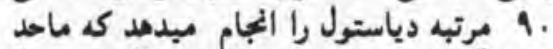

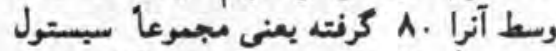

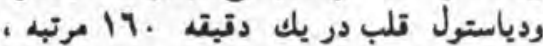

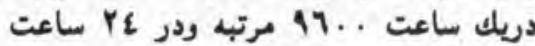

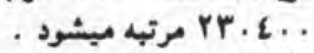

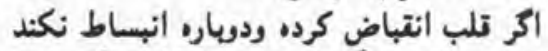

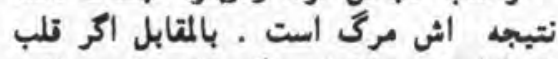

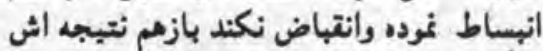

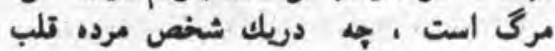

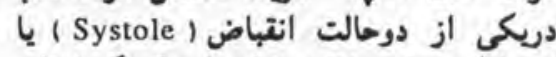

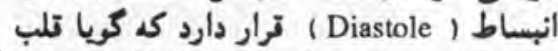

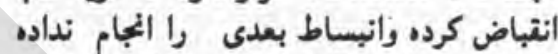

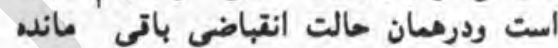

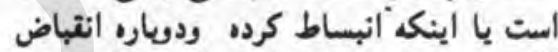

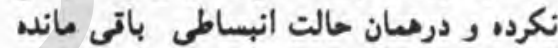

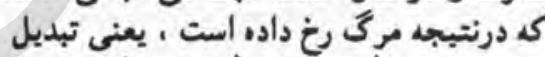
نشدن سيستول به دياستول ويا برغيا برعكس تبديل

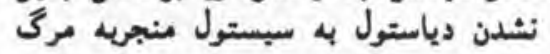

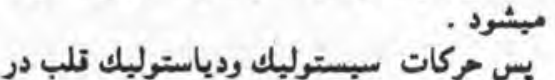

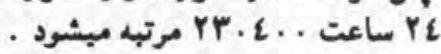

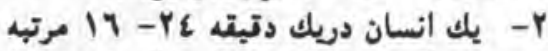

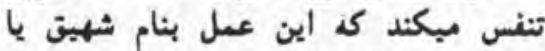
(Instperation)

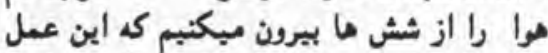

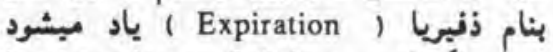

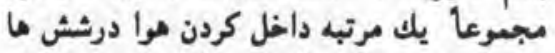

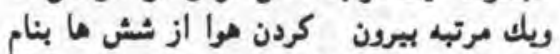

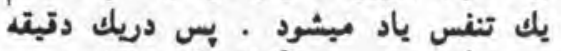
بيست تنفس صورت كرفته كه شامل بئ بيست

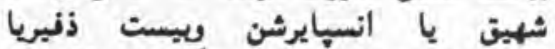

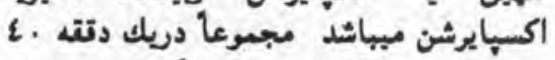

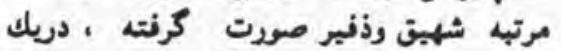

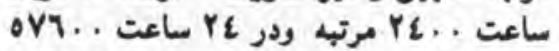

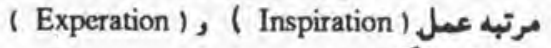
صورت ميكيرد . مرل هركا، موا داخل شش ماثبرد ماثده واز آن بآن بيرون

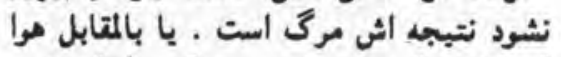

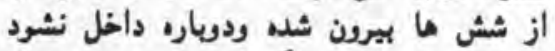

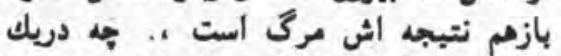

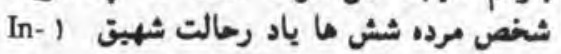
( speration تبديل نشده است ويا دروالت (Experation) 
كرديد . فيودالها ومكمرانان مهلى كل زوان

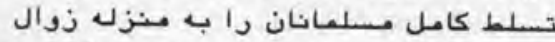

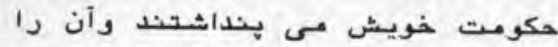

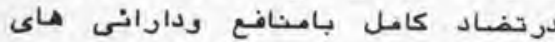

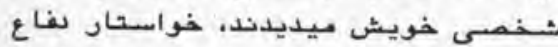

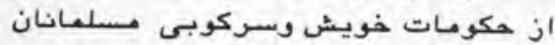

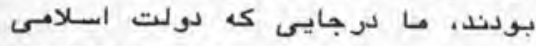

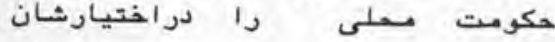
فرارميداد ، سمت از نبرد كشيده وباج مى برداختند

ب هين ترتيب روهانيون اليان ومداهب مختلف ، ظظهود وانتشار اسلام

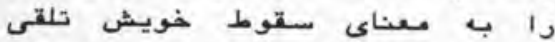

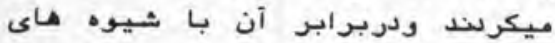

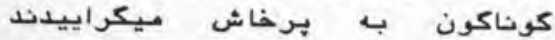

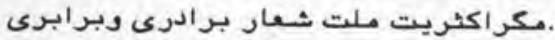

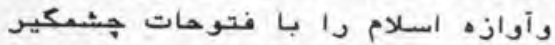

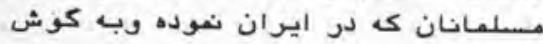
ايـان رسيده بو د، درحالت شـلك ويقين

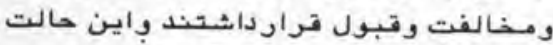

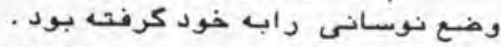

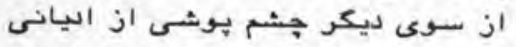

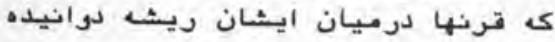
كارساده نى نبود . همبنان بلديرش

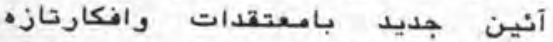

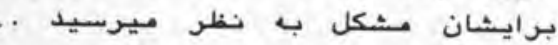
ازجهتى هم وضع اجتماعى مردم كي

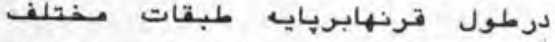

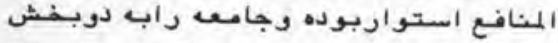

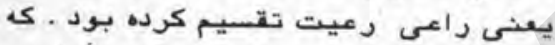

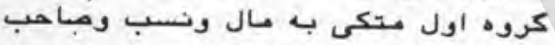

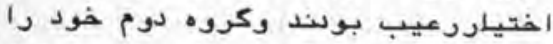

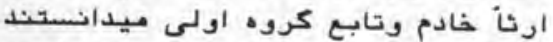

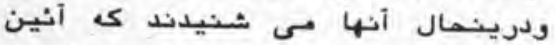

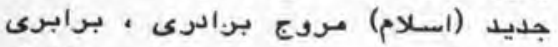

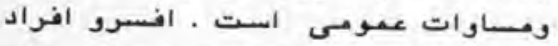

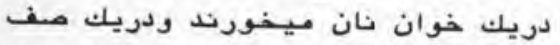

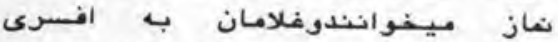

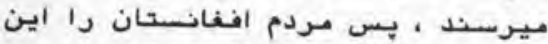

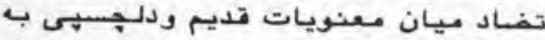

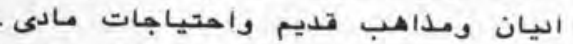

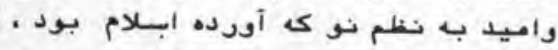

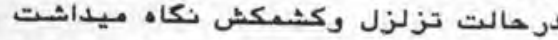

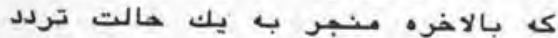

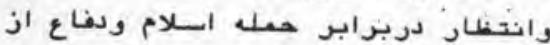

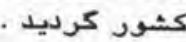

در جنين حالتى بين مقدس اسبلام با

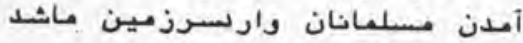

افنانستان أن ريز از ابلدكا نرمنكُ نبز خبلى

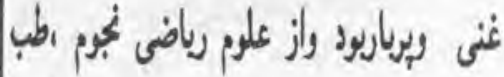

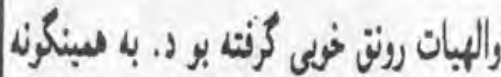

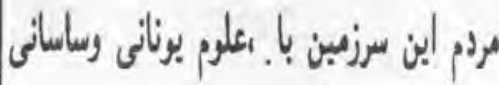

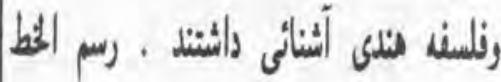

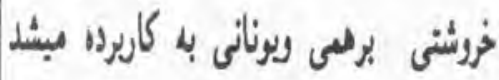

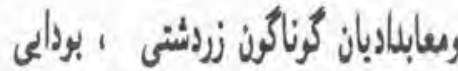

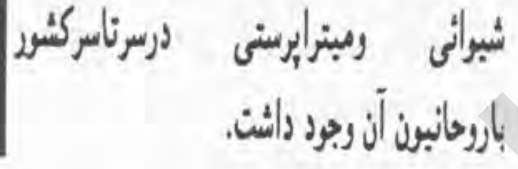

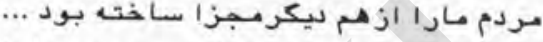

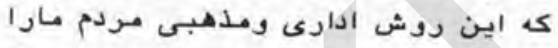

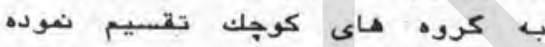

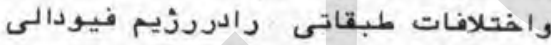

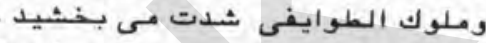

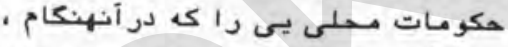

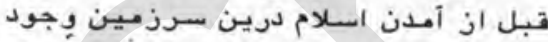
داشت وتعداد شـان بـ هفده هكومت ميرسيده ، جغرافيه نويسان عرب جنين :دكر دأده اند :

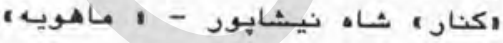

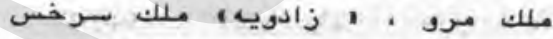

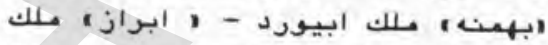

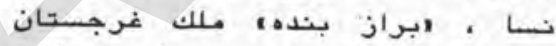

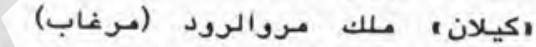

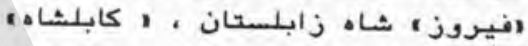

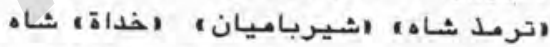

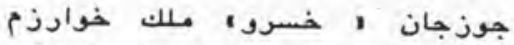

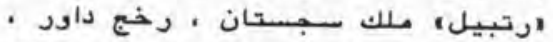

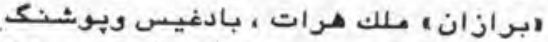

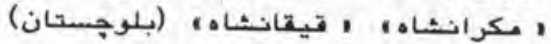

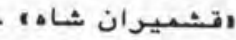

درحاليك هكوان ماهـات بزركتر جون

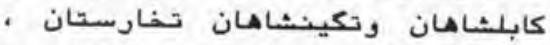

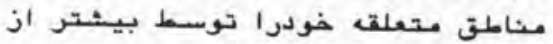

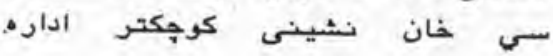
مينهورند بـ هرحال ، شعار برادرى وبرابرى مارى

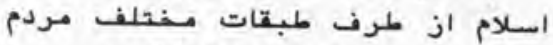
افغانستان بار اكنشهاى كوناكون روبرد

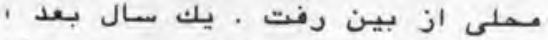
قارن هراتى ، در نيشايور بـ بـ بركز

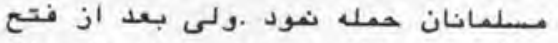

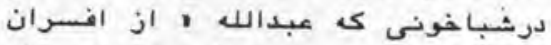

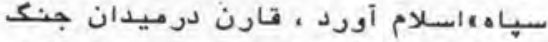
كشت شبد · بدين مورت آورد دوره اول

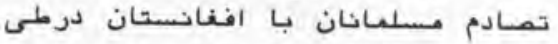

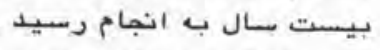

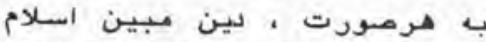

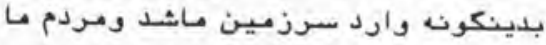
بدان كرويدند كه أهدن اين بين جدانيا

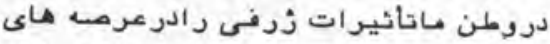

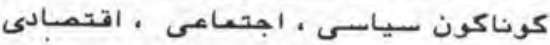

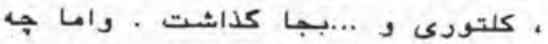

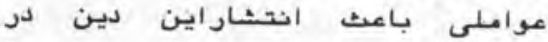
هنكاميك تمادم وتماس مسلمانان

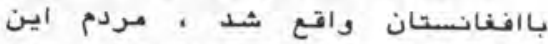

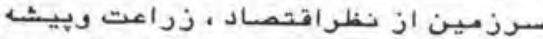
درى نسبت بـ فاتحان مسلعان (عربهان

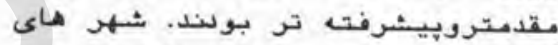

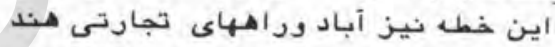

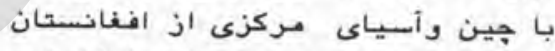

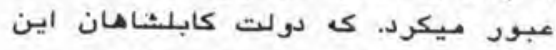

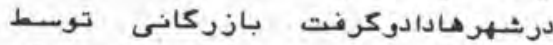

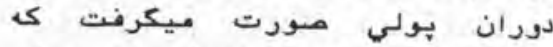

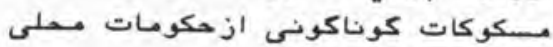

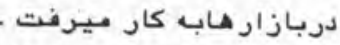

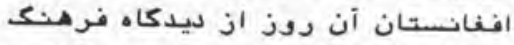

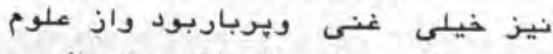

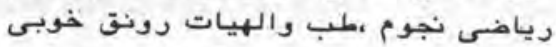

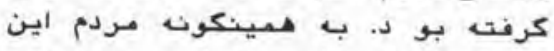

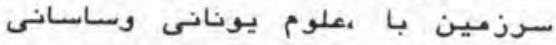

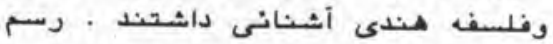

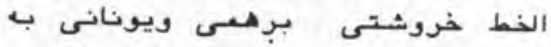

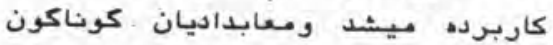

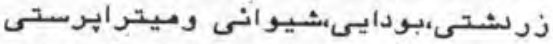
درسرتاسـركشور بارودانيون آن وجود

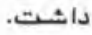
ادبيات ملاهبى موجود بوده رتعدد

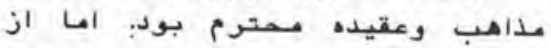

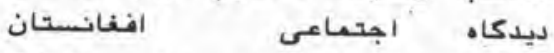

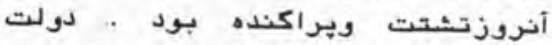

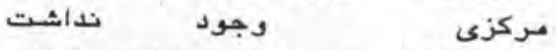

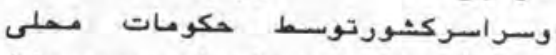

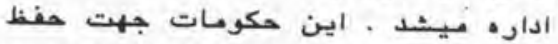

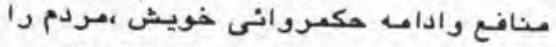

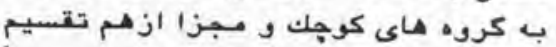

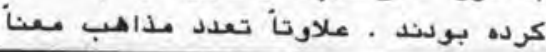



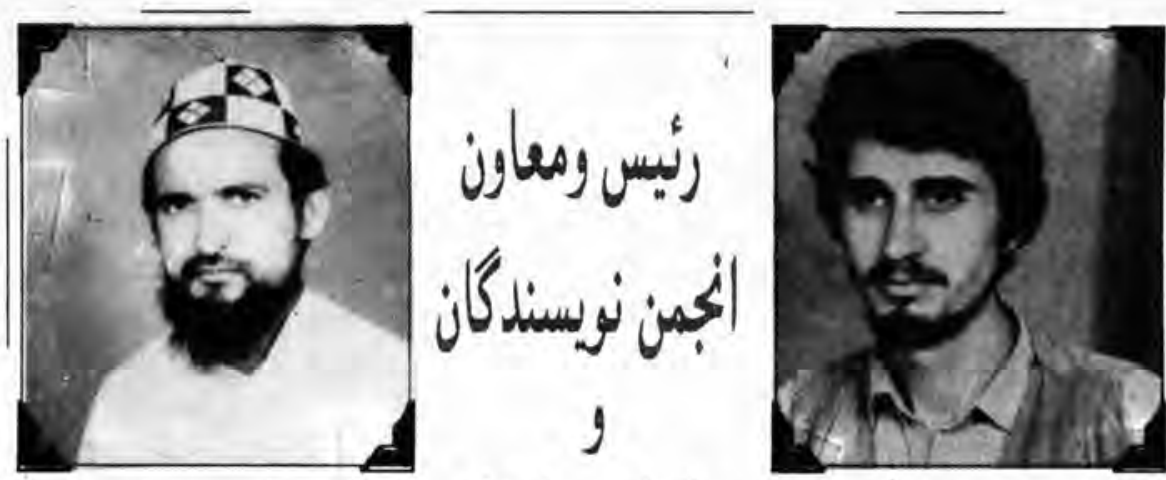

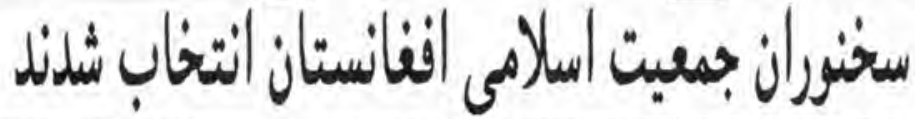

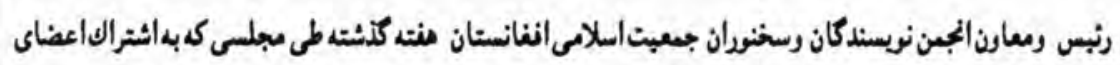

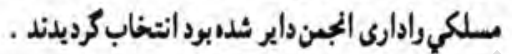

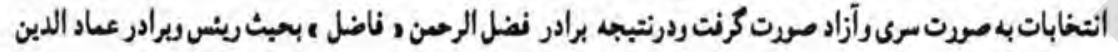

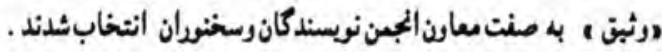

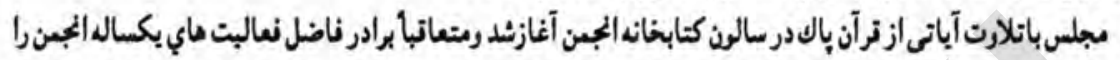

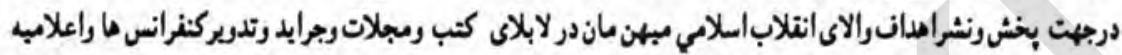

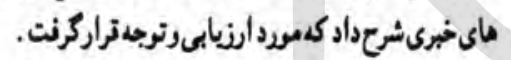

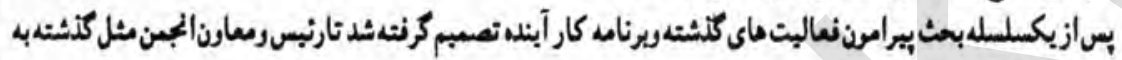

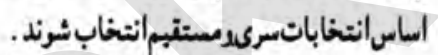

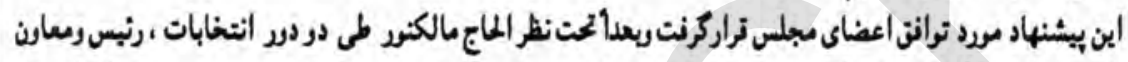

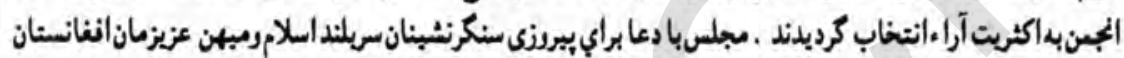

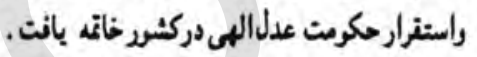

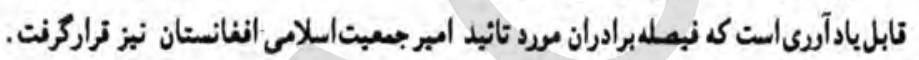

ومعانى جديد وارد زبان ماكرديد · دوح

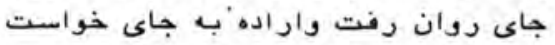

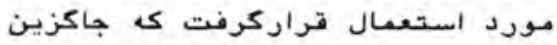

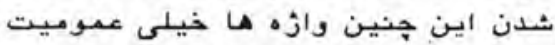

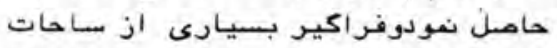

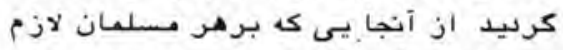

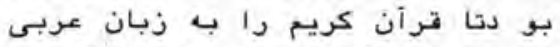
بخواند ، اين زبان درميان نوكرائن

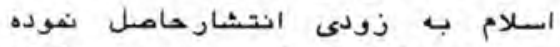

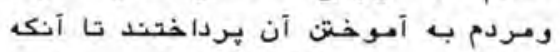
بـ زودى منحيث زبان لينى ،علمى لونى وسياسس درين كوثـ أسيـاقد فراز آورد

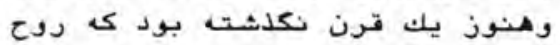

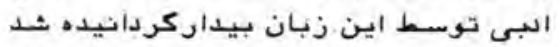

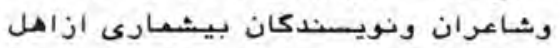
اين خطل قلم بـ لمست كثيدند وكر انمابـ

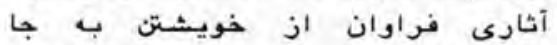
(ادامه دارد)
نميتوان درهيـه دين ديكر برائش همتا

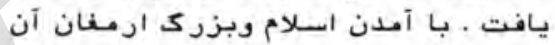

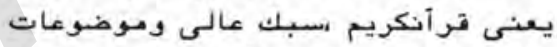

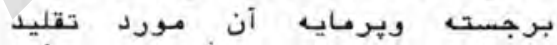
قراركرفت . سـبك نوشـتار وكفتارتغييز

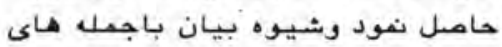
سليس ودوان ،متانت وابهت وتوضيع ونون بان

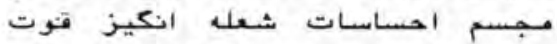
كرفت وبارزتر كرديد . يكتعدأد مفاهيم

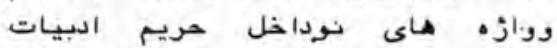

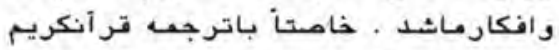
البيات مارنك خو وجلوه تاز ه كرفت كي

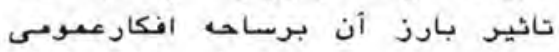

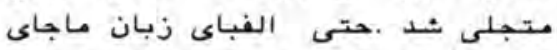

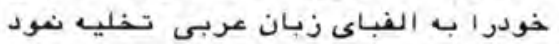

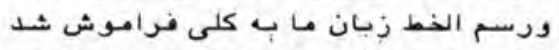

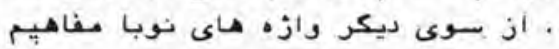

برعلاوه عواملى كي برشعرليم نيروى وني

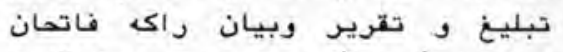

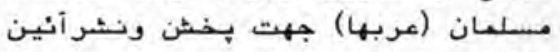

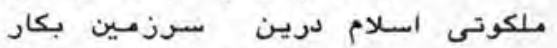

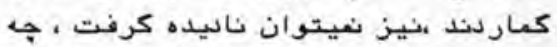

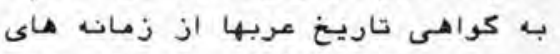

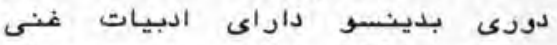
ونيروى شكفت انكيز تقرير وريبان

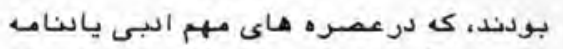

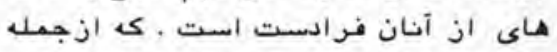

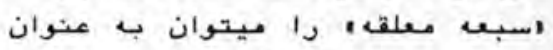

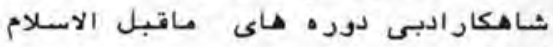

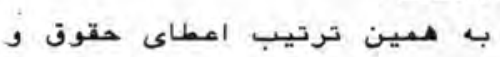

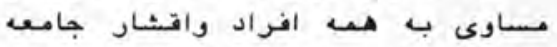

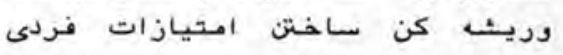
وجمعى ، تفرق هاى محيطى ، لسمانى

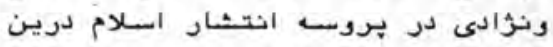

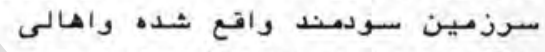

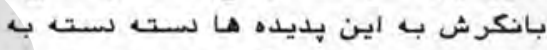

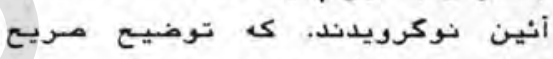

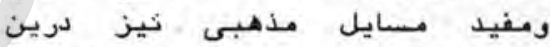

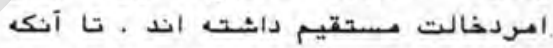

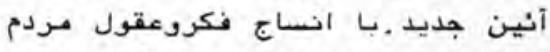

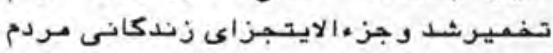

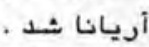

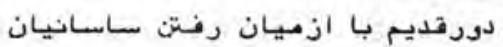
انجام يافت ودور جديدى بامكمروانى بانى

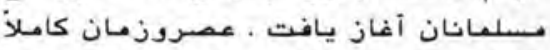

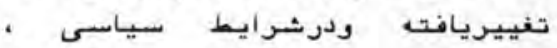

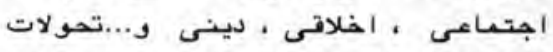

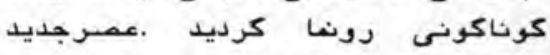

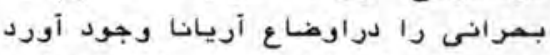

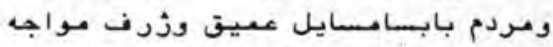

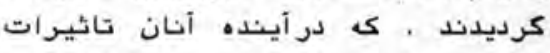

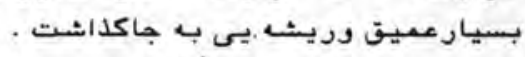

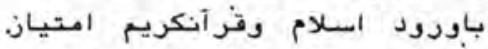

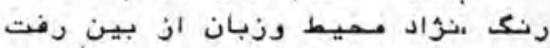

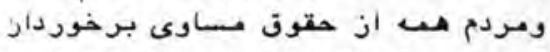

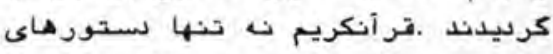

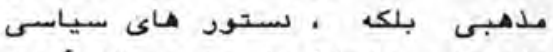

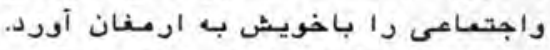

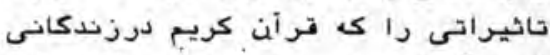

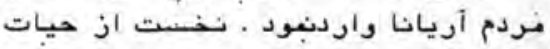

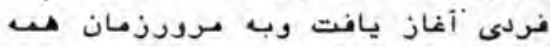

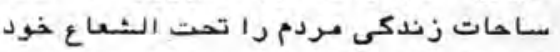

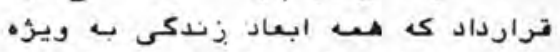

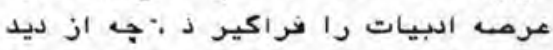

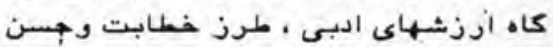

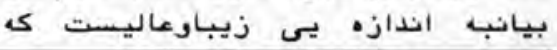




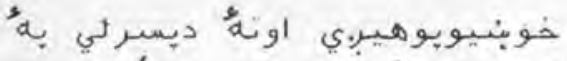

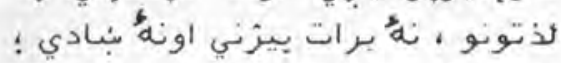

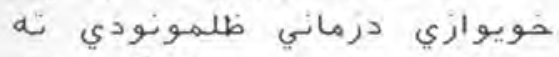
مجبوركري،هيه دريه دروكرئي أوحيل

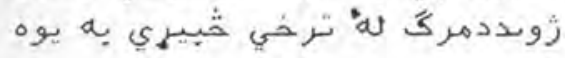

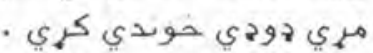

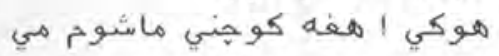

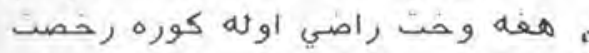

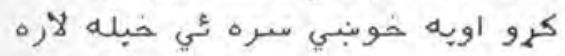

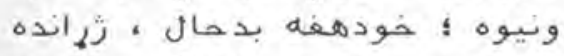

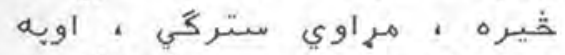

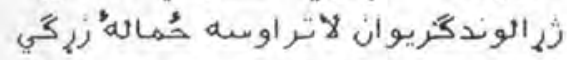

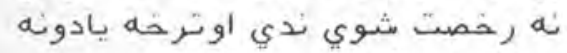

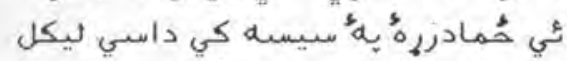

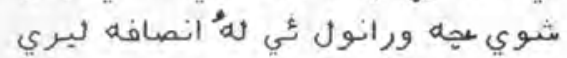
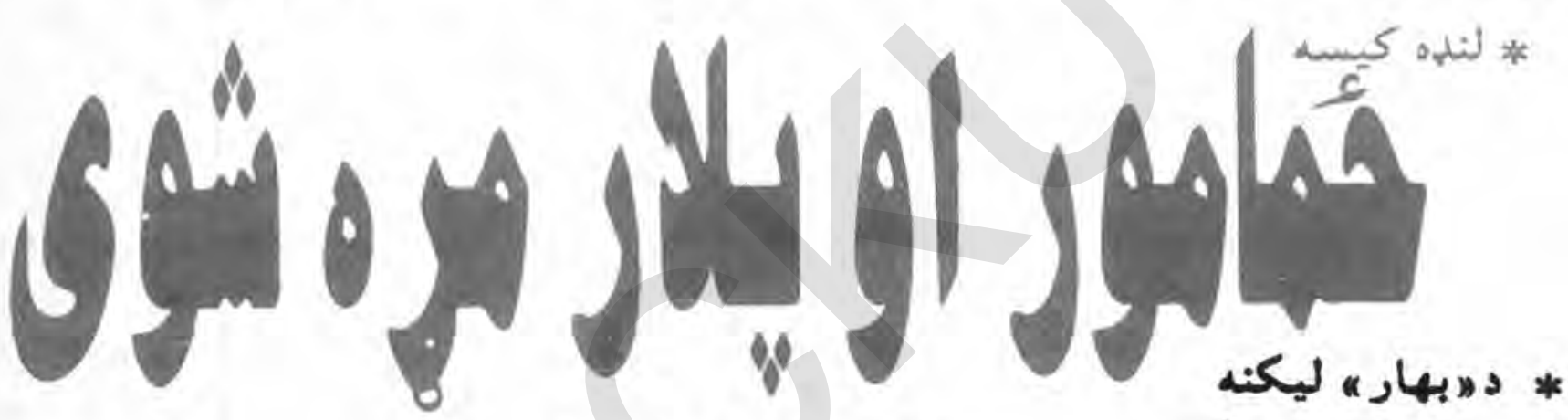

تواي مادي مسئولينو،

-

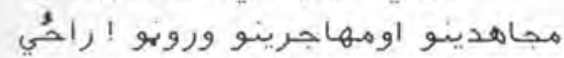

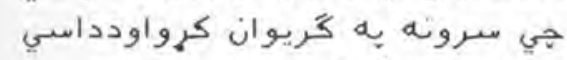
كوجيانوله" تريخ زوندانه عبرانه

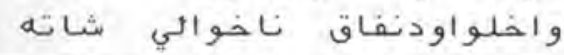

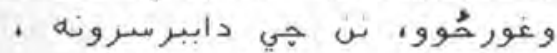

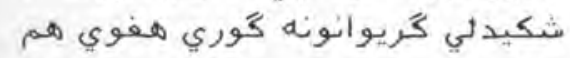

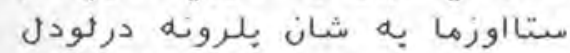

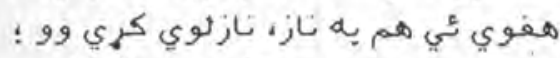

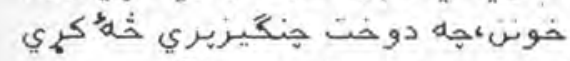

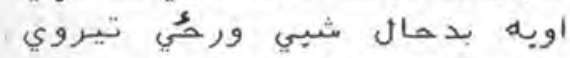

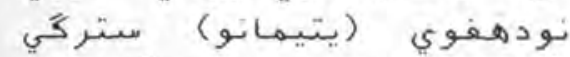

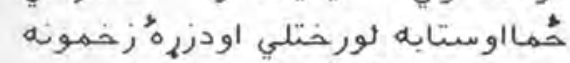

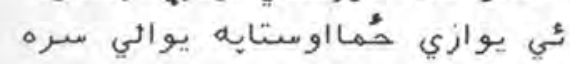

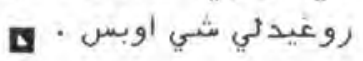

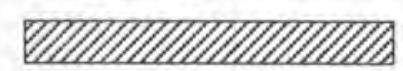

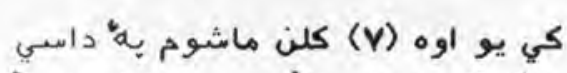

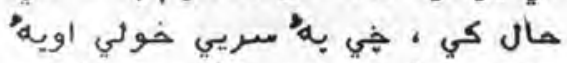

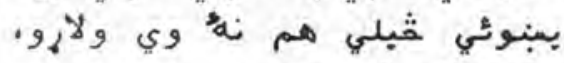
اوهمداناره تكراروي

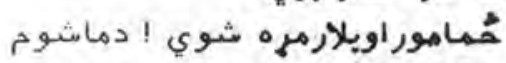

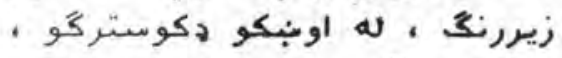

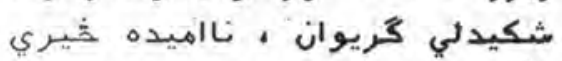

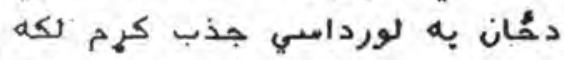
مقناطيس ميله جي دانهي داوسبني كوحني

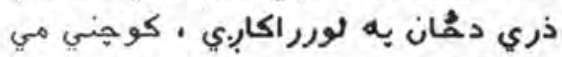

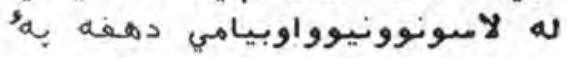

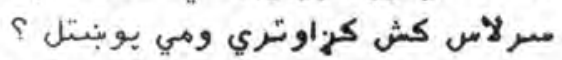

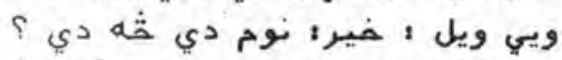

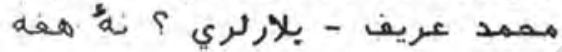

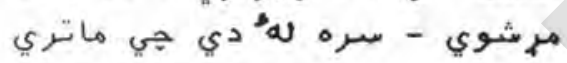

D دجمعي ورحُ اود وري مياشتي ونهان

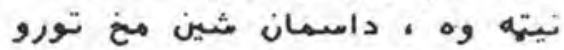

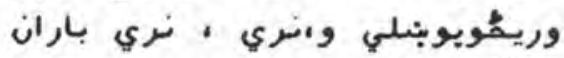

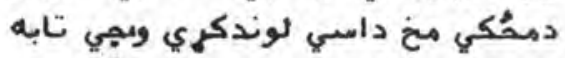

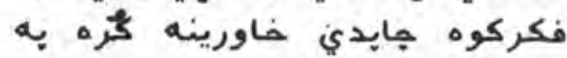

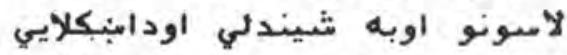
ورببنلي ده ، له نري باران مسره يومُاي الهي

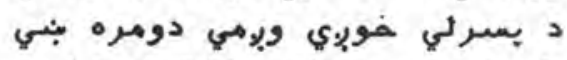

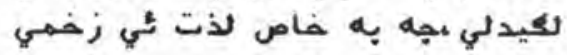

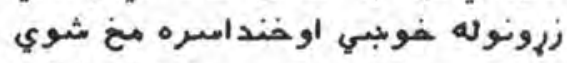

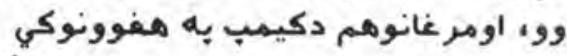

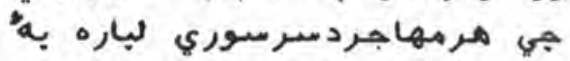

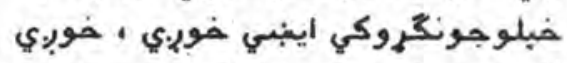

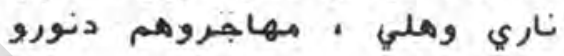

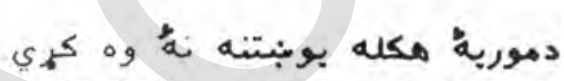

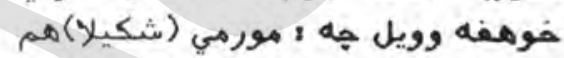

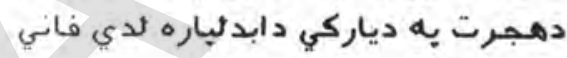

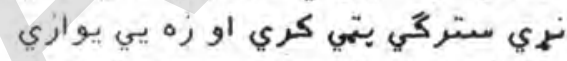

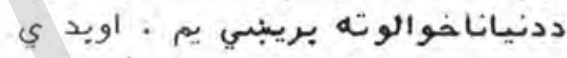

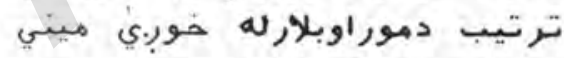

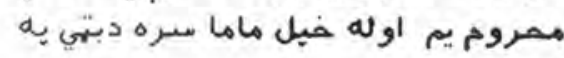

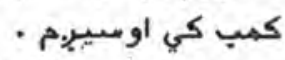

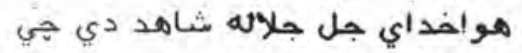

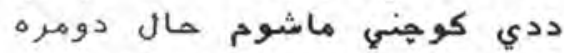

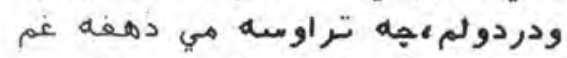

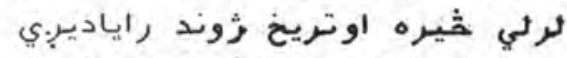

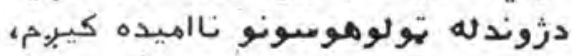

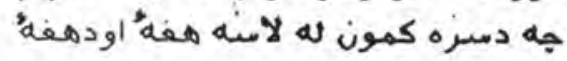

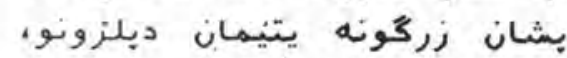

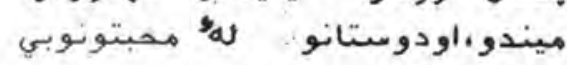

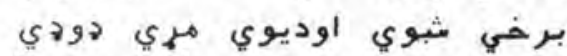

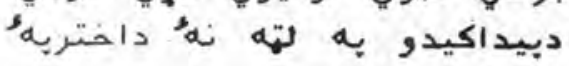

خلكويه شان دنوي كال يه راتلوسره

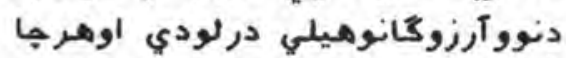

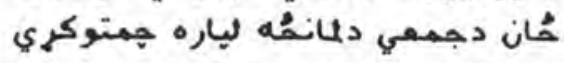

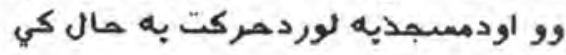
- نبكاريدل زه هم ددي حلي ملكري وم .هاهم

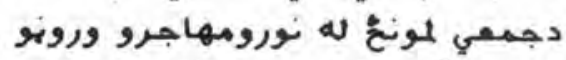

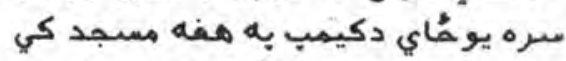

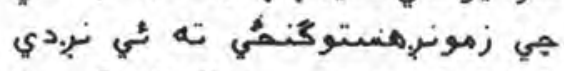

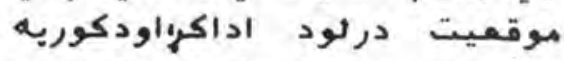

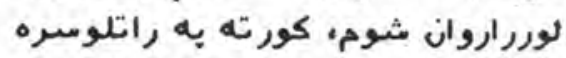

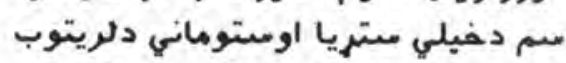
لياره بيده شبوم ، مترقي مي لانه دي دي دئي

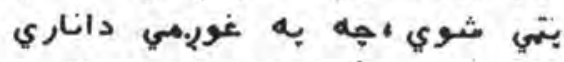

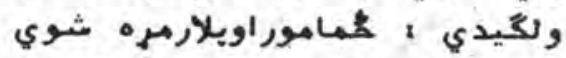

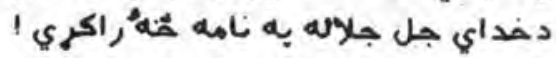
دي تكراري نازو ويبر اومويلي ته ثئي

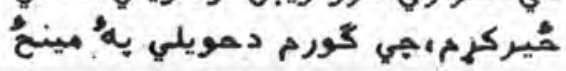


جنگ روس ها از ينجا عبورنمايند .

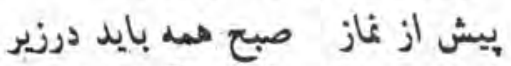
كوتلى كه روسها ميآيند ، آماده باشند

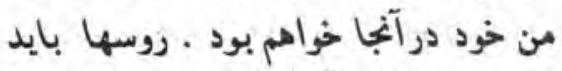

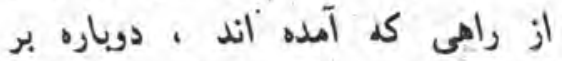
كردانيده شوند . شرم است كه روسها ازئ

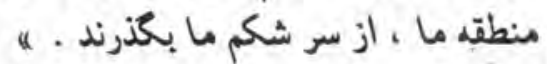

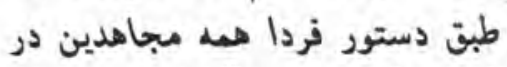

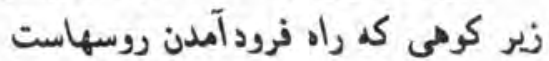

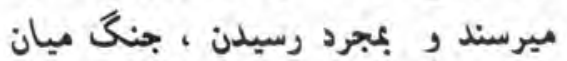

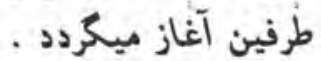
جنگ از صبح تاعصر ادامه ميابد

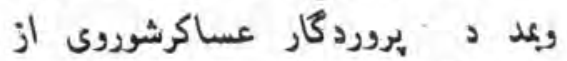
كوهى كه بائين آهده بودند

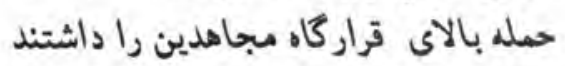

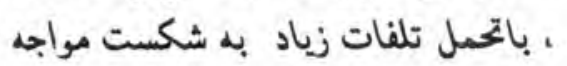
ميشوند ودو بارب بر ميخردند ، بائ راين

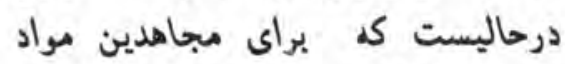
خوراكه كافى وجو دندارد، وسلاح هاي

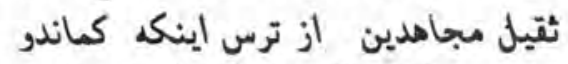

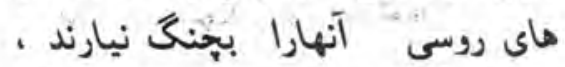

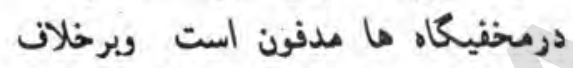

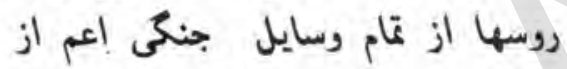

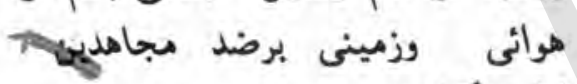
كارميكرنتند .

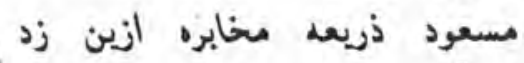

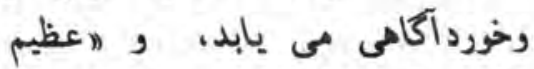
خانه را بخاطر دستور سختى كه بالأى مأى

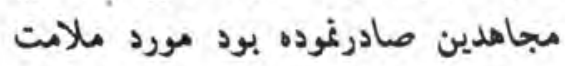

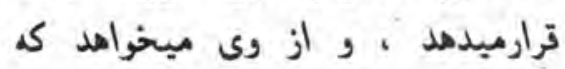
دوباره نبايد درين شرايط دشوار سخت وديد

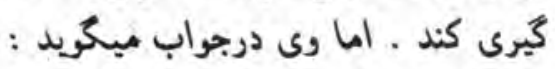

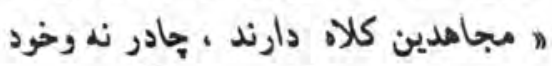
بال

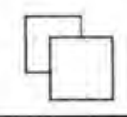

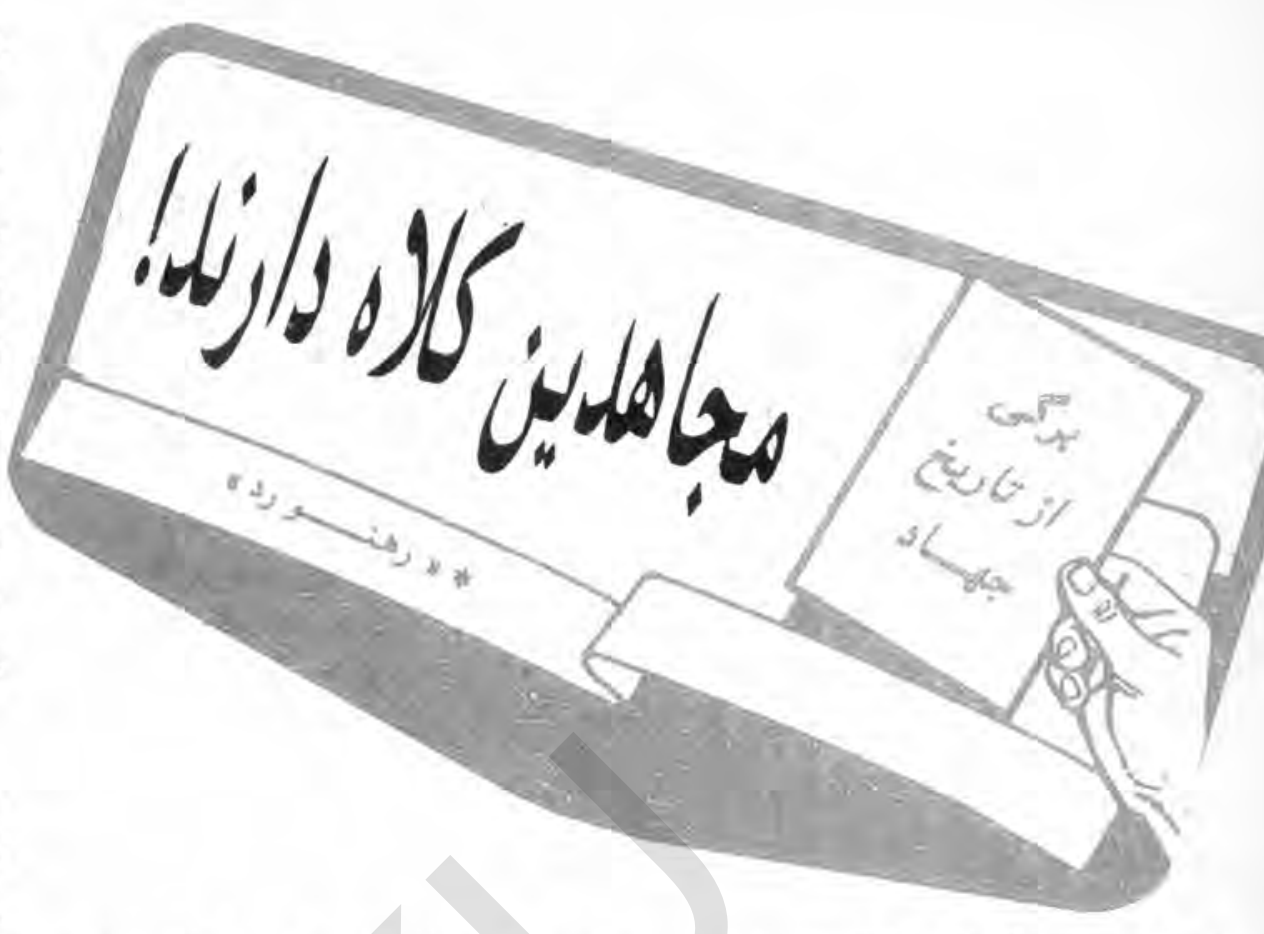

موصون جند بارزخم برداشته وهم

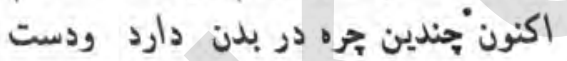

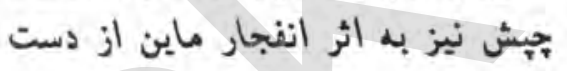
رفته است . يكى از شهكاربهاى " اعظيم خان"

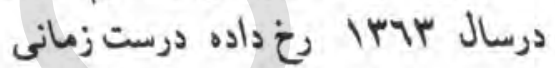
كه روسها از بالاترين نيروى خود هليه

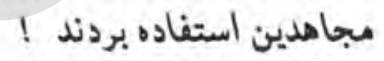
شب هنكام يك قطعه از نيروهاى خاص شوروى درارتفاعات مشرف برقراركاه حصارك جابجا ميكردد واز فشنكهاى شان برميآيد كه صبح فردا قراركاه حصارك كه قومندانى آنراي"

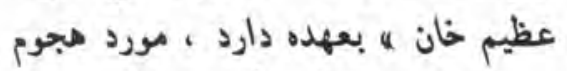

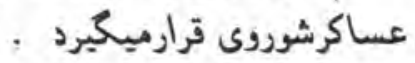

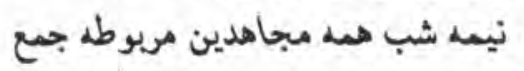

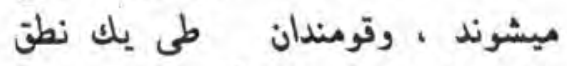
ساده وطنى وكوتاه ميكويد :

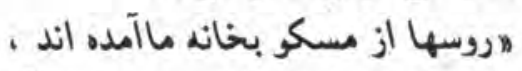

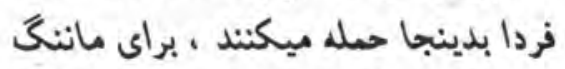

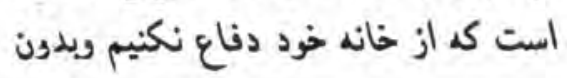

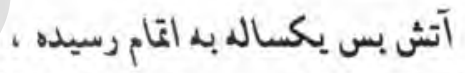

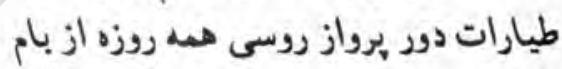
تا شام برسر وروى بنجشير آتش وآهن

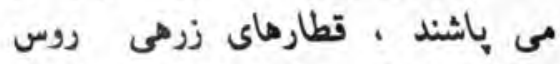

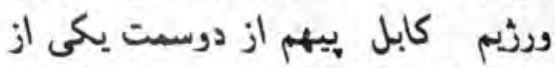
صوب كابل وديحرى از سوى شعال براى دري يك نبرد سرنوشت ساز وارد بنجشير ودري

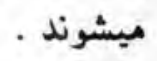
ازجانب مباهدين قومندان يك جناح جبهل ينجشير | عظيم خان ه ، انتخاب كرديده ، ريكه لياقت وشجاعت اورا در امر تومنده ورهبرى شباهدين فيدي

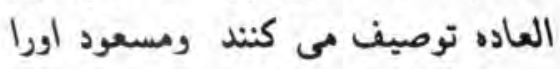

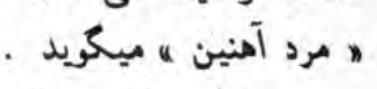

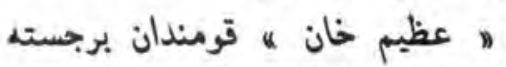
ايست كه از ساليان اول جهان هاد بدينسو كارنامه هاى درخشانى بياد كار كذاشته

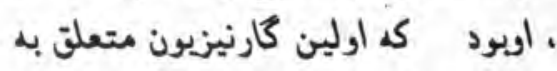

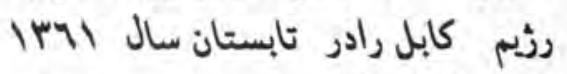

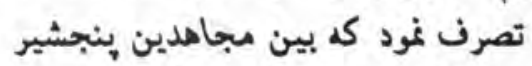

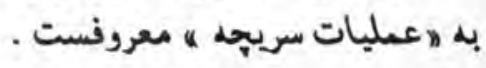


فغان زبوم اختلان وناى او

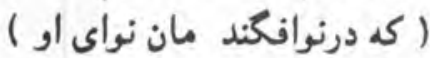
فغان زبال نحس ونكبت آورش

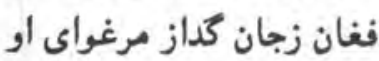
نواى او جو زهر قاتل است وما بجان كنيم سعى درثراى او

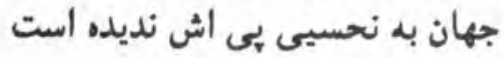
كجسته از زحل شده دو بإى او ناو فسوس از انقلاب با شكوه ما ما دول

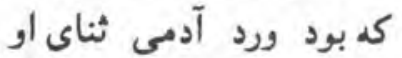
كنون بزير بال اين كجسته بوم فسرده وخفه شده صداى او براي مماشده برادرى به عصر مادئ ازآن با او جنا شده است جائ او بوري كرنته جاش بوف آز وكسب جاه آنداه تعهد وورع شده فداي او اوني جنان طويل كثته راه اختلاف ( كد 3م شود خرد درانتهاى او ) (

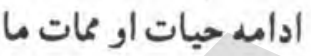
صلاح قلبهاى ما فناى او او عصاره جهاد باك وخون مال مان تجمل وزير وخويش هاى او جاو تبد براي جاه وكنج شايكان

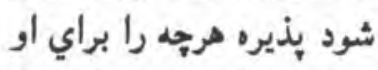
كجاست آنكه زانده كرسنكان

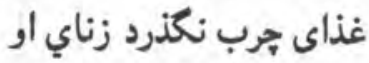
كجاست آنكه از يتيم ماكند نوازشى وينكرد بكاي او اوني تمسكي به حبل حق نكرده ايم

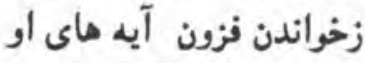

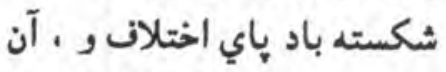
كه سعى ميكند دراعتلاي او اولاقو ، ان *
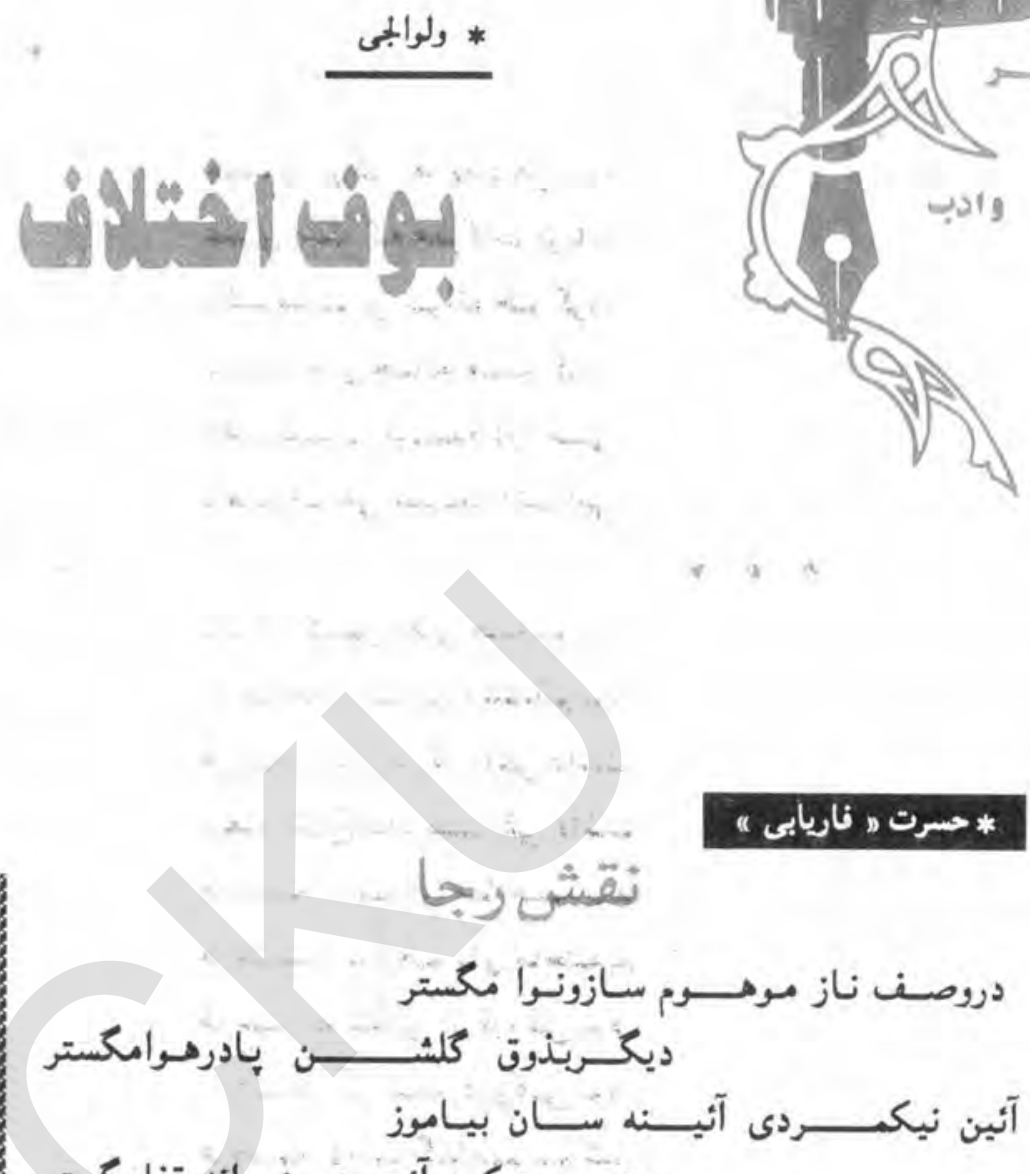

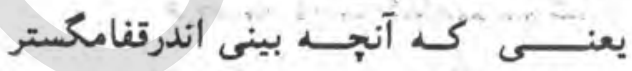

ننكست بهـــــرهستـى ازآبـرو كذشتن

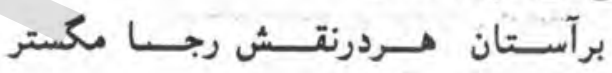

دربـزم حق برسـتان بيجـاست خـرقد ودلَّ

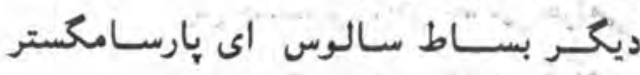

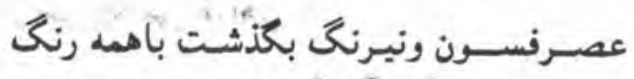

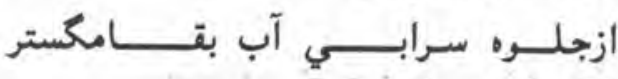

عرض شكست هستى اظهار دون طبعى است ارجـ

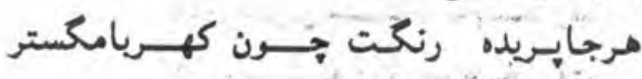

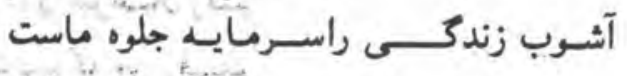

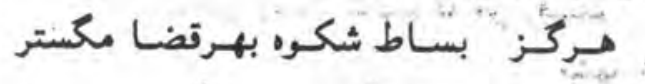

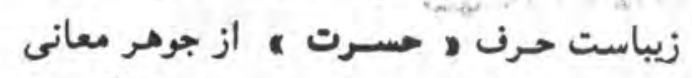

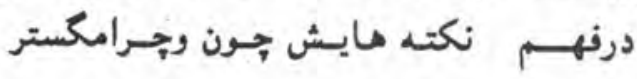


جسـون بـرى رها به دامن بادم

عرى است كه مبركاب فريادم

باشـومتسـرين تسرانه خـو كرده

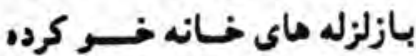

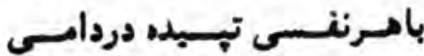

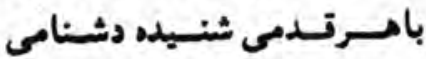

$* * *$

بك دردكــــن بلاى جـانسم بو د سرسـتخ تسرين دشعنانم بود هرييكل نشان مرى باغى داشت ييغام شـكستن جـــراغى داشت

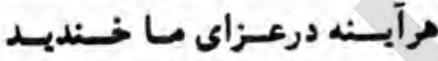

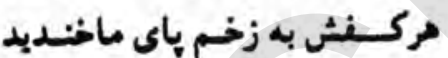

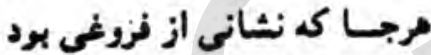

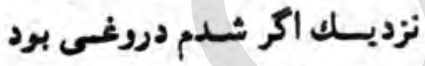

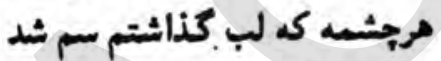

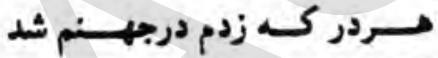

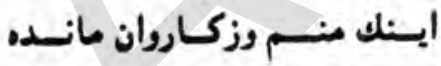

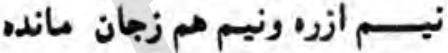

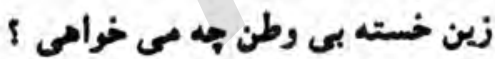

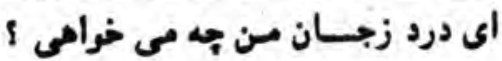

***

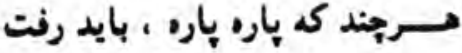

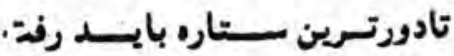
اي دوست به ذوت سوخستن رفتم

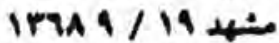

برخيز وسوار شـــوكه من رفستم

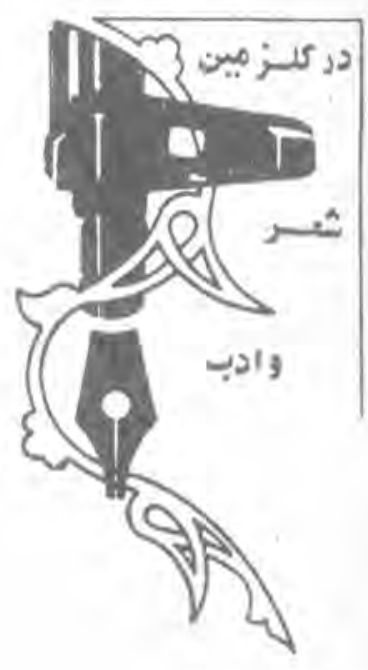

عصست قانع

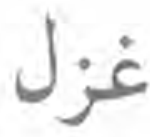

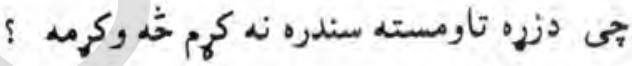

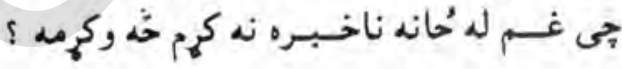
* * *

دروند سكـــــ مي دجنون له لوري نه راخرزى

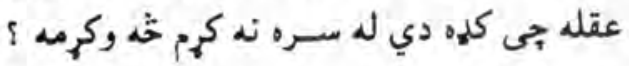
* * *

لبرخومي اوبنكي دجانان وطن به ياد باكى كره

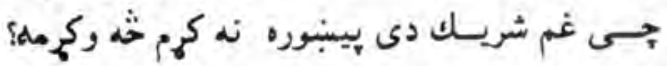
***

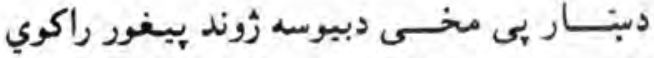
لاردصحرا حي خحان ته غوره نه كئ خه وكرمه ؟

$$
\text { *** }
$$

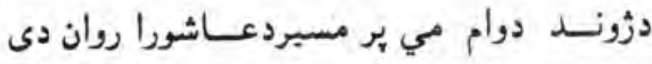

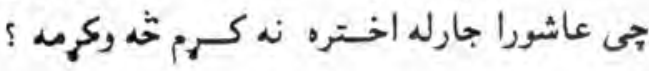
* * *

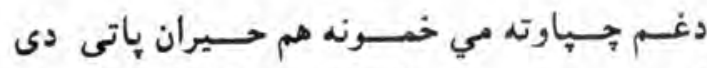

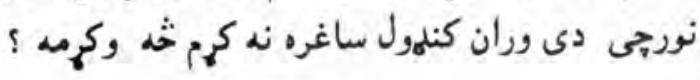
* * *

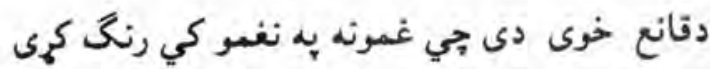

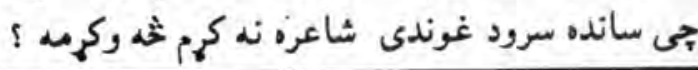




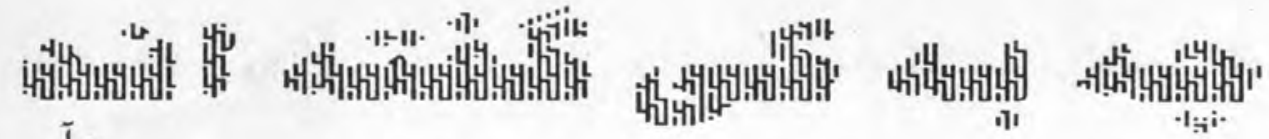
$\tau_{*}$

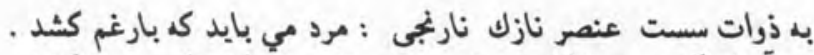

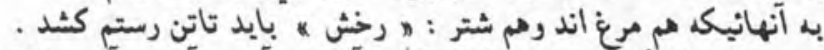

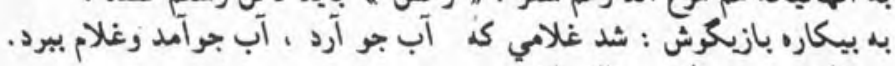

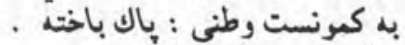

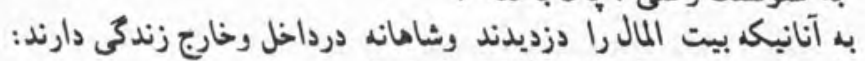

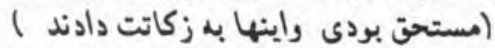

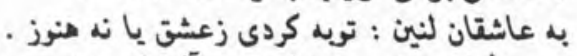

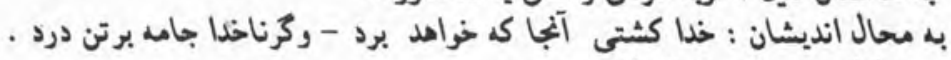

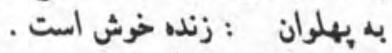

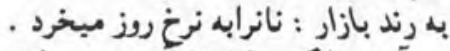

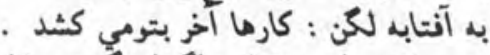

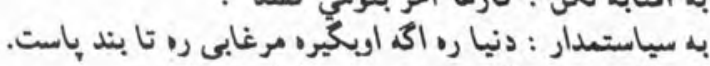

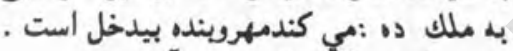

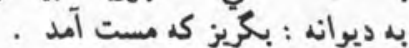

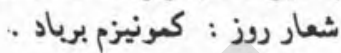

نوت : رخش ، اسب معرون يل زابلى رستم بود .

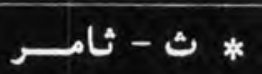

ازتـديم ايـام ، تـاريـخ نيـاكانسش نكر

آنكهـ رام مركزنشد برزوس وهم برانكليس

قهـرمانى هـا و سـريازى گردانسش نكر

$$
\text { ازجهـاد و جهـد و ازيــكارمـردان غيور }
$$

بيكـرلينن زبون و خـوار و ويرانش نكر

نـزدمخلـوق خـداكردن بريسـانسـ نكر

حال كــرديده بهـرسو، يرت وياشانش نكر

$$
\text { همجــو بت قدخـم نمودى سالهـادرياي او }
$$

بسكه ياشـيد زهـم كفـركمونيزم درجهان

شوروشــوق مـــردم آزاد خواهانـش نكر

نعــره هاى ارمنىى ، قـزات وتركانسش نكر

$$
\text { سالهاجـون بـرده مى بـودندزيرجترورس }
$$

$$
\text { جنـبش لتـوانسى و ليــتونى و اسـتونيا }
$$

شـور و ميسجان وقيام تاجكستانش نكر

$$
\begin{aligned}
& \text { ازخداخواهم هـى مجو كمونيزم درجهان }
\end{aligned}
$$

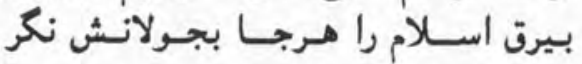

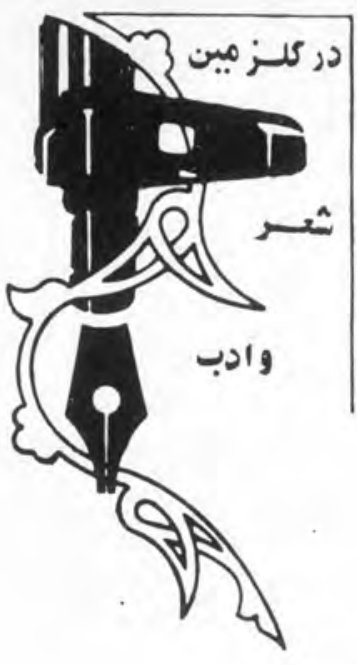

\section{* استاد آثينه |لله |لمبر}

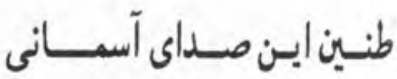
هنز اندركهنستان بإيدار است

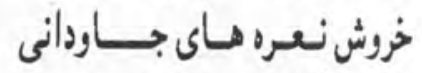
هـنـوز آزاده مردانزا شـعار است 


\section{(ازخون شهيدانت كثور همه كلزار است ()}

اي جان بدر برخيز ! جون تاج بسر بر خيز بانسور درخشانست بافتـ وظفريرخيز !

$$
\begin{aligned}
& \text { از جهد جهـاد توكسور هـسه آزاد است بـانت }
\end{aligned}
$$

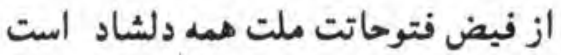

هـم مسكـن ومأوايت ازتـازه به بنياد است است

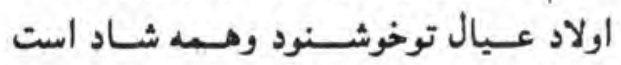

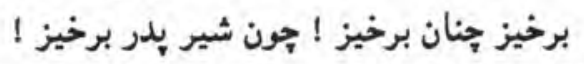

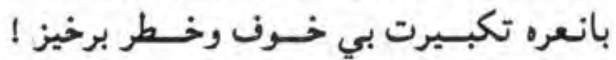

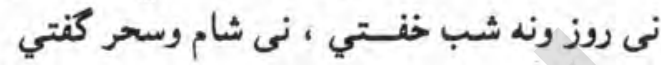

درسنكر خـود بـيدار ، باديده تر كفتي

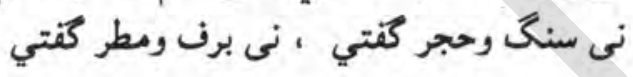

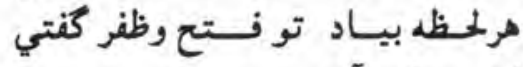

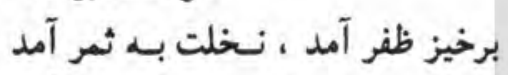

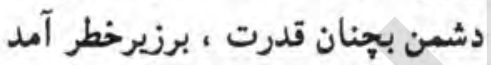

$$
\begin{aligned}
& \text { ارواح شهيدانت جون شاد وخرامان است }
\end{aligned}
$$

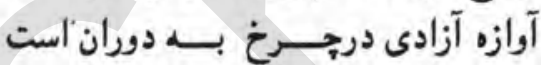

برعزم وثبات تسوعالم هـه حسيران است

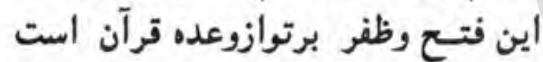

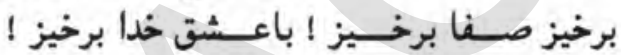

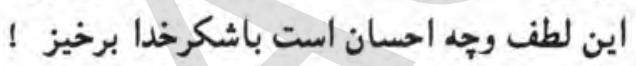

$$
\begin{aligned}
& \text { از هرســرش آئي آغـوش وطن باز است }
\end{aligned}
$$

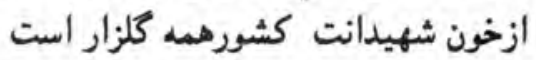

ازفضل خداوندى بينى كه جه اسراراست

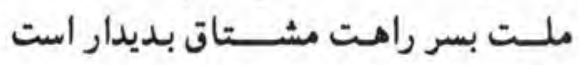

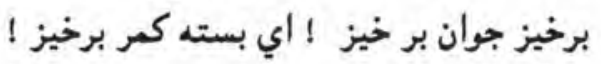

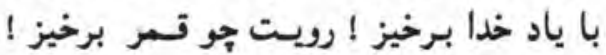

$$
\begin{aligned}
& \text { ازعزم وثبات تو خسون هـه جوش آمد آداد } \\
& \text { در دورجهان مردم برجوش وخروش آمد }
\end{aligned}
$$

عالم زجـنين شوكت يكباره بهوش آمد

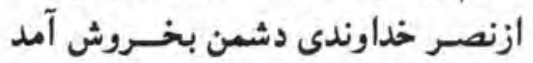

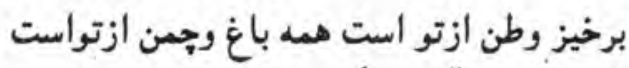

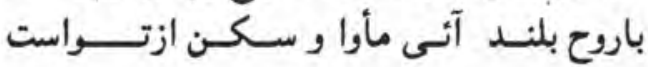

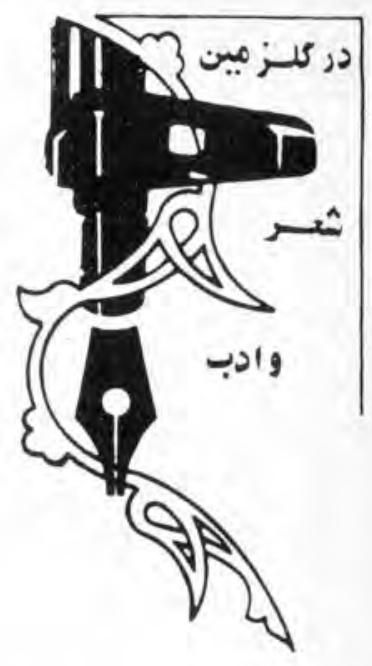

نورالدين " مخذدوم " 
از بسكه زن وفرزند جانش كه بقريان است

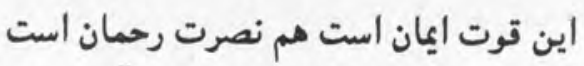

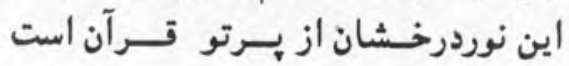

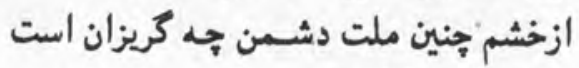

$$
\begin{aligned}
& \text { برخيز توراحت كن كشورتوحفاظت كن }
\end{aligned}
$$

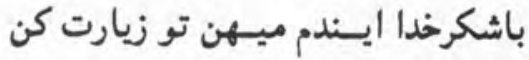

$$
\begin{aligned}
& \text { خرسان سيه تطبى بركثته بدر رفتند } \\
& \text { يك قســت مردارش برزيرسقررفتند برند }
\end{aligned}
$$

هرجند كه بركـشتند باخون جكررفتند

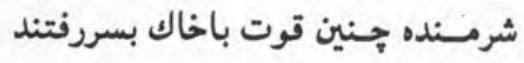

$$
\begin{aligned}
& \text { برخـيز امان خيزد اسلام وجهان خيزد }
\end{aligned}
$$

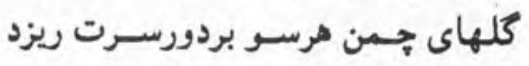

$$
\begin{aligned}
& \text { برخيز بدر كويد آواره يستيمانست } \\
& \text { مشتاق بديدار است همبستروجانانت }
\end{aligned}
$$

نازد بـجهان مـلت از غيـرت وجدانت

برسوى وطن باز آ، بانور درخشانت

$$
\begin{aligned}
& \text { برخيز جنان برخيز ! جون شيرويلنگ برخيز } \\
& \text { نيروى تو ايمان است ، هوشياروزرنگ برني برخيز }
\end{aligned}
$$

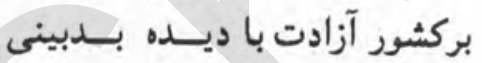

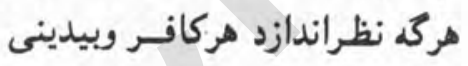

رسواى جهان گردد برخاك خورد بينى

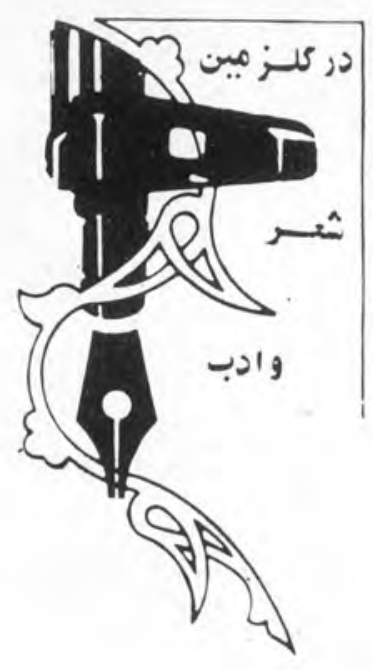

هم كشته اسيرآيد امروز كه مي بيـنى بردي

$$
\begin{aligned}
& \text { برخيز جهان بيند با جشم هنان بيند } \\
& \text { يكدست به قرآنت شمـشيرعيان بيند }
\end{aligned}
$$

بشكست به بازويت زيجسير غلامى را

ازدورجهان جيدى اين ظلمت شامى را

اسلام جهان كويند ،اينكونه بيامى را

آزاده سرشـتي توزيبــنده مــقامى را

$$
\begin{aligned}
& \text { برخيز جوان برخيز ! رويت جو قمر برخيز }
\end{aligned}
$$

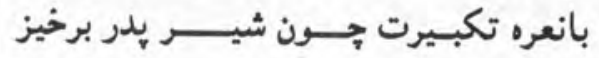

$$
\begin{aligned}
& \text { برتونظر رحمت اين مثده بشارت باد }
\end{aligned}
$$

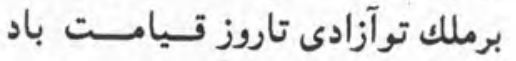

باعزوشرف هرجا مأوا ومقامت باد

دستش به دعا ملت درحقت اجابت باد باد

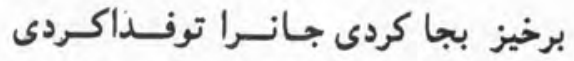

$$
\begin{aligned}
& \text { تاجت بنهد " مخدوم " برسركه وفاكردى }
\end{aligned}
$$




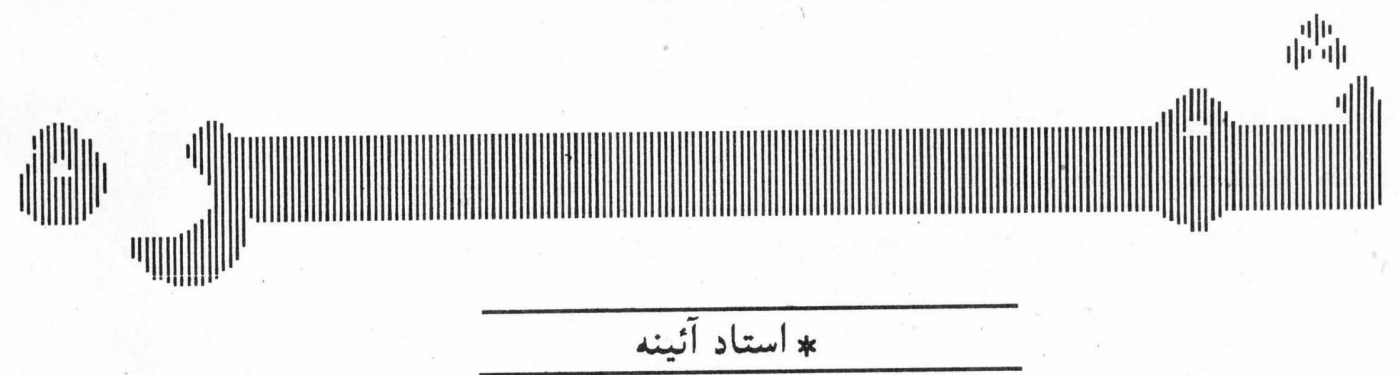

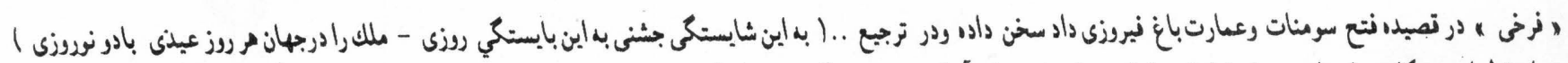

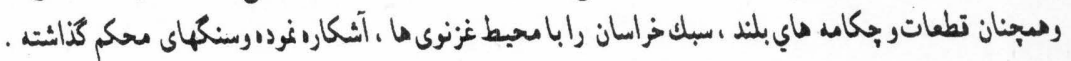

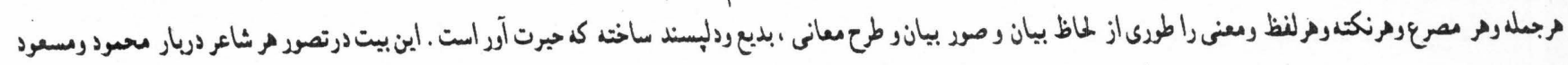
بود1:

$$
\text { سنسانه كثت وكهن شد حديث آسكندر }
$$

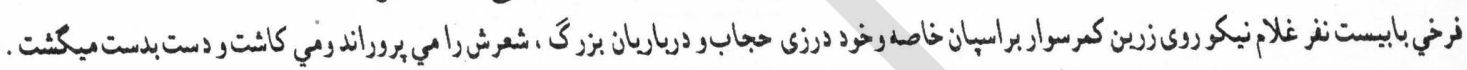

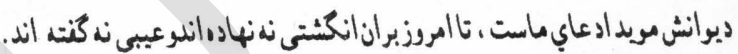

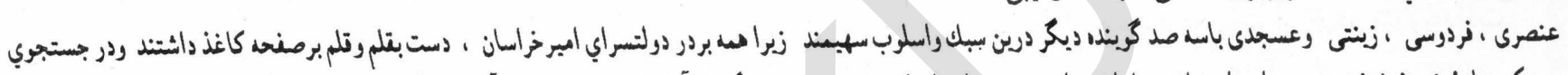

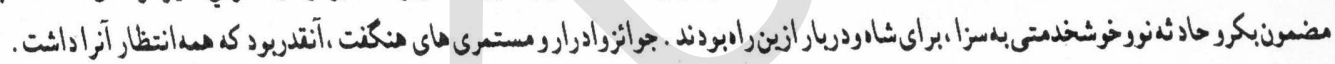

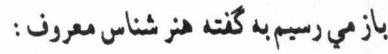

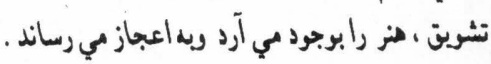

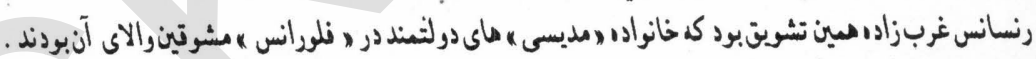

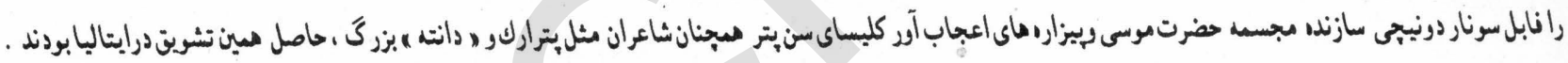

\section{* * *}

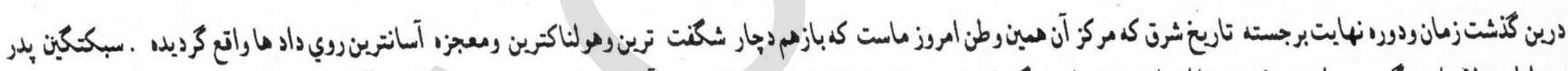

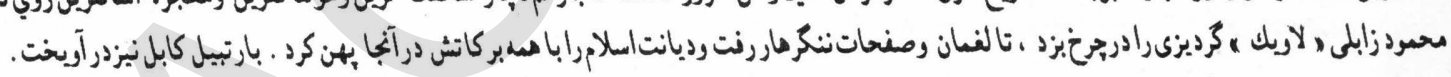

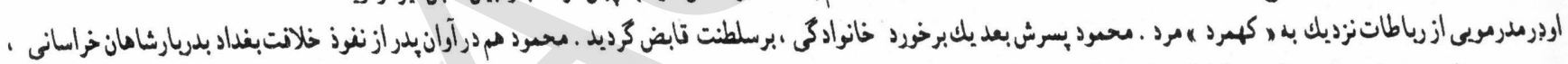

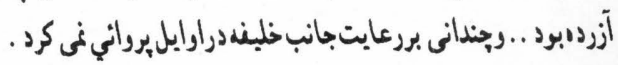

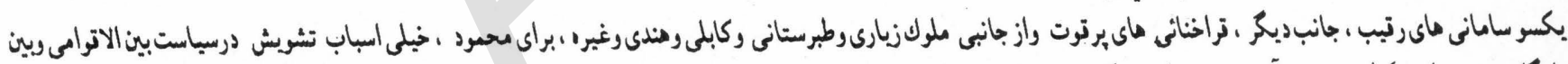

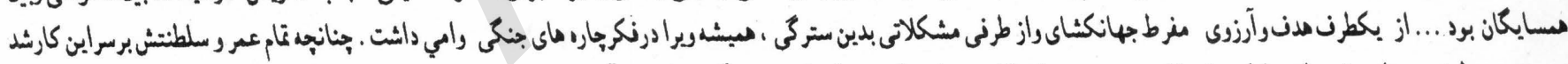

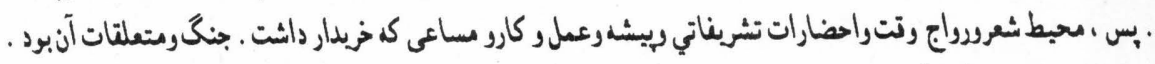

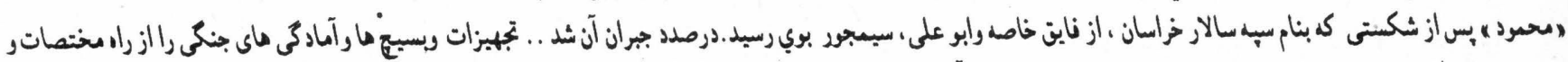

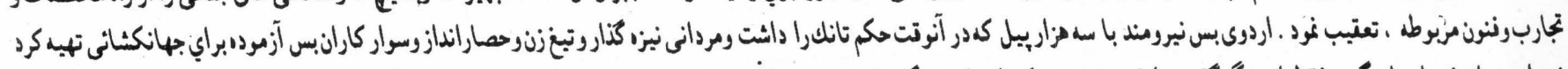

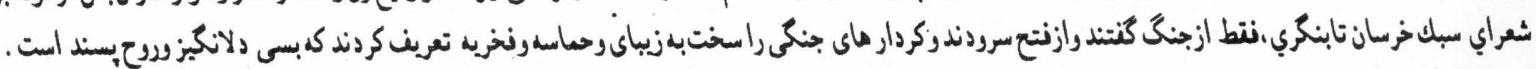

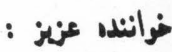

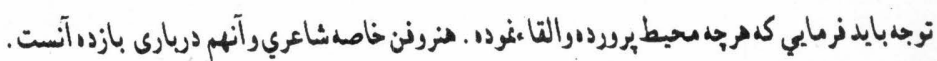

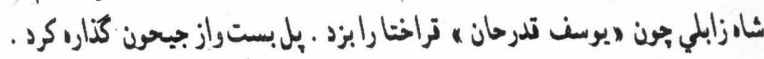

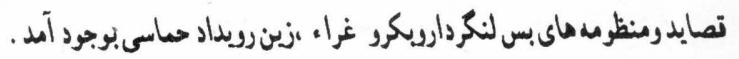

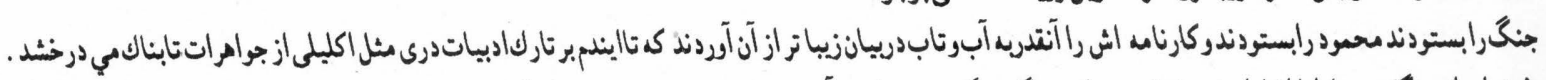

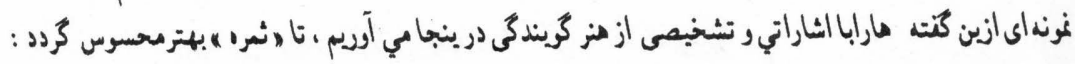

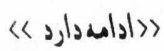




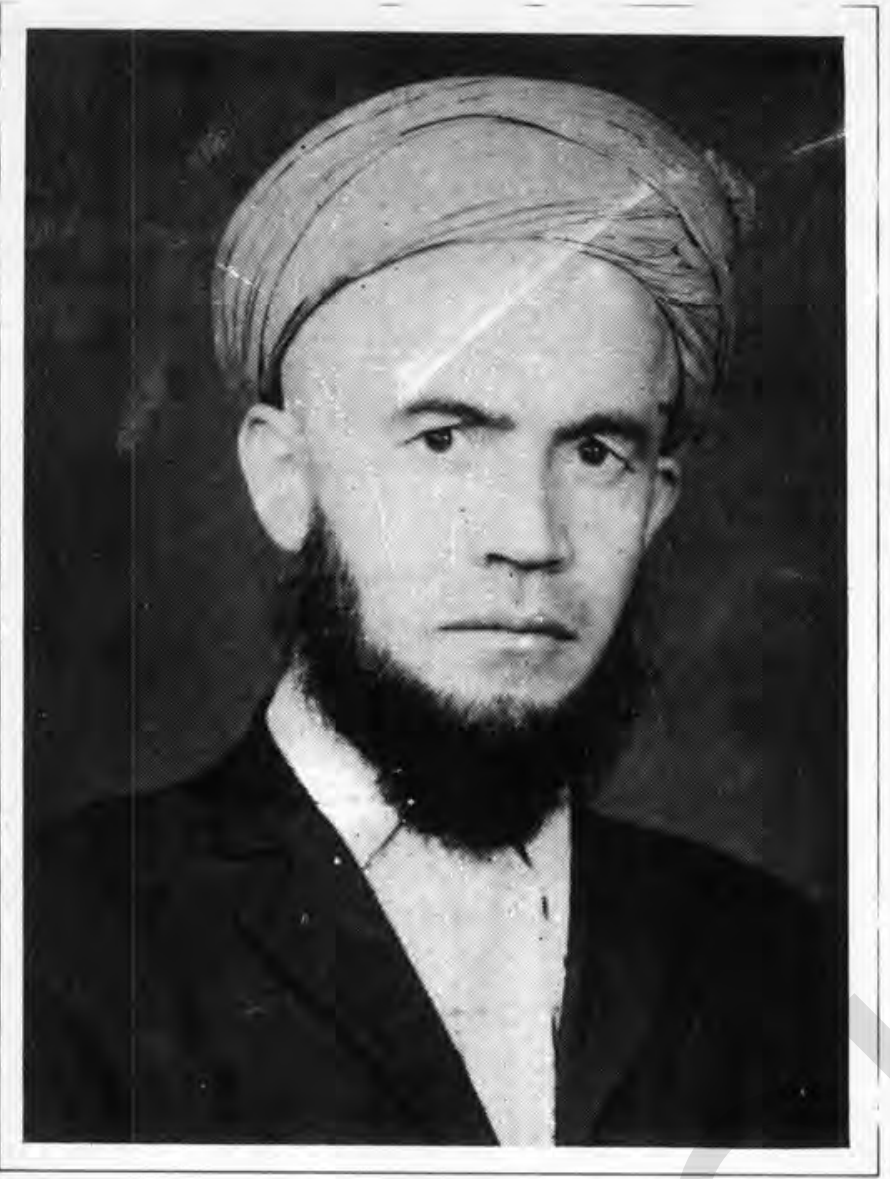

خاموشنباشيدرعليدنابساماني ماكروزكارتلم برداريدوبه

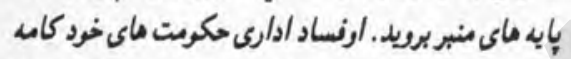

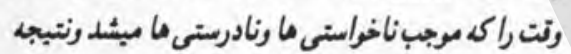

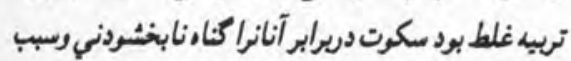

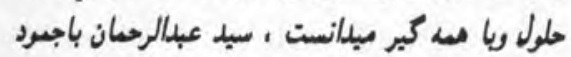
رتعصب /مل دانش سخت مخالف بو د، وتحصيل را را مكثاى مبارزهودعوتمبدانست. باخرافات كه ساخته ويرداخته جهل وناأكامى ماست

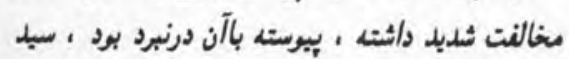

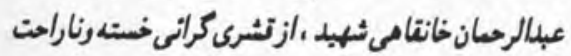

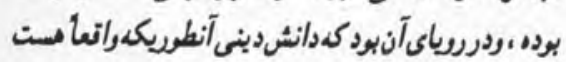

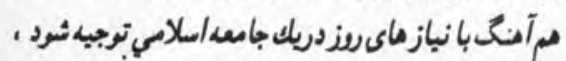
واينمستخلف رعتب ماندكى مسلمانهاكة/زخود باختكمي

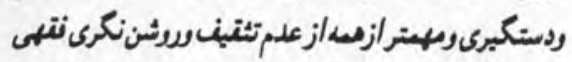
وضعبن بودن جذيات عتبدرى /ست ، بايد جاره اساسى

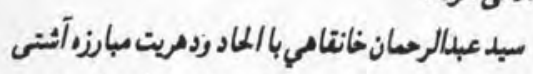

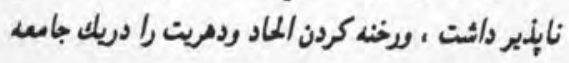

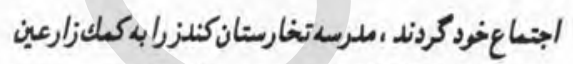

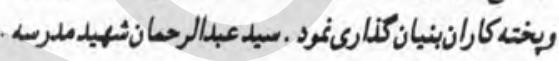
مذكور را بخاطر شكوفانى استعداد ما وذرق نويسندكى

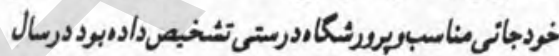

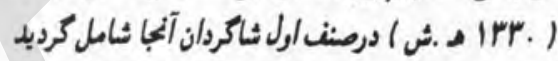
ودرملرسه مذكر در بهلوى بيشبرد دروس مسلكي خودبه

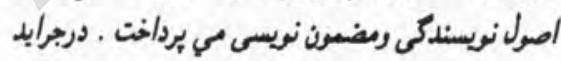
ومجلات وتت از تببل جريس اتحاد بغلان ومجله النلاح

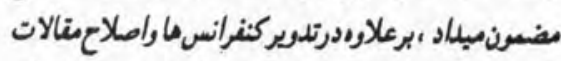
طلاب ملرسكسهربارزداشت ، سيد عبدالرحمانشهيدانسان

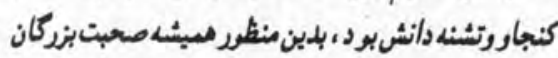

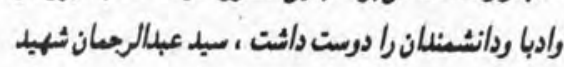

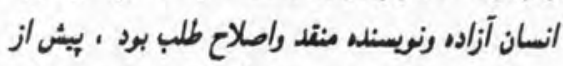

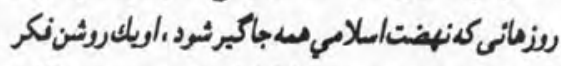
نقاد بود وارضاع اجتماعى رالحليل ونتد مينسود ، ربالائى

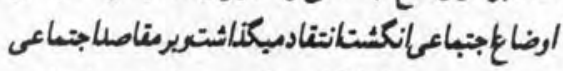
ربذ ماكت نبوده تلم انكار مي كشيد ، زمعاند يك داعى

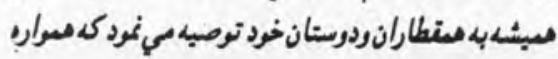

.110

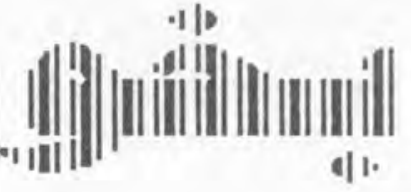

1.

1. - 11
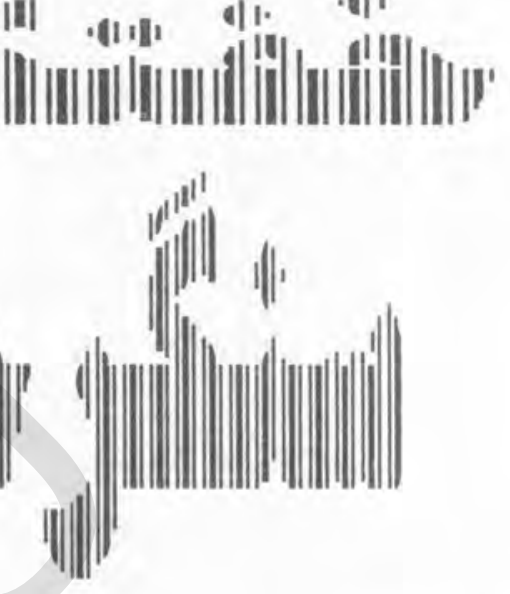

\section{شهيد مولوى سيد عبدالرحمان خانقاهى}

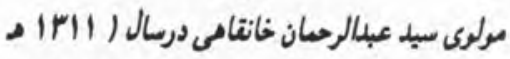

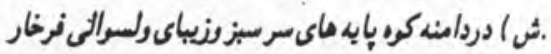

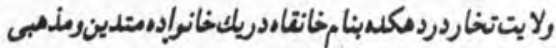
ازودودمانساداتجشمبرجهانكشرود.

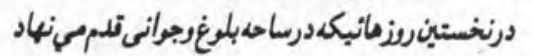

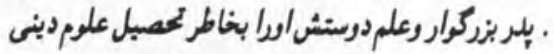

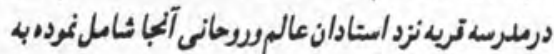
نراكيرى علومدينى كي ميراث/جداد ونياكانش بود ، تشويق وترغيب نمرد . سيد عبدالرحمان ثهيد با استعلاد سرئار

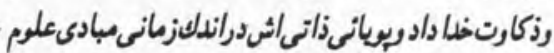

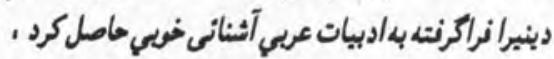

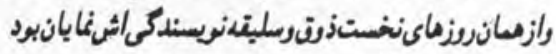

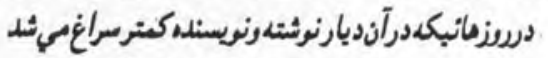

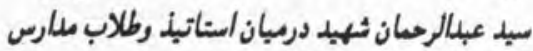

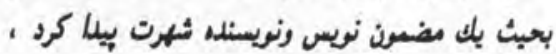
درسالهانى كى مولوى غلام سربر بان مرحوم بنكر تاسبس

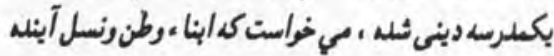
در بيلوى علوم دينى از مضامبن ماينس واصول انشاء.

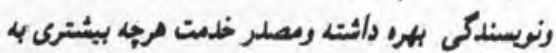




\section{شهيد ملإ محمد يعقوب}

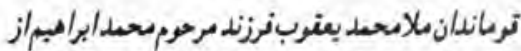

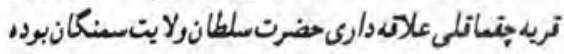

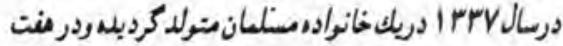

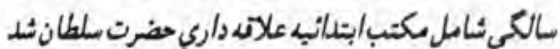

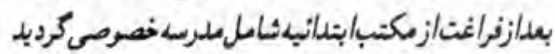

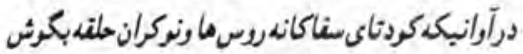

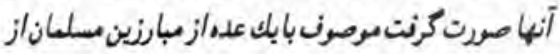

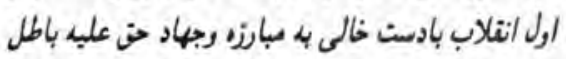

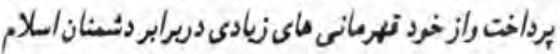

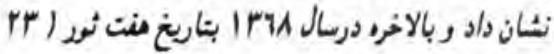

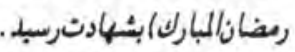

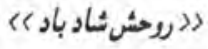

* * * شهيد ملا محمد علم

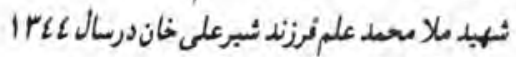

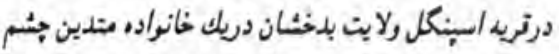
بذنباكشود بعلازسن منت سالكى ثامل ملرساتريشخريش

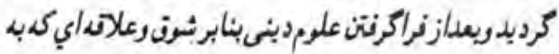
جهاد درراء خلا جل جلاله داشت درسال . وابا به جهاد

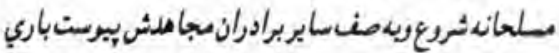

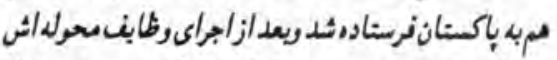

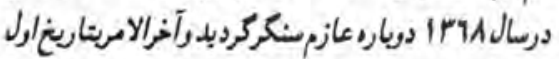

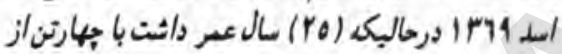
مسنكرانش دريك جنك رياريى توسط عناصر خود

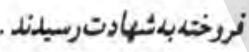

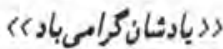

* * *

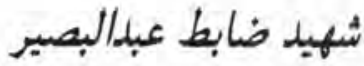

ظابط عبدالبعبر نرزند عزت بيك دربك خانواده مندين واسلام دوست درفريه ياصف راغ تولد بانثا وعرئ ثشيرين

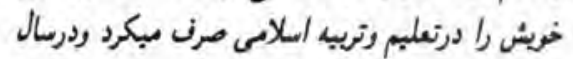

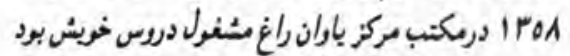

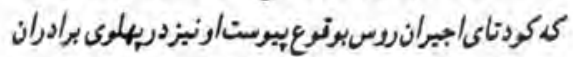

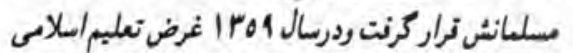

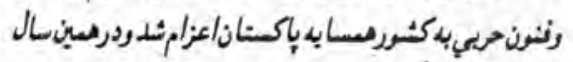

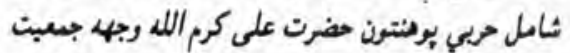

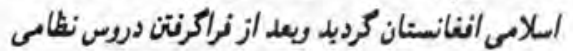

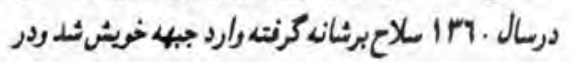

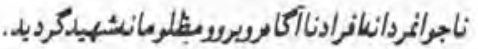
》" روحش ثشاد بيادش

$$
\text { شيهيد خيراللة }
$$

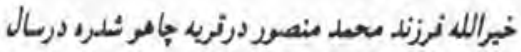

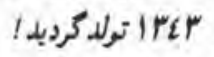

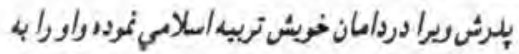

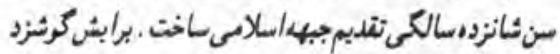

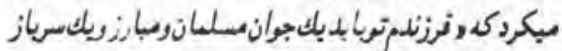

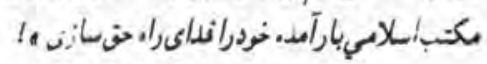

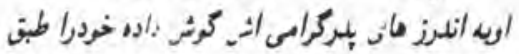

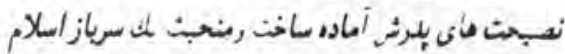

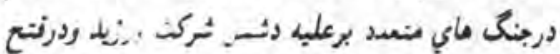

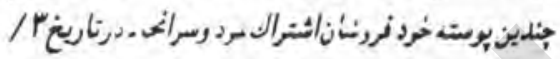

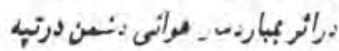

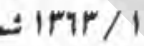

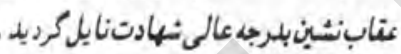

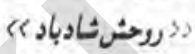

\section{** *}

$$
\text { شهيد عبدالخنان }
$$

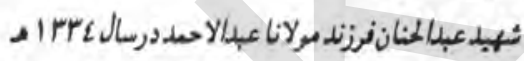

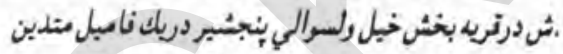

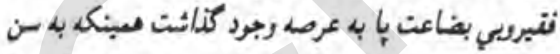

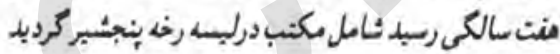

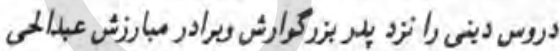

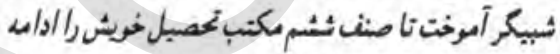

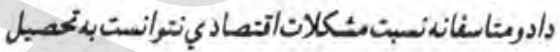

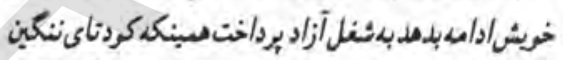

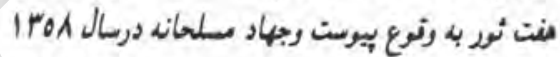

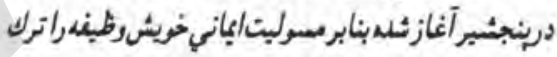
كنته رامى سنكر جهاد كردبد درمبان مردم ومجاهدين

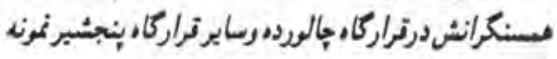
اخلاقتقوارصاونتبود.

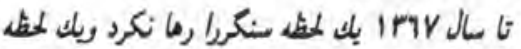

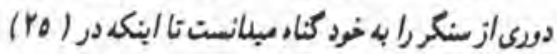
جلي سال 11111 درمنطته سنكدان اندراب درونت

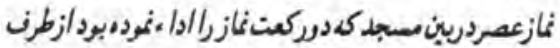

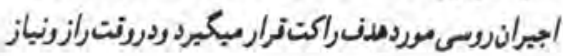

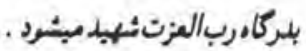

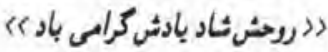

اسلامي ودربين جرانان ونرزندان مسلمانها افيوف/ ستعلار

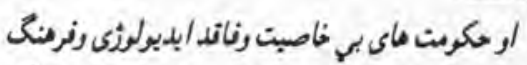

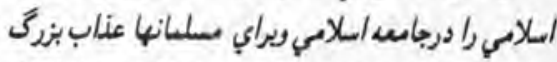

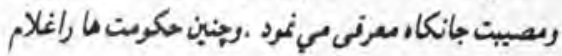

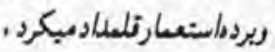

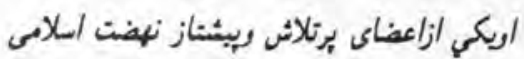
كشريود ودرتحت مريرسنى نهضت، عليه الحاد ودمريت

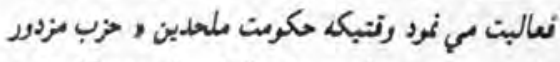

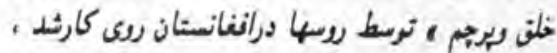

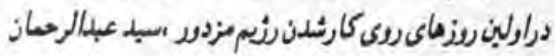
خانقامى ومولوى امين الله وارياب محعد ونورالله خان راراز

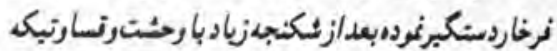

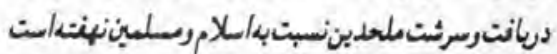

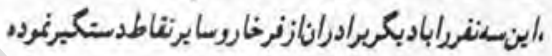
بيثهادترسانبدند. بيا ينترتبب يكمي/زنسخصينبامي/سلامي ومبارزين راه

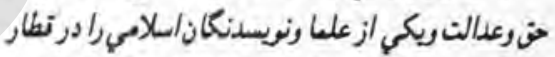

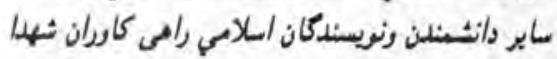
كلكونكن منمودند.

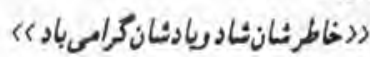

\section{***}

شهيد قوماندان حبيب الرحمن * * ثران

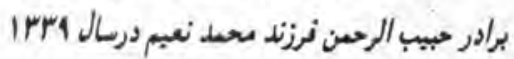

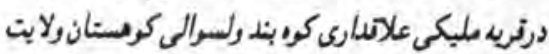

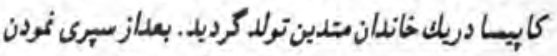

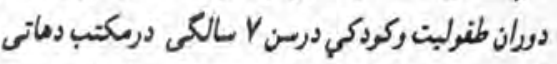
شامل بعلاز نراغت /ز حنف سور به تحعبل علوم ديني

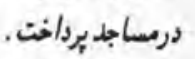

بعدازكودتأى صبا، خلنبها ازتحصبل ابا برزيلد برعلبي

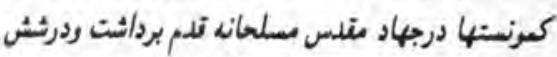

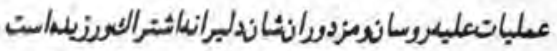

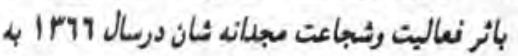
نيصله شسوراى توماندانهاى منطقه رمنظورى متام محترم

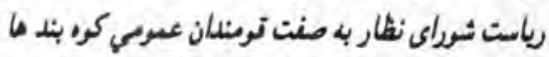

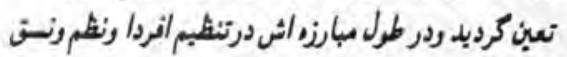

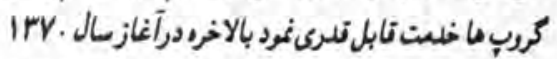

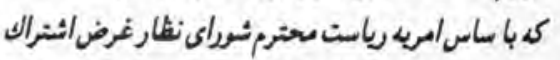

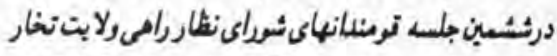
بودند درعرض راه ( راتع بنكمي ولايت تخار ) با كعين 


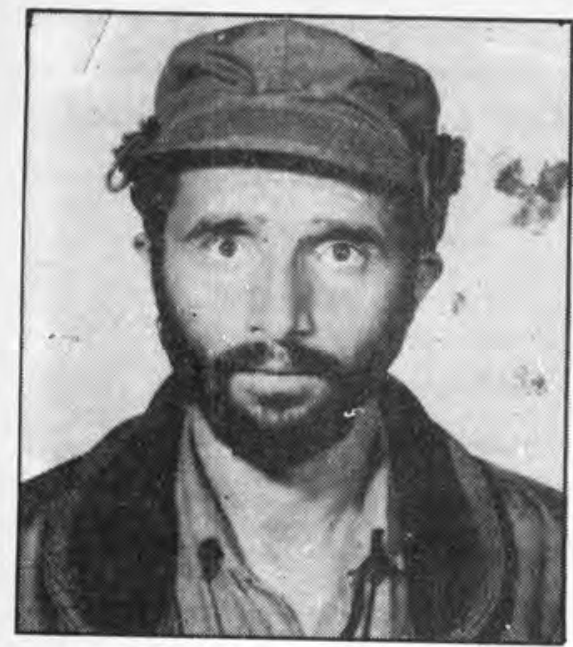

* شهيدعبدالحنان *

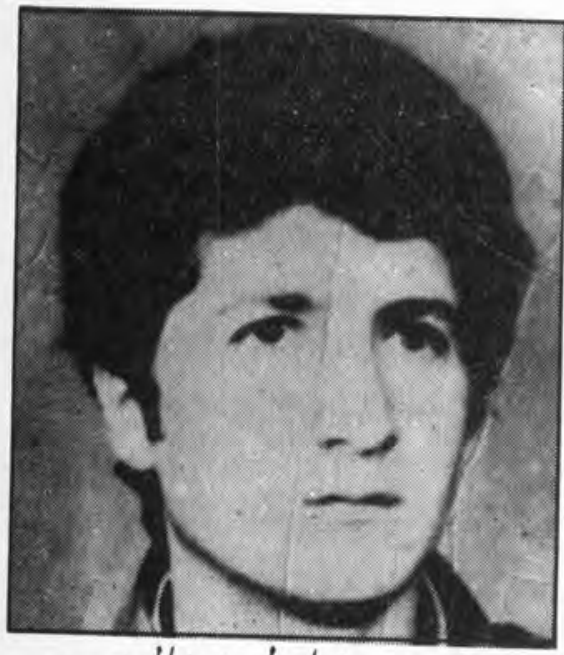

* شهيد ضابط عبدالبصير

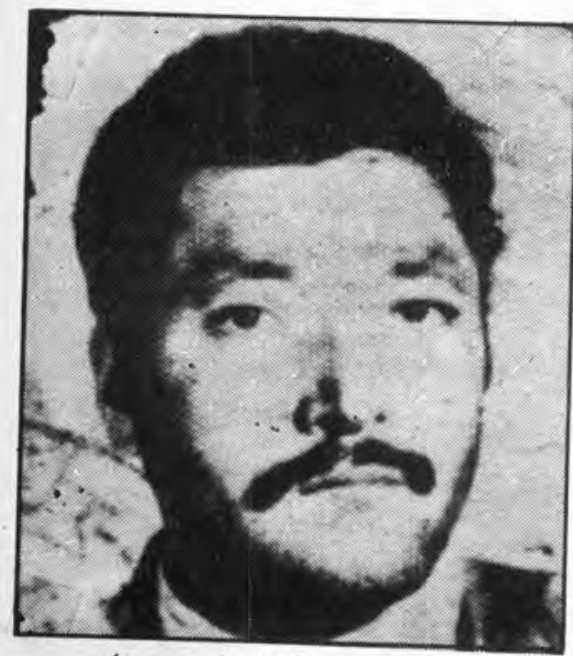

* شهيدقوماندان بهرام
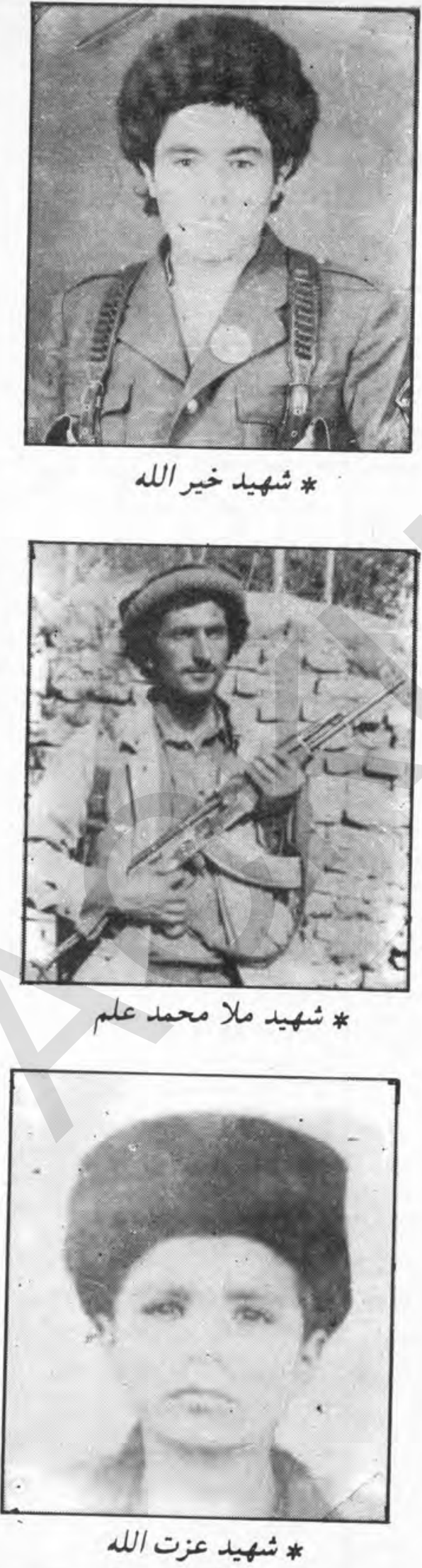
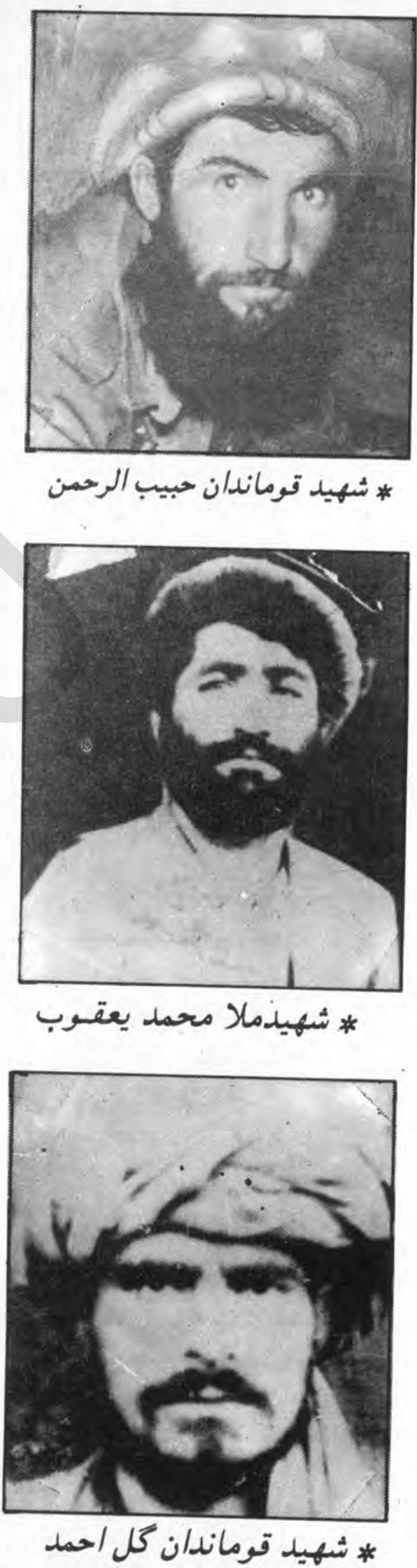

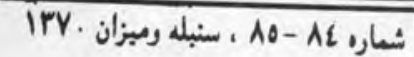




\section{شهيد محمد حسن}

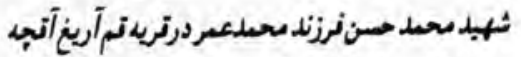

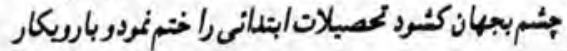

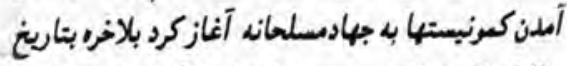

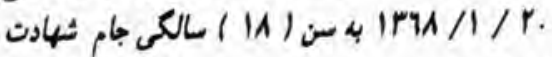

نوشيد.

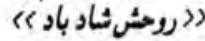 \\ ** * \\ شهيد شاه جهان}

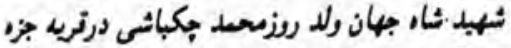

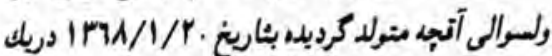

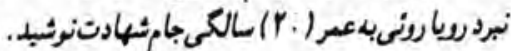

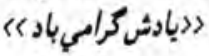

$* * *$

شهيد خذايداو.

ثهيد خلابدارولد دوران باى درتريه جينجيجي جوزجان

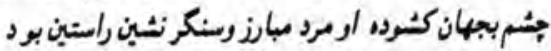

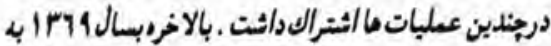

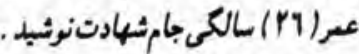

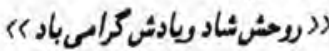

\section{*** \\ شهيد عبدالقيوم "ش}

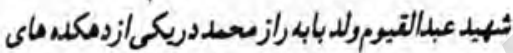

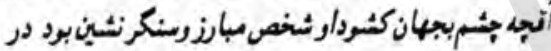

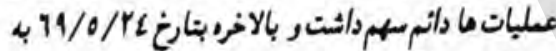
سن (بال) سالكى جامشهادتنوشيد.

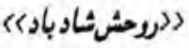

***

\section{شهيد /سدالله}

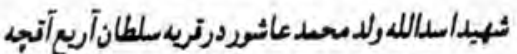

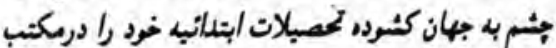

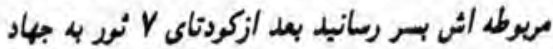

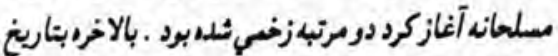

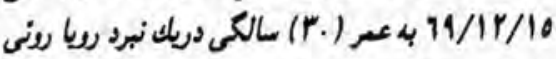

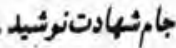

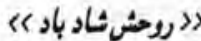

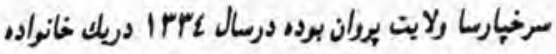

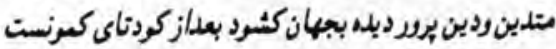

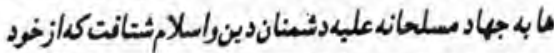

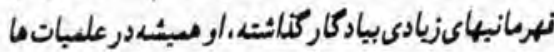

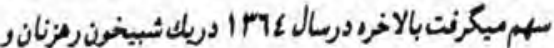

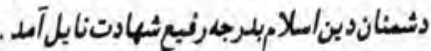

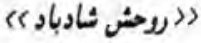

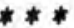

$$
\text { شهيد تروى باى " شي }
$$

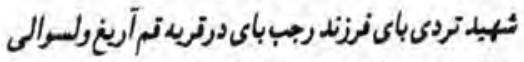

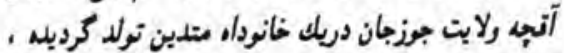

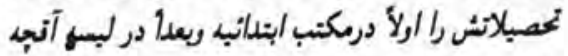

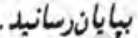

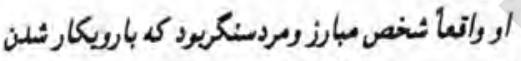

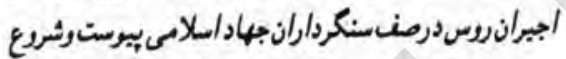

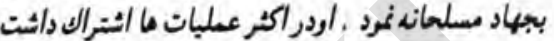

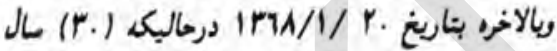
داشتدريك برخرد ريا رونى جامثهادتنوئيد.

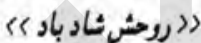

\section{**}

شهيد قوماندان دوست محمد

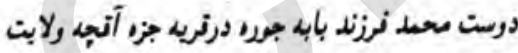

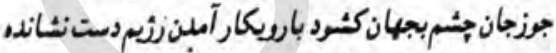

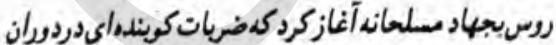

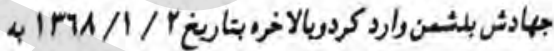
سنبيستردورالكم جامئهادتنوئشيد.

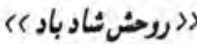

\section{شهيد رجب باى تئ}

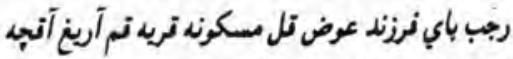

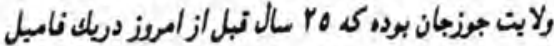

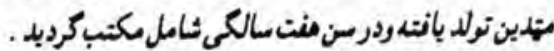

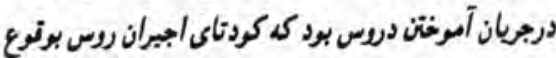

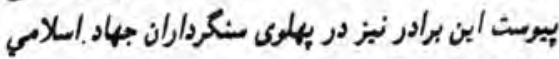

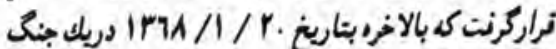

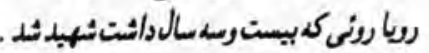

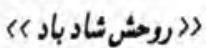

ين مدت مستوليت بك كروب رابلرش داشت بعال بنا

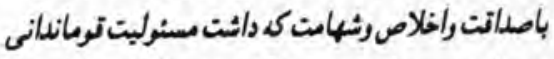

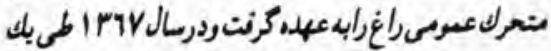

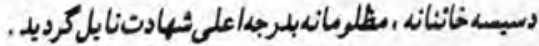

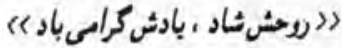

شهيد قوماندان كُل احمد ثهيد توماندان كل احلد فرزنلهاجي صديار دروسال

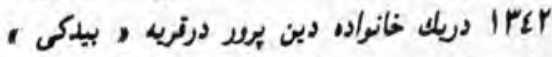

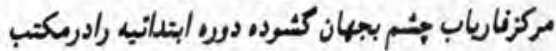

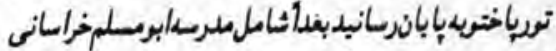
كردبد

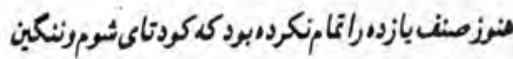

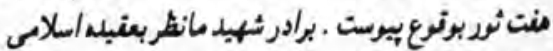

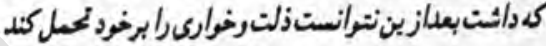

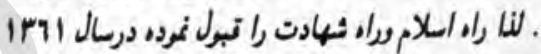

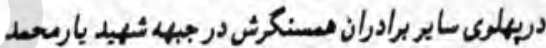

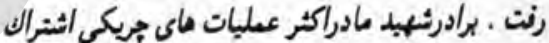

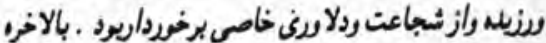

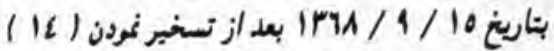

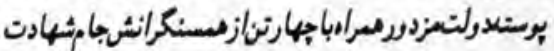
رانوشيد.

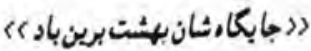

***

عزت الله شهيد

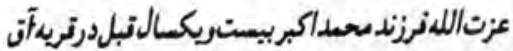

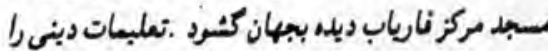
درنزد /مام مسجد فراكرنت بعد ازسن منت سالكي ثنامل

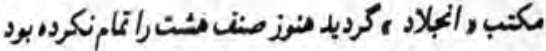

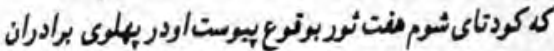

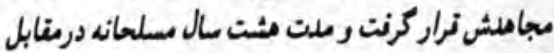

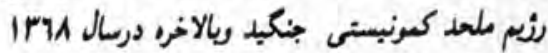

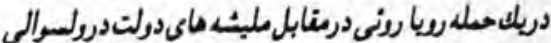
نيصارجامشهادتنوشيد.

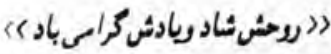

شهيد قوماندان بهرام ترمانان بهرام ولد ميرحيلرغان مسكون نري، تلندر 


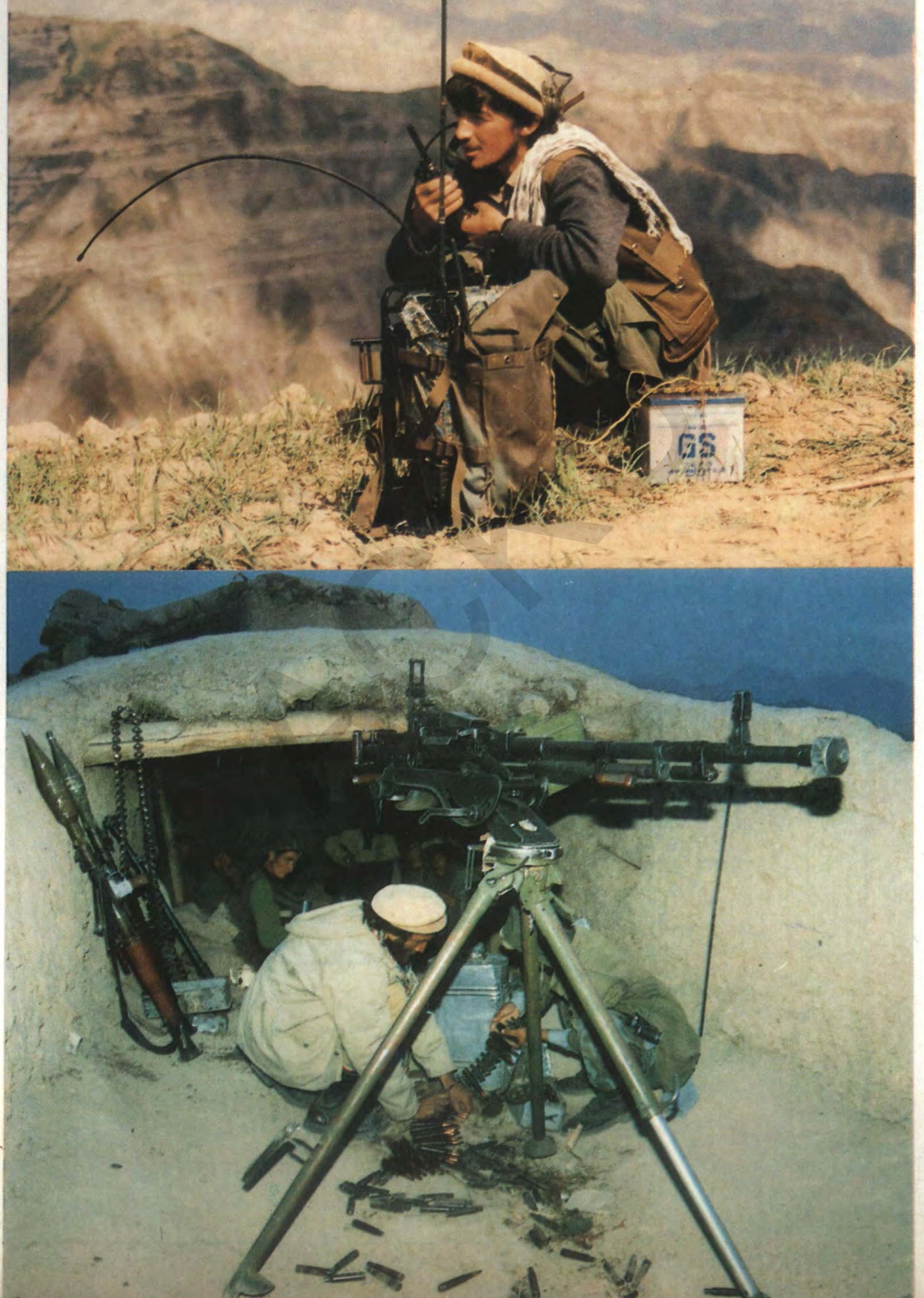

